Instituto Superior de Ciências do Trabalho e da Empresa

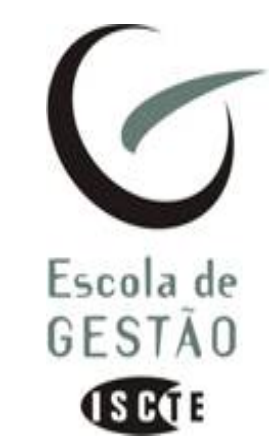

\title{
SIGNALLING WITH DIVIDENDS? NEW EVIDENCE FROM EUROPE
}

\author{
Elisabete Fátima Simões Vieira \\ Thesis submitted for the degree of \\ Doctor in Business Administration \\ Specialisation in Finance
}

Supervisor:

Prof. Doutora Clara Patrícia Costa Raposo

Co-financiado pelo Fundo Social Europeu. Entidade Beneficiária: Instituto Superior de Contabilidade e Administração da Universidade de Aveiro

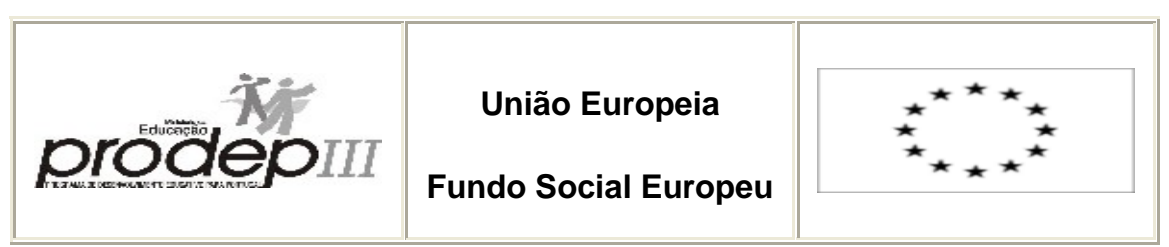

October 2005 
"The important thing is never stop questioning"

Albert Einstein 
LIST OF TABLES ............................................................................................... viii

LIST OF FIGURES ......................................................................................

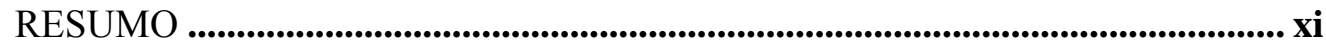

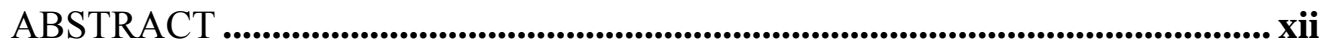

ACKNOWLEDGMENTS ........................................................................................ xiii

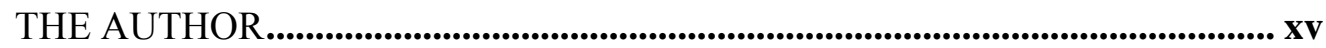

\section{CHAPTER 1}

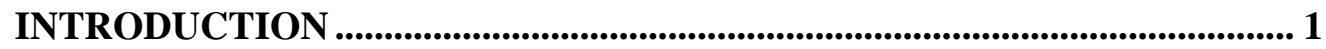

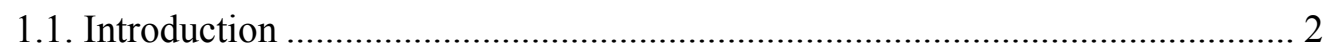

1.2. Motivation and Objectives of this Study ….............................................. 5

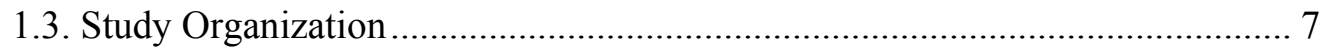

\section{CHAPTER 2}

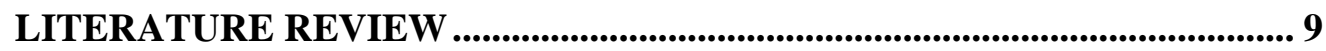

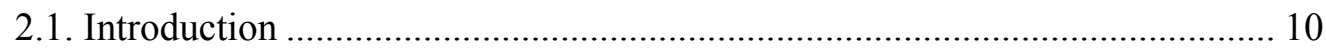

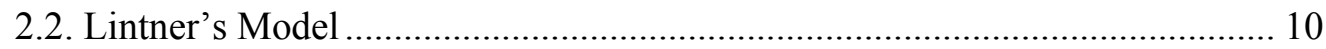

2.3. The Dividend Policy Irrelevance Hypothesis .............................................. 12

2.4. Main Factors Affecting Dividend Policy .................................................. 15

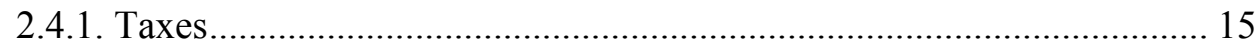

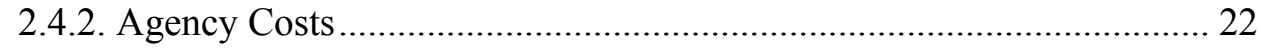

2.4.3. Uncertainty Associated with Future Remuneration Flows................... 26

2.4.4. Information Asymmetry and the Dividend Signalling Hypothesis ....... 27

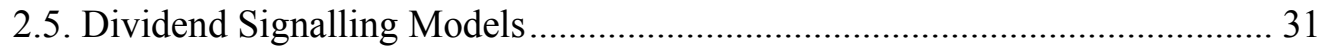

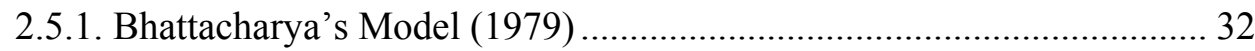

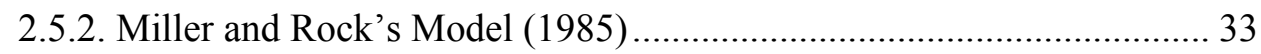

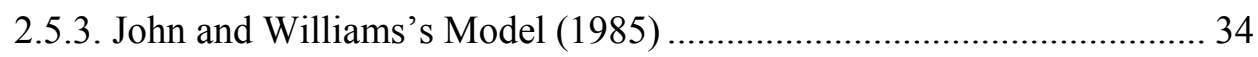

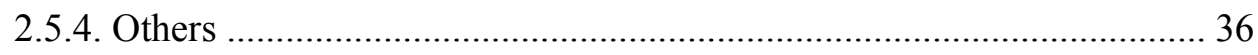

2.6. Empirical Tests on the Information Content of Dividends .......................... 38

2.6.1. The Effect of Dividend Announcements on Future Earnings .............. 39 
2.6.2. The Effect of Dividend Announcements on Share Prices

2.6.3. The Effect of Dividend Announcements on Market Expectation

Revisions 85

2.6.4. The Effect of Dividend Announcements on a Firm's Risk 87

2.7. Evolution of Firms' Propensity to Pay Dividends........................................ 89

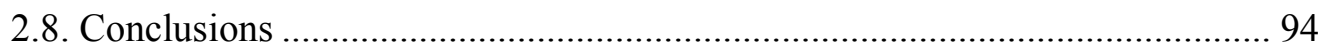

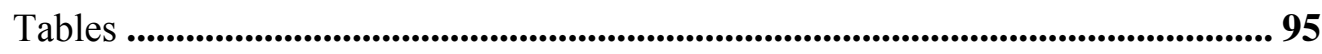

\section{CHAPTER 3}

THE EFFECT OF DIVIDEND ANNOUNCEMENTS ON SHARE PRICES AND ON FUTURE PERFORMANCE......................................... 101

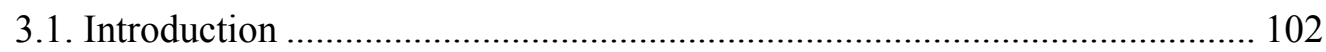

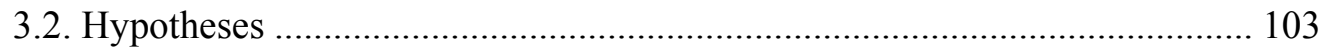

3.2.1. Hypothesis $1-$ Relation Between Dividend Change Announcements and the Market Reaction............................................ 103

3.2.2. Hypothesis 2 - Relation between Dividend Changes and Firm's

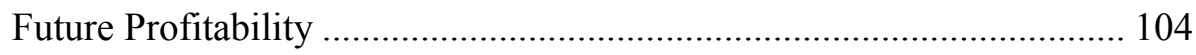

3.2.2.1. Sub-Hypothesis 2A - Relation between Dividend Changes

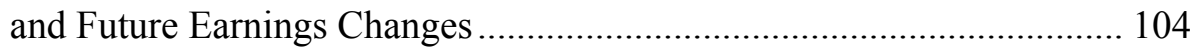

3.2.2.2. Sub-Hypothesis 2B - Relation between Dividend Changes and Accounting Performance Measures ................................................ 105

3.2.2.3. Sub-Hypothesis 2C - Relation between Dividend Changes and Operating Performance Measures................................................. 106 3.2.2.4. Sub-Hypothesis 2D - Relation between Dividend Changes and Market Expectations of Future Earnings ....................................... 107

3.3. Sample Selection and Methodology …................................................... 109

3.3.1. Sample Selection ...................................................................... 109

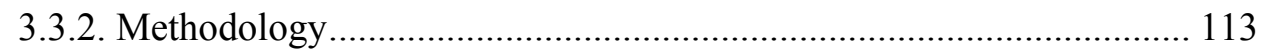

3.3.2.1. Methodology to Test Hypothesis 1 - Relation between Dividend Change Announcements and the Market Reaction.................. 116

3.3.2.2. Methodology to Test Hypothesis 2 - Relation between Dividend Changes and Firm's Future Profitability ....................122 
3.3.2.2.1. Methodology to test sub-hypothesis $2 \mathrm{~A}$ - relation

between dividend changes and future earnings changes.

3.3.2.2.2. Methodology to test sub-hypothesis $2 \mathrm{~B}$ - relation between dividend changes and accounting performance measures ...... 126

3.3.2.2.3. Methodology to test sub-hypothesis $2 \mathrm{C}$ - relation between dividend changes and operating performance measures

3.3.2.2.4. Methodology to test sub-hypothesis $2 \mathrm{D}$ - relation

between dividend changes and market expectations of future

earnings 129

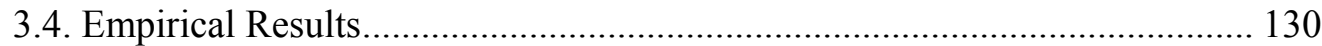

3.4.1. Time Trends in Cash Dividends ........................................................ 131

3.4.2. Description of the Sample .................................................................. 136

3.4.3. Test Results of the First Hypothesis - Relation Between Dividend

Change Announcements and The Market Reaction ............................... 144

3.4.3.1. Abnormal Returns ................................................................ 144

3.4.3.2. Market Reaction to Dividend Change Announcements

During Up and Down Markets ......................................................... 151

3.4.3.3. Relation between Dividend Changes and Abnormal Returns .... 152

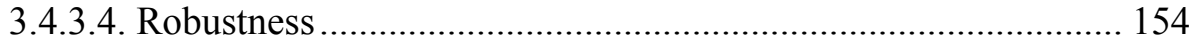

3.4.4. Test Results of the Second Hypothesis - Relation Between

Dividend Change Announcements and The Market Reaction

3.4.4.1. Test Results of Sub-hypothesis $\mathrm{H}_{2 \mathrm{~A}}$ - Relation between

Dividend Changes and Future Earnings Changes 156

3.4.4.1.1. Regression results assuming linear mean reversion in earnings 156

3.4.4.1.2. Regression results controlling for the non-linear patterns in the behaviour of earnings (Fama and French Model, 2000)

3.4.4.2. Test Results of Sub-hypothesis $\mathrm{H}_{2 \mathrm{~B}}$ - Relation between Dividend Changes and Accounting Performance Measures

3.4.4.3. Test Results of Sub-hypothesis $\mathrm{H}_{2 \mathrm{C}}$ - Relation between

Dividend Changes and Operating Performance Measures

3.4.4.4. Test Results of Sub-hypothesis $\mathrm{H}_{2 \mathrm{D}}$ - Relation between

Dividend Changes and Market Expectations of Future Earnings............ 175

3.5. Conclusions 
Tables

\section{CHAPTER 4}

THE EFFECT OF DIVIDEND ANNOUNCEMENTS ON FUTURE

EARNINGS CONDITIONED TO THE RELATION BETWEEN

DIVIDEND CHANGE ANNOUNCEMENTS AND THE MARKET

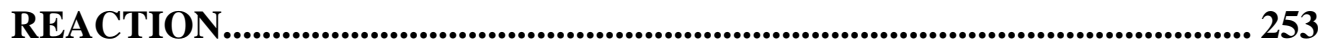

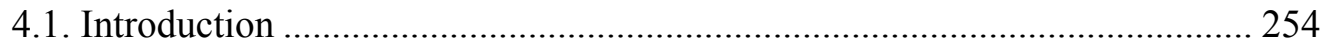

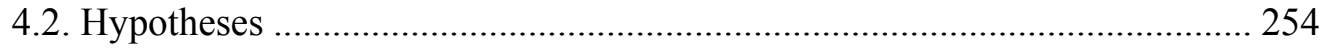

4.2.1. Hypothesis 3A - Relation between Dividend Changes and Future Earnings for the Events with a Positive Relation between Dividend

Change Announcements and the Market Reaction............................... 256

4.2.2. Hypothesis 3B - Relation between Dividend Changes and Future Earnings for the Events with a Negative Relation between Dividend Change Announcements and the Market Reaction................................. 257

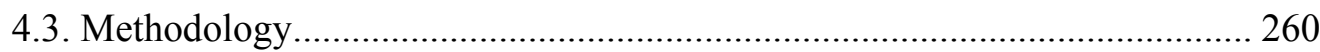

4.3.1. Methodology to Test Hypothesis 3A - Relation between Dividend Changes and Future Earnings for the Events with a Positive Relation between Dividend Change Announcements and the Market Reaction ... 260

4.3.2. Methodology to Test Hypothesis 3B - Relation between Dividend Changes and Future Earnings for the Events with a Negative Relation between Dividend Change Announcements and the Market Reaction

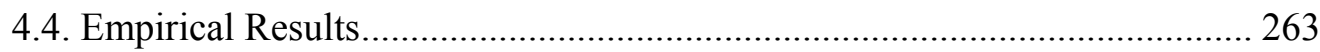

4.4.1. Test Results of Hypothesis 3A - Relation between Dividend Changes and Future Earnings for the Events with a Positive Relation between Dividend Change Announcements and the Market Reaction ... 264 4.4.2. Test Results of Hypothesis 3B - Relation between Dividend Changes and Future Earnings for the Events with a Negative Relation between Dividend Change Announcements and the Market Reaction

4.5. Conclusions 271

Tables 274 


\section{CHAPTER 5}

THE EFFECT OF FIRM-SPECIFIC FACTORS ON THE MARKET REACTION TO DIVIDEND ANNOUNCEMENTS

5.1. Introduction 290

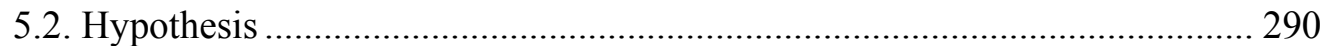

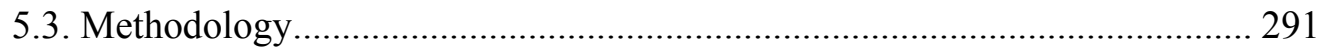

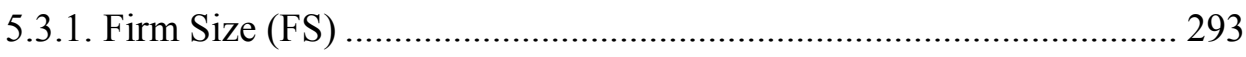

5.3.2. Percentage Change in Dividends (PCD) ............................................ 294

5.3.3. Earnings Growth (EG) ................................................................... 294

5.3.4. Market to Book Ratio (MB) .............................................................. 294

5.3.5. Price/Earnings Ratio (PER) ............................................................... 295

5.3.6. Debt/Equity Ratio (DE) ................................................................... 295

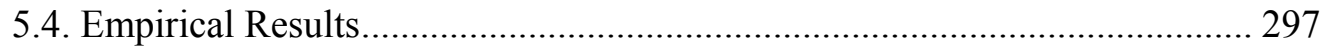

5.4.1. Relation between the Market Reaction to Dividend Change Announcements and the Firm-specific Characteristics ........................... 298

5.4.2. Relation between the Market Reaction to Dividend Increase and Dividend Decrease Announcements and Firm-specific

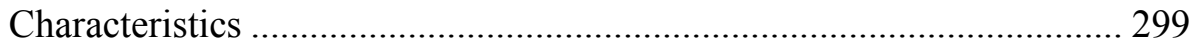

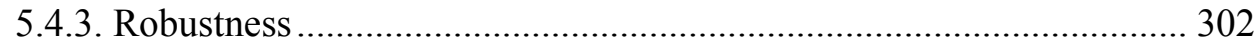

5.4.4. Relation between the Probability of a Negative (Positive) Market

Reaction to Dividend Increase (Decrease) Announcements and Firmspecific Characteristics ........................................................................ 303

5.4.5. Differences in Firm-specific Characteristics according the Distinct Market Reaction to Dividend Change Announcements ......................... 305

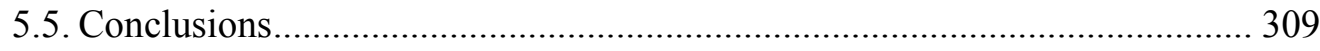

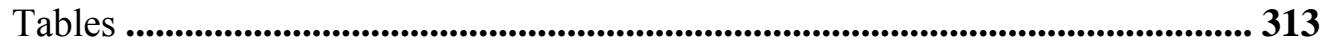

\section{CHAPTER 6}

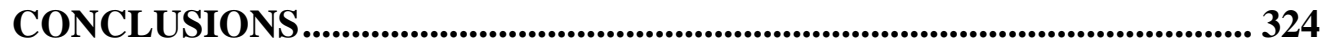

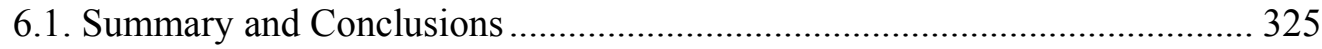

6.2. Suggestions for Future Research ............................................................. 328

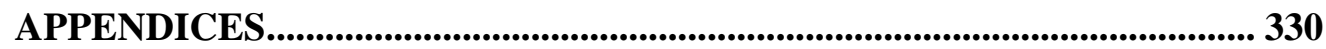

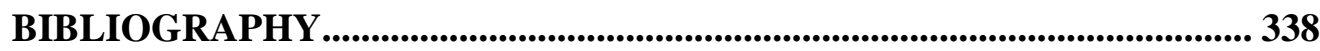




\section{LIST OF TABLES}

Table 2.1 - Summary findings of the main studies on the effect of dividend

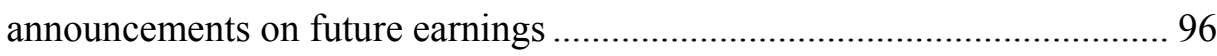

Table 2.2 - Summary findings of the main studies on the effect of dividend announcements on share prices 97

Table 2.3 - Summary findings of the main studies on the effect of dividend announcements on market expectations revisions

Table 2.4 - Summary findings of the main studies on the effect of dividend announcements on a firms' risk

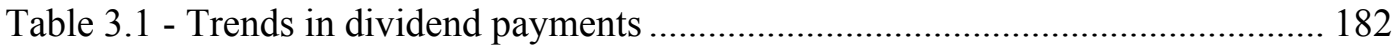

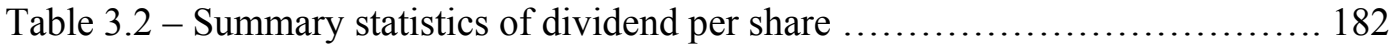

Table 3.3 - Dividend statistics by industry breakdown .......................... 184

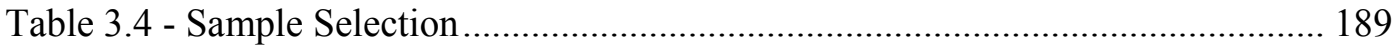

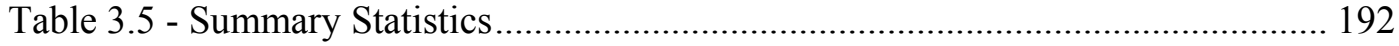

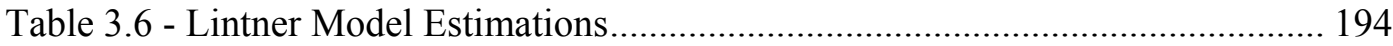

Table 3.7 - Abnormal returns for the announcement period ...................................... 195

Table 3.8 - Abnormal returns for the announcement period in up and down markets. 199

Table 3.9 - Regression of market reaction on dividend changes............................... 201

Table 3.10 - Regression of earnings changes on dividend changes and correlation

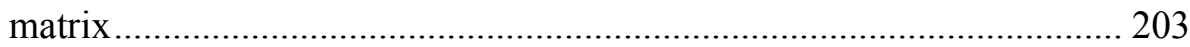

Table 3.11 - Regression of earnings changes on dividend changes using Fama and

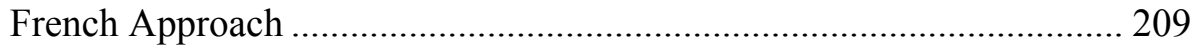

Table 3.12 - Regression of profitability measures changes on dividend changes ........ 213

Table 3.13 - Change in post-announcement measures ............................................... 228

Table 3.14 - Change in post-announcement measures grouped by operating performance

Table 3.15 - Regression of cumulative abnormal returns on future performance measures 237

Table 3.16 - Regression of price minus book value on dividend changes 251 
Table 4.1 - Sub Sample Selection

Table 4.2 - Regression of earnings changes on dividend changes for positive association between dividend change announcements and subsequent market reaction

Table 4.3 - Regression of earnings changes on dividend changes for positive association between dividend change announcements and subsequent market reaction using Fama and French Approach.

Table 4.4 - Regression of earnings changes on dividend changes for negative association between dividend change announcements and subsequent market reaction 283

Table 4.5 - Regression of earnings changes on dividend changes for negative association between dividend change announcements and subsequent market reaction using Fama and French Approach

Table 5.1 - Regression of BHAR on firm specific variables and correlation matrix ... 314

Table 5.2 - Regression of BHAR on firm specific variables with dummies..... 317

Table 5.3 - Logistic regression of the negative (positive) reaction to dividend increase (decrease) announcements and firm specific variables 320

Table 5.4 - Selected specific variables for the sub-samples of events, according to the relationship between dividend change announcements and the BHAR ..... 323 


\section{LIST OF FIGURES}

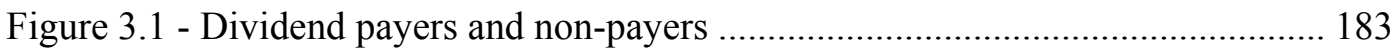

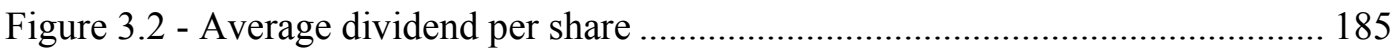




\section{RESUMO}

A política de dividendos é um dos tópicos mais debatidos na literatura financeira. Uma das suas vertentes baseia-se no conteúdo informativo dos dividendos, que impulsionou a investigação, tanto a nível teórico como prático. De acordo com a hipótese da sinalização dos dividendos, o anúncio da alteração de dividendos afecta a rendibilidade das acções pois transmite ao mercado as previsões dos gestores acerca das perspectivas futuras das empresas. Uma questão interessante, e ainda não explorada, é a evidência de uma reacção adversa do mercado às variações de dividendos.

Esta dissertação analisa os pressupostos clássicos da hipótese da sinalização dos dividendos. Não encontramos evidência de uma relação positiva entre os anúncios de variação de dividendos e a reacção do mercado para o mercado francês, e apenas uma fraca evidência para as amostras de Portugal e do Reino Unido. Depois de controlarmos a não linearidade dos lucros, os resultados sugerem que as variações de dividendos não sinalizam variações nos lucros futuros. Contudo, encontramos alguma evidência, especialmente no Reino Unido, para o fenómeno designado de "window dressing” e para a hipótese de maturidade.

Foi efectuada uma análise inovadora para investigar a relação entre a reacção do mercado às variações de dividendos e as alterações nos lucros futuros. Pretende-se compreender porque é que por vezes o mercado reage negativamente (positivamente) a aumentos (diminuições) de dividendos. Adicionalmente, tentamos identificar factores específicos das empresas que contribuam para a reacção adversa do mercado. A evidência sugere que empresas com uma reacção negativa aos anúncios de aumento de dividendos têm, em média, maior dimensão, bem como um crescimento dos lucros e um nível de endividamento mais baixos.

Palavras-chave: Dividendos, Hipótese de Sinalização, Reacção Adversa do Mercado, Factores Específicos das Empresas

Classificação JEL: G35, G32 


\begin{abstract}
The dividend policy is one of the most debated topics in the finance literature. One of the different lines of research on this issue is based on the information content of dividends, which has motivated a significant amount of theoretical and empirical research. According to the dividend signalling hypothesis, dividend change announcements trigger share returns because they convey information about management's assessment of firms' future prospects. An interesting issue, not yet explored, is the empirical evidence of an adverse market reaction to dividend changes.

We analyse the classical assumptions of dividend signalling hypothesis. The evidence gives no support for a positive relation between dividend change announcements and the market reaction for French firms, and only a weak support for the Portuguese and the UK firms. After accounting for non-linearity in the mean reversion process, the global results do not give support to the assumption that dividend change announcements are positively related with future earnings changes. Nevertheless, we found some evidence, especially in the UK market, of the window dressing phenomenon and the maturity hypothesis.

We introduce a new approach to investigate the relationship between the market reaction to dividend changes and future earnings changes with the purpose of understanding why the market sometimes reacts negatively (positively) to dividend increases (decreases). Moreover, we try to identify firm-specific factors that contribute in explaining the adverse market reaction to dividend change announcements. The evidence suggests that firms with a negative market reaction to dividend increase announcements have, on average, higher size, lower earnings growth rate and lower debt to equity ratios.
\end{abstract}

Key Words: Cash Dividends, Signalling Hypothesis, Adverse Market Reaction, Firmspecific Factors

JEL Classification: G35, G32 


\section{ACKNOWLEDGMENTS}

It is a pleasure to be able to express my acknowledgements to all those whom, in several ways, made this research possible.

Firstly, I would like to express my deepest gratitude to my supervisor Clara Raposo, whose close examination of this dissertation through many drafts has helped to focus and strengthen it considerably. She has gone far beyond what might have been expected from a dissertation chair, including her enthusiasm, support and dedication, which constituted a motivation for this work.

Special thanks are due to the ISCA - University of Aveiro, who granted me a leave of absence and partly funded my research, and to Ministério da Educação for financial support via the Prodep program. I am also grateful to several institutions that cooperated in the data collection process: Euronext Lisbon for allowing access to Dhatis database and documents, some Portuguese firms for copies of their financial statements, London Stock Exchange and Euronext Paris for their assistance. My special appreciation also goes to the collaboration of the host institution, ISCTE, for allowing access to the Datastream and Bloomberg databases.

Foremost, I am grateful to Professors Patricia Ryan, Abeyratna Gunasekarage, Luís Rodrigues, Partington Graham and Raymond King for their encouragement in this research topic and for their helpful suggestions. I also thank Professors João Pedro Nunes and José Paulo Esperança for their input in the early stages of the dissertation plan, and José Dias Curto for his econometric opinions. I am also indebt to the anonymous referees and conference attendants for their relevant comments.

I would specially like to thank my friends and ISCA-UA colleagues for their emotional support, but they are too numerous to name individually. In particular, I thank Ana Paula, Eliane, Graça, Carla and Patrícia for their spiritual support and Vasco for his computing assistant.

Finally, I can never thank enough my family for the continuing support always received. To my brothers, father and, in particular, to my mother for baby-sitting for me so many times. Lastly, and most specially, thanks to my husband and children. I could not have accomplished this thesis without my children's happiness and my husband's love and encouragement. 
To my parents, to Abílo, Gonçalo and Rita 


\section{THE AUTHOR}

Elisabete Fátima Simões Vieira obtained her Undergraduate degree in Business Administration from the Universidade Católica Portuguesa de Lisboa, Lisbon, Portugal, in July 1990.

After a period of management functions in Portuguese firms, she subsequently joined the Management Department, in October 1991, of the Instituto Superior de Contabilidade e Administração - Universidade de Aveiro, where she taught several courses, particularly in the Finance domain.

In 1996 she concluded the Masters degree in Management, specialisation in Finance, at the Universidade do Minho, Escola de Economia e Gestão.

In September 2001 she started the classes of the Doctoral Research Programme, specialisation in Finance, at the Instituto Superior de Ciências do Trabalho e da Empresa, ISCTE. In June 2003 she presented her thesis project. After being approved, she started her doctoral research study. She was provided with a leave of absence, from Ministério da Educação, Prodep programme, during three years.

During the preparation of this thesis she made two presentations related to it in peerrefereed international conferences. 


\section{CHAPTER 1}

INTRODUCTION 


\subsection{INTRODUCTION}

In this thesis we investigate the impact of dividend change announcements in the firm value and future performance of three European countries: France, Portugal and the UK. Ahead of the analysis of market reaction to dividend change announcements and of firms' future profitability, we wish to test the maturity hypothesis and the "windowdressing" phenomenon. In particular, we intend to carefully analyse the cases in which dividend changes and share prices move in opposite directions, trying to find possible explanations for these occurrences, which might be related with firms-specific factors.

The dividend policy is one of the most important decisions that a financial manager has to take and is a financial decision clearly related with investors' equity return, which can be divided into two components: capital gains and dividends.

Given its importance in the corporate finance domain, it has been the subject of intensive theoretical modelling and empirical examination. However, and in spite of all the research done in this domain, it is still not possible to determine the optimal level of earnings to be distributed to shareholders as dividends. Research has resulted in an indication of the factors that contribute to a high or low dividend policy. This is far from being a peaceful matter in the corporate finance context and the dividend puzzle remains a controversial topic in the academic corporate finance literature. In fact, about 30 years ago, Black (1976, p. 5) wrote "The harder we look at the dividend picture, the more it seems like a puzzle, with pieces that just don't fit together.", Feldstein and Green (1983, p. 17) argue that "the nearly universal policy of paying substantial dividends is the primary puzzle in the economics of corporate finance". More recently, Brealey, Myers and Marcus (2001) enumerated a list of problems not yet solved in the finance domain, one of which being the dividend topic and Allen and Michaely (2003) pointed out that the empirical evidence on dividend signalling is far from conclusive, which evidences this is not a finished research topic, reinforcing the previous opinions. After over three decades since Black's paper, the dividend puzzle persists.

While authors as Gordon (1959) and Lintner (1962) sustain earnings distribution, there are others, mainly since the 1970's, who defend non distribution, based on the negative correlation between dividends and firms market value e.g. Lintzenberger and Ramaswamy (1979). There are others still in the compromise position, sustaining the 
dividends irrelevance, like Miller and Modigliani (1961), Friend and Puckett (1964), Black and Scholes (1974) and Miller and Scholes (1978).

Miller and Modigliani (1961) sustain that, in a perfect capital market, and given a certain investment policy, dividends are irrelevant for firms' shares value, that is, firms' value is independent of the dividend policy. However, when empirical studies of the past decades are analysed, we find that a change in dividend policy has a significant impact on share prices, which suggests that dividends have some influence in firms valuation.

Theoretical investigations and empirical studies have been conducted to find rational justifications for dividend payments, in order to understand their true role in the firm's valuation. These justifications have as a basis the main market imperfections, like taxes, agency costs and information asymmetry. In what concerns the information asymmetry and the dividend policy, which is more related with our empirical research, we can refer the signalling theory and the free cash flows hypothesis. The signalling theory, associated to the dividend content information hypothesis, sustains that dividend policy acts as a vehicle for transmitting private information from firm's managers to the market. The second theory postulates that dividends work as a vehicle to drain excess cash flows.

Bhattacharya (1979), John and Williams (1985) and Miller and Rock (1985) developed the signalling theory classic models, showing that, under imperfect information, dividends will act as a signal of expected cash flows. These models' underlying idea is that firms adjust dividends to signal their future evolution prospects, reducing the information asymmetry. Therefore, dividend increases signal an improvement in a firm's future situation, which should reflect an increase in share prices, while dividend decreases suggest their worsening conditions, for which there will be, according to this theory, a decrease in share prices.

There has been a significant number of empirical tests showing that dividend change announcements are positively associated with share returns in the days surrounding the dividend change announcement, such as Pettit (1972, 1976), Aharony and Swary (1980), Asquith and Mullins (1983), Benesh, Keown and Pinkerton (1984), Dhillon and Johnson (1994), and, more recently, Lee and Ryan (2000, 2002) and Gurgul, Madjosz and Mestel (2003), among others. Their conclusions point to the existence of dividend information content, or signalling effect. Nevertheless, several studies have not 
supported evidence for a positive relation between dividend changes and the market reaction, as the studies of Lang and Litzenberger (1989), Benartzi, Michaely and Thaler (1997), and, more recently, Conroy, Eades and Harris (2000), Chen, Firth and Gao (2002) and Abeyratna and Power (2002).

In addition, it is well documented that dividend change announcements are positively associated with future earnings. Brickley (1983), Aharony and Dotan (1994), Chen and Wu (1999), Nissim and Ziv (2001), Arnott and Asness (2001), and, very recently, Dhillon, Raman and Ramírez (2003), along with others, contribute to this evidence. However, empirical studies by Watts (1973), DeAngelo, DeAngelo and Skinner (1992, 1996), Benartzi, Michaely and Thaler (1997), Grullon, Michaely and Swaminathan (2002) and Benartzi et al. (2005) find little or no evidence that dividend changes predict abnormal increases in earnings.

Furthermore, several studies found evidence of a significant percentage of cases where share prices reactions are opposite to the dividend changes direction, like the works of Asquith and Mullins (1983), Benesh, Keown and Pinkerton (1984), Born, Mozer and Officer (1988), Dhillon and Johnson (1994) and Healy, Hathorn and Kirch (1997) ${ }^{1}$, which seems to us an interesting research domain, not yet explored by empirical works. To the best of our knowledge, only the work of Healy, Hathorn and Kirch (1997) has approached this puzzling case, analysing the American market and just for the case of an adverse market reaction to the dividend initiation announcements.

Summarising, several theories have been proposed in explaining why firms pay or do not pay dividends. While many earlier studies point out the tax-preference theory, the more recent ones emphasise agency cost and signalling of dividend announcements and payments. However, after so many years of research, the dividend puzzle is yet unsolved and the words of Black (1976) may well apply in today's context.

In this context, the purpose of this research is to investigate the impact of dividend change announcements on both the market reaction to dividend change announcements and on firms' future profitability. In addition, we wish to test the maturity hypothesis and the "window-dressing" phenomenon. In particular, we intend to carefully analyse the cases in which dividend changes and share prices move in opposite directions,

\footnotetext{
${ }^{1}$ The percentage of these cases oscillates between 20\% Benesh, Keown and Pinkerton (1984) and 42.5\% Healy, Hathorn and Kirch (1997).
} 
trying to find possible explanations for these occurrences, which might be related with firms-specific factors ${ }^{2}$.

Overall, evidence in this study gives only a weak support for the dividend signalling hypothesis in the United Kingdom (UK) market, which is in agreement with our expectations, given the differences among the analysed countries. In the UK, where information asymmetry is supposedly higher than in the other two countries considered, managers tend to use dividends, in some extent, as a mechanism to mitigate that asymmetry. In France and in Portugal, countries characterised by a bank-based system, and where information asymmetry is less severe than in the UK, there is no pronounced need to use dividends to convey information to the market, being the signalling effect of dividends less important. This evidence is consistent with the axiom that there is a smaller signalling function in the bank-based system. Moreover, we find some support to the maturity hypothesis in all three samples, it being stronger in the UK market.

Finally, the results indicate that firms' specific factors have some influence on the market reaction to dividend change announcements in the two out of three samples considered.

Next we will present the main motivations for conducting this study.

\subsection{MOTIVATION AND OBJECTIVES OF THIS STUDY}

The relevance of dividend policy in corporate finance, the different results obtained on empirical conducted by now (namely in what concerns the relationship between dividend changes and future profitability) and the relative frequency with which we may observe an opposite relation between share prices reaction and dividend changes, are the main reasons for our research in this domain, with the purpose of trying to fit another piece on the dividend "puzzle".

Our study will try to correct some limitations of previous work in the dividend policy field and to provide additional relevant evidence to the "information content of

\footnotetext{
${ }^{2}$ Taxes may also be an influencing factor for this phenomenon, given the fiscal disadvantage of dividends face to capital gains on most markets. According to this effect, the market reaction to dividend changes should be opposite to their change. Although this analysis is not part of this work, it will be a path for future researches.
} 
dividend" hypothesis, which may be interesting to academics. In addition, the study of the effects of dividend change announcements on both share prices and on future profitability might be interesting to investors, because it will help them to make decisions about their investments, i.e., buying and selling shares, and to market analysts, since their forecasts and recommendations will be more feasible if analysts understand whether the dividend policy affect firms and markets.

The importance of this study, and its distinction faced to others conducted on this domain, is based on the following reasons:

- The study examines market behaviour in face of the dividend change announcements, so as to provide relevant additional evidence to the "information content of dividend" hypothesis. Miller and Modigliani (1961) asserted that the effect of the dividend policy on share prices is a matter of considerable importance to firms administration, who must set dividend policy, to investors to select their portfolios and to economists to analyse, understand and assess capital market performance;

- It analyses a vast group of performance measures, both economics and financial, before and after dividend change announcements, as well as in a short and long term perspective, which allows verifying to what extent the future performance is in consonance with dividend changes, and it allows making some considerations about the window dressing effect and the maturity hypothesis. The vast tests done represents an innovation relative to previous research, which just assumes a set of profitability measures;

- It gives special emphasis on the cases where the market reacts differently than would be expected under the signalling theory, that is, the enigmatic cases when the market reacts negatively to dividend increases and positively to dividend decreases. To the best of our knowledge, this is the first work to study this phenomenon in detail;

- Examining the possible reasons that lead to an opposite relation between market reaction and dividend change announcements has not been previously done in the finance literature;

- This research analyses three European markets with different characteristics: the Portuguese, the French and the UK markets. On one hand, the empirical work 
considers some markets that have not yet been explored, such as France and Portugal, which are clearly in need of research, since the great body of the empirical research has been carried out on the American market, and, in a smaller number, in other developed countries, such as Canada and the UK. Todate there is lack of evidence on how European firms behave in terms of their dividend policies and little is still known about dividend policy of firms operating outside the Anglo-American corporate governance system. Indeed, for the Portuguese market, as far as we know, our study is the first to empirically analyse the dividend signalling hypothesis. On the other hand, this analysis allows comparing results of several samples, detecting differences or similarities of behaviour in the analysed markets, testing the impact of differences in corporate governance systems across the sample countries and see whether these differences result in higher information asymmetries in market-based countries (UK) than in bank-based countries (France and Portugal).

In this context, we will try to contribute to the resolution of the debate by providing further evidence on the roles of the dividend signalling hypothesis in explaining the information content of dividend change announcements.

\subsection{STUDY ORGANIZATION}

The remainder of this dissertation takes the following structure. In Chapter 2, the study reviews both the theoretical and empirical research developed along the years in this domain, namely the effect of dividend change announcements on share prices and firms future profitability. Firstly, we begin by analysing the irrelevance of dividend policy hypothesis [Miller and Modigliani, 1961]. Secondly, we analyse the main factors affecting dividend policy, in particular the dividend signalling role of dividends. In addition, we make a summary of the main empirical tests that have been done regarding the information content of dividend change announcements. At the close of this chapter a summary of the evolution in the propensity to pay cash dividends can be found.

The development of testable hypotheses, the description of the study methodology, as well as the empirical analysis are structured into three chapters, according to the approach we want to explore. We start by investigating, in Chapter 3, the relation 
between current changes in dividends and both the market reaction in the announcement period and the future profitability. We introduce some detail in the existing methodology in order to improve the potential conclusions. This chapter covers the development of the testable hypotheses, the explanation about the procedure for selecting the sample, the description of the methodology and, finally, reports and discusses the empirical results.

In Chapter 4 we examine the effect of dividend change announcements on future earnings, conditioned on the relation between these announcements and the market reaction. We focus the analysis on the cases of dividend increases (decreases) with a subsequent negative (positive) market reaction, starting by splitting the sample into distinct categories, according to the relation between dividend change announcements and the share price movements in the announcement period. This procedure arises because of the previous studies evidence of the adverse relation between dividend changes and market reaction. This rose some doubts about the dividend information content hypothesis. As in the previous chapter, we present the hypotheses, the methodology and the empirical results.

In Chapter 5 we address firm-specific factors in order to analyse whether other information accessible to the market at the dividend announcement date can convey information to shareholders beyond that of dividend announcements itself, helping the market to understand a firm's dividend change announcements.

Finally, Chapter 6 summarises the main results obtained and discusses the conclusions of this research. To close the chapter, we suggest directions for future research. 
CHAPTER 2

\section{LITERATURE REVIEW}




\subsection{INTRODUCTION}

In this chapter we try to cover the main aspects related with dividend policy payout, including the classic theoretical models, the main factors affecting the dividend policy and the more relevant empirical works done in this domain. We summarise the recent studies referring to the evolution of the propensity to pay dividends. According to the empirical work we intent to develop in our thesis, the most important part of this chapter is composed by the sub sections 2.5 and 2.6 , since they are closer related to the purpose of our dissertation. We finalise with the main conclusions associated with the factors affecting the dividend policy.

\subsection{LINTNER'S MODEL}

The first empirical study accomplished in the dividend policy domain was performed by Lintner (1956). In its classic study, carried out in the United States (US), Lintner showed that managers tend to smooth dividends over time. He also argued that managers are extremely reluctant to decrease the level of dividends, because they are afraid of sending negative information to the market. They are also afraid of raising the levels of dividends, due to the fear of having to decrease them in the future. Dividend policy, which is more often followed by companies, is based on the maintenance of a stable level of dividends through the years, increasing the level only when there are perspectives that growth can be maintained in the future. Lintner selected 28 companies, analysing a period of seven years (1947 to 1953) and surveyed the views of firms' managers ${ }^{3}$ about dividends and dividend policy.

Lintner's study allowed coming to a group of conclusions, from which we highlight the following ones:

- Company managers consider dividend policy definition a priority;

- Earnings are the primary factor determining the degree of dividend changes;

\footnotetext{
${ }^{3}$ The interviews were with corporate chief executives officers and chief financial officers.
} 
- Managers seem to believe that shareholders prefer stable dividends and that the market puts a premium on such stability, recognising that shareholders prefer a steady increase of dividends;

- Managers focus more on dividend changes than on absolute levels;

- Most managers avoid making changes to dividends that have a significant probability of being reversed in the near future;

- Firms seem to have a long-term target payout ratio and tend to make periodic partial adjustments to the target payout rather than changing their payout when a change in earnings occurs. They are equally reluctant to decrease dividends;

- The mean payout ratio found, based on the survey of the twenty-eight managers was $50 \%$. Despite the small size of the sample and the temporal displacement, this ratio is not very different from the one recently found by Grullon and Michaely (2002). These authors found a mean value of $48.55 \%$, in the period between 1990 and $2000^{4}$.

Lintner postulated that the most important elements of the dividend policy decision of companies could be explained by the following equations:

$$
\begin{gathered}
\mathrm{d}_{\mathrm{i}, \mathrm{t}}-\mathrm{d}_{\mathrm{i}, \mathrm{t}-1}=\mathrm{a}_{\mathrm{i}}+\mathrm{c}_{\mathrm{i}}\left(\mathrm{d}^{*}{ }_{i, t}-\mathrm{d}_{\mathrm{i},(\mathrm{t}-1)}\right)+\varepsilon_{\mathrm{i}, \mathrm{t}} \\
\text { and } \\
d^{*}{ }_{i, t}=a_{\mathrm{i}} \mathrm{E}_{\mathrm{i}, \mathrm{t}}
\end{gathered}
$$

where, for firm i:

$$
\begin{aligned}
\mathrm{d}_{\mathrm{i}, \mathrm{t}} & =\text { desired dividend payment during year } \mathrm{t} \\
\mathrm{d}_{\mathrm{i}, \mathrm{t}} & =\text { dividend payment during year } \mathrm{t} ; \\
\mathrm{d}_{\mathrm{i}, \mathrm{t}-\mathrm{t}} & =\text { dividend paid during year } \mathrm{t}-1 ; \\
\mathrm{i} & =\text { target payout ratio; } \\
\mathrm{E}_{\mathrm{i}, \mathrm{t}} & =\text { earnings during year } \mathrm{t} ; \\
\mathrm{a}_{\mathrm{i}} & =\text { constant, related to dividend growth; } \\
\mathrm{c}_{\mathrm{i}} & =\text { partial adjustment factor; } \\
\mathrm{i}, \mathrm{t} & =\text { residual term. }
\end{aligned}
$$

Thus, it can be concluded that dividends depend, on the one hand, on the earnings of a company in the current exercise and on the other hand, on the dividends paid in the previous year. Moreover, the more conservative the company's management, the slower

\footnotetext{
${ }^{4}$ However, this value has tended to decrease in recent years, since in the period between 1995 and 2000 , the mean ratio is $41 \%$.
} 
is the growth, and the adjustment factor will be smaller, since management propose payout ratios that could vary positively in relation to previous years, but do not need to be reversed in the future.

Although Lintner was the first author to present the modern theory of dividends, subsequent empirical studies confirm and enlarge Lintner's work. Fama and Babiak (1968) investigated Lintner's (1956) model, analysing the data of 392 industrial companies in the period from 1946 to 1964. They concluded that the model performs well. The authors documented managers' reluctance to change dividends and found empirical support for the smoothing of dividends. Others obtained similar results, such as DeAngelo, DeAngelo and Skinner $(1992,1996)$ and Dewenter and Warther (1998).

Three recent studies find evidence of the stability of dividend policy outside the US market. Beiner (2001) studied the Swiss market, Kumar (2003) the Indian market, and Omet (2004) the Jordanian market, all of them finding evidence of firms following stable cash dividend policies. However, in contrast with these results, Sahu (2002), analysing the Indian market, failed to find any empirical evidence supporting the stable dividend hypothesis, since it appeared to be no statistically significant linear relationship between dividend stability and share market returns.

\subsection{THE DIVIDEND POLICY IRRELEVANCE HYPOTHESIS}

The effect of dividend policy on the value of a firm is one of the topics most thoroughly studied on corporate finance. It is, however, controversial, so that no consensus was reached about the influence of dividend changes on a firm's value.

The dividend policy irrelevance hypothesis states that dividend policy affects neither a company's value nor its cost of capital. Thus, there is no particular dividend policy that allows an increase in shareholder wealth. The proponents of this theory are Miller and Modigliani (hereafter referred to as MM, 1961), two Nobel laureates. They were the first researchers to carry out a rigorous analysis of the effect of dividend payout policy 
in a firm's value ${ }^{5}$, writing a paper that is considered a classic in dividend policy literature, proposing the irrelevance of dividends to a firm's value.

MM extended their analysis of the capital structure to the dividend policy. In this work, they demonstrated that, under some conditions that characterise a perfect market ${ }^{6}$, investors' rational behaviour in the market and perfect certainty, the value of a firm is independent of its dividend policy, being this decision irrelevant to a company's value maximisation. Thus, it may be concluded that investors are indifferent to the dividend policy adopted by a company.

Assuming investors display rational behaviour, MM argue that investors are interested in their global return, and not whether they receive it in the form of dividends or capital gains. In addition, they sustain that the value of the firm is only determined by its capacity to obtain earnings through its assets (investment policy) and through its business risk, and not by the way the net earnings are divided between dividends and retained earnings. Thus, the dividend will be the difference between earnings and investments, being residual.

Having proved the irrelevance of financing decisions based on the "homemade leverage" concept, they also emphasised the concept of "homemade dividends" in order to prove dividend policy irrelevance for a firm's value. The underlying idea is that shareholders can replicate any desired stream of payments by purchasing and selling equity. Therefore, investors would not pay a premium for a certain dividend policy, as they can replicate this policy by investing cash payments or selling shares, so the important factor for the determination of a firm's value is its investment decisions.

MM concluded that given a firm's investment policy, the dividend payout policy it chooses to follow will affect neither the current price of its shares nor the total return to its shareholders. The current value of a firm will be independent of the current dividend decisions, even when they consider the presence of uncertainty about future profits,

${ }^{5}$ While Lintner (1956) used an empirical approach to dividend policy, this work has a theoretical approach.

${ }^{6}$ MM's work is based on the context of "perfect capital markets", considering the following hypotheses:

- No taxes, brokerages fees, or other transaction costs occur when securities are transitioned;

- No agency costs occur;

- No buyer or seller of securities is large enough for his transactions to have an appreciable impact on market prices;

- All traders have the same expectations relating to firms' investments, earnings and future dividends;

- All traders have equal and costless access to the relevant information;

- Investment policy is defined in advance and does not change with dividend policy; investment and financial decisions do not change. 
investment or dividends or the presence of debt financing, concluding that the dividend policy irrelevance remains valid. Moreover, MM demonstrated that, given no taxes and no transaction costs, the choice between dividend payments and share repurchases is irrelevant.

If MM's theory were correct, it would not lead to a better dividend policy for a firm, since it would not affect its value. In this context, shareholders are indifferent to a choice between dividends and capital gains. Rao (1987, p. 490) shares this opinion, writing: "In the simplified world of perfect markets it can be argued that dividends will have no influence on the impact on share prices."

However, we do not find a consensus on this topic, and a difference of opinions persists, in spite of many academic and professional studies that have been made in this domain. After the publication of MM's work, a considerable group of investigators tried to justify the existence of dividends. In fact, the theory does not explain why the market is so interested in dividend announcements, or why managers spend a lot of time trying to define dividend levels.

The MM (1961) theory is defined in a context of perfect and complete capital markets. However, in the real world, some of these assumptions can be violated, and the dividend policy can, therefore, influence a firm's value. Some of the elements that can be violated are as follows:

\section{1- No Taxes}

In the absence of taxes, investors are indifferent to whether the increment to their wealth takes the form of dividends or capital gains. However, if dividends and capital gains are taxed differently, it will become preferable to adopt the lower cost alternative. In the great majority of the cases, capital gains will be preferred to dividends, since cash dividends are taxed at a higher rate than capital gains;

\section{2- Symmetric information}

In a market with symmetric information, all the participants have exactly the same information set. In practice, this is rare because managers have inside information about the future profit prospects for their firms. Thus, dividends can convey some information to the market about the company value. In this context, dividend policy can affect firm value, becoming important for the market; 


\section{3- Complete contracts}

With the establishment of complete contracts there would not be agency problems between managers and shareholders. If this assumption does not hold, dividend policy can lead managers to act in agreement with the shareholders' interests. High payout ratios motivate managers to be more disciplined in the use of companies' resources. Consequently, firms' value increases;

\section{4- No transaction costs}

In the real world, any transaction involves costs, which will reduce a firm's value. Thus, any change in dividend policy can modify the value of a firm;

\section{5- Complete markets}

If markets are not complete, there can be different groups of customers with distinct objectives about current and future consumption, so firms can increase their value, adjusting their dividend policy, accordingly to one or another group of customers.

A vast number of empirical researches following MM (1961) are related to the fact that some of these assumptions do not hold in a real world. Most of the resulting explanations were related to market imperfections. Many of these factors influence, in a positive or negative way, the dividend policy. Given their importance, we will analyse, in the subsequent sections, the most relevant factors affecting dividend policy.

\subsection{MAIN FACTORS AFFECTING DIVIDEND POLICY}

In this section we summarise the main factors affecting dividend policy, such as taxes, agency costs and the signalling content of dividends.

\subsubsection{TAXES}

MM (1961) have shown that in a perfect world, investors may be indifferent to the amount of dividend, as it has no influence on the value of a firm. However, in the context of differential tax treatment of dividends and capital gains (usually dividends 
have heavier taxes than capital gains), they may matter. It suggests that, in the presence of taxes, investors would prefer smaller or no dividends.

The relationship between tax rates and the preference for dividends on the part of the investors is a subject that has been thoroughly investigated. The difference between tax rates on dividends and on capital gains influences shareholder wealth, their preference for dividends and, consequently, managers' decisions about dividend policy, since they want to maximise the firm's market value. As in general capital gains tax is lower than dividend tax, rational investors tend to exhibit a certain aversion to dividends. Farrar and Selwyn (1967) and Brennan (1970) emphasise that, in distinct fiscal regimes where dividend tax is higher than capital gains tax, shareholders prefer different dividend policies, according to the tax they will pay. This phenomenon suggests that investors should demand a higher return (before taxes) for shares with high payout ratios, in order to be compensated for the disadvantageous tax treatment of dividends compared to capital gains. This implies the existence of a positive correlation between dividend yield and the risk-adjusted return. However, different authors have tested this hypothesis and arrived to different results. While Black and Scholes (1974) and Miller and Scholes (1982) did not find evidence of a tax effect, Litzenberger and Ramaswamy (1979, 1982), Rosenberg and Marathe (1979), Gordon and Bradford (1980), Morgan (1982) and Ang and Peterson (1985), among others, concluded that there is a positive relationship between return on equity (ROE) and the dividend yield.

The literature in this domain has been divided into two different groups: studies that are based on the Capital Asset Pricing Model (CAPM), such as the work of Brennan (1970) and Litzenberger and Ramaswamy $(1979,1980)$, and studies that analyse the behaviour surrounding the ex-dividend day, such as the work of Elton and Gruber (1970) and Frank and Jagannathan (1998).

Brennan (1970) was the first author to develop a version of CAPM, including dividends as an explanatory variable for return on assets. The results suggest evidence of a tax effect, so, according to the author, firms should not distribute dividends due to the fiscal disadvantage of these in relation to capital gains, with the aim of maximising a firm's value. Other authors tested the same relationship type, including Poterba and Summers (1984), Keim (1985), Chen, Grundy and Stambaugh (1990) and Kalay and Michaely (2000). 
Black and Scholes (1974, p. 1) made one of the first studies in this domain, concluding "it is not possible to demonstrate that the expected returns on high yield common stocks differ from the expected returns on low yield common stocks either before or after taxes". After the shares risk adjustment through the CAPM model, the authors found evidence that share return before taxes is not related to dividend policy, defending the irrelevance of this policy, even in a taxed world. Black (1976) referred to the fact that firms pay high amounts of dividends, in spite of the existence of other earnings payment methods less onerously taxed (for example, share repurchases) as the "dividend puzzle",

Litzenberger and Ramaswamy $(1979,1982)$ verified that the higher the dividend yield, the higher the return demanded by shareholders to compensate for the dividend tax disadvantage, which is consistent with Brennan (1970), in the sense that the positive coefficient of the dividend yield is evidence of a dividend tax effect. Kalay and Michaely (2000) carried out a similar study, but excluding from the sample the weeks that contained the dividend announcement day and the ex-dividend day, finding a positive and statistically significant dividend yield coefficient. Thus, they conclude that the underlying reason for the Litzenberger and Ramaswamy results would not be the information conveyed by dividend announcements.

Poterba and Summers (1984) analysed a sample of British shares for the period between 1955 and 1981, in different fiscal regimes, before and after the introduction of capital gains taxes, in 1965. They found evidence that tax rates affect the equilibrium between dividends and share return. They documented, however, that in situations of more unfavourable taxes, dividends are also distributed, which did not help them to make progress to solve the "dividend puzzle". In agreement with Allen and Izan (1992), the justification for this phenomenon can be obtained through agency costs arguments. More recently, Bell and Jenkinson (2002) examine the impact of a major change in dividend taxation introduced in the UK in July 1997, by considering the ex-dividend day behaviour of share prices. The whole sample contains 8,837 observations and covers the period of 30 months before and after the Finance Act 1997. The results

\footnotetext{
${ }^{7}$ According to DeAngelo and DeAngelo (2004), the "dividend puzzle" is actually two distinct enigmas: the "payout puzzle" and the "repurchase puzzle". The essence of the "payout puzzle" is that a tax on distribution should cause firms to eliminate cash payouts and the second puzzle refers to the fact that, despite their tax advantages, repurchases have not displaced dividends as the preferred form of payout. For a detailed analysis of this two distinct enigmas, see the theoretical work of Braton (2004), which he called "the new dividend puzzle".
} 
provide strong support for the hypothesis that taxation affects the valuation of firms. In addition, the authors found evidence of the clientele effect.

Buckley et al. (1998) argue that managers should avoid dividends only if the alternative use is less onerous, in contrast to some authors who pointed out that dividend tax means that firms should not pay dividends at all. According Grinblatt and Titman (1998), taxes favour share repurchases rather than dividends. The associated gain depends on the following: (1) difference between capital gains tax and dividend tax; (2) the share acquisition price and (3) the timing of share sales.

Amihud and Murgia (1997) analysed dividend policy in the German market, where dividends, in contrast to what happens in the American market, do not present a fiscal disadvantage compared to capital gains. Bhattacharya (1979), John and Williams (1985) and Bernheim and Wantz (1995) support the hypothesis that because dividend tax is higher than capital gains tax, dividends convey information on a firm's future value. So, in Germany, dividends should not present information content, given the different fiscal regime. Amihud and Murgia investigated the effects of dividend changes on shareholder value for 200 firms listed on the Frankfurt Börse during the period 1988 to 1992. Their sample consists of 255 dividend increase announcements and 51 dividend decrease announcements. The authors found a statistically significant cumulative abnormal return for the announcement day of $+0.96 \%$ for dividend increases and $-1.73 \%$ for dividend decreases, which is in line with the studies of Pettit (1972) and Aharony and Swary (1980), who analysed the American market, which are not consistent with dividend signalling with taxes. The authors also found evidence that, in spite of earnings announcement being made before dividend announcements, the latter continue to hold information content. This evidence suggests the presence of other reasons, besides taxes, that make dividends convey information to the market. The authors emphasise that due to less informative accounting rules in Germany than in the US, dividends convey valuable information to the market.

Fama and French (1998) find a positive relation between share value and dividends, contrary to the dividend tax hypothesis. They deduce that dividends convey information about profitability and that this information effect obscures its tax effect.

Harris, Hubbard and Kemsley (2001) analysed the retained earnings returns in several countries with different fiscal regimes. They found higher discount rates in the US and 
in Japan, where dividends have higher taxes than in countries such as Australia, France, Germany and the UK, where there is a tax credit facet to dividends.

Prevostt, Rao and Wagster (2002) and Zhen Li (2003) tested the tax effects on shareholder wealth. The former authors considered five important events concerning the eventual adoption of full dividend imputation in New Zeland, a small and infrequently traded market. Their results show that shareholders of low-debt firms experienced significant wealth gain while shareholders of high-debt firms experienced significant wealth losses, which is a strong support for the tax shield hypotheses that suggest that the loss of interest tax shields may offset any value gained from dividend imputation for high-debt firms. The latter author tested the taxes effects during the period from 1989 to 2000, considering a final sample of 9,748 American quarterly dividend change announcements. Zhen Li separates the negative tax effect of dividend from its positive information or agency cost effect and he found that the dividend tax penalty erodes the positive wealth effect of dividend and that the presence of a tax advantaged marginal investor mitigates the negative tax effect.

Reddy (2003) analysed the influence of change in tax regime on the dividend policy of Indian firms and concluded that tax regime changes have not really influenced the dividend behaviour of firms and that the trade-off theory does not hold true in the Indian context. One year later, Omet (2004) examines the dividend policy behaviour of 44 firms listed on the Jordanian capital market, for the period from 1985 to 1999, analysing also the impact (if any) on the dividend behaviour of the Government imposition of a $10 \%$ tax rate on dividends in $1996^{8}$. His main findings are: (1) firms are reluctant to decrease their cash dividends and prefer to gradually increase them; (2) firms have stable dividend policies; (3) lagged dividend per share is more important than current earnings per share in determining current dividend per share and (4) the imposition of tax on dividends had no impact on the dividend behaviour. In sum, Omet find evidence that support Lintner (1956) model, but find no support to the tax influence on dividends. Summarising, the fiscal effect is the strongest argument in favour of low dividend payments. However, after more than three decades of intensive research effort, no consensus has yet emerged. Furthermore, several studies suggest that dividend taxes are not important for a firm's wealth, as is the case of Miller and Scholes (1982) and, more recently, Auerbach and Hasset (2000). This implies that investors will be indifferent to a

\footnotetext{
${ }^{8}$ Till 1996, investors have been enjoying a zero tax rate both on capital gains and dividends.
} 
choice between dividends and capital gains. Thus, firm value may be not related to the dividend policy, even in a taxed world. This is a motivation to explore other factors that can influence a firm's dividend policy.

The dividend policy can be still associated with the clientele effect that, as we will see, is also associated to taxes. As some shareholders prefer high dividends, while others prefer them low, the clientele effect supports the idea that dividend policy answers to shareholder needs. This reduces the dividend policy impact on a firm's market value.

In fact, empirical tests completed by Pettit (1977) and Lewellen et al. (1978) show evidence that the dividends of shareholders' portfolios are related to their tax rates. Shareholders with higher (lower) taxes tend to select shares with low (high) dividend payments, preferring (dividends) capital gains to dividends (capital gains) because they pay less tax. The exception is investors that need liquidity. With tax credit, firms with investments in the equity of others prefer dividends, because their tax rate is lower than that of capital gains. Masulis and Trueman (1988) have developed a model, which led them to conclude that investors with differing tax liabilities will not be uniform in their ideal firm dividend policy. As the tax liability on dividends increases (decreases), the dividend payment decreases (increases), while earnings reinvestment increases (decreases). This result supports the clientele theory.

The clientele effect was originally suggested by MM (1961) who asserted that each firm tends to catch the attention of a specific "clientele" according to its particular payout ratio. Perhaps this effect is a possible reason for management reluctance in changing payout ratios in order to avoid transaction costs to shareholders.

Several authors analyse the clientele effect through the relationship between the share price decrease in the ex-dividend date period and the dividend amount, concluding that share price decrease is smaller than the dividend amount, like Elton and Gruber (1970), Kalay (1982), Eades, Hess and Kim (1984) and Poterba and Summers (1984) for the American market, Lakanishok and Vermaelen (1983) for the Canadian market, Michaely and Murgia (1995) for the Italian market and Frank and Jagannathan (1998) for the Hong Kong market, where there are no tax rates either for dividends nor capital gains. However, Kalay (1982) argued that it is not possible to infer the existence of the clientele effect from the magnitude of the share price decrease, because results can be influenced by transaction costs and not by marginal tax rates, which can bias the results. 
Elton and Gruber (1970) carried out empirical work on the American market and asserted that MM were right when they proposed the clientele effect hypothesis. The authors show that shareholders with higher tax rates prefers capital gains to dividends in relation to those that have lower taxes, thus supporting the clientele effect. According Elton and Gruber, the share price after the dividend should drop less than the dividend value approximately (1-dividend tax rate) . Frank and Jagannathan (1998) examined the ex-dividend date share price behaviour in the Hong-Kong market, finding evidence that the medium share price decrease is lower than the dividend amount.

Harris, Roenfeldt and Cooley (1983) examined a sample of large firms in the period between 1968 and 1976, in order to verify whether firms with high debt level have shareholders with low tax rates, and vice-versa. They found evidence that tax rates were negative and significantly correlated with debt level, giving support to the clientele effect hypothesis in firms with debt.

Eades, Hess and Kim (1984) examined the ex-dividend date return of several types of shares. When they analysed common shares, they conclude that the ex-dividend date return is consistent with the hypothesis that dividend tax rate is superior to that of capital gains. This evidence supports the clientele effect and Elton and Gruber's (1970) results. Examining the behaviour of non-taxed organizations, they found a significantly positive return for share dividends and share splits [confirmed by Grinblatt, Masulis and Titman (1984)] and a significantly negative return for non-taxed dividends, a result consistent with neither the clientele effect nor the taxes. The authors try to find possible reasons for the abnormal results ${ }^{9}$, but do not find justification for them.

Pettit (1977) tested the clientele effect, examining portfolio composition for the period between 1964 and 1970. The evidence suggests the existence of clientele effect, but it does not show that the share prices are determined by the dividend policy set by firms. However, Lewellen et al. (1978) used Pettit's data and arrived at different conclusions. Although the results show that the tax rate was negatively and significantly correlated with dividend yield, a marginal tax rate increase of $10 \%$ was associated with a decline of only $+0.1 \%$ in asset returns. This result provides only weak evidence of the clientele effect. Koski and Sruggs (1998) also find weak evidence of the clientele effect. More recently, Zeng (2003) studied the Canadian market, founding evidence, although not

\footnotetext{
${ }^{9}$ Such as the ex-dividend date error, the weekday effect, the dividend announcement effect and the normality assumption.
} 
strong, consistent with the tax clientele hypothesis, since firms paying dividends had significantly higher institutional ownership than firms not paying dividends ${ }^{10}$.

Very recently, Graham and Kumar (2005) investigate the relation between retail investor and dividend preferences, analysing 77,995 households in the US for the period from 1991 to 1996 . The authors test the proposition that, given clienteles, a dividend increase will be greeted more positively at a firm with a low tax clientele than it will at firm with a high tax clientele. There evidence is consistent with dividend clienteles and reinforces the findings from previous studies that have provided indirect or direct support for the existence of tax clienteles Elton and Gruber (1970), Kalay (1982), Eades, Hess and Kim (1984) and Lakanishok and Vermaelen (1986) . However, not all the studies found evidence that supports, at least in a strong way, the clientele effect hypothesis Lewellen et al. (1978), Koski and Sruggs (1998) and Zeng (2003) .

\subsubsection{AgENCY COSTS}

The existence of potential conflicts of interest among parties involved in agency relations (bondholders, shareholders and managers) cause agency costs. A way of controlling these costs can be, according to some authors, the existence of dividends. An agency cost explanation of payout practice first appeared in the 1980s, being putt forward by several authors, such as Rozeff (1982), Easterbrook (1984) and Jensen (1986). In relation to dividend policy, the conflicts of interest between shareholders and managers, on one side, and shareholders and bondholders on the other, assume special significance.

The first conflict of interest that can influence dividend policy is the conflict between managers and shareholders. When ownership and control are separated, conflicts of interest may be developed between managers (agents) and shareholders (principals).

Two main works in the agency theory domain are the ones of Easterbrook (1984) and Jensen (1986). The former formulates the hypothesis of dividends being used to avoid excess cash flow under managers' control. Easterbrook suggests that dividend payments may help reduce both agency costs and overinvestment problems because they force

\footnotetext{
${ }^{10}$ Their empirical tests also support the signalling hypothesis, the agency theory and the liquidity
} hypothesis. 
managers to raise funds in financial markets more frequently than if the firm was not paying dividends. Jensen's premise is that managers with large amounts of free cash flow may use it in ways that is not in the shareholders' best interests. In that way, dividend payments reduce the level of free cash flow to be spent and, consequently, reduce agency costs. Jensen and Meckling (1976) have already stated that high payout will result in the reduction of free cash flow available to managers and this restricts the empire building efforts of managers.

Rozeff (1982) suggests that, in the absence of taxes, it is possible to have an optimal dividend policy, justified by agency costs reductions when firms increase the payout ratio. Several years after, Saxena (1999) develop a model to explain dividend payout ratios of firms. The data was drawn from the same source as Rozeff. The author concludes that a firm's dividend policy will depend, inversely, on past growth rate, future growth rate, systematic risk and the percentage of common shares hold by insiders and, directly, on the number of common shareholders. These relationships are comparable to Rozeff's (1982) study.

Lie (2000) investigated the relationship between excess cash flow and dividend policy and found that firms with dividend increases had excess cash flow. He also found evidence that market reaction to special dividend announcements and to share repurchases was positively related with the excess cash flow amounts and negatively related with investment opportunities, measured through Tobin's $\mathrm{Q}^{11}$. These results support the idea that by limiting superfluous investments through dividend payments, shareholder wealth will rise and, consequently, agency costs will decrease.

La Porta et al. (2000) tested two dividend agency models, examining the relationship between shareholder protection and dividend policy in 33 countries. They considered two hypotheses. The first hypothesis, associated with the outcome model, states that when shareholders have a greater capacity to obtain their goals through firms' managers (in the countries with a higher shareholder protection), they will press managers to distribute higher dividends. The second hypothesis, associated with the substitute

\footnotetext{
${ }^{11}$ Tobin's Q ratio divides the market value of all a firm's debt plus equity by the replacement value of the firm's assets. Firms with a $\mathrm{Q}$ ratio above 1 have an incentive to invest that is probably greater than firms with a $\mathrm{Q}$ ratio below 1. So, firms with high $\mathrm{Q}$ ratios tend to be those with attractive investment opportunities or a significant competitive advantage and firms with Tobin's Q below 1 tend to be those which do not have a significant potential growth, consequently having abnormal and positive returns when they announce dividend increases.
} 
model, consider that due to market forces, management will pay high dividends in countries where protection is not so high. According to their results, in countries with higher shareholder protection, dividends are higher than in the countries with low protection, supporting the idea that investors use their power to force dividend payments. They reached the conclusion that, while the outcome model foresees that the stronger the rights of the minority shareholders, the higher tend to be the dividend payments, the substitute model foresees the opposite. Thus, shareholders have the opportunity to reduce agency costs, forcing managers to pay dividends. The evidence that minority shareholders force firms to pay dividends to restore cash suggests some agreement with free cash flow hypothesis.

Rao (1987) pointed out that shareholders that are afraid of losing firms control prefer a low dividend policy, so that it is not necessary for firms to issue new equity, diluting it with new shareholders. Allen, Bernardo and Welch (2000) pointed out that because firms have taxes advantages face to private investor, the organizations prefer to invest in firms with higher payout ratios. Shleifer and Vishny (1986) suggested that because of conflict of interest, management could be monitories by shareholders with more equity and firms would increase their value.

In a recent study, Borokhovich et al. (2004) explore the hypothesis that dividends reduce agency costs, using a final sample of 192 quarterly dividend increase announcements collected from Compustat, for the period between 1992 through 1999 and they find no evidence that dividend increases reduce agency costs.

The second conflict of interest can occur between shareholders and bondholders. In the relationship between them, the main issue is the impact that dividend payments can have on a firm's value, both on equity and liabilities values. When a firm pays dividends, its value will decrease according to the dividend amount. This decrease is reflected in both equity and liabilities. However, while shareholders receive after-tax dividends, bondholders do not receive anything, so shareholders prefer firms to pay dividends, while bondholders prefer firms not to pay them. The shareholder's preference for dividends is stronger when firms have high levels of debt. Several studies have examined the conflict of interest between shareholders and bondholders and related them with dividend policy, such as Jensen and Meckling (1976), Myers (1977), and Handjinicolaou and Kalay (1984). 
Myers (1977) and Jensen and Meckling (1976) argued that, in some circumstances, shareholders try to expropriate creditors' wealth, namely through dividend payments. Shareholders can reduce investments and increase dividends - dividends financed by investments - or increase debt to pay dividends - dividends financed by liabilities. In both cases, the liabilities market value will decrease and equity value will increase. The authors suggest that both shareholders and bondholders can agree to dividends restriction. In fact, several debt contracts contain limitations to dividend payments.

Handjinicolaou and Kalay (1984) analysed the effect of dividend change announcements on equity and liabilities prices. If dividend changes occur to reduce wealth of the creditors, then a dividend increase should have a positive impact on share prices and a negative impact on liabilities price. The opposite will happen for dividend decreases. Their results show evidence of a significant decrease in liabilities value in the case of dividend decrease announcements, but the value change is not significant when dividend increases are announced, so their results do not guarantee support for the wealth expropriation hypothesis. However, the evidence is consistent with the informative content hypothesis.

DeAngelo and DeAngelo (1990) found evidence that firms in financial distress are more reluctant to suppress than reduce dividends. The authors found that most of the sampled firms presented debt contracts with restrictive clauses to dividends in the years they reduced them, giving credibility to the agency theory, mainly because sample is essentially composed of large size firms. However, this was not the only determinant of dividend decreases, since a significant number of firms's decreased dividends even in the absence of obligatory restrictive clauses.

Farinha (2003) analyses the managerial entrenchment hypothesis, drawn from the agency literature, in the UK market. The prediction is that below the entrenchment level, insider ownership and dividend policies can be seen as substitute corporate governance devices, leading to a negative relationship between these two variables. After such critical level, dividend policy may become a compensating monitoring force and the relation between the variables will be positive. The sample includes 693 firms in the first period (1987-1991) and 609 firms in the second one (1992-1996). Consistent with the predictions, Farinha found evidence of a strong U-shaped relationship between dividend payouts and insider ownership. After the critical entrenchment level, in the region of $30 \%$, the coefficient of insider ownership changes from negative to positive. 
Globally, the results justify the agency explanation for dividend policy.

\subsubsection{UNCERTAINTY ASSOCIATED WITH FUTURE REMUNERATION FLOWS}

Two additional factors for a high dividend policy that are frequently mentioned are related to each other: the preference for current return and the resolution of uncertainties. Shareholders believe that dividends are less risky than capital gains and, in a traditional view, they prefer high to low dividends. This fact is known in the corporate finance world as "a-bird-in-the-hand" fallacy. Because of the relationship between risk and return, an investor preferring dividends accepts a lower return than one preferring capital gains, because the former are current, while the later are future and potential, involving risk.

Gordon (1961) argued that firms with a high dividend policy are more attractive to shareholders because they remove, or at least, decrease their uncertainty. Moreover, Lintner (1962) and Gordon (1963) argue that investors prefer to receive current dividends to capital gains because they are less risky. Also, the study of Long (1978) concludes that shareholders attribute a greater value to dividends than to the same amounts of capital gains (before tax). Some years later, Bailey (1988), studying the Canadian market, found that shares paying cash dividends had a premium over shares paying stock dividends.

As we can value assets by discounting expected future dividends, and since most distant dividends present greater uncertainty, share prices tend to be lower for firms that pay smaller dividends in the near future, because the discount rate reflects a larger risk and, consequently, a smaller present value. Graham, Dodd and Cottle (1962) argue that firms should present a high payout ratio because short-term dividends present value is superior to the long-term dividends, and because the share prices of a firm that pays dividends should be superior to a similar firm that does not pay dividends.

Poterba (1986) made a study about the company Citizens Utilities, that pays share dividends and cash dividends, finding the following evidences: (1) the relative share prices of firms paying share dividends have been higher since 1976; (2) the ratio of share dividends to cash dividends has a mean value of 1.134 during the period from 1976 to 1984 and (3) the share price decrease on the ex-dividend day of firms with cash 
(share) dividends is smaller than (almost equal to) the dividend value. These results are consistent with shareholder preference for capital gains instead of dividends, unlike the conclusions obtained by the previous authors.

In spite of the vast research in the dividend policy domain, there is no significant evidence supporting shareholder preference for dividends because of the uncertainty associated with future capital gains.

\subsubsection{INFORMATION ASYMMETRY AND THE DIVIDEND SIGNALLING HYPOTHESIS}

The capital market is not perfect, but not only because of taxes or agency costs. Another important imperfection is related to information transmission. Assuming that managers have better information than investors concerning future cash flows, many investigators suggest that dividends can convey information about a firm's future prospect. So, dividends can be either a way to transmit information unknown by the market or a way to change the perception of the market to a firm's future prospect.

Dividend payments and their relative changes lead us to think that a firm's management sends information to the market. This phenomenon is known as information content of dividends ${ }^{12}$. When we consider that information is not freely available and is expensive, a cheaper way of obtaining it is through the dividend policy: an important tool that can be used to benefit shareholders. Dividend changes can influence share prices if investors believe those changes convey useful information. Globally, firms manage dividends according to managers' future earnings expectations, so a dividend increase is a management signal to the market that they expect to have a good future performance, while a dividend decrease will have the contrary effect.

Several empirical works from the last decade show that share prices usually rise with a dividend increase announcement, and tend to fall with a decrease. Thus, it seems that dividends provide information to the market, showing evidence of the information content of dividends and suggesting equally that shareholders prefer dividends over capital gains. A dividend decrease announcement tends to be seen as a sign that a firm is

12 The "dividend content information" hypothesis was first suggested by MM (1961). This expression refers to the hypothesis that states that dividends convey information to the market about a firm's future prospects. This information allows shareholders to preview more accurately a firm's future earnings. 
suffering from financial distress, indicating that managers cannot sustain the dividend policy in the future (thus decreasing expectations about dividends in the future). This implies a decrease in the present value of future dividends, and, consequently, in the share price. On the other hand, an unexpected dividend increase gives good news to the market. It is seen as a signal that management foresees a future cash flow increase in a sustainable way, which implies a share price increase. According to Ross, Westerfield and Jordan (1998), this increase is not due to the dividend increase itself, but is due to the expectation of larger future dividends.

Stable and predictable dividends provide smaller uncertainty to investors than variable dividends, namely for their information content effect and because many shareholders use dividends for current consumption. Their decrease can provoke anxiety and force them to sell shares in order to ensure the expected revenue. Lintner (1956) found evidence for managers' preference to stable dividends, concluding, among others aspects, that managers are reluctant to dividend changes that might be reversible.

According to Brealey and Myers (1998), whose opinion is based on Lintner's (1956) work, the way dividends are set can be related to four factors: (1) each firm has a long term target payout ratio; (2) managers give more attention to dividend changes than their absolute amount; (3) dividend changes tend to be in equilibrium with long term sustainable earnings changes, so that dividends do not have temporary oscillations and, finally, (4) managers are reluctant to make dividend changes that can be reversed, due to concerns about the possibility of needing to omit dividend payments.

Fama and Babiak (1968) investigated several models to explain dividend behaviour, covering a 17-year period. They found evidence that firms increase dividends only when they are sure of the possibility of maintaining them unchanged until the next increase. Horne and Wachowicz (1998) suggested that investors prefer stable dividends, paying a premium for such stability. These results are consistent with Lintner's (1956) opinion that firms try to have a stable dividend policy.

Some authors found evidence that markets react negatively to unfavourable dividend changes, e.g. Aharony and Swary (1980). These results suggest that investors react to the information conveyed by dividend change announcements. The information asymmetry related to dividend announcement suggests that insiders have more information than outsiders about firms' future prospects, and could use dividends to send signals to shareholders, releasing private information to the market. The presence 
of information asymmetry may also mean that managers need to signal their ability to generate higher future earnings with the help of high dividend payouts Bhattacharya (1979), John and Williams (1985) and Miller and Rock (1985). However, the credibility of signals depends on the cost of signalling.

According to the opinion of Copeland and Weston (1992), one of the most important effects of the dividend content information argument is that it suggests the possibility of an optimal dividend policy. The benefits of dividend change announcements should be considered together with their fiscal disadvantages, to find an optimal payout ratio. The arguments against the relevance of the signalling hypothesis are associated with the uncertainty about the information that dividend announcements really signal to the market, and what are the reasons that make them superior to other seemingly less onerous information techniques ${ }^{13}$.

More recently, behavioural theories have been developed asserting the importance of psychological factors, in the domain of both dividend and investment policy. For example, Shefrin and Statman (1984) present an explanation for investors' preference of dividends over capital gains based on the self-control theory, and in the desire to save and to restrict them from consuming too much in the present. Shefrin and Statman suggest that investors have a preference for dividends over capital gains, because they avoid decisions about consumption level and about selling part of their stock, claiming that this benefit is enough to compensate contradictory effects, such as the dividend tax effect. This behavioural explanation, although arguing for a positive dividend policy in global terms, does not contribute to the definition of the optimal dividend policy, being unable to explain the share price positive (negative) reaction to the dividend increase (decrease) announcements. Kahneman and Tversky (1982) hypothesised that the sale of shares causes more investor regret and anxiety than the spending of the cash received from dividend payments. These two models state that dividends and capital gains are not perfect substitutes.

Recently, Baker, Powell and Veit (2002) send a survey to 630 North American Securities Dealers Automated Quotation (NASDAQ) firm managers whose dividend payments from 1996 to 1997 were regular, to analyse their opinion about dividend policy. In a general way, the results suggest that managers believe dividend policy is

\footnotetext{
${ }^{13}$ For more detail, see Easterbrook (1984).
} 
important and relevant to a firm's value. They emphasise the importance of dividend regularity, in line with Lintner's (1956) model. Thus, dividend policy cannot be seen as residual. Of the four reasons analysed by the authors for the dividend payments signalling theory, taxes, agency costs and the "bird-in-the-hand" fallacy - the one providing a strong support for dividend payments was the signalling theory, a finding consistent with a large part of the empirical evidence of recent years. Managers give poor support for taxes and agency costs as reasons for dividend payments. This last situation is surprising, especially because of the empirical evidence supporting the agency costs theory. As expected, they did not find support for the "bird-in-the-hand" fallacy. These results are in accordance with the ones of Bradley, Capozza and Seguin (1998), who concluded that signalling theory is better than agency theory in explaining firms' dividend policy. Furtheremore, Baker, Powell and Veit find some support for the assumption that dividend policy is associated to a firm's life cycle. This idea was defended by Damodaran (1997) and, more recently, analysed empirically by Grullon, Michaely and Swaminathan (2002).

Summarising, of the factors affecting the dividend policy, the taxes seem to be the argument contributing most to low dividend payments, while the preference for current revenues and the signalling theory are the strongest arguments in favour of high dividend payments, being the last one the most important. However, the evidence associated with the dividend content information hypothesis is not consensual: although there is a vast number of works supporting this hypothesis, there is also a significant number of studies that find no evidence for it.

Of the several aspects analysed in the previous sections, the one most strongly linked with our research topic concerns the information that dividends could convey to the market, and how this information can affect firms' share prices and future profitability. In this context, we propose to analyse in more detail the evolution of the dividend information content domain, including the theoretical models (section 2.5) and the most important empirical tests reported in the last decades (section 2.6). 


\subsection{DIVIDEND SIGNALLING MODELS}

MM (1961) show that in a perfect and complete capital market, the dividend policy of a firm does not affect its value, concluding that dividend policy is irrelevant. However, several empirical studies point to a different market reaction according the dividend change announcements, suggesting the existence of information in dividend change announcements, which is referred as the dividend information content hypothesis, also called the signalling effect. MM (1961, p.430) pointed out that: "what might be called the "informational content" of dividends...investors are likely to interpret a change in the dividend rate as a change in management's views of future prospects for the firm", suggesting that the market could interpret a dividend change as managers attempt to convey externally information on a firm's future prospects.

Some years later, Bhattacharya (1979), John and Williams (1985) and Miller and Rock (1985) developed the signalling models based on the information asymmetry hypothesis. These authors showed that, in a world of asymmetric information, better informed insiders use dividends as a costly signal to convey their firm's future prospect to less informed outsiders. Thus, a dividend increase signals an improvement on firm's performance, while a decrease suggests a worsening of its future profitability. Consequently, a dividend increase (decrease) should be followed by an improvement (reduction) in a firm's profitability, earnings and growth. Moreover, there should be a positive relationship between dividend changes and subsequent share price reaction.

Bhattacharya's (1979) model is closely related to the Ross model (1977). The author assumes that outside investors have imperfect information about a firm's profitability and that cash dividends are taxed at a higher rate than capital gains. If firms convey this information through dividend announcements, the better the news, the higher the dividends will be. Miller and Rock (1985) suggest managers know more than shareholders about a firm's current earnings and that, presumably, dividend announcements transmit this information to the market. The authors suggested that firms whose shares have a larger reaction to the information conveyed to the market should be those that have a stronger information asymmetry. John and Williams (1985) conclude that the empirically observed positive relationship between profitability and dividend yield is due both to the information effect and to taxes. In sum, the Bhattacharya's (1979) model is based on financing asymmetric costs, Miller and Rock's 
(1985) work is based on the cost of foregone investment opportunities and John and Williams's (1985) model is based on the tax differential between dividends and capital gains.

The signalling models associated with dividends constitute an important maker for us to understand the way that dividend announcements convey new, reliable and relevant information about firms to the market, while the empirical tests done in this domain allow us to analyse the effects that dividend change announcements have on share prices, as well as on a firm's profitability. Signalling models predict a positive relationship between dividend change announcements and both the share price reactions and future earning changes. In the following section, we will analyse the empirical studies carried out in the meantime, which results are mixed.

\subsubsection{BHATTACHARYA’S MODEL (1979)}

Bhattacharya (1979) developed a model with the purpose of explaining the reasons for firms paying dividends. If investors believe a firm's value is directly related to dividend amounts, one of the most effective ways to signal the market about a firm's value will be an unexpected dividend change announcement. Moreover, the author asserts that the magnitude of the dividend is directly associated with the signal dimension transmitted to the market, which was proved by Asquith and Mullins (1983), among other studies.

Bhattacharya developed a one period model, in which managers' decisions are in agreement with shareholder interests. The model assumes that at time zero, managers commit to a specific dividend policy; at the end of the period, the firm will use cash flows obtained in the project to pay the dividends set at time zero. If cash flows generated in the period are not enough to pay the dividends, the firm should use outside financing, even with transaction costs, to pay the dividend initially established. This model assumes that firms pay dividends even when they are taxed and that dividends and share repurchases are perfect substitutes, such that the final result will be the same, independent of the way the information is conveyed to the market.

Although it was a significant step in dividend policy research and in the development of signalling models, the work of Bhattacharya (1979) was criticised by several authors, mainly for not explaining the reason why firms use dividends to signal their future 
prospects. Lease et al. (2001) criticise Bhattacharya's study because it did not clarify the meaning of the idea of firms committing themselves to a specific dividend level, since this is not a contractual obligation.

This model leaves some questions unanswered, namely the reason why firms tend to smooth dividends or why firms use dividends to signal information, instead of using less onerous means, such as a newspaper announcement. In agreement with Allen and Michaely (2003), it seems that firms could better signal the information if they made share repurchases instead of cash dividends, because of lower rates.

Probably due to theoretical assumptions assumed to construct theoretical models, which not verify in the real world, as well as due to questions not yet answered, other signalling models have appeared in the meantime.

\subsubsection{Miller AND RoCK’s MODEL (1985)}

Miller and Rock (1985) analysed announcement effects and their consequences under conditions of asymmetric information considering a two period model. At time zero firms invest in a project and, at time one, use the cash flows generated by it to pay dividends and to reinvest in new projects. At time two, the situation repeats. The model assumes that managers have private information about firms' future earnings.

The authors begin by analysing dividend and investment decisions in the context of asymmetric information. So, at the moment of the dividend announcement, the earnings are only known by the firm's management, but not by external investors. This information difference affects the perception that each of the parties has about the firm's value, since, when managers are evaluating the firm, they consider not only the public dividend announcements, but also the unannounced earnings. In agreement with the authors, if the market is rational, the company evaluation done by the market will be in agreement with the managers' evaluation.

According Miller and Rock dividends make sense as signals of good news but not bad. For firms that have good performances, and, consequently, with good news to convey, the signalling cost can be worthwhile to avoid giving the market the false expectation that earnings are not enough to justify dividend payments. 
Introducing the asymmetry of information hypothesis, the authors showed that: (1) the dividend announcement effect on share prices depends on unanticipated operational cash flow changes; (2) the information conveyed by an unexpected earnings change is similar to that conveyed by an unexpected dividend change; (3) firms with a higher capacity for cash flow generation pay sufficiently high dividends. It is not attractive for firms to reduce investments in order to pay the same dividend amounts. The authors conclude that a signalling equilibrium can be reached, where dividends convey information about future cash flows, but the investment will be lower and the dividend payment higher than those in the perfect information diffusion context.

Some criticisms have been made on the Miller and Rock model. If earnings are announced to the market before dividend announcements, shareholders will have access to this information, a situation not assumed in the model. Another problem is the presence of earnings correlation over time. Although Miller and Rock's theory does not have difficult assumptions to interpret, it is not clear if, in the presence of taxes, dividends would continue to be the best signalling method, or if share repurchases would be a cheaper way of transmitting information to the market. Despite recent

successes in constructing signalling equilibrium with dividends, some important questions remain unanswered. John and Williams (1985) are other authors that tried to develop a dividend equilibrium model.

\subsubsection{JOHN AND WILLIAMS’s MODEL (1985)}

John and Williams (1985) have developed a model that identifies the dividend effect under personal taxation, while Miller and Rock (1985) mainly discuss the earnings effect. They developed an equilibrium signalling model where taxable dividends and share repurchases are not related, unlike in the models of Bhattacharya (1979) and Miller and Rock (1985), where they are considered to be perfect substitutes.

John and Williams make the following assumptions: taxes are paid only on dividends, and the tax level is the same for all the shareholders; no transaction costs are incurred when issuing, retiring or trading shares; all sources and uses of firm's funds are fully observed by outsiders through costless public audits; management can sell some shares to cover cash requirements and finally, managers have better information about firms' 
future expected cash flows and investment opportunities than outside investors, which is consistent with information asymmetry.

The model can be analysed based on Riley's (1979) ${ }^{14}$ results, and assumes that dividend payments benefits differ among firms. For firms with better future prospects, the premium the market pays for shares with higher dividends compensates for the additional taxes paid by shareholders and the reduction of dilution suffered by actual shareholders ${ }^{15}$, while firms with less favourable prospects do not pay such high dividends, since tax costs exceed the gains derived from dilution reduction.

If dividends have a significant cost, only firms with good performances will be compensated for incurring dividend fiscal costs. So, firms with bad performances do not have an incentive to mimic successful ones. In equilibrium, insiders in firms with truly more valuable future cash inflows distribute larger dividends and receive higher prices for their shares.

John and Williams' most important results are the following: (1) in a signalling equilibrium model, firms that expect larger future cash flows should pay higher dividends, and, consequently, share prices will increase; (2) the optimal dividend policy causes smooth dividends associated with operational cash flows, in such way that dividend changes must be lower than cash flow changes; (3) firms that pay dividends have clienteles that look for liquidity and, consequently, request regular cash and (4) higher dividends are associated, ceteris paribus, with higher share prices, while lower dividends are associated with lower share prices, also asserted by Bhattacharya (1979).

This model, although innovative, has some weaknesses. Firstly, it assumes that shareholders cover their liquidity needs by selling shares and do not consider other financing possibilities both for insiders and outsiders. Secondly, it is not obvious that this model supports the smooth dividend hypothesis, proposed by Lintner (1956) and supported by several authors, like Fama and Babiak (1968). If a firm's future evolution prospects are unstable, and if dividends convey this information to the market, they will be different from year to year. This phenomenon is difficult to reconcile with the evidence that firms smooth dividends.

\footnotetext{
${ }^{14}$ For a summarised analysis of Riley (1979) results see John and Williams (1985, p. 1060-1064 and 1067-1068).

${ }^{15}$ If firms do not distribute dividends and shareholders need cash, they will sell shares, resulting in an equity dilution.
} 
In summary, these three theoretical studies suggest that dividends are potentially useful as signals of the future earnings stream of the firm. However, they assume that dividends are the only signalling mechanism ${ }^{16}$. To overcome some weaknesses of these models, several other authors have developed theories associated with the signalling phenomenon.

\subsubsection{OTHERS}

Ambarish, John and Williams (1987) developed a one period model, considering investments, dividends and share repurchases. Ofer and Thakor (1987) examine dividend signalling in conjunction with share repurchases, concluding that a share repurchase elicits a higher price reaction, on average, than a dividend announcement, and Williams (1988) developed a model covering several periods, showing that, in equilibrium, firms pay dividends, select investments in order to maximize the net present value and issue new shares.

Kumar (1988) developed a dividend signalling theory, where managers make investment decisions knowing firms' true productivity, while outsiders do not know this. His theory is consistent with smooth dividends because small changes in productivity do not cause changes in dividends. However, this study does not explain why share repurchases are not used as an alternative to dividends. Consistent with Kumar' analysis relating to productivity, are the results of Cyert, Kang and Kumar (1996). They analysed several factors, such as the productivity, risk level, previous earnings and dividend changes frequency for a sample of 726 firms listed on New York Stock Exchange (NYSE) for the 1946-1987 period. Besides, they conclude that firms with more persistent earnings tend to change dividends more frequently and others that present a higher risk level tend to decrease dividends more frequently.

Bernheim (1991) asserts that the signalling effect happens because dividends have higher tax rates than share repurchases. In his model, firms control taxes, changing dividend payments as an alternative to share repurchases. As in the John and Williams's model, this model does not supply a clear explanation of dividend smoothing.

\footnotetext{
${ }^{16}$ Other signalling mechanisms have been analysed in subsequent studies, such as share repurchases Ofer and Thakor (1987) and the investment opportunities of the firms Ambarish, John and Williams (1987) and Lang and Litzenberger (1989) .
} 
The model developed by Allen, Bernardo and Welch (2000) state that dividends work as a sign of favourable news. In this model, firms pay dividends because they are interested in attracting a clientele segment of well-informed customers. Because of the fiscal disadvantage, firms that pay dividends will attract essentially investments and pension funds. In agreement with the authors, these investors gain an advantage in identifying firms with higher quality. Other firms do not feel motivated to mimic the higher quality ones because they do not want their true value to be revealed. So, dividend payments increase institutional shareholders' probability of detecting a firm's quality. Firms that pay dividends tend not to decrease their amount, because their institutional customers would punish them for that, so dividends tend to stay relatively constant, confirming the smooth dividend hypothesis. Furthermore, Allen, Bernardo and Welch do not consider dividends and share repurchases as substitutes (just as John and Williams), since, according to them, firms with asymmetric information or agency problems tend to use dividends instead of share repurchases.

Recently, Grullon, Michaely and Swaminathan (2002) presented an alternative explanation relating dividend changes and company risk changes, called the maturity hypothesis. It links dividend policy with firms' life cycle. As a firm moves to the maturity phase, its systematic risk decreases because of its asset risk decrease and because of the scarcity of growth opportunities that, by itself, presents risk. Because investment opportunities are scarce in this phase, although it results in a future profitability decline, it also causes a free cash flow increase, permitting an increase in dividend payments. According to the maturity hypothesis, firms increase dividends when investment opportunities are scarce, causing a decrease both in systematic risk and profitability. Thus, a dividend increase announces that firms are in the maturity phase. If, on the one hand, it is a favourable new (risk decrease), on the other it is an unfavourable new (decrease in earnings). Thus, the empirical evidence of a positive market reaction to dividend increase announcements could be a signal that news associated with risk decrease dominates news associated with profitability decrease. Allen and Michaely (2003) share this opinion. 
We can conclude that dividends are a key question, because managers can use them to convey information to the market concerning future earnings or cash flows, which is assumed in the dividend signalling models ${ }^{17}$.

Now, we will analyse several empirical tests carried out with the purpose of exploring the effect that dividend change announcements to convey private information to the market have on a firm's value.

\subsection{EMPIRICAL TESTS ON THE INFORMATION CONTENT OF DIVIDENDS}

MM (1961) suggested that, if managers' expectations of firms' future earnings affect dividend policy decisions, then, changes in dividend policy would convey information to the market on the future earnings of their companies, which concept is known as the information content of dividends. The first empirical studies in this topic were called tests of the information content of dividends, and were analysed in two different ways: on one hand, the dividends could be used as a future cash flows sign, as considered, for example, by Bhattacharya (1979). On the other hand, dividends could provide information concerning earnings, as defined by Miller and Rock (1985).

In a general way, the market reacts positively to dividend increase announcements and negatively to their decrease. This phenomenon has been documented by many studies, for example those of Pettit (1972), Charest (1978), Aharony and Swary (1980), Healy and Palepu (1988) and Michaely, Thaler and Womack (1995), in the case of the dividends, and by Ikenberry, Lakonishok and Vermaelen (1995), in the case of share repurchases. The evidence is consistent with managers having more information than external investors, and with dividends or share repurchases providing information on future cash flows Bhattacharya (1979) and Miller and Rock (1985), or on the capital cost (Grullon and Michaely (2002) and Grullon, Michaely and Swaminathan (2002) .

\footnotetext{
17 There are several theoretical signalling models based on alternative dividends, but they are not in the scope of this research.
} 
The capacity dividend announcements have to convey information to the market has been basically analysed empirically in the following aspects:

- Whether future earnings forecasts are better when there are dividend changes announcements, the hypothesis being the following: dividend changes should be followed by subsequent earnings changes in the same direction;

- When unexpected dividend changes are announced, to what extent do share prices vary in the same direction as the dividend changes? The dividend information content hypothesis postulates that unexpected dividend changes should be accompanied by share price changes in the same direction;

- Whether market expectation revisions concerning future earnings vary or not in the same direction as the dividend changes. The associated hypothesis states that unanticipated changes in dividends should be followed by revisions in the market's expectations of future earnings in the same direction as the dividend change;

- The extent to which a company risk is associated to dividend changes. The hypothesis suggests that a dividend announcement should be negatively related to a firm's risk.

All of the above implications are necessary but not sufficient conditions for dividend signalling. Although most of the empirical works emphasise the second implication, that unexpected dividend changes are associated with share price changes in the same direction, the first condition is the most basic one: earnings changes will follow dividend changes. If such a condition is not met, we can conclude that dividends do not have, per se, the potential to convey information to the market.

Next, we present the results of some empirical tests, organised in agreement with the implications of the dividend information content referred to above.

\subsubsection{The EFFECT OF DIVIDEND ANNOUNCEMENTS ON FUTURE EARNiNGS}

The underlying hypothesis in the studies conducted in this domain postulates that dividend changes should be followed by subsequent earnings changes, in the same direction, providing evidence that dividend changes convey credible information about the future prospects of dividend paying firms. 
If, in fact, one of the functions of a dividend is the transmission of private information to the market, the forecasts of future earnings of companies based on the information from dividends should be more effective than the predictions accomplished without this type of information. Consequently, and in agreement with the theory, a dividend change should be followed by a change in the firms' earnings in the same direction. Several studies were conducted in the last few years with the purpose of providing evidence of dividend information content.

One of the first works done in this area was that of Watts (1973), which analysed the hypothesis that knowing current dividends improves future earnings forecasts, when contrasted with forecasts based only on past and present earnings ${ }^{18}$. His study had as motivation the fact that, although the dividend information content hypothesis is acknowledged and accepted peacefully, there were, until the date of that study, few empirical tests to prove the hypothesis. The author's main goal was to test the hypothesis that dividends contain information concerning firms' future earnings. To that effect they used a sample of 310 companies listed in the American market, analysing a period of 20 years (1947 to 1966). Watts tested whether current and past levels of dividends and earnings could explain future earnings. Their results suggest that, on average, the relationship between future earnings and dividend changes is positive, which is consistent with the dividend information content hypothesis. However, all the tests done in this work suggest that earnings changes that can come from the information conveyed by dividends are not significant. Thus, Watts (1973) concluded that the information content has no economic meaning because it did not allow for obtaining abnormal returns after having considering transaction costs, in the case of investors having monopolistic access to the information.

Gonedes (1978) came to similar conclusions to those of Watts, stating that, in general, if there is some information in dividends, it is very scarce. In fact, analysing a sample of 285 American companies, covering the period from 1946 to 1972, Gonedes found evidence that annual dividends do not reflect information besides that which is conveyed by yearly earnings, which is inconsistent with the dividend information

\footnotetext{
${ }^{18}$ As we said before, Lintner (1956) was one of the first authors to develop a model that tries to explain the value of dividends paid as a function of past earnings and dividends, suggesting that present dividends depend on current as past earnings. In fact, although Lintner's (1956) and Fama and Babiak's (1968) traditional models agree that the dividend decision is conditioned by the level of past and current earnings, present extensions of these models, as developed by Marsh and Merton (1987) and Kao and Wu (1994) associate the choice of dividends to the expectations of future earnings.
} 
content hypothesis. The author obtains results consistent to Lintner's (1956) model and similar to the ones obtained by Fama and Babiak (1968).

Penman (1983) analysed the American market, in the period between 1968 and 1973. After allowing for managers' forecasts of future earnings, he found evidence that there is information contained in dividends, but that the information does not seem to be significant. Penman's results suggest that, when managers forecast significant increases in earnings, on average they do not adjust dividends according to that forecast.

Garrett and Priestley (2000) findings are consistent with Watts (1973) and Penman (1983) results. The authors propose a behavioural model of dividend policy of the aggregate stock market, considering an earnings series over the period 1871 to 1997. They find strong evidence that dividends convey information about current unexpected permanent earnings, but do not signal the future level of earnings of the firm. Moreover, the authors' findings are consistent with the notion of dividend smoothing.

Brickley (1983) analysed the possible existence of special dividend announcement information signalling in a period of approximately 10 years (1969 to 1979), comparing it with the effect of regular dividends. In general, the results support the idea that managers use dividend increases to convey information to the market concerning the future potential of firms. The evidence of positive abnormal returns in the days surrounding the special dividend announcement is consistent with the hypothesis that this type of dividend conveys positive information to the market. The author rejected the null hypothesis that market reaction to changes in special dividends is bigger than or equal to that in the case of regular dividends, with similar dimensions, suggesting that regular dividend increases convey more information to the market than special dividend increases. In fact, the statistical results show that future earnings are more favourable in the case of increases on regular dividends than on special ones.

Somewhat more in line with the theory are the results of Healy and Palepu (1988), who focused their work on dividend initiations and omissions by firms listed either on the NYSE or the American Stock Exchange (AMEX), basing their work on Asquith and Mullins' (1983) sample. These authors analysed whether changes in dividend policy convey information about future earnings. Generally, their results indicate that companies that initiated and omitted dividends presented significant increases or decreases in their annual earnings, at least in the years of the dividend policy change and the previous year. Their results are consistent with those of Lintner (1956), Fama 
and Babiak (1968) and Watts (1973), which suggest that the initiation or omission of dividends can, partly, be predicted by changes in current and past earnings. Their results show that for the 131 firms that had begun dividend payment ${ }^{19}$, earnings increased rapidly in the past but continued to increase during the two following years. These results are consistent with the hypothesis that managers consider a firm's past and current performance, as well as expectations of future earnings, when they decide to initiate a dividend payment. However, for firms that omitted dividends ${ }^{20}$ (172 companies), the results contradicted the theory: earnings decreased in the announcement year, but improved significantly the following years. The authors suggested that earnings changes are partially anticipated at dividend announcement date, concluding that the initialisation and the omission of dividends are interpreted by the market as managers' forecasts about, respectively, earnings increases or decreases.

In the same year, Born, Moser and Officer (1988) tested the hypothesis that dividend increases (decreases) are followed by an improvement (decrease) in the growth rate of quarterly earnings, having analysed companies listed in NYSE and in AMEX, which changed their dividend policy after a period of stability. The sample resulted in 175 initialisations, 62 maintenances, 186 increases, 40 decreases and 10 omissions of dividends, in the period from 1962 to 1985 . These five groups were analysed separately. The authors considered the first three situations as constituting "good news" and the last two "bad news." When analysing the hypothesis that market reaction is positively related to dividend change announcements, they concluded that the excess return in the three days surrounding the announcement date is consistent with the signalling dividend hypothesis $^{21}$. In spite of that, more than $20 \%$ of companies in each of the five groups presented returns in the opposite direction to that predicted by signalling hypothesis, which shows that market reaction to the announcement of change in dividend policy is complex. The authors also found evidence that the increase in the growth rate of quarterly earnings after dividend announcement is positive and significantly different from zero in the three cases considered as "good news", which is consistent with the dividend information content hypothesis. However, for the two cases considered as "bad news", no evidence was found of the deterioration of earnings growth rate, as would be

\footnotetext{
${ }^{19}$ Or reinitiate their payment after a period of at least ten years of non-distribution.

${ }^{20}$ Or stop paying dividends after a period of at least ten years of paying them continuously.

21 The returns were of $1.46 \%, 3.02 \%, 1.46 \%,-6.55 \%$ and $-9.22 \%$, in the cases of initialisation, maintenance, increase, decrease and omission of dividends, respectively, which are statistically significant results.
} 
expected according to theoretical models. This last result is conforms to Healy and Palepu's (1988) evidence, in the case of dividend omissions, in which the results were contradictory to what the theory predicted.

Aharony and Dotan (1994) conducted their work so as to analyse to what extent the announcement of quarterly dividends conveys useful information to the market on a firm's future returns. They also analysed the relation between unexpected dividends changes and earnings on the subsequent quarters, compared to the information contained in the current and most recent earnings. They analysed a large sample, covering the period from 1967 to 1990, and the results show that firms that increase (decrease) their dividends obtain, on average, higher (lower) unexpected earnings in the subsequent periods than those who do not change dividends. So, they conclude that there is a strong association between dividend changes and subsequent earnings, conclusions that still apply when the unexpected earnings are introduced as an explanatory variable. These findings are consistent with the hypothesis that quarterly dividend changes predict future earnings.

In the same year, Olson and MaCann's (1994) work appeared, having as its main objective to test, in general terms, the connection between dividends and earnings. Their study was based on a sample of American companies that paid dividends for a period of 48 quarters, from 1978 and 1989, with available data on the Compustat II file. The results show that dividends improve firms' earnings forecasts, a result consistent with the dividend signalling theory. They also found that, according to the residual model of dividend policy, the inclusion of earnings in analysed models improves dividend forecasts. Many firms whose dividends were useful to forecast earnings also showed an influence of earnings on forecast dividends, which indicates that many companies that follow a dividend signalling policy tend also to follow a residual policy, and vice-versa.

A few years later, considering only the special case of dividend omissions, Szewczyk, Tsetsekos and Zantout (1997) analysed the relationship between dividend omissions and future earnings. They wish to discover whether dividend omissions reflect a decrease in past earnings, indicating that managers see that reduction as permanent and not transitory, or whether dividend omissions provide information concerning future earnings, as analysed also by Healy and Palepu (1988). They used a sample composed of 147 dividend omission announcements in the American market in the period from 1980 to 1988 . The authors found a negative and statistically significant abnormal share 
return on the announcement period (considered by the authors as the announcement day in the newspaper and the previous day) of $-4.5 \%$. Szewczyk, Tsetsekos and Zantout found evidence that omission announcements occur after a period of decline in expectations related to current earnings. However, in the case of future earnings, they concluded that, although forecasts of earnings growth rate for the announcement year and the following year are negative and statistically significant, in a longer time period the same does not happen. In a five-year period the forecasts are positive, although not significant. According to the results, the authors maintain that dividend omissions are related to past and short-term earnings, but not to long-term earnings.

Penman and Sougiannis (1997) analysed the relation between dividends and subsequent earnings, controlling the signalling effect. Their study was applied to a group of firms present in the Compustat database with available information for the period between 1970 and 1989. The authors found a negative relation between dividends and future earnings, which contrasts with the positive relations expected according to the dividend signalling models. They attributed this negative relation to the displacement property expectation of lower (higher) future earnings as a result of a decrease (increase) of available funds for reinvestment, due to the increase (decrease) of dividends. Penman and Sougiannis pointed out the importance of controlling for the displacement effect when analysing the signalling effect ${ }^{22}$.

Brook, Charlton and Hendershott (1998) concluded that investors seem to interpret dividend policy changes as signals of future expected returns. In fact, while making an empirical test comparing three groups of firms, one with permanent increase of cash flows (101 firms), one with temporary increases (45 firms) and one with no increases (34 firms), they found evidence that dividend policy is used as a way of signalling to the market future cash flow increases. They found a direct relation between positive cash flows, dividends and share returns, which supports the hypothesis that dividend changes convey information on the future level of cash flow. They also concluded that companies tend only to convey good news, which is consistent with the results obtained by DeAngelo, DeAngelo and Skinner (1996) who found evidence that managers do not signal inversions in long-term earnings growth.

${ }^{22}$ When we analyse the price signalling effect, we are controlling for the displacement effect by considering the announcement date and not the ex-dividend date, so we do not have the problem of splitting these two effects. 
Mozes and Rapaccioli (1998) analysed the relation between dividend changes and future earnings for the period 1980 to 1990 in the American context. They provide evidence that future earnings decline is associated with large dividend increases, while future earnings increases are associated with small dividend increases, showing that their conclusions were robust to a number of different test procedures. They conclude that large dividend increases signal future earnings decline due to the lack of reinvestment opportunities for a firm, postulating that analysts seem to be capable of distinguishing between dividend increases that signal increased future earnings and dividend increases that signal decreased future earnings. However, they found evidence that dividend declines do not provide a signal about future earnings decline.

Chen and $\mathrm{Wu}(1999)$ examined the dynamic relationship between dividends, earnings and share prices, as well as their consequences for the signalling theory, based on a sample of 431 American firms that changed quarterly dividends at least 40 times, during the period between 1965 and 1992. The authors found evidence that dividend changes provide useful information about future earnings forecasts, which is consistent with the dividend information content hypothesis. However, the dividend's capacity to convey information on future earnings decreases after a five-quarter period. Dividend changes not being related to long-term earnings are consistent with the results obtained by several authors, namely Szewczyk, Tsetsekos and Zantout (1997).

Billings and Morton (1999) investigated whether investors' expectations concerning earnings include information on dividends, and whether the latter is in addition to the information reflected in the earnings component. They consider the firms listed in 1996 and 1997, with available data on Center for Research in Security Prices (CRSP), obtaining a sample of 18,474 observations. Their results point to a relation between dividend changes and future earnings, suggesting that dividends are informative about future earnings. The authors found support for the market model reflecting additional information given by dividends.

Four recent studies that document a significant positive relationship between dividend changes and future earnings are the ones of Arnott and Asness (2001, 2003), Nissim and Ziv (2001) and Dhillon, Raman and Ramírez (2003).

Arnott and Asness (2001) test whether dividend policy forecasts future growth in a firm's earnings, and they reached the conclusion that low payout ratios precede low earnings growth, while high ratios precede significant earnings growths. This 
conclusion is consistent with a world in which managers have private information they send to the market through dividend policy, which is consistent with the theory of signalling dividends.

Nissim and Ziv (2001) investigated the relation between dividend changes and future profitability of American companies, trying to explain future earnings through dividend changes. The sample consists of companies listed on the NYSE or AMEX with current dividends declared between 1963 and 1998. The selection criteria resulted in a sample of 100,660 observations, of which 811 observations are dividend decreases, 13,221 are increases and the remaining 86,634 are observations of no-change dividends. Using different methodologies, they found strong evidence that dividend changes provide information about the level of profitability in subsequent years, supporting the dividend information content hypothesis. They determine the mean excess share return during the three days surrounding the announcement date, obtaining a value of $-4.97 \%$ for the dividend decrease sample, $0.00 \%$ for the no-change and $+0.87 \%$ for the dividend increase sample; both the values of dividend increases and decreases are statistically significant. The results are asymmetric for dividend increases and decreases, which is consistent with Healy and Palepu (1988), who studied the special case of dividend initiations and omissions. Their results allowed the authors to conclude that dividends are positively related with earnings changes in the two years after dividend changes. Even with the introduction of many control variables and different approach measures, the results stayed robust. Dividend increases are associated with future profitability for at least four years after a dividend change, whereas dividend decreases are not related to future. The authors hypothesised that the lack of association between dividend decreases and future profitability is due to accounting conservatism. These results are similar to the ones of Billings and Morton (1999) and Arnott and Asness (2003), who show that the payout ratio is positively related to future earnings growth. However, Nissim and Ziv and Arnott and Asness papers differ in two important ways. First, Arnott and Asness's tests consider payout ratio policy, not dividend changes. Finally, their results are for aggregate market, not a cross-section of differential company growth.

Nissim and Ziv (2001) postulate that return on equity is a good ratio to control earnings and to improve the proxy for expected earnings. Thus, they considered it as an additional explanatory variable. They found evidence that the dividend coefficient is significant in about $50 \%$ of the cases when the following year's earnings are considered 
as a dependent variable. Using more conventional approaches, it is significant in only $25 \%$ of the analysed period. Moreover, the authors argue that a possible reason for some previous studies not finding a significant relationship between dividend changes and future earnings is due to the omission of variables or to econometric issues.

Very recently, Dhillon, Raman and Ramírez (2003) have analysed the information content of dividends by focusing on the use of dividend expectations. The authors pointed out empirical tests of dividend signalling models should incorporate dividend forecast since their results highlight a potential sample misclassification arising from the extensively used naïve dividend change method. As stated by Yoon and Starks (1995, p. 1005), "this model may not be realistic...because the model does not incorporate the market's most recent expectation since the last dividend payment. ${ }^{, 23}$ Dhillon, Raman and Ramírez analysed a sample of firms announcing no dividend changes where investors (analysts) were expecting a change, based on a sample of 5,511 dividend announcements made by 1,005 firms between 1994 and 1996, concluding that the price reaction to dividend surprises is significantly greater than that for naïve dividend changes, suggesting that dividend forecasts have information beyond that conveyed by the naïve approach.

When the authors analysed market reaction to dividend announcements, they found a two-day mean excess return (using the naïve model) of $+0.35 \%$ for dividend increases and $-2.19 \%$ for dividend decreases, both being statistically significant at 1 percent level. These results are similar to those found in previous studies. Interestingly, the means excess return for the no dividend change sample is $-0.13 \%$, also statistically significant at the same level ${ }^{24}$. Dhillon, Raman and Ramírez judge this is because no change in dividends often reflects a negative dividend surprise (about $28 \%$ of this sample) and is associated with negative share price reaction and negative earnings changes.

Moreover, the authors provide evidence of a significant positive relation between dividend surprises and firms' contemporaneous and future earnings surprises ${ }^{25}$. These findings contrast sharply with earlier studies that did not find such a relation, with the exception of Nissim and Ziv (2001) and Arnott and Asness (2001, 2003). Dhillon,

\footnotetext{
${ }^{23}$ However, often authors do not have access to the information of dividend forecasts in the database available. This is our case, because in Datastream we do not have dividend forecasts, as well as other important data we need, such as the date of dividend and earnings announcements.

24 Although this sample is usually not investigated in event studies, Aharony and Swary (1980) found that, on average, the reaction to no change dividend announcements is insignificant.

${ }^{25}$ Using the naïve dividend changes approach, this relation is not significant. They suggest the sample misclassification as a possible explanation for this result.
} 
Raman and Ramírez's results are consistent with signalling models postulating an information content of dividends, where firms use dividends to convey information to the market about future prospects of the firm, namely their future earnings.

Mougoué and Rao (2003) studied the temporal behaviour of dividends and earnings for a sample of 215 Compustat firms for a 30-year period (1962-1991), broken down into non-utility firms (143) and utility firms (72). They find that approximately one-fifth of the non-utility firms and a third of the utility firms exhibits a temporal relationship between dividends and earnings, what is consistent with the signalling hypothesis of dividends. Furthermore, the authors examined the firm characteristics differences between signalling and non-signalling firms. Although the results show no significant differences in firm characteristics between signalling and non-signalling utility firms, they find that signalling non-utility firms tend to be smaller, have a lower growth rate of total assets and have a higher leverage ratio than the respective non-signalling firms.

Probably the different results of the empirical work analysed so far may be due, among other reasons, to the difficulty of measuring unexpected earnings.

Analysts' earning forecasts are often pointed out as the reason for dividend decreases like in the works of DeAngelo and DeAngelo (1990) and DeAngelo, DeAngelo and Skinner (1992), Skinner (2004) and Joos and Plesko (2004a, 2004b), among others . In these studies, earnings decrease forecasts precede dividend decreases. These works analyse the dividend policy adjustments in a context of losses or earnings decreases.

DeAngelo and DeAngelo (1990) studied the dividend policy adjustments of 80 firms listed on NYSE that obtained losses for at least three years, during 1980 and 1985. Their results suggest that managers react quickly and aggressively to financial distress, decreasing dividends. They also concluded that dividend decreases are more frequent than their omission, suggesting managerial reluctance to omit and not simply reduce dividends, particularly when firms have long dividend histories. In this last case, companies reduce dividends more often than they omit them, to preserve the continuity of dividends payment. Marsh and Merton (1987) also maintain that the persistence of earnings is a determinant of dividend changes.

DeAngelo, DeAngelo and Skinner (1992) analysed the relationship between dividend reductions and losses and the information conveyed by dividend changes about the earnings performance of 167 NYSE industrial firms with at least one annual loss during 
1980 and 1985, comparing the results with a sample of 440 firms with no losses during the same period. Their results indicate that annual losses are an important determinant to dividend decreases in firms with stable earnings and high dividends. The authors concluded that annual losses are, as a first approach, a necessary condition for dividend reductions (they find that $50.9 \%$ of the firms with at least one loss during 1980-1995 reduced dividends, compared to $1 \%$ of the firms without losses), however, it is not a sufficient condition for reduction, since $49.1 \%$ of the 167 firms of the sample did not reduce dividends in the first year of loss. Their analysis indicates that firms are more likely to decrease dividends with larger annual losses consistent with Lintner (1956) and with larger future problems about earnings consistent with MM (1961). Their findings support signalling hypothesis in that dividend changes improve the ability to predict future earnings performance.

In 1996, the same authors made another empirical work, finding no evidence of dividends providing a useful sign of future earnings, so they concluded that dividend policy is not meaningful as a signalling mechanism. However, DeAngelo, DeAngelo and Skinner (1996) examined dividend increases, whereas several authors that suggest that dividend changes convey information about future earning changes analysed dividend initiations, such as the case of Healy and Palepu (1988), making it possible for dividends to work as a signal in some cases, and not in others. This work examines informativeness of dividends, analysing 145 firms listed on the NYSE, whose annual earnings decreased, after nine or more years of continuous growth. Analysing the market reaction to dividend increases in the year of the first earnings decrease after a long growth period ${ }^{26}$, they found an abnormal return in the announcement period (the announcement day and the previous one) of $+0.66 \%$, small but statistically significant, indicating that the market recognised a modest contribution of dividend increases to convey relevant information to the market. This result is similar to that obtained by Aharony and Swary (1980) and Brickley (1983). Looking at long-term reaction, the abnormal accumulated returns during the years that go from the announcement to the third year after that were of $-10.34 \%$, not statistically different from the returns in the year of the announcement, of $-10.17 \%$. Trying to find possible reasons for the inexistence of informative signals on future earnings, such as possible management

\footnotetext{
${ }^{26}$ According to the authors, about $68.3 \%$ of the sample firms increased dividends in the year the earnings dropped.
} 
errors or modest dividend values, the authors put forward a theory based on behaviour: managers are over-optimistic, i.e. they over-estimate future earnings, even when growth perspectives have disappeared. This opinion can be seen as similar to the Shefrin and Statman (1984) argument that maintains that psychological reasons lead investors to value dividends, even with the tax disadvantages.

Lipson, Maquieira and Megginson (1998) used DeAngelo, DeAngelo and Skinner (1996) methodology and compared public companies, which had recently started to pay dividends ${ }^{27}$ with those that, in the same industry, did not pay them. The companies that begun dividend payments were, in general, more profitable and older than those in the control group, that, although becoming public it the same industry, had not started paying dividends during the analysed period. This study was based on a sample of 114 firms, which started dividend payments from 1980 to 1990.99 companies composed the control sample. The announcement day abnormal returns were $+1.24 \%$, positive and statistically significant, but lower than the return of $+3.9 \%$, found by Healy and Palepu (1988). This difference, according to the authors, could be due to the fact that investors would consider dividend initiations more likely in this sample than in the sample of Healy and Palepu, whose companies had not paid dividends for ten years. Consistent with these last authors' results, Lipson, Maquieira and Megginson found evidence that earnings increased after the beginning of dividends, although they had increased only during the first year. However, contrasting with the results of DeAngelo, DeAngelo and Skinner (1996), the earning increases in the two years following dividend initiations were more favourable to the firms that had started dividend payments. These authors' results suggest that managers do not start dividend payments until they believe they can manage dividend policy through future earnings. In global terms, the results obtained by the authors provide some support to the dividend signalling hypothesis.

Using a larger sample over a long period from 1871 until 2002, Skinner (2004) finds that when firms paying large dividends experience a loss, the loss is more likely caused by special items, and more likely to reverse than a loss reported by a firm that does not pay large dividends. In related work, Joos and Plesko (2004b) examine a large sample of loss firms, collected from Compustat for the years from 1971 to 2000, and the timing of loss reversals. They show the losses of firms that continue to pay dividends are more

\footnotetext{
${ }^{27}$ Initial dividends were considered by the authors to be the first dividend paid after the firms went public, as long as they continued to pay dividends for at least two more consecutive years.
} 
likely to reverse than those of non-dividend paying firms, and that eliminating a dividend is associated with a decrease in the likelihood the loss will reverse in the immediate future. The results of these two studies are in conflict with the finding of Benartzi, Michaely and Thaler (1997) that dividend cuts reliably signal an increase in future earnings.

In another study of the same year, Joos and Plesko (2004a) examine the dividend signalling hypothesis in a sample of firms for which dividend increases are particularly costly, namely loss firms with negative cash flows, for the same period of the previous study (1971-2000). The sample has 60,026 firm-year observations for loss firms, with 18,121 observations with positive cash flows and the remaining 41,905 observations with negative cash flows. The authors find that the predictive power of dividend increases for future return on assets is greater for these firms than to loss firms with positive cash flows, consistent with the predictive power of the dividend signal being stronger when its cost is higher. In agreement with Nissim and Ziv (2001), Joos and Plesko find dividends help to predict a firm's future performance when the dividend signal is costly. Indeed, the paper's evidence strongly supports the hypothesis that costly dividend increases by loss firms with negative cash flows consistently predict future measures of performance better than dividend increases by other loss firms. Overall, their results provide support for the dividend signalling hypothesis.

Recently, there are some studies done outside the US market, like Reddy (2003), Kumar (2003) and Goergen, Renneboog and Silva (2005).

Reddy (2003) examines the dividend behaviour of Indian firms listed on National Stock Exchange and Bombay Stock Exchange during the period from 1990 to 2001 and attempts to explain this behaviour with the help of dividends theory, namely the signalling hypothesis. He followed DeAngelo, DeAngelo and Skinner (1992) approach and shows that, for the Indian Market, current losses are an important determinant of dividend reductions for firms with an established track record. Although $96.6 \%$ of the 236 firms that had at least one negative earnings year during the period of analysis had reduced dividends for at least one year, $52.4 \%$ of the firms that recorded positive earnings during the entire sample period had reduced dividends for at least one year. The author has compared his results with those of DeAngelo, DeAngelo and Skinner (1992) and concludes that the incidence of dividend reduction is much severe in Indian firms that in the American market. Furthermore, he concludes that dividend changes are 
impacted more by contemporaneous and lagged earnings performance rather than future earnings performance. These results are consistent with the findings of Benartzi, Michaely and Thaler (1997).

In the same year, Kumar (2003) study the dividend policy in the same market as Reddy (2003), but in a quite different perspective. Kumar uses a large panel of Indian corporate firms (in the context of an emerging market) listed on the Bombay Stock Exchange over the period 1994-2000. The final sample has 2,575 firms, resulting in an unbalanced panel data of 5,224 observations. When Kumar tests Lintner's model, the results show evidence that the model holds. The author finds evidence in support the hypothesis that there is a positive association between dividends and earnings trend. Moreover, he concludes that ownership is one of the important variables that influence the dividend payout policies, but does not influence it uniformly.

Goergen, Renneboog and Silva (2005) recently developed a study that analysed dividend change decisions in the context of the German market, and the relation it might have with past, current and future earnings. Their sample consists of 221 listed industrial firms over the period 1984 to 1993. During these years, there was, first, an initial period of market economic expansion and after, a period of economical recession. In general, the authors concluded that German firms benefit from a more flexible dividend policy than those of the American and British markets, essentially concerning dividend decreases and omissions. Consistent with Lintner's (1956) results, the authors found that earnings are vital to a decision to change dividends, being even more so in the case of losses: about $80 \%$ of the sample firms omitted dividends in the first year they obtained losses, after at least five years of profits and dividend payments. These results are in contrast with those of DeAngelo, DeAngelo and Skinner (1992), since according to these authors, only $15 \%$ of the companies that obtained losses omitted dividends and only about 51\% reduced dividends. In a previous study, DeAngelo and DeAngelo (1990) found that managers with a long tradition of paying dividends have only a small propensity to decrease dividends. In this case, firms tend to decrease dividends only if the earnings problem is permanent.

Moreover, Goergen, Remeboog and Silva (2005) postulated that a majority of the sample firms quickly restored the initial level of dividends payment after their omission or reduction, since about $45 \%$ and $76 \%$ of the companies restored the initial level of dividends in the first or second year, respectively, following their omission or reduction. 
These last results contradict Lintner's (1956) and MM's (1961) view that managers only change dividends if they believe that earnings will be permanently, not temporarily affected, and suggest that, in Germany, dividends have a less important signalling role than in the US or the $\mathrm{UK}^{28}$.

Fernández and Jorge (2003) tried to identify variables that influence the dividend policy of different European markets. Their results support Lintner's (1956) conclusions that managers try to smooth dividends and are reluctant to decrease them. They find strong support for the signalling theory in Anglo-Saxon countries (the UK and Holland), weak evidence for Italy and France, and no support for this theory in the cases of Germany, Switzerland and Spain.

According to empirical evidence, firms that increase their dividends are expected to have a better performance before that announcement than those who decrease them. Several authors analysed this question, such as Charest (1978), Michaely, Thaler and Womack (1995) and Benartzi, Michaely and Thaler (1997).

Charest (1978) based his study in a sample of 1,720 dividend changes greater than or equal to $10 \%$, after two years or more of paying dividends, finding 1,193 cases of dividend increases and 527 decreases. The sample covers the period from January 1947 to June 1968 and refers to firms listed on NYSE. Charest found that, on average, firms that announce dividend increases presented positive excess returns in the year prior to the announcement, as well as in the two following years, while the firms that announced dividend decreases showed negative returns in the year prior to the announcement and in the following two years after that as well. The dividend increase (decrease) announcement month was the one showing the highest (lowest) average return, which could be an indication that the market recognises the dividend information content of the announcement period ${ }^{29}$. In the case of dividend decreases, the effect was greater, which supports evidence of asymmetric behaviour in the market when it comes to dividend increases or decreases. The same behaviour was found in several subsequent studies, e.g. Aharony and Swary (1980), Healy and Palepu (1988), Michaely, Thaler and Womack (1995) and Nissim and Ziv (2001). The average accumulated return in the year prior to the dividend announcements was about $+8 \%$ for increases and about $-13 \%$,

\footnotetext{
${ }^{28}$ This aspect may be due to the fact that there is no fiscal disadvantage to dividends when faced with capital gains in the German market.

${ }^{29}$ However, the potential effect of earnings announcements was not isolated, so this conclusion is somewhat doubtful.
} 
for decreases. For performance after dividend announcements, Charest (1978) found an abnormal return of about $+4 \%$ in the two years after a dividend increase announcement and a negative return of roughly $-8 \%$ in the case of firms that decreased dividends. There is also a more evident effect in the cases of decreasing dividends concerning the year prior to the announcement, as well as in the year that follows it.

Michaely, Thaler and Womack (1995) studied two extreme situations: dividend initiations and omissions. They found an excess return in the announcement period of $+3.4 \%$ and $-7 \%$, respectively for dividend initiations and omissions. The long-term excess returns were, respectively, $+24 \%$ and $-15.3 \%$. Furthermore, they found evidence of firms that initiate dividends having better performance than those that omit them.

Benartzi, Michaely and Thaler (1997) analysed the issue of whether dividend changes signal future or past earnings. They considered a sample of 1,025 firms listed on NYSE or AMEX, during the period 1979-1991. They found a lagged and contemporaneous relation between dividend changes and earnings. However, consistent with Watts' (1973) and DeAngelo, DeAngelo and Skinner' (1996) evidence, their analysis shows that in the two years following dividend increases, earnings changes are unrelated to the sign and magnitude of dividend changes. In line with Healy and Palepu (1988), these authors found evidence of earnings increase in the two years following dividend decreases. Moreover, the authors used the Michaely, Thaler and Womack (1995) sample to analyse extreme cases of dividend initiations and omissions, and the results mimicked those of Healy and Palepu. Whether in the case of dividend initiations or omissions, earnings improved in the two years after the dividend announcement. If in the first case the evidence is consistent with signalling theory, the same does not apply in the second situation. Moreover, they calculated the average excess return in the three days surrounding the dividend change announcement, finding a value of $-2.53 \%$ for the case of dividend decreases and of $+0.81 \%$ for dividend increases. Determining returns for three years after dividend changes, they found a return of $+1.4 \%$ for the case of dividend decreases and $+8 \%$ for increases; only the latter was statistically significant. Although the values found by Michaely, Thaler and Womack (1995) were significantly higher, we should have in mind that dividend omissions and initiations are more dramatic than dividend increases and decreases. Thus, the price reaction would be more significant for the more dramatic events. 
Benartzi, Michaely and Thaler concluded that firms that increase their dividends signal to the market that the increases in earnings in the dividend announcement year and the following year seem to be more permanent than the earnings increases in firms that did not increase their dividends. This conclusion suggests the presence of informative content in dividends, as in Lintner's (1956) perspective, in the sense that management only increases dividends when there is a belief that earnings will have a sustained growth. Benartzi, Michaely and Thaler concluded that according to their results, dividends react to changes in past and current earnings, rather than acting as forecasts of future earnings. The authors conclude that firms that increased dividends presented earnings changes significantly positive in the dividend announcement year and the following year, especially those companies with bigger dividend changes, while firms that announced dividend decreases presented negative earning changes in the year prior to the announcement, which is statistically significant, and consistent with the idea that firms that increase dividends have better performance than those who decrease them.

More recently, Lee and Ryan (2002) analyse the dividend signalling hypothesis and the issue of whether earnings cause dividends or vice-versa. For a sample of 133 dividend initiations and 165 dividend omissions, they find that dividend payment is influenced by recent performance of earnings, and free cash flows. They also find evidence of positive (negative) earnings growth preceding dividend initiations (omissions).

Recently, Grullon, Michaely and Swaminathan (2002), Koch and Sun (2004) and Benartzi et al. (2005) confirm the conclusions of Benartzi, Michaely and Thaler (1997).

Grullon, Michaely and Swaminathan (2002) use a sample of 7,642 dividend change announcements from firms listed on NYSE and AMEX, between 1967 and 1993, of which 6,284 were dividend increase announcements and 1,358 were decreases. Their results, as well as those of Benartzi, Michaely and Thaler (1997) contradict dividend signalling models, as their results indicate that dividend changes do not transmit information about earnings growth or level of earnings. Tests conducted by these authors show that, for their sample, earnings not only do not increase, but even decrease. When analysing performance as a consequence of dividend policy change, the authors looked at a short-term perspective, as well as a medium and long-term perspective. The average annual returns were $+1.34 \%$ and $-3.71 \%$, respectively for the dividend increases and decreases. For the three years after the dividend changes, the return shows a significant improvement after the dividend declines. 
Moreover, Grullon, Michaely and Swaminathan (2002) analyse the effect of dividend changes on firms' systematic risk, concluding that for firms that increased dividends, systematic risk decreased after a decision to change dividends, resulting in a decline of the cost of capital, and, consequently, a positive reaction of prices to this type of announcement. The reaction was opposite in the case of dividend decreases, where there could be a risk increase as a consequence of negative dividend changes. Their analysis allowed the authors to say that the effect of risk dominates the effect associated with returns.

The results of Grullon, Michaely and Swaminathan are, partly, consistent with Lintner's (1956) model and with the hypothesis of free cash flow of Jensen (1986). In the first situation, they found evidence that the payout ratio increased permanently in firms that increased dividends, which suggests that these companies wished to keep a high level of dividends. Regarding the free cash flow hypothesis Jensen (1986) and Lang and Litzenberger (1989), the authors stated that firms that increased dividends maintained the level of future capital expenditure, and, in fact, this hypothesis claims that firms increase cash flow payments in anticipation of a decrease in investment opportunities. In spite of these two pieces of evidence, neither Lintner's model nor Jensen's can fully explain the authors' results, so they provide an alternative explanation, which they denominated "maturity hypothesis". According to their explanation, an increase of dividends is part of the process of a firm moving from a phase of growth to maturity ${ }^{30}$. After dividend increases, the authors found a decrease in systematic risk. As firms have fewer investment opportunities, there is a consequent decrease of investment returns, as well as in the growth rate of earnings. As there is a decrease in capital expenditures, the free cash flow increases. Thus, maturity generates available cash flow that can be distributed to shareholders as dividends.

Koch and Sun (2004) examine the role of changes in dividends in informing investors about the persistence of past earnings changes, shifting the focus to the role of dividend changes in altering investors' perceptions of past earnings. Their sample consists of 6,395 dividend change announcements made by 1,682 NYSE, AMEX and NASDAQ

\footnotetext{
${ }^{30}$ During the growth period firms have a lot of projects with positive net present values (NPV) available. Thus, the earnings are high, the cash expenses are significant and the available cash flows are low. With continued growth, more competitors enter the same industry, the market share decreases and earnings decline. During the transition period, investment opportunities begin to decline and firms have more free cash flow. When they enter the maturity phase, investment return is near capital cost and available cash flow is high, so firms can increase dividends.
} 
firms between 1983 and 1999. Overall, their results are similar to the ones documented by Benartzi, Michaely and Thaler (1997). The authors found evidence consistent with the hypothesis that the market interprets changes in dividends as information about the persistence of past earnings changes. This evidence suggests that part of the dividend announcements effect is a delayed reaction to past earnings news.

Benartzi et al. (2005) analyse the relation between dividends and earnings changes, based on the model of Fama and French (2000). For their study they considered 2,637 firms listed on the NYSE and AMEX for the period between 1963 and 1999, having 12,371 cases of dividend increases, 971 decreases and 22,918 cases of no dividend changes. After analysing the sample, they concluded, like Michaely, Thaler and Womack (1995), among other authors, that dividend decreases are a rarer phenomenon than increases, but much more extreme in terms of magnitude. The firms that increased dividends were bigger and more profitable than the others.

They started to apply Nissim and Ziv's (2001) methodology concluding that, when the earnings expectations model is linear, dividend changes convey some information about future earnings changes. However, they criticise the work of these authors, showing that Nissim and Ziv's assumption of the reversion in earnings is inappropriate. Previous studies indicate that the reversion process in the case of earnings is highly non- linear (Fama and French (2000) . Benartzi et al. dealt with this question using a model of unexpected earnings that explicitly controls the non-linear behaviour of earnings, based on the work of Fama and French (2000). Globally, they did not find evidence that dividend changes would contain information on future earnings growth, suggesting that dividend changes are an unreliable means to future earnings forecasts.

The main results of Benartzi et al. are the following: (1) after having controlled the nonlinear model in earnings behaviour, dividend changes do not contain information about future returns changes; (2) dividend changes are negatively correlated with future asset returns changes; this result is consistent with the work of Grullon, Michaely and Swaminathan (2002); (3) earnings models that include dividend changes do not have a better performance than those that do not include dividend changes.

Finally, the authors conclude their work stating that dividend changes are not useful in future earning changes forecasts, and that if dividends signal anything, it is neither earnings nor returns. These results are inconsistent with the signalling dividend model, 
and with some empirical evidence. However, these studies had not contemplated earnings non-linearity.

Consistent with both the maturity hypothesis of Grullon, Michaely and Swaminathan (2002) and the signalling hypothesis, are the results of Lai, Song and Fung (2004). In this recent study, the authors examine why firms significantly increase dividends by focusing on the post announcement firms' characteristics. Their sample consists of 6,215 dividend increase announcements of firms listed on NYSE and AMEX from 1967 to 1997. The authors group the sample on the basis of post-announcement performance (cash flow returns) and the evidence suggests that some firms increase dividends because they are at the maturity stage (the bottom performance group), while other firms (the top performance group) try to signal the market. Therefore, Lai, Song and Fung conclude that the maturity hypothesis and the signalling hypothesis can co-exist.

One of the most important assumptions of the signalling hypothesis is that dividend changes are positively related to future changes in earnings. Globally, the evidence does not consistently support this rule. During the last thirty years, there have been several empirical studies that challenge the signalling model of dividends, such as those of Watts (1973), Gonedes (1983), Penman (1983), DeAngelo, DeAngelo and Skinner (1996), Benartzi, Michaely and Thaler (1997) and, more recently, Grullon, Michaely and Swaminathan (2002), who found little or no evidence that dividend changes forecast abnormal earnings changes. However, Nissim and Ziv (2001) and most recently Dhillon, Raman and Ramírez (2003) documented a significant positive relationship between dividend changes and future earnings. Lease et al. (2001) pointed out that the weakness of future earnings supported on dividends is based on the fact that the market interprets dividends signalling as a function of firms' investment opportunities ${ }^{31}$. Summarising, if firms try to signal the market through dividend policy, this is not always a sign of future earnings growth, and the market sometimes does not get the message.

Table 2.1 summarises the main studies conducted on the effect of dividend change announcements on future earnings forecasts. As we observe in this table, the empirical

\footnotetext{
31 The investment opportunities and the internal transactions that surround the dividends announcement date may be seen as variables that restrain the informative content of dividends. To analyse this aspect see John and Lang's (1991) work. Studies such as those of Lang and Litzenberger (1989) and Holder, Langrehr and Hexter (1998) suggest that the information content of dividends may well depend on a firm's investment opportunities.
} 
evidence is mixed. Dividend policy thus continues to remain a puzzle and the research in this domain is still an unfinished process...

\subsubsection{The EFfect of Dividend ANNouncements on Share Prices}

The underlying hypothesis of the studies done in this domain is that unexpected dividend changes should be positively associated with share price changes ${ }^{32}$, providing evidence that financial markets interpret correctly dividend changes.

There have been a significant number of empirical tests carried out with the purpose of analysing the effect caused by dividend change announcements on share prices. In general, they show that dividend change announcements lead to a change in share prices in the same direction.

Pettit (1972) found strong support for the assertion that dividend change announcements convey information to the market and concluded that this information is superior to that sent by earnings announcements. Pettit based his study on the dividend change announcements of 625 firms with shares listed on NYSE, in the period between January 1964 and June 1968. There were about 1,000 announcements throughout this period. The author concluded that most of the information implied by dividend announcements is reflected in share prices at the end of the announcement period. He asserts that dividend increase announcements are followed by a significant increase in share prices, and that dividend decrease announcements are followed by a significant decrease in prices. Pettit's results have been criticised by several authors because his study was based on observed dividends, instead of unexpected dividend changes.

Pettit (1976) performed a study to evaluate which factors could explain the different results of Watts (1973) and Pettit (1972), because while Watts (1973) did not find conclusive evidence that there is a significant relation between dividend changes and share prices, Pettit (1972) asserts that they were related. Pettit refers that Watts's results may be due to the use of an inappropriate methodology that may lead to the interaction

\footnotetext{
32 A positive association between dividend change announcements and share price reactions is also consistent with the free cash flow hypothesis Jensen (1986). As have been tested by Lang and Litzenberger (1989), firms with high levels of free cash flow will have tendency to overinvest, accepting investment projects with negative NPV. In this context, a dividend increase (decrease) will reduce (increase) the extent of overinvestment and increase (decrease) the firm's market value.
} 
of the information effect related to the declaration of dividends and earnings. Having restructured Watts and Pettit methodologies (1972), Pettit (1976) showed that if Watts had used a different method, his results would have been similar to Pettit's (1972). These results suggest that dividend announcements convey relevant information to the market. Laub (1976) supported Pettit's results (1976) by finding evidence of dividend announcement effect and disagreed with Watts's conclusions (1973).

Kwan (1981) improved Watts' methodology (1973), emphasising the isolation of dividends information in relation to other sources of information that were publicly available, including information about earnings, a point ignored by Watts. He considered 183 dividend change announcements, including 20 cases related to decreases and omissions of dividends of firms listed on NYSE between 1973 and 1977. Kwan concluded that Lintner's (1956) and Fama and Babiak's (1968) models both perform well in the identification of dividends information. The empirical evidence supports Pettit's results (1972) since dividends convey information to the market; there is also statistically significant evidence of an abnormal return when firms announce unexpected dividend changes. Ross (1977) also argues that an increase in dividends is a clear message because: (1) firms that do not anticipate higher earnings cannot carry it out, and (2) managers have the incentive to "tell the truth".

Aharony and Swary (1980) tested the extent to which information regarding dividend announcements is useful to the market, and concluded that quarterly dividend change announcements convey more information than those of earnings announcements ${ }^{33}$. Based on a sample of 149 industrial firms listed on NYSE between 1963 and 1976, Aharony and Swary found support for the hypothesis that changes in quarterly dividends provide useful information, which affects share prices, reaching conclusions similar to Pettit's (1972) concerning the relation between dividend changes and share prices, maintaining the result even when controlling for the earnings announcements effect in the same period. For a sample of 384 dividend changes, the authors report average significant excess returns on the announcement day of $+0.36 \%$ in case of dividend increases, and $-1.13 \%$ for dividend decreases. Their results support the dividend information content hypothesis as well as the semi-strong market efficiency, since, on average, share prices adjust in an effective way to new public information about quarterly dividends.

\footnotetext{
${ }^{33} \mathrm{He}$ considered dividend announcements that differ from earnings announcements by at least 11 days.
} 
Bernheim and Wantz (1995) analysed the market reaction to dividend increases in a context of different fiscal regimes. The sample consists of 12,961 dividend increase announcements from 1962 to 1988, considering firms listed on NYSE, AMEX and NASDAQ. The authors' main conclusion is that there is a positive and strong relation between tax rates and the share price reaction by monetary unit (m.u.) to dividends ${ }^{34}$. Subsequently Bernheim and Wantz divided the sample into three different groups, in accordance with dividend rates: group I, characterised by high taxes (before 1982); group II, with median taxes, (1982 to 1986), and group III which covers 1987 and 1988, with more reduced taxes. According to the signalling theory, the share price reaction by m.u. to dividends should decrease from situation I to situation II and from II to III [John and Williams, (1985)]. Effectively, in the period of higher dividend taxes, the market reaction to their payment is more favourable, which is consistent with the dividend signalling hypothesis, because as they become costlier, the signals conveyed to the market are more revealing and significant.

Fernández and Jorge (1999) conclude that dividends are relevant in explaining share market value, which leads the authors to believe that investors consider dividends to be a sign about firms' future economic prospects. This work was based on a sample of non-financial firms listed on London Stock Exchange (LSE), in the period between 1991 and 1996, resulting in a total of 4,752 observations. The several tests done by the authors allowed them to reach the following conclusions: (1) the lower the earnings level, the more sensitive firms are to dividends; (2) dividend policy is sensitive to firms' size, because the smaller the firm, the higher the expectations are regarding future earnings; (3) dividends are more important when their increase is followed by a decrease in operational income, and they are less relevant when their decrease is followed by earnings increases, since the expectations regarding future prospects are partially advanced by positive earnings changes and (4) dividends have higher relevance when their absolute increase is followed by an increase in the payout ratio, because in this way investors believe investment opportunities would not be diminished. Globally, their results are consistent with the dividend content information hypothesis, since in accordance with this hypothesis, a dividend decrease announcement may be a pessimistic message transmitted by firms' managers regarding the expectations of future prospects.

\footnotetext{
${ }^{34}$ The author refers to the share price reaction to m.u. of dividends as "bang-for-the-buck".
} 
Lippert, Nixon and Pilotte (2000) analysed a sample of 295 dividend increase announcements from 274 firms over the year 1992. These firms were selected from a database that considered the 1,000 biggest American firms. The mean abnormal return found by the authors in the period of dividend increase announcements (considered as the announcement day and the day before) was $0.43 \%$, positive and statistically different from zero, a result consistent with the dividend content information hypothesis. However, unlike the evidence of Asquith and Mullins (1983) and Ofer and Siegel (1987), among others, Lippert, Nixon and Pilotte did not find evidence that dividend dimension affects share prices.

Viswanath, Kim and Pandit (2002) analysed the dividend signalling hypothesis for a sample of NYSE and AMEX listed firms that declared quarterly dividends from July 1986 to June 1995 . The final sample has 12,756 observations. The results differ by the sign of the dividend surprise. They only support the dividend signalling hypothesis for negative dividend surprises, and only for the earlier sub-period in the sample. Data for positive dividend changes is inconsistent with the signalling explanation, but consistent with the overinvestment and wealth transfer hypotheses.

Amihud and Li (2002) found a decreasing share price reaction to dividend change announcements since the mid-1970s, in the US market. The authors suggest that the decline in the information content of dividend announcements is partly because of the rise in shareholdings by institutional investors that are more sophisticated and informed, since the price reaction to dividend news is smaller in firms with high institutional holdings. Moreover, Amihud and Li concluded that the new information that would be conveyed by dividend news is already incorporated into the share price of firms with high institutional holdings by the time of the announcement.

From these empirical tests, we may conclude that, in global terms: (1) dividend changes are positively related to share price reaction when they are announced; (2) share price reaction is related to the magnitude of dividend changes and (3) price reaction is not symmetric in the case of dividend increases and decreases; dividend decreases have a higher impact on share prices. In sum, a firm's value goes in the same direction as the dividend change announcement, adjusting proportionately to the magnitude of and in the same direction as dividend changes.

Some studies have emphasised extreme dividend changes cases, such as dividend initiations and dividend omissions. 
Asquith and Mullins (1983) and Richardson, Sfecik and Thompson (1986) studied the effect of the first dividend announcement on the shareholder wealth. Both studies found a strong support for the effect of dividend announcements on share returns.

Asquith and Mullins (1983) compose a sample of 168 firms that either initiated dividend payments after a long haul (after a 10 year hiatus) or paid dividends for the first time during the 1963-1980 period, and, similar to those of Aharony and Swary (1980), the results show that the dividend announcement has more information than any other kind of announcement, as dividends may be used as a simple and understandable sign of the way that firm managers interpret the present performance of firms and their future evolution perspectives ${ }^{35}$. Their results are consistent with the opinion that dividends convey useful information to investors, since they report an average two-day excess return of $+3.7 \%$, which is statistically significant. However, it should be pointed out that about $32 \%$ of the firms in their sample show a negative market reaction to the initiation of dividends, which was not analysed by the authors. They conclude that the market shows a strong and positive reaction to the first dividend announcement. Although in a soft way, this reaction is maintained with subsequent dividends.

After, Richardson, Sefcik and Thompson (1986) consider a sample of 192 firms that paid quarterly dividends for the first time between 1969 and 1982. They found strong evidence for an increase in the volume of transactions during the week of the announcement, which is related to the effect of the information content of dividends. With regard to returns, they found evidence of a positive effect on cumulative mean return of $+4 \%$ during the announcement week. This result was similar to that of Asquith and Mullins (1983). Besides, the authors found weak support for the clientele's effect.

Dielman and Oppenheimer (1984) examine the investor's behaviour surrounding dividend payment announcements, in order to make some contribution to the dividend content information hypothesis. To do so, they analysed, between 1969 and 1977, four different groups of firms listed on NYSE, according to their dividend policies. The first group contained firms that initiated or resumed dividend payments, the second included firms whose dividend increases were greater than or equal to $25 \%$; the third was formed of firms that reduced dividends by at least $25 \%$ and the last group had firms that omitted the payment of dividends. In general, they found a significant positive abnormal return for the first and the second groups and an abnormal but significantly negative return in

\footnotetext{
${ }^{35}$ Their results also support the hypothesis of semi-strong efficiency of markets.
} 
the third and fourth groups. According to the authors, their results provide strong support to the dividend information content hypothesis, which is even more significant when firms omit dividends.

Michaely, Thaler and Womack (1995) analysed the market reaction to dividend initiation and omission announcements, considering both the short and the long term. They examined a sample of 561 dividend initiations and 887 dividend omissions of firms listed on NYSE and AMEX, covering the period between 1964 and 1988. Their study showed that the market reacts in a severe way to these announcements. The excess mean return in the 3 days surrounding the announcement was $+3.4 \%$ for the dividend initiations, and $-7 \%$ for the omissions. These results allow us to conclude that the market reacts asymmetrically to dividend increases or decreases, as well as to dividend initiations or omissions. In fact, Michaely, Thaler and Womack found evidence that the magnitude of price reaction in the short term is bigger in the case of dividend omissions than in the case of initiations, thus dividend decreases have higher information content than increases, possibly because reductions are less usual or because they have a higher magnitude. Other authors obtained similar results. Healy and Palepu (1988) found a $+3.9 \%$ increase in the prices in their sample of dividend initiations and a $-9.5 \%$ decrease in their sample of omissions. This difference also applies to non-extreme dividend changes. Aharony and Swary (1980) found evidence of excess returns of $+0.4 \%$ for dividend increase announcement day and $-1.1 \%$ for the announcement of dividend decreases and Grullon, Michaely and Swaminathan (2002), considering dividend changes greater than $12.5 \%$, found an average abnormal return on the three days surrounding the dividend change announcements of $+1.3 \%$ for dividend increases and $-3.7 \%$ for dividend decreases.

For the long-term analysis, Michaely, Thaler and Womack (1995) considered a 3-year period and concluded that price changes in cases of dividend initiation announcements were positive and statistically significant, with adjusted market returns of about $25 \%$ in the three years after dividend initiations. In the case of omissions, a more robust result, price changes were negative and also significant, showing a negative return of $-15 \%$. Michaely, Thaler and Womack (1995) found evidence that the omission dividend announcements have a greater impact on prices than dividend initiation announcements. This impact might explain, at least partly, why managers are so reluctant to decrease the level of dividends. 
Healy, Hathorn and Kirch (1997) examined the relationship between earnings momentum and the capital market's reception of a firm's initial dividend announcement, emphasising the enigmatic case of a negative market reaction to the first cash dividend. They analysed a sample of 181 firms with initial dividend announcements $^{36}$ in the years 1976-1985. They found that firms with low earnings growth generate higher excess returns than firms with high earnings growth. The authors pointed out that firms with significant growth can probably convey to the market the idea that they cannot maintain this growth in the future or that they do not have the prospect of good investment opportunities, which may be treated by the market as a sign of an economic activity decline, while firms with more reduced earnings growth rates can signal improvement in their future economic prospects.

When they analysed the cumulative abnormal return for the two days surrounding dividend announcements (days -1 and 0 ), they found an average value of $+1.7 \%$, significant at a $1 \%$ level. This result is consistent with the one found by Dielman and Oppenheimer (1984), of $+2.2 \%$, lower than the values found by Asquith and Mullins (1983), +3.7\%, and Michaely, Thaler and Womack (1995), 3.4\%, and higher than Romon's (2000) value, who found a value of $+0.8 \%$ for dividend increases.

They also found evidence that $42.5 \%$ of the firms show a negative abnormal return in the two days analysed, which once more, is consistent with Asquith and Mullins's results (1983) that found a value of 31.9\%, Dhillon and Johnson (1994), with a value of about 50\%, and, very recently, Borokhovich et al. (2004), with a value of $41.7 \%$. Healy, Hathorn and Kirch supported the idea that the market reaction can be connected to firmspecific factors. In fact, the authors found differences in the characteristics of firms with a negative capital market reaction and the other firms when an initial dividend was announced. They observed that firms with negative capital market reactions, on average, have lower dividend yields, lower price/earning ratios (PER), higher debt/equity ratios, and higher current ratios. Analysing the relation between the probability of a negative market reaction to an initial dividend announcement and the firm's specific characteristics, they found negative and statistically significant values for the dividend yield and PER variables and positive and significant values for the debt/equity and current ratios variables. The behaviour related to the dividend yield suggests that

\footnotetext{
${ }^{36}$ The initial dividends were defined as the first dividend after a non-payment for at least 10 years. The firms that paid special or extra dividends were not considered in the sample.
} 
investors react positively to higher dividend yields. In the case of PER, the results show that investors seem to believe that firms with high PERs are signalling continuing growth opportunities. The behaviour with respect to the debt/equity ratio suggests that the market is more likely to react negatively when a firm's debt is high because of the greater risk of covenant violations. Similarly, the positive coefficient of the current ratio suggests that investors perceive an initial dividend payment as increasing the risk of debt covenant violations. Generally, the evidence of Healy, Hathorn and Kirch (1997) is consistent with firms using initial dividend announcements to signal their future economic prospects. In addition, when they analysed the future performance of firms, they found evidence supporting the dividend signalling hypothesis.

Some years later, Ryan, Besley and Lee (2000) examined share price reactions to announcements of initiation and omission of dividends, like Michaely, Thaler and Womack (1995), but considering NASDAQ firms during the period 1976-1991. Their results provide strong support for the dividend signalling hypothesis in the explanation of dividend changes. However, they cannot rule out free cash flow arguments as a partial complement to the general signalling hypothesis. They found a return for the event window $(-1,0)$ of $+4.1 \%$ for dividend initiations and $-1.8 \%$ for dividend omissions, and a return for the event window $(-1,+1)$ of, respectively, +5.1 and $-5.7 \%$, all statistically significant. Unlike Michaely, Thaler and Womack, these authors do not reveal a greater reaction to dividend omissions than to dividend initiations. Additionally, Ryan, Besley and Lee found results consistent with the semi-strong form of market efficiency for the omitted dividend sample, as this sample does not see a significant wealth change immediately prior to or after the omission ${ }^{37}$.

In the same year, Lee and Ryan (2000) analysed a sample of 126 dividend initiations and 162 dividend omissions for industrial firms listed on the NYSE and the AMEX, finding strong support for the dividend signalling hypothesis that the level of information conveyed drives the share price reactions. Two years later, Lee and Ryan (2002) provide further support for the dividend signalling hypothesis, analysing a sample of 133 dividend initiations and 165 dividend omissions for NYSE firms covering the period between 1976 and 1989.

\footnotetext{
${ }^{37}$ Aharony and Swary's (1980) also found evidence for the semi-strong form of market efficiency.
} 
Boehme and Sorescu (2002) analysed several extensions to Michaely, Thaler and Womack's (1995) sample, showing that, not including the shares of the sample's bigger firms, the positive change in share prices after dividend announcements was limited to a period between 1964 and 1998. The authors analysed the long-term performance of shares after the initiation or resumption of dividends ${ }^{38}$, in the period between 1927 and 1998, for firms listed on NYSE, AMEX or NASDAQ. The final sample has 2,886 events, with 1,645 dividend initiations and 1,241 dividend resumptions. Boehne and Sorescu concluded that the long-term abnormal return after dividend declarations seems to be significant, but only when portfolios are equally weighted, and limited to the three years after dividend initiations or resumptions. Weighting the values by firm size, the results show that the returns are statistically insignificant, suggesting that share price changes are restricted to the smaller firms of the sample. Moreover, they found evidence of risk reduction after dividend announcements, being negatively related to abnormal returns, which agree with Grullon, Michaely and Swaminathan's results (2002).

According to the signalling theory, dividend omissions should result in a more pronounced adjustment of the market than dividend reductions, but some authors showed that this is not always the case, such as Benesh, Keown and Pinkerton (1984) and Christie (1994).

Benesh, Keown and Pinkerton (1984) found evidence of share price decreases higher in the case of dividend decreases than omissions. These authors analysed the market reaction to significant dividend changes using Aharony and Swary's (1980) methodology. They considered four groups of samples: dividend omissions after four successive quarters of dividend payments, dividend decreases of at least $25 \%$, increases equal to or greater than $25 \%$ and finally dividend initiation payments (or resumptions of dividends after a hiatus of four quarters). The sample has 28 dividend omissions, 32 decreases, 34 increases and 45 dividend initiations, occurred between 1971 and 1978. The earnings announcements are separated by at least 11 days from dividend announcements. This hiatus is consistent with Aharony and Swary's (1980) methodology, which allows compare the results and control the earnings announcement effect. After the empirical tests, the authors found an yearly mean return of about $-8 \%$ in the announcement period (days -1 and 0 ) for the dividend omissions and about $-10 \%$

\footnotetext{
${ }^{38}$ They considered as dividends resumption the cases in which firms restarted dividend payment after a hiatus of 33 to 180 months.
} 
for the dividend decreases. As these values are statistically significant, the authors concluded that the information conveyed to the market is relevant when significant dividend reductions are announced.

Additionally, they found that reaction to dividend increases is weaker than reaction to dividend decreases, which means that the market has a stronger reaction to negative changes of dividends than to positive ones. These results support the studies that conclude that market reaction to dividend decrease or omissions announcements is stronger than to dividend increases or initiations. In the last two cases, reactions are stronger for dividend initiations possibly because dividend initiation declarations are harder to predict and therefore, are a bigger surprise to the market. The yearly mean return on the announcement period (days -1 and 0 ) for dividend initiations was $+4.3 \%$, which is close to the $+3.8 \%$ found by Bulan, Subramanian and Tanlu (2004) and the $+3.7 \%$ found by Asquith and Mullins (1983) and greater than the value found by Aharony and Swary (1980), of about 1\%. These results suggest that dividend initiation announcements contain more relevant information than those of dividend increases. Thus, Benesh, Keown and Pinkerton's results (1984) support the dividend content information hypothesis. However, the authors found that about $21.9 \%$ to $62.5 \%$ of the sample firms showed an adverse reaction, in that dividend initiations or increases led to share price decreases and dividend omissions or decreases led to share prices increases. This evidence justifies attempts to understand this behaviour.

Christie (1994) had reached to similar conclusions. Using a sample of 492 dividend omissions and 475 dividend reductions, in the period between 1962 and 1985, Christie concluded that dividend reductions led to share price decreases greater than those resulting from dividend omissions.

Although the market reacts negatively to dividend decreases, Grullon and Michaely (2002) found evidence that market reaction to dividend decreases is significantly less negative for firms that repurchase shares than for those that do not. They based their empirical study on a sample of 1,255 dividend decrease announcements from 1974 to 1996. In the case of firms that repurchased shares, the market reaction was close to zero in the face of dividend decreases, while in firms that did not repurchase shares this reaction was highly negative. These results support the idea that dividends and shares repurchase are close substitutes, which is consistent with the signalling patterns of Bhattacharya (1979) and Miller and Rock (1985). In this case, investors understand that 
dividends are being replaced by repurchase of shares, so their reaction to dividend decreases is less aggressive, as only a minor penalty is attributed to them.

Kalay and Loewenstein (1986) studied whether dividend announcement timing contains relevant information. Their empirical evidence shows that the market expects bad news to be sent out later on. Indeed, the authors confirmed these expectations. Kalay and Loewenstein analysed 2,766 dividend announcements in the year 1981, testing as null hypothesis that dividend announcements do not affect share returns. They divided the sample into five different groups: (1) announcements made on the expected date; (2) announcements made at least five days before expected; (3) announcements made at least five days after expected; (4) announcements made earlier than expected, but within five days of the expected date and (5) announcements published after expected, but in a period within five days of the expected date. If timing is important, significantly different price reactions will be found on the several portfolios, supporting the existence of dividend content information hypothesis on the announcement timing. If reactions are not different among the portfolios, the conclusion will be the opposite.

The results obtained in this study show that share returns surrounding late announcements are negative, although they are not statistically significant, so, later announcements convey, on average, negative information, while for early or on schedule announcements, the return is significantly positive. According to Kalay and Loewenstein (1986), the market interprets correctly the postponement of dividend announcements as containing negative information. When the announcements are reported late, the market gradually adjusts share prices between the expected and effective announcement date. That is why the price change on the dividend announcement day is lower than when the dividends are announced in advance. Thus managers can reduce the immediate impact of a negative announcement, postponing it. However, it is not clear what the forthcoming benefits in this situation might be.

There are authors looking for evidence in particular markets: (1) European or other markets not yet very explored, like the studies of Gugler and Yurtoglu (2003) and Lasfer and Zenonos (2004) and (2) emerging markets, as Aivazian, Booth and Cleary (2003a, 2003b). Simultaneously, Travlos, Trigeorgis and Vafaes (2001) and Gurgul, Madjosz and Mestel (2003) analyse markets with very small samples.

Romon (2000) has analysed the French market, examining the effect of regular dividend announcements on share prices for firms listed on the Paris Stock Exchange that 
distributed a regular dividend each year between 1991 and 1995. After adopting an approach to control for earnings announcements and to proxy for dividend announcement dates ${ }^{39}$, he found a positive abnormal return of $0.8 \%$, for the case of dividend increases, statistically significant, in the period -1 to +1 . For dividend no changes, the abnormal returns are not statistically significant. Those results support the dividend information content hypothesis.

Gugler and Yurtoglu (2003) analyse 736 dividend change announcements in Germany, where ownership concentration is very high, over the period from 1992 to 1998. Their results show that the market reacts more negatively when large uncontrolled shareholders reduce the dividends they are willing to pay out to the minority shareholders, suggesting a considerable monitoring function of large shareholders other than the largest shareholder. According to the authors, large shareholders may be beneficial, because they have superior incentives and capacity to monitor corporate managers. However, concentrated ownership has agency problems, since large shareholders have also the incentive and capacity to expropriate small and outside shareholders. Gugler and Yurtoglu suggest that to arrive at more efficient capital markets in Europe, better minority shareholder rights protection and increased transparency are called for.

Gurgul, Madjosz and Mestel (2003) examined reactions to dividend announcements using data from the Austrian market, a very small market compared to other Western European markets, and they showed that dividend policy is an important source of information for investors on Austrian share markets. Their sample consists of 175 dividend announcements associated with 22 firms listed on the Austrian share market. In line with most related studies in other markets they find evidence that dividend increases (decreases) induce a significant positive (negative) reaction in share prices and constant dividends leave share prices unchanged. The average abnormal return on the announcement day was $+0.65 \%$ for dividend increases and $-1.29 \%$ for dividend decreases. In the case of constant dividends, the average abnormal return was $-0.01 \%$. The authors' results support the hypothesis that investors mainly prefer regular and higher payments to capital gains, as well as that bad news has a stronger impact on financial markets that good news. Furthermore, Gurgul, Madjosz and Mestel (2003)

\footnotetext{
39 As the author said, in France they do not possess a database gathering dividends and earnings announcement dates.
} 
found evidence of semi-strong market efficiency, since the results provide evidence that the Austrian share market digests news on dividends at least within one day, as there were no subsequent abnormal price changes after the announcement day.

Lasfer and Zenonos (2004) test the information content of dividend announcements in four European markets: UK, Germany, France and Italy. The final sample consists of a total of 12,577 dividend announcement events in the UK, 1,412 both in Germany and France and 873 in Italy, for the period from August 1987 to August 2002. The authors found that announcement dates abnormal returns are not significant in France (in contrast with Romon results), Germany and Italy, but significant in the UK. The authors relate their results to differences across countries in the corporate governance systems and the level of information asymmetries. Generally, they lead to the conclusion that in the UK, where information asymmetry is high, managers use dividends as a mechanism to mitigate information asymmetries.

Travlos, Trigeorgis and Vafaes (2001) develop an empirical study in order to analyse the market reaction to cash and share dividend increase announcements of firms listed on the Cyprus Stock Exchange, considered as an emerging capital market. They used a sample of 41 cash dividend increase announcements corresponding to 31 firms and 39 share dividend announcements corresponding to 30 firms. They consider the period from 1985 to 1995. The authors found a positive and significant abnormal return after the dividend increase announcements both for cash and share dividends, being more pronounced in the latter. In fact, when the announcement period is considered as the five days surrounding the dividend announcements (day -2 to 2 , where zero is the dividend announcement day), the cumulative mean abnormal return was of $+1.9 \%$ and $+1.5 \%$, respectively, in the cases where they considered the market pattern and the adjusted market pattern. For a two-day period ( -1 and 0$)$, the values were $+0.7 \%$ and $+0.6 \%$, being the latter statistically significant. These results agree with those obtained in several tests carried out in developed capital markets, such as the case of Aharony and Swary (1980), Asquith and Mullins (1983) and more recently Grullon, Michaely and Swaminathan (2002).

However, developing supplementary tests, Travlos, Trigeorgis and Vafeas did not find evidence of alternative explanations for dividend policy, apart from the signalling effect. The authors point out two possible explanations for this phenomenon: the reduced sample dimension and the presence of investors not able to distinguish the 
influence of dividend policy on the value of firms with different information characteristics, agency relations or liquidity. Glen et al. (1995) have already analysed the dividend policy of firms in emerging markets and observed that dividends have little signalling content in these markets, as well as these markets are less concerned with volatility in dividends over time, being dividend smoothing over time less important than in advanced capital markets.

Aivazian, Booth and Cleary $(2002,2003 a)$ analysed the interaction between dividend policy and the type of debt issued by a firm, being the latter based on a sample of emerging markets.

In the first study, Aivazian, Booth and Cleary (2002) found an interaction between the two variables. Their sample consists of American firms with available data on Compustat database in the period between 1981 and 1999, containing a total number of 127,516 observations. They assert that it is more likely that firms with access to the public debt market show higher dividend payout ratios than those with access to bank debt; they should follow closely Lintner's (1956) style of dividend smoothing policy. Since the latter type of firm transmits information to the banks when it asks for loans, some of it considered confidential, it would not have as much necessity to resort to dividends to solve agency or signalling problems. In addition, Aivazian, Booth and Cleary found that firms which pay more dividends are of larger size, are more profitable and show lower debt ratios. They documented that the probability of firms paying dividends increases with earnings and decreases with debt level, as well as with the existence of growth opportunities, and that the probability decreased throughout the sample period. Their evidence is consistent with the results of Fama and French (2001). Aivazian, Booth and Cleary (2003a) considered markets with different characteristics concerning the financing system, analysing eight emerging markets in the period between 1980 and 1990, and comparing them with the dividend policy of 100 American firms in the same period. In the US there is a financing system predominantly based on the capital market, in contrast to emerging markets, where the financing system is a bank-based system.

The authors formulated the hypothesis that dividend policy is different in emerging markets, based on the fact that dividend policy is more important in countries where firms issue debt in the capital market (such as the US) rather than mainly through the banks, which they denominate as "substitute hypothesis". As these entities have access 
to company information, some of it classified as confidential, there is no pronounced need to resort to dividends to transmit information to the market, i.e. the signalling effect will be less important. Furthermore they analysed an alternate hypothesis called the "complement hypothesis", which states that dividends, instead of substituting for other information control mechanisms and agency problems, reinforce them, functioning as an attraction to capital in markets characterised by some lack of transparency and weak investment protection. The results show that firms in emerging markets are less reluctant to change dividends (decrease or increase them). In general, it is harder to foresee dividend changes in these markets because a firm's performance is similar in cases of both an increase and a decrease in dividends. The greater instability and unpredictability of dividends in these emerging markets is consistent with the axiom that there is a smaller signalling function in the bank-based system. These results validate the ones obtained in the preceding work [Aivazian, Booth and Cleary (2002)] regarding American firms which issue mainly bank debt.

Aivazian, Booth and Cleary (2003a) found evidence supporting the substitute hypothesis and not the complement hypothesis in emerging markets, that is, they support the assumption that dividend policy is a device less viable for signalling future earnings in this type of market, compared to the American market. So, there is no evidence that emerging markets firms emphasise dividend payments to signal or to minimise agency costs. In addition, the authors analysed Lintner's (1956) model. Although this model had shown a good performance in the American market, finding coefficients similar to the ones of Dewenter and Warther (1998), the same did not happen in emerging markets. Current dividends are shown to be less sensitive to past dividends in emerging markets than in the American market.

In another study, Aivazian, Booth and Cleary (2003b) examined the influence of some performance ratios on the dividend policy definition for firms in eight emerging markets (classified as bank-oriented countries), comparing the results with a sample of 99 American firms (market oriented country). The authors began by finding that emerging and US markets firms exhibit a similar dividend behaviour, as dividends are explained by profitability, debt and the market-to-book ratio. However, the emerging market firms are more sensitive to some factors, such as the return on equity ratio and debt ratios, which may be a consequence of the financial system in which they operate. Also, those 
firms seem to be more affected by the asset mix (dividends are negatively related to the assets' tangibility ${ }^{40}$ ), which seems to be due to their great reliance on bank debt.

Countries that show higher return on equity ratios are the ones that pay larger dividends. The financial situation affects earnings distributions, since higher debt ratios match up lower dividend payments. Against expectations, the authors found evidence of a positive effect between the market-to-book ratio and dividend payments. Additionally, they found weak evidence that a firm's business risk or dimension affect in a significant way the earnings amount to be distributed to investors. They observed that, although emerging market firms operate under more financial constrains, they pay higher dividends than their US counterparts, which is still a puzzle without solution. Aivazian, Booth and Cleary (2003b) conclude that the heavy reliance on bank financing and the relative small emphasis placed on external capital markets as a source of finance in developing economies alleviates the informational asymmetry problems and reduces the signalling value associated with dividends. As a result, dividends are less sticky in less developed capital markets.

Woolridge (1983), Handjinicolaou and Kalay (1984) and Dhilon and Johnson (1994) analysed the dividend announcement effect on both the share prices and bond prices.

Woolridge's (1983) study relied on 411 dividend change announcements referring to 225 firms listed on NYSE, between 1970 and 1977. This author showed that results are consistent with the dividend content information hypothesis as well as the wealth transfer hypothesis, but the main factor influencing share reaction to dividend changes is the signalling effect, which dominates the latter.

Handjinicolaou and Kalay (1984) found that in a sample of 255 nonconvertible bonds connected to firms listed on NYSE, which had announced at least one dividend payment during 1975 and 1976, bond prices were not affected by unexpected dividend increases, but they reacted negatively to dividend reductions. For the authors this price behaviour is consistent with the dividend content information hypothesis. They also suggest that unexpected dividend increase announcements tend to increase a firm's market value.

Dhillon and Johnson (1994) found that not only share prices but also bond prices change significantly in reaction to the announcement of changing dividends. Their

\footnotetext{
${ }^{40}$ According to the authors this situation may be due to the fact that the higher the percentage of fixed assets in total assets, the lower the weight of current assets to face short-term bank debt, which is the main financing source in most of these countries.
} 
sample consists of dividend increase and decrease announcements, including the extreme cases of dividend initiations and omissions ${ }^{41}$, for firms listed on NYSE and AMEX, in the period between 1978 and 1987. They obtained 171 announcements: 61 increases (15 initiations and 46 increases above 30\%) and 70 decreases (19 omissions, 43 decreases above $30 \%$ and 8 minor decreases). Dhillon and Johnson used methodologies developed by other authors, namely by Handjinicolaou and Kalay (1984). The results show a positive and significant reaction of share prices to dividend increases of about $+1.0 \%$ and a negative reaction of bond prices. When dividend decreases are announced, the return is $-2.0 \%$, negative and statistically significant, and the bond prices rise. This behaviour supports the wealth redistribution hypothesis as bond prices move in the opposite direction to share prices. The authors' evidence does not contradict the dividend content information hypothesis, as share price variation went in the same direction as dividend changes. These authors, like Born, Moser and Officer (1988), Asquith and Mullins (1983) and Benesh, Keown and Pinkerton (1984) found evidence that about a third of their sample showed a reaction of share market price opposite to the direction of dividend changes.

Lang and Litzenberger (1989), Denis, Denis and Sarin (1994), Yoon and Starks (1995) and Lee and Ryan (2000), as well as testing the signalling hypothesis, also tested the free cash flow or overinvestment hypothesis, which states that returns reaction to dividend change announcements is higher for firms that overinvest. To analyse this hypothesis, they used the Tobin's Q ratio. However, they obtained different results.

Lang and Litzenberger (1989) tested the free cash flow hypothesis. They identified firms with over-investment as those that show a Tobin's Q less than one. Analysing dividend changes higher than $10 \%$, they found that, for dividend increase announcements, the firms with a Q lower than one showed a better performance than those that had a Q higher than one. Regarding dividend decrease announcements, the firms with a Q less than one showed a higher price decrease than the other firms. The authors showed that the reaction of share price is higher in the case of firms which exhibit Tobin's Q less than one, which is the case for firms that overinvest. If managers overinvest, a dividend increase will reduce the investment (namely on projects with a negative NPV) and increase the firm's market value, while a dividend decrease will

\footnotetext{
${ }^{41}$ The authors consider as dividend omissions the cases in which the firms omit dividend payments after a payment period of at least 2 years, and as initiations, the cases of first dividend or resumption of dividend payments, after a period of five years without earnings distribution.
} 
have the opposite effect, by diminishing the firm's market value. Another conclusion they reached is that firms that underinvest usually have a smaller share price reaction to dividend decrease announcements. The authors claim their results support the cash flow theory, but they are inconsistent with the signalling hypothesis, unlike the conclusions obtained by several authors, e.g. Healy and Palepu (1988) and Ofer and Siegel (1987). So, the evidence agrees with the hypothesis that dividend changes for firms with overinvestment convey information to the market about their investment policy.

Yoon and Starks (1995) repeated Lang and Litzenberger's test, but they covered a wide period. In their study, the share prices reaction to dividend decreases was similar both in firms with a $\mathrm{Q}$ higher or lower than one, but for dividend increases it was different, agreeing with the results obtained by Lang and Litzenberger. Nevertheless, when they controlled the dividend yield and firm size, Yoon and Starks found a symmetrical reaction both in the case of dividend increases and dividend decreases on the firms with higher and lower Q, which is not consistent with the free cash flow hypothesis.

Denis, Denis and Sarin (1994) prove that firms with a Q less than unity increase (decrease) their capital expenditures following dividend increases (decreases), which is opposite to the axiom of the overinvestment hypothesis. Based on a sample of 6,777 dividend changes above 10\% (5,992 increases and 785 decreases), in the period between 1962 and 1988, they found that announcement period excess returns are positively related to the magnitude of dividend changes and to the dividend yield, but unrelated to Tobin's Q. Their results support the signalling hypothesis, but provide little support for the overinvestment hypothesis, unlike Lang and Litzenberger's (1989) results.

Lee and Ryan (2000) found that the free cash flow hypothesis plays a significant but asymmetric role in explaining the information content of dividend changes. The magnitude of the negative share price reactions to omission announcements increases with the perceived level of free cash flow and the reactions to initiation announcements, on the other hand, are insensitive to the perceived level of free cash flow.

Some empirical studies were developed in order to detect any possible interaction between earnings and dividends announcements, such as the case of Kane, Lee and Marcus (1984) and Chang and Chen (1991) in the American market, Easton (1991), in the Australian market, Lonie et al. (1996) and Abeyratna and Power (2002), both in the UK market, Conroy, Eades and Harris (2000) in the Japanese market and more recently, Chen, Firth and Gao (2002) in the Chinese market. 
Kane, Lee and Marcus (1984) examined abnormal share returns on the dates surrounding earnings and dividend announcements, in the years between 1979 and 1981, finding evidence of a significant interaction effect between these two variables. Their evidence suggests that earnings as well as dividends contain information, and the interaction between these two kinds of announcements explains better the abnormal share price performance than information about unexpected earnings or dividends level, considered separately. However, their sample includes only events in which both announcements occur within 10 days of each other. Thus, the results cannot be generalised to all dividend and earnings announcements.

Easton (1991) analyses the Australian market, where earnings and dividends are usually announced simultaneously, as in the English market. This allows handling the limitation of the last authors. Easton applies Kane, Lee and Marcus methodology to a sample of 896 financial reports corresponding to 339 industrial firms listed on the Melbourne Stock Exchange, in the period between 1978 and 1980. The results obtained are consistent with those of Kane, Lee and Marcus, since they found evidence of the interaction effect between the two kinds of announcement and evidence of earnings and dividend announcements affecting abnormal returns.

Chang and Chen (1991) analysed the interaction effect between current earnings and dividend announcements on common share returns over the period from 1981 to 1984 . They found evidence that the information content of unexpected earnings and dividends is not affected by the announcement pattern and that there is no interaction between the two types of signals released concurrently, which is not consistent with other authors, such as Kane, Lee and Marcus (1984), with whom they have compared the results.

Lonie et al. (1996) compute dividend change and earnings announcement effects for the UK share market. One of the main contributions of this work is its investigation on whether dividend announcements contain information beyond that which is related to the earnings announcements. Their sample consists of 620 firms, which announced annual dividends from January to June, 1991. From the whole sample 354 firms increased their dividends, 114 reduced them and the rest (152 firms) kept dividends constant. The sample reveals the existence of firms' reluctance to decrease dividends after a short-term decline in earnings. Indeed, $83 \%$ of the firms that kept dividends constant showed a decrease in earnings and, among the firms that increased dividends, about $40 \%$ showed lower earnings than in the preceding year. Lonie et al. find, for a 
two-day window (days 0 and -1 ), statistically significant abnormal returns of $+2.0 \%$ for dividend increases and $-2.4 \%$ for dividend decreases, similar to the magnitude of the abnormal return obtained by Aharony and Swary (1980) in their analysis of the US market. These results support the dividend information content hypothesis. Interestingly, in contrast with most other studies, this study also reports a positive excess return of about $+1.5 \%$ on the day immediately before the announcement of dividend no changes. The authors point out that this happens possibly because investors' doubts about dividends disappear when firms announce no changes dividend. In general, the abnormal return during the period of dividend and earnings announcements is in accordance with the signalling theory.

The results show that the market reacts more positively to earnings and dividends increases than to just dividend increase announcements. In cases in which dividends increase and the earnings decrease, the market reacts worse when this information is known than when only the dividend increases are transmitted regardless of earnings changes. On the other hand, when the information conveyed to the market indicates a decrease both in earnings and dividends, the negative abnormal return is lower than when only the dividend decreases are transmitted. Finally, when dividends stay unchanged, the abnormal return is not significant for earnings decreases, but it is significantly positive for earnings increases.

The results evidencing a significant interaction between earnings and dividend announcements show that both of them influence firms' returns. The evidence is similar to Kane, Lee and Marcus's (1984), Easton's (1991) and Abeytana and Power's (2002). Nevertheless, and unlike the Kane, Lee and Marcus results, but consistent with DeAngelo, DeAngelo and Skinner's work (1992), the authors conclude that current earnings constitute the dominant signal to capital markets, while dividends constitute only a partial signal. They still conclude that dividend announcements may be seen as a substitute for current earnings, although to a lesser extent, functioning as a signalling mechanism. Through them, managers can transmit information to the market about a firm's future performance. This conclusion agrees with Ofer and Siegel (1987) results.

Conroy, Eades and Harris (2000) studied the dividend announcement effect on share price changes in the Japanese market, where managers simultaneously announce dividends and current earnings, as well as predictions for the following year. Their sample is based on 3,890 observations of firms listed on Tokyo Stock Exchange, in the 
period from 1988 to 1993 . In general, the results indicate that the market reacts in a significant way to the information announced by firms regarding earnings and dividends. Prices react significantly to surprises ${ }^{42}$ with respect to earnings predictions provided by managers for the following year. After controlling the effect regarding earnings, the authors verified that the surprises related to managers' predictions about subsequent dividends have some influence on share prices, but this is not as significant as earnings predictions. Nevertheless, the results suggest that current dividend announcements have no effect on share prices, which is consistent with MM' (1961) proposition. Thus, Conroy, Eades and Harris conclude that, at least in Japan, earnings dominate dividends regarding their capability to explain share price changes and point out that share price movements are, mostly, justified by information that comes from earnings. This is in agreement with Lonie et al. (1996), but in contrast with Kane, Lee and Marcus (1984) conclusions. However, one must be cautious when comparing the results of the Japanese market with any other, because they are quite different ${ }^{43}$.

Abeyratna and Power (2002) analysed the financial performance of the UK firms after dividend change announcements, taking into consideration the signals send to the capital market on the same day, through earnings change announcements. They considered the UK firms listed that simultaneously announced earnings and dividends between 1989 and 1993, and they obtained a sample of 1,787 announcements. Firstly, Abeyratna and Power (2002) started by determining the abnormal return related to the earnings and dividend announcement period (days -1 to +1 ) in several situations, according to the change direction of the two parameters, and the results obtained support the dividend signalling hypothesis, since every time that dividends increased the abnormal return showed positive and statistically significant values, regardless of earnings variation. In the case of dividend no changes the return was not significant, and when a simultaneous dividend and earnings decrease was observed, the abnormal return was negative and statistically significant. The only exception was when dividend decreases were followed by earnings increases. However, the return was positive but

\footnotetext{
${ }^{42}$ The authors designate as surprises differences between the value of the variable announced by the managers and the prediction that formerly had been made by financial analysts. For greater detail see Conroy, Eades and Harris (2000, p. 1206).

${ }^{43}$ Dewenter and Warther (1998) have compared dividend policies of Japanese and US firms. They found that Japanese announcements are met with smaller share price reactions than the concomitant US announcements and that Keiretsu firms are also found to cut dividends more often than either independent Japanese firms or US. To analyse the main characteristics of the Japanese market, see Conroy, Eades and Harris (2000, p. 1202 and next).
} 
statistically insignificant. The abnormal return of firms reporting good news (simultaneous increase of dividend and earnings) was $+1.7 \%$, and for firms with bad news (simultaneous decrease of the two indicators) it was $-1.9 \%$, both statistically significant. The magnitude of the excess return in the case of a decrease in variables is higher than for their increase, which is consistent with the evidence shown in previous studies.

When they analysed some profitability, solvency, activity and liquidity ratios, Abeyratna and Power concluded, as was expected, that the best performance of profitability ratios occurred in cases in which dividends as well as earnings increased; this situation is similar to solvency ratios. The worst liquidity ratios occurred in cases where dividends decreased, however there do not seem to be any significant differences in the firm's credit policy.

After that, they analyse the long-term, considering a five-year period after the announcements. They observed that firms that simultaneously decreased both parameters showed a significant financial performance improvement throughout this period. The observed improvement in profitability ratios agrees with the evidence found by DeAngelo, DeAngelo and Skinner (1996) and Benartzi, Michaely and Thaler (1997) and, in the case of dividend omissions, by Healy and Palepu (1988). Firms that decreased dividends and increased earnings were only able to recover the profitability levels of the year of the announcement at the end of the five-year period. On the other hand, the financial performance of firms that increased dividends remained sensibly stable or worsened during this period; they were unable to maintain a performance superior to that achieved before dividend announcements. This result is similar to that of Benartzi, Michaely and Thaler (1997), who concluded, in a US market study, that firms that increase their dividends, obtain significant earnings increase in the year before and in the year of the announcement, but do not show significant growth in subsequent years. Regarding debt ratios, they increase gradually in the years following the announcements in the case of dividend increases, and decrease in the case of firms that simultaneously decrease dividends and earnings. In the first case, the results seem to support the signalling theory in the context of asymmetric information [Jensen (1986)], because free cash flows are reduced in investments with negative NPV. In the second case, the results show an attempt to fulfil obligations to the bondholders, which seems to have been successfully as these firms increased their liquidity in the period 
subsequent to the announcement. By comparing the group of firms that decreased both earnings and dividend with other groups, they conclude that the first group was the one showing a better performance in terms of profitability, solvency and liquidity, and the differences observed were, in most cases, statistically significant.

Subsequently, Abeyratna and Power used the regression method to analyse the relation between the signals transmitted by earnings and dividends and a firm's performance. They found strong support for the existence of an interaction effect between dividend and earnings announcements. Once more they confirmed a significant improvement in profitability and liquidity ratios in firms that decreased both dividend and earnings. In the presence of this evidence, the authors questioned the signalling theory hypothesis. Abeyratna and Power suggested that dividend decreases may not mean bad news transmitted to the market about future earnings, as proposed by signalling theory, but may reflect an effort made by managers to solve firm's financial problems ${ }^{44}$.

Chen, Firth and Gao (2002) studied the information content effect of dividend and earnings announcements in the Chinese market, a recent market, where firms have been listed for about 10 years. Their sample consists of 1,499 cash and share dividend announcements and earnings conveyed to the market by A-Shares ${ }^{45}$ listed on Shangai Securities and on Shenzhen Stock Exchanges, in the period from 1994 to 1997. The methodology adopted by the authors was based on those used by Kane, Lee and Marcus (1984), Easton (1991) and Leftwich and Zmijewski (1994). Like these authors, Chen, Firth and Gao found an interaction effect between variables, mainly between earnings and share dividends. They found evidence that capital markets seem to incorporate the information transmitted by earnings announcements, since there is a positive relation between earnings changes and share prices for the analysed firms. The share dividend announcements reinforce the signal given by earnings when they change in the same direction, and alter the signal transmitted by earnings when they change in the opposite direction. This behaviour is consistent with the results obtained by several authors, including Kane, Lee and Marcus (1984), Easton (1991) and Leftwich and Zmijewski (1994). Finally, cash dividends show a limited signalling role, as the authors did not find a significant relationship between them and share returns. This evidence is consistent with the dividend policy irrelevance hypothesis supported by MM (1961).

\footnotetext{
${ }^{44}$ We wonder if this is not one of the reasons why Fama and French (2001) and Banerjee, Gatchev and Spindt (2002), among others, found evidence of a propensity decrease for dividend payments.

${ }^{45}$ A-Shares are sold to domestic investors, while B-Shares are sold to foreigner investors.
} 
However, dividends are very unstable on the Chinese market, which can weaken their signalling role.

Summarising, in all these studies, whose methodology is similar, the results support the existence of an interaction effect between the two kinds of announcements, except in the study of Chang and Chen, on the US market.

Elfakhani (1995) tested a signalling system that accounts for the interaction, not between earnings and dividends announcements, but between financial statements and dividend announcements. The dividend signal that comes after the balance sheet information has three components: the content favourableness (flat, good, bad or ambiguous), the sign of dividend changes and, finally, the role of dividend signal (confirmatory, clarificatory or unclear). His sample contains 3,897 events of dividend changes, whose data were obtained from the CRSP and Compustat tapes. Under these conditions, dividends are less efficient and have little value to the market. One surprising result is that dividend decreases brought on positive market reaction in the announcement period. This can be consistent only if there is other corporate good news. Furthermore, signals made by dividend increases associated with corporate bad news induced a negative market reaction. Elfakhani concludes that the market reaction to dividend change announcements is more dependent on the expected content favourableness, than on the sign of dividend changes.

Some studies analyse the information content of special dividends. We will briefly point out some of these works.

Ryan and Lee (1998) examined the information content of specially designated dividends (special, year-end or extra, as they are usually designated) and, after measuring the wealth and variance effects of dividend announcements independently from each other, they found evidence of a significant positive wealth effect around their announcements, indicating that these dividends may convey more than merely transitory information. There does not seem to be a difference in the reaction of investors in high versus low growth firms (measured by Tobin's Q) with regard to the payment of a special dividend. Ryan and Lee provide some support for the signalling hypothesis.

DeAngelo, DeAngelo and Skinner (2000) studied the capital market's reaction to special dividend announcements, basing their analysis on firms listed on NYSE. The authors notice that special dividend payments have been disappearing throughout the 
last 45 years. Nowadays it is considered a rare phenomenon. As the authors comment (p. 310), "During the 1940s, 61.7\% of dividend-paying NYSE firms paid at least one special, while only $4.9 \%$ did so during the first half of the 1990s". The disappearance of this kind of dividend is inconsistent with the idea that they have an economically important signalling function. Nevertheless, in spite of their global decrease, the incidence of special dividends increased significantly in the last few years. Although firms that stop paying special dividends substituted them by regular dividends, the total value of dividends did not change significantly. This result gives evidence that firms tend to consider special and regular dividends close substitutes. Furthermore, DeAngelo, DeAngelo and Skinner observed a significantly positive capital market reaction of about $1 \%$, related to special dividend announcements. However, the market reaction is not related, in a systematic way, to the sign or the magnitude of the change in the payment of this kind of dividend.

In short, and based on the tests analysed so far, we can say that generally, dividend initiations and increases cause significantly positive reactions in share prices, while dividend reductions or omissions result in significantly negative changes in prices, which is consistent with dividend signalling theory. However, it is important to emphasise that some works that support the signalling theory have found evidence of a significant percentage of firms in their samples whose share price reaction was opposite to the signal of dividend changes, such as Asquith and Mullins (1983), Benesh, Keown and Pinkerton (1984) and Dhillon, Raman and Ramírez (2003), among others.

Asquith and Mullins (1983) found evidence supporting the dividend information content hypothesis. However, they verified that about $32 \%$ of their sample firms showed a negative market reaction to dividend initiations. Afterwards, Benesh, Keown and Pinkerton (1984) and Born, Moser and Officer (1988) showed that in 20 to $60 \%$ of the cases, the market reacted positively to dividend decreases and negatively to their increases. More recently, Dhillon and Johnson (1994) and Healy, Hathorn and Kirch (1997) found evidence of this enigmatic behaviour in about 34\% (for dividend initiations) and $27 \%$ (for omissions) of the cases in the first study, and $42.5 \%$ of the cases in the latter. Although Sant and Cowan (1994) have found a negative reaction to dividend omission announcements in the announcement period, the results show that almost $23.4 \%$ of the sample had a reverse reaction, with a positive reaction to dividend omission announcements. In two recent studies, about $43 \%$ Dhillon, Raman and 
Ramírez (2003) and 41.7\% Borokhovich et al. (2004) of the dividend increase announcements are associated with an adverse market reaction.

Of all these authors, only Healy, Hathorn and Kirch (1997) tried to identify firmspecific factors as a possible explanation for this evidence. In fact, several authors have documented a relationship between the valuation effect of dividend changes and firmspecific variables, such as Asquith and Mullins (1983), Eddy and Seifert (1988), Haw and Kim (1991) and Mitra and Owers (1995).

Ghosh and Woolridge (1988) focused on the identification of firm-specific factors that contribute significantly to the impact of dividend announcements on share prices. They concluded that the most significant factors are the magnitude of dividend change, the firm's size, the share performance before the announcement date and the negative information released before the dividend change. Asquith and Mullins (1983) have already found that market reaction to dividend announcements depends on the magnitude of the dividend payment.

Some authors found a negative relationship between firm size and abnormal returns surrounding the dividend announcements, such as Eddy and Seifert (1988), for a sample of large dividend increases, covering the period from 1983 through 1985, Haw and Kim (1991), for a sample of 126 firms in the period 1975 to 1984 and Mitra and Owers (1995), who analysed 80 dividend initiations between 1976 and 1987.

Healy, Hathorn and Kirch's (1997) results suggest that a firm's dividend yield, PER, debt/equity ratio and current ratio have an effect on the probability that the capital market will react negatively to an initial dividend announcement, since firms whose market reaction was negative documented lower dividend yield ratio and PER and higher debt/equity ratio, current ratio and growth earnings before the announcement.

In this context, because of a significant number of cases with an adverse market reaction to dividend change announcements and, as the best of our knowledge, because no studies try to examine this phenomenon suspiciously, we think it might be an opportunity for research.

Globally, we can say that the role of signalling dividends is greater for the relationship between dividend change announcements and the market reaction than between dividend changes and future earnings changes, which can be seen in Table 2.2, which exhibit the main studies relating share price reactions to dividend announcements. 
In spite of the evidence that supports the signalling effect, some studies do not find evidence of a significant relation between dividend changes and the subsequent market reaction e.g. Lang and Litzenberger (1989), Conroy, Eades and Harris (2000) and Abeyratna and Power (2002) . According to these last studies, it seems that the market sometimes does not receive the signal conveyed by dividend announcements.

Considering the effect of dividend change announcements on both future earnings and share prices, the evidence show studies that empirically try to validate theoretical dividend models, are sometimes inconclusive or in some cases even contradictory. Possible causes of these inconsistencies were pointed out by some authors to be the empirical method applied or the period of the sample Watts (1973) and the frequency of sample observation Laub (1976). Frankfurter and Wood (2002) have examined some empirical studies of corporate dividend policy determining whether the choice of method of analysis, frequency of sampling observation or sample period influences the results of tests of dividend policy. In contrast to what was believed, they conclude that these factors do not significantly affect the studies' results. So, it seems there must be other reasons for the contradictive and mixed results found in the literature...

\subsubsection{The Effect of Dividend Announcements on MARKet Expectation REVISIONS}

The third implication of signalling theory is connected with the relation between dividend changes and market prospects revision regarding future earnings. Theoretically, it is assumed that this relation might be positive.

While some studies found evidence that dividend changes provide information about firms' performance, like Asquith and Mullins (1983), Healy and Palepu (1988) and Nissim and Ziv (2001), others found different results, such as the cases of Watts (1973), Gonedes (1978) and Benartzi et al. (2005), which did not find an economically significant relation between dividends and future earnings.

Ofer and Siegel (1987) analysed the relationship between unexpected changes in the dividend policy announcements and unexpected performance changes. They observed 781 dividend changes for firms listed on NYSE and AMEX to examine how analysts 
change their forecasts about firms' current earnings following dividend change announcements, using the analysts' earnings forecasts, as an approach to the market expectations. The authors showed that the market reviews its future earning expectations based on unexpected dividend changes. Consistent with the positive association between dividend and current earnings changes (in the years of the dividend change) Ofer and Siegel state that those adjustments made by financial analysts are positively related to the magnitude of unexpected dividend changes. The empirical evidence also shows that after unexpected dividend announcements, analysts adjust their earnings forecasts in a consistent and rational way. Ofer and Siegel's results are consistent with the hypothesis that unexpected dividend changes signal information to the market about firms' performance and provide support to dividend signalling models.

Sant and Cowan (1994) studied the effect of dividend omissions on share return volatility, on security-analyst forecasts of earnings and on future earnings. Their empirical study was based on a sample of 381 dividend omissions during the period 1962 to 1987 . They reported a negative reaction to dividend omission announcements, founding a cumulative average abnormal return (in days -1 and 0 ) of $-10.7 \%$, which is close to the mean $-9.5 \%$ observed by Healy and Palepu (1988). Their evidence is consistent with information transmission through dividends, since their omissions precede increases in return variance, risk (measured by beta) and in the dispersion of analysts' forecasts of earnings. This increase in dispersion implies that the absence of dividends makes earnings forecasts less certain and leads to greater disagreement among analysts.

Yoon and Starks (1995) showed that there is a significant relation between a firm's dividends and current earnings. They analysed 3,748 dividend increases and 431 decreases, in the period between 1969 and 1988 for firms listed on NYSE, with the purpose of examining possible explanations for the wealth effects that surround dividend change announcements. Their main conclusions are the following: (1) dividend increases (decreases) are associated with subsequent increases (decreases) in capital expenses in the three years after dividend changes; (2) dividend change announcements are associated with revisions in firms' earnings forecasts made by analysts. For dividend increases, they tend to change their forecasts of the current and long-term earnings, but for dividend decreases, they only review the current earnings. This result probably explains the asymmetric share price reaction to dividend change 
announcements (more pronounced in the case of dividend decreases), which is consistent with Bhattacharya's (1979) ${ }^{46}$ signalling model.

Very recently, Mikhail, Walther and Willis (2003) examined analysts' forecast revisions to new information released by a firm's management, conditional on earnings quality. While Yoon and Starks (1995) documented that analysts revise their forecasts for current earnings following dividend changes in a consistent way, Mikhail, Walther and Willis, analysing 4,305 dividend changes between 1980 and 1997, predicted that the analysts' revisions are less (more) pronounced for firms with higher (lower) earnings quality ${ }^{47}$. They found that analysts' forecast revisions following dividend increases are inversely related to firms' earnings quality, which is consistent with their prediction. However, their results for dividend decreases are generally not statistically significant.

The main studies on the effect of dividend announcements on changes in market expectations can be found in Table 2.3. Globally, the tests confirm that unexpected dividend changes bring about revisions of market expectations.

\subsubsection{THE EFFECT OF DIVIDEND ANNOUNCEMENTS ON A FIRM’s RISK}

According to the theory, it is assumed that dividend changes and risk vary inversely, since when a dividend increase is announced a firm's risk decreases and when the announcement concerns a dividend decrease, the firm's risk increases.

This type of analysis is recent, but several authors found evidence of an inverse relation between dividend announcements and a firm's risk, such as Dielman and Oppenheimer (1984), Dyl and Weigand (1998), and Grullon, Michaely and Swaminathan (2002), among others.

Dielman and Oppenheimer (1984), in their study of NYSE listed firms, reached the conclusion that dividends are associated with a firm's risk. Their tests show evidence of a decrease in the risk measure that quantifies a firm's systematic or non-diversifiable

\footnotetext{
${ }^{46}$ Several empirical studies found a stronger share price reaction in the case of dividend decreases e.g. Michaely, Thaler and Womack (1995), Nissim and Ziv (2001) and Grullon, Michaely and Swaminnathan's (2002).

${ }^{47}$ The authors have proposed several proxies to measure earnings quality, such as the adjusted $\mathrm{R}^{2}$ from regressions of future operating cash flows on prior aggregate earnings. These proxies were criticised by Nissim (2003).
} 
risk ( ) for firms that resume, initiate or increase dividends, and an increase in for firms that omitted or decrease dividends.

Allen and Rachim (1996) developed an empirical study to analyse the relation between a firm's dividend policy and its share risk in the Australian market, considering 173 firms that change their dividend policy between 1972 and 1985. After controlling for the influence of other variables which may have impact on price volatility, such as the firm's size and debt level, they concluded that there is a significantly negative reaction between dividend payout ratio and share price volatility, as was foreseen. The most significant variables to price volatility are earnings volatility and debt, the former with a positive relation and the latter with a negative one.

Dyl and Weigand (1998) tested the hypothesis that dividend initiation payments give rise to a reduction in a firm's risk. They based their empirical study on a sample of 240 firms listed on NYSE and AMEX, which initiate dividend payments between 1972 and 1993. The authors present the idea that management decisions to start dividend payments provide new information to the market about a firm's risk and named this idea as the "risk-information hypothesis", which states that a firm's risk decreases after the initiation of dividend payments, finding support for this hypothesis. In fact, earnings variance decreased about $14 \%$ in the period after dividend payment, a statistically significant change. The systematic risk measure changed from 1.40 to 1.22 respectively, before and after the initiation of dividend payments, also significant. Thus, both the total and the systematic risks are significantly lower after the initiation of dividend payments. According to the authors, the risk decrease occurs because of the reduction of earnings volatility and the decrease of unexpected news regarding earnings. Furthermore, the authors state that dividend initiation announcements transmit information about a firm's risk reduction and that the market understands this, supporting the hypothesis that dividend announcements convey to the market the manager's knowledge about a firm's risk.

Gwilym, Morgan and Thomas (2000) analysed the impact of dividend stability on a firm's profitability and risk, using a sample formed by all the firms listed on LSE whose data were available on London Share Price Database (LSPD) between 1975 and 1997. The authors found an inverse and significant relation between firms' systematic risk (measured by ) and dividend stability, in all the cases in which a firm's dividend yield was non-zero, which suggests that a low level of systematic risk can be signalled to the 
market through a combination of a stable dividend policy and a moderately low dividend yield, since systematic risk decreases as the dividend yield is smaller, with the exception of the case in which this ratio is null.

Recently, Grullon, Michaely and Swaminathan (2002) analysed the relation between dividend policy changes and a firm's risk and growth. The main goal of this work is to relate dividend policy changes with a firm's life cycle. The authors found evidence that dividend increases suggest that firms are in a transition phase between the growth and the maturity phase, since in the latter, investment opportunities start to reduce as well as the level of required resources, thus allowing higher cash flow, which could be used for dividend payments. Supporting their work on CAPM model, they concluded that firms that increase dividends had a significant decrease in systematic risk, while firms in which dividends decreased, incurred a significant increase in risk. These results are consistent with the previous ones, e.g. Dielman and Oppenheimer (1984), Dyl and Weigand (1998) and Gwilym, Morgan and Thomas (2000). They also found that firms that increase dividends incur a return on assets decrease, which points to a decrease in systematic risk. Moreover they state that the higher the systematic risk decrease the more positive the market reaction is to dividend announcements. For this reason we can presume that risk changes might explain share price reaction to dividend change announcements.

The main tests that contribute to the evidence of a negative relationship between dividend change announcements and the subsequent firms' risk are summarised in Table 2.4.

Following the analysis of several effects associated with dividend change announcements, we will report some of the recent research work which analyses the evolution of firms' propensity to pay dividends in recent decades.

\subsection{EVOLUTION OF FIRMS' PROPENSITY TO PAY DIVIDENDS}

Recently some empirical studies reported the phenomenon of the low propensity of firms to dividend payment, sustaining investors' expectations regarding dividend payments also decreased. The first studies on this topic have analysed the US market. 
Fama and French (2001) have studied the dividend payment decrease phenomenon in recent years on the American market. The number of firms that pay dividends has decreased significantly during the 1980's and 1990's, since in 1978, 66.5\% of firms listed on NYSE, AMEX and NASDAQ (excluding financial organizations and public utility) distributed dividends, while in 1999 this percentage was only $20.8 \%$. The authors state that there are three main factors for the dividend payment decision, which are profitability, growth and a firm's size. The firms that pay dividends tend to be the ones of larger size, higher profitability, but the ones having fewer growth opportunities. On the whole, and apart from these characteristics, firms tend to pay fewer dividends. The small propensity to pay dividends suggests that the perceived benefits of dividends have been decreasing through time, namely because of the fiscal disadvantage of it related to capital gains. If we consider share repurchases as an extra earnings payment to investors, the increase of share repurchases in the 1990s may imply an increase in the target payout ratio of dividends. However, it is necessary to be cautious as the global ratio disguises the evidence of a low propensity to dividend payments. As the evidence shows that share repurchases happen in firms that pay dividends, dividend decline is still unexplained ${ }^{48}$. About this phenomenon, Bratton (2005) refers that if dividends were the sole means of paying out cash, the payout ratio would have declined even more.

Banerjee, Gatchev and Spindt (2002) develop Fama and French's approach to evaluate the market liquidity increase effect on dividend payments between 1963 and 2001. The authors considered the hypothesis that market liquidity increase is negatively related to the proportion of firms that pay dividends, finding evidence that supports this hypothesis, since their results show that part of the lower motivation to pay dividends seems to be explained by the share transaction increase. When they estimated the probability that firms will pay dividends, taking into account the three factors defined by Fama and French (2001) - profitability, growth and firms size - they conclude that larger and more profitable firms pay higher dividends, while those that have more growth opportunities pay lower dividends, which is consistent with the former authors' results. Banerjee, Gatchev and Spindt conclude that the inferior propensity to dividend

\footnotetext{
${ }^{48}$ Reynolds (2004) and Brav et al. (2005) examine the determinants of the choice between dividends and share repurchases, concluding that firms do not appear to randomly choose between the various payout choices. Reynolds (2004) observes the choice is the result of a deliberate and specific decision made by the firm in the interest of shareholders' wealth maximising, based on firms' characteristics and Brav et al. (2005) conclude that maintaining the dividend level is on par with investment decisions, while repurchases are made out of the residual cash flow after investment spending.
} 
payment is not significantly influenced by fiscal reasons or by a firm's share repurchase policy.

Baker and Wurgler (2002) analyse possible causes for the change in the propensity to dividend payments between 1963 and 2000, emphasising the propensity decrease in the period after 1978, already documented by Fama and French (2001). They conclude that the best explanation for the disappearance of dividends is offered by the "catering theory of dividend ${ }^{49}$," Dividend payment by firms responds to investor demand for dividend proxies by the dividend premium, the difference between the market-to-book ratios of dividend payers and non-payers in a given year. Baker and Wurgler find no support for the asymmetric information theory or the clienteles' theory in influencing, at least in a significant way, the propensity to pay dividends.

DeAngelo, DeAngelo and Skinner (2004) find evidence of a substantial increase in the concentration of earnings as well as dividends between 1978 and 2000. In the last year, the 25 largest dividend paying firms account for over $50 \%$ of the earnings and dividends paid. The authors conclude that the "repurchase puzzle" is not yet solved, since share repurchases have not displaced dividends as the preferred form of payout, despite their tax advantages. Like Baker and Wurgler, they argue that the aggregate evidence does not support either signalling or the clientele hypothesis.

Bulan, Subramanian and Tanlu (2004) study the changes in the characteristics of American listed firms around dividend initiations during the period 1963 to 1998 and suggest that the timing of dividend initiations is best explained by a synthesis of the maturity hypothesis Grullon, Michaely and Swaminathan (2002) with the catering theory Baker and Wurgler (2002) . Initiators are large firms, with slow growth and high profitability, as predicted by the maturity hypothesis ${ }^{50}$. However, they find no significant decline in risk around a dividend initiation, in contrast with Grullon, Michaely and Swaminathan's results for dividend increases. Their results are in line with the predictions of the catering theory, since dividend initiations are more likely when the premium is higher. In sum, initiations tend to occur when mature firms find an appropriate moment: when market sentiment favours dividends. Contrary to the signalling theory, Bulan, Subramanian and Tanlu find that dividend initiations do not

\footnotetext{
${ }^{49}$ According to the authors, the catering theory supports the idea that firms tend to pay dividends when the share prices of the firms that distribute dividends are higher than those that do not pay it.

${ }^{50}$ In the mature stage of their life cycle, these firms generate a lot of cash, but do not find many profitable investment opportunities.
} 
signal any significant change in the growth rate or profitability of a firm. Furthermore, they conclude that repurchases and dividends play different roles, not being substitute methods of paying out cash.

Very recently, Loderer and Roth (2005) examine whether the cash that firms distribute to their shareholders justifies the firm's share prices, studying a sample of firms traded on the NYSE, AMEX and NASDAQ in the 1926-2002 period. They found evidence that the importance of ordinary dividends as a means of cash distribution has fallen during the past three decades to a level between $10 \%$ and $49 \%$. Moreover, their results show that small firms pay cash dividends less frequently than the large firms and NASDAQ firms tend to pay ordinary dividends less often than AMEX and NYSE firms. Their results suggest a contemporaneous improvement in market liquidity. Furthermore, the evidence found is roughly consistent with information efficient markets.

Recent studies extend the analysis to other countries in addition to the US, such as Reddy (2003), Ferris, Sen and Yui (2004) and Osobov (2004).

Reddy (2003) follow the Fama and French (2001) approach to analyse the impact of profitability, size and growth on the dividend payout of Indian firms over the 1990-2001 period. Their results document a decline in dividend-paying firms ${ }^{51}$. Further, they found that dividend-paying firms are more profitable and larger in size than non-paying firms, which is in agreement with Fama and French's (2001) results. However, they found no significant relation between a firm's growth and dividend payments, which contradicts the findings of Fama and French.

Sen and Yui (2004) test whether the recent disappearance of dividends is solely a US phenomenon or part of a more global trend, analysing eleven common law and fourteen civil law countries over the period from 1990 to $2001^{52}$. In general, their findings are consistent with patterns observed for US firms. They find that the propensity to pay dividends declines over there sample period and is most pronounced for firms incorporated in common law countries ${ }^{53}$. They find that the growing incidence of nondividend paying firms is explained by the increase in the percentage of firms that have

\footnotetext{
${ }^{51}$ The percentage of Indian firms paying dividends has declined from $60.5 \%$ in 1990 to $32.1 \%$ in 2001 .

52 The classification of the countries between common or civil law was based on La Porta et al. (1998). Examples of common law countries are Australia, Canada, Hong Kong, Thailand, UK and US, and civil law countries are Japan, France, Italy, Germany, Spain and Switzerland.

${ }^{53}$ At the beginning of their sample period, $81.4 \%$ of the sample firms pay dividends, but by 2001 , this value declines to only $58.3 \%$. The US and Canadian firms exhibit the greatest decrease in the number of dividend payers.
} 
never paid dividends. What appears to be sensitive to the legal regime is the resistance to initiating dividends, more evident on common law nations. Furthermore, Ferris, Sen and Yui find that firms in common law countries tend to be more profitable, to have more abundant growth opportunities and to be bigger than their civil law counterparts.

Osobov (2004) analyses corporate dividend decisions of international firms, using the methodology of Fama and French (2001). The countries included in the analysis are the US, Canada, UK, Germany, France and Japan, for the period between 1981 and 2002. The results indicate a decline in the propensity of firms to pay dividends in all countries, although the magnitude of the decline and the percents of payers at the end of the study vary across countries ${ }^{54}$. The author evaluates whether firm size, profitability and growth opportunities affect dividend decisions. Larger and more profitable firms are more likely to pay dividends in all countries, while the effect of growth opportunities depends on the country's legal origin. Consistent with the findings of La Porta et al. (2000) and Fama and French (2001), the relationship between growth opportunities and the likelihood of dividend payments in the US, Canada and UK is negative. However, in Germany, France, and Japan it is mixed. The author replicates the tests of Baker and Wurgler (2002) to evaluate the catering hypothesis and the results are consistent with catering theory in the common law countries but not in the civil law countries. Furthermore, Osobov finds results consistent with the agency theory. The high concentration of dividends among few large firms, which is consistent with some authors' evidence such as DeAngelo, DeAngelo and Skinner (2004), challenges the signalling theory. The results cast some doubts on equilibrium clientele theories and on signalling theories as candidate common explanations of the declining propensity to pay dividends. Moreover, Osobov finds no significant relationship between the propensity to pay dividends and share repurchases, which is consistent with the evidence of Fama and French (2001).

\footnotetext{
${ }^{54}$ While in the US and Canada the proportion of dividend payers in 2002 is about $20 \%$, the corresponding proportion in the UK, Germany and France are in the range of 42.7 to $61.0 \%$ and in Japan is $83.8 \%$.
} 


\subsection{CONCLUSIONS}

Briefly, and somewhat in accordance with Allen and Michaely's (2003) opinion, the empirical tests carried out to analyse the assumptions of dividend signalling theory, allow us to conclude the following:

- The relationship between dividend changes and subsequent earnings changes is sometimes inconsistent with what is predicted by the theory. The information send by firms to the market is not always related to future earnings growth or cash flow;

- Although the empirical evidence supporting the positive relationship between dividend change announcements and the subsequent share price reactions, some recent studies have not supported this idea. The market is not always able to catch the signal sent by firms;

- Generally, unexpected dividend changes are associated with market earnings revisions;

- There is evidence of a negative relationship between dividend changes and firms risk.

Although the recent evidence of a decline in the propensity of firms to pay dividends, they continue to be a relevant topic in the finance literature. The different results of such a huge number of studies and the evidence of a significant percentage of cases where the market reaction to dividend change announcements is opposite to the expected reaction show the debate over the empirical validity of the dividend-signalling hypothesis remains alive in the literature... 
TABLES 
Table 2.1 - Summary findings of the main studies on the effect of dividend announcements on future earnings

\begin{tabular}{|c|c|c|c|c|c|c|}
\hline \multirow{2}{*}{ Research } & \multirow{2}{*}{ Country } & \multirow{2}{*}{ Period } & \multirow{2}{*}{$\begin{array}{l}\text { Type of dividend } \\
\text { announcements }\end{array}$} & \multirow{2}{*}{ Sample } & Signalling Hypothesis & \multirow{2}{*}{ Main conclusions } \\
\hline & & & & & Support $\quad$ No support & \\
\hline Watts (1973) & US & $1945-1968$ & Dividend changes & Firms: 310 & & $\begin{array}{l}\text { The relationship between dividend changes } \\
\text { and future earnings changes is positive, but } \\
\text { does not lead to abnormal returns }\end{array}$ \\
\hline Healey and Palepu (1988) & US & $1969-1980$ & $\begin{array}{l}\text { Dividend initiations } \\
\text { and omissions }\end{array}$ & $\begin{array}{l}\text { Initiations: } 131 \\
\text { Omissions: } 172\end{array}$ & & $\begin{array}{l}\text { The dividend initiations (omissions) } \\
\text { announcements causes future earnings to } \\
\text { increase (decrease) significantly }\end{array}$ \\
\hline Aharony and Dotan (1994) & US & $1967-1990$ & Dividend changes & $\begin{array}{l}\text { Increases: } 3,786 \\
\text { Decreases: } 538\end{array}$ & & $\begin{array}{l}\text { The dividend increase (decrease) } \\
\text { announcements are associated with higher } \\
\text { (lower) unexpected future earnings }\end{array}$ \\
\hline Michaely, Thaler and Womack (1995) & US & 1979-1991 & Dividend changes & Firms: 1,025 & & $\begin{array}{l}\text { Dividend changes do not signal } \\
\text { unexpected future earnings changes }\end{array}$ \\
\hline DeAngelo, DeAngelo and Skinner (1996) & US & $1980-1987$ & Dividend increases & Firms: 145 & & $\begin{array}{l}\text { There is no evidence that dividend } \\
\text { increases provide an useful sign of future } \\
\text { earnings }\end{array}$ \\
\hline Benartzi, Michaely and Thaler (1997) & US & $1979-1991$ & Dividend changes & Firms: 1,025 & & $\begin{array}{l}\text { Dividends react to changes in past and } \\
\text { current earnings, rather than acting as a } \\
\text { forecast of future earnings }\end{array}$ \\
\hline Chen and Wu (1999) & US & $1965-1992$ & Dividend changes & Firms: 431 & & $\begin{array}{l}\text { Dividend changes provide useful } \\
\text { information about future earnings forecasts }\end{array}$ \\
\hline Nissim and Ziv (2001) & US & $1963-1997$ & Dividend changes & $\begin{array}{l}\text { Increases: } 12,105 \\
\text { No changes: } 19,004 \\
\text { Decreases: } 697\end{array}$ & & $\begin{array}{l}\text { Dividend changes provide information } \\
\text { about the level of profitability in } \\
\text { subsequent years }\end{array}$ \\
\hline Grullon, Michaely and Swaminathan (2002) & US & $1967-1993$ & Dividend changes & $\begin{array}{l}\text { Increases: } 6,284 \\
\text { Decreases: } 1,358\end{array}$ & & $\begin{array}{l}\text { Dividend changes do not transmit } \\
\text { information about future earnings }\end{array}$ \\
\hline Benartzi et al. (2005) & US & 1693-1999 & Dividend changes & $\begin{array}{l}\text { Increases: } 12,375 \\
\text { No changes: } 22,918 \\
\text { Decreases: } 971\end{array}$ & & $\begin{array}{l}\text { Dividend changes are an unreliable means } \\
\text { to future earnings forecasts }\end{array}$ \\
\hline
\end{tabular}


Table 2.2 - Summary findings of the main studies on the effect of dividend announcements on share prices

\begin{tabular}{|c|c|c|c|c|c|c|}
\hline \multirow{2}{*}{ Research } & \multirow{2}{*}{ Country } & \multirow{2}{*}{ Period } & \multirow{2}{*}{$\begin{array}{l}\text { Type of dividend } \\
\text { announcements }\end{array}$} & \multirow{2}{*}{ Sample } & Signalling Hypothesis & \multirow{2}{*}{ Main conclusions } \\
\hline & & & & & Support $\quad$ No support & \\
\hline Pettit (1972) & US & $1967-1969$ & Dividend changes & Firms: 135 & & $\begin{array}{l}\text { Dividend changes and share price movements in } \\
\text { the announcement period are positively and } \\
\text { strongly related }\end{array}$ \\
\hline Aharony and Swary (1980) & US & $1963-1976$ & Dividend changes & Firms: 149 & & $\begin{array}{l}\text { Dividend changes and share price movements in } \\
\text { the announcement period are positively and } \\
\text { strongly related }\end{array}$ \\
\hline Asquith and Mullins (1983) & US & 1964-1980 & Dividend initiations & Firms: 168 & & $\begin{array}{l}\text { The market shows a strong and positive reaction to } \\
\text { the first dividend announcements }\end{array}$ \\
\hline Dielman and Oppenheimer (1984) & US & $1969-1977$ & Dividend changes & Firms: 202 & & $\begin{array}{l}\text { Dividend changes and market abnormal returns } \\
\text { are positively and significantly related }\end{array}$ \\
\hline Handjinicolaou and Kalay (1984) & US & $1975-1976$ & Dividend decreases & Firms: 255 & & $\begin{array}{l}\text { The market reacts negatively to dividend decrease } \\
\text { announcements }\end{array}$ \\
\hline Kalay and Loewenstein (1986) & US & 1981 & Dividend timing & Firms: 969 & & $\begin{array}{l}\text { The market correctly interprets deferral of } \\
\text { announcements to convey negative information }\end{array}$ \\
\hline Healey and Palepu (1988) & US & $1969-1980$ & $\begin{array}{l}\text { Dividend initiations } \\
\text { and omissions }\end{array}$ & $\begin{array}{l}\text { Initiations: } 131 \\
\text { Omissions: } 172\end{array}$ & & $\begin{array}{l}\text { The share prices in the announcement period } \\
\text { increases (decreases) with dividend initiations } \\
\text { (omissions) announcements }\end{array}$ \\
\hline Lang and Litzenberger (1989) & US & $1979-1984$ & Dividend changes & Changes: 429 & & $\begin{array}{l}\text { Dividend change announcements support the } \\
\text { overinvestment hypothesis over the signalling } \\
\text { hypothesis }\end{array}$ \\
\hline Michaely, Thaler and Womack (1995) & US & 1964-1988 & $\begin{array}{l}\text { Dividend initiations } \\
\text { and omissions }\end{array}$ & $\begin{array}{l}\text { Initiations: } 561 \\
\text { Omissions: } 997\end{array}$ & & $\begin{array}{l}\text { Dividend omission (initiations) announcements } \\
\text { are associated with a price drop (increase) }\end{array}$ \\
\hline
\end{tabular}


Table 2.2 - Summary findings of the main studies on the effect of dividend announcements on share prices (continued)

\begin{tabular}{|c|c|c|c|c|c|c|c|}
\hline \multirow{2}{*}{ Research } & \multirow{2}{*}{ Country } & \multirow{2}{*}{ Period } & \multirow{2}{*}{$\begin{array}{l}\text { Type of dividend } \\
\text { announcements }\end{array}$} & \multirow{2}{*}{ Sample } & \multicolumn{2}{|c|}{ Signalling Hypothesis } & \multirow{2}{*}{ Main conclusions } \\
\hline & & & & & Support & No support & \\
\hline Healey, Hathorn and Kirch (1997) & US & $1967-1985$ & Dividend initiations & Firms: 106 & & & $\begin{array}{l}\text { The market shows a positive reaction to dividend } \\
\text { initiation announcements }\end{array}$ \\
\hline Fernández and Jorge (1999) & UK & 1991-1996 & Dividend changes & Firms: 4,752 & & & $\begin{array}{l}\text { Dividend change announcements are relevant in } \\
\text { the share prices reaction }\end{array}$ \\
\hline Chen, Firth and Gao (2002) & China & 1994-1997 & Dividend changes & $\begin{array}{l}\text { Increases: } 335 \\
\text { No changes: } 530 \\
\text { Decreases: } 367\end{array}$ & & & $\begin{array}{l}\text { Dividend changes are not significantly related } \\
\text { with share returns in the announcement period }\end{array}$ \\
\hline Abeyratna and Power (2002) & UK & $1989-1993$ & Dividend changes & $\begin{array}{l}\text { Increases: } 1,340 \\
\text { No changes: } 280 \\
\text { Decreases: } 167\end{array}$ & & & $\begin{array}{l}\text { In the long term, dividend and earnings reductions } \\
\text { events outperform dividend increases events }\end{array}$ \\
\hline Viswanath, Kim and Pandit (2002) & US & 1986-1995 & Dividend changes & Changes: 12,756 & & & $\begin{array}{l}\text { Only support the dividend signalling hypothesis } \\
\text { for negative dividend surprises }\end{array}$ \\
\hline
\end{tabular}


Table 2.3 - Summary findings of the main studies on the effect of dividend announcements on market expectations revisions

\begin{tabular}{|c|c|c|c|c|c|c|}
\hline \multirow{2}{*}{ Research } & \multirow{2}{*}{ Country } & \multirow{2}{*}{ Period } & \multirow{2}{*}{$\begin{array}{l}\text { Type of dividend } \\
\text { announcements }\end{array}$} & \multirow{2}{*}{ Sample } & Signalling Hypothesis & \multirow{2}{*}{ Main conclusions } \\
\hline & & & & & Support No support & \\
\hline Ofer and Siegel (1987) & US & 1976-1984 & Dividend changes & Changes: 781 & & $\begin{array}{l}\text { Analysts review earnings forecasts } \\
\text { after the unexpected dividend changes }\end{array}$ \\
\hline Sant and Cowan (1994) & US & $1962-1987$ & Dividend Omissions & Omissions: 381 & & $\begin{array}{l}\text { Dividend omissions precede increases } \\
\text { in the dispersion of analysts' forecast } \\
\text { of earnings }\end{array}$ \\
\hline Yoon and Starks (1995) & US & $1969-1988$ & Dividend changes & $\begin{array}{l}\text { Increases: } 3,748 \\
\text { Decreases: } 431\end{array}$ & & $\begin{array}{l}\text { Analysts forecasts of current and long- } \\
\text { term earnings tend to change with } \\
\text { dividend changes }\end{array}$ \\
\hline Mikhail, Walther and Willis (2003) & US & 1980-1997 & Dividend changes & $\begin{array}{l}\text { Increases: } 3,913 \\
\text { Decreases: } 392\end{array}$ & & $\begin{array}{l}\text { The relation between dividend changes } \\
\text { and analysts' forecast revisions is only } \\
\text { significant for dividend increases }\end{array}$ \\
\hline
\end{tabular}


Table 2.4 - Summary findings of the main studies on the effect of dividend announcements on a firms' risk

\begin{tabular}{|c|c|c|c|c|c|c|}
\hline \multirow{2}{*}{ Research } & \multirow{2}{*}{ Country } & \multirow{2}{*}{ Period } & \multirow{2}{*}{$\begin{array}{l}\text { Type of dividend } \\
\text { announcements }\end{array}$} & \multirow{2}{*}{ Sample } & Signalling Hypothesis & \multirow{2}{*}{ Main conclusions } \\
\hline & & & & & Support $\quad$ No support & \\
\hline Dielman and Oppenheimer (1984) & US & 1969-1977 & Dividend changes & Firms: 202 & & $\begin{array}{l}\text { The firms that increase } \\
\text { dividends decline their risk }\end{array}$ \\
\hline Allen and Rachim (1996) & Australia & $1972-1985$ & Dividend changes & Firms: 173 & & $\begin{array}{l}\text { There is a negative reaction } \\
\text { between dividend changes } \\
\text { and firms' risk }\end{array}$ \\
\hline Dyl and Weigand (1998) & US & $1972-1993$ & Dividend Initiations & Firms: 240 & & $\begin{array}{l}\text { After dividend initiation } \\
\text { announcements, the earnings } \\
\text { volatility are significantly } \\
\text { lower }\end{array}$ \\
\hline Grullon, Michaely and Swaminathan (2002) & US & $1967-1993$ & Dividend changes & $\begin{array}{l}\text { Increases: } 6,284 \\
\text { Decreases: } 1,358\end{array}$ & & $\begin{array}{l}\text { Dividend increases are } \\
\text { associated with a significant } \\
\text { decrease in systematic risk }\end{array}$ \\
\hline
\end{tabular}




\section{CHAPTER 3}

THE EFFECT OF DIVIDEND ANNOUNCEMENTS ON SHARE PRICES AND ON FUTURE PERFORMANCE 


\subsection{INTRODUCTION}

As we have seen when revising the literature, the majority of the empirical tests done on

the dividend signalling hypothesis domain explore the effects of the dividend change announcements on share prices and on future earnings. The evidence is mixed. Although it is well documented that there is a strong positive association between dividend changes and both future earnings and share price reactions in the days surrounding the dividend change announcements, several studies have failed to support these two relations. In this context, we will try to provide further evidence on the information content of dividend change announcements.

In this chapter we intend to explore two typical tests examined in prior research: the market reaction around the dividend announcements and the association between dividend changes and future earnings. With this purpose, we formulate two hypotheses: the first hypothesis will analyse the relationship between dividend change announcements and the share price movements on the announcement period and the second hypothesis will analyse the relationship between dividend change announcements and the firm's future profitability. Extending the analysis, namely by introducing different profitability measures, dividing the sample into distinct groups and considering distinct approaches, represents an innovation compared to the classical studies.

After the identification of the hypotheses to be tested, we describe the sample selection and proceed with the definition of the methodology to test the formulated hypotheses. Empirical studies are done essentially in the US, thus the countries we consider are in need of research, especially two out of the three countries: Portugal and France.

As a background, we first analyse the trends in the dividend payment pattern of the nonfinancial listed firms on the three markets that constitutes the samples. Secondly, we provide empirical evidence on whether dividend change announcements are associated with subsequent share price reactions based on event studies and regression analysis. Thirdly, we investigate the relationship between dividend change announcements and firm's future performance, considering as future performance several distinct measures. Finally, we remark the key conclusions. 


\subsection{HYPOTHESES}

We will formulate two hypotheses based on the dividend signalling assumptions. In the first hypothesis, we will analyse the relationship between dividend change announcements and the share price movements around dividend announcements, an issue already analysed by several authors. In the second hypothesis, we wish to analyse the relationship between dividend change announcements and the firm's future profitability. To test this hypothesis we will consider different measures of future performance, in order to examine distinct features of dividend policy. So, we will consider several measures as the future profitability: firstly, the future earnings changes; secondly, we will consider some accounting performance measures; thirdly, we will consider different operating performance measures and, finally, we will try to find a proxy for the market expectations of future earnings. Consequently, we will formulate several sub-hypotheses.

\subsubsection{Hypothesis 1 - Relation Between Dividend Change AnNouncements AND THE MARKET REACTION}

Consistent with many studies in this domain, we start by analysing the relation between dividend changes and the share price movements on the announcement period. To do so, we formulate the following alternative hypothesis:

\section{$H_{1}$ : "The dividend changes are associated with a subsequent share price reaction in the same direction"}

This hypothesis reflects the signalling theory assumption that dividend announcements convey information to the market about firm's future profitability. Consistent with this theory, a positive relation should exist between dividend changes and the subsequent share prices reaction. So, if we reject the null hypothesis we will give support to the dividend information content hypothesis and to the signalling theory for the case of dividend increases ${ }^{55}$, since signalling theory requires using a costly signal to reveal private information (dividends in this case). For dividend reductions, we will give

\footnotetext{
${ }^{55}$ It is hard to imagine a firm using dividend reductions to signal negative information. Miller and Rock (1985, p. 1045) noted "Dividends make sense as signals for the good-news, not the bad-news firms".
} 
support to the dividend information content hypothesis, since, according to this hypothesis, dividends have information because it is costly to lie, which may mean that it is financially too costly to continue paying dividends in the face of declining prospects.

\subsubsection{HyPotheSIS 2 - RELATION BETWEEN DIVIDEND CHANGES AND FIRM'S FUTURE Profitability}

After analysing the relation between dividend changes and the share price movements around dividend announcements, we will evaluate the relation between dividend changes and future firm profitability. The testable hypothesis, in its alternate form, is:

$$
\begin{aligned}
& \mathrm{H}_{2}: \text { "Dividend increases (decreases) are associated with superior (inferior) } \\
& \text { future performance" }
\end{aligned}
$$

Rejection of the null hypothesis associated with $\mathrm{H}_{2}$ is consistent with dividend signalling model assumptions that management has proprietary information concerning the firm's future performance prospects. On the other hand, if we fail to reject the null hypothesis, it may suggest that dividends may not always contain information about future profitability.

To test this hypothesis we will consider different measures of future performance, which allow us to examine distinct features of dividend policy. Therefore, we will formulate several sub-hypotheses.

\subsubsection{Sub-Hypothesis $2 \mathrm{~A}$ - Relation between Dividend Changes and Future Earnings Changes}

Firstly, we will start by considering future earnings changes as future performance. In order to analyse the relationship between dividend change announcements and future earnings changes, we will formulate the following alternative sub-hypothesis:

$$
\begin{aligned}
& H_{2 A} \text { : "Dividend increases (decreases) are associated with future earnings } \\
& \text { increases (decreases)" }
\end{aligned}
$$


Although we expect a positive relation between dividend changes and future earnings changes, the prior empirical evidence is not consistent. Several studies, e.g., Healy and Palepu (1988) and Nissim and Ziv (2001), have found support for this theory, but others, such as DeAngelo, DeAngelo and Skinner (1996), Benartzi, Michaely and Thaler (1997) and, more recently, Benartzi et al. (2005) found no relation between dividend changes and future earnings.

\subsubsection{Sub-Hypothesis 2B - Relation between Dividend Changes and Accounting Performance Measures}

Secondly, we will consider as firms' future performance other accounting performance measures such as profitability measures (return on assets and return on equity), financial risk measures such as liquidity ratios and debt ratios, as well as a cash flow measure. This will allow us to address issues concerning the window dressing phenomenon as well as to see if dividend changes are associated with future cash flows.

When managers suspect that future prospects are less favourable or that the firm's growth is not sustainable, they can initiate or increase dividend payments in an attempt to obtain a (temporary) favourable impact on share prices. In this situation, dividend increases can be seen as window dressing or an attempt to mimic firms with better performance prospects. In addition, some profitability and financial ratios will become worse in the future. According to Miller and Rock's (1985) signalling model, firms that falsely mimic the performance signals of higher performing firms will be punished by the market as soon as the false signal is recognised.

We will formulate this sub-hypothesis according the assumptions of dividend signalling models, so, in its alternate form, it will be:

\section{$H_{2 B}$ : "Dividend increases (decreases) are associated with superior (inferior) future performance measures"}

If we reject the null hypothesis associated with $\mathrm{H}_{2 \mathrm{~B}}$, and the relation between dividend changes and future performance measures is direct, the results will be consistent with the dividend signalling model. If we reject the null hypothesis associated with $\mathrm{H}_{2 \mathrm{~B}}$ but the relation between the variables is negative, we can have evidence of the presence of the window dressing phenomenon. On the other hand, if we fail to reject the null 
hypothesis, it may suggest that dividends may not always contain information about future profitability.

\subsubsection{Sub-Hypothesis $2 \mathrm{C}$ - Relation between Dividend Changes and Operating Performance Measures}

Thirdly, we will analyse and confront the maturity and the signalling hypotheses. Consistent with the maturity hypothesis suggested by Grullon, Michaely and Swaminathan (2002), a dividend increase may convey information about a decrease in investment opportunities, an expected decrease in the return on assets or a decrease in the earnings growth rate, conveying also information about the decrease of the systematic risk because of less riskier investments. Although there are two inverse effects associated with dividend increases, the theory does not tell us which one dominates. If we relate the maturity hypothesis and the signalling hypothesis, we can test whether dividend increases are a sign of maturity or used by firms to convey to the market their future prospects. If dividend increase announcements are used to signal the market about their future prospects (signalling hypothesis), these events will experience improvement in future operating performance, increases in capital expenditure, and should also experience an increase in asset and sales growth after the dividend increase announcement. On the other hand, if dividend increase announcements are a sign of maturity, firms that increase dividends will experience a decline in profitability and a decline (or at least no increase) in their capital expenditures. In addition, they will have lower asset and sales growth. This analysis needs to be cautious because, according to Lai, Song and Fung (2004), these two hypotheses can co-exist. In this context, we need to identify some measures to classify firms. The post-announcement performance, the capital expenditures and the sales and asset growth are four choices because they have distinct predictions about future behaviour in the two distinct hypotheses.

We will formulate this sub-hypothesis according the assumptions of dividend signalling models, so, in its alternate form, it will be:

\footnotetext{
$H_{2 C}$ : "Dividend increases are associated with superior operating performance, increases in capital expenditure and should experience an increase in sales growth"
} 
If we reject the null hypothesis associated with $\mathrm{H}_{2 \mathrm{C}}$, and the relation between dividend changes and future measures considered in the alternate hypothesis is direct, as predicted in the alternate hypothesis, the results will be consistent with the dividend signalling model. If we reject the null hypothesis associated with $\mathrm{H}_{2 \mathrm{C}}$ but the relation between the variables is negative, we can have evidence of the maturity hypothesis. Indeed, according to the maturity hypothesis, we expect that dividend increases are associated with inferior operating performance (or, at least, not superior), decreases in capital expenditure (or, at least, not increases), and should experience a decrease in sales growth. In fact, if a firm increases its dividends to signal its future performance, we should expect the dividend increase announcements to be associated with subsequent improvement in profitability, while a firm in the maturity stage may increase its dividends as it experiences a decline in future profitability. On the other hand, if we fail to reject the null hypothesis, we will find no support for either the signalling or the maturity hypotheses.

\subsubsection{Sub-Hypothesis 2D - Relation between Dividend Changes and Market Expectations of Future Earnings}

Finally, we will try to examine the relation between dividend change announcements and the market expectations of future earnings. We begin by considering the relationship between dividend change announcements and earnings changes. However, current earnings may not reflect the market's expectations surrounding the dividend announcements date. In order to overcome this problem, some authors, like Offer and Siegel (1987) and Nissim and Ziv (2001) have used the analysts' earnings forecasts in order to have a proxy for the market's earnings expectations. Unfortunately, as with analysts' dividend forecasts, we do not have access to this information. In this context, we will try to find a proxy for the market expectations of future earnings.

Ohlson (1995) has developed a model of a firm's market value, considering an economy with risk neutrality and homogeneous beliefs. Based on finance theory, he represents market value of the firm as the present value of future expected dividends:

$$
P_{t}=\sum_{\tau=1}^{\infty}\left(1+R_{f}\right)^{-\tau} e_{t}\left[\tilde{d}_{t+\tau}\right]
$$


where:

$\mathrm{P}_{\mathrm{t}} \quad=$ market value, or price, of the firm's equity at date $\mathrm{t}$;

$\mathrm{d}_{\mathrm{t}} \quad=$ dividends paid at date $\mathrm{t}$;

$\mathrm{R}_{\mathrm{f}} \quad=$ risk-free rate;

$\mathrm{e}_{\mathrm{t}} . \quad=$ expected value operator conditioned on the date $\mathrm{t}$ information.

The model imposes the clean surplus relation (CSR) which states that the change in book value equals earnings minus dividends:

$$
B V_{t}=B V_{t-1} \dashv E_{t}-d_{t}
$$

where:

$$
\begin{aligned}
& \mathrm{BV}_{\mathrm{t}}=\text { book value of equity at the end of year } \mathrm{t} \\
& \mathrm{E}_{\mathrm{t}}=\text { earnings in year } \mathrm{t}
\end{aligned}
$$

Ohlson recognises the importance of the accounting rule stating that dividends reduce current book value but not current earnings, and in order to respect it, he introduced the following constraints in the model:

$$
\begin{gathered}
\partial B V_{t} / \partial d_{t}=-1 \\
\partial E_{t} / \partial d_{t}=0
\end{gathered}
$$

He defines abnormal earnings (AE) as the earnings minus a charge for the use of capital, so it can be expressed as:

$$
A E_{t}=E_{t}-B V_{t-1} * R_{f}
$$

Ohlson shows that, given the dividend discount model, the abnormal earnings and the CSR, it can be derived the residual income model:

$$
P_{t}=B V_{t}+\sum_{\tau=1}^{\infty}\left(1+R_{f}\right)^{-\tau} e_{t}\left[\widetilde{A} E_{t+\tau}\right]
$$

provided that $e_{t}\left[\widetilde{B} V_{t+\tau}\right] /\left(1+R_{f}\right)^{\tau} \rightarrow 0$ as . He concludes that a firm's value equals its book value adjusted for the present value of anticipated abnormal earnings.

If we pass the term referring to $\mathrm{BV}_{\mathrm{t}}$ in the right hand side of the expression 3.5 to the left hand side, we can say that the difference between market and book value measures the present value of anticipated abnormal earnings, which can be seen as the firm's 
future profitability. Thus, if we test the relationship between the difference of market and book value a market based measure for the future expected profitability $\left(\mathrm{P}_{t}-\mathrm{BV}_{\mathrm{t}}\right)$ and dividend changes, we can tell something about the dividend information content hypothesis. Moreover, it has the merit of examining the information content of dividends on the expected future profitability globally, and not in a specific year.

We formulate the following alternative sub-hypothesis to examine the relation between current dividends and the market expectations of the firms' future prosperity:

$$
\begin{aligned}
& H_{2 D} \text { : "Dividend increases (decreases) are associated with superior (inferior) } \\
& \text { expectations of the firm's future prosperity" }
\end{aligned}
$$

According to the dividend information content hypothesis, we expect a positive association between dividend changes and the market expectations of future earnings. If we fail to reject the null hypothesis associated with $\mathrm{H}_{2 \mathrm{D}}$, we will find no support for the dividend signalling theory.

\subsection{SAMPLE SELECTION AND METHODOLOGY}

After the identification of the research purposes, it is necessary to define which data we must collect as well as the methodology to be used in order to test the formulated hypotheses and, consequently, to obtain the main conclusions that are revealed by the empirical work.

\subsubsection{SAMPLE SELECTION}

Our purpose is to analyse different European markets, so we opt to explore the UK, the French and the Portuguese markets. Although they are all European markets, they are different from each other for several reasons.

Firstly, the UK is one of the most important European capital markets and is comparable with US studies, since the firms listed on this market distribute quarterly dividends, whereas the French and Portuguese markets distribute dividends annually. The French market is also a representative European market, but Portugal is a very 
small market compared to other Western European markets, considered by several authors and databases as an emerging market ${ }^{56}$. Additionally, these two markets are less intensively researched.

Secondly, we have differences in these countries associated with the ownership of equity. In Portugal and France ownership tends to be more concentrated than in the $\mathrm{UK}^{57}$ and this is expected to mitigate the information asymmetry problem. This would lower the importance of dividends as a signalling mechanism and consequently share price reaction to dividend change announcements would be expected to be lower in countries where ownership is more concentrated (in our study, Portugal and France).

Thirdly, bank debt is an important source of funds in Portugal and France (although to a lesser extent in the later case). UK firms are even less dependent on banks for external funding, and so banks have less monitoring activity and less access to information in the UK than in the other two countries. In a bank-based system, the asymmetric information and agency problems are solved in a different way than in a market-based system (the case of UK market), and it will influence dividend policy in a different way. Consequently, the need to use dividends as a signalling device may be less pronounced in Portugal and France, as they present financial model banking based system, than in the UK market, which is a market-based country, like the US ${ }^{58}$.

Finally, the fourth reason why we expect to find different results among samples is related to the legal rules covering protection of corporate shareholders, which can influence the dividend policy La Porta et al. (1998) and Aivazian, Booth and Cleary (2002) . Basically, we have two main systems of law: the common law and the civil law. The first one is based on decisions of the UK courts and the second one, whose authoress is attributed to Napoleon, found its nature in Roman ideology. La Porta et al. (1998) examined these rules and their origin. They analysed different civil laws, such as common-law countries (which includes UK) and French civil-law countries (including

\footnotetext{
${ }^{56}$ Like the Emerging Markets Data Base (EMDB).

${ }^{57}$ According Crama et al. (2003), in France all large (disclosing) shareholders combined own more than $52 \%$ of the equity capital, in contrast with the UK where they control only about $40 \%$ of the voting rights. In Portugal, we find a value of about $65 \%$, which is similar to the ones of Germany, Spain and Italy, according to the same study.

${ }^{58}$ Low et al. (2001) analysed the relationship between the theories of banking and dividend policy examining whether bank monitoring and firm dividend signals complement one another to resolve information asymmetries. His evidence provides that banks serve an important signalling role in influencing investors' assessment of the dividend decisions of small firms.
} 
the Portuguese and French markets) ${ }^{59}$. They conclude that common-law countries generally have the strongest legal protection of investors and French civil-law countries have the weakest, and that the concentration of ownership of shares is negatively related to investor protections, which leads civil-law countries to develop substitute mechanisms for poor investor protection. In addition, Demirguc-Kunt and Levine (1999) study a cross-section of up to 150 countries to illustrate how financial systems differ around the world and conclude, among other things, that countries with a common law tradition tend to have strong protection for shareholders rights and tend to be more market-based, while countries with a French civil law tend to have underdeveloped financial systems and poor protection of shareholder rights. Moreover, whereas UK is a country of Anglo-Saxon influence, where information asymmetry and agency costs problems are high and, consequently, firms need to signal to the market their private information, the other two countries are characterised by a continental influence $^{60}$. In such countries, information asymmetries are supposedly low and so firms are not likely to use dividend payments to signal their private information.

Given these characteristics, we expect to find more similarity between the French and the Portuguese markets rather than between the UK and the other two markets, finding also a weaker support to the dividend signalling theory in Portugal and France than in the UK.

The sample is drawn from dividend announcements of firms listed on the Euronext Lisbon (EL), Euronext Paris (EP) and LSE. For the French and UK markets, we consider the dividend announcements between $1994^{61}$ and 2002. Announcement dates are available on Bloomberg database and all other needed information is available on Datastream database. For the Portuguese market we consider the dividend announcements between 1988 and $2002^{62}$. Because Bloomberg and Datastream lack

\footnotetext{
${ }^{59}$ They considered also the German and Scandinavian civil law countries. For more detail, namely about the rules origin, see La Porta et al. (1998, p. 1118-1119).

${ }^{60}$ The Anglo-Saxon system is a system where the number of listed firms is large, the process of acquiring control is effectively market oriented, i.e., a liquid capital market with frequently traded ownership and control rights, and with a few corporate holdings or interlocked patterns of ownership. In continental influence countries, ownership is typically concentrated in a few hands holding large block of shares of corporate equity and control rests with corporate insiders.

${ }^{61}$ The first year (1994) is conditioned by the availability of announcement dates on Bloomberg database.

${ }^{62}$ For the Portuguese sample we consider a longer period than for the two other samples, in order to maximise the number of observations, since this is a small market, with a small number of dividend events (as we will see later).
} 
information on the Portuguese market, we obtain data from Dhatis, an EL database and we also needed to collect some financial statements directly from the companies.

To be included in the final sample, the dividend announcements must satisfy the following criteria:

1) The firm is not a financial institution. This criterion helps improve the homogeneity of the sample since financial institutions have different accounting categories and rules;

2) The firm is listed on the respective stock exchanges the year before and two years after the dividend events. This criterion controls for firms being listed and de-listed from one year to the next and minimises the survivorship bias;

3) The firm's financial data is available on the Datastream database (or the Dathis database in the case of Portugal ${ }^{63}$ ) at the year before and two years after the dividend events and announcement dates are available on Bloomberg database;

4) The company paid an ordinary dividend in the current and previous year. This criterion excludes dividend initiation and omission events;

5) For the Portuguese and French market, we consider that the firms' earnings announcements or other contaminate announcements, such as stock splits, stock dividends and mergers, did not occur within 5 trading days of the dividend announcement. This criterion is likely to free the sampling period of any contaminating or noisy announcement effects. For the UK market we exclude all these announcements, except the case of earnings announcements. For the UK market, dividends and earnings are usually announced in the same date. We, therefore, exclude the dividend events for which dividends and earnings information were announced on separate dates, which is a small number ${ }^{64}$. In addition, we need to adapt the methodology in order to separate the two effects (dividends and earnings).

Since we want to analyse dividend changes ${ }^{65}$, our sample includes dividend events (increases, no change and decreases) from 1995 to 2002 for the French and the UK

\footnotetext{
${ }^{63}$ For the Portuguese sample we needed to collect financial statements additionally on Euronext dossiers, Comissão do Mercado de Valores Mobiliário (CMVM), Diário da República and directly from some firms. The Portuguese data was one of the most onerous information to obtain.

${ }^{64}$ We exclude 6 events with dividends and earnings announced on separate dates.

${ }^{65} \mathrm{We}$ will not consider dividend initiations and omissions because their inclusion would generate a bias in the results, since they are followed by a more significant market reaction, as it was documented by Healy and Palepu (1988).
} 
markets and from 1989 to 2002 for the Portuguese market. The samples include 84 firms for Portugal and a total of 380 events; 93 firms for France and a total of 356 events and 524 firms for the UK and a total of 3,278 events. Table 3.4 summarises the sample data.

In the following subsection we describe the variables used. Appendix 1 contains the definitions of the variables used throughout the entire study.

\subsubsection{METHODOLOGY}

We will choose the methodology that, in our point of view, is the most appropriate to test the hypotheses formulated, which entails mainly sensitivity analysis, event studies and panel data analysis, which endows regression analysis of both a spatial and temporal dimension, to estimate the parameters of interest.

Our samples are an unbalanced panel data, but, as Baltagi and Chang (1994, p. 67) have shown, "making the data balanced, by dropping observations, worsens the performance of these estimators when compared to those from the entire unbalanced data". The panel data approach has several advantages compared to the cross-sectional approach used in financial research. Due to an increase in the number of observations, degrees of freedom are increased and the problem of multicollinearity is reduced, thus the efficiency of econometric estimates is improved. In addition, panel data can control for individual heterogeneity due to the hidden factors, which is neglected in time-series or crosssection estimations leading to biased results Verbeek (2004) and Baltagi (1995) . Heterogeneity is captured by firms specific fixed effects or random effects components based on the characteristics of the data set. In short, panel data can enrich empirical analysis in ways that may not be possible if we use only cross-section or time series data Gujarati, (2003) .

Employing the panel data methodology, we will use the three common techniques for estimating models with panel data, which are the pooled ordinary least squares (OLS) ${ }^{66}$,

\footnotetext{
${ }^{66}$ Despite its simplicity, the pooled OLS model assumes that the intercept value of all the firms are the same and that the slope coefficients of the independent variables are all identical for all the firms.
} 
the fixed effects model (FEM), and the random effects model (REM) ${ }^{67}$. We cannot run dynamic panel regressions, as we need a minimum of six consecutive years for a company to be included Gaud et al. (2005). If we consider this condition, we would not have enough data to analyse the Portuguese and the French markets. Subsequently, we will use proper test statistics, namely an F-statistic and the Hausman (1978) test to choose the most appropriate model for our samples ${ }^{68}$. We compare the pooled OLS and the FEM with an F-statistic that tests the null hypothesis that the constant terms are all equal, thus, it tests the significance of the firms' effects. Under the null hypothesis, the efficient estimator is pooled least squares. If the pooled OLS regression is the best estimation method, it means that in the events there is no significant firm effect. As Greene (2000, p. 560) wrote, "If we take the is to be the same across all units, then OLS provides consistent and efficient estimates of and ". In addition, the Hausman statistic tests the null hypothesis that REM is appropriate for the particular sample compared to the FEM and allows us to decide which of the model gives the best estimation. The Hausman test allows verifying the presence of correlation between the unobservable heterogeneity and the explanatory variables. This consists of comparing the coefficients of the estimates for fixed effects and the estimates for random effects. The null hypothesis is that the coefficients on both models are similar. If the coefficients differ from each other, the fixed effects estimation is simultaneously consistent and efficient. Consequently, if we do not reject the null hypothesis, we will interpret the REM results $^{69}$. On the other hand, if we reject the null hypothesis, we will analyse the FEM results. We present the standard errors corrected for heteroscedasticity and covariance, based on the White's (1980) heteroscedasticity consistent standard errors method ${ }^{70}$.

Before beginning to test the hypotheses already formulated in the precedent section, and for each market, we will begin by analysing briefly the trends in the dividend payment

\footnotetext{
${ }^{67}$ We will not eliminate outliers or use the winsorizing method for two reasons. First, because we are using unbalanced panel data, and second, because we think influential observations are simply a true statement about the market. Moreover, the results were qualitatively similar when we winsorize the independent variables at the 1 and the 99 percentiles.

${ }^{68}$ See Appendix 2 for a description of the F test and Appendix 3 for the Hausman (1987) test.

${ }^{69}$ The FEM can be interpreted as a classical regression model, as well. If $\mathrm{N}$ is small enough, then the model can be estimated by OLS with the same regressors and with dummy variables indicating the different firms (to identify the firms effect), the different years (to identify the period effect), or both of them Greene (2000, p.561) .

${ }^{70}$ Violation of the assumption that the residuals are homocedastic has potentially serious implications on inferences based on these results. Thus, the application of panel data regressions, ignoring the possibility of a non-constant disturbance variance (heteroscedasticity) would lead to estimators that are unbiased and consistent but no longer efficient. See Appendix 4 for a brief description of the White (1980) test.
} 
pattern for the sample period, considering all the non-financial listed firms whose data are available on Datastream or Dhatis databases, and not only the filtered samples, in order to obtain global market trends and compare these results with several studies done in the US market, like the ones of Fama and French (2001), Baker and Wurgler (2002) and Reynolds (2004), as well as abroad the US market, such as the recent studies of Ferris, Sen and Yui (2004), applied to eleven common law and fourteen civil law countries, and Osobov (2004), applied to US, Canada, UK, Germany, France and Japan.

After analysing the trends in the dividend payment pattern, we will illustrate our sample, with the initial events, the filters and the final events, and show also a summary statistics on dividend events.

In addition, we would like to test for the stability in the dividend policy of the different European countries considered in our study. Based on Omet (2004), we will use the following model:

$$
D_{i, t}=\alpha_{i}+\beta_{1} \mathrm{EPS}_{\mathrm{i}, \mathrm{t}}+\beta_{2} \mathrm{D}_{\mathrm{i}, \mathrm{t}-1}+\varepsilon_{i, t}
$$

where:

$$
\begin{array}{ll}
\mathrm{D}_{\mathrm{i}, \mathrm{t}} & =\text { dividend per share } \mathrm{i} \text { announced in year } \mathrm{t} ; \\
\mathrm{D}_{\mathrm{i}, \mathrm{t}-1} & =\text { dividend per share } \mathrm{i} \text { announced in year } \mathrm{t}-1 ; \\
\text { EPS }_{\mathrm{i}, \mathrm{t}} & =\text { earnings per share } \mathrm{i} \text { in year } \mathrm{t} .
\end{array}
$$

For this test, we start by considering the total number of cash dividend during the sample period, excluding dividend events with missing data and excluding also the firms which did not have at least five years of cash dividend to have enough cash dividend years for testing stability Dewenter and Wharther (1998) . This model allows seeing if the sample firms follow stable cash dividend policies and compare our conclusion with the results of Lintner's (1956) classical paper, as well as with other recent studies, such as Aivazian, Booth and Cleary (2003a) and Omet (2004).

After that global analysis, we will apply the methodology to test the hypotheses formulated above. 


\subsubsection{Methodology to Test Hypothesis 1 - Relation between Dividend Change Announcements and the Market Reaction}

When examining the stock market reaction to the dividend announcement events, we employ a conventional event-study methodology.

We assume that dividends follow a random walk ${ }^{71}$; the average dividend change for a random sample of firms is, therefore, expected to be zero, so the dividend changes were used as the proxy for the unexpected dividend changes. This proxy (naïve dividend changes) has been used in other studies, such as in Nissim and Ziv (2001) and Benartzi el al. (2005). It captures the unexpected component of dividends with some error, but we do not have access to analysts' dividend forecasts ${ }^{72}$. However, we can justify the use of this model by the manager's aversion to modify dividends, unless this modification provides information.

Although the UK usually distributes quarterly dividends, we will analyse the annual dividends as Datastream only provides the total yearly dividends per share (DPS). In addition, we have two reasons that can support the use of analysing annual and not quarterly dividends. Firstly, dividends are defined having as a base of annual earnings and not quarterly Watts, (1973) . DeAngelo (1990), DeAngelo et al. (1992) and Lonie et al. (1996) focus their studies on annual dividend data since, as statistical analysis and questionnaire survey evidence from managers suggests, dividend policy tends to be determined on a yearly basis. Lintner's (1956, p. 103) survey to managers revealed that “...dividends were uniformly considered in terms of annual periods". Secondly, this approach allows us to compare the results of the three markets of our sample, since the other two markets have annual dividends.

In addition, we need to adapt the methodology when analysing the UK sample. UK firms usually announce both dividends and earnings simultaneously making it difficult to separate out the dividend announcement effect from that of earnings. However, it gives the opportunity to incorporate the interaction of the joint signals into the analysis.

\footnotetext{
${ }^{71}$ We define the dividend process to be a martingale, having the background in the reluctance to change dividends evidence, which assumes that managers are averse to change dividends unless they perceive substantial changes in the future economic situation of their firm.

${ }^{72}$ In fact, Dhillon, Raman and Ramírez (2003) showed that the naïve dividend expectations model is not the best model to determine the unexpected dividends. Instead, they suggest the use of dividends analysts' forecasts. However, we do not have access to this information.
} 
Therefore, for the UK market, the impact of earnings announcements is examined by dividing the total sample into six categories, according to the scheme presented below:

\begin{tabular}{lcccc}
\hline \multirow{2}{*}{ Announcement Type } & \multicolumn{3}{c}{ Dividends } \\
\cline { 3 - 5 } & & Increases & No-changes & Decreases \\
\hline \multirow{2}{*}{ Earnings } & Increases & DIEI & DNCEI & DDEI \\
& Decreases & DIED & DNCED & DDED \\
\hline
\end{tabular}

Type of events for the UK, according the relation between dividends and earnings

Thus, we will analyse the following situations: dividend increase-earnings increase (DIEI), dividend increase-earnings decrease (DIED), dividend no-change-earnings increase (DNCEI), dividend no-change-earnings decrease (DNCED), dividend decrease-earnings increase (DDEI), and dividend decrease-earnings decrease (DDED). We will pay special attention to the cases where dividend and earning changes take opposite directions (DIED and DDEI).

The general adaptation will consist on the division of the sample in these groups, or considering dummy variables that distinguish the different situations in the regressions, in order to isolate the impact of dividend announcements and investigate whether dividends provide information beyond that provided by earnings announcements. According to Aharony and Swary (1980) and Eddy and Sheifer (1992) dividend change announcements should provide information beyond what is provided by earnings announcements. As we go through the methodology analysis, we will present the modifications done in the UK sample analysis.

The annual dividend change corresponding to the dividend announcement is defined as the difference between the announced dividend in year $\mathrm{t}$ and the prior year dividend, scaled by the announcement day share price $^{73}$ :

$$
\Delta D_{i, t}=\frac{D_{i, t}-D_{i, t-1}}{P_{i, 0}}
$$

where:

$$
\begin{aligned}
D_{i, t} & =\text { change of dividend per share } \mathrm{i} \text { for year } \mathrm{t} \\
\mathrm{P}_{\mathrm{i}, 0} & =\text { price of share } \mathrm{i} \text { in the announcement day. }
\end{aligned}
$$

\footnotetext{
${ }^{73}$ Although deflating the dividend change by the prior dividend is not unusual, deflating by price is more prevalent in the literature and is likely to be a better measure. See Nissim (2003) for an extensive discussion of the merits of normalizing the change in dividends by price per share.
} 
The classical procedure for event studies is to investigate whether there are abnormal returns around the dividend announcement date. The announcement effect exists if abnormal returns are significant.

To measure the market reaction to dividend change announcements we opt to consider three approaches to determine the abnormal returns. Using various alternative event specifications we test the robustness of our results. Firstly, we use the standard CAPM. Secondly, we consider the abnormal returns calculated from a buy-and-hold strategy, denominated by buy-and-hold abnormal returns (BHARs). Finally, we estimate abnormal returns as market-adjusted returns to test the robustness of our results. The first two approaches will be used according to the market considered ${ }^{74}$ and the last one is used for the three markets.

We now present the three approaches to calculate abnormal returns in order to measure the market reaction to dividend change announcements.

\section{Approach A: CAPM}

We begin to measure the market reaction to dividend change announcements considering the abnormal returns calculated through the CAPM:

$$
A R_{i, t}=\mathrm{R}_{\mathrm{i}, \mathrm{t}}-\left[\mathrm{R}_{\mathrm{f}, \mathrm{t}}+\beta_{\mathrm{i}}\left(\mathrm{R}_{\mathrm{m}, \mathrm{t}}-\mathrm{R}_{\mathrm{f}, \mathrm{t}}\right)\right]
$$

where:

$$
\begin{aligned}
\mathrm{AR}_{\mathrm{i}, \mathrm{t}} & =\text { abnormal return for share } \mathrm{i} \text { in day } \mathrm{t} \\
\mathrm{R}_{\mathrm{i}, \mathrm{t}} & =\text { return for share } \mathrm{i} \text { in day } \mathrm{t} \\
\mathrm{R}_{\mathrm{f}, \mathrm{t}} & =\text { risk-free rate in day } \mathrm{t} \\
\mathrm{R}_{\mathrm{m}, \mathrm{t}} & =\text { market return for day } \mathrm{t} \\
\mathrm{i} & =\text { systematic risk of share } \mathrm{i}
\end{aligned}
$$

The parameter i, measured as $\operatorname{cov}\left(\mathrm{R}_{\mathrm{i}, \mathrm{t}}, \mathrm{R}_{\mathrm{m}, \mathrm{t}}\right) / \operatorname{var}\left(\mathrm{R}_{\mathrm{m}, \mathrm{t}}\right)$, is estimated for each share, by an OLS regression based on market model, considering the period from day $\mathrm{t}=-120$ to day $=+120$, excluding the 31 days around dividend announcements $(t=-15$ to $t=+15)$.

\footnotetext{
74 For example, for the Portuguese market, we do not have enough historical price data to calculate firm's beta, so, we will only consider the BHAR approach. For the other two markets, we will analyse the two methods.
} 
The 3-day cumulative abnormal return (CAR) is used to measure the market reaction to the dividend announcements and is calculated surrounding the announcement date as ${ }^{75}$ :

$$
C A R_{i, t}=\sum_{t=-1}^{t=1}\left(\mathrm{AR}_{\mathrm{i}, \mathrm{t}}\right)
$$

where $\mathrm{t}=0$ is the dividend announcement day in the stock exchange journal.

If the information content hypothesis is correct, the CAR should be significantly different from zero. The hypothesis predicts that the shares of those firms that announce dividend increases (decreases) should, on average, earn positive (negative) abnormal returns, while the shares of firms that do not modify their dividends should, on average, earn normal returns.

\section{Approach B: BHARs Strategy}

The second approach consists of determining the abnormal returns according to the BHARs $^{76}$ strategy. The abnormal return for a share is defined as the geometrically compounded (buy-and-hold) return on the share minus the geometrically compounded return on the market index. Therefore, the "buy-and-hold" abnormal return for share $\mathrm{i}$

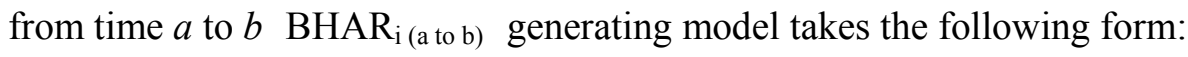

$$
\operatorname{BHAR}_{i(a t o b)}=\prod_{t=a}^{b}\left(1+R_{i, t}\right)-\prod_{t=a}^{b}\left(1+R_{m, t}\right)
$$

The time period $a$ to $b$ constitutes three trading days from $\mathrm{t}=-1,0+1$.

The average abnormal returns are calculated as follows:

$$
\overline{B H A R}=\frac{1}{\mathrm{~N}} \sum_{\mathrm{i}=1}^{\mathrm{N}} \mathrm{BHAR}_{\mathrm{i}}
$$

where $\mathrm{N}$ is the number of observations.

\footnotetext{
${ }^{75}$ We consider 3-day CAR since the disclosure of the dividend information to the market may have occurred on the day before the formal reporting of such news in the financial press (day $t=-1)$ and it allows the market to adjust for its reaction the day after the announcement (day $t=+1)$. Moreover, as it was shown by Brown and Warner (1985), the longer the event window, the lower the power of the test statistically.

${ }^{76}$ Barber and Lyon (1997) investigated the bias sources in abnormal returns. They suggest that CARs are subject to a measurement, a new listing and a skewness bias, which all lead to positively biased test statistics. BHARs are subject to a new listing, a skewness (which is worse than that for CARs) and a rebalancing bias, which leads to negatively biased test statistics. However, in assessing these different biases, Barber and Lyon (1997, p.347) states that "we favor the use of buy-and-hold abnormal returns to cumulative abnormal returns on conceptual grounds".
} 


\section{Approach C: Market-adjusted Returns}

The last method $^{77}$ we use to estimate abnormal returns to check the sensitivity of our results is the market-adjusted returns. We subtract the market return from the corresponding share return over the announcement period.

Then, the 3-day cumulative adjusted abnormal return (CAAR) is considered as a measure of market reaction to the dividend announcements and is calculated surrounding the announcement date as follows:

$$
C A A R_{i, t}=\sum_{t=-1}^{t=1}\left(\mathrm{R}_{\mathrm{i}, \mathrm{t}}-R_{m, t}\right)
$$

This approach makes the assumption that the beta for all firms is 1. Although this is conceptually less correct than the use of CAPM, the difference is minimal over a threeday window and, most importantly, it overcomes the thin trading problem of the Portuguese market. Given the lack of liquidity for the period examined, in certain days no trading took place for some of the shares.

In addition, we test whether dividend change announcements matter based on market conditions by examining the market's reaction to dividend change announcements during up and down markets. From an asset pricing perspective, we would expect that the market responses to dividend change announcements would not be a function of the state of the market ${ }^{78}$. From a signalling perspective, however, we would expect an asymmetric reaction. We would expect that in down markets dividend increases should have higher price reactions than in up markets, and dividend decreases would have lower (less negative) price reactions in down markets than up markets. Further, if the maintenance of dividends provides information, then we would also expect that the abnormal return would be higher in down markets than in up markets ${ }^{79}$.

\footnotetext{
${ }^{77}$ We analyse alternative measures because results can vary with the methodology used to measure excess returns Fama (1998).

${ }^{78}$ The market should respond similarly to increases in dividends in either an up or down market and not changing a dividend would likely have little effect from an asset pricing perspective regardless of the overall state of the market Goldstein and Fulter (2003, p. 19) .

${ }^{79}$ In down markets, investors' perceptions of future profits tend to be lower, while investors tend to have positive outlooks on future earnings during up markets. Therefore, increasing dividends in down markets provides a much stronger signal about the future than a similar increase during an up market. Similarly, not changing dividends during up markets likely provides little additional information to investors. However, during a down market, when investors should be more pessimistic about the overall economic outlook, not changing a dividend provides investors with a reassuring signal that the company is not headed for bankruptcy. Finally, decreasing dividends in down markets may be expected by investors thus
} 
Similarly to Goldstein and Fulter (2003), we classify an up market as a month during which the monthly return on the market Index considered for that country is positive, while a down market is one where the Index posted a negative monthly return. We will analyse whether the differences in abnormal returns (calculated according to the different approaches presented before: CAR, BHAR and CAAR) between up and down markets are statistically significant for the three groups of events (increases, decreases and no changes). To see if the mean differences are significant, we will use the test $t$ for the difference between means as well as the Kruskal-Wallis test ${ }^{80}$.

To explore the relation between the wealth effect and dividend changes, the market's reaction to dividend change announcements is regressed against dividend changes. For the Portuguese and French samples, the following regression model is estimated:

$$
C A R 3_{i}=\alpha+\beta_{1} \mathrm{DI} \times \Delta \mathrm{D}_{\mathrm{i}, 0}+\beta_{2} \mathrm{DD} \times \Delta \mathrm{D}_{\mathrm{i}, 0}+\varepsilon_{i, t}
$$

where:

$\mathrm{CAR}_{\mathrm{i}}=$ cumulative abnormal return for share $\mathrm{i}$ on the 3 -day period, as formulated in the 3 approaches: equations $3.9,3.10$ and 3.12 ;

DI $=$ dummy variable that takes value 1 if dividend increases and zero otherwise;

DD = dummy variable that takes value 1 if dividend decreases and zero otherwise.

If dividend changes convey information about a firm's future prospects, as suggested by the dividend information content hypothesis, we expect ${ }_{1}$ and ${ }_{2}$ to be positive and statistically significant, reflecting a significant positive relationship between dividend change announcements and the magnitude of share price reactions to these announcements. We address also the question of whether no change dividend announcements have influence on the cumulative abnormal return, being revealed by the constant term of regression $3.13 \mathrm{a}$. In what concerns the UK sample, we need to adapt equation $3.13 \mathrm{a}$ in order to capture the influence of interactive dividend and earnings signals on the cumulative abnormal return of the sample events. For this purpose, the regression is adapted in the following way:

convey less information than when firms decrease dividends in up markets when everything is supposed to go well Goldstein and Fulter (2003, p. 19) .

${ }^{80}$ See Appendix 5 for a description of Kruskal-Wallis test. 


$$
\begin{aligned}
C A R 3_{i}= & a \dashv \beta_{1} \text { DIEI } \times \Delta \mathrm{D}_{\mathrm{i}, 0} \dashv \beta_{2} \text { DIED } \times \Delta \mathrm{D}_{\mathrm{i}, 0} \dashv \beta_{3} \text { DDEI } \Delta \mathrm{D}_{\mathrm{i}, 0} \dashv \\
& +\beta_{4} \text { DDED } \times \Delta \mathrm{D}_{\mathrm{i}, 0}+\varepsilon_{i, t}
\end{aligned}
$$

In the regression, variables DIEI, DIED, DDEI and DDED are dummy variables which take the value of 1 if the situation expressed by the letters is true, and zero otherwise. For example, the DIEI is a dummy variable that takes the value of 1 if both dividend and earnings have increased, and zero otherwise. The dummy variable referring to dividend no changes is excluded from the model to prevent the problem of over specification; the intercept term, therefore, may be interpreted as the scenario where dividends are constant, conveying no significant news to the market. The coefficients 1 to 4 represent the influence of the dividend changes on the performance measured, conditioned on the earnings behaviour.

\subsubsection{Methodology to Test Hypothesis 2 - Relation between Dividend Changes and Firm's Future Profitability}

To test the relation between dividend changes and the future performance, we consider several measures of future performance, formulating four different sub-hypotheses.

\subsection{Methodology to test sub-hypothesis $2 \mathrm{~A}$ - relation between dividend changes and future earnings changes}

Firstly, we start by considering as future performance the future earnings changes, in order to analyse the relationship between dividend change announcements and future earnings changes.

Some authors have investigated the time series behaviour of accounting earnings. The evidence suggests that annual earnings are well described as a random walk Ball and Watts (1972) and Watts and Leftwich (1977), so the average earnings changes for a random sample of firms are therefore expected to be zero and, consequently, the change in earnings measures unexpected profitability ${ }^{81}$.

\footnotetext{
${ }^{81}$ The evidence on the time series of quarterly earnings indicate that they do not follow a random walk but, instead, they contain an adjacent component, as was suggested by Brown and Rozeff (1979).
} 
We express annual earnings changes as the difference between earnings in year $\mathrm{t}$ and earnings in year $\mathrm{t}-1$, scaled by the book value of equity at the end of year $t-1^{82}$. The standardized change in earnings for share $i$ in year $t, E_{i, t}$, is therefore defined as:

$$
\Delta E_{i, t}=\frac{\left(\mathrm{E}_{\mathrm{i}, \mathrm{t}}-E_{i, t-1}\right)}{B V_{i, t-1}}
$$

${ }^{82}$ We scale earnings changes by the book value of equity in order to compare our results with the ones of Nissim and Ziv (2001) and Benartzi et al. (2005), among others. Moreover, see Nissim and Ziv (2001, p. 2117) for an explanation of the merits of deflating the earnings changes by the book value of equity. 
where:

$$
\begin{array}{ll}
\mathrm{E}_{\mathrm{i}, \mathrm{t}} & =\text { earnings before extraordinary items for share } \mathrm{i} \text { in year } \mathrm{t} \\
\mathrm{BV}_{\mathrm{i}, \mathrm{t}-1} & =\text { book value of equity for share } \mathrm{i} \text { at the end of year } \mathrm{t}-1 .
\end{array}
$$

We define year 0 as the fiscal year of the dividend announcement and use earnings before extraordinary items to eliminate the transitory components of earnings. Moreover, we match the dividend announcements made during fiscal year $t$ to the earnings in the fiscal year $t$.

In order to verify if the results of Nissim and Ziv (2001) and Benartzi et al. (2005) hold in our samples, we examine the relation between dividend changes and future earnings changes based on Nissim and Ziv (2001). For the Portuguese and French markets, we consider the following regression:

$$
\begin{aligned}
\left(\mathrm{E}_{i, \tau}-E_{i, \tau-1}\right) / B V_{i,-1} & =a \dashv \beta_{1} \mathrm{DI} \times \Delta \mathrm{D}_{\mathrm{i}, 0} \dashv \beta_{2} \mathrm{DD} \times \Delta \mathrm{D}_{\mathrm{i}, 0} \dashv \beta_{3} R O E_{i, \tau-1} \dashv \\
& +\beta_{4}\left(E_{i, 0}-E_{i,-1}\right) / B V_{i,-1}+\varepsilon_{i, t}
\end{aligned}
$$

where:

$$
\begin{aligned}
\mathrm{E}_{\mathrm{i},} & =\text { earnings before extraordinary items for share } \mathrm{i} \text { in year relative to } \\
& \text { the dividend event year (year } 0) ; \\
= & 1 \text { and } 2 \\
\mathrm{BV}_{\mathrm{i},-1}= & \text { book value of equity for share } \mathrm{i} \text { at the end of year }-1 ; \\
\mathrm{ROE}_{\mathrm{i},-1}= & \text { return on equity for share } \mathrm{i} \text {, calculated as } \mathrm{E}_{\mathrm{i},-1} / \mathrm{BV}_{\mathrm{i},-1 .} .
\end{aligned}
$$

For the UK market, as we have done before, we adapt the regression in order to consider the influence of interactive dividend and earnings signal on the future earnings changes. Thus, the regression becomes expressed as:

$$
\begin{aligned}
\left(\mathrm{E}_{i, \tau}-E_{i, \tau-1}\right) / B V_{i,-1}= & a \dashv \beta_{1} \text { DIEI x } \Delta \mathrm{D}_{\mathrm{i}, 0}-\beta_{2} \text { DIED } \times \Delta \mathrm{D}_{\mathrm{i}, 0}- \\
& +\beta_{3} \text { DDEI } \Delta \mathrm{D}_{\mathrm{i}, 0}+\beta_{4} \text { DDED } \mathrm{x} \Delta \mathrm{D}_{\mathrm{i}, 0}+\beta_{5} R O E_{i, \tau-1}+3.15 \mathrm{~b} \\
& +\beta_{6}\left(E_{i, 0}-E_{i,-1}\right) / B V_{i,-1}+\varepsilon_{i, t}
\end{aligned}
$$

We address the question of whether the announcements of no change in dividends are informative to the market, a question unanswered by a significant number of prior research studies regarding the information content of dividend announcements. The significance of non-change dividends is revealed by the constant term ( ) in the regression 3.15. In addition, tests for the correlation among independent variables are analysed, in order to detect econometric problems, such as multicollinearity. 
The regression 3.15 includes the return on equity and past changes in earnings to control for the mean reversion of earnings. However, these regressions assume that the rate of mean reversion is uniform across all observations. In fact, these models assume that the relation between future earnings and past earnings levels and changes is linear, which is strongly criticized by Benartzi et al. (2005, p. 3), "The assumption of linear mean reversion in earnings made by $N Z$ is inappropriate ${ }^{, 83}$. To overcome the problem of the mean reversion process of earnings being highly non-linear, we use the modified partial adjustment model suggested by Fama and French (2000) and adopted recently by Benartzi et al. (2005) as a control for the non-linearity in the relation between future earnings changes and lagged earnings levels and changes. The model is the following:

$$
\begin{aligned}
\left(\mathrm{E}_{i, \tau}-E_{i, \tau-1}\right) / B V_{i, 1}= & \alpha+\beta_{1} \Delta \mathrm{D}_{\mathrm{i}, 0}+\left(\begin{array}{l}
\gamma_{1}+\gamma_{2} N D F E D_{0}+\gamma_{3} N D F E D_{0} * D F E_{1,0}+ \\
\gamma_{4} P D F E D_{0} * D F E_{1,0}
\end{array}\right) * \mathrm{DFE}_{i, 0} \\
& +\left(\lambda_{1}+\lambda_{2} N C E D_{0}+\lambda_{3} N C E D_{0} * C E_{i, 0}+\lambda_{4} P C E D_{0} * C E_{i, 0}\right) * \mathrm{CE}_{i, 0}+\varepsilon_{i, t}
\end{aligned}
$$

where:

$$
\begin{aligned}
\mathrm{DFE}_{\mathrm{i}, 0}= & \mathrm{ROE}_{\mathrm{i}, 0}-\mathrm{E} \mathrm{ROE}_{\mathrm{i}, 0} ; \\
\mathrm{E} \mathrm{ROE}_{\mathrm{i}, 0}= & \text { fitted value from the cross-sectional regression of } \mathrm{ROE}_{\mathrm{i}, 0} \text { on the } \\
& \log \text { of total assets in year }-1 \text {, the market-to-book ratio of equity in } \\
& \text { year }-1, \text { and } \mathrm{ROE}_{\mathrm{i},-1} ; \\
= & \left(\mathrm{E}_{\mathrm{i}, 0}-\mathrm{E}_{\mathrm{i},-1}\right) / \mathrm{BV}_{\mathrm{i},-1} ; \\
\mathrm{CE}_{\mathrm{i}, 0}= & \text { dummy variable that takes value } 1 \text { if } \mathrm{DFE}_{\mathrm{i}, 0} \text { is negative and } 0 \\
\mathrm{NDFED}_{0}= & \text { otherwise; } \\
\operatorname{PDFED}_{0}= & \text { dummy variable that takes value } 1 \text { if } \mathrm{DFE}_{\mathrm{i}, 0} \text { is positive and } 0 \\
& \text { otherwise; } \\
\mathrm{NCED}_{0}= & \text { dummy variable that takes value } 1 \text { if } \mathrm{CE}_{\mathrm{i}, 0} \text { is negative and } 0 \\
& \text { otherwise; } \\
\operatorname{PCED}_{0}= & \text { dummy variable that takes value } 1 \text { if } \mathrm{CE}_{\mathrm{i}, 0} \text { is positive and } 0 \\
& \text { otherwise. }
\end{aligned}
$$

As discussed in Fama and French (2000) and pointed out by Benartzi et al. (2005), the dummy variables and squared terms are designated to pick up the documented nonlinearities in the mean reversion and autocorrelation of earnings ${ }^{84}$.

\footnotetext{
${ }^{83}$ In fact, prior empirical evidence indicates that the mean reversion process of earnings is highly nonlinear see Brooks and Buckmaster (1976) and Fama and French (2000) .

${ }^{84}$ Specifically, these variables are meant to capture the fact that large changes in earnings revert faster than small changes and that negative changes revert faster than positive changes.
} 


\subsection{Methodology to test sub-hypothesis $2 \mathrm{~B}$ - relation between dividend changes and accounting performance measures}

Next, we would like to explore the post announcement financial performance of dividend changes considering other performance measures. Therefore, we will consider as firms' future performance accounting performance measures such as profitability measures (return on assets and return on equity), financial risk measures such as liquidity ratios, and debt ratios as well as a cash flow measure. This will allow us to address issues concerning the window dressing phenomenon as well as to see if dividend changes are associated with future cash flows.

For testing the respective sub-hypothesis, we consider a regression similar to the regression 3.15 but with five different dependent variables measuring aspects of financial performance: two profitability measures: the return on assets (ROA) and ROE; a gearing measure: the debt to equity ratio $(\mathrm{D} / \mathrm{E})$; a liquidity measure: working capital ratio (WCR) and cash flow (CF) measure. The following regression model is estimated:

$$
P M_{i, \tau}-P M_{i, \tau-1}=a \dashv \beta_{1} \mathrm{DIx} \Delta \mathrm{D}_{\mathrm{i}, 0} \dashv \beta_{2} \mathrm{DD} \times \Delta \mathrm{D}_{\mathrm{i}, 0} \dashv \beta_{3} \mathrm{PM}_{i, \tau-1} \dashv \beta_{4}\left(\mathrm{PM}_{\mathrm{i}, 0}-\mathrm{PM}_{\mathrm{i}, 1}\right) \dashv \varepsilon_{i, t} \quad 3.17 \mathrm{a}
$$

where:

$$
\begin{aligned}
\mathrm{PM}_{\mathrm{i},}= & \text { profitability measure that consists of five financial performance } \\
& \text { measures (ROA, ROE, } \mathrm{D} / \mathrm{E}, \mathrm{WCR} \text { and } \mathrm{CF}) \text { at date ; } \\
= & 1 \text { and } 2 ; \\
\mathrm{ROA}_{\mathrm{i},}= & \text { return on assets for share } \mathrm{i} \text {, computed as operating income before } \\
& \text { depreciation divided by book value of assets at the end of year ; } \\
\mathrm{ROE}_{\mathrm{i},}= & \text { return on equity for share } \mathrm{i} \text {, at the end of year ; } \\
\mathrm{D} / \mathrm{E}_{\mathrm{i},}= & \text { debt to equity ratio for share } \mathrm{i} \text {, calculated as the book value of total } \\
& \text { debt divided by the total book capital at the end of year ; } \\
\mathrm{WCR}_{\mathrm{i},=} & \text { working capital ratio for share } \mathrm{i} \text {, computed as total current assets } \\
& \text { divided by total current liabilities at the end of year ; } \\
\mathrm{CF}_{\mathrm{i},}= & \text { cash flow for share } \mathrm{i}, \text { computed as operating income before } \\
& \text { depreciation minus interest expense, income taxes and preferred } \\
& \text { stock dividends scaled by the total assets at the end of year . }
\end{aligned}
$$

For the UK sample, in order to consider the different relations between dividend and earnings announcements, we adapt this regression in the following way:

$$
\begin{aligned}
P M_{i, \tau}-P M_{i, \tau-1}= & a \dashv \beta_{1} \text { DIEI } \times \Delta \mathrm{D}_{\mathrm{i}, 0}+\beta_{2} \text { DIED } \times \Delta \mathrm{D}_{\mathrm{i}, 0}+\beta_{3} \text { DDEI } \times \Delta \mathrm{D}_{\mathrm{i}, 0} \dashv \\
& +\beta_{4} \text { DDED } \times \Delta \mathrm{D}_{\mathrm{i}, 0}+\beta_{5} \mathrm{PM}_{i, \tau-1}+\beta_{6}\left(\mathrm{PM}_{\mathrm{i}, 0}-\mathrm{PM}_{\mathrm{i}, 1}\right)+\varepsilon_{i, t}
\end{aligned}
$$


For consistency, we replace the change in earnings with the change in the profitability measure considered and the ROE with the particular variable considered in each regression.

Based on dividend signalling hypothesis assumptions, we expect that dividend increasing firms display further improvements in their financial profiles during the post announcement periods. On the other hand, dividend decreasing firms should demonstrate a further deterioration in reported financial performance in the post announcement years.

\subsection{Methodology to test sub-hypothesis $2 \mathrm{C}$ - relation between dividend changes and operating performance measures}

In addition, we would like to evaluate different post-announcement measures in order to analyse the maturity hypothesis of Grullon, Michaely and Swaminathan (2002).

In agreement with the signalling hypothesis assumptions, we expect dividend increases to be associated with superior operating performance, increases in capital expenditure and with an increase in sales growth. However, according to the maturity hypothesis, we expect that dividend increases are associated with inferior operating performance (or, at least, not superior), decreases in capital expenditure (or, at least, not increases), and should experience a decrease in sales growth.

We will use the post-announcement performance because the signalling hypothesis and maturity hypothesis have distinct predictions about future profitability. We also choose post-announcement capital expenditures ${ }^{85}$ as well as sales growth because these two variables are important to distinguish the signalling and maturity hypothesis. We measure the operating performance by the ROA Grullon, Michaely and Swaminathan (2002), the capital expenditure (CE) is calculated as a percentage of the beginning-ofyear total assets and the sales growth rate (SG) is the change in sales, as a percentage of previous year's sales. Our intention is to verify if the variables' post-announcement behaviour is in agreement with the predictions of the signalling hypothesis or the maturity hypothesis.

\footnotetext{
${ }^{85}$ For the Portuguese sample, the Datastream has no sufficient data about capital expenses, and this information is not available on the financial statements. Hence, we will not use this variable for this sample. However, we will consider the capital expenses for the other two samples, as we consider it will be important to interpret the results.
} 
Firstly, we will analyse the behaviour of the variables before and after the year of the dividend change announcements. We will also compute the abnormal operating performance, as well as the other variables, as paired differences between the dividendchanging firm and the control firm, considered as our sub-sample of firms that did not change dividends, which was constructed by the same sample selection criteria as the dividend-changing firm. We match sample firms with control firms based on ROA and the activity code.

Secondly, we group all dividend-increasing firms in our sample into three groups based on the post-announcement operating performance (ROA): top performance group, middle performance group and bottom performance group to see whether different operating performance groups have different variables behaviour and whether the signalling and the maturity hypotheses can co-exist ${ }^{86}$. Finally, we examine the determinants of the initial market reaction to dividend increase announcements and focus the analyses on the extent to which the initial market reactions anticipate the operating performance, capital expenditures and changes in sales growth. The following equation, based on Grullon, Michaely and Swaminathan (2002), is used to investigate these issues:

$$
\begin{aligned}
C A R 3_{i}= & a \dashv \beta_{1} \Delta \mathrm{DI}_{\mathrm{i}, 0}-\beta_{2}\left(R O A_{i, 0}-R O A_{i,-1}\right) \dashv \beta_{3} \Delta R O A_{i, 2} \dashv \beta_{4}\left(S G_{i, 0}-S G_{i,-1}\right)- \\
& +\beta_{5} \Delta S G_{i, 2}+\beta_{6}\left(C E_{i, 0}-C E_{i,-1}\right)+\beta_{7} \Delta C E_{i, 2}+\varepsilon_{i, t}
\end{aligned}
$$

where:

$$
\begin{aligned}
\mathrm{DI}_{\mathrm{i}, 0}= & \text { dividend increase changes per share } \mathrm{i} \text { in the announcement year; } \\
\mathrm{ROA}_{\mathrm{i}, 2}= & \text { measure of the abnormal change in profitability during the two } \\
& \text { years after dividend changes, computed as }\left(\mathrm{ROA}_{\mathrm{i}, 2}+\mathrm{ROA}_{\mathrm{i}, 1}\right) / 2 \\
& -\mathrm{ROA}_{\mathrm{i}, 0} ; \\
\mathrm{SG}_{\mathrm{i}, 0}= & \text { sales growth rate for share } \mathrm{i} \text {, computed as a percentage of the } \\
& \text { previous year's sales; } \\
\mathrm{SG}_{\mathrm{i}, 2}= & \text { change in } \mathrm{SG} \text { during the two years after the dividend changes, } \\
& \text { computed as }\left(\mathrm{SG}_{\mathrm{i}, 2}+\mathrm{SG} \mathrm{G}_{\mathrm{i}, 1}\right) / 2-\mathrm{SG}_{\mathrm{i}, 0} ; \\
\mathrm{CE}_{\mathrm{i}, 0}= & \text { capital expenditure for share } \mathrm{i} \text {, calculated as capital expenditures } \\
& \text { to the beginning of year total assets; } \\
\mathrm{CE}_{\mathrm{i}, 2}= & \text { change in } \mathrm{CE} \text { during the two years after the dividend changes, } \\
& \text { computed as }\left(\mathrm{CE}_{\mathrm{i}, 2}+\mathrm{CE}_{\mathrm{i}, 1}\right) / 2-\mathrm{CE}_{\mathrm{i}, 0} .
\end{aligned}
$$

\footnotetext{
${ }^{86}$ A more detailed analysis of the co-existence of the maturity hypothesis and signalling hypothesis is beyond the scope of our thesis at this stage; however, it constitutes an interesting theme for future research and further development of the study.
} 
For the UK sample, in order to consider the two different relations between dividend increases and earnings changes, we adapt this regression in the following manner:

$$
\begin{aligned}
C A R 3_{i} & =a \dashv \beta_{1 A} \Delta \mathrm{DIEI}_{i, 0} \dashv \beta_{1 B} \Delta \mathrm{DIED}_{\mathrm{i}, 0} \dashv \beta_{2}\left(R O A_{i, 0}-R O A_{i,-1}\right) \dashv \beta_{3} \Delta R O A_{i, 2} \dashv \\
& +\beta_{4}\left(S G_{i, 0}-S G_{i,-1}\right)+\beta_{5} \Delta S G_{i, 2}+\beta_{6}\left(C E_{i, 0}-C E_{i,-1}\right)+\beta_{7} \Delta C E_{i, 2}+\varepsilon_{i, t}
\end{aligned}
$$

If investors at least partially recognise the relationship between current dividend increases and future changes in profitability, capital expenses and sales growth, then this should be reflected in the initial market reaction, and the coefficients will be statistically significant.

\subsection{Methodology to test sub-hypothesis $2 \mathrm{D}$ - relation between dividend changes and market expectations of future earnings}

Hypothesis $\mathrm{H}_{2 \mathrm{D}}$ was formulated in order to test the relationship between dividend change announcements and the market expectations of future earnings. According to the dividend information content hypothesis, we expect a positive association between the two variables.

In regression 3.15 we have used earnings changes as the dependent variable. However, current earnings may not reflect the market's expectations surrounding the dividend announcements date. In order to overcome this problem, and based on Ohlson's (1995) model, we develop a proxy for the market's earnings expectations. We conclude that the difference between market and book value measures the present value of anticipated abnormal earnings, which can be seen as the firm's future profitability.

According to expression 3.5 , if we test the relationship between the difference of market and book value (P-BV) and dividend changes, we can tell something about the dividend information content hypothesis. It has also the merit of examining the information content of dividends on the expected future profitability globally, and not in a specific year. We will estimate the following regression to examine the relation between current dividends and the market expectations of the firms' future prosperity:

$$
\begin{aligned}
\left(\mathrm{P}_{\mathrm{i}, \mathrm{d}}-B V P S_{i,-1}\right) / B V P S_{i,-1} & =a \dashv \beta_{1} \mathrm{DI} \Delta \Delta \mathrm{D}_{\mathrm{i} 0} \dashv \beta_{2} \mathrm{DD} \times \Delta \mathrm{D}_{\mathrm{i}, 0} \dashv \\
& +\beta_{3}\left(E_{i, 0}-E_{i,-1}\right) / B V_{i,-1}+\varepsilon_{i, t}
\end{aligned}
$$


where:

$$
\begin{aligned}
\mathrm{P}_{\mathrm{i}, \mathrm{d}} & =\text { the price per share } \mathrm{i} \text { on the day after the dividend announcement; } \\
\mathrm{BVPS}_{\mathrm{i},-1}= & \text { book value per share } \mathrm{i} \text { at the end of year }-1 \text { relative to the } \\
& \text { dividend event year (year } 0) .
\end{aligned}
$$

For the UK sample, in order to consider the different relations between dividend and earnings changes, we adapt the regression in the following way:

$$
\begin{aligned}
\left(\mathrm{P}_{\mathrm{i}, \mathrm{d}}-B_{V P S_{i,-1}}\right) / B V P S_{i,-1} & =a+\beta_{1 A} \text { DIEI x } \Delta \mathrm{D}_{\mathrm{i} 0}+\beta_{1 B} \text { DIED x } \Delta \mathrm{D}_{\mathrm{i}, 0} \dashv \\
& +\beta_{2 A} \operatorname{DDEI~} \Delta \mathrm{D}_{\mathrm{i} 0}+\beta_{2 B} \operatorname{DDED} \times \Delta \mathrm{D}_{\mathrm{i} 0}+ \\
& +\beta_{3}\left(E_{i, 0}-E_{i,-1}\right) / B V_{i,-1}+\varepsilon_{i, t}
\end{aligned}
$$

The sign and significance of 1 and ${ }_{2}$ coefficients will reflect whether or not market participants consider dividend changes to have any information content when developing their expectations of the firm's future profitability. According to the dividend information content hypothesis, we expect 1 and 2 to be positive and significant, reflecting a positive association between dividend changes and the market expectations of future earnings.

$\mathrm{H}_{1}$ and $\mathrm{H}_{2 \mathrm{~A}}$ are consistent with the major prior studies that analyse the market reaction around dividend change announcements and the relation between dividend changes and future earnings, and therefore, allowing to compare our results with those obtained by previous researchers. The other sub-hypotheses introduce some innovations.

\subsection{EMPIRICAL RESULTS}

We start this section by presenting the trends in the dividend payment pattern of the non-financial listed firms on the three markets. Secondly, we provide empirical evidence on whether dividend change announcements are associated with subsequent share price reactions based on event studies and regression analysis. Thirdly, we investigate the relationship between dividend change announcements and firm's future performance. In this stage, we start by considering as future performance the future earnings changes. Specifically, we use a modified partial adjustment model as a control for the non-linearity in the relation between future earning changes and lagged earnings levels and changes. Then, we consider as firms' future performance other accounting 
performance measures such as profitability measures, financial risk measures, debt ratios and a cash flow measure in order to address issues concerning the window dressing phenomenon as well as to see if dividend changes are associated with future cash flows. Considering other variables, such as capital expenses and sales growth, we test the maturity hypothesis. We finish this third stage by examining the relationship between dividend change announcements and the market expectations of future earnings.

\subsubsection{TIME TRENDS IN CASH DIVIDENDS}

We begin by examining the trends in the dividend payment pattern of Portuguese, French and the UK non-financial listed firms during the period 1988-2002, 1992-2002 and 1994-2002, respectively for the Portuguese, French and the UK markets ${ }^{87}$. We exclude financial firms to be consistent with other studies done in this subject, like the ones of Fama and French (2001) and Banerjee, Gatchev and Spindt (2002).

Table 3.1 shows the total number of non-financial firms listed on EL, EP and LSE each year during the period considered in each country, and the number of firms that, for each year, pay cash dividends (payers) and do not pay cash dividends (non-payers), according to the information available on Datastream database.

The Portuguese market is smaller than other Western European markets, namely the UK and French markets, as we can see by the smaller number of non-financial listed firms. We want to begin by emphasising the significant decline in the total number of nonfinancial firms listed on EL during the sample period. It has fallen from 140 in 1988, to 43 , in 2002 , representing a decline of about $69.3 \%$. The decline along the period is due, in part, to firms disappearing through merger and acquisitions or bankruptcy. The Portuguese market specificities of instability, illiquidity and thin trading influence this general behaviour. Although this decline is continuous, it declines sharply from 1991 to 1992. During this specific period the market suffered a structural and functional reform, with the publication of the Securities Market Code and the establishment of the

\footnotetext{
${ }^{87}$ These different periods are determined by the availability of the information obtained from EP and SLE about the firms listed each year in the respective stock exchange.
} 
Portuguese Securities Market Commission (CMVM). The new rules of supervision and market regulation lead to a significant number of delisted firms.

The number of non-financial firms that paid dividends has fallen continuously from 93 firms in 1988 to only 18 in 2002. However, the percentage of companies paying dividends has declined only from $66.43 \%$ in 1988 to $41.86 \%$ in 2002 . This is explained by the fact that the total number of firms listed on EL also declined significantly, as we said before and which can be seen also in Figure 3.1. So, both the decline of the numerator (the number of dividend payers) and the denominator (the number of sample firms) contribute to the softer decline of percents. In the last two years the percentage of firms that do not pay dividends became higher than that of dividend payers, which coincides with a period of market recession ${ }^{88}$.

In France, the total number of non-financial firms listed on EP has decreased continuously during the sample period. It has decreased from 414 firms in 1992, to 224, in 2002. However, the number of non-financial firms that paid dividends has grown continuously from 1992 (101 firms) to 2001 (150 firms), representing an increase of 48.5\%. However, from 2001 to 2002, the number of dividend payers has fallen to 146, but we cannot say firms become less likely to pay dividends, as the total number of nonfinancial firms has also declined. The percentage of dividend payers increased from $24.40 \%$ to $65.18 \%$ in the $1992-2002$ period, which is significant. The difference between absolute and relative values is due to the relevant decrease of the total number of non-financial firms listed on EP. Although Osobov (2004) found a low percentage decline in dividend payers in the French market, he points out the fact that the percentage of payers is significantly higher than the percentage of dividend nonpayers $^{89}$. The increase of the numerator (the number of dividend payers) and the decrease of the denominator (the number of sample firms) contribute to the higher growth of the percentage. Surprisingly, in 1999, the number of dividend payers became higher than that of dividend non-payers, and this relation is maintained until 2002, as we can see easily in Figure 3.1.

\footnotetext{
${ }^{88}$ The decline in the percent of firms paying dividends raises the issues of what are the characteristics of dividend payers and if firms with these characteristics become less likely to pay dividends, but we will not address these questions since this is beyond the scope of this study.

${ }^{89}$ Although he finds a percentage of dividend payers of $62.9 \%$ for 2001 and $61.0 \%$ for 2002 , we find the percentages of, respectively, $61.73 \%$ and $65.18 \%$, which are not very different.
} 
The UK market is the most significant capital market in our study. It shows an increase in the total number of non-financial firms listed on LSE during the period from 1994 to 2000, in contrast to what happens in Portugal and France. It has increased from 753 firms in 1994, to 984, in 2000. However, this number declined during the two subsequent years, and, in 2002, this number has declined to 940. In fact, the year 2001 was characterised by a slowing down in the world economic growth, which can explain this evolution. The number of non-financial firms that paid dividends has increased continuously from 1994 to 2000, but it has decreased in 2001 and 2002. In spite of the decrease in the number of dividend payers, in percentage it does not happen, because the number of total non-financial firms has a higher decline. The percentage of dividend payers is slightly higher than the percentage of non-dividend payers, as we can also see in Figure 3.1. The same evidence was found by Osobov (2004) and Ferris, Sen and Yui $(2004)^{90}$.

Overall, the evidence found in several recent studies of the decline of firms paying dividends in different markets, such as the US market Fama and French (2001) and Baker and Wurgler (2002), several common and civil law countries, including European Markets Ferris, Sen and Yui (2004) and Osobov (2004) and the Indian market Reddy (2003), being this last one a small market, are consistent with our findings for Portugal, and, partially for the UK, but in contrast with France results. Moreover, the results suggest that European markets have a higher percentage of dividend payers firms, independently of the evolution. In the year of 1999, the percentage of firms paying dividends in the US market was 20.8\% Fama and French (2001), in India was 32.1\%, including financial firms Reddy (2003), and we find a percentage of $67.86 \%$ for Portugal, $53.14 \%$ for France and $53.17 \%$ for the UK market.

Table 3.2 contains some summary statistics concerning the DPS. In Portugal, the average DPS has ranged from 1988 to 2002 between 0.15 (2002) and 0.64 Euros (2001) and the maximum value has ranged from 0.70 (2002) to 10.47 (2001). The last two

\footnotetext{
${ }^{90}$ Our numbers for the French and the UK markets differ from the ones of Osobov (2004) and Ferris, Sen and Yui (2004). However, the first author collected his data from Worldscope database and the latter authors obtain the data on the July 2002 edition of the Company Analysis database (a Thompson Financial product). We obtain the number of firms listed in each year directly from EP, for the French market, and from LSE, for the UK market and the information of dividend payers in Datastream database. Osobov and our study consider only the non-financial firms. In 2001, the last common year for the three studies, the percentage of dividend payers for the French market was $59.3 \%, 62.9 \%$ and $61.7 \%$ and for the UK market was 53.0\%, 60.4\% and 53.1\%, respectively in the Ferris, Sen and Yui, Osobov and in our study.
} 
years present very different values for the average DPS, being 2001 the year with the higher standard deviation (2.16). However, the year of 2001 is highly influenced by a unique dividend of 10.47 euros. If we ignore this dividend, we will have an average of 0.19 (one of the lowest), a maximum value of 1.00 and a standard deviation of 0.24 , which is more consistent with the recession period of 2001-2002, as it can be seen in Figure 3.2, as well as by the lowest values for the minimum DPS both in 2001 and 2002 , of 0.01 euros.

The fact that the percentage of firms paying dividends has been relatively constant whereas the average dividend paid has decreased, namely in the 1995-2002 period, implies that companies which have been paying dividends have paid lower amounts, except a small number of bigger size firms.

In France, the DPS values are highly influenced by a unique firm with extreme dividends (in average, above 90 Euros), as we can see in Figure 3.2. Thus, we decide to ignore this firm for DPS analysis. According to Table 3.2, the average DPS (in Euros) has ranged from 1992 to 2002 between 1.34 (1996) and 1.91 (1993). The average DPS has been stable in the last five years, with an increase tendency, which is consistent with firms smoothing their dividends. The minimum DPS is also stable. The higher movements are observed in the maximum dividends that ranged from 1992 to 2002 between 10.98 (1996) and 52.85 (1993 and 1994).

In the UK market, the average DPS values (in $£$ ) have increased continuously from 6.33 , in 1994 to 9.83 , in 2002. The tendency of a continuous increase in the average DPS could be interpreted as an indication of firms smoothing their dividends. The high values for the standard deviation can be explained by the significant different between the minimum and maximum values of DPS.

The UK firms pay higher dividends than the Portuguese and French markets, probably because it is one of the most important European capital markets.

Industry trends from the length period can be seen in Table 3.3. Panel A shows the average DPS and Panel B the percentage of dividend payers, both by industry breakdown.

Portugal shows evidence of an unstable market, as we can see in Panel A, with some activity sectors that simply omitted the dividend payments along the period. There are two main reasons for that to happen: some of the firms have been delisted during the 
analysed period and others have been closed, namely because they went bankrupt, such as in the agriculture and textile sectors. From the sectors with regular dividend payments in 1988-2002, firms in the telecommunication, machines and electrical equipment and metallurgy sectors have paid more dividends whereas construction and restaurants, hotels and leisure have paid the lowest levels.

In Panel B we can see some instability in the percentage of dividend payers along the period 1988-2002. It can be due to two different kinds of reasons: first, it can be caused by a relative frequency that some firms are listed and delisted in the EL from one year to the other and the fact that some sectors have a small number of firms, and, in some sectors, only one firm such as the case of electricity and tobacco sectors. Finally, it must be a signal that the Portuguese market does not have such a smoothing dividend policy like the US or the UK markets, but it has a more volatile dividend policy, such as the case of the German market Goergen, Renneboog and Silva (2005) . Chemicals and IT systems along with metallurgy sectors have the highest share of dividend payers along the period. However, among them, only the metallurgy sector pays the higher DPS, as we have seen in Panel A. In contrast, transport activities and wholesale trade have the lowest percentage of dividend payers. Chemicals, construction, mineral non metallic industries and other services sectors are the ones that have a greater stability in the dividend payers' percentage along the period, which, in global terms, coincides with the sectors that have more stability in the firms being listed between 1988 and 2002.

For the French market, and as we have done for the DPS analysis, we exclude a firm with extreme dividend payments; otherwise the results for its sector would be inconsistent. As we can see in Panel A, all the activity sectors paid dividends during the period 1992-2002, except for the tobacco sector, which have listed firms since 1995 (Panel B) and begun paying dividends in 2000 (Panel A). From the sectors with regular dividend payments in 1992-2002 period, firms in the food and beverages and real estate sectors have paid more dividends whereas IT systems and machines and electrical equipment have paid the lowest levels.

In Panel B we can see that, globally, the percentage of dividend payers has grown continuously along the period 1992-2002. Automobile and construction sectors have the highest share of dividend payers along the period. In contrast, diversified industries and services have the lowest percentage of dividend payers. The paper sector presents a 
significant increase in the percentage of dividend payers, but this is mainly because of the significant decrease of the number of listed firms in this sector of activity.

In the UK market, all the activity sectors paid dividends during the period 1994-2002, except for the metallurgy sector, which has begun paying dividends in 1999. From the sectors with regular dividend payments in 1994-2002 period, firms in the agriculture and tobacco sectors have paid higher average DPS whereas telecoms and IT systems have paid the lowest levels.

In Panel B we can see that the percentage of dividend payers has grown in some activity sectors, but is has declined in others. Construction, electricity, mineral non metallic products and paper sectors have the highest increase in their percentage of dividend payers. In contrast, agriculture, telecoms, IT and diversified services have the more important decrease in the percentage of dividend payers.

In sum, these results show some evidence of industry and countries effects in dividend payments $^{91}$.

\subsubsection{DESCRIPTION OF THE SAMPLE}

The samples of Portugal, French and the UK consist of dividend changes of firms listed on the respective stock exchange, during the period 1989 to 2002, for Portugal, and 1995 to 2002 for the other two markets. The sample selection will be filtered in accordance with the conditions defined in the section 3.3.1 (sample selection).

Table 3.4 reports the number of dividend events classified by sample selection criteria (Panel A) as well as the dividend events by years (Panel B) for the three markets considered in this study.

The Portuguese sample consists of dividend changes of firms listed on EL during the period 1989 to 2002 . The initial sample contains 529 observations. The sample selection criteria resulted in a final sample of an unbalanced panel of 380 events: 158 increases, 121 decreases and 101 no change observations, which corresponds to 84 companies listed on EL, although not all firms have been listed on the stock market for the whole period. Of the 149 events eliminated from the sample, 17 have other type of dividend

\footnotetext{
${ }^{91}$ Maybe this is a phenomenon to explore in future research.
} 
announcements in the same date, 108 are associated with firms not listed on the EL the year before and two years after the events, 13 have earnings or other contaminating announcements within 5 trading days of the dividend change announcement and 11 have missing data. As we can see, Portugal is a small market, with a small number of listed firms and a reduced number of events ${ }^{92}$.

According to Panel B, the most frequent year of dividend changes is 1989, with 26 increases, 16 no changes and 16 decreases. It is interesting to see that in the period 1997-1999 the dividend increases are more frequent than the other events, whereas in 2000-2002 they are more similar to the other events, denoting a convergence in the number of events.

The French sample consists of dividend changes of firms listed on EP during the period 1995 to 2002 . The initial sample contains 1,056 observations. The sample selection criteria resulted in a final sample of an unbalanced panel data of 356 events: 235 increases, 62 decreases and 59 no change observations, which corresponds to 93 companies listed on EP, not listed the whole period. Of the 700 events eliminated from the sample, 599 have missing announcement dates on Bloomberg database ${ }^{93}, 3$ have other type of dividend type announcements in the same date, 22 are associated with firms not listed on the EP the year before and two years after the events, and 76 have earnings or other contaminating announcements within 5 trading days of the dividend change announcement ${ }^{94}$. Unfortunately, as we can see, the announcement dates missing, per $s i$, is responsible for about $85.57 \%$ of the excluded events. Otherwise, our sample would be much more significant.

Panel B shows that the recent period between 2000 and 2002 is the one with a higher number of dividend events, being 2000 the year with more dividend increases (54) and 2001 with more dividend no changes (28) and dividend decreases (20).

The UK sample consists of dividend changes during the period 1995 to 2002, of firms listed on LSE. The initial sample consists of 3,559 events. The sample selection criteria

\footnotetext{
${ }^{92}$ We only have knowledge of two works that have smaller samples. They are the works of Gurgul, Majdosz and Mestel (2003) that analysed the Austrian market and have a sample of 74 dividend increases, 27 decreases and 74 no-change dividends and Travlos, Trigeorgis and Vafaes (2001) that analysed the case of dividend increases in the Cyprus market, with a sample of 41 increases.

${ }^{93}$ We try to obtain dividend announcements date on EP, but they do not have a database with this information (they only have the payment data). We could not also obtain this information on the Autorité des Marchés Financiers (AMF).

${ }^{94}$ In France, as well as in the UK market, dividends and earnings are usually announced at the same date.
} 
resulted in a final sample of an unbalanced panel data of 3,278 events: 2,662 increases, 273 decreases and 343 no change events, which corresponds to 524 firms listed on LSE, although not all firms have been listed on the stock market for the whole period. Of the 281 events eliminated from the sample, 212 have missing announcements dates on Bloomberg database, 26 have other types of dividend announcements in the same date, 3 are associated with firms not listed on the LSE the year before and two years after the events, 29 have contaminating announcements within 5 trading days of the dividend change announcement, 6 events have dividend and earnings announcements on separate dates and 5 events are excluded because of missing data.

As Panel B shows, the recent period between 2000 and 2002 is the one with a higher number of dividend events, being 2000 the period with more dividend increases (366) and 2002 with more dividend no changes (63) and dividend decreases (49).

In sum, the preponderance of dividend increases over no-change and decreases in the three samples is consistent with prior results that firms are reluctant to cut dividends, such as Lintner (1956). However, in relative terms, the percentage of dividend events is very distinct in the different samples. We would like to emphasise, for the Portuguese sample, the significant number of dividend decreases (about 32\% of sample events), when compared with the French and the UK samples, as well as the major number of empirical works in this domain, namely in the US market. If we compare the samples of several studies in different markets, we find that our percentages are similar to the ones of some emergent markets, such as Thailand and Korea, and not with Anglo-Saxon, as we can see schematically:

\begin{tabular}{llcccc}
\hline & & & \multicolumn{3}{c}{ Percentage of Dividends } \\
\cline { 5 - 6 } \multicolumn{1}{c}{ Study } & Market & Period & Increases & No-Change & Decreases \\
\hline Our Study & Portugal & $1989-2002$ & 41.6 & 26.6 & 31.8 \\
& France & $1995-2002$ & 66.0 & 16.6 & 17.4 \\
& UK & $1995-2002$ & 81.2 & 10.5 & 8.3 \\
Nissim and Ziv (2001) & US & $1963-1997$ & 38.1 & 59.7 & 2.2 \\
Abeyratna and Power (2002) & UK & $1989-1993$ & 75.0 & 15.7 & 9.3 \\
Gurgul, Majdosz and Mestel (2003) & Austria & $1992-2002$ & 42.3 & 42.3 & 15.4 \\
Aivazian, Booth and Cleary (2003b) & Thailand & $1981-1990$ & 47.0 & 22.6 & 30.4 \\
& Korea & $1981-1990$ & 42.0 & 14.6 & 43.4 \\
& Malaysia & $1981-1990$ & 37.0 & 31.6 & 31.4 \\
\hline
\end{tabular}

Samples of several studies in different markets

One possible explanation for these sample statistics may be the exposure of emerging and Portuguese markets to more economic risks. The French and the UK percentage of 
dividend changes, especially the case of the UK sample, are similar to the ones of Abeyratna and Power (2002), for the UK market.

In the 3 markets we saw that the year of 2001 was characterised by a decrease in the dividend increase events and an increase in the dividend decrease events, which is in accordance with the slowing down of the world economic growth.

Table 3.5 provides summary statistics on dividend events in the dataset and some financial ratios. Ratios are sometimes skewed when divided by small numbers, so we report the mean and median, along with the standard deviation. We consider the changes in DPS both in monetary units and in percentage. The standard ratios for analysing dividend policy are the payout ratio, which is the ratio of the DPS to the earnings before extraordinary items per share and the dividend yield, which is the DPS divided by the share price on the day before the dividend announcement. We analyse the debt ratio as a measure of credit worthiness, computed as the total debt divided by the total assets and the return on equity as a measure of profitability, calculated as the earnings before extraordinary items divided by the equity. Finally, the current ratio is used as a measure of liquidity, which is the current asset divided by the current debt. All the accounting variables are considered at the end of the fiscal year before the dividend announcement.

In what concerns the Portuguese sample, and for all the dividend events, the mean DPS is 0.46 euros, with a median of 0.35 , the mean dividend payout is $64.1 \%$, with a median of $44 \%$ and the dividend yield mean is 0.13 . The rate of changes in DPS relative to the previous year has a mean (median) of 2.06 percent ( 0 percent). The mean debt ratio is 0.39. The current ratio averaged 1.99 and the return on equity $8.9 \%$. Overall, the Portuguese sample can be described as consisting of relatively low debt firms ${ }^{95}$, with high payout and liquidity ratios and relatively profitable.

Examining the observations of each group of dividend events, we can observe that dividend decrease events are associated with a weaker financial position than that of dividend increases, with higher debt ratios, lower ROEs and lower liquidity ratios. DPS

\footnotetext{
95 Aivazian, Booth and Cleary (2003a) found higher debt ratios for emerging markets and a lower value for the US sample.
} 
are higher for dividend increases ${ }^{96}$. No change dividends are in a middle range, but tend to have higher debt ratios.

The French sample presents a mean DPS of 1.24 euros, with a median of 0.86 , the mean dividend payout is $29.6 \%$ and the median is $18 \%$ and the dividend yield mean is $0.02^{97}$. The mean debt ratio is 0.25 . The rate of changes in DPS relative to the previous year has a mean (median) of 13.05 percent (9.22 percent). The current ratio averaged 1.36 and the return on equity $5.1 \%$. Overall, the French sample can be described as consisting of low debt firms, with relatively high dividend per share, low dividend payout and relatively low equity return.

Examining the observations classified into the three different groups based on dividend changes behaviour (increases, no changes and decreases), we can observe that dividend decreases events are associated with a weaker financial position than that of dividend increases, with higher debt ratios ( 0.27 versus 0.25$)$, lower ROE (4.2\% versus $5.2 \%)$ and lower liquidity ratios (1.32 versus 1.39$)$. DPS are higher for dividend increases (1.32 versus 1.04). No change dividends are in a middle range, with higher profitability, but lower liquidity.

The UK sample presents a mean DPS of 8.47 pounds, with a median of 6.36 , the mean dividend payout is 0.51 , with a median of 0.43 . The rate of changes in DPS relative to the previous year has a mean (median) of 13.91 percent ( 9.66 percent). The mean debt ratio is 0.21 . The current ratio averaged 1.48 and the ROE is $13.1 \%$. Overall, the UK sample can be described as consisting of profitable firms (the UK firms present the higher value for the ROE), with low debt and high dividend payments. Comparing the values of dividend increases and dividend decreases, the results show that dividend decrease events are associated with a weaker financial position than dividend increases, with higher debt ratios ( 0.23 versus 0.21$)$ and lower ROE (4.2\% versus $14.5 \%)$. Firms that neither cut nor increased their dividends are in a middle range where they tended to have higher current ratios, but are less profitable.

Similar to DeAngelo and DeAngelo (1990) and Nissim and Ziv (2001), we observe that for all the countries the dividend increases, although more frequent than dividend decreases, are smaller in magnitude. In fact, the average decrease in DPS (percentage of

\footnotetext{
${ }^{96}$ The mean dividend payout for the sub-sample of dividend increases, of 0.46 is equal to the value found by Omet (2004), in his sample of Jordanian firms for the period 1985-1999.

${ }^{97}$ Romon (2000) found an average dividend yield of 0.023 in his French sample, for the period between 1991 and 1995 , similar to our value.
} 
change in DPS) is 0.35 euros (42.20\%), compared with an average increase in dividends of nearly 0.19 euros (37.57\%) in Portugal. In France, the average decrease in DPS (percentage of change in DPS) is 0.36 euros (23.74\%), compared with an average increase in dividends of nearly 0.25 euros $(26.37 \%)$ and finally, in the UK market, the average decrease in DPS (percentage of change in DPS) is 2.27 pounds $(27.16 \%)$, compared with an average increase in dividends of nearly 1.05 pounds (19.94\%).

Comparing the three sample statistics, we can see that, for all the events, the UK sample has higher DPS, is the most profitable sample, and present the lowest value for the debt ratio, which is in agreement with a developed capital market, such as the US.

Some of our UK and France results are similar to the ones found by Aivazian, Booth and Cleary (2003a) for the US sample in the period between 1981 and 1999. These authors found a mean value of 0.01 for the dividend yield, a 0.25 mean for the debt ratio and a mean of 1.38 for the current ratio, which are similar to the results we find for the French market, which mean values are, respectively of $0.02,0.25$ and 1.37 . They also found a mean of 0.41 for the dividend payout and a mean of $13 \% \mathrm{ROE}$, which are similar to the results we find for the UK market, whose mean values are, respectively, of 0.50 and $13.1 \%$.

Overall, these results could be interpreted as an indication that the UK market is the main capital market of our sample and Portugal is the small one, being the French market in a middle position.

In order to test for the stability in the dividend policy, we run the regression 3.6 . We exclude the firms which did not have at least five years of cash dividend to have enough cash dividend years for testing stability Dewenter and Wharther (1998) . Table 3.6 reports the estimates of Lintner's model. We report, for each country, the pooled OLS, the FEM and the REM results as well as the F test and the Hausman's statistic results in order to choose the best model to work with.

For the Portuguese sample, this methodology enables us to determine 51 listed firms, with a total of 383 observations. As we can see, the significant value of the Hausman statistic indicates that the FEM is more appropriate than the REM. However, when we test the significance of the firm-specific effects with the F test, we do not reject the null hypothesis that the constant terms are all equal because it is not statistically significant. 
Under the null hypothesis, the efficient estimation is pooled least squares, so, we will analyse the results obtained with the estimation of pooled OLS.

Based on pooled OLS results, we can see that the value of the constant term is positive and significant, being an indication that firms are reluctant to decrease their cash dividends, preferring to increase them gradually. However, the value of the lagged dividends coefficient is positive but not statistically significant when corrected for heteroscedasticity, showing no evidence that the lagged dividends determine the dividend policy. In addition, this value is equal to 0.197 , which is very small, suggesting no evidence that Portuguese firms have stable dividend policies. For the US market, Dewenter and Warther (1998) found a value of 0.945 for this coefficient, with data from 1982 to 1993 and Aivazian, Booth and Cleary (2003a) found the value of 0.878, considering the period from 1980 through 1990. For the Jordanian firms (an emerging market) Omet (2004) found a coefficient of lagged dividends of 0.480 and Aivazian, Booth and Cleary (2003a) found coefficients for emerging markets ranging from 0.083 (Turkey) to 0.611 (Zimbabwe). Benzinho (2004) found a value of 0.352 for the Portuguese market, which is different from our value; however, he studied a smaller sample in a different period ${ }^{98}$. In other words, the speed of adjustment (c) in the Portuguese case is 0.803 . It suggests that Portugal firms do not smooth their dividends, as when the Lintner adjustment factor is equal to +1 , this means that firms do not smooth dividends at all. The US speed of adjustment ranges from 0.055 to $0.122^{99}$, in Japan is 0.094 , in the Jordanian market is 0.520 and in the emerging markets the speed of adjustment ranges from 0.389 to 0.917 . The speed of adjustment coefficients is an indication that US dividends are smoother than Portuguese dividends, as well as emerging countries. Once again, our results are more similar to the ones of the emerging markets than the US market. Consequently, the dividend policy for the US firms is more easily predictable than in Portugal. Finally, the earnings per share coefficient, although statistically significant, is low (0.079), especially when compared with the one of the US (0.170). In the emerging markets, the values range from 0.034 (Korea) to 0.446 (Turkey). Benzinho (2004) found a coefficient similar to ours, of 0.078. These results are an indication that in the US, any change in earnings is more directly reflected in

\footnotetext{
${ }^{98}$ Benzinho (2004) has a sample of 34 firms and a total of 335 observations, for the period between 1990 and 2002, and he opts for the REM.

99 Lintner (1956) found a seep of adjustment rate of approximately 0.30 . However, he tested his smoothing theory with data from 1918 through 1941 and Choe (1990) documented that the speed of adjustment parameter for US firms falls to about 0.15 in the early $1970 \mathrm{~s}$.
} 
cash dividends than in Portugal. On the whole, these results do not support the Lintner smoothing model, suggesting that in Portugal dividend policy plays a less significant role in signalling than it does in the US market.

In what concerns the French sample, we have 136 listed firms, with a total of 978 observations. In order to test the significance of the firms' effects, we calculate the F statistic, which is statistically significant, so we reject the null hypothesis that the constant terms are all equal, and, therefore, the restricted regression (pooled) seems to be invalid. Thus, we need to compare the results obtained with the estimation of FEM and REM through the Hausman statistic to see which of the models gives the best estimation. The hypothesis that the individual effects are uncorrelated with the other regressors in the model is rejected since the Hausman test is statistically significant. This indicates that, for the French sample, the FEM is the most appropriate specification of Lintner's model.

Based on the FEM results, we can see that the value of the lagged dividend per share is equal to 0.060 . Although it is positive, it is statistically not significant and one of the lowest values found for this coefficient. Consequently, the speed of adjustment (c) in the French market is one of the highest, of 0.94 , near the +1 limit in which firms do not smooth dividends. Consequently, the results suggest that dividend policy for French firms is less predictable than in Portugal. Finally, the earnings per share coefficient, of 0.046, although statistically significant, is lower than the one found for the Portuguese sample, with any change in earnings being less directly reflected in cash dividends than in Portugal. On the whole, these results suggest that, in accordance to the Portuguese results, dividend policy in France is not about smoothing dividends. Thus, in Portugal and France, dividend policy plays a less significant role in signalling than it does in the US market, as we have expected.

Finally, for the UK market we have 467 listed firms, with a total of 3,348 observations. The F value is significant, and, therefore, the pooled OLS model seems to be invalid. Like the French sample, in this case the FEM is also appropriate, whereas the fixed effects estimation is simultaneously consistent and efficient. On the contrary, the estimation that would result from REM would be consistent, but not efficient.

One important point for the FEM results for the UK sample is that Lintner model works remarkably well for the UK firms with an adjusted $\mathrm{R}^{2}$ of $94.4 \%$, suggesting that dividend policy for the UK firms is highly predictable. The coefficient of the lagged 
dividend per share is positive and statistically significant, with a value of 0.800 , which is similar to the ones found in the US market by Dewenter and Warther (1998), of 0.945 and, especially, by Aivazian, Booth and Cleary (2003a), of 0.878. This result is an indication that, like the US firms, also the UK firms have stable dividend policies. In other words, the speed of adjustment in the UK case is 0.200 , which means that UK firms, as well as the US firms, smooth dividends. Finally, the earnings per share coefficient is positive, but low and not significant (0.012), so, the main factor that determines the dividends in the UK sample is the lagged dividends. Overall, we find evidence supporting the Lintner smoothing model, suggesting that dividend policy for the UK firms, in accordance with the US firms, is highly predictable.

Comparing the three countries, we find evidence supporting the Lintner model only for the UK, suggesting this market smooth the dividends. Thus, we conclude that, as expected, dividend policy plays a less significant role in signalling in Portugal and France, than in the UK. Probably because the reliance of civil law countries, like Portugal and France, on bank debt and their closely held nature reduce the information problems in the context of outside capital. In a study made by Goergen, Renneboog and Silva (2005) in the Germany market (which is also a civil law country), the authors conclude that in German, because of the concentrated ownership, firms may not need to use dividends as a signal, which is in agreement with our conclusion.

After the analysis of the smoothing dividend model, we will start to test the two hypotheses formulated in the preceding section.

\subsubsection{Test Results of the First Hypothesis - Relation BetWeEn Dividend Change AnNouncements ANd The MARKet ReACtion}

\subsubsection{Abnormal Returns}

In order to verify whether dividend changes are associated with subsequent share price reactions in the same direction, we consider three approaches to calculate abnormal 
returns: abnormal returns based on the CAPM, buy-and-hold and market-adjusted abnormal returns ${ }^{100}$.

Table 3.7 provides the abnormal returns for the announcement period and other different periods. Panel A presents the cumulative abnormal returns with returns calculated based on CAPM. Panel B presents the market adjusted buy-and-hold abnormal returns for dividend announcements ${ }^{101}$ and finally, Panel $\mathrm{C}$ shows the crosssectional distribution of the three-day abnormal returns based on the BHAR results, the only AR measure that is common to all three samples.

In what concerns the Portuguese sample, we can see that (Panel B) for the event period and the dividend no change announcements, we find a non-significant buy-and-hold abnormal return. This supports the hypothesis that firms that leave their dividends unchanged communicate no significant new information to the market. In what concerns dividend change announcements, although dividend increases and decreases show, respectively, a positive and a negative return on the announcement period - which is the expected signal - the returns are only statistically significant for the case of dividend decreases, at a 10\% level. The result concerning dividend decrease announcements suggest that they convey relevant information to the market. However, the lack of reaction when dividend increases are announced can be due to the market illiquidity or to the concentration of the corporate ownership, which makes dividend announcements less relevant. These results suggest that dividend increase announcements contain less relevant information than do dividend decrease announcements. The market reaction asymmetry between dividend increase and decrease announcements was also found by several authors, such as Aharony and Swary (1980) and Nissim and Ziv (2001). One feasible reason is the managerial reluctance to cut or omit dividends.

Concerning the other periods considered, dividend no changes has a significant value for the abnormal return in the period preceding the announcement date ( -5 to -2$)$, indicating market anticipation. The market reaction to dividend decrease announcements is reinforced in the period -2 to +2 , since the abnormal return is significant at $1 \%$, which suggests that the market reacts in the five days surrounding the announcement date. Finally, it seems that the market reacts later in the case of dividend

\footnotetext{
${ }^{100}$ For the case of Portugal, we only consider buy-and-hold and market-adjust abnormal returns because, as we have already said, we do not have enough historical price data to calculate firm's beta.

${ }^{101}$ We have repeated the tests using market-adjust returns considering $=1$ for all the three samples and the results were similar, so we did not present the results.
} 
increase announcements, since the BHAR value is statistically different from zero in the period $(+2$ to +5$)$, which suggests the inefficiency of the market. These results suggest that the need to use dividends as a signalling device must be less pronounced in Portugal than in the US and UK (where the major number of studies found statistically significant abnormal returns), where corporate ownership is more dispersed and stock markets are more important, namely in the firms' financing. Although to-date little is still known about dividend policy of firms operating outside the Anglo-American corporate governance system, Goergen, Renneboog and Silva (2005) also find that in Germany, because of the concentrated ownership, firms may not need to use dividends as a signal. Our results also suggest that the Portuguese market can be nearer to developing countries than to the US or UK markets, in accordance with the opinion of Aivazian, Booth and Cleary (2003b), who conclude that the heavy reliance on bank financing and the relative small emphasis placed on external capital markets as a source of finance in developing economies alleviates the informational asymmetry problems and reduces the signalling value associated with dividends. Furthermore, in what concerns dividend decreases, it suggests that investors prefer dividends over capital gains, confirmed by evidence found, in the Portuguese market, by Fernandes and Martins (2002). These authors found that if firms decrease the payment of dividends, shareholders prefer to decline their consumption level instead of selling shares, which shows evidence of a preference for dividends over capital gains and gives support to the Shefrin and Statman (1984) conclusions.

In what concerns the French sample, Panel A presents the cumulative abnormal returns with returns calculated based on CAPM. All the CARs for the announcement period present insignificant values. Considering the no change announcements, it supports the hypothesis that firms that leave their dividends unchanged communicate no significant new information to the market. Regarding dividend change announcements, although dividend increases and decreases show, respectively, a positive and a negative return on the announcement period, which is the expected signal, the abnormal returns are found to be statistically not different from zero. This evidence is similar to Lasfer and Zenonos (2004) who also obtain statistically insignificant share price reaction around the dividend announcement dates in the French market. However, as regards the dividend increases, our results are in contrast with the ones of Romon (2000), who found a positive and significant cumulative abnormal return between days -1 and +1 , of $0.78 \%$. 
The difference in results can maybe be related with the proxy the author used for the dividends announcement date ${ }^{102}$ and the different period of the sample (his sample consists of French firms listed on EP, distributing a regular dividend between 1991 and 1995). The insignificant abnormal returns on the announcement period, as in Portugal, could be attributed to the low levels of information asymmetry, as firms tend to be family owned, with bank-based systems and with high ownership concentration.

Regarding the other periods, dividend no changes and dividend decreases have a significant value for the abnormal return in the period preceding the announcement date (-5 to -2$)$, indicating market anticipation. The market reaction to dividend no change announcements is reinforced in the period -2 to +2 , since the abnormal return is significant at $5 \%$, which suggest that the market reacts in the five days surrounding the announcement date. It seems that the market reacts later in the case of dividend increase announcements, since the CAR value is statistically different from zero at $1 \%$ level in the period $(+2$ to +5$)$, suggesting the inefficiency of the market. Finally, we observe that dividend decreases lead to a higher market reaction that dividend increases, like in the Portuguese market.

Panel B shows the market adjusted buy-and-hold returns for dividend announcements. In global terms, although the level of significance is lower than in the CAR approach, results are similar to the ones obtained by CAR, so the conclusions maintain the same.

Overall, the results are in accordance with the ones of the Portuguese sample, suggesting that the need to use dividends as a signalling device must be less pronounced in France and in Portugal than in the US and UK.

Because all firms in the UK sample announced both dividends and earnings on the same day, it was impossible to isolate the dividend announcements from the earnings announcements. Therefore, we divide the sample into 6 categories, as we have mentioned before: Dividend increase-earnings increase (DIEI), dividend increaseearnings decrease (DIED), dividend no-change-earnings increase (DNCEI), dividend no-change-earnings decrease (DNCED), dividend decrease-earnings increase (DDEI), and dividend decrease-earnings decrease (DDED).

\footnotetext{
102 To collect dividend announcement dates Romon used the "load date" of Datastream as being a day after the announcement day. However, this does not seem to be the case, as in some cases, the "load date" provided is the pay-day corresponding to the dividend payment, and in other cases, the date is exactly the same for a number of years. For this reason, we opt to use the announcement date of Bloomberg database.
} 
A summary descriptive statistics for these groups are provided below:

\begin{tabular}{lccc}
\hline Category & $\begin{array}{c}\text { No of } \\
\text { observations }\end{array}$ & $\begin{array}{c}\text { \% of the } \\
\text { events }\end{array}$ & $\begin{array}{c}\text { \% of total } \\
\text { observations }\end{array}$ \\
\hline DIEI & 1,931 & 72.5 & 58.9 \\
DIED & 731 & 27.5 & 22.3 \\
DI & 2,662 & 100.0 & 81.2 \\
\cline { 2 - 4 } DNCEI & 141 & 41.1 & 4.3 \\
DNCED & 202 & 58.9 & 6.2 \\
DNNC & 343 & 100.0 & 10.5 \\
DDEI & 108 & 39.6 & 3.3 \\
DDED & 165 & 60.4 & 5.0 \\
\cline { 2 - 4 } DD & 273 & 100.0 & 8.3 \\
\cline { 2 - 4 } Total & 3,278 & & 100.0 \\
\hline Summary descriptive statistics for the six group events of the UK sample
\end{tabular}

According to this table, the DIEI group dominates the entire sample (58.9 percent), with the DIED (22.3 percent), DNCED (6.2 percent) and DDED (5 percent) groups each representing a minority of the total number of events studied. As expected, the smallest number of observations (108) was found in the DDEI group (3.3 percent). If we analyse the different categories that compose the three main events (dividend increases, dividend no-changes and dividend decreases) we can see that, of the 2,662 events of dividend increases, 1,931 (72.5 percent) announced higher profits and 731 (27.5 percent) disclosed a fall in profits. Of the 343 events that did not change dividends, 141 (41.1 percent) present an increase in earnings and 202 (58.9 percent) present a decrease. Finally, of the 273 events of dividend cuts, 108 (39.6 percent) announced an increase in earnings, while the majority, 165 events (60.4 percent) reported a fall in earnings. Our relative values are similar to the ones found by Abeyratna and Power (2002), except for the two groups of dividend decreases, as they found a smaller percentage for DDEI (17 percent) and, consequently, a higher percentage for DDED (83 percent).

The abnormal returns for the UK sample are presented also in Table 3.7, but considering the different six groups defined above. Panel A presents the cumulative abnormal returns based on CAPM.

The abnormal returns for the three-day announcement period only support the dividendsignalling hypothesis for the dividend increase events. The DIEI and DIED samples earned statistically significant positive abnormal returns of, respectively, $1.68 \%$ and $1.81 \%$. These results are similar to several tests made in the US and the UK, namely the ones found by Abeyratna and Power (2002) and Lasfer and Zenonos (2004) for the UK 
market. The other events present exceptions to the results expected by the dividendsignalling hypothesis. Both the dividend no-change groups as well as the dividend decrease groups present a significant positive excess return, being all the abnormal returns statistically significantly different from zero at $1 \%$ level. If no dividend news is being signalled to the market, one might assume that no abnormal share price movements are expected. However, in the DNCEI case, we might suppose that the earnings increase announcement has a stronger power than the dividend no-change announcements, and the prices go up by the influence of the earnings increase, which may be an indication that earnings have an information utility behind that of the dividend announcements. But in contrast with this indication is that the DNCED group also has a positive and significant abnormal return. Abeyratna and Power (2002) found also positive excess returns for these two groups, but they found no significant values. Similar to the conclusion of Lonie et al. (1996), this could happen because investor's doubts about dividends disappear when firms announce dividends maintenance.

One surprising result is that dividend decreases brought on positive reactions. Indeed, the dividend decrease results are in contrast with several works that found a negative and significant abnormal return for dividend decrease announcements, such as Dhillon and Johnson (1994) and Grullon, Michaely and Swaminathan (2002) for the US market and Abeyratna and Power (2002) and Lasfer and Zenonos (2004) for the UK market. However, these last authors found a negative value for the DDED group, but a positive abnormal return for the DDEI sample, although not statistically significant, which is mentioned by them as an exception to the dividend-signalling hypothesis. Perhaps this is an indication that dividend decreases not always reveal bad news. This could be an indication that dividend decrease announcements are sending to the market good news. The investors might interpret them as an attempt to keep resources for future growth opportunities Mozes and Rapaccioli (1998) or an effort from managers to solve financial problems. Moreover, the dividend decreases could also be smaller than expected by the market, and reacts positively Abeyratna and Power (2002). All the excess returns are statistically significant in the periods -2 to +2 and -5 to +5 , which suggests the market reacts also in a longer period rounding the announcement date ${ }^{103}$.

\footnotetext{
${ }^{103}$ To evaluate the robustness of the results, we repeated the analysis using two different periods, the period between the announcement day and the day after $(0,+1)$ and the abnormal return in the day after the announcement day $(+1)$ and the results were similar.
} 
As we can see in Panel B, the results based on the BHAR method are quite similar, so we maintain our conclusions.

Overall, the results of the abnormal returns for the UK market are in accordance with the dividend-signalling hypothesis only for the case of dividend increases samples. As in previous evidence, and in the other two samples of our study, the market reacts strongly to dividend decreases announcements. The larger market reaction to dividend changes happens in the UK market, which is in accordance Miller and Rock (1985) opinion, as they suggested that firms whose shares have a larger reaction to dividends should be those that have a stronger information asymmetry, and the UK has higher information asymmetry than France and Portugal.

Panel C of Table 3.7 presents the cross-sectional distribution of the three-day abnormal returns for the three samples: Portugal, France and the UK.

Results show that for the dividend increase events, $45.57 \%$ of the cases for Portugal, $45.96 \%$ for France and $37.80 \%$ and $38.71 \%$ of the cases for the UK, respectively for the DIEI and DIED cases, have negative excess returns which is consistent with several authors that have found a negative perverse relationship between dividend change announcements and share prices reactions, such as Asquith and Mullins (1983), who found a value of 31.9\%, Dhillon and Johnson (1994), 40\%, and Healy, Hathorn and Kirch (1997) who found that $42.5 \%$ of the firms that initiate dividend payments have negative excess returns. In a very recent study, Dhillon, Raman and Ramírez (2003) found that about $43 \%$ of the dividend increases announcements sample presents an adverse market reaction. Heaton (2002) suggested that the negative share price reaction to the announcement of a dividend increase can be due to the fact that if managers are overly optimist about future performance, dividends can be set too high to allow the firm to retain sufficient cash flows.

For the case of dividend decreases, results show that $39.67 \%$ (Portugal), $53.23 \%$ (France) and $57.41 \%$ and $59.39 \%$ of these events for the UK, respectively for the DDEI and DDED cases, have positive excess returns. Benesh, Keown and Pinkerton (1984) and Born, Moser and Officer (1988) have found that about 20 to $60 \%$ of the sample events presents a market positive reaction to dividend decrease announcements. Dhillon and Johnson (1994) and Sant and Cowan (1994) found, respectively, a percentage of $27 \%$ and $23.4 \%$ of the events with a positive reaction to dividend omission announcements. The high percentage of dividend decrease events with positive excess 
returns might explain the positive abnormal return mean we found in the UK market (Panel A and B).

These results motivate us for further research about the phenomenon of an inverse relationship between dividend changes and the share prices reaction.

\subsubsection{Market Reaction to Dividend Change Announcements During Up and Down Markets}

In addition, we examine the market's reaction to dividend change announcements during up and down markets, in order to test whether dividend change announcements matter based on market conditions. The results are shown in Panel A of Table 3.8 for CAR returns and in Panel B for the case of BHAR returns ${ }^{104}$.

For the Portuguese sample, the results based on BHAR are shown in Panel B. As we can see, price reactions to dividend increases are lower in down markets than in up markets. In addition, firms that maintained their current dividend levels in down markets experienced negative returns while firms that maintained their current dividend levels in up markets experienced positive returns. These results disagree with the expected evidence under the signalling hypothesis. Further, dividend decreases have less negative returns if announced during down markets than up markets, which is expected under the signalling view. The fact that the return of dividend decreases is negative and statistically significant during up markets suggests that when firms cut dividends when the market is doing well, it is a clearer signal that they are having problems. In spite of these results, all the $t$ values for the difference between the means of the two subgroups as well as the Kruskal-Wallis statistic are statistically not significant, providing no evidence of asymmetric responses in up and down markets.

For the French sample, we have the results based both on CAR (Panel A) and BHAR (Panel B). As the results show, although we find an asymmetric reaction to dividend change announcements in some of the cases, namely for the dividend increases and decreases in Panel A and dividend no changes as well as dividend decreases in Panel B, the differences between abnormal return in the announcement period for up and down markets are statistically not significant, except for the difference of dividend increase

\footnotetext{
${ }^{104}$ To evaluate the robustness of the results, we repeated the tests using as dependent variable the marketadjust returns considering $=1$ for all firms and the results were similar, so we did not present the results.
} 
announcements in Panel A, which is significant, but only at $10 \%$ level. In addition, our results disagree with the expected evidence under the signalling hypothesis, since, according to this hypothesis, we would expect that in down markets dividend increases should have higher price reactions than in up markets, and dividend decreases would have lower (less negative) price reactions in down markets than up markets, and it does not happen. In general, our results for the French sample are in accordance with our results for the Portuguese sample and in contrast to the results of Goldstein and Fulter (2003) for the US market, providing no evidence of asymmetric responses in up and down markets. Furthermore, our evidence gives support to the asset pricing perspective.

For the UK sample the results show evidence of positive abnormal returns for all type of events, in both up and down markets. As we have said before, this is in accordance with the dividend signalling hypothesis only for the dividend increase events. Although the results show that in down markets dividend increases have higher price reactions than in up markets when the abnormal returns are calculated through the BHAR method (Panel B) and dividend decreases have lower price reactions in down markets than up markets (Panel A and B), as expected by the dividend signalling hypothesis, the difference between the abnormal returns in the two market stages are not statistically significant, except for the case of DIED, and only for the Kruskal-Wallis test at 5\% level. Thus, we find no evidence of a distinct behaviour between um and down markets.

To summarise the results so far, there is no evidence of asymmetric responses in up and down markets in the three samples, which is in contrast to the results of Goldstein and Fulter (2003) for the US market. Generally, the results give support to the asset pricing perspective.

\subsubsection{Relation between Dividend Changes and Abnormal Returns}

In order to analyse the relation between the wealth effect and dividend changes, we estimate equation 3.13. The output from this regression is reported in Table 3.9. Panel A shows the results considering the dependent variable as CAR and Panel B considers the dependent variable as BHAR.

For the Portuguese sample we only have the regression results with the BHAR as dependent variable (Panel B). As the results of the Hausman statistic show, we do not 
reject $\mathrm{H}_{0}$, which indicates that the REM is more appropriate than the FEM. However, when we test the significance of the firm-specific effects with the F test, we do not reject the null hypothesis that the constant terms are all equal. Thus, we will analyse the results obtained with the estimation of pooled OLS.

Based on pooled OLS results, we can see that, overall, the cross-sectional regression confirms the event study results. The negative slope, which captures the effects of no change announcements, is not statistically significant, showing that a zero change in dividends by itself holds little useful information to the market. The coefficients for dividend changes are positive, suggesting that the magnitude of the positive (negative) share price reaction increases with the intensity of the positive (negative) information being conveyed. However, only the coefficient on dividend increases is statistically significant at $1 \%$ level. This result suggests that dividend increases convey useful information to the market. Consequently, we only reject the null hypothesis for dividend increases, supporting the dividend-signalling hypothesis only for this type of announcement. In what concerns the dividend decreases we cannot reject the null hypothesis and thus our results do not support this hypothesis. It seems that the market does not understand the signal given by firms through dividend decrease announcements, or, at least, does not react.

For the French sample, the F statistic, testing the hypothesis that the constant terms are all equal, is not statistically significant, so we do not reject the null hypothesis that the constant terms are all equal, and, therefore, the restricted regression (pooled) seems to be the most appropriate. Thus, independently of the Hausman statistic results, the model best estimation is the pooled OLS, both in Panel A and B.

The cross-sectional regression confirms the event study results. The results of Panel A and B are quite similar. Since none of the coefficients are statistically significant, besides the fact that the coefficient on dividend increase announcements has a negative value, we cannot reject the null hypothesis and thus our results do not support the dividend-signalling hypothesis.

Finally, we analyse the UK results. The F value is significant for both the regressions, and, therefore, the pooled OLS model seems to be invalid. Thus, we need to compare the results obtained with the estimation of FEM and REM through the Hausman statistic to see which of the models gives the best estimation. As the hypothesis that the individual effects are uncorrelated with the other regressors in the model cannot be 
rejected, we conclude that of the two alternatives we have considered, the REM is the best model for the UK sample.

The constant term is statistically significant, showing a significant impact of dividend no change announcements on market reaction, which is not predicted by the dividendsignalling hypothesis, but could be associated with investors' doubts disappearance about dividends. In what concerns the other coefficients, only the one for DIED is statistically significant, but only in Panel A and only at $10 \%$ level. As the coefficient presents a negative value, it is an indication that dividend increase announcements are perceived as to provide little information beyond the earnings announcements, when the last one convey bad news about earnings. This result is consistent with the Lonie et al. (1996) finding that in cases in which dividends increase and the earnings decrease, the market reacts worsely when this information is known than when only the dividend increases are transmitted. It seems that current earnings constitute the dominant signal to capital markets, while dividends constitute only a partial signal, which is in accordance with DeAngelo, DeAngelo and Skinner (1992), Lonie et al. (1996) and Conroy, Eades and Harris (2000) studies but in contrast with the opinion of Pettit (1972), Aharony and Swary (1980) and Eddy and Sheifer (1992). The relation between DIED events and the CAR could also be negative due to several reasons, such as the possibility that the managers try to signal falsely, but investors recognise this and reacts negatively or that the dividend payment was larger than expected and the market interpret it as firms not having available investment opportunities to sustain future earnings Healy, Hathorn and Kirch (1997) .

The negative signal of the coefficient on DDEI, although not significant, could be an indication that although the dividend decreases, the return measure surrounding the announcement has increased. This is in accordance with Woolridge and Ghosh (1985) opinion that a dividend cut, if combined with earnings increase, may signal good news to the market, in contrast with the prediction of the information content hypothesis.

\subsubsection{Robustness}

To evaluate the robustness of the results, we repeat the regression analysis using alternative deflators for dividend changes and alternative measures o the abnormal return. We consider the rate of change in dividend per share relative to the dividend of 
the previous year in spite of the share price and we consider the market-adjusted returns considering $=1$ for all firms. In all cases we obtain similar results ${ }^{105}$, so our conclusions are kept unchanged.

The results so far do not allow rejecting the null hypothesis that dividend changes are not associated with a subsequent share price reaction in the same direction, at least for all the different types of dividend change announcements, so we do not find strong support to the dividend signalling hypothesis. This is in accordance to what we have predicted for the Portuguese and French sample, for reasons explained before, related, namely, with the bank based system, the concentrated ownership of equity and the level of protection of corporate shareholders.

For the UK sample, our results seem to be nearer to the conclusions of the authors that do not find evidence of a significant market reaction to dividend change announcements, such as Lang and Litzenberger (1989), Benartzi, Michaely and Thaler (1997), and, more recently, Conroy, Eades and Harris (2000), Benartzi et al. (2005) and Chen, Firth and Gao (2002).

The analysis so far has been confined to a comparison of dividend change announcements and the subsequent market reaction. In the next section, we take into account the relation between dividend change announcements and future firm profitability.

\subsubsection{Test Results of THE SECOND Hypothesis - RELATiOn BETWEen DiVIDEND Change AnNouncements AND THE MARKET REACtion}

To analyse the relationship between dividend change announcements and future performance, we formulate distinct sub-hypotheses, where the main difference is the variable we use to measure the future performance.

\footnotetext{
105 For simplicity reasons, the results are not reported in the study but available from authors upon request.
} 


\subsubsection{Test Results of Sub-hypothesis $\mathbf{H}_{2 \mathrm{~A}}$ - Relation between Dividend Changes and Future Earnings Changes}

We start by considering future earnings changes as future performance with the purpose to test whether dividend change announcements contain information about future earnings, consistent with the assumption of the dividend signalling model.

\subsection{Regression results assuming linear mean reversion in earnings}

We consider the regression 3.15 , which allows for distinct coefficients on the different types of dividend events and controls for the earnings variations in the dividend change year. In addition, for the UK sample, it allows for the different combinations between dividends and earnings behaviour. To examine whether dividend changes contain information on future earnings changes, incremental to the earnings variations, we consider the earnings changes, deflated by the book value of equity ${ }^{106}$ as an additional control variable. Since we identify dividend events (dividend increases, decreases, and no-changes) in the years 1989 through 2002, for the Portuguese sample, and in the years 1995 through 2002, for the French and the UK sample, and we have earnings data through 2002, the sample includes dividend events that occurred until 2001 for $=1$ and until 2000 for $=2$.

We start by estimating the Pearson correlations among the independent variables. Panel A of Table 3.10 presents the correlation matrix among the exogenous variables along with the statistical significance. For both the Portuguese and French samples, only the ROE is statistically correlated with the change in current earnings, and, in the French sample, it only happens for $=1$. For the UK sample, the results point out for a significant correlation among the coefficients on dividend and earnings changes, as well as a negative correlation between DIED and ROE, a positive correlation between DDED and ROE and, as expected, a significant positive correlation between the ROE and the change in current earnings. For $=2$, the results show a smaller number of variables with high correlation. Beyond the significant correlation among some coefficients on dividend and earnings changes, the results only point out for a

\footnotetext{
106 This can create influential observations when book value is close to zero. However, we do not have in our sample any case where book value is less than $10 \%$ of total assets.
} 
significant positive correlation between the ROE and the change in current earnings. It makes sense to observe a significant relationship between ROE and the change in current earnings as the ROE is a predictor of earnings changes Freeman, Ohlson and Penman (1982). In general, although we have some significant correlations, the coefficients are not very high (always bellow 50\%), so it does not appear to be sufficiently large to cause concern about multicollinearity problems ${ }^{107}$.

The output from the regression 3.15 is reported in Panel B of Table $3.10^{108}$. For both the Portuguese and the French sample, the F value is significant for $=1$ and $=2$, and, therefore, the pooled OLS model seems to be invalid. Thus, we need to compare the FEM and REM through the Hausman statistic to see which of the models is best. As the hypothesis that the individual effects are uncorrelated with the other repressors in the model is rejected, we conclude that of the two alternatives we have considered, the FEM is the best model for the Portuguese and the French samples. In what concerns the UK sample, we do not reject the null hypothesis that the constant terms are all equal, and, therefore, the restricted regression (pooled) seems to be the most appropriate.

For the Portuguese sample, we can see that, although the coefficients on dividend changes have the expected signal, they are not statistically significant, meaning that dividend change announcements have no influence in future earnings. Nissim and Ziv (2001) suggested that a possible explanation for the lack of correlation between dividend decreases and future earnings can be due to accounting conservatism ${ }^{109}$. In both years ( $=1$ and 2 ), the coefficient on ROE is negative and significant, which means that ROE is an important predictor of earnings changes, in accordance with Freeman, Ohlson and Penman (1982). The coefficient for earnings changes is statistically insignificant for $=1$ and 2 , showing no evidence of recent earnings performance being predictive of short term earnings performance.

\footnotetext{
${ }^{107}$ Multicollinearity refers to the existence of linear relationship among some or all explanatory variables of a regression model. Gujarati (2003) states that multicollinearity is a question of degree and not of kind. Therefore, we need to measure its degree in any particular sample, and not the presence or the absence of multicollinearity. The author suggests that the multicollinearity could be a serious problem when the correlation coefficient is in excess of 0.8 .

${ }^{108}$ Unlike Nissim and Ziv (2001) and Benartzi et al. (2005) we do not report the time series means of the cross-sectional coefficients based on annual regressions because we have a small number of annual observations, which raises the question of how reliable the coefficients are in such regressions. Using panel data regressions, we avoid this problem.

${ }^{109}$ For more detail of this explanation, see Nissim and Ziv (2001, p. 2126).
} 
In what concerns the French sample, the results are not very different from those of Portugal. For $=1$ and 2 , none of the coefficients on dividend changes are statistically significant, suggesting that dividend change announcements do not signal future earnings. The coefficient on ROE is negative and significant at $1 \%$ level, which means that $\mathrm{ROE}$ is an important predictor of earnings changes. In addition, only for $=1$, the coefficient on current earnings changes is significant, suggesting that recent earnings performance is predictive of short term earnings performance.

Finally, for the UK sample, we can see that for $=1$, both the coefficients on dividend decrease announcements, independently of the earnings changes, are negative and statistically significant. This can be an indication that dividend decrease announcements contain information on future earnings, incremental to the earnings changes in the dividend change year. The coefficients on ROE and on current earnings changes are both negative and statistically significant, showing evidence of the predictive power of ROE and of current earnings changes about future earnings performance. However, this predictive power only happens on short term, since for $=2$, all these coefficients are near zero. Besides the coefficients mentioned before are not statistically significant for $=2$, the coefficient on both dividend and earnings increase announcements is positive and significant. This can be an indication that, when firms announce dividend and earnings increases simultaneously, this announcement conveys information to the market about managers' perspective of firms' future earnings, which is consistent with the information content of dividend hypothesis. Moreover, as the coefficient on dividend increase and earnings decrease announcements is negative, although insignificant, this suggests that earnings announcements have information power beyond that of dividend announcements. This is in agreement with Francis, Schipper and Vincent (2005), who conclude that, for single class shares, earnings informativeness exceeds dividends informativeness.

We would like to point out that, although the adjusted $\mathrm{R}^{2}$ is relatively low for all the regressions, the value found for this statistic by other authors is also relatively small. Nissim and Ziv (2001) found values between 0.136 and 0.146 and Benartzi et al. (2005) found values between 0.099 and 0.116 .

To see if dividend increases (decreases) indicate that current year earnings will be higher (lower) than the previous year's earnings, we repeat this analysis for $=0$, not 
considering the independent variable on current earnings changes. The results show no evidence that dividend changes are positively related to current earnings changes, since only for the Portuguese sample and only for dividend decreases, the coefficient was statistically significant, and only at 5\% level. When comparing the UK results, it suggests that dividend change announcements convey some information to the market about future earnings, but not about current earnings.

Summarising the results obtained so far, we can see that for both the Portuguese and the French samples, we could not reject the null hypothesis that dividend increases (decreases) are not associated with future earnings increases (decreases). Consequently, we are unable to find any evidence to support the view that changes in dividends have information content about future earnings changes, and, consequently, the results cannot support the assumption of dividend signalling hypothesis that dividend change announcements are positively related with future changes in earnings. These results are consistent with the early findings of Watts (1973), as well as some recent studies, such as the ones of Benartzi, Michaely and Thaler (1997), Benartzi et al. (2005) and Grullon, Michaely and Swaminathan (2002), all of them obtained in the US market.

In the UK sample, we reject the null hypothesis for some of the coefficients on dividend changes. The results indicate that when the model of earnings expectations is linear, the dividend decrease announcements for $=1$ and dividend and earnings increase announcements for $=2$ convey some information about future earnings changes, which is partially consistent with Nissim and Ziv (2001), Benartzi et al. (2005) and Dhillon, Raman and Ramirez (2003). On global terms, only for the UK we find weak support for the information content of dividend hypothesis, since the results show that only some changes are informative about future earnings changes, and not on the two subsequent years.

\subsection{Regression results controlling for the non-linear patterns in the behaviour of earnings (Fama and French Model, 2000)}

Table 3.11 reports the re-estimated coefficients of the regression models using the Fama and French (2000) methods in order to overcome the problem of the mean reversion process of earnings being non-linear, according to the regression 3.16. Panel A 
presents the results considering dividend changes, without distinguishing between dividend increases or decreases. The $\mathrm{F}$ and the Hausman statistics indicate that the most appropriate model is the pooled OLS on the Portuguese and the UK samples and the FEM on the French sample, for $=1$, and the pooled OLS for $=2$. Panel B presents the results distinguishing the different types of dividend change announcements. In this situation, the pooled OLS model is the most appropriate for the Portuguese sample, the FEM for $=1$ and the pooled OLS for $=2$ are the best for the French sample, and the FEM for $=1$ and the REM for $=2$ are the most appropriate for the UK sample.

When we consider dividend changes without distinguishing between dividend increases or decreases (Panel A), we find no evidence that the magnitude of dividend changes contains information about future earnings, both for Portugal and France. For the UK, the coefficient on dividend changes is negative and statistically significant for the first year following the dividend change, showing a reverse relationship between dividend change announcements and future earnings.

When dividend increases and decreases are treated separately (Panel B), the results for the Portuguese sample show that only for the second year following the dividend changes $(=2)$, the coefficient on dividend increases is statistically significant. Neither of the other coefficients on dividend changes is significantly different from zero. For the French sample, none of the coefficients on dividend changes is statistically significant, similarly to the previous results. For the UK sample, only for $=1$ there are significant coefficients on dividend changes. Both the coefficients on dividend decreases, independently of the earnings changes, are negative and statistically significant. All the other coefficients are not significant. On global terms we can notice that, comparing the results from Table 3.10 to those of Table 3.11, the non-linear model explains a larger fraction of the cross-sectional variation in earnings changes than the linear model. Specifically, for the Portuguese sample, that maintain the same type of model as the most appropriate (pooled OLS), we find that the adjusted- $\mathrm{R}^{2}$ increases from $50.0 \%$ to $59.6 \%(=1)$ and from $8.9 \%$ to $10.8 \%(=2)$, and for the French sample, for $=1$ (whose best model is the FEM), the adjusted- $\mathrm{R}^{2}$ increases from $41.1 \%$ to $45.6 \%$.

Consistent with the findings of Fama and French (2000) and Benartzi et al. (2005), this evidence indicates that the linear model misses some information about the behaviour of earnings that seems to be correlated with dividend changes. 
Summarising, accounting for non-linearities in the mean reversion process, leads to the conclusion that changes in dividends are not very useful in predicting future earnings changes. For the French sample, we could not reject the null hypothesis that dividend increases (decreases) are not associated with future earnings increases (decreases). For the Portuguese sample, we only reject the null hypothesis for the coefficient on dividend increases for $=2$ and for the UK sample, we reject the null hypothesis for the coefficients on dividend decrease announcements at the 5\% level, and only for $=1$. On global terms, the results cannot give strong support to the assumption of dividend signalling hypothesis that dividend change announcements are positively related with future changes in earnings. These results are quite similar to the ones of Benartzi et al. (2005), who conclude that, after controlling for the non-linear patterns in the behaviour of earnings, dividend changes contain no information about future earnings.

\subsubsection{Test Results of Sub-hypothesis $\mathbf{H}_{2 \mathrm{~B}}$ - Relation between Dividend Changes and Accounting Performance Measures}

After analysing the relationship between dividend change announcements and future earnings changes, we will consider some other performance measures in order to analyse the post announcement performance of dividend change announcements. Therefore, we formulate the second sub-hypothesis to analyse the relation between dividend changes and some accounting measures. Testing this sub-hypothesis is possible to examine whether changes in dividends forecast future profitability and to analyse the window dressing phenomenon. For that, we consider a regression similar to 3.15 but with five different dependent variables to measure distinct aspects of financial performance: two profitability measures: the ROE and the return on assets $(\mathrm{ROA})^{110}$; a gearing measure: the debt to equity ratio $(\mathrm{D} / \mathrm{E})$; a liquidity measure: working capital ratio (WCR) and the cash flow (CF).

The pooled least squares, as well as the FEM and the REM estimation results of regression 3.17 are shown in Table 3.12, from Panel A to Panel E, respectively for the

\footnotetext{
${ }^{110}$ This variable is widely used to measure firm performance, such as by Barber and Lyon (1997), Fama and French (2000) and Benartzi et al. (2005). According the last authors, ROA dominates the ROE in several aspects: i) the ROE is very sensitive to changes in capital structure while the ROA is not; ii) ROA is not affected by factors such as special items and income taxes that usually obscure the ROE. Moreover, Barber and Lyon (1997) show that the ROA is a good measure to detect abnormal operating performance.
} 
profitability measures of ROA, ROE, D/E, WCR and CF. The best model for each regression is highlighted, being in most of the regressions, the FEM. The most significant regressions are the regression on ROE for the UK, on WCR for Portugal and on Cash Flow for the French sample, as we can see by the higher levels of the adjusted coefficient of determination (e.g. adjusted $\left.\mathrm{R}^{2}\right)^{111}$.

In almost all cases, the coefficients on the lagged performance measure are negative and statistically significant, showing a negative relationship between the lagged performance and the future change in these performance measures.

Panel A shows the cases where the profitability measure is the ROA. Regarding the coefficients on dividend changes, most coefficients are indistinguishable from zero. Consistent with the evidence of Benartzi et al. (2005), these results indicate that firm profitability is not positively associated with past change in dividends. The exceptions are the coefficients on dividend increases for $=1$, in the Portuguese sample, the coefficient on dividend decreases for $=2$, in the French sample, and, finally, in the UK sample, the one on dividend increases and earnings decreases for $=1$, all of them negative. This result is in accordance with Grullon, Michaely and Swaminathan (2002), who found evidence of a negative relation between dividend changes and the subsequent return on assets, suggesting evidence of the maturity hypotheses instead of the dividend signalling hypothesis.

Panel B shows the case where the profitability measure is the ROE. The results suggest the lack of correlation between dividend changes and future profitability for the Portuguese and the French samples. However, in the UK sample, we have evidence of a negative and significant relationship between dividend increases and future profitability for $\quad=1$ (independently of earnings changes) and between dividend increases and earnings decreases and future profitability for $=2$, which is consistent with the results of Abeyratna and Power (2002). Overall, these results are not consistent with the dividend signalling hypothesis.

\footnotetext{
${ }^{111}$ In order to simplify the presentation of the tables, we do not report the correlation matrix of the exogenous variables (otherwise, we will need to present 30 schemes of correlations). Variables show low correlations. The higher coefficient in Portugal is near the $70 \%$, between $\mathrm{WCR}_{-1}$ and $\left(\mathrm{WCR}_{0}-\mathrm{WCR}_{-1}\right)$, for $=1$. In France and in the UK, the higher correlation coefficients are between $\mathrm{ROE}_{-1}$ and $\left(\mathrm{ROE}_{0}-\mathrm{ROE}_{-1}\right)$, for $=1$, but still below $70 \%$ in France and below $60 \%$ in the UK. In general, the correlation coefficients do not appear to be sufficiently large to cause concern about multicollinearity problems.
} 
Panel $\mathrm{C}$ reports the case where the performance measure is the $\mathrm{D} / \mathrm{E}$ gearing measure. None of the coefficients is significant in the Portuguese sample. In the French sample, the coefficient on dividend decreases is positive and statistically significant for $=1$ and with a $10 \%$ level, suggesting a weak evidence of correlation between dividend changes and future debt to equity ratio. For the case of the UK, the coefficients on DIEI, DIED and DDEI for $=1$ are statistically significant at $1 \%$, being the first one negative, contrary to what is expected, and the other two positive. Except for the negative coefficient (DIEI), the other significant coefficients are in accordance with the dividend signalling hypothesis ${ }^{112}$.

Panel D reports the case where the performance measure is the WCR liquidity measure. For the Portuguese sample, the coefficient on dividend increases is negative but only statistically significant for $=2$ and the coefficient on dividend decreases is positive and statistically significant for both $=1$ and $=2$. The coefficients on dividend changes in the French sample are both significant for $=1$, being the coefficient on dividend increases positive, and the one of dividend decreases negative. For the UK sample, only for $=2$ we have a coefficient statistically significant, and positive, which is the one of dividend and earnings increases. Because of the different signals obtained, we do not have evidence of a clear relationship between dividend changes and the future liquidity. However, the evidence of the dividend decrease associated with better future liquidity ratios, in the case of the French sample, in addition with the evidence that dividend decreases are not significantly associated with future earnings changes (Table 3.11, Panel B) suggests that, according to Abeyratna and Power (2002), dividend decreases may not be bad news to the market concerning firms' future earnings, as assumed by signalling theory, but rather reflect managers' decisions to solve firms' financial problems.

Finally, Panel E reports the case where the performance measure is CF. The results show that for the first year after the dividend announcements, the relation between dividend increases and CF variation is negative and statistically significant for the Portuguese sample. For the UK sample, the relation between both dividend and earnings

\footnotetext{
${ }^{112}$ The dividend signalling hypothesis argues that managers increase dividends when they are optimistic about the future performance of the firm and that they decrease dividends when they are pessimistic. According this hypothesis, we would expect dividend increasing (decreasing) firms to increase (decrease) there debt level, since they will have an improvement (deterioration) in their future debt capacity and in their ability to serve larger debt.
} 
decreases (DDED) and CF variation is positive and statistically significant for $=1$, and the relation between dividend increases and earnings decreases (DIED) and CF variation is negative and statistically significant for $=2$. The evidence that cash flow decreases after the dividend increases is consistent with the maturity hypothesis Grullon, Michaely and Swaminathan (2002) and not with the signalling theory. All the other coefficients on dividend changes are indistinguishable from zero. It appears that firms do not signal impending cash flow jumps by raising their dividends.

Analysing the cases where we reject the null hypothesis of no significant relation between dividend changes and future performance measures, we can see that, in global terms, dividend increases are associated with a decrease in ROA, ROE and in $\mathrm{CF}$, and dividend decreases are associated with an improvement in the ROA and a decrease in the debt to equity ratio. The evidence related to the liquidity measure is mixed.

The evidence of a deterioration of the performance measures the year after the dividend increase announcements is contrary to the expected results based on the assumptions of the dividend signalling theory and to the results of Brook, Charlton and Hendershott (1998) and can be interpreted as an indication of the presence of the window dressing phenomenon, the maturity hypothesis or the attempt to mimic firms with better performance prospects. According to Miller and Rock's (1985) signalling model, firms that falsely mimic the performance signals of higher performing firms will be punished by the market as soon as the false signal is recognised. In addition, some profitability and financial ratios will become worse in the future. The negative relation between dividend increases and both ROA and CF is consistent with the maturity hypothesis suggested by Grullon, Michaely and Swaminathan (2002), that a dividend increase may convey information about a decrease in the return on assets due to the decrease in investment opportunities. These results indicate that firm profitability is not positively associated with past change in dividends, which is consistent with the evidence of Benartzi et al. (2005).

Furthermore, for the UK, some of these results might explain the evidence of a negative and significant relation between DIED events and the market reaction found in Table 3.9, beyond the earnings information power. The market reacts negatively to dividend increases and, indeed, the future performance as been deteriorated. The coefficient on DIED is negative and statistically significant when the dependent variables are the ROA 
(Panel A) for $=1$ and the ROE (Panel B) for both the periods. Moreover, the relation between DIED and future earnings, although not statistically significant, is negative for the two periods (Table 3.10), showing evidence of a difficulty to sustain future earnings. Summarising the results of this sub-hypothesis, we fail to reject the null hypothesis associated with $H_{2 B}$ for several coefficients on dividend changes for the three markets, especially for the French market. It suggests that dividends may not always contain information about future profitability. Therefore, we do not find strong evidence of the dividend signalling hypothesis. For the cases in which we reject the null hypothesis, we find stronger evidence of a negative relationship between dividend changes and future performance measures. Thus, in general, our evidence gives no support to the dividend signalling hypothesis which predicts a positive association between dividend change announcements and subsequent performance measures, but, instead, provides some support for the window dressing phenomenon and the maturity hypothesis Grullon, Michaely and Swaminathan (2002) as well as the free cash flow hypothesis Jensen (1986) since the evidence of declining return on assets is consistent with firms increasing their cash payouts in anticipation of a declining investment opportunity set as predicted by the free cash flow hypothesis.

To see whether the maturity hypothesis can explain the results obtained in this section, we will test the next sub-hypothesis, formulated with the purpose of searching this assumption.

\subsubsection{Test Results of Sub-hypothesis $\mathrm{H}_{2 \mathrm{C}}$ - Relation between Dividend Changes and Operating Performance Measures}

Now we will evaluate different post-announcement measures in order to analyse the maturity hypothesis of Grullon, Michaely and Swaminathan (2002).

We start by analysing the average values of the considered variables in the pre and postannouncement period, as well as their difference. Table 3.13 presents the mean values for the ROA (Panel A), the sales growth rate (Panel B) and the capital expenditures (Panel C) for the year before the dividend change announcements, the change announcements year (year 0) and the two years after the dividend change, as well as the 
mean differences between period 1 and 0 and between period 2 and $0^{113}$. In addition, Table 3.13 reports the abnormal values for the three performance measures, computed as paired differences between the dividend-changing firm and the control firm, considered as the sub-samples of firms that did not change dividends. We match sample firms with control firms based on the ROA and the activity code. While the adjusted results may be more robust, the simple values are easier to interpret.

In what concerns the ROA, and looking for the sub-sample values, the results show, for all three countries, a significant decline in the ROA during the two years after the increase in dividends at the $1 \%$ level. The difference between the ROA on year 0 and the preceding year is positive for the French market $(0.2 \%)$ and negative for Portugal and the UK, although not significant for the DIED events in the $\mathrm{UK}^{114}$. The adjusted decline in the ROA after the dividend increase is not statistically significant, except for the UK sample. The results show that dividend-increasing firms experience a period of declining ROA after the dividend increase announcements, being the matching firm adjusted results in agreement with this behaviour. These results are, globally, in accordance with the ones obtained by Grullon, Michaely and Swaminathan (2002). For dividend decreasing firms we have mixed results, but the differences in the ROA during the two years after the decrease in dividends are not statistically significant.

Regarding the SG (Panel B), the evidence is different, depending on the sample. For the Portuguese sample, the results show that dividend increases are associated with a continuous decline in the SG rate after the dividend increase announcements, being these differences statistically insignificant. In the French market we have an increase in the SG rate the year after the dividend announcements, but a decline in this index from year 0 to year 2. However, these changes are essentially zero. For the UK sample, the results show a significant decline in the SG rate during the two years after the increase in dividends, except for the DIED events, whose decline is not statistically significant for the difference between year 1 and year 0 . This is in contrast to an increase of the SG rate of $1.9 \%$ experienced in the French market during the year prior to the dividend increase. Although for the other two markets the difference between the SG rate between year 0 and the year preceding the dividend announcement is negative, this

\footnotetext{
113 As we have pointed before, Datastream has no sufficient data about capital expenses for the Portuguese sample, so, we will not use this variable for this sample.

${ }^{114}$ For simplicity, we do not report the differences between the announcement year and the preceding year.
} 
decline is not so robust, as it is only significant at the 5\% level for the Portuguese sample. The adjusted SG rate differences are only statistically significant for the French sample. The results show that dividend-increasing UK firms experience a period of declining SG after the dividend increase announcements. For dividend decreasing firms we have mixed results, but the differences in the SG rate during the two years after the decrease in dividends are not statistically significant for almost all the situations.

Finally, Panel $\mathrm{C}$ presents the results concerning the capital expenditure behaviour. In France, the results show a decline in the CE during the two years after the increase in dividends. However, it is only statistically significant at the $10 \%$ level for the difference between the announcement year and two years after the event. In the UK, the results show an increase in the $\mathrm{CE}$ from the dividend announcement year to the subsequent year, and a decline from the event year to two years after the announcing period. However, only the difference in the CE for the DIEI events between the announcement year and two years after the event is statistically significant at the $10 \%$ level. Comparing the CE means values in the announcement year and the preceding year we can see they present a decline, but the difference is not statistically significant, except for the case of DIED, in the UK sample, and only at a 5\% level. In the French sample, the capital expenditure is lower than that of control firms, and statistically significant for several cases, which is in accordance with the results of Lai, Song and Fung (2004). Nevertheless, in the UK, the values for the paired differences are not significant. For dividend decreases, the changes in the $\mathrm{CE}$ are statistically not significant.

The significant decrease of $\mathrm{SG}$ and ROA for the two years after the DIED announcements might be an additional explanation for the negative relation between DIED and the CAR, found in Table 3.9.

In summary, the results show that dividend-increasing firms move to a period of a significant decline of the ROA for all three countries, a significant decline of the SG in the UK market and a decline in the CE both in France and in the UK, but not always significant. These results could be interpreted as an indication that the variables postannouncement behaviour are in agreement with the predictions of the maturity hypothesis Grullon, Michaely and Swaminathan (2002) and Lai, Song and Fung (2004) and, consequently, we cannot give support to the alternative sub-hypothesis $H_{2 C}$, formulated according to the assumptions of dividend signalling theory. These results confirm, in general terms, the ones obtained in the precedent sub-hypothesis. 
Moreover, the evidence giving some support to the maturity hypothesis is stronger for the UK market.

Although we find some evidence for the maturity hypothesis, it cannot fully explain the results of all the three samples, especially in what concerns the SG and the CE analysis. In this context, we split the dividend increase events into three groups, based on the post-announcement operating performance (ROA): top performance group, middle performance group and bottom performance group, to see whether different operating performance groups have different behaviour and whether the signalling and the maturity hypotheses can co-exist ${ }^{115}$. The results are reported in Table 3.14 for the ROA (Panel A), the sales growth rate (Panel B) and the capital expenditures (Panel C).

The results of the top performance group and the bottom performance group are somewhat different.

The bottom performance group shows a generalised and significant worsening in the ROA in the periods after the dividend increases announcements. The evidence related with the SG rate present mixed evidence. For the Portuguese and the French samples, the changes in the SG are not statistically significant. In the UK sample, the performance is worse in the two years after the dividend increases. However, the values are statistically significant for only half of the situations. In what concerns the $\mathrm{CE}$ behaviour, it declines both in France and in the UK in the two years after the announcement period. Although the decline is essentially zero in France, in the UK it is statistically significant at $1 \%$ level for both the periods in the DIEI events. Summarising, we find that the bottom-performance group experience significant deterioration in ROA, lower capital expenditures, although not always significant, and a tendency of lower sales growth, but statistically significant in about half of the cases. The features of these firms confirm to those of the maturity firms. The evidence is consistent with the findings of Benartzi, Michaely and Thaler (1997), Grullon, Michaely and Swaminathan (2002) and Lai, Song and Fung (2004). However, when analysing the paired differences performance, the results are not as strong as the previous evidence since it does not present a consistent behaviour. In some cases the performance of those firms are worse than that of their control firms following the announcements, especially

\footnotetext{
${ }^{115}$ A more detailed analysis of the co-existence of the maturity hypothesis and signalling hypothesis is beyond the scope of our thesis at this stage; however, it constitutes an interesting theme for future research and further development of the study.
} 
in the French sample, and in other cases the opposite happens, namely in the UK sample, for the case of the ROA.

The top performance group shows a non linear reaction in the performance measures in the two years after the announcement period. For all the samples, the ROA shows an improvement the year after the dividend increases, but it is not statistically significant. However, two years after the ROA experiences deterioration in relation to the announcement period. A worsening in the sales growth is verified in the two years after the dividend changes for the Portuguese sample and the UK sample in the case of the DIEI events. In the French market, the results show an improvement in the sales growth, however it is not statistically significant. None of the changes in capital expenses are statistically different from zero. However, when analysing the paired differences performance, the results show a more consistent behaviour, although not conclusive. The top-performance group, relative to the control group, shows a significant improvement in the ROA for all the samples in the year after the dividend announcement, and higher growth in sales after the event year, but only for the DIEI events in the UK sample, being the other situations not significant. Finally, none of the capital expenditures changes are statistically different from zero. The evidence gives only weak support to the hypothesis that this group of firms sends signals to the market about their positive future prospects. Lai, Song and Fung (2004) found evidence that strongly support this hypothesis, for the US market.

Combining the results of the bottom performance and the top performance events, we find that the characteristics of the former firms are somewhat consistent with those of the maturity hypothesis. The features of the second group are not clear. Overall these results present little consistency with the signalling hypothesis.

Concluding, and based on the relationship between dividend increases and both the subsequent ROA and the CF (Table 3.12), the behaviour of the operating performance variables in the post-announcement period for the whole sample (Table 3.13) and the results for the groups of dividend increase events based on operating performance (Table 3.14), we find some evidence of the maturity hypothesis, consistent with the results of Grullon, Michaely and Swaminathan (2002) and Lai, Song and Fung (2004). Moreover, we find only weak evidence, and essentially in the UK market, of the signalling hypothesis, whether Lai, Song and Fung (2004) found strong support for this hypothesis. Furthermore, we cannot discard the possibility that the maturity hypothesis 
and the signalling hypothesis can co-exist, as Lay, Song and Fung (2004) have suggested. Indeed, their evidence suggests that some firms increase dividends because they are at the maturity stage, while some firms try to signal, with the authors concluding that the maturity hypothesis and the signalling hypothesis can co-exist.

If market investors at least partially recognise the relationship between current dividend increases and future changes in profitability, capital expenses and sales growth, then this should be reflected in the initial market reaction. To explore this issue, we regress, for dividend increase events, the announcement period abnormal returns on changes in future ROA, changes in SG and future capital expenditures, according to regression 3.18. The pooled OLS, as well as the FEM and the REM estimation for the regression results are shown in Table 3.15, considering the initial market reaction as the CAR (Table A) and the BHAR measures (Panel B). For each situation, we report the results for the full dividend increases sample, as well as the bottom and top performance groups, to see whether the results hold when we split the sample into groups based on the future performance. We will analyse the results of the best model, according to the $\mathrm{F}$ statistic and the Hausman test.

When we verify the correlation coefficients between the explanatory variables ${ }^{116}$, they indicate, for all three samples, a high negative correlation between the change of the measure in the announcement period and the change in the measure during the two years after the dividend change announcements, for all the performance measures. For the correlation between $\left(\mathrm{ROA}_{\mathrm{i}, 0}-\mathrm{ROA}_{\mathrm{i},-1}\right)$ and $\mathrm{ROA} i, 2$, the correlation coefficients value range from -0.75 (French sample, bottom performance group) to -0.95 (UK sample, top performance DIED group); for the correlation between $\left(\mathrm{SG}_{\mathrm{i}, 0}-\mathrm{SG}_{\mathrm{i},-1}\right)$ and $\mathrm{SG}_{\mathrm{i}, 2}$, the correlation coefficients value range from -0.66 (UK sample, bottom performance DIEI group) to -0.97 (UK sample, bottom performance DIED group) and finally, for the correlation between $\left(\mathrm{CE}_{\mathrm{i}, 0}-\mathrm{CE}_{\mathrm{i}, 1}\right)$ and $\mathrm{CE}_{\mathrm{i}, 2}$, the correlation coefficients value range from -0.80 (French sample, top performance group) to -0.99 (UK sample, full DIED sample). When we consider the coefficient correlations that are above $0.8,{ }^{117}$ France reduces the cases in which the correlation is considered high for the top and the bottom groups, and the UK reduces it for the bottom DIEI group.

\footnotetext{
${ }^{116}$ Once again, for simplicity reasons, we do not report the correlation matrix.

${ }^{117}$ Suggested by Gujarati (2003) as the value from what we could have multicollinearity problems.
} 
In this context, we have two alternatives: do nothing or follow some rules of thumb ${ }^{118}$. For several reasons we opted for the first option. Firstly, although Gujarati (2003, p. 344) pointed out that "If multicollinearity is less than perfect, the regression coefficients, although determinate, possess large standard errors (in relation to the coefficients themselves), which means the coefficients cannot be estimated with great precision or accuracy", he also said (p. 349) that "it is true that...estimators are unbiased". In addition, Achen (1982, p. 82-83) concludes that "multicollinearity violates no regression assumptions...the only effect of multicollinearity is to make it hard to get coefficient estimates with small standard error". Secondly, several authors, such as Gujarati (2003) and Johnston and DiNardo (2001) agree that the multicollinearity is essentially a data deficiency problem and not a problem of a statistical technique in general. Thirdly, beyond the correlation between independent variables, we have other rules of thumb to detect the strength of the multicollinearity, such as the variance inflation factor (VIF) and an $\mathrm{R}^{2}$ high $^{119}$ but few significant $\mathrm{t}$ ratios, and according them, it does not appear to cause serious concern about multicollinearity problems. Fourthly, we are combining cross-sectional and time series data, which is the support for a procedure to address the problem of multicollinearity ${ }^{120}$. Fifty, we are using a model similar to the one of Grullon, Michaely and Swaminathan (2002), and it will be interesting to compare our results. Curto (2002) points out that if it is important to analyse the influence of an explanatory variable in the dependent variable behaviour, it could be more important to let it in the model than to drop it. Finally, the data are produced by the functioning of the economic system, and the multicollinearity can reflect the nature of that system Johnston and DiNardo (2001) . Therefore, we will analyse the results obtained in this regression model, being aware that the $t$ ratio of one or more coefficients tends to be statistically insignificant because of the increase in the estimated standard errors.

When we look for the full dividend increases samples, we can see that the announcement period returns are negatively and significantly related to dividend increases in France, for the BHAR measure (Panel B) and in the UK for the situation of both dividend and earnings increases for the CAR measure (Panel A). All the other

${ }^{118}$ There are no sure methods to address the problem of multicollinearity, but only a few rules of thumb Gujarati (2003) .

${ }_{119}$ Gujarati (2003) suggested a VIP in excess of 10 and an $\mathrm{R}^{2}$ in excess to 0.8 or 0.9 .

${ }^{120}$ Due to an increase in the number of observations, degrees of freedom are increased and the problem of multicollinearity is reduced, thus the efficiency of econometric estimates is improved Baltagi and Chang (1994) . 
coefficients on dividend increases are essentially zero. These results are consistent with the ones obtained in Table 3.9. In what concerns the performance coefficients, we can see a strong positive relationship between initial market reaction (with both the CAR and the BHAR measures) and current, as well as future capital expenditures for the two markets which consider these two variables in the regression: the French and the UK market, in the sub-sample of DIEI. In the DIED sub-sample none of the coefficients are statistically significant. In the Portuguese sample, we find a strong negative relationship between the initial market reaction (Panel B) and current, as well as future change in the ROA. These results suggest that market investors recognise some relationship between current dividend increases and future changes in profitability, in the case of the Portuguese sample, and capital expenditures, in the French and the UK markets. Grullon, Michaely and Swaminathan (2002) and Lai, Song and Fung (2004) found evidence of a strong negative relationship between CAR and future changes in return on assets, as we find in the Portuguese sample. The reason why the market reacts positively when investors anticipate a firm's future profitability to decline can be explained, as suggested by Grullon, Michaely and Swaminathan (2002, p. 438), by "an expected decrease in the agency costs of free cash flows ${ }^{\prime \prime 21}$. This point of view is closer to the maturity hypothesis. However, the positive relationship between market reaction to dividend increase announcements and current and future capital expenditures in the French and the UK samples showing that the market reacts positively when investors anticipate firm's capital expenditures to increase is closer to the signalling hypothesis. Investors can react positively to dividend increases expecting that managers have good prospects about future opportunities in positive NPV projects. The split of the sample into two distinct groups according to future operating performance, as we have done before, can help in the explanation of these relationships.

When we compare the results of the top and bottom performance groups, we see that there are some differences. We first focus on the bottom performance groups, which are associated with the maturity firms, as we have seen before. Almost all the coefficients are statistically insignificant, with the exception of the French market, with a negative coefficient on dividend increases for the CAR measure (Panel A) and positive and

\footnotetext{
${ }^{121}$ When a firm is in the maturity stage, it is very likely that it has excess cash. The managers can either pay it out or invest the excess cash in projects with negative NPV. Investors may interpret the dividend increase announcements as good news that managers are not going to waste the excess resources investing in negative NPV projects.
} 
significant coefficients on the two CE measures for the BHAR (Panel B). Lai, Song and Fung (2004) found a strong negative relationship between initial market reaction and future changes in operating performance as well as current capital expenses. For the top performance groups, which are more associated with the signalling hypothesis, we find a strong positive relationship between the initial market reaction (for both the CAR and the BHAR measures) and the current ROA for the UK sample, in the DIEI group. The coefficients for the DIED group are insignificant. For the French sample, we find positive and significant coefficients on current and future ROA and on future capital expenditures for the CAR measure, and positive and significant coefficients on future ROA and capital expenditures for the BHAR measure. For the Portuguese market, we find a strong positive relationship between the BHAR measure and the dividend increases, the current and the future ROA changes and a strong negative relationship between the market reaction and the current as well as the future changes in sales growth. The evidence of a positive and significant relationship between market reaction and the current ROA is in accordance with Lai, Song and Fung (2004) and is in accordance with signalling hypothesis assumptions. The evidence that the market reaction is positively related to capital expenditures could be consistent with this group of firms being in the signalling group because investors can recognise these firms to have sufficient positive NPV projects, and is in agreement with the full sample results. Although the evidence of a negative relationship between the market reaction and the current and the future changes in sales growth in the Portuguese sample is consistent with the evidence found in Table 3.14, it is not associated with the signalling hypothesis. So, once more, the characteristics of this group are not clear, but present some consistency with the signalling hypothesis.

The fact that, for the Portuguese and the French samples (considering the BHAR) the coefficients on current and future operating performance are positive and significant in the top performance group (signalling sample) but negative and insignificant in the bottom performance group (maturity sample), could be an indication that investors correctly anticipate the positive performance of signalling firms and the deterioration of operating performance of maturity firms. It seems that investors react to the different group in a diverse way. In the other samples we have also different behaviours between the two groups, but not so robust. Nevertheless, the differences suggest that investors do not view the two groups as the same. With respect to the capital expenditures and the 
sales growth the differences are not considerable, except for the Portuguese sample, where the coefficient of sales growth is negative and significant in the top performance group and negative but insignificant in the bottom performance group.

Although we have decided not to use remedial measures to address the problem of multicollinearity because of the reasons explained so far, in order to test the robustness of the results, we have analysed the consequence of dropping the collinear variables. By doing this, we obtain similar results to the Portuguese and the French sample, so, for these two countries, the conclusions remain the same. For the UK sample, the explanatory variable $\left(\mathrm{ROA}_{\mathrm{i}, 0}-\mathrm{ROA}_{\mathrm{i},-1}\right)$ is the only one with different results, but only for the full sample groups and the top DIED group. Whereas in the original model this variable was positive but statistically insignificant, it is now also positive, but statistically significant at the 5\% level. The significant relationship between the initial market reaction (both with the BHAR and CAR measures) and the current ROA for the top DIED group reinforces the evidence of the signalling hypothesis, as we have already found a significant relation between the same variables in the top DIEI group.

Summarising the results, we find some evidence of the maturity hypothesis, essentially in the analysis of the full sample, consistent with the results of Grullon, Michaely and Swaminathan (2002) and Lai, Song and Fung (2004) and some evidence of the signalling hypothesis in the top performance group, which is in agreement with the latter authors' results. Furthermore, we find some evidence that investors react differently to the two distinct groups in the Portuguese and in the French market (although in a weaker proportion in the last one). In the UK sample, a distinct behaviour is not so evident. Consequently, the overall results give weak support to the evidence that the market reacts differently to the distinct groups. The results are quite consistent with the Lai, Song and Fung (2004) study, although they found a stronger support to the evidence that investors do not view the two groups in the same way.

Finally, we will try to examine the relationship between dividend change announcements and the market expectations of future earnings, generating a proxy for the market expectations of future earnings. We will test the next sub-hypothesis, formulated with the purpose of analysing this assumption. 


\subsubsection{Test Results of Sub-hypothesis $\mathbf{H}_{2 D}$ - Relation between Dividend Changes and Market Expectations of Future Earnings}

To examine the relationship between dividend changes and the market expectations of the firms' future prosperity, we ran regression 3.19, considering the pooled OLS, the FEM and the REM. Results are shown in Table 3.16. According to the F statistic and the Hausman test, the best model for the Portuguese and the UK market is the FEM and for the French market is the REM ${ }^{122}$.

In what concerns the coefficient on earnings changes, we can see that, with the exception of France, where it is essentially zero, the coefficient is statistically significant in the Portuguese and in the UK samples, showing a significant relation between current and future profitability. However, this relation is positive in the UK market, but negative in the Portuguese case.

The relationship between future expected profitability and the dividend changes is quite different in the three markets considered.

In Portugal, none of the coefficients on dividend changes are statistically significant, suggesting that the market catches no information on dividend changes and thus, recognises no information content in dividend changes. Consequently, for this market, we fail to reject the null hypothesis of no relationship between dividend changes and the market expectations of the firm's future prosperity, finding no support to the dividend signalling hypothesis. This is, globally, in accordance with the conclusions we obtained when we tested the first hypothesis.

For the French sample, the results show a significant negative relation between the future expected profitability and dividend increases, which is opposite to the expected signal. The coefficient on dividend decreases is statistically insignificant. These results suggest that the market perceives reverse information in dividend increases and recognise any information content in dividend decreases. When testing the first hypothesis, we also find a negative relationship, although not significant, between

\footnotetext{
${ }^{122} \mathrm{We}$ do not present the correlation coefficients between independent variables for questions of simplicity and because they point out for very low correlation coefficients. The sample with higher coefficients is the UK. However, the higher correlation coefficient is between DIEI and DIED, which point out a negative correlation, but still low the 0.15 . Thus, it does not appear to cause multicollinearity problems.
} 
dividend increases and the subsequent market reaction (Table 3.9). This surprising result could be associated with the fact that, although the market expects future earnings to increase, it might believe that dividend increases would result in a poorer earnings growth rate or that dividend increases will be lower than forecasted by analysts, reacting negatively. Additionally, it could be associated with the maturity hypothesis, with investors expecting a decrease in the future profitability through the lack of good investment opportunities Mozes and Rapaccioli (1998) and Grullon, Michaely and Swaminathan (2002) . Once again, we feel that we must explore the problem of the reverse relationship between dividend change announcements and the market reaction.

When it comes to the UK market, we find a strong negative relationship between DIED and the expectations of the firm's future prosperity, which is in accordance with the results obtained in Table 3.9, but contrary to the expected signal, like in the French market. The fact that the coefficient on DIED is negative and significant, but the coefficient on DIEI is positive and insignificant, could be interpreted as an indication that the earnings constitute the dominant signal to the market, while dividends constitute only a partial signal, which is in accordance with our previous results and the results obtained by Lonie et al. (1996), DeAngelo, DeAngelo and Skinner (1992) and Conroy, Eades and Harris (2000). In addition, we find a strong positive relationship between DDEI and DDED and the dependent variable, showing evidence of a direct relationship between dividend decreases and the market expectations of the firm's future prosperity. The significant negative relation between dividend increases and earnings decreases (DIED) events and the dependent variable is surprising and needs further analysis, like the case of the negative and significant relationship between dividend increases and future profitability found in the French market.

Overall, we can say that, for the Portuguese market, we fail to reject the null hypothesis associated with $H_{2 D}$, finding no support to the dividend signalling hypothesis. For the UK dividend decrease events (DDEI and DDED), we find a significant and direct relationship between them and the dependent variable, rejecting the null hypothesis and, consequently, finding support for the hypothesis that, in this market, dividend decreases are directly associated with the market expectations of the firm's future prosperity. However, contrary to the expected signal, we find negative and significant values for the coefficients on dividend increases, in the French market, and on DIED, in the UK market, rejecting the null hypothesis for these two situations. This is evidence of 
an inverse relationship between these variables and the expectations of the firm's future prosperity. Therefore, we do not find evidence supporting the dividend information content hypothesis for these events. Besides, it is evidence of a reverse behaviour dilemma, which is in need of research.

The empirical research done so far is associated with two classic issues in the dividend policy domain: the market reaction around the dividend change announcements and the association between dividend changes and future earnings. If we compare the results obtained until now, we will reach to some conclusions about the classical assumptions of the dividend signalling models.

\subsection{CONCLUSIONS}

Summarising the results obtained when testing the hypothesis one and two (considering the several sub-hypotheses), we can reach to the following main conclusions:

- The abnormal returns for the three-day announcement period only support the dividend content hypothesis for the dividend increase events in the UK market. In the Portuguese and in the French markets we find no significant market reaction to dividend change announcements, which do not support the hypothesis that dividend changes communicate significant new information to the market. This is in agreement with the expected results that the need to use dividends as a signalling device must be less pronounced in France and in Portugal than in the UK, namely by the effect of concentrated corporate ownership, firm's financing and level of protection of corporate shareholders. The results obtained are consistent with several studies, namely Goergen, Renneboog and Silva (2005), Lasfer and Zenonos (2004) and Abeyratna and Power (2002);

- There are a significant percentage of cases where the relation between dividend change announcements and share price reaction is reverse. This evidence is consistent with the findings of Dhillon and Johnson (1994), Sant and Cowan (1994) and Healy, Hathorn and Kirch (1997), among other authors. The positive market reaction to dividend decrease announcements in the UK market is an enigmatic situation reflecting this reverse reaction. This evidence motivates us for 
further research about the phenomenon of an inverse relationship between dividend changes and market reaction;

- The regression results do not allow rejecting the null hypothesis that dividend changes are not associated with a subsequent market reaction in the same direction for all the different types of dividend change announcements, so we do not find strong support to the dividend signalling hypothesis. This is in accordance to what we have predicted for the Portuguese and French sample. For the UK sample, our results seem to be nearer to the conclusions of the authors that do not find evidence of a significant market reaction to dividend change announcements, such as Lang and Litzenberger (1989), Benartzi, Michaely and Thaler (1997), and, more recently, Conroy, Eades and Harris (2000), Chen, Firth and Gao (2002) and Benartzi et al. (2005);

- For the Portuguese and the French market, we find evidence that dividend change announcements have no influence on future earnings. Consequently, we are unable to find any evidence to support the view that changes in dividends have information content about future earnings changes, and, consequently, the results cannot support the assumption of dividend signalling hypothesis that dividend change announcements are positively related with future changes in earnings. These results are consistent with the early findings of Watts (1973) and Benartzi, Michaely and Thaler (1997), as well as some recent studies, such as the ones of Grullon, Michaely and Swaminathan (2002) and Benartzi et al. (2005), all of them obtained in the US market. For the UK market, we find evidence that only dividend decrease announcements contain information on future earnings, incremental to the current earnings, but just for the first year after the dividend change announcement, thus, we find only weak support for the information content of dividend hypothesis in the UK market. The UK results also suggest that earnings announcements have information power beyond that of dividend announcements, consistent with the findings of Lonie et al. (1996), DeAngelo, DeAngelo and Skinner (1992) and Conroy, Eades and Harris (2000).;

- Comparing dividend change announcements with future performance measures, our evidence gives no support to the dividend signalling hypothesis which predicts a positive association between dividend change announcements and subsequent performance measures, but, instead, provide some support for the window dressing phenomenon and the free cash flow hypothesis of Jensen (1986), and a 
stronger support for the maturity hypothesis Grullon, Michaely and Swaminathan (2002) . This evidence is reinforced with the hypothesis $\mathrm{H}_{2 \mathrm{C}}$ tests, where variables post-announcement behaviour are in agreement with the predictions of the maturity hypothesis, giving some support to that hypothesis Grullon, Michaely and Swaminathan (2002) and Lai, Song and Fung (2004). This evidence is stronger for the UK market;

- When we split the dividend increase events into distinct groups according the post-announcement operating performance, we find that the characteristics of the bottom performance group are somewhat consistent with those of the maturity hypothesis but the characteristics of the top performance group are not clear, presenting, however, weak consistency with the signalling hypothesis. In addition, we cannot discard the possibility that the maturity hypothesis and the signalling hypothesis can co-exist, as Lay, Song and Fung (2004) have suggested;

- When we consider a future prosperity approach, analysing the relation between dividend change announcements and the market expectations of the firm's future prosperity, the general results give no support to the dividend signalling hypothesis. However, we find evidence of a reverse relationship between dividend increase events and firm's future prosperity in the French and in the UK market, which emphasises, once more, the necessity of extensive analysis;

- Overall, we do not find support to the dividend signalling content hypothesis, which is consistent with some recent studies, such as those of DeAngelo, DeAngelo and Skinner (1996), Benartzi, Michaely and Thaler (1997), Abeyratna and Power (2002) and Benartzi et al. (2005). The fragile support we find in some tests is associated with the UK market that leads us to believe that in countries with concentrated ownership firms do not need to use dividends as a signal, which is in accordance with Goergen, Renneboog and Silva (2005) conclusions.

After analysing the classical assumptions of the dividend signalling models, we will combine tests that analyse simultaneously the market reaction to dividend announcements and the association between dividend changes and future earnings and we will also explore the enigmatic cases of a negative relation between dividend change announcements and the subsequent market reaction, in order to try explaining the reverse behaviour between dividend change announcements and the subsequent market reaction. 
TABLES 


\section{Table 3.1 - Trends in dividend payments}

This table reports the number of non-financial firms listed on EL in the period 1988-2002, on EP in the period 1992-2002 and on LSE in the period 1994-2002, as well as the number of firms in two different dividend groups: dividend payers (firms that pay dividends in year $t$ ) and dividend non-payers. The firm must be listed on December of year $t$ to be in the sample for that year.

\begin{tabular}{|c|c|c|c|c|c|}
\hline \multicolumn{6}{|c|}{ Trends in Dividend Payments } \\
\hline \multirow{2}{*}{ Year } & \multicolumn{2}{|c|}{ Payers } & \multicolumn{2}{|c|}{ Non-Payers } & \multirow{2}{*}{$\begin{array}{l}\text { Total No } \\
\text { of Firms }\end{array}$} \\
\hline & $\mathrm{N}^{\mathrm{o}}$ & $\%$ & $\mathrm{~N}^{\mathrm{o}}$ & $\%$ & \\
\hline \multicolumn{6}{|c|}{ Portugal: Period 1988-2002 } \\
\hline 1988 & 93 & 66.43 & 47 & 33.57 & 140 \\
\hline 1989 & 93 & 72.09 & 36 & 27.91 & 129 \\
\hline 1990 & 82 & 65.60 & 43 & 34.40 & 125 \\
\hline 1991 & 75 & 60.48 & 49 & 39.52 & 124 \\
\hline 1992 & 51 & 69.86 & 22 & 30.14 & 73 \\
\hline 1993 & 37 & 60.66 & 24 & 39.34 & 61 \\
\hline 1994 & 29 & 51.79 & 27 & 48.21 & 56 \\
\hline 1995 & 26 & 50.98 & 25 & 49.02 & 51 \\
\hline 1996 & 30 & 58.82 & 21 & 41.18 & 51 \\
\hline 1997 & 31 & 55.36 & 25 & 44.64 & 56 \\
\hline 1998 & 37 & 61.67 & 23 & 38.33 & 60 \\
\hline 1999 & 38 & 67.86 & 18 & 32.14 & 56 \\
\hline 2000 & 31 & 58.49 & 22 & 41.51 & 53 \\
\hline 2001 & 23 & 46.94 & 26 & 53.06 & 49 \\
\hline 2002 & 18 & 41.86 & 25 & 58.14 & 43 \\
\hline \multicolumn{6}{|c|}{ France: Period 1992-2002 } \\
\hline 1992 & 101 & 24.40 & 313 & 75.60 & 414 \\
\hline 1993 & 111 & 29.13 & 270 & 70.87 & 381 \\
\hline 1994 & 109 & 29.54 & 260 & 70.46 & 369 \\
\hline 1995 & 120 & 33.15 & 242 & 66.85 & 362 \\
\hline 1996 & 120 & 36.59 & 208 & 63.41 & 328 \\
\hline 1997 & 124 & 40.79 & 180 & 59.21 & 304 \\
\hline 1998 & 129 & 45.74 & 153 & 54.26 & 282 \\
\hline 1999 & 144 & 53.14 & 127 & 46.86 & 271 \\
\hline 2000 & 141 & 53.61 & 122 & 46.39 & 263 \\
\hline 2001 & 150 & 61.73 & 93 & 38.27 & 243 \\
\hline 2002 & 146 & 65.18 & 78 & 34.82 & 224 \\
\hline \multicolumn{6}{|c|}{ UK: Period 1994-2002 } \\
\hline 1994 & 358 & 47.54 & 395 & 52.46 & 753 \\
\hline 1995 & 398 & 47.95 & 432 & 52.05 & 830 \\
\hline 1996 & 429 & 48.04 & 464 & 51.96 & 893 \\
\hline 1997 & 456 & 48.72 & 480 & 51.28 & 936 \\
\hline 1998 & 487 & 49.80 & 491 & 50.20 & 978 \\
\hline 1999 & 511 & 53.17 & 450 & 46.83 & 961 \\
\hline 2000 & 512 & 52.03 & 472 & 47.97 & 984 \\
\hline 2001 & 507 & 53.09 & 448 & 46.91 & 955 \\
\hline 2002 & 507 & 53.94 & 433 & 46.06 & 940 \\
\hline
\end{tabular}


Figure 3.1 - Dividend payers and non-payers

This figure shows the total number of non-financial firms listed on EL, EP and LSE, as well as the number of payers (firms that pay dividends in year $t$ ) and dividend non-payers. The firm must be listed on December of year $t$ to be in the sample for that year.

Portugal: 1988-2002

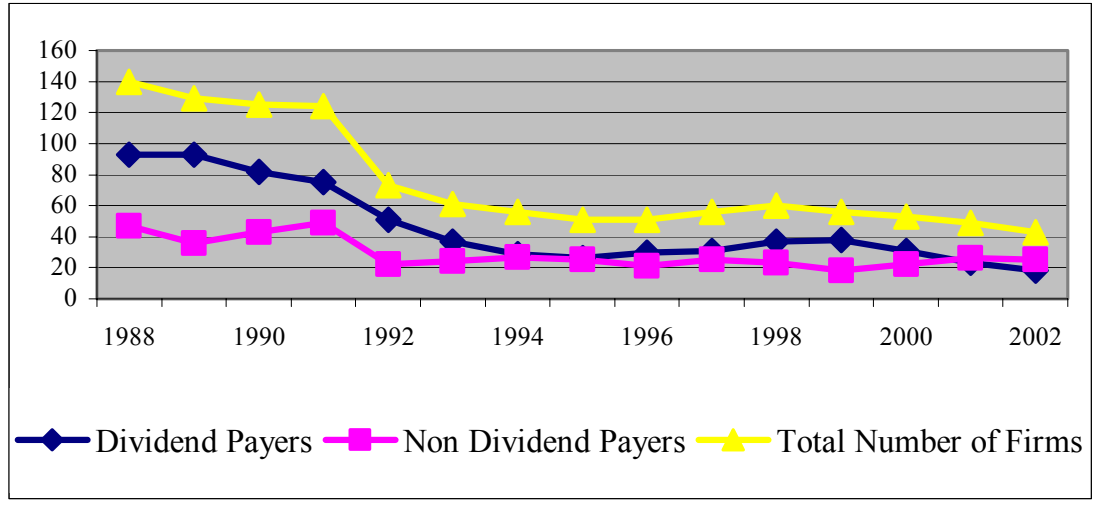

France: 1992-2002

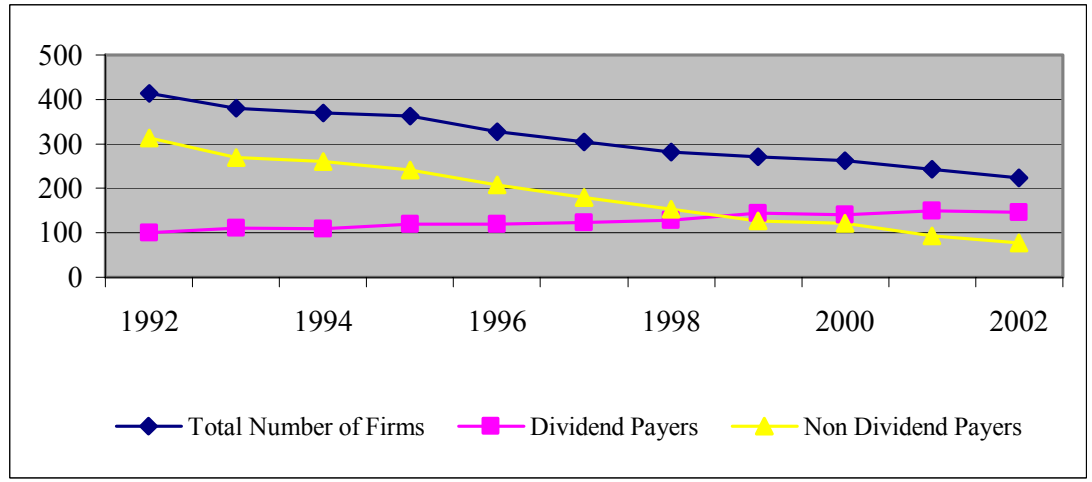

UK: 1994-2002

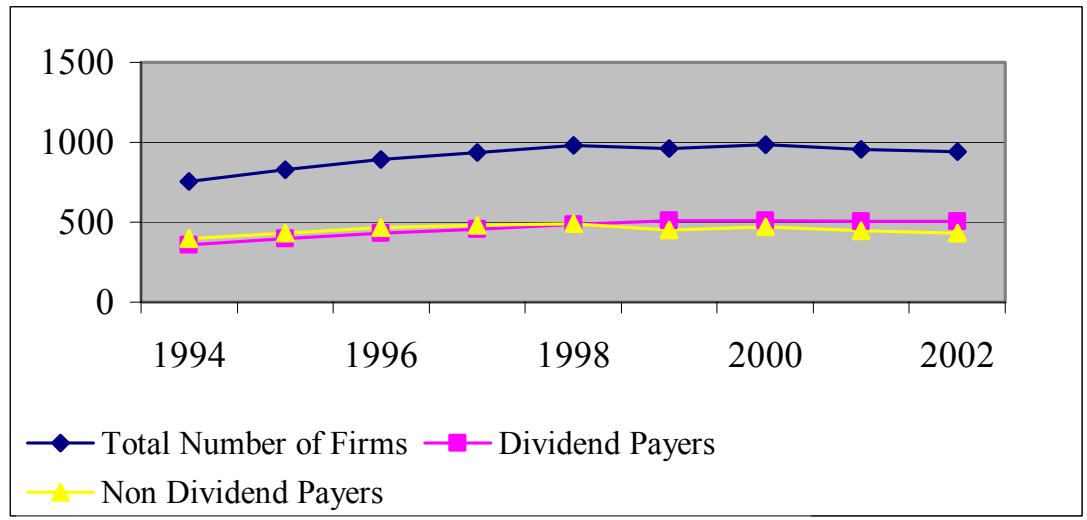




\section{Table 3.2 - Summary statistics of dividend per share}

This table reports the dividend per share (DPS) of non-financial firms listed on EL in the period 19882002, on EP in the period 1992-2002 and on LSE in the period 1994-2002. The firm must be listed on December of year $t$ to be in the sample for that year.

\begin{tabular}{|c|c|c|c|c|c|}
\hline \multicolumn{6}{|c|}{ Summary statistics of DPS } \\
\hline Year & $\begin{array}{c}\text { Dividend } \\
\text { Payers }\end{array}$ & $\begin{array}{l}\text { Minimum } \\
\text { DPS }\end{array}$ & $\begin{array}{l}\text { Maximum } \\
\text { DPS }\end{array}$ & $\begin{array}{c}\text { Average } \\
\text { DPS }\end{array}$ & $\begin{array}{c}\text { Std. } \\
\text { Deviation }\end{array}$ \\
\hline \multicolumn{6}{|c|}{ Portugal: Period 1988-2002, $€$} \\
\hline 1988 & 93 & 0.02 & 1.55 & 0.51 & 0.34 \\
\hline 1989 & 93 & 0.05 & 2.49 & 0.48 & 0.39 \\
\hline 1990 & 82 & 0.02 & 2.37 & 0.51 & 0.42 \\
\hline 1991 & 75 & 0.05 & 2.84 & 0.48 & 0.38 \\
\hline 1992 & 51 & 0.03 & 1.50 & 0.41 & 0.30 \\
\hline 1993 & 37 & 0.10 & 1.95 & 0.46 & 0.37 \\
\hline 1994 & 29 & 0.10 & 1.50 & 0.45 & 0.37 \\
\hline 1995 & 26 & 0.10 & 0.75 & 0.34 & 0.17 \\
\hline 1996 & 30 & 0.12 & 0.87 & 0.36 & 0.18 \\
\hline 1997 & 31 & 0.09 & 1.80 & 0.42 & 0.32 \\
\hline 1998 & 37 & 0.10 & 1.50 & 0.41 & 0.29 \\
\hline 1999 & 38 & 0.09 & 2.24 & 0.46 & 0.41 \\
\hline 2000 & 31 & 0.09 & 1.00 & 0.39 & 0.27 \\
\hline 2001 & 23 & 0.01 & 10.47 & 0.64 & 2.16 \\
\hline 2002 & 18 & 0.01 & 0.70 & 0.15 & 0.17 \\
\hline \multicolumn{6}{|c|}{ France: Period 1992-2002, € } \\
\hline 1992 & 101 & 0.02 & 14.48 & 1.57 & 2.33 \\
\hline 1993 & 111 & 0.02 & 52.85 & 1.91 & 5.16 \\
\hline 1994 & 109 & 0.02 & 52.85 & 1.90 & 5.19 \\
\hline 1995 & 120 & 0.02 & 14.48 & 1.43 & 2.13 \\
\hline 1996 & 120 & 0.01 & 10.98 & 1.34 & 1.61 \\
\hline 1997 & 124 & 0.02 & 25.15 & 1.57 & 2.64 \\
\hline 1998 & 129 & 0.01 & 16.77 & 1.51 & 2.04 \\
\hline 1999 & 144 & 0.01 & 19.82 & 1.61 & 2.28 \\
\hline 2000 & 141 & 0.02 & 19.82 & 1.63 & 2.23 \\
\hline 2001 & 150 & 0.01 & 19.82 & 1.74 & 2.29 \\
\hline 2002 & 146 & 0.04 & 25.00 & 1.83 & 2.58 \\
\hline \multicolumn{6}{|c|}{ UK: Period 1994-2002, $£$} \\
\hline 1994 & 358 & 0.01 & 37.00 & 6.33 & 5.55 \\
\hline 1995 & 398 & 0.10 & 38.00 & 6.46 & 5.87 \\
\hline 1996 & 429 & 0.10 & 38.00 & 6.95 & 6.21 \\
\hline 1997 & 456 & 0.01 & 76.11 & 7.49 & 7.30 \\
\hline 1998 & 487 & 0.10 & 65.92 & 7.87 & 7.52 \\
\hline 1999 & 511 & 0.06 & 70.97 & 8.30 & 8.11 \\
\hline 2000 & 512 & 0.10 & 70.97 & 8.95 & 8.95 \\
\hline 2001 & 507 & 0.05 & 78.00 & 9.31 & 9.35 \\
\hline 2002 & 507 & 0.13 & 88.75 & 9.83 & 10.34 \\
\hline
\end{tabular}




\section{Figure 3.2 - Average dividend per share}

This figure shows the average DPS of non-financial firms listed on EL, EP and LSE. The firm must be listed on December of year $t$ to be in the sample for that year. We have also considered the average DPS excluding the sample extreme DPS value.

Portugal: 1988-2002, $€$

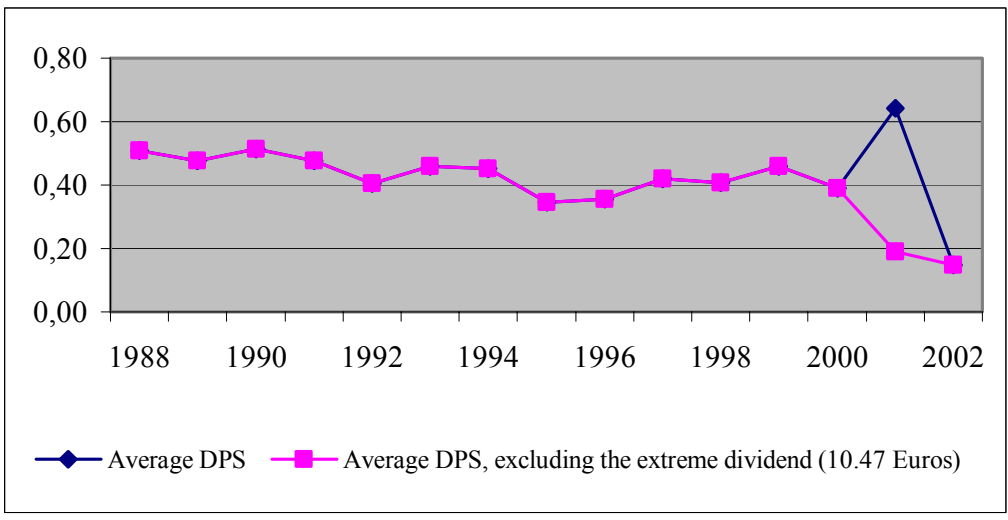

France: 1992-2002, $€$

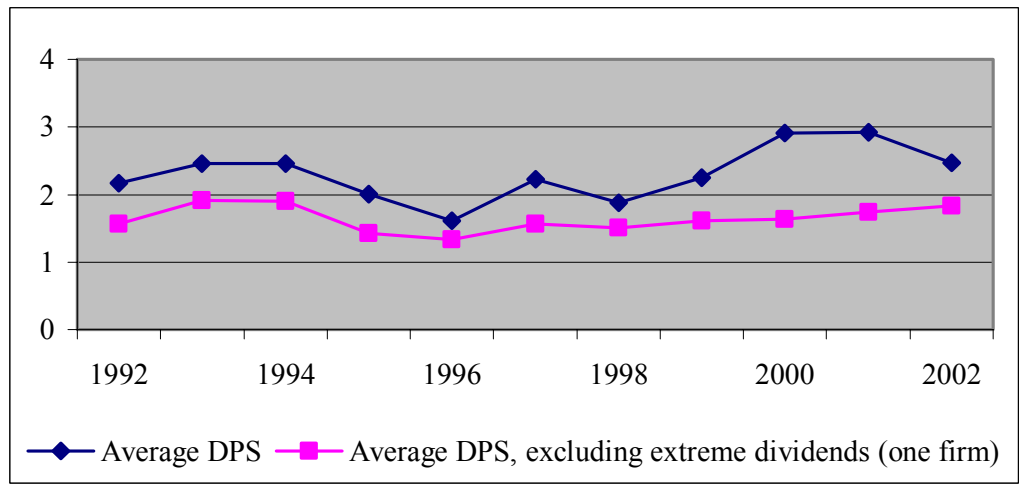

UK: 1994-2002, $£$

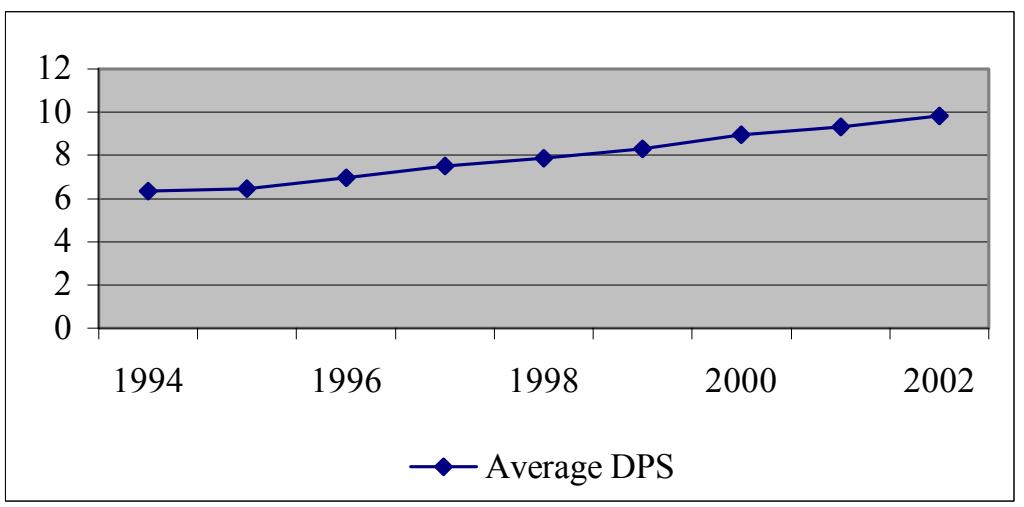




\section{Table 3.3 - Dividend statistics by industry breakdown}

This table reports the average DPS (Panel A) and the percentage of dividend payers (Panel B) by nonfinancial firms listed on EL, EP and LSE, classified by industry type. The firm must be listed on December of year $t$ to be in the sample for that year.

\begin{tabular}{|c|c|c|c|c|c|c|c|c|c|c|c|c|c|c|c|}
\hline \multicolumn{16}{|c|}{ Portugal } \\
\hline \multicolumn{16}{|c|}{ Panel A: Average DPS During 1988-2002 - Industry Breakdown, $€$} \\
\hline Industry & 1988 & 1989 & 1990 & 1991 & 1992 & 1993 & 1994 & 1995 & 1996 & 1997 & 1998 & 1999 & 2000 & 2001 & 2002 \\
\hline griculture & 0.33 & 0.34 & 0.42 & 0.35 & 0.15 & - & - & - & - & - & - & - & - & - & \\
\hline Automobile & 0.70 & 0.70 & 0.50 & 0.30 & 0.40 & 0.40 & 0.36 & 0.40 & 0.15 & 0.37 & 0.40 & 0.65 & 1.00 & 0.20 & 0.08 \\
\hline Chemicals & 0.55 & 0.42 & 0.38 & 0.48 & 0.34 & 0.43 & 0.23 & 0.37 & 0.44 & 0.40 & 0.48 & 0.37 & 0.23 & 0.10 & 0.11 \\
\hline Communications & 1.14 & 2.19 & 2.37 & 2.84 & 1.21 & 0.59 & 0.65 & - & 0.45 & 0.69 & 1.19 & 1.63 & 0.20 & - & 0.10 \\
\hline Construction & 0.42 & 0.26 & 0.30 & 0.23 & 0.22 & 0.21 & 0.19 & 0.27 & 0.21 & 0.22 & 0.26 & 0.21 & 0.23 & 0.03 & 0.06 \\
\hline Diversified Retailers & 0.29 & 0.24 & 0.27 & 0.37 & 0.19 & - & - & - & - & - & - & - & - & - & - \\
\hline Electricity & - & - & - & - & - & - & - & - & - & - & 0.65 & 0.70 & 0.70 & 0.14 & 0.11 \\
\hline Food and Beverages & 0.45 & 0.45 & 0.52 & 0.53 & 0.39 & 0.57 & 0.46 & 0.27 & 0.35 & 0.31 & 0.41 & 0.57 & 0.32 & - & - \\
\hline Informatic Systems & 1.02 & 1.02 & 0.91 & 0.59 & 0.50 & 0.50 & 0.15 & 0.25 & 0.25 & 0.25 & 0.25 & 0.25 & 0.25 & 0.25 & - \\
\hline Machines and Electrical Equipment & 0.53 & 0.61 & 1.05 & 0.73 & 0.96 & 1.06 & 1.15 & 0.40 & 0.42 & 0.36 & 0.30 & 0.35 & - & - & - \\
\hline Metallurgy & 0.61 & 0.52 & 0.47 & 0.29 & 0.50 & 0.45 & 0.45 & 0.28 & 0.24 & 1.15 & 0.47 & 0.75 & 1.00 & 1.00 & - \\
\hline Mineral non Metallic Industries & 0.56 & 0.43 & 0.43 & 0.47 & 0.36 & 0.37 & 0.28 & 0.33 & 0.38 & 0.54 & 0.45 & 0.42 & 0.38 & 0.68 & 0.70 \\
\hline Other Services Rendered to Firms & 0.55 & 0.57 & 0.53 & 0.50 & 0.49 & 0.47 & 0.73 & 0.45 & 0.48 & 0.49 & 0.40 & 0.40 & 0.36 & 0.07 & 0.07 \\
\hline Paper & 0.29 & 0.47 & 0.35 & 0.52 & 0.25 & - & - & 0.25 & 0.26 & 0.17 & 0.19 & 0.17 & 0.42 & 5.25 & 0.05 \\
\hline Real Estate & 0.87 & 1.00 & 0.40 & 0.37 & 0.25 & 0.25 & 0.25 & 0.25 & 0.25 & 0.15 & 0.15 & 0.15 & 0.15 & 0.15 & - \\
\hline Restaurants. Hotels and Leisure & 0.42 & 0.36 & 0.30 & 0.26 & 0.24 & 0.30 & 0.25 & 0.25 & 0.15 & 0.19 & 0.18 & 0.26 & 0.53 & 0.19 & 0.25 \\
\hline Textiles & 0.59 & 0.41 & 0.41 & 0.52 & 0.24 & - & - & - & - & - & - & - & - & - & - \\
\hline Tobacco & 1.00 & - & 1.00 & - & 1.00 & 1.10 & 0.50 & 0.40 & 0.50 & - & - & - & - & - & - \\
\hline Transport Activities & 0.31 & 0.51 & 0.86 & 0.62 & 0.42 & 0.35 & - & - & - & - & 0.52 & 0.76 & 0.26 & 0.32 & 0.24 \\
\hline Whl & 0.39 & 0.33 & 0.30 & 0.46 & 0.25 & - & - & - & - & - & - & 0.40 & 0.40 & - & - \\
\hline \multicolumn{16}{|c|}{ Panel B: Percentage of Dividend Payers by Industry Breakdown } \\
\hline Industry & 1988 & 1989 & 1990 & 1991 & 1992 & 1993 & 1994 & 1995 & 1996 & 1997 & 1998 & 1999 & 2000 & 2001 & 2002 \\
\hline griculture & 80.0 & 80.0 & 60.0 & 50.0 & 100.0 & - & - & - & - & - & - & - & - & - & - \\
\hline Automobile & 33.3 & 33.3 & 33.3 & 50.0 & 50.0 & 100.0 & 100.0 & 100.0 & 100.0 & 100.0 & 50.0 & 50.0 & 50.0 & 50.0 & 100.0 \\
\hline Chemicals & 66.7 & 100.0 & 85.7 & 62.5 & 83.3 & 100.0 & 100.0 & 100.0 & 66.7 & 100.0 & 100.0 & 100.0 & 66.7 & 66.7 & 66.7 \\
\hline Communications & 100.0 & 100.0 & 100.0 & 100.0 & 100.0 & 100.0 & 100.0 & 0.0 & 50.0 & 50.0 & 50.0 & 33.3 & 33.3 & 0.0 & 33.3 \\
\hline Construction & 93.3 & 90.0 & 91.8 & 90.9 & 88.9 & 100.0 & 71.4 & 33.3 & 60.0 & 60.0 & 71.4 & 57.1 & 50.0 & 60.0 & 60.0 \\
\hline Diversified Retailers & 40.0 & 66.7 & 50.0 & 60.0 & 100.0 & - & - & - & - & - & - & - & - & - & - \\
\hline Electricity & - & - & - & - & - & - & - & - & - & 0.0 & 100.0 & 100.0 & 100.0 & 100.0 & 100.0 \\
\hline Food and Beverages & 61.1 & 73.3 & 76.9 & 76.9 & 60.0 & 50.0 & 75.0 & 75.0 & 50.0 & 66.7 & 66.7 & 100.0 & 50.0 & 0.0 & 0.0 \\
\hline Informatic Systems & 40.0 & 80.0 & 60.0 & 66.7 & 33.3 & 100.0 & 100.0 & 100.0 & 100.0 & 100.0 & 100.0 & 100.0 & 100.0 & 100.0 & 0.0 \\
\hline Machines and Electrical Equipment & 80.0 & 60.0 & 66.7 & 100.0 & 100.0 & 100.0 & 100.0 & 50.0 & 50.0 & 100.0 & 100.0 & 50.0 & 0.0 & 0.0 & 0.0 \\
\hline Metallurgy & 80.0 & 80.0 & 50.0 & 42.9 & 33.3 & 33.3 & 33.3 & 50.0 & 100.0 & 100.0 & 100.0 & 100.0 & 100.0 & 100.0 & - \\
\hline Mineral non Metallic Industries & 77.8 & 71.4 & 71.4 & 71.4 & 100.0 & 60.0 & 50.0 & 66.7 & 83.3 & 66.7 & 80.0 & 80.0 & 80.0 & 33.3 & 33.3 \\
\hline Other Services Rendered to Firms & 53.8 & 81.8 & 81.8 & 72.7 & 88.9 & 88.9 & 66.7 & 66.7 & 77.8 & 54.5 & 54.5 & 77.8 & 70.0 & 50.0 & 20.0 \\
\hline Paper & 100.0 & 66.7 & 50.0 & 50.0 & 50.0 & 0.0 & 0.0 & 33.3 & 66.7 & 66.7 & 66.7 & 66.7 & 66.7 & 100.0 & 100.0 \\
\hline Real Estate & 100.0 & 100.0 & 50.0 & 66.7 & 50.0 & 50.0 & 50.0 & 50.0 & 50.0 & 50.0 & 50.0 & 100.0 & 100.0 & 100.0 & - \\
\hline Restaurants. Hotels and Leisure & 83.3 & 71.4 & 53.8 & 42.9 & 57.1 & 42.9 & 16.7 & 20.0 & 25.0 & 60.0 & 60.0 & 80.0 & 100.0 & 100.0 & 100.0 \\
\hline Textiles & 80.0 & 70.0 & 80.0 & 55.6 & 33.3 & 0.0 & 0.0 & - & - & - & - & - & - & - & - \\
\hline Tobacco & 100.0 & 0.0 & 100.0 & 0.0 & 100.0 & 100.0 & 100.0 & 100.0 & 100.0 & 0.0 & - & - & - & - & - \\
\hline Transport Activities & 45.5 & 50.0 & 40.0 & 40.0 & 50.0 & 20.0 & 0.0 & 0.0 & 0.0 & 0.0 & 50.0 & 50.0 & 50.0 & 66.7 & 66.7 \\
\hline Wholesale Trade & 60.0 & 80.0 & 40.0 & 33.3 & 50.0 & 0.0 & 0.0 & 0.0 & 0.0 & 0.0 & 0.0 & 50.0 & 50.0 & 0.0 & 0.0 \\
\hline
\end{tabular}


Table 3.3 - Dividend statistics by industry breakdown (continued)

\begin{tabular}{|c|c|c|c|c|c|c|c|c|c|c|c|}
\hline \multicolumn{12}{|c|}{ France } \\
\hline \multicolumn{12}{|c|}{ Panel A: Average DPS During 1992-2002 - Industry Breakdown, $€$} \\
\hline Industry & 1992 & 1993 & 1994 & 1995 & 1996 & 1997 & 1998 & 1999 & 2000 & 2001 & 2002 \\
\hline Aerospace, Airlines and Airports & 0.24 & 1.05 & 0.36 & 0.36 & 0.46 & 0.53 & 1.64 & 1.83 & 2.68 & 3.29 & 2.08 \\
\hline Agriculture & 0.76 & 0.76 & 0.76 & 0.76 & 2.77 & 1.83 & 1.45 & 1.60 & 2.44 & 3.05 & 1.64 \\
\hline Automobile & 0.41 & 0.45 & 0.46 & 0.41 & 0.57 & 0.58 & 0.61 & 0.73 & 0.86 & 1.28 & 1.02 \\
\hline Chemicals & 2.40 & 2.42 & 2.63 & 2.30 & 2.12 & 2.07 & 2.33 & 2.02 & 2.18 & 2.23 & 2.70 \\
\hline Communications & 0.33 & 0.37 & 0.39 & 0.39 & 0.35 & 0.41 & 0.62 & 0.66 & 0.79 & 1.14 & 0.52 \\
\hline Construction & 2.13 & 2.32 & 2.08 & 2.03 & 1.88 & 2.00 & 1.96 & 1.97 & 2.45 & 2.43 & 2.20 \\
\hline Diversified Industry & 0.99 & 0.76 & 0.76 & 0.76 & 0.76 & 1.52 & 1.83 & 2.00 & 2.50 & 1.62 & 1.93 \\
\hline Diversified Retailers & 0.52 & 0.62 & 0.70 & 0.74 & 0.78 & 0.80 & 1.03 & 1.11 & 1.19 & 1.11 & 1.30 \\
\hline Diversified Services & 1.04 & 1.28 & 1.07 & 1.52 & 0.79 & 0.92 & 1.26 & 1.37 & 1.53 & 5.50 & 3.50 \\
\hline Food and Beverages & 1.63 & 1.75 & 1.71 & 1.80 & 1.33 & 3.06 & 2.86 & 3.23 & 3.11 & 3.32 & 4.38 \\
\hline Informatic Systems & 0.60 & 0.41 & 0.47 & 0.63 & 0.54 & 0.66 & 0.62 & 0.47 & 0.62 & 0.52 & 0.61 \\
\hline Machines and Electrical Equipment & 0.38 & 0.38 & 0.26 & 0.31 & 0.50 & 0.56 & 0.84 & 0.80 & 0.71 & 0.66 & 0.58 \\
\hline Media and Publicity & 0.10 & 0.15 & 0.16 & 0.71 & 0.65 & 0.64 & 0.69 & 0.81 & 0.85 & 0.92 & 1.04 \\
\hline Metallurgy & 0.69 & 0.69 & 0.69 & 1.14 & 1.19 & 1.19 & 0.90 & 0.86 & 0.86 & 0.86 & 1.49 \\
\hline Mineral non Metallic Products & 0.95 & 0.97 & 0.97 & 1.00 & 0.92 & 1.16 & 1.05 & 1.07 & 1.25 & 1.65 & 1.36 \\
\hline Other Services Rendered to Firms & 1.17 & 0.98 & 0.72 & 0.74 & 1.16 & 1.12 & 1.04 & 0.90 & 0.98 & 1.18 & 1.41 \\
\hline Paper & 0.27 & 0.27 & 0.27 & 0.27 & 1.66 & 2.16 & 1.60 & 1.62 & 1.26 & 1.85 & 1.74 \\
\hline Real Estate & 3.44 & 5.49 & 5.48 & 2.65 & 2.70 & 2.64 & 2.31 & 2.87 & 2.33 & 1.99 & 2.72 \\
\hline Restaurants. Hotels and Leisure & 1.10 & 1.42 & 1.62 & 1.30 & 0.69 & 0.59 & 0.76 & 0.89 & 1.12 & 1.29 & 1.33 \\
\hline Textiles & 0.77 & 0.70 & 0.76 & 0.81 & 0.72 & 1.31 & 1.32 & 1.43 & 1.44 & 1.47 & 1.59 \\
\hline Tobacco & - & - & - & - & - & - & - & - & 0.48 & 0.55 & 0.55 \\
\hline Transport Activities & 0.88 & 1.09 & 1.09 & 1.09 & 1.14 & 1.54 & 0.96 & 1.13 & 1.17 & 1.40 & 2.05 \\
\hline Wholesale Trade & 0.44 & 0.48 & 0.47 & 0.49 & 0.57 & 0.62 & 0.71 & 0.78 & 0.85 & 0.93 & 0.91 \\
\hline \multicolumn{12}{|c|}{ Panel B: Percentage of Dividend Payers by Industry Breakdown } \\
\hline Industry & 1992 & 1993 & 1994 & 1995 & 1996 & 1997 & 1998 & 1999 & 2000 & 2001 & 2002 \\
\hline Aerospace, Airlines and Airports & 50.0 & 60.0 & 50.0 & 50.0 & 50.0 & 50.0 & 50.0 & 33.3 & 50.0 & 66.7 & 100.0 \\
\hline Agriculture & 14.3 & 14.3 & 16.7 & 20.0 & 16.7 & 50.0 & 50.0 & 50.0 & 33.3 & 25.0 & 66.7 \\
\hline Automobile & 66.7 & 83.3 & 69.2 & 83.3 & 90.9 & 90.9 & 81.8 & 81.8 & 91.7 & 91.7 & 83.3 \\
\hline Chemicals & 50.0 & 52.9 & 42.1 & 55.6 & 58.8 & 58.8 & 70.6 & 87.5 & 75.0 & 85.7 & 85.7 \\
\hline Communications & 50.0 & 33.3 & 40.0 & 40.0 & 40.0 & 50.0 & 60.0 & 60.0 & 50.0 & 50.0 & 37.5 \\
\hline Construction & 59.1 & 56.5 & 63.6 & 71.4 & 78.9 & 78.9 & 75.0 & 93.8 & 72.2 & 77.8 & 93.8 \\
\hline Diversified Industry & 5.0 & 5.9 & 5.9 & 6.7 & 8.3 & 8.3 & 11.1 & 14.3 & 20.0 & 40.0 & 50.0 \\
\hline Diversified Retailers & 15.4 & 19.0 & 23.5 & 25.0 & 27.8 & 31.3 & 33.3 & 45.5 & 55.6 & 85.7 & 85.7 \\
\hline Diversified Services & 1.7 & 4.0 & 4.5 & 2.6 & 6.1 & 6.9 & 7.7 & 9.1 & 11.1 & 20.0 & 33.3 \\
\hline Food and Beverages & 38.5 & 41.7 & 45.7 & 46.2 & 48.6 & 54.5 & 53.3 & 53.3 & 54.8 & 57.1 & 56.5 \\
\hline Informatic Systems & 18.2 & 22.2 & 30.0 & 30.0 & 36.4 & 41.7 & 54.5 & 60.0 & 56.3 & 50.0 & 52.9 \\
\hline Machines and Electrical Equipment & 13.6 & 17.6 & 16.7 & 16.7 & 18.8 & 18.8 & 21.4 & 25.0 & 33.3 & 45.5 & 63.6 \\
\hline Media and Publicity & 23.1 & 30.8 & 33.3 & 35.7 & 50.0 & 66.7 & 60.0 & 66.7 & 54.5 & 62.5 & 62.5 \\
\hline Metallurgy & 8.3 & 9.1 & 8.3 & 13.3 & 20.0 & 25.0 & 28.6 & 28.6 & 33.3 & 50.0 & 50.0 \\
\hline Mineral non Metallic Products & 35.3 & 37.5 & 37.5 & 42.9 & 42.9 & 54.5 & 66.7 & 75.0 & 75.0 & 75.0 & 50.0 \\
\hline Other Services Rendered to Firms & 37.5 & 50.0 & 40.0 & 44.4 & 55.6 & 62.5 & 83.3 & 85.7 & 75.0 & 54.5 & 54.5 \\
\hline Paper & 12.5 & 12.5 & 14.3 & 16.7 & 40.0 & 50.0 & 66.7 & 66.7 & 66.7 & 100.0 & 100.0 \\
\hline Real Estate & 34.5 & 36.5 & 39.6 & 42.2 & 48.7 & 47.5 & 58.8 & 63.6 & 64.5 & 75.0 & 75.0 \\
\hline Restaurants. Hotels and Leisure & 36.4 & 55.0 & 42.9 & 52.4 & 55.0 & 52.6 & 57.1 & 61.9 & 57.1 & 70.0 & 78.9 \\
\hline Textiles & 40.0 & 45.5 & 41.7 & 50.0 & 50.0 & 66.7 & 66.7 & 66.7 & 50.0 & 50.0 & 71.4 \\
\hline Tobacco & - & - & - & 0.0 & 0.0 & 0.0 & 0.0 & 0.0 & 50.0 & 50.0 & 50.0 \\
\hline Transport Activities & 11.8 & 12.5 & 13.3 & 13.3 & 14.3 & 23.1 & 41.7 & 55.6 & 50.0 & 71.4 & 71.4 \\
\hline Wholesale Trade & 37.5 & 42.9 & 42.9 & 42.9 & 42.9 & 42.9 & 42.9 & 50.0 & 50.0 & 50.0 & 62.5 \\
\hline
\end{tabular}

(Continue) 
Table 3.3 - Dividend statistics by industry breakdown (continued)

\begin{tabular}{|c|c|c|c|c|c|c|c|c|c|}
\hline \multicolumn{10}{|c|}{ UK } \\
\hline \multicolumn{10}{|c|}{ Panel A: Average DPS During 1994-2002 - Industry Breakdown, £ } \\
\hline Industry & 1994 & 1995 & 1996 & 1997 & 1998 & 1999 & 2000 & 2001 & 2002 \\
\hline Aerospace, Airlines and Airports & 5.82 & 5.91 & 5.96 & 6.82 & 7.61 & 8.43 & 9.15 & 10.17 & 10.19 \\
\hline Agriculture & 7.41 & 7.75 & 8.46 & 9.94 & 10.96 & 11.67 & 11.78 & 15.81 & 19.00 \\
\hline Automobile & 9.95 & 9.66 & 10.50 & 8.99 & 8.93 & 9.46 & 9.88 & 10.90 & 10.07 \\
\hline Chemicals & 9.31 & 9.83 & 9.18 & 10.02 & 10.09 & 9.93 & 10.97 & 12.03 & 12.60 \\
\hline Communications & 4.12 & 3.26 & 3.95 & 4.18 & 3.91 & 4.16 & 4.29 & 4.28 & 3.35 \\
\hline Construction & 5.32 & 5.68 & 6.04 & 6.63 & 6.87 & 7.22 & 7.85 & 8.15 & 8.69 \\
\hline Diversified Industry & 5.00 & 4.93 & 5.72 & 6.48 & 7.08 & 6.37 & 7.00 & 9.33 & 9.00 \\
\hline Diversified Retailers & 6.43 & 6.53 & 8.38 & 12.15 & 12.98 & 12.48 & 12.46 & 10.70 & 11.29 \\
\hline Diversified Services & 6.22 & 6.47 & 7.43 & 7.95 & 8.27 & 8.59 & 9.17 & 8.98 & 9.10 \\
\hline Electricity & 16.51 & 17.66 & 18.84 & 21.68 & 23.82 & 25.31 & 30.50 & 31.32 & 35.73 \\
\hline Food and Beverages & 8.12 & 8.46 & 8.97 & 9.10 & 9.61 & 10.69 & 11.87 & & 13.02 \\
\hline Informatic Systems & 3.30 & 3.08 & 3.07 & 3.29 & 3.46 & 5.43 & 5.63 & 5.93 & 5.95 \\
\hline Machines and Electrical Equipment & 4.17 & 4.04 & 4.36 & 4.73 & 4.95 & 5.34 & 6.17 & & 7.10 \\
\hline Media and Publi & 6.47 & 7.07 & 7.33 & 7.26 & 7.31 & 7.11 & 7.35 & 7.13 & 7.18 \\
\hline Metallurgy & - & - & - & - & - & 5.44 & 7.73 & 5.56 & 9.12 \\
\hline Mineral non Metallic Products & 4.88 & 5.58 & 5.56 & 5.94 & 6.72 & 8.32 & 53 & 9.44 & 10.64 \\
\hline Other Services F & 6.16 & 6.22 & 6.26 & 6.48 & 6.46 & 6.74 & 7.32 & 8.08 & 8.17 \\
\hline Paper & 3.94 & 4.61 & 5.04 & & 6.18 & & & & \\
\hline Real Estate & 6.48 & 6.5 & 6.83 & 7.24 & 7.67 & 8.71 & 10.09 & 10.51 & 11.99 \\
\hline Restaurants. Hotels and Leisure & 4.67 & 4.71 & 5.32 & 5.64 & 5.75 & 6.40 & 6.55 & & 7.45 \\
\hline Textiles & 6.37 & 5.28 & 7.46 & & 7.5 & & & & 8.49 \\
\hline Tobacco & 11.23 & 12.11 & 13.25 & 15.58 & 17.44 & 16.91 & 22.73 & & 27.58 \\
\hline & 7.01 & 7.26 & 7.44 & 7.78 & 8.76 & 7.84 & 9.33 & & 12.25 \\
\hline Wholesale Trade & 5.99 & 6.81 & 8.22 & 8.06 & 9.38 & 10.64 & 9.93 & & \\
\hline \multicolumn{10}{|c|}{ Panel B: Percentage of Dividend Payers by Industry Breakdown } \\
\hline Industry & 1994 & 1995 & 1996 & 1997 & 1998 & 1999 & 2000 & 2001 & 2002 \\
\hline Aerospace, Airlines and & 66.7 & 68.8 & 75.0 & 80.0 & 70.6 & 70.6 & 70.6 & & 64.7 \\
\hline Agriculture & 57.1 & 57. & 53.3 & & 43.8 & 35 & .5 & & 35.3 \\
\hline Automobile & 55.6 & 42.3 & 40.7 & 44.4 & 41.4 & 50.0 & 54.5 & 52.4 & 52.4 \\
\hline Chemicals & 30.5 & 32.4 & 35.1 & 33.8 & 33.7 & 35.8 & 35.4 & & 37.0 \\
\hline Communica & 54.5 & 66.7 & 61.5 & 61 & 57.1 & 40.0 & 33.3 & & 29.6 \\
\hline Construction & 56.8 & 57.0 & 58.0 & 57.8 & 60.2 & 65.8 & 69.7 & 79.7 & 79.7 \\
\hline Diversif & 22.2 & 37.5 & 42.9 & 50.0 & 33.3 & 44.4 & 50.0 & 50.0 & 50.0 \\
\hline Divers & 39.1 & 41.7 & 41.7 & 36.4 & 36.2 & 46.3 & 50.0 & 49 & 50.0 \\
\hline Diversified Services & 58.5 & 57.1 & 52.6 & 56.8 & 56.5 & 58.1 & 52.7 & 51.6 & 51.0 \\
\hline Electricity & 33.3 & 44.4 & 44.4 & 50.0 & 62.5 & 55.6 & 55.6 & 55.6 & 62.5 \\
\hline Food a & 49.2 & 49.2 & 50.0 & 55.7 & 52.2 & 53.7 & 55.6 & 60.0 & 58.3 \\
\hline Informatic Systems & 39.3 & 41.5 & 37.3 & 32.1 & 33.9 & 33.8 & 25.0 & 24.8 & 28.7 \\
\hline Machines and Electrical Equipment & 46.3 & 48.3 & 49.2 & 53.1 & 59.0 & 67.3 & 63.6 & 64.2 & 65.4 \\
\hline Media and Publicity & 44.4 & 38.1 & 39.6 & 41.2 & 42.9 & 50.9 & 52.7 & 57.4 & 56.6 \\
\hline Metallurgy & 0.0 & 0.0 & 0.0 & 0.0 & 0.0 & 28.6 & 33.3 & 40.0 & 25.0 \\
\hline Mineral non Metallic Products & 31.8 & 29.2 & 30.4 & 33.3 & 33.3 & 36.8 & 41.7 & 60.0 & 60.0 \\
\hline Other Services Rendered to Firms & 64.7 & & & & & & 73.5 & & 67.6 \\
\hline Paper & 33.3 & 33.3 & 33.3 & 33.3 & 33.3 & 50.0 & 100.0 & 100.0 & 100.0 \\
\hline Real Estate & 49.0 & 48.3 & 46.0 & 45.5 & 45.8 & 49.3 & 50.7 & 54.1 & 60.3 \\
\hline Restaurants. Hotels and Leisure & 44.4 & 48.8 & & & & 54.5 & 54.5 & & 51.9 \\
\hline Textiles & 29.6 & 33.3 & 38.5 & 40.0 & 43.5 & 47.6 & 42.1 & 41.2 & 41.2 \\
\hline Tobacco & 100.0 & 100.0 & 50.0 & 66.7 & 100.0 & 100.0 & 100.0 & 100.0 & 100.0 \\
\hline Transport Activities & 42.9 & 42.3 & 46.4 & & 48.6 & 59.4 & 65.5 & 65.5 & 67.9 \\
\hline Wholesale Trade & 71.4 & 75.9 & 70.0 & 78.1 & 75.8 & 70.6 & 78.8 & 73.5 & 80.0 \\
\hline
\end{tabular}




\section{Table 3.4 - Sample Selection}

This table reports the number of dividend events for the Portuguese, the French and the UK samples, classified by sample selection criteria (Panel A) as well as the frequency of dividend changes by year (Panel B). To be included in the final sample, a dividend announcement must satisfy the following criteria: 1) The firm is not a financial institution; 2) The firm is listed on the respective stock exchange the year before and two years after the dividend events; 3) The firm's financial data is available on the Datastream or Dhatis (in the Portuguese sample) database at the year before and two years after the dividend events; 4) The firm paid an annual ordinary dividend in the current and previous year; 5) For the Portuguese and French samples, the dividend, earnings or other potentially contaminating announcements did not occur within 5 trading days of each other. For the UK firms we consider the same condition, except for earnings announcements. As they are simultaneous in almost the cases, we exclude dividend announcements which earnings announcements are announced on separate dates.

\begin{tabular}{|c|c|c|c|c|}
\hline \multicolumn{5}{|l|}{ Portuguese Sample } \\
\hline Panel A: Sample & $\begin{array}{l}\text { Dividend } \\
\text { Increases }\end{array}$ & $\begin{array}{l}\text { No } \\
\text { Change }\end{array}$ & $\begin{array}{l}\text { Dividend } \\
\text { Decreases }\end{array}$ & Total \\
\hline Total number of dividend events & 210 & 139 & 180 & 529 \\
\hline Dividend events with other dividend types declaration events & 4 & 5 & 8 & 17 \\
\hline $\begin{array}{l}\text { Dividend events with firms not listed in the stock exchange the } \\
\text { year before and two years after the events }\end{array}$ & 40 & 24 & 44 & 108 \\
\hline $\begin{array}{l}\text { Dividend events which earnings or other potentially } \\
\text { contaminating announcements occurs within } 5 \text { days of the }\end{array}$ & & & & \\
\hline dividend change announcement & 4 & 3 & 6 & 13 \\
\hline Dividend events with missing data & 4 & 6 & 1 & 11 \\
\hline Total excluded dividend events & 52 & 38 & 59 & 149 \\
\hline Total number of dividend events for analysis & 158 & 101 & 121 & 380 \\
\hline Events Percentage $(\%)$ & 41.58 & 26.58 & 31.84 & 100.00 \\
\hline
\end{tabular}

Panel B: Frequency of dividend changes by year

\begin{tabular}{ccccccccc}
\hline & \multicolumn{2}{c}{ Dividend Increases } & \multicolumn{2}{c}{ No Change } & \multicolumn{2}{c}{ Dividend Decreases } & \multicolumn{2}{c}{ Total for Year } \\
\cline { 2 - 8 } & Number & $\begin{array}{c}\text { Percent. } \\
(\%)\end{array}$ & Number & $\begin{array}{c}\text { Percent. } \\
(\%)\end{array}$ & Number & $\begin{array}{c}\text { Percent. } \\
(\%)\end{array}$ & $\begin{array}{c}\text { Percent. } \\
(\%)\end{array}$ \\
\hline 1989 & 26 & 16.46 & 16 & 15.84 & 16 & 13.22 & 58 & 15.26 \\
1990 & 21 & 13.29 & 5 & 4.95 & 14 & 11.57 & 40 & 10.53 \\
1991 & 13 & 8.23 & 14 & 13.86 & 11 & 9.09 & 38 & 10.00 \\
1992 & 12 & 7.59 & 9 & 8.91 & 15 & 12.40 & 36 & 9.47 \\
1993 & 9 & 5.70 & 13 & 12.87 & 6 & 4.96 & 28 & 7.37 \\
1994 & 5 & 3.16 & 6 & 5.94 & 11 & 9.09 & 22 & 5.79 \\
1995 & 5 & 3.16 & 6 & 5.94 & 6 & 4.96 & 17 & 4.47 \\
1996 & 6 & 3.80 & 6 & 5.94 & 4 & 3.31 & 16 & 4.21 \\
1997 & 11 & 6.96 & 4 & 3.96 & 5 & 4.13 & 20 & 5.26 \\
1998 & 14 & 8.86 & 3 & 2.97 & 6 & 4.96 & 23 & 6.05 \\
1999 & 16 & 10.13 & 5 & 4.95 & 4 & 3.31 & 25 & 6.58 \\
2000 & 9 & 5.70 & 7 & 6.93 & 8 & 6.61 & 24 & 6.32 \\
2001 & 5 & 3.16 & 2 & 1.98 & 10 & 8.26 & 17 & 4.47 \\
2002 & 6 & 3.80 & 5 & 4.95 & 5 & 4.13 & 16 & 4.21 \\
\hline Total & $\mathbf{1 5 8}$ & $\mathbf{1 0 0 . 0 0}$ & $\mathbf{1 0 1}$ & $\mathbf{1 0 0 . 0 0}$ & $\mathbf{1 2 1}$ & $\mathbf{1 0 0 . 0 0}$ & $\mathbf{3 8 0}$ & $\mathbf{1 0 0 . 0 0}$ \\
\hline
\end{tabular}


Table 3.4 - Sample Selection (continued)

\begin{tabular}{|c|c|c|c|c|}
\hline \multicolumn{5}{|l|}{ French Sample } \\
\hline Panel A: Sample & $\begin{array}{l}\text { Dividend } \\
\text { Increases }\end{array}$ & $\begin{array}{c}\text { No } \\
\text { Change }\end{array}$ & $\begin{array}{l}\text { Dividend } \\
\text { Decreases }\end{array}$ & Total \\
\hline Total number of dividend events & 539 & 317 & 200 & 1,056 \\
\hline Missing announcement dates on Bloomberg & 240 & 243 & 116 & 599 \\
\hline Dividend events with other dividend types declaration events & 2 & 1 & 0 & 3 \\
\hline $\begin{array}{l}\text { Dividend events with firms not listed in the stock exchange the } \\
\text { year before and two years after the events }\end{array}$ & 12 & 5 & 5 & 22 \\
\hline $\begin{array}{l}\text { Dividend events which earnings or other potentially } \\
\text { contaminating announcements occurs within } 5 \text { days of the }\end{array}$ & & & & \\
\hline dividend change announcement & 50 & 9 & 17 & 76 \\
\hline Dividend events with missing data & - & - & - & - \\
\hline Total excluded dividend events & 304 & 258 & 138 & 700 \\
\hline Total number of dividend events for analysis & 235 & 59 & 62 & 356 \\
\hline Events Percentage (\%) & 66.01 & 16.57 & 17.42 & 100.00 \\
\hline
\end{tabular}

Panel B: Frequency of dividend changes by year

\begin{tabular}{ccccccccc}
\hline & \multicolumn{2}{c}{ Dividend Increases } & \multicolumn{2}{c}{ No Change } & \multicolumn{2}{c}{ Dividend Decreases } & \multicolumn{2}{c}{ Total for Year } \\
\cline { 2 - 8 } & Number & $\begin{array}{c}\text { Percent. } \\
(\%)\end{array}$ & Number & $\begin{array}{c}\text { Percent. } \\
(\%)\end{array}$ & Number & $\begin{array}{c}\text { Percent. } \\
(\%)\end{array}$ & $\begin{array}{c}\text { Percent. } \\
(\%)\end{array}$ \\
\hline 1995 & 3 & 1.28 & 2 & 3.39 & 0 & 0.00 & 5 & 1.40 \\
1996 & 24 & 10.21 & 1 & 1.69 & 4 & 6.45 & 29 & 8.15 \\
1997 & 30 & 12.77 & 3 & 5.08 & 7 & 11.29 & 40 & 11.24 \\
1998 & 35 & 14.89 & 4 & 6.78 & 5 & 8.07 & 44 & 12.36 \\
1999 & 29 & 12.34 & 9 & 15.25 & 8 & 12.90 & 46 & 12.92 \\
2000 & 54 & 22.98 & 8 & 13.56 & 10 & 16.13 & 72 & 20.22 \\
2001 & 27 & 11.49 & 28 & 47.46 & 20 & 32.26 & 75 & 21.07 \\
2002 & 33 & 14.04 & 4 & 6.79 & 8 & 12.90 & 45 & 12.64 \\
\hline Total & $\mathbf{2 3 5}$ & $\mathbf{1 0 0 . 0 0}$ & $\mathbf{5 9}$ & $\mathbf{1 0 0 . 0 0}$ & $\mathbf{6 2}$ & $\mathbf{1 0 0 . 0 0}$ & $\mathbf{3 5 6}$ & $\mathbf{1 0 0 . 0 0}$ \\
\hline
\end{tabular}


Table 3.4 - Sample Selection (continued)

\begin{tabular}{|c|c|c|c|c|}
\hline \multicolumn{5}{|l|}{ UK Sample } \\
\hline Panel A: Sample & $\begin{array}{l}\text { Dividend } \\
\text { Increases }\end{array}$ & $\begin{array}{l}\text { No } \\
\text { Change }\end{array}$ & $\begin{array}{c}\text { Dividend } \\
\text { Decreases }\end{array}$ & Total \\
\hline Total number of dividend events & 2,838 & 380 & 341 & 3,559 \\
\hline Missing announcement dates on Bloomberg & 124 & 26 & 62 & 212 \\
\hline Dividend events with other dividend types declaration events & 20 & 2 & 4 & 26 \\
\hline $\begin{array}{l}\text { Dividend events with firms not listed in the stock exchange the } \\
\text { year before and two years after the events }\end{array}$ & 1 & 1 & 1 & 3 \\
\hline $\begin{array}{l}\text { Dividend events which potentially contaminating announcements } \\
\text { (except earnings announcements) occurs within } 5 \text { days of the }\end{array}$ & & & & \\
\hline dividend change announcement & 24 & 4 & 1 & 29 \\
\hline $\begin{array}{l}\text { Dividend events which dividends and earnings information were } \\
\text { announced on separate dates }\end{array}$ & 4 & 2 & 0 & 6 \\
\hline Dividend events with missing data & 3 & 2 & 0 & 5 \\
\hline Total excluded dividend events & 176 & 37 & 68 & 281 \\
\hline Total number of dividend events for analysis & 2,662 & 343 & 273 & 3,278 \\
\hline Events Percentage $(\%)$ & 81.21 & 10.46 & 8.33 & 100.00 \\
\hline
\end{tabular}

Panel B: Frequency of dividend changes by year

\begin{tabular}{ccccccccc}
\hline & \multicolumn{2}{c}{ Dividend Increases } & \multicolumn{2}{c}{ No Change } & \multicolumn{2}{c}{ Dividend Decreases } & \multicolumn{2}{c}{ Total for Year } \\
\cline { 2 - 8 } & Number & $\begin{array}{c}\text { Percent. } \\
(\%)\end{array}$ & Number & $\begin{array}{c}\text { Percent. } \\
(\%)\end{array}$ & Number & $\begin{array}{c}\text { Percent. } \\
(\%)\end{array}$ & $\begin{array}{c}\text { Percent. } \\
(\%)\end{array}$ \\
\hline 1995 & 273 & 10.26 & 36 & 10.50 & 18 & 6.59 & 327 & 9.98 \\
1996 & 310 & 11.65 & 35 & 10.20 & 18 & 6.59 & 363 & 11.07 \\
1997 & 329 & 12.36 & 40 & 11.66 & 22 & 8.06 & 391 & 11.93 \\
1998 & 339 & 12.73 & 39 & 11.37 & 40 & 14.65 & 418 & 12.75 \\
1999 & 358 & 13.45 & 28 & 8.16 & 51 & 18.68 & 437 & 13.33 \\
2000 & 366 & 13.75 & 49 & 14.29 & 35 & 12.82 & 450 & 13.73 \\
2001 & 360 & 13.52 & 53 & 15.45 & 40 & 14.65 & 453 & 13.82 \\
2002 & 327 & 12.28 & 63 & 18.37 & 49 & 17.95 & 439 & 13.39 \\
\hline Total & $\mathbf{2 , 6 6 2}$ & $\mathbf{1 0 0 . 0 0}$ & $\mathbf{3 4 3}$ & $\mathbf{1 0 0 . 0 0}$ & $\mathbf{2 7 3}$ & $\mathbf{1 0 0 . 0 0}$ & $\mathbf{3 , 2 7 8}$ & $\mathbf{1 0 0 . 0 0}$ \\
\hline
\end{tabular}




\section{Table 3.5 - Summary Statistics}

This table reports some descriptive statistics for dividend event observations during the sample period. DPS is the dividend per share. Dividend changes are the changes in DPS relative to the previous year, calculated both in monetary units and in percentage. Payout ratio is the DPS divided by the earnings before extraordinary items per share. Dividend yield is the DPS divided by the share price on the day before the dividend announcement. Debt ratio is the total debt divided by the total assets. Return on equity is the earnings before extraordinary items divided by the equity. Current ratio is the current asset divided by the current debt. All the accounting variables are considered at the end of the fiscal year before the dividend announcement.

\begin{tabular}{|c|c|c|c|c|c|c|c|c|}
\hline \multicolumn{9}{|c|}{ Summary Statistics } \\
\hline \multicolumn{9}{|c|}{ Portugal: 1989-2002 } \\
\hline & DPS, $€$ & $\begin{array}{c}\text { Dividend } \\
\text { Changes, } \\
€ \\
\end{array}$ & $\begin{array}{c}\text { Dividend } \\
\text { Changes, } \\
(\%) \\
\end{array}$ & $\begin{array}{c}\text { Payout } \\
\text { Ratio }\end{array}$ & $\begin{array}{c}\text { Dividend } \\
\text { Yield }\end{array}$ & $\begin{array}{l}\text { Debt } \\
\text { Ratio }\end{array}$ & $\begin{array}{c}\text { Return } \\
\text { on } \\
\text { Equity } \\
\end{array}$ & $\begin{array}{c}\text { Current } \\
\text { Ratio }\end{array}$ \\
\hline & \multicolumn{8}{|c|}{ All dividend events $(\mathrm{N}=380)$} \\
\hline Mean & 0.458 & -0.031 & 2.055 & 0.641 & 0.132 & 0.389 & 0.089 & 1.989 \\
\hline Median & 0.349 & 0.000 & 0.000 & 0.440 & 0.059 & 0.368 & 0.074 & 1.335 \\
\hline \multirow[t]{2}{*}{ Stand. Dev. } & 0.624 & 0.771 & 46.153 & 1.251 & 0.288 & 0.213 & 0.086 & 3.055 \\
\hline & \multicolumn{8}{|c|}{ Dividend increases $(\mathrm{N}=158)$} \\
\hline Mean & 0.631 & 0.193 & 37.573 & 0.458 & 0.145 & 0.367 & 0.109 & 2.261 \\
\hline Median & 0.449 & 0.100 & 20.000 & 0.318 & 0.073 & 0.343 & 0.091 & 1.410 \\
\hline \multirow[t]{2}{*}{ Stand. Dev. } & 0.902 & 0.776 & 42.093 & 0.698 & 0.346 & 0.205 & 0.086 & 4.075 \\
\hline & \multicolumn{8}{|c|}{ No changes $(\mathrm{N}=101)$} \\
\hline Mean & 0.350 & 0.000 & 0.000 & 0.539 & 0.136 & 0.432 & 0.078 & 1.920 \\
\hline Median & 0.324 & 0.000 & 0.000 & 0.414 & 0.050 & 0.426 & 0.057 & 1.328 \\
\hline \multirow[t]{2}{*}{ Stand. Dev. } & 0.208 & 0.000 & 0.000 & 0.693 & 0.238 & 0.216 & 0.079 & 2.338 \\
\hline & \multicolumn{8}{|c|}{ Dividend decreases $(\mathrm{N}=121)$} \\
\hline Mean & 0.322 & -0.350 & -42.197 & 0.965 & 0.111 & 0.382 & 0.071 & 1.691 \\
\hline Median & 0.249 & -0.175 & -41.176 & 0.882 & 0.051 & 0.374 & 0.054 & 1.257 \\
\hline Stand. Dev. & 0.246 & 0.959 & 23.613 & 1.936 & 0.240 & 0.218 & 0.087 & 1.734 \\
\hline \multicolumn{9}{|c|}{ France: 1995-2002 } \\
\hline & DPS, $€$ & $\begin{array}{c}\text { Dividend } \\
\text { Changes, } \\
€ \\
\end{array}$ & $\begin{array}{c}\text { Dividend } \\
\text { Changes, } \\
(\%) \\
\end{array}$ & $\begin{array}{c}\text { Payout } \\
\text { Ratio }\end{array}$ & $\begin{array}{c}\text { Dividend } \\
\text { Yield }\end{array}$ & $\begin{array}{l}\text { Debt } \\
\text { Ratio }\end{array}$ & $\begin{array}{c}\text { Return } \\
\text { on } \\
\text { Equity } \\
\end{array}$ & $\begin{array}{c}\text { Current } \\
\text { Ratio }\end{array}$ \\
\hline & \multicolumn{8}{|c|}{ All dividend events $(\mathrm{N}=356)$} \\
\hline Mean & 1.243 & 0.102 & 13.046 & 0.296 & 0.020 & 0.247 & 0.051 & 1.365 \\
\hline Median & 0.860 & 0.055 & 9.222 & 0.180 & 0.018 & 0.248 & 0.045 & 1.177 \\
\hline \multirow[t]{2}{*}{ Stand. Dev. } & 1.267 & 0.498 & 32.848 & 2.672 & 0.016 & 0.136 & 0.040 & 0.541 \\
\hline & \multicolumn{8}{|c|}{ Dividend increases $(\mathrm{N}=235)$} \\
\hline Mean & 1.319 & 0.250 & 26.367 & 0.371 & 0.021 & 0.246 & 0.052 & 1.392 \\
\hline Median & 0.910 & 0.130 & 15.797 & 0.166 & 0.018 & 0.246 & 0.046 & 1.205 \\
\hline \multirow[t]{2}{*}{ Stand. Dev. } & 1.336 & 0.417 & 30.497 & 3.244 & 0.018 & 0.133 & 0.038 & 0.537 \\
\hline & \multicolumn{8}{|c|}{ No changes $(\mathrm{N}=59)$} \\
\hline Mean & 1.148 & 0.000 & 0.000 & 0.202 & 0.020 & 0.237 & 0.054 & 1.301 \\
\hline Median & 0.830 & 0.000 & 0.000 & 0.200 & 0.018 & 0.214 & 0.049 & 1.190 \\
\hline \multirow[t]{2}{*}{ Stand. Dev. } & 0.995 & 0.000 & 0.000 & 0.335 & 0.013 & 0.142 & 0.039 & 0.504 \\
\hline & \multicolumn{8}{|c|}{ Dividend decreases $(\mathrm{N}=62)$} \\
\hline Mean & 1.042 & -0.362 & -23.742 & 0.098 & 0.019 & 0.265 & 0.042 & 1.324 \\
\hline Median & 0.640 & -0.150 & -18.7686 & 0.224 & 0.016 & 0.276 & 0.037 & 1.097 \\
\hline Stand. Dev. & 1.218 & 0.680 & 22.163 & 1.007 & 0.012 & 0.140 & 0.046 & 0.589 \\
\hline
\end{tabular}


Table 3.5 - Summary Statistics (continued)

\begin{tabular}{|c|c|c|c|c|c|c|c|c|}
\hline \multicolumn{9}{|c|}{ Summary Statistics } \\
\hline \multicolumn{9}{|c|}{ UK: 1995-2002 } \\
\hline & 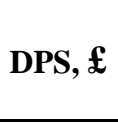 & $\begin{array}{c}\text { Dividend } \\
\text { Changes, } \\
\mathrm{E} \\
\end{array}$ & $\begin{array}{c}\text { Dividend } \\
\text { Changes, } \\
(\%)\end{array}$ & $\begin{array}{c}\text { Payout } \\
\text { Ratio }\end{array}$ & $\begin{array}{c}\text { Dividend } \\
\text { Yield }\end{array}$ & $\begin{array}{l}\text { Debt } \\
\text { Ratio }\end{array}$ & $\begin{array}{c}\text { Return } \\
\text { on } \\
\text { Equity }\end{array}$ & $\begin{array}{c}\text { Current } \\
\text { Ratio }\end{array}$ \\
\hline & \multicolumn{8}{|c|}{ All dividend events $(\mathrm{N}=3278)$} \\
\hline Mean & 8.474 & 0.661 & 13.906 & 0.509 & 0.035 & 0.207 & 0.131 & 1.478 \\
\hline Median & 6.355 & 0.500 & 9.655 & 0.429 & 0.030 & 0.186 & 0.133 & 1.302 \\
\hline \multirow[t]{2}{*}{ Stand. Dev. } & 7.930 & 2.061 & 32.355 & 0.812 & 0.024 & 0.164 & 0.201 & 0.922 \\
\hline & \multicolumn{8}{|c|}{ Dividend increases $(\mathrm{N}=2662)$} \\
\hline Mean & 8.757 & 1.047 & 19.941 & 0.453 & 0.032 & 0.208 & 0.145 & 1.446 \\
\hline Median & 6.550 & 0.650 & 11.355 & 0.415 & 0.028 & 0.186 & 0.141 & 1.290 \\
\hline \multirow[t]{2}{*}{ Stand. Dev. } & 8.189 & 1.780 & 31.606 & 0.273 & 0.021 & 0.165 & 0.191 & 0.822 \\
\hline & \multicolumn{8}{|c|}{ No change $(\mathrm{N}=343)$} \\
\hline Mean & 7.432 & 0.000 & 0.000 & 0.902 & 0.048 & 0.182 & 0.061 & 1.702 \\
\hline Median & 6.000 & 0.000 & 0.000 & 0.630 & 0.044 & 0.169 & 0.074 & 1.339 \\
\hline \multirow[t]{2}{*}{ Stand. Dev. } & 6.113 & 0.000 & 0.000 & 2.381 & 0.029 & 0.147 & 0.207 & 1.532 \\
\hline & \multicolumn{8}{|c|}{ Dividend decreases $(\mathrm{N}=273)$} \\
\hline Mean & 7.103 & -2.272 & -27.160 & 0.621 & 0.044 & 0.229 & 0.042 & 1.489 \\
\hline Median & 5.165 & -1.070 & -20.471 & 0.483 & 0.036 & 0.213 & 0.072 & 1.363 \\
\hline Stand. Dev. & 7.282 & 3.088 & 23.434 & 0.627 & 0.034 & 0.178 & 0.230 & 0.713 \\
\hline
\end{tabular}




\section{Table 3.6 - Lintner Model Estimations}

This table reports the regression of current earnings per share and the previous dividend per share on current dividend per share. $D_{i, t}$ is the dividend per share $i$ announced in year $t ; D_{i, t-1}$ is the dividend per share $\mathrm{i}$ announced in year $\mathrm{t}-1$ and $\mathrm{EPS}_{\mathrm{i}, \mathrm{t}}$ is the earnings per share $\mathrm{i}$ in year $\mathrm{t}$. The table presents the results estimated using pooled OLS, FEM and REM. The numbers in parentheses are the t-statistics corrected for heteroscedasticity using the White (1980) method. It reports the F test, a test for the equality of sets of coefficients, and the Hausman (1978) test, a test with $\mathrm{H}_{0}$ : random effects are consistent and efficient, versus $\mathrm{H}_{1}$ : random effects are inconsistent, in order to choose the most appropriate model for each particular sample.

\begin{tabular}{|c|c|c|c|c|c|c|}
\hline \multicolumn{7}{|c|}{$D_{i, t}=\alpha_{i}+\beta_{1} \mathrm{EPS}_{\mathrm{i}, \mathrm{t}}+\beta_{2} \mathrm{D}_{\mathrm{i}, \mathrm{t}-1}+\varepsilon_{i, t}$} \\
\hline \multicolumn{7}{|c|}{ Portugal } \\
\hline \multirow{3}{*}{ Constant } & Pooled OLS & & FEM & & REM & \\
\hline & 0.289 & $*$ & & & 0.115 & $*$ \\
\hline & (4.216) & & & & $(5.124)$ & \\
\hline \multirow[t]{2}{*}{ Earnings } & 0.079 & $*$ & 0.057 & $* *$ & 0.057 & $*$ \\
\hline & (2.674) & & $(2.687)$ & & $(4.699)$ & \\
\hline \multirow[t]{2}{*}{ Lagged Dividends } & 0.197 & & 0.018 & & 0.597 & $*$ \\
\hline & (1.224) & & $(0.160)$ & & $(15.201)$ & \\
\hline $\mathrm{N}$ & 383 & & 383 & & 383 & \\
\hline Adjusted $\mathrm{R}^{2}$ & 0.093 & & 0.110 & & 0.002 & \\
\hline Test F & 1.14 & & & & & \\
\hline \multirow[t]{2}{*}{ Hausman Test } & & & 59.66 & * & & \\
\hline & \multicolumn{4}{|c|}{ France } & & \\
\hline Coefficient & Pooled OLS & & FEM & & REM & \\
\hline \multirow[t]{2}{*}{ Constant } & 0.656 & $* *$ & & & 0.895 & $*$ \\
\hline & $(1.908)$ & & & & $(11.761)$ & \\
\hline \multirow[t]{2}{*}{ Earnings } & -0.008 & & 0.046 & $* * *$ & 0.000 & \\
\hline & $(-0.172)$ & & (1.816) & & $(0.004)$ & \\
\hline \multirow[t]{2}{*}{ Lagged Dividends } & 0.645 & $*$ & 0.060 & & 0.477 & * \\
\hline & $(5.418)$ & & $(0.535)$ & & (18.527) & \\
\hline $\mathrm{N}$ & 978 & & 978 & & 978 & \\
\hline Adjusted $\mathrm{R}^{2}$ & 0.560 & & 0.799 & & 0.717 & \\
\hline Test F & 9.57 & $*$ & & & & \\
\hline \multirow[t]{2}{*}{ Hausman Test } & & & 283.64 & $*$ & & \\
\hline & & UK & & & & \\
\hline Coefficient & Pooled OLS & & FEM & & REM & \\
\hline \multirow[t]{2}{*}{ Constant } & 0.279 & $*$ & & & 0.369 & $*$ \\
\hline & $(4.154)$ & & & & $(6.242)$ & \\
\hline \multirow[t]{2}{*}{ Earnings } & 0.018 & $* *$ & 0.012 & & 0.019 & $*$ \\
\hline & $(2.225)$ & & (1.277) & & (13.211) & \\
\hline \multirow[t]{2}{*}{ Lagged Dividends } & 0.997 & $*$ & 0.800 & $*$ & 0.984 & $*$ \\
\hline & $(50.317)$ & & (11.217) & & $(15.580)$ & \\
\hline $\mathrm{N}$ & 3,348 & & 3,348 & & 3,348 & \\
\hline Adjusted $\mathrm{R}^{2}$ & 0.938 & & 0.944 & & 0.941 & \\
\hline Test F & 1.85 & $*$ & & & & \\
\hline Hausman Test & & & 334.59 & $*$ & & \\
\hline
\end{tabular}

* $\quad$ Significantly different from zero at the $1 \%$ level

** $\quad$ Significantly different from zero at the $5 \%$ level

*** Significantly different from zero at the $10 \%$ level 


\section{Table 3.7 - Abnormal returns for the announcement period}

This table reports the abnormal returns for the announcement period and for different event periods. Cumulative abnormal returns based on the CAPM (Panel A) for the dividend events of the French and the UK samples are calculated as follows:

$$
C A R_{t}=\sum_{t=a}^{t=b}\left(\mathrm{AR}_{\mathrm{i}, \mathrm{t}}\right)
$$

where $\mathrm{CAR}_{\mathrm{t}}$ is the cumulative abnormal return between days a and $\mathrm{b} . \mathrm{AR}_{\mathrm{i}, \mathrm{t}}$ is the abnormal return for share $\mathrm{i}$ in day $\mathrm{t}$ computed as:

$$
A R_{i, t}=\mathrm{R}_{\mathrm{i}, \mathrm{t}}-\left[\mathrm{R}_{\mathrm{f}, \mathrm{t}}-\beta_{\mathrm{i}}\left(\mathrm{R}_{\mathrm{m}, \mathrm{t}}-\mathrm{R}_{\mathrm{f}, \mathrm{t}}\right)\right]
$$

where $R_{i, t}$ is the return for share $i$ in day $t, R_{f, t}$ is the risk-free rate in day $t, R_{m, t}$ is the market return for day $t$ and ${ }_{i}$ is the systematic risk of share $i$. Market-adjusted buy-and-hold returns (Panel B) for the dividend events of the three samples are calculated for the different event periods as follows:

$$
\text { BHAR }_{i(a \text { to } b)}=\prod_{t=a}^{b}\left(1+R_{i, t}\right)-\prod_{t=a}^{b}\left(1+R_{m, t}\right)
$$

where $\mathrm{BHAR}_{\mathrm{i}(\mathrm{a} \text { to } \mathrm{b})}$ is the abnormal return for share $\mathrm{i}$ from time $\mathrm{a}$ to $\mathrm{b} ; \mathrm{R}_{\mathrm{i}, \mathrm{t}}$ is the return for share $\mathrm{i}$ in day $\mathrm{t}$ and $\mathrm{R}_{\mathrm{m}}$, is the market return for day t. The market return is based on the PSI-Geral Index for Portugal, CAC-40 Index for France and FTSE-100 Index for the UK. $t$-Statistics are calculated based on the crosssectional variance in the mean abnormal return and are reported in parentheses. In Panel $\mathrm{C}$ we have the

\begin{tabular}{|c|c|c|c|c|c|c|}
\hline \multicolumn{7}{|c|}{ Panel A: CAR mean for different periods } \\
\hline \multicolumn{7}{|c|}{ France } \\
\hline & Sample & Mean & Mean & Mean & Mean & Mean \\
\hline & Size & Days -5 to -2 & Days -2 to +2 & Days -1 to +1 & Days -5 to +5 & Days +2 to +5 \\
\hline \multirow[t]{2}{*}{ Increases } & $\mathrm{N}=235$ & -0.0014 & 0.0026 & 0.0027 & $0.0091 * *$ & $0.0078^{*}$ \\
\hline & & $(-0.497)$ & $(0.779)$ & $(1.097)$ & $(2.261)$ & $(2.996)$ \\
\hline \multirow[t]{2}{*}{ Non-Changes } & $\mathrm{N}=59$ & $0.0146^{* *}$ & $0.0120 * *$ & 0.0034 & $0.0226 * *$ & 0.0045 \\
\hline & & $(2.009)$ & $(2.417)$ & $(0.723)$ & $(2.333)$ & $(0.941)$ \\
\hline \multirow[t]{5}{*}{ Decreases } & $\mathrm{N}=62$ & $0.0089 * * *$ & -0.0030 & -0.0032 & 0.0003 & -0.0055 \\
\hline & & $(1.702)$ & $(-0.392)$ & $(-0.470)$ & $(0.027)$ & $(-1.385)$ \\
\hline & & & UK & & & \\
\hline & Sample & Mean & Mean & Mean & Mean & Mean \\
\hline & Size & Days -5 to -2 & Days -2 to +2 & Days -1 to +1 & Days -5 to +5 & Days +2 to +5 \\
\hline \multirow[t]{2}{*}{ DIEI } & $\mathrm{N}=1,931$ & $0.0049^{*}$ & $0.0199 *$ & $0.0168^{*}$ & $0.0256^{*}$ & $0.0039^{*}$ \\
\hline & & $(5.165)$ & $(11.275)$ & $(10.493)$ & $(11.980)$ & $(3.874)$ \\
\hline \multirow[t]{2}{*}{ DIED } & $\mathrm{N}=731$ & $0.0030 * * *$ & $0.0218 *$ & $0.0181^{*}$ & $0.0248^{*}$ & $0.0037 * *$ \\
\hline & & $(1.778)$ & $(7.249)$ & $(6.451)$ & $(7.036)$ & $(2.078)$ \\
\hline \multirow[t]{2}{*}{ DNCEI } & $\mathrm{N}=141$ & 0.0010 & $0.0319^{*}$ & $0.0275^{*}$ & $0.0372 *$ & $0.0087 * * *$ \\
\hline & & $(0.279)$ & $(4.405)$ & $(4.370)$ & $(3.998)$ & (1.694) \\
\hline \multirow[t]{2}{*}{ DNCED } & $\mathrm{N}=202$ & 0.0018 & $0.0261 *$ & $0.0217^{*}$ & $0.0239^{*}$ & 0.0004 \\
\hline & & $(0.540)$ & $(4.483)$ & $(3.868)$ & $(3.367)$ & $(0.114)$ \\
\hline \multirow[t]{2}{*}{ DDEI } & $\mathrm{N}=108$ & 0.0004 & $0.0185 * *$ & $0.0202 *$ & $0.0209 * *$ & 0.0003 \\
\hline & & $(0.082)$ & $(2.390)$ & $(2.815)$ & $(2.222)$ & $(0.064)$ \\
\hline \multirow[t]{3}{*}{ DDED } & $\mathrm{N}=165$ & $0.0126^{*}$ & $0.0228 *$ & $0.0200^{*}$ & $0.0333^{*}$ & 0.0008 \\
\hline & & $(3.157)$ & $(3.256)$ & $(3.145)$ & $(3.665)$ & $(0.173)$ \\
\hline & & & & & & (Continue) \\
\hline$*$ & Si & $c$ & (1) & & & \\
\hline$* *$ & & (2) & 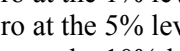 & & & \\
\hline$* * *$ & Significant & fferent from $\mathrm{z}$ & ro at the $10 \%$ & & & \\
\hline
\end{tabular}
cross-sectional distribution of 3 day abnormal returns for dividend change announcements, based on the BHAR results, common to all the three samples. 
Table 3.7 - Abnormal returns for the announcement period (continued)

\begin{tabular}{|c|c|c|c|c|c|c|}
\hline \multicolumn{7}{|c|}{ Panel B: BHAR mean for different periods } \\
\hline & Sample & Mean & Mean & Mean & Mean & Mean \\
\hline & Size & Days -5 to -2 & Days -2 to +2 & Days -1 to +1 & Days- 5 to +5 & Days +2 to +5 \\
\hline \multicolumn{7}{|c|}{ Portugal } \\
\hline Increases & $\mathrm{N}=158$ & $\begin{array}{l}0.0042 \\
(1.233)\end{array}$ & $\begin{array}{l}0.0055 \\
(1.361)\end{array}$ & $\begin{array}{c}0.0034 \\
(1.172)\end{array}$ & $\begin{array}{l}0.0136^{* *} \\
(2.389)\end{array}$ & $\begin{array}{l}0.0056^{* * * *} \\
(1.804)\end{array}$ \\
\hline Non-Changes & $\mathrm{N}=101$ & $\begin{array}{l}0.0077 * * \\
(2.148)\end{array}$ & $\begin{array}{l}-0.0009 \\
(-0.219)\end{array}$ & $\begin{array}{l}-0.0022 \\
(-0.638)\end{array}$ & $\begin{array}{l}0.0101 * * * \\
(1.790)\end{array}$ & $\begin{array}{l}0.0045 \\
(1.277)\end{array}$ \\
\hline Decreases & $\mathrm{N}=121$ & $\begin{array}{c}0.0000 \\
(-0.014) \\
\end{array}$ & $\begin{array}{l}-0.0108^{*} \\
(-2.648) \\
\end{array}$ & $\begin{array}{l}-0.0056^{* * *} \\
(-1.755) \\
\end{array}$ & $\begin{array}{c}-0.0074 \\
(-1.376) \\
\end{array}$ & $\begin{array}{l}-0.0019 \\
(-0.555) \\
\end{array}$ \\
\hline \multicolumn{7}{|c|}{ France } \\
\hline & Sample & Mean & Mean & Mean & Mean & Mean \\
\hline & Size & Days -5 to -2 & Days -2 to +2 & Days -1 to +1 & Days- 5 to +5 & Days +2 to +5 \\
\hline Increases & $\mathrm{N}=235$ & $\begin{array}{l}-0.0043 \\
(-1.465)\end{array}$ & $\begin{array}{l}0.0010 \\
(0.301)\end{array}$ & $\begin{array}{c}0.0019 \\
(0.737)\end{array}$ & $\begin{array}{c}0.0032 \\
(0.774)\end{array}$ & $\begin{array}{l}0.0060 * * \\
(2.175)\end{array}$ \\
\hline Non-Changes & $\mathrm{N}=59$ & $\begin{array}{l}0.0077 \\
(1.146)\end{array}$ & $\begin{array}{l}0.0094 * * * \\
(1.843)\end{array}$ & $\begin{array}{c}0.0051 \\
(0.971)\end{array}$ & $\begin{array}{l}0.0164 * * * \\
(1.716)\end{array}$ & $\begin{array}{c}0.0032 \\
(0.598)\end{array}$ \\
\hline \multirow[t]{4}{*}{ Decreases } & $\mathrm{N}=62$ & $\begin{array}{l}0.0070 \\
(1.300)\end{array}$ & $\begin{array}{l}-0.0052 \\
(-0.704)\end{array}$ & $\begin{array}{l}-0.0025 \\
(-0.400)\end{array}$ & $\begin{array}{l}-0.0026 \\
(-0.209)\end{array}$ & $\begin{array}{l}-0.0080^{* * *} \\
(-1.818)\end{array}$ \\
\hline & \multicolumn{6}{|c|}{ UK } \\
\hline & Sample & Mean & Mean & Mean & Mean & Mean \\
\hline & Size & Days -5 to -2 & Days -2 to +2 & Days -1 to +1 & Days- 5 to +5 & Days +2 to +5 \\
\hline DIEI & $\mathrm{N}=1,931$ & $\begin{array}{l}0.0053 * \\
(5.271)\end{array}$ & $\begin{array}{c}0.0211 * \\
(11.684)\end{array}$ & $\begin{array}{c}0.0174 * \\
(10.704)\end{array}$ & $\begin{array}{c}0.0279 * \\
(12.534)\end{array}$ & $\begin{array}{l}0.0045^{*} \\
(4.273)\end{array}$ \\
\hline DIED & $\mathrm{N}=731$ & $\begin{array}{l}0.0043 * * \\
(2.450)\end{array}$ & $\begin{array}{l}0.0237 * \\
(7.603)\end{array}$ & $\begin{array}{l}0.0192 * \\
(6.544)\end{array}$ & $\begin{array}{l}0.0289 * \\
(7.746)\end{array}$ & $\begin{array}{l}0.0056^{*} \\
(2.917)\end{array}$ \\
\hline DNCEI & $\mathrm{N}=141$ & $\begin{array}{l}0.0024 \\
(0.650)\end{array}$ & $\begin{array}{l}0.0336^{*} \\
(4.422)\end{array}$ & $\begin{array}{l}0.0288 * \\
(4.551)\end{array}$ & $\begin{array}{l}0.0436^{*} \\
(4.374)\end{array}$ & $\begin{array}{l}0.0112 * * * \\
(1.921)\end{array}$ \\
\hline DNCED & $\mathrm{N}=202$ & $\begin{array}{l}0.0047 \\
(1.401)\end{array}$ & $\begin{array}{l}0.0266^{*} \\
(4.309)\end{array}$ & $\begin{array}{l}0.0220 * \\
(3.846)\end{array}$ & $\begin{array}{l}0.0312^{*} \\
(4.123)\end{array}$ & $\begin{array}{l}0.0044 \\
(1.210)\end{array}$ \\
\hline DDEI & $\mathrm{N}=108$ & $\begin{array}{l}0.0009 \\
(0.185)\end{array}$ & $\begin{array}{l}0.0173 * * \\
(2.157)\end{array}$ & $\begin{array}{l}0.0195 * * \\
(2.567)\end{array}$ & $\begin{array}{l}0.0189 * * * \\
(1.896)\end{array}$ & $\begin{array}{l}-0.0013 \\
(-0.260)\end{array}$ \\
\hline \multirow[t]{2}{*}{ DDED } & $\mathrm{N}=165$ & $\begin{array}{l}0.0150 * \\
(3.508)\end{array}$ & $\begin{array}{l}0.0241^{*} \\
(3.437)\end{array}$ & $\begin{array}{l}0.0187^{*} \\
(2.901)\end{array}$ & $\begin{array}{l}0.0403^{*} \\
(4.167) \\
\end{array}$ & $\begin{array}{l}0.0052 \\
(1.085) \\
\end{array}$ \\
\hline & & & & & & (Continue) \\
\hline $\begin{array}{ll}* & \mathrm{Si} \\
* * & \mathrm{Si} \\
* * * & \mathrm{Si}\end{array}$ & ficantly & $\begin{array}{l}\text { erent from ze } \\
\text { erent from ze }\end{array}$ & $\begin{array}{l}\text { ro at the } 5 \% \text { leve } \\
\text { ro at the } 10 \% \text { lev }\end{array}$ & & & \\
\hline
\end{tabular}


Table 3.7 - Abnormal returns for the announcement period (continued)

\begin{tabular}{|c|c|c|c|c|c|c|c|c|c|c|}
\hline \multicolumn{11}{|c|}{ Panel C - Cross-sectional distribution of 3 day abnormal } \\
\hline \multicolumn{11}{|c|}{$\begin{array}{ll} & \text { Portugal } \\
\end{array}$} \\
\hline & \multicolumn{3}{|c|}{ Dividend Increases } & \multicolumn{3}{|c|}{ Dividend Non-Changes } & & \multicolumn{3}{|c|}{ Dividend Decreases } \\
\hline Size of 3-day & $\mathbf{N}^{\mathbf{o}}$ & $\%$ & Cum. & $\mathbf{N}^{\mathbf{0}}$ & $\%$ & Cum. & Size of 3-day & $\mathbf{N}^{\mathbf{o}}$ & $\%$ & Cum. \\
\hline \multirow{3}{*}{$\begin{array}{c}\text { Abnormal Return } \\
\text { (AR) }\end{array}$} & of & of & $\%$ of & of & of & $\%$ of & Abnormal Return & of & of & $\%$ of \\
\hline & Events & Events & Events & Events & Events & Events & (AR) & Events & Events & Events \\
\hline & $N=158$ & & & $\mathrm{~N}=101$ & & & & $\mathrm{~N}=121$ & & \\
\hline $\mathrm{AR}<-0.12$ & 0 & 0.00 & 0.00 & 0 & 0.00 & 0.00 & $0.12<\mathrm{AR}$ & 1 & 0.83 & 0.83 \\
\hline$-0.12 \leq \mathrm{AR}<-0.06$ & 3 & 1.90 & 1.90 & 7 & 6.93 & 6.93 & $0.06<\mathrm{AR} \leq 0.12$ & 5 & 4.13 & 4.96 \\
\hline$-0.06 \leq \mathrm{AR}<-0.04$ & 5 & 3.16 & 5.06 & 4 & 3.96 & 10.89 & $0.04<\mathrm{AR} \leq 0.06$ & 1 & 0.83 & 5.79 \\
\hline$-0.04 \leq \mathrm{AR}<-0.02$ & 19 & 12.03 & 17.09 & 7 & 6.93 & 17.82 & $0.02<\mathrm{AR} \leq 0.04$ & 15 & 12.40 & 18.18 \\
\hline$-0.02 \leq \mathrm{AR}<0.00$ & 45 & 28.48 & 45.57 & 32 & 31.68 & 49.50 & $0.00<\mathrm{AR} \leq 0.02$ & 26 & 21.49 & 39.67 \\
\hline $0.00 \leq \mathrm{AR}<0.02$ & 52 & 32.91 & 78.48 & 31 & 30.69 & 80.20 & $-0.02<\mathrm{AR} \leq 0.00$ & 44 & 36.36 & 76.03 \\
\hline $0.02 \leq \mathrm{AR}<0.04$ & 20 & 12.66 & 91.14 & 12 & 11.88 & 92.08 & $-0.04<\mathrm{AR} \leq-0.02$ & 9 & 7.44 & 83.47 \\
\hline $0.04 \leq \mathrm{AR}<0.06$ & 7 & 4.43 & 95.57 & 3 & 2.97 & 95.05 & $-0.06<\mathrm{AR} \leq-0.04$ & 12 & 9.92 & 93.39 \\
\hline $0.06 \leq \mathrm{AR}<0.12$ & 5 & 3.16 & 98.73 & 5 & 4.95 & 100.00 & $-0.12<\mathrm{AR} \leq-0.06$ & 8 & 6.61 & 100.00 \\
\hline \multirow[t]{2}{*}{$0.12 \leq \mathrm{AR}$} & 2 & 1.27 & 100.00 & 0 & 0.00 & 100.00 & $\mathrm{AR} \leq-0.12$ & 0 & 0.00 & 100.00 \\
\hline & 158 & 100.00 & & 101 & 100.00 & & & 121 & 100.00 & \\
\hline \multicolumn{11}{|c|}{ France } \\
\hline & \multicolumn{3}{|c|}{ Dividend Increases } & \multicolumn{4}{|c|}{ Dividend Non-Changes } & \multicolumn{3}{|c|}{ Dividend Decreases } \\
\hline Size of 3-day & $\mathbf{N}^{\circ}$ & $\%$ & Cum. & $\mathbf{N}^{\circ}$ & $\%$ & Cum. & Size of 3-day & $\mathbf{N}^{\mathbf{o}}$ & $\%$ & Cum. \\
\hline \multirow{3}{*}{$\begin{array}{c}\text { Abnormal Return } \\
\text { (AR) }\end{array}$} & of & of & $\%$ of & of & of & $\%$ of & Abnormal Return & of & of & $\%$ of \\
\hline & Events & Events & Events & Events & Events & Events & (AR) & Events & Events & Events \\
\hline & $\mathrm{N}=\mathbf{2 3 5}$ & & & $\mathrm{N}=59$ & & & & $\mathrm{~N}=62$ & & \\
\hline $\mathrm{AR}<-0.12$ & 2 & 0.85 & 0.85 & 0 & 0.00 & 0.00 & $0.12<\mathrm{AR}$ & 1 & 1.61 & 1.61 \\
\hline$-0.12 \leq \mathrm{AR}<-0.06$ & 9 & 3.83 & 4.68 & 4 & 6.78 & 6.78 & $0.06<\mathrm{AR} \leq 0.12$ & 2 & 3.23 & 4.84 \\
\hline$-0.06 \leq \mathrm{AR}<-0.04$ & 13 & 5.53 & 10.21 & 4 & 6.78 & 13.56 & $0.04<\mathrm{AR} \leq 0.06$ & 7 & 11.29 & 16.13 \\
\hline$-0.04 \leq \mathrm{AR}<-0.02$ & 35 & 14.89 & 25.11 & 6 & 10.17 & 23.73 & $0.02<\mathrm{AR} \leq 0.04$ & 7 & 11.29 & 27.42 \\
\hline$-0.02 \leq \mathrm{AR}<0.00$ & 49 & 20.85 & 45.96 & 11 & 18.64 & 42.37 & $0.00<\mathrm{AR} \leq 0.02$ & 16 & 25.81 & 53.23 \\
\hline $0.00 \leq \mathrm{AR}<0.02$ & 60 & 25.53 & 71.49 & 13 & 22.03 & 64.41 & $-0.02<\mathrm{AR} \leq 0.00$ & 9 & 14.52 & 67.74 \\
\hline $0.02 \leq \mathrm{AR}<0.04$ & 42 & 17.87 & 89.36 & 8 & 13.56 & 77.97 & $-0.04<\mathrm{AR} \leq-0.02$ & 10 & 16.13 & 83.87 \\
\hline $0.04 \leq \mathrm{AR}<0.06$ & 9 & 3.83 & 93.19 & 10 & 16.95 & 94.92 & $-0.06<\mathrm{AR} \leq-0.04$ & 5 & 8.06 & 91.94 \\
\hline $0.06 \leq \mathrm{AR}<0.12$ & 15 & 6.38 & 99.57 & 3 & 5.08 & 100.00 & $-0.12<\mathrm{AR} \leq-0.06$ & 4 & 6.45 & 98.39 \\
\hline \multirow[t]{2}{*}{$0.12 \leq \mathrm{AR}$} & 1 & 0.43 & 100.00 & 0 & 0.00 & 100.00 & $\mathrm{AR} \leq-0.12$ & 1 & 1.61 & 100.00 \\
\hline & 235 & 100.00 & & 59 & 100.00 & & & 62 & 100.00 & \\
\hline
\end{tabular}


Table 3.7 - Abnormal returns for the announcement period (continued)

Panel C - Cross-sectional distribution of 3 day abnormal returns for dividend change announcements

\begin{tabular}{|c|c|c|c|c|c|c|c|c|c|c|c|c|c|c|c|c|c|c|c|}
\hline \multicolumn{20}{|c|}{ UK } \\
\hline \multirow[b]{2}{*}{$\begin{array}{c}\text { Size of 3-day } \\
\text { Abnormal Return } \\
\text { (AR) }\end{array}$} & \multirow[b]{2}{*}{$\begin{array}{c}\mathrm{N}^{\circ} \\
\text { Events } \\
\mathrm{N}=\mathbf{1 , 9 3 1}\end{array}$} & \multirow{2}{*}{$\begin{array}{c}\text { DIEI } \\
\% \\
\text { of } \\
\text { Events }\end{array}$} & \multirow[b]{2}{*}{$\begin{array}{c}\text { Cum. \% } \\
\text { of } \\
\text { Events }\end{array}$} & \multicolumn{3}{|c|}{ DIED } & \multicolumn{3}{|c|}{ DNCEI } & \multicolumn{3}{|c|}{ DNCED } & \multirow[b]{2}{*}{$\begin{array}{c}\text { Size of 3-day } \\
\text { Abnormal Return } \\
\text { (AR) }\end{array}$} & \multicolumn{3}{|c|}{ DDEI } & \multicolumn{3}{|c|}{ DDED } \\
\hline & & & & $\begin{array}{c}\mathrm{N}^{\circ} \\
\text { Events } \\
\mathrm{N}=731\end{array}$ & $\begin{array}{c}\% \\
\text { of } \\
\text { Events }\end{array}$ & $\begin{array}{c}\text { Cum. \% } \\
\text { of } \\
\text { Events }\end{array}$ & $\begin{array}{c}\mathrm{N}^{\circ} \\
\text { Events } \\
\mathrm{N}=141\end{array}$ & $\begin{array}{c}\% \\
\text { of } \\
\text { Events }\end{array}$ & $\begin{array}{c}\text { Cum. \% } \\
\text { of } \\
\text { Events }\end{array}$ & $\begin{array}{c}\mathrm{N}^{\mathrm{o}} \\
\text { Events } \\
\mathrm{N}=202\end{array}$ & $\begin{array}{c}\% \\
\text { of } \\
\text { Events }\end{array}$ & $\begin{array}{c}\text { Cum. \% } \\
\text { of } \\
\text { Events }\end{array}$ & & $\begin{array}{c}\mathrm{N}^{\circ} \\
\text { Events } \\
\mathrm{N}=108\end{array}$ & $\begin{array}{c}\% \\
\text { of } \\
\text { Events }\end{array}$ & $\begin{array}{c}\text { Cum. \% } \\
\text { of } \\
\text { Events }\end{array}$ & $\begin{array}{c}\mathrm{N}^{\circ} \\
\text { Events } \\
\mathrm{N}=165\end{array}$ & $\begin{array}{c}\% \\
\text { of } \\
\text { Events }\end{array}$ & $\begin{array}{l}\text { Cum. \% } \\
\text { of } \\
\text { Events }\end{array}$ \\
\hline $\mathrm{AR}<-0.12$ & 52 & 2.69 & 2.69 & 28 & 3.83 & 3.83 & 1 & 0.71 & 0.71 & 8 & 3.96 & 3.96 & $0.12<\mathrm{AR}$ & 12 & 11.11 & 11.11 & 15 & 9.09 & 9.09 \\
\hline$-0.12 \leq \mathrm{AR}<-0.06$ & 117 & 6.06 & 8.75 & 51 & 6.98 & 10.81 & 10 & 7.09 & 7.80 & 11 & 5.45 & 9.41 & $0.06<\mathrm{AR} \leq 0.12$ & 14 & 12.96 & 24.07 & 26 & 15.76 & 24.85 \\
\hline$-0.06 \leq \mathrm{AR}<-0.04$ & 104 & 5.39 & 14.14 & 41 & 5.61 & 16.42 & 9 & 6.38 & 14.18 & 12 & 5.94 & 15.35 & $0.04<\mathrm{AR} \leq 0.06$ & 12 & 11.11 & 35.19 & 14 & 8.48 & 33.33 \\
\hline$-0.04 \leq \mathrm{AR}<-0.02$ & 195 & 10.10 & 24.24 & 61 & 8.34 & 24.76 & 20 & 14.18 & 28.37 & 18 & 8.91 & 24.26 & $0.02<\mathrm{AR} \leq 0.04$ & 12 & 11.11 & 46.30 & 24 & 14.55 & 47.88 \\
\hline$-0.02 \leq \mathrm{AR}<0.00$ & 262 & 13.57 & 37.80 & 102 & 13.95 & 38.71 & 11 & 7.80 & 36.17 & 30 & 14.85 & 39.11 & $0.00<\mathrm{AR} \leq 0.02$ & 12 & 11.11 & 57.41 & 19 & 11.52 & 59.39 \\
\hline $0.00 \leq \mathrm{AR}<0.02$ & 321 & 16.62 & 54.43 & 102 & 13.95 & 52.67 & 25 & 17.73 & 53.90 & 29 & 14.36 & 53.47 & $-0.02<\mathrm{AR} \leq 0.00$ & 16 & 14.81 & 72.22 & 19 & 11.52 & 70.91 \\
\hline $0.02 \leq \mathrm{AR}<0.04$ & 264 & 13.67 & 68.10 & 87 & 11.90 & 64.57 & 14 & 9.93 & 63.83 & 15 & 7.43 & 60.89 & $-0.04<\mathrm{AR} \leq-0.02$ & 11 & 10.19 & 82.41 & 17 & 10.30 & 81.21 \\
\hline $0.04 \leq \mathrm{AR}<0.06$ & 193 & 9.99 & 78.09 & 80 & 10.94 & 75.51 & 12 & 8.51 & 72.34 & 27 & 13.37 & 74.26 & $-0.06<\mathrm{AR} \leq-0.04$ & 5 & 4.63 & 87.04 & 8 & 4.85 & 86.06 \\
\hline $0.06 \leq \mathrm{AR}<0.12$ & 301 & 15.59 & 93.68 & 123 & 16.83 & 92.34 & 23 & 16.31 & 88.65 & 31 & 15.35 & 89.60 & $-0.12<\mathrm{AR} \leq-0.06$ & 12 & 11.11 & 98.15 & 16 & 9.70 & 95.76 \\
\hline \multirow[t]{2}{*}{$0.12 \leq \mathrm{AR}$} & 122 & 6.32 & 100.00 & 56 & 7.66 & 100.00 & 16 & 11.35 & 100.00 & 21 & 10.40 & 100.00 & $\mathrm{AR} \leq-0.12$ & 2 & 1.85 & 100.00 & 7 & 4.24 & 100.00 \\
\hline & 1,931 & 100.00 & & 731 & 100.00 & & 141 & 100.00 & & 202 & 100.00 & & & 108 & 100.00 & & 165 & 100.00 & \\
\hline
\end{tabular}




\section{Table 3.8 - Abnormal returns for the announcement period in up and down markets}

This table reports the abnormal returns for the announcement period in up and down markets. Cumulative abnormal returns based on the CAPM (Panel A) for dividend events of the French and the UK samples are calculated as follows:

$$
C A R_{t}=\sum_{t=-1}^{t=1}\left(\mathrm{AR}_{\mathrm{i}, \mathrm{t}}\right)
$$

where $\mathrm{CAR}_{\mathrm{t}}$ is the 3-day cumulative abnormal return and $\mathrm{AR}_{\mathrm{i}, \mathrm{t}}$ is the abnormal return for share $\mathrm{i}$ in day $\mathrm{t}$ computed as:

$$
A R_{i, t}=\mathrm{R}_{\mathrm{i}, \mathrm{t}}-\left[\mathrm{R}_{\mathrm{f}, \mathrm{t}}-\beta_{\mathrm{i}}\left(\mathrm{R}_{\mathrm{m}, \mathrm{t}}-\mathrm{R}_{\mathrm{f}, \mathrm{t}}\right)\right]
$$

where $R_{i, t}$ is the return for share $i$ in day $t ; R_{f, t}$ is the risk-free rate in day $t ; R_{m, t}$ is the market return for day $\mathrm{t}$ and ${ }_{\mathrm{i}}$ is the systematic risk of share $\mathrm{i}$. The market is considered as up market (down market) when the market index return is greater than 0 (is 0 or less). $t$-Statistics are reported in parentheses. For the difference of the means we compute the $t$ value and the value of the Kruskal-Wallis test, both reported in parenthesis. Market-adjusted buy-and-hold returns (Panel B) for the dividend events of the three samples are calculated as follows:

$$
\text { BHAR }_{i(-1 t o 1)}=\prod_{t=-1}^{1}\left(1+R_{i, t}\right)-\prod_{t=-1}^{1}\left(1+R_{m, t}\right)
$$

where $\mathrm{BHAR}_{\mathrm{i}(-1 \text { to } 1)}$ is the abnormal return for share $\mathrm{i}$ from days -1 to $1, \mathrm{R}_{\mathrm{i}, \mathrm{t}}$ is the return for share $\mathrm{i}$ in day

\begin{tabular}{|c|c|c|c|}
\hline \multicolumn{4}{|c|}{ Panel A: CAR mean in up and down markets } \\
\hline \multicolumn{4}{|c|}{$\begin{array}{c}\text { France } \\
\end{array}$} \\
\hline \multirow[b]{2}{*}{ Increases } & Up market & Down market & Difference \\
\hline & $\begin{array}{l}0.0088 \\
(2.687)^{*}\end{array}$ & $\begin{array}{l}-0.0018 \\
(-0.510)\end{array}$ & $\begin{array}{c}0.0105 \\
(1.986)^{* * *} \\
(3.598)^{* * *}\end{array}$ \\
\hline \multirow[t]{3}{*}{ No Change } & 0.0036 & 0.0034 & 0.0002 \\
\hline & $(0.429)$ & $(0.594)$ & $(-0.099)$ \\
\hline & & & $(0.011)$ \\
\hline \multirow[t]{3}{*}{ Decreases } & 0.0049 & -0.0076 & 0.0124 \\
\hline & $(0.481)$ & $(-0.855)$ & $(0.475)$ \\
\hline & & & $(0.585)$ \\
\hline \multicolumn{4}{|c|}{ UK } \\
\hline \multirow{4}{*}{ DIEI } & Up market & Down market & Difference \\
\hline & 0.0192 & 0.0140 & 0.0051 \\
\hline & $(9.260)^{*}$ & $(5.658)^{*}$ & $(1.454)$ \\
\hline & & & $(6.032)^{* *}$ \\
\hline \multirow[t]{3}{*}{ DIED } & 0.0184 & 0.0178 & 0.0006 \\
\hline & $(4.650)^{*}$ & $(4.471)^{*}$ & $(0.159)$ \\
\hline & & & $(0.616)$ \\
\hline \multirow[t]{3}{*}{ DNCEI } & 0.0241 & 0.0311 & -0.0070 \\
\hline & $(2.690)^{*}$ & $(3.516)^{*}$ & $(-0.790)$ \\
\hline & & & $(0.072)$ \\
\hline \multirow[t]{3}{*}{ DNCED } & 0.0223 & 0.0212 & 0.0011 \\
\hline & $(2.630)^{* *}$ & $(2.823)^{*}$ & $(0.122)$ \\
\hline & & & $(0.071)$ \\
\hline \multirow[t]{3}{*}{ DDEI } & 0.0297 & 0.0101 & 0.0196 \\
\hline & $(3.111)^{*}$ & $(0.937)$ & $(0.936)$ \\
\hline & & & $(2.382)$ \\
\hline \multirow[t]{3}{*}{ DDED } & 0.0294 & 0.0092 & 0.0202 \\
\hline & $(3.458)^{*}$ & $(0.793)$ & $(1.598)$ \\
\hline & & & $(1.492)$ \\
\hline \\
\hline \multicolumn{4}{|c|}{ Significantly different from zero at the $1 \%$ level } \\
\hline Sig1 & \multicolumn{3}{|c|}{ Significantly different from zero at the $5 \%$ level } \\
\hline$* * *$ & \multicolumn{3}{|c|}{ Significantly different from zero at the $10 \%$ level } \\
\hline
\end{tabular}
$t$ and $R_{m, t}$ is the market return for day $t$. The market return is based on the PSI-Geral Index for Portugal, CAC-40 Index for France and FTSE-100 Index for the UK. 
Table 3.8 - Abnormal returns for the announcement period in up and down markets (continued)

\begin{tabular}{|c|c|c|c|}
\hline \multicolumn{4}{|c|}{ Panel B: BHAR mean in up and down markets } \\
\hline \multicolumn{4}{|c|}{ Portugal } \\
\hline & Up market & Down market & Difference \\
\hline Increases & $\begin{array}{l}0.0055 \\
(1.160)\end{array}$ & $\begin{array}{l}0.0009 \\
(0.291)\end{array}$ & $\begin{array}{l}0.0046 \\
(1.241) \\
(0.050)\end{array}$ \\
\hline No Change & $\begin{array}{l}0.0025 \\
(0.667)\end{array}$ & $\begin{array}{l}-0.0083 \\
(-1.342)\end{array}$ & $\begin{array}{l}0.0108 \\
(1.330)\end{array}$ \\
\hline Decreases & $\begin{array}{l}-0.0078 \\
(-2.094)^{* *}\end{array}$ & $\begin{array}{l}-0.0031 \\
(-0.579)\end{array}$ & $\begin{array}{l}-0.0047 \\
(-0.744)\end{array}$ \\
\hline & & & $(0.186)$ \\
\hline \multicolumn{4}{|c|}{ France } \\
\hline \multirow[b]{2}{*}{ Increases } & Up market & Down market & Difference \\
\hline & $\begin{array}{l}0.0028 \\
(0.827)\end{array}$ & $\begin{array}{l}0.0012 \\
(0.329)\end{array}$ & $\begin{array}{l}0.0016 \\
(0.299) \\
(0.020)\end{array}$ \\
\hline No Change & $\begin{array}{l}-0.0027 \\
(-0.272)\end{array}$ & $\begin{array}{l}0.0076 \\
(1.219)\end{array}$ & $\begin{array}{c}-0.0103 \\
(-1.541) \\
(0.508)\end{array}$ \\
\hline \multirow[t]{2}{*}{ Decreases } & $\begin{array}{l}0.0008 \\
(0.077)\end{array}$ & $\begin{array}{l}-0.0044 \\
(-0.544)\end{array}$ & $\begin{array}{l}0.0052 \\
(0.030)\end{array}$ \\
\hline & & & $(0.096)$ \\
\hline \multicolumn{4}{|c|}{ UK } \\
\hline & Up market & Down market & Difference \\
\hline DIEI & $\begin{array}{c}0.0162 \\
(7.726)^{*}\end{array}$ & $\begin{array}{c}0.0187 \\
(7.420)^{*}\end{array}$ & $\begin{array}{c}-0.0025 \\
(-0.848) \\
(0.0581)\end{array}$ \\
\hline DIED & $\begin{array}{c}0.0168 \\
(4.108)^{*}\end{array}$ & $\begin{array}{l}0.0215 \\
(5.121)^{*}\end{array}$ & $\begin{array}{l}-0.0047 \\
(-0.761) \\
(3.864)^{* *}\end{array}$ \\
\hline DNCEI & $\begin{array}{l}0.0221 \\
(2.492)^{*}\end{array}$ & $\begin{array}{l}0.0360 \\
(3.989)^{*}\end{array}$ & $\begin{array}{c}-0.0140 \\
(-1.394) \\
(0.893)\end{array}$ \\
\hline DNCED & $\begin{array}{l}0.0220 \\
(2.611)^{* *}\end{array}$ & $\begin{array}{l}0.0220 \\
(2.814)^{*}\end{array}$ & $\begin{array}{l}0.0000 \\
(0.081) \\
(0.008)\end{array}$ \\
\hline DDEI & $\begin{array}{l}0.0265 \\
(2.612)^{* *}\end{array}$ & $\begin{array}{l}0.0119 \\
(1.046)\end{array}$ & $\begin{array}{l}0.0147 \\
(0.499) \\
(1.145)\end{array}$ \\
\hline DDED & $\begin{array}{l}0.0240 \\
(2.802)^{*}\end{array}$ & $\begin{array}{l}0.0127 \\
(1.298)\end{array}$ & $\begin{array}{l}0.0113 \\
(0.895) \\
(0.350)\end{array}$ \\
\hline
\end{tabular}

* $\quad$ Significantly different from zero at the $1 \%$ level

** $\quad$ Significantly different from zero at the $5 \%$ level

*** $\quad$ Significantly different from zero at the $10 \%$ level 


\section{Table 3.9 - Regression of market reaction on dividend changes}

This table reports the regression of dividend changes on market's reaction considering the dependent variable as CAR (Panel A) and BHAR (Panel B). $\mathrm{CAR}_{3}$ is the cumulative abnormal return on the 3-day period as calculated by equation 3.9 $\mathrm{BHAR}_{3}$ is the buy and hold accumulated abnormal return on the 3day period as calculated by equation $3.10 ; D_{i, t}$ is the dividend per share change for year $t$; DI is a dummy variable that takes value 1 if dividend increases and zero otherwise; DD is a dummy variable that takes value 1 if dividend decreases and zero otherwise; DIEI is a dummy variable that takes value 1 if both dividend and earnings increase and zero otherwise; DIED is a dummy variable that takes value 1 if dividend increases and earnings decrease and zero otherwise; DDEI is a dummy variable that takes value 1 if dividend decreases and earnings increases and zero otherwise; DDED is a dummy variable that takes value 1 if both dividend and earnings decrease and zero otherwise. The table presents the results estimated using pooled OLS, FEM and REM. The numbers in parentheses are the t-statistics corrected for heteroscedasticity using the White (1980) method. It reports the F test, a test for the equality of sets of coefficients, and the Hausman (1978) test, a test with $\mathrm{H}_{0}$ : random effects are consistent and efficient, versus $\mathrm{H}_{1}$ : random effects are inconsistent, in order to choose the most appropriate model for each particular sample.

\begin{tabular}{|c|c|c|c|}
\hline \multicolumn{4}{|c|}{$\begin{array}{l}\text { Panel A: Dependent variable - CAR } \\
\end{array}$} \\
\hline \multicolumn{4}{|c|}{$C A R 3_{i}=a+\beta_{1}$ DI $\times \Delta \mathrm{D}_{\mathrm{i}, 0}+\beta_{2} \mathrm{DD} \times \Delta \mathrm{D}_{\mathrm{i}, 0}+\varepsilon_{i, t}$} \\
\hline \multicolumn{4}{|c|}{$\begin{array}{ll}\text { France } \\
\end{array}$} \\
\hline Coefficient & Pooled OLS & FEM & REM \\
\hline Constant & $\begin{array}{c}0.002 \\
(1.004)\end{array}$ & & $\begin{array}{c}0.003 \\
(0.822)\end{array}$ \\
\hline \multirow[t]{2}{*}{ DI } & -0.076 & $-0.591 * *$ & -0.237 \\
\hline & $(-0.445)$ & $(-2.417)$ & $(-0.884)$ \\
\hline \multirow[t]{2}{*}{ DD } & 0.113 & $0.458 * *$ & 0.216 \\
\hline & (1.160) & $(2.534)$ & $(1.198)$ \\
\hline $\mathrm{N}$ & 356 & 356 & 356 \\
\hline Adjusted $\mathrm{R}^{2}$ & 0.003 & 0.008 & 0.236 \\
\hline Test F & 1.05 & & \\
\hline Hausman Test & & 2.57 & \\
\hline \multicolumn{4}{|l|}{ 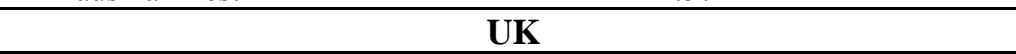 } \\
\hline \multicolumn{4}{|c|}{$\begin{aligned} C A R 3_{i}= & a+\beta_{1} \text { DIEI } \times \Delta \mathrm{D}_{\mathrm{i}, 0}+\beta_{2} \text { DIED } \mathrm{x} \Delta \mathrm{D}_{\mathrm{i}, 0}+\beta_{3} \text { DDEI } \times \Delta \mathrm{D}_{\mathrm{i}, 0} \dashv \\
& +\beta_{4} \text { DDED } \times \Delta \mathrm{D}_{\mathrm{i}, 0}+\varepsilon_{i, t}\end{aligned}$} \\
\hline Coefficient & Pooled OLS & FEM & REM \\
\hline Constant & $\begin{array}{r}0.019 * \\
(12.061)\end{array}$ & & $\begin{array}{c}0.019 * \\
(9.174)\end{array}$ \\
\hline DIEI & $\begin{array}{c}-0.084 \\
(-0.234)\end{array}$ & $\begin{array}{l}-0.579 * * * \\
(-1.687)\end{array}$ & $\begin{array}{c}-0.343 \\
(-1.088)\end{array}$ \\
\hline DIED & $\begin{array}{c}-0.378 \\
(-0.863)\end{array}$ & $\begin{array}{l}-0.959 * * \\
(-2.191)\end{array}$ & $\begin{array}{l}-0.685^{* * *} \\
(-1.770)\end{array}$ \\
\hline DDEI & $\begin{array}{l}-0.266 \\
(-1.413)\end{array}$ & $\begin{array}{c}-0.194 \\
(-0.828)\end{array}$ & $\begin{array}{c}-0.235 \\
(-0.859)\end{array}$ \\
\hline DDED & $\begin{array}{c}0.004 \\
(0.023)\end{array}$ & $\begin{array}{c}0.022 \\
(0.147)\end{array}$ & $\begin{array}{c}0.008 \\
(0.062)\end{array}$ \\
\hline $\mathrm{N}$ & 3,278 & 3,278 & 3,278 \\
\hline Adjusted $\mathrm{R}^{2}$ & 0.000 & 0.036 & 0.159 \\
\hline Test F & $1.24^{*}$ & & \\
\hline \multirow[t]{2}{*}{ Hausman Test } & & 6.64 & \\
\hline & & & (Continue) \\
\hline $\begin{array}{ll}* & \text { Significant } \\
* * & \text { Significan } \\
* * * & \text { Significan }\end{array}$ & $\begin{array}{l}\text { rent from zero a } \\
\text { rent from zero a } \\
\text { rent from zero a }\end{array}$ & $\begin{array}{l}6 \text { level } \\
0 \text { level } \\
\% \text { level }\end{array}$ & \\
\hline
\end{tabular}


Table 3.9 - Regression of market reaction on dividend changes (continued)

\begin{tabular}{|c|c|c|c|}
\hline \multicolumn{4}{|c|}{ Panel B: Dependent variable - BHAR } \\
\hline$B H A R \quad 3_{i}=$ & $\beta_{1} \mathrm{DI} \times \Delta \mathrm{D}$ & $\beta_{2}$ DD $\times \Delta$ & $-\varepsilon_{i, t}$ \\
\hline \multicolumn{4}{|c|}{ Portugal } \\
\hline Coefficient & Pooled OLS & FEM & REM \\
\hline Constant & $\begin{array}{c}-0.001 \\
(-0.414)\end{array}$ & & $\begin{array}{c}-0.001 \\
(-0.217)\end{array}$ \\
\hline DI & $\begin{array}{c}\text { 0.011* } \\
(9.457)\end{array}$ & $\begin{array}{c}0.014^{*} \\
(6.381)\end{array}$ & $\begin{array}{c}0.013 \\
(1.522)\end{array}$ \\
\hline DD & $\begin{array}{c}0.007 \\
(1.252)\end{array}$ & $\begin{array}{c}0.003 \\
(0.633)\end{array}$ & $\begin{array}{c}0.004 \\
(0.334)\end{array}$ \\
\hline $\mathrm{N}$ & 380 & 380 & 380 \\
\hline Adjusted $\mathrm{R}^{2}$ & 0.001 & 0.011 & 0.224 \\
\hline Test F & 1.05 & & \\
\hline Hausman Test & \multicolumn{3}{|c|}{0.76} \\
\hline \multicolumn{4}{|c|}{ France } \\
\hline Coefficient & Pooled OLS & FEM & REM \\
\hline Constant & $\begin{array}{c}0.002 \\
(0.966)\end{array}$ & & $\begin{array}{c}0.003 \\
(0.915)\end{array}$ \\
\hline DI & $\begin{array}{c}-0.103 \\
(-0.437)\end{array}$ & $\begin{array}{l}-0.950^{*} \\
(-3.641)\end{array}$ & $\begin{array}{c}-0.349 \\
(-1.287)\end{array}$ \\
\hline DD & $\begin{array}{c}0.109 \\
(0.855)\end{array}$ & $\begin{array}{l}0.668 * \\
(3.637)\end{array}$ & $\begin{array}{c}0.259 \\
(1.428)\end{array}$ \\
\hline $\mathrm{N}$ & 356 & 356 & 356 \\
\hline Adjusted $\mathrm{R}^{2}$ & 0.001 & 0.026 & 0.237 \\
\hline Test F & 1.12 & & \\
\hline Hausman Test & & $7.10 * *$ & \\
\hline \multicolumn{4}{|l|}{ Hausman Test } \\
\hline \multicolumn{4}{|c|}{$\begin{aligned} \text { BHAR } 3_{i} & =a+\beta_{1} \text { DIEI } \times \Delta \mathrm{D}_{\mathrm{i}, 0}+\beta_{2} \mathrm{~L} \\
& +\beta_{4} \text { DDED } \times \Delta \mathrm{D}_{\mathrm{i}, 0}+\varepsilon_{i, t}\end{aligned}$} \\
\hline Coefficient & Pooled OLS & FEM & REM \\
\hline Constant & $\begin{array}{r}0.019^{*} \\
(11.900)\end{array}$ & & $\begin{array}{c}0.020 * \\
(9.055)\end{array}$ \\
\hline DIEI & $\begin{array}{c}0.026 \\
(0.070)\end{array}$ & $\begin{array}{c}-0.541 \\
(-1.528)\end{array}$ & $\begin{array}{c}-0.276 \\
(-0.855)\end{array}$ \\
\hline DIED & $\begin{array}{c}-0.322 \\
(-0.732)\end{array}$ & $\begin{array}{l}-0.863 * * * \\
(-1.960)\end{array}$ & $\begin{array}{c}-0.611 \\
(-1.542)\end{array}$ \\
\hline DDEI & $\begin{array}{c}-0.223 \\
(-1.110)\end{array}$ & $\begin{array}{c}-0.158 \\
(-0.645)\end{array}$ & $\begin{array}{c}-0.195 \\
(-0.698)\end{array}$ \\
\hline DDED & $\begin{array}{c}0.006 \\
(0.034)\end{array}$ & $\begin{array}{c}-0.004 \\
(-0.026)\end{array}$ & $\begin{array}{c}-0.006 \\
(-0.039)\end{array}$ \\
\hline $\mathrm{N}$ & 3,278 & 3,278 & 3,278 \\
\hline Adjusted $\mathrm{R}^{2}$ & 0.000 & 0.039 & 0.163 \\
\hline Test $\mathrm{F}$ & $1.26^{*}$ & & \\
\hline Hausman Test & & 7.27 & \\
\hline
\end{tabular}

* $\quad$ Significantly different from zero at the $1 \%$ level

** $\quad$ Significantly different from zero at the $5 \%$ level

$* * * \quad$ Significantly different from zero at the $10 \%$ level 


\section{Table 3.10 - Regression of earnings changes on dividend changes and correlation matrix}

This table reports the estimation of a regression relating earnings changes to dividend changes and the correlations between the independent variables. Panel A presents the Pearson correlations between independent variables, for years $=1$ and $=2$ (year 0 is the event year). E denotes earnings before extraordinary items in year ; $\mathrm{BV}_{-1}$ is the book value of equity at the end of year $-1 ; \mathrm{D}_{\mathrm{i}, 0}$ is the annual change in the cash dividend payment, scaled by the share price in the announcement day; DI is a dummy variable that takes the value 1 if dividend increases and 0 otherwise; DD is a dummy variable that takes the value 1 if dividend decreases and 0 otherwise; DIEI is a dummy variable that takes value 1 if both dividend and earnings increase and zero otherwise; DIED is a dummy variable that takes value 1 if dividend increases and earnings decrease and zero otherwise; DDEI is a dummy variable that takes value 1 if dividend decreases and earnings increases and zero otherwise; DDED is a dummy variable that takes value 1 if both dividend and earnings decrease and zero otherwise; $\mathrm{ROE}_{-1}$ is equal to the earnings before extraordinary items in year -1 scaled by the book value of equity at the end of year -1 . Panel B presents the regression results estimated using pooled OLS, FEM and REM. The numbers in parentheses are the tstatistics corrected for heteroscedasticity using the White (1980) method. It reports the F test, a test for the equality of sets of coefficients, and the Hausman (1978) test, a test with $\mathrm{H}_{0}$ : random effects are consistent and efficient, versus $\mathrm{H}_{1}$ : random effects are inconsistent, in order to choose the most appropriate model for each particular sample.

\begin{tabular}{|c|c|c|c|c|}
\hline \multicolumn{5}{|c|}{ Panel A: Pearson correlations between independent variables (significance in parenthesis) } \\
\hline \multicolumn{5}{|c|}{ Portugal } \\
\hline & \multicolumn{4}{|c|}{$=1$} \\
\hline & $\mathrm{DI} \times \Delta \mathrm{D}_{\mathrm{i}, 0}$ & $\mathrm{DD} \times \Delta \mathrm{D}_{\mathrm{i}, 0}$ & $\mathrm{ROE}_{\mathrm{i},-1}$ & $\left(\mathrm{E}_{\mathrm{i}, 0}-\mathrm{E}_{\mathrm{i},-1}\right) / \mathrm{BV}_{\mathrm{i},-1}$ \\
\hline DI $x \Delta \mathrm{D}_{\mathrm{i}, 0}$ & 1.000 & $\begin{array}{c}0.038 \\
(0.474)\end{array}$ & $\begin{array}{c}0.012 \\
(0.825)\end{array}$ & $\begin{array}{l}-0.069 \\
(0.194)\end{array}$ \\
\hline $\mathrm{DD} \times \Delta \mathrm{D}_{\mathrm{i}, 0}$ & & 1.000 & $\begin{array}{c}0.043 \\
(0.424)\end{array}$ & $\begin{array}{c}0.029 \\
(0.589)\end{array}$ \\
\hline $\mathrm{ROE}_{\mathrm{i},-1}$ & & & 1.000 & $\begin{array}{c}0.484 * \\
(0.000)\end{array}$ \\
\hline \multirow[t]{3}{*}{$\left(\mathrm{E}_{\mathrm{i}, 0}-\mathrm{E}_{\mathrm{i},-1}\right) / \mathrm{BV}_{\mathrm{i},-1}$} & & & & 1.000 \\
\hline & \multicolumn{4}{|c|}{$=2$} \\
\hline & DI x $\Delta \mathrm{D}_{\mathrm{i}, 0}$ & $\mathrm{DD} \times \Delta \mathrm{D}_{\mathrm{i}, 0}$ & $\mathrm{ROE}_{\mathrm{i},-1}$ & $\left(\mathrm{E}_{\mathrm{i}, 0}-\mathrm{E}_{\mathrm{i},-1}\right) / \mathrm{BV}_{\mathrm{i},-1}$ \\
\hline DI $x \Delta \mathrm{D}_{\mathrm{i}, 0}$ & 1.000 & $\begin{array}{c}0.074 \\
(0.173)\end{array}$ & $\begin{array}{c}0.056 \\
(0.302)\end{array}$ & $\begin{array}{l}-0.003 \\
(0.958)\end{array}$ \\
\hline $\mathrm{DD} \times \Delta \mathrm{D}_{\mathrm{i}, 0}$ & & 1.000 & $\begin{array}{c}0.017 \\
(0.758)\end{array}$ & $\begin{array}{c}0.009 \\
(0.875)\end{array}$ \\
\hline $\mathrm{ROE}_{\mathrm{i},-1}$ & & & 1.000 & $\begin{array}{c}0.298 * \\
(0.000)\end{array}$ \\
\hline$\left(\mathrm{E}_{\mathrm{i}, 0}-\mathrm{E}_{\mathrm{i},-1}\right) / \mathrm{BV}_{\mathrm{i},-1}$ & & & & 1.000 \\
\hline
\end{tabular}

* $\quad$ Significantly different from zero at the $1 \%$ level

** $\quad$ Significantly different from zero at the $5 \%$ level

$* * * \quad$ Significantly different from zero at the $10 \%$ level 
Table 3.10 - Regression of earnings changes on dividend changes and correlation matrix (continued)

\begin{tabular}{|c|c|c|c|c|}
\hline \multicolumn{5}{|c|}{ Panel A: Pearson correlations between independent variables (significance in parenthesis) } \\
\hline \multicolumn{5}{|c|}{ France } \\
\hline & \multicolumn{4}{|c|}{$=1$} \\
\hline \multirow[b]{2}{*}{$\mathrm{DI} \times \Delta \mathrm{D}_{\mathrm{i}, 0}$} & $\mathrm{DI} x \Delta \mathrm{D}_{\mathrm{i}, 0}$ & $\mathrm{DD} \times \Delta \mathrm{D}_{\mathrm{i}, 0}$ & $\mathrm{ROE}_{\mathrm{i},-1}$ & $\left(\mathrm{E}_{\mathrm{i}, 0}-\mathrm{E}_{\mathrm{i},-1}\right) / \mathrm{BV}_{\mathrm{i},-1}$ \\
\hline & 1.000 & $\begin{array}{c}0.061 \\
(0.286)\end{array}$ & $\begin{array}{l}-0.020 \\
(0.731)\end{array}$ & $\begin{array}{c}0.026 \\
(0.655)\end{array}$ \\
\hline $\mathrm{DD} \times \Delta \mathrm{D}_{\mathrm{i}, 0}$ & & 1.000 & $\begin{array}{l}-0.015 \\
(0.790)\end{array}$ & $\begin{array}{l}-0.040 \\
(0.489)\end{array}$ \\
\hline $\operatorname{ROE}_{i,-1}$ & & & 1.000 & $\begin{array}{c}0.485^{*} \\
(0.000)\end{array}$ \\
\hline \multirow[t]{3}{*}{$\left(\mathrm{E}_{\mathrm{i}, 0}-\mathrm{E}_{\mathrm{i},-1}\right) / \mathrm{BV}_{\mathrm{i},-1}$} & & & & 1.000 \\
\hline & \multicolumn{4}{|c|}{$=2$} \\
\hline & $\mathrm{DI} \times \Delta \mathrm{D}_{\mathrm{i}, 0}$ & $\mathrm{DD} \times \Delta \mathrm{D}_{\mathrm{i}, 0}$ & $\mathrm{ROE}_{\mathrm{i},-1}$ & $\left(\mathrm{E}_{\mathrm{i}, 0}-\mathrm{E}_{\mathrm{i},-1}\right) / \mathrm{BV}_{\mathrm{i},-1}$ \\
\hline DI x $\Delta \mathrm{D}_{\mathrm{i}, 0}$ & 1.000 & $\begin{array}{c}0.090 \\
(0.173)\end{array}$ & $\begin{array}{l}-0.078 \\
(0.238)\end{array}$ & $\begin{array}{l}-0.003 \\
(0.966)\end{array}$ \\
\hline $\mathrm{DD} \times \Delta \mathrm{D}_{\mathrm{i}, 0}$ & & 1.000 & $\begin{array}{l}-0.013 \\
(0.840)\end{array}$ & $\begin{array}{l}-0.024 \\
(0.715)\end{array}$ \\
\hline $\mathrm{ROE}_{\mathrm{i},-1}$ & & & 1.000 & $\begin{array}{c}0.023 \\
(0.728)\end{array}$ \\
\hline \multirow[t]{2}{*}{$\left(\mathrm{E}_{\mathrm{i}, 0}-\mathrm{E}_{\mathrm{i},-1}\right) / \mathrm{BV}_{\mathrm{i},-1}$} & & & & 1.000 \\
\hline & & & & (Continue) \\
\hline $\begin{array}{ll}* & \text { Signifi } \\
* * & \text { Signifi } \\
* * * & \text { Signifi }\end{array}$ & $\begin{array}{l}\text { different from } \\
\text { different from } \\
\text { different from }\end{array}$ & $\begin{array}{l}\text { e } 1 \% \text { level } \\
5 \% \text { level } \\
\text { e } 10 \% \text { level }\end{array}$ & & \\
\hline
\end{tabular}


Table 3.10 - Regression of earnings changes on dividend changes and correlation matrix (continued)

\begin{tabular}{|c|c|c|c|c|c|c|}
\hline \multicolumn{7}{|c|}{ Panel A: Pearson correlations between independent variables (significance in parenthesis) } \\
\hline \multicolumn{7}{|c|}{ UK } \\
\hline & \multicolumn{6}{|c|}{$=1$} \\
\hline \multirow{3}{*}{ DIEI x $\Delta \mathrm{D}_{\mathrm{i}, 0}$} & DIEIx $\Delta \mathrm{D}_{\mathrm{i}, 0}$ & DIED x $\Delta \mathrm{D}_{\mathrm{i}, 0}$ & DDEIx $\Delta \mathrm{Di}, 0$ & DDED x $\Delta \mathrm{D}_{\mathrm{i}, 0}$ & $\mathrm{ROE}_{\mathrm{i},-1}$ & $\left(\mathrm{E}_{\mathrm{i}, 0^{-}}-\mathrm{E}_{\mathrm{i},-1}\right) / \mathrm{BV}_{\mathrm{i},-1}$ \\
\hline & 1.000 & $-0.152 *$ & $0.050 *$ & $0.071^{*}$ & $0.037 * *$ & -0.023 \\
\hline & & $(0.000)$ & $(0.008)$ & $(0.000)$ & $(0.047)$ & $(0.215)$ \\
\hline \multirow[t]{2}{*}{ DIED x $\Delta \mathrm{D}_{\mathrm{i}, 0}$} & & 1.000 & 0.023 & 0.033 & $-0.039 * *$ & -0.006 \\
\hline & & & $(0.231)$ & $(0.084)$ & $(0.041)$ & $(0.763)$ \\
\hline \multirow[t]{2}{*}{ DDEI x $\Delta \mathrm{D}_{\mathrm{i}, 0}$} & & & 1.000 & -0.011 & -0.020 & 0.030 \\
\hline & & & & $(0.574)$ & $(0.296)$ & $(0.115)$ \\
\hline \multirow[t]{2}{*}{ DDED x $\Delta \mathrm{D}_{\mathrm{i}, 0}$} & & & & 1.000 & $0.062 *$ & 0.008 \\
\hline & & & & & $(0.001)$ & $(0.685)$ \\
\hline \multirow[t]{2}{*}{$\mathrm{ROE}_{\mathrm{i},-1}$} & & & & & 1.000 & $0.237^{*}$ \\
\hline & & & & & & $(0.000)$ \\
\hline \multirow[t]{3}{*}{$\left(\mathrm{E}_{\mathrm{i}, 0}-\mathrm{E}_{\mathrm{i},-1}\right) / \mathrm{BV}_{\mathrm{i},-1}$} & & & & & & 1.000 \\
\hline & \multicolumn{6}{|c|}{$=2$} \\
\hline & DIEIx $\Delta D_{i, 0}$ & DIED x $\Delta \mathrm{D}_{\mathrm{i}, 0}$ & DDEIx $\Delta \mathrm{Di}, 0$ & DDED x $\Delta \mathrm{D}_{\mathrm{i}, 0}$ & $\mathrm{ROE}_{\mathrm{i},-1}$ & $\left(\mathrm{E}_{\mathrm{i}, 0}-\mathrm{E}_{\mathrm{i},-1}\right) / \mathrm{BV}_{\mathrm{i},-1}$ \\
\hline \multirow[t]{2}{*}{ DIEI $x \Delta \mathrm{D}_{\mathrm{i}, 0}$} & 1.000 & $-0.161 *$ & $0.054^{*}$ & $0.077 *$ & -0.017 & -0.024 \\
\hline & & $(0.000)$ & $(0.008)$ & $(0.000)$ & $(0.411)$ & $(0.253)$ \\
\hline \multirow[t]{2}{*}{ DIED x $\Delta \mathrm{D}_{\mathrm{i}, 0}$} & & 1.000 & 0.023 & 0.032 & -0.007 & -0.012 \\
\hline & & & $(0.268)$ & $(0.117)$ & $(0.717)$ & $(0.553)$ \\
\hline \multirow[t]{2}{*}{ DDEI x $\Delta \mathrm{D}_{\mathrm{i}, 0}$} & & & 1.000 & -0.011 & 0.015 & -0.019 \\
\hline & & & & $(0.597)$ & $(0.468)$ & $(0.360)$ \\
\hline \multirow[t]{2}{*}{$\operatorname{DDED} \times \Delta \mathrm{D}_{\mathrm{i}, 0}$} & & & & 1.000 & 0.029 & -0.008 \\
\hline & & & & & $(0.163)$ & $(0.710)$ \\
\hline \multirow[t]{2}{*}{$\mathrm{ROE}_{i,-1}$} & & & & & 1.000 & $0.057 *$ \\
\hline & & & & & & $(0.005)$ \\
\hline$\left(\mathrm{E}_{\mathrm{i}, 0}-\mathrm{E}_{\mathrm{i},-1}\right) / \mathrm{BV}_{\mathrm{i},-1}$ & & & & & & 1.000 \\
\hline
\end{tabular}

* $\quad$ Significantly different from zero at the $1 \%$ level

** $\quad$ Significantly different from zero at the $5 \%$ level

$* * * \quad$ Significantly different from zero at the $10 \%$ level 
Table 3.10 - Regression of earnings changes on dividend changes and correlation matrix (continued)

\begin{tabular}{|c|c|c|c|c|c|c|}
\hline $\begin{array}{l}\text { Panel B: } \\
\left(\begin{array}{lll}\mathrm{E}_{i, \tau} & E_{i, \tau} & 1\end{array}\right) / B V_{1}=c\end{array}$ & $+\beta_{1} \mathrm{DIx} \Delta \mathrm{D}_{\mathrm{i}, 0}+\beta_{2}$ & $\beta_{2} \mathrm{DD}$ & $\mathrm{D}_{\mathrm{i}, 0}+\beta_{3} R O E_{i, \tau}$ & ${ }_{t 1}+\beta_{4}\left(E_{i, 0}\right.$ & $\left.E_{i, 1}\right) / B V_{i, 1}$ & $+\varepsilon_{i, t}$ \\
\hline & & Por & & & & \\
\hline Coefficient & Pooled OLS & & FEM & & REM & \\
\hline & & & $=1$ & & & \\
\hline Constant & 0.028 & $* *$ & & & 0.048 & $*$ \\
\hline & $(2.537)$ & & & & $(2.694)$ & \\
\hline DI $x \Delta D_{i, 0}$ & -0.019 & $* *$ & 0.005 & & 0.001 & \\
\hline & $(-2.302)$ & & (0.498) & & $(0.053)$ & \\
\hline $\mathrm{DD} \times \Delta \mathrm{D}_{\mathrm{i}, 0}$ & 0.018 & & 0.035 & & 0.034 & \\
\hline & $(0.497)$ & & $(0.709)$ & & $(0.490)$ & \\
\hline $\mathrm{ROE}_{\mathrm{i},-1}$ & -0.442 & $*$ & -0.725 & $*$ & -0.687 & $*$ \\
\hline & $(-3.587)$ & & $(-4.578)$ & & $(-8.931)$ & \\
\hline$\left(\mathrm{E}_{\mathrm{i}, 0}-\mathrm{E}_{\mathrm{i},-1}\right) / \mathrm{BV}_{\mathrm{i},-1}$ & -0.346 & $*$ & 0.055 & & -0.008 & \\
\hline & $(-2.765)$ & & $(0.400)$ & & $(-0.116)$ & \\
\hline $\mathrm{N}$ & 364 & & 364 & & 364 & \\
\hline Adjusted $\mathrm{R}^{2}$ & 0.50 & & 0.602 & & 0.691 & \\
\hline Test $\mathrm{F}$ & 2.11 & $*$ & & & & \\
\hline Hausman Test & & & 62.09 & $*$ & & \\
\hline & & & $=2$ & & & \\
\hline Constant & 0.008 & & & & 0.027 & \\
\hline & $(0.992)$ & & & & $(1.458)$ & \\
\hline DI $x \Delta D_{i, 0}$ & 0.152 & $*$ & 0.053 & & 0.075 & \\
\hline & $(2.642)$ & & $(0.674)$ & & $(0.585)$ & \\
\hline $\mathrm{DD} \times \Delta \mathrm{D}_{\mathrm{i}, 0}$ & -0.041 & & 0.036 & & 0.02 & \\
\hline & $(-0.681)$ & & $(0.630)$ & & $(0.210)$ & \\
\hline $\mathrm{ROE}_{i,-1}$ & -0.39 & $*$ & -0.701 & $*$ & -0.642 & $*$ \\
\hline & $(-3.947)$ & & $(-4.618)$ & & $(-9.373)$ & \\
\hline$\left(\mathrm{E}_{\mathrm{i}, 0}-\mathrm{E}_{\mathrm{i},-1}\right) / \mathrm{BV}_{\mathrm{i},-1}$ & 0.129 & & -0.106 & & -0.022 & \\
\hline & (1.020) & & $(-1.071)$ & & $(-0.329)$ & \\
\hline $\mathrm{N}$ & 346 & & 346 & & 346 & \\
\hline Adjusted $\mathrm{R}^{2}$ & 0.089 & & 0.234 & & 0.407 & \\
\hline Test F & 1.78 & $*$ & & & & \\
\hline Hausman Test & & & 79.5 & $*$ & & \\
\hline & & & & & (Contin & iue) \\
\hline Signific: & tly different from & zero & the $1 \%$ level & & & \\
\hline$* * \quad$ Signific & tly different from & zero & the $5 \%$ level & & & \\
\hline$* * * \quad$ Signific & tly different from & zero & the $10 \%$ level & & & \\
\hline
\end{tabular}


Table 3.10 - Regression of earnings changes on dividend changes and correlation matrix (continued)

\begin{tabular}{|c|c|c|c|c|c|c|}
\hline $\begin{array}{l}\text { Panel B: } \\
\left(\begin{array}{ll}\mathrm{E}_{i, \tau} & E_{i, \tau}\end{array}\right) / B V_{1}=\end{array}$ & $-\beta_{1} \mathrm{DI} x \Delta \mathrm{D}_{\mathrm{i}, 0}+\beta$ & $\beta_{2} \mathrm{DD}$ & $\mathrm{i}, 0_{0}+\beta_{3} R O E_{i, \tau}$ & ${ }_{1}+\beta_{4}\left(E_{i, 4}\right.$ & $\left.E_{i, 1}\right) / B V_{i, 1}$ & \\
\hline & & Fre & & & & \\
\hline Coefficient & Pooled OLS & & FEM & & REM & \\
\hline & & & $=1$ & & & \\
\hline Constant & $\begin{array}{r}0.007 \\
(0.870)\end{array}$ & & & & $\begin{array}{r}0.022 \\
(3.146)\end{array}$ & * \\
\hline $\mathrm{DI} \times \Delta \mathrm{D}_{\mathrm{i}, 0}$ & $\begin{array}{r}0.236 \\
(0.876)\end{array}$ & & $\begin{array}{r}0.171 \\
(0.539)\end{array}$ & & $\begin{array}{r}0.184 \\
(0.437)\end{array}$ & \\
\hline $\mathrm{DD} \times \Delta \mathrm{D}_{\mathrm{i}, 0}$ & $\begin{array}{r}-0.051 \\
(-1.614)\end{array}$ & & $\begin{array}{r}0.007 \\
(0.057)\end{array}$ & & $\begin{array}{r}-0.062 \\
(-0.237)\end{array}$ & \\
\hline $\mathrm{ROE}_{\mathrm{i},-1}$ & $\begin{array}{r}-0.216 \\
(-1.582)\end{array}$ & & $\begin{array}{r}-0.728 \\
(-3.833)\end{array}$ & * & $\begin{array}{r}-0.533 \\
(-6.477)\end{array}$ & * \\
\hline$\left(\mathrm{E}_{\mathrm{i}, 0}-\mathrm{E}_{\mathrm{i},-1}\right) / \mathrm{BV}_{\mathrm{i},-1}$ & $\begin{array}{r}-0.218 \\
(-1.777)\end{array}$ & $* * *$ & $\begin{array}{r}-0.228 \\
(-2.141)\end{array}$ & $* *$ & $\begin{array}{r}-0.274 \\
(-3.378)\end{array}$ & $*$ \\
\hline $\mathrm{N}$ & 311 & & 311 & & 311 & \\
\hline Adjusted $\mathrm{R}^{2}$ & 0.102 & & 0.411 & & 0.565 & \\
\hline Test $\mathrm{F}$ & 2.11 & $*$ & & & & \\
\hline Hausman Test & & & 62.09 & $*$ & & \\
\hline & & & $=2$ & & & \\
\hline Constant & $\begin{array}{r}0.014 \\
(1.243)\end{array}$ & & & & $\begin{array}{r}0.036 \\
(4.322)\end{array}$ & \\
\hline DI x $\Delta \mathrm{D}_{\mathrm{i}, 0}$ & $\begin{array}{r}0.539 \\
(1.185)\end{array}$ & & $\begin{array}{r}0.017 \\
(0.067)\end{array}$ & & $\begin{array}{r}0.096 \\
(0.214)\end{array}$ & \\
\hline $\mathrm{DD} \times \Delta \mathrm{D}_{\mathrm{i}, 0}$ & $\begin{array}{r}-0.069 \\
(-0.359)\end{array}$ & & $\begin{array}{r}-0.229 \\
(-1.183)\end{array}$ & & $\begin{array}{r}-0.19 \\
(-0.554)\end{array}$ & \\
\hline $\mathrm{ROE}_{\mathrm{i},-1}$ & $\begin{array}{r}-0.454 \\
(-2.565)\end{array}$ & $* *$ & $\begin{array}{r}-1.012 \\
(-9.384)\end{array}$ & $*$ & $\begin{array}{r}-0.867 \\
(-12.928)\end{array}$ & \\
\hline$\left(\mathrm{E}_{\mathrm{i}, 0}-\mathrm{E}_{\mathrm{i},-1}\right) / \mathrm{BV}_{\mathrm{i},-1}$ & $\begin{array}{r}0.007 \\
(0.053)\end{array}$ & & $\begin{array}{r}-0.146 \\
(-1.229)\end{array}$ & & $\begin{array}{r}-0.086 \\
(-1.061)\end{array}$ & \\
\hline $\mathrm{N}$ & 236 & & 236 & & 236 & \\
\hline Adjusted $\mathrm{R}^{2}$ & 0.167 & & 0.508 & & 0.678 & \\
\hline Test F & 1.78 & $*$ & & & & \\
\hline Hausman Test & & & 79.5 & $*$ & & \\
\hline & & & & & (Cont & inue) \\
\hline $\begin{array}{ll}* & \text { Significa } \\
* * & \text { Significa } \\
* * * & \text { Significa }\end{array}$ & $\begin{array}{l}\text { different from } \\
\text { different from } \\
\text { different from }\end{array}$ & zero & $\begin{array}{l}1 \% \text { level } \\
5 \% \text { level } \\
10 \% \text { level }\end{array}$ & & & \\
\hline
\end{tabular}


Table 3.10 - Regression of earnings changes on dividend changes and correlation matrix (continued)

\begin{tabular}{|c|c|c|c|c|c|c|}
\hline \multicolumn{7}{|c|}{$\begin{array}{l}\text { Panel B: } \\
\left(\mathrm{E}_{i, \tau}-E_{i, \tau-1}\right) / B V_{i,-1}=a+\beta_{1} \mathrm{DIEI} \times \Delta \mathrm{D}_{\mathrm{i}, 0}+\beta \\
+\beta_{5} R O E_{i, \tau-1}+\beta_{6}\left(E_{i, 0}-E_{i,-1}\right) / B V_{i,-1}+\varepsilon_{i, t}\end{array}$} \\
\hline \multicolumn{7}{|c|}{ 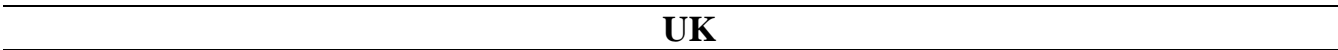 } \\
\hline \multirow[t]{2}{*}{ Coefficient } & \multicolumn{2}{|l|}{ Pooled OLS } & \multicolumn{2}{|l|}{ FEM } & REM & \\
\hline & \multicolumn{5}{|c|}{$=1$} & \\
\hline \multirow[t]{2}{*}{ Constant } & 0.013 & & & & 0.013 & \\
\hline & (1.158) & & & & (1.177) & \\
\hline \multirow{2}{*}{ DIEI x $\Delta \mathrm{D}_{\mathrm{i}, 0}$} & -1.499 & & -0.813 & & -1.254 & \\
\hline & $(-1.260)$ & & $(-0.592)$ & & $(-0.767)$ & \\
\hline \multirow[t]{2}{*}{ DIED x $\Delta \mathrm{D}_{\mathrm{i}, 0}$} & -1.542 & & 0.109 & & -0.93 & \\
\hline & $(-0.736)$ & & $(0.054)$ & & $(-0.464)$ & \\
\hline \multirow[t]{2}{*}{ DDEI $\times \Delta \mathrm{D}_{\mathrm{i}, 0}$} & -6.98 & $* *$ & -7.454 & $* *$ & $-7.124 *$ & * \\
\hline & $(-2.402)$ & & $(-2.361)$ & & $(-4.780)$ & \\
\hline \multirow[t]{2}{*}{ DDED $x \Delta \mathrm{D}_{\mathrm{i}, 0}$} & -1.816 & $* * *$ & -2.768 & $*$ & -2.176 * & ** \\
\hline & $(-1.861)$ & & $(-2.754)$ & & $(-2.387)$ & \\
\hline \multirow[t]{2}{*}{$\mathrm{ROE}_{\mathrm{i},-1}$} & -0.102 & $* * *$ & -0.129 & $* * *$ & $-0.111 *$ & $*$ \\
\hline & $(-1.861)$ & & $(-1.885)$ & & $(-4.461)$ & \\
\hline \multirow[t]{2}{*}{$\left(\mathrm{E}_{\mathrm{i}, 0}-\mathrm{E}_{\mathrm{i},-1}\right) / \mathrm{BV}_{\mathrm{i},-1}$} & -0.188 & * & -0.263 & * & $-0.22 *$ & * \\
\hline & $(-3.258)$ & & $(-4.873)$ & & $(-10.963)$ & \\
\hline $\mathrm{N}$ & 2811 & & 2811 & & 2811 & \\
\hline Adjusted $\mathrm{R}^{2}$ & 0.053 & & 0.041 & & 0.169 & \\
\hline Test $\mathrm{F}$ & 0.93 & & & & & \\
\hline \multirow[t]{2}{*}{ Hausman Test } & & & 73.44 & $*$ & & \\
\hline & & & $=2$ & & & \\
\hline \multirow[t]{2}{*}{ Constant } & -0.011 & & & & -0.008 & \\
\hline & $(-0.844)$ & & & & $(-0.545)$ & \\
\hline \multirow[t]{2}{*}{ DIEI $x \Delta \mathrm{D}_{\mathrm{i}, 0}$} & 2.946 & $* * *$ & 2.429 & & 2.734 & \\
\hline & (1.795) & & $(1.375)$ & & $(1.251)$ & \\
\hline \multirow[t]{2}{*}{ DIED x $\Delta \mathrm{D}_{\mathrm{i}, 0}$} & -0.36 & & -0.809 & & -0.567 & \\
\hline & $(-0.157)$ & & $(-0.372)$ & & $(-0.206)$ & \\
\hline \multirow[t]{2}{*}{ DDEI x $\Delta \mathrm{D}_{\mathrm{i}, 0}$} & 1.517 & & -0.62 & & 0.667 & \\
\hline & $(0.322)$ & & $(-0.234)$ & & $(0.303)$ & \\
\hline \multirow[t]{2}{*}{$\operatorname{DDED} \times \Delta \mathrm{D}_{\mathrm{i}, 0}$} & 0.115 & & -0.246 & & -0.025 & \\
\hline & $(0.210)$ & & $(-0.345)$ & & $(-0.021)$ & \\
\hline \multirow[t]{2}{*}{$\mathrm{ROE}_{\mathrm{i},-1}$} & -0.089 & & -0.142 & $* *$ & -0.109 * & * \\
\hline & $(-1.632)$ & & $(-2.311)$ & & $(-3.679)$ & \\
\hline \multirow[t]{2}{*}{$\left(\mathrm{E}_{\mathrm{i}, 0}-\mathrm{E}_{\mathrm{i},-1}\right) / \mathrm{BV}_{\mathrm{i},-1}$} & 0.037 & & 0.036 & & 0.037 & \\
\hline & $(0.622)$ & & $(0.628)$ & & (1.584) & \\
\hline $\mathrm{N}$ & 2359 & & 2359 & & 2359 & \\
\hline Adjusted $\mathrm{R}^{2}$ & 0.004 & & 0.003 & & 0.137 & \\
\hline Test $\mathrm{F}$ & 0.81 & & & & & \\
\hline Hausman Test & & & 7.5 & & & \\
\hline
\end{tabular}

* $\quad$ Significantly different from zero at the $1 \%$ level

** $\quad$ Significantly different from zero at the $5 \%$ level

*** Significantly different from zero at the $10 \%$ level 


\section{Table 3.11 - Regression of earnings changes on dividend changes using Fama and French Approach}

This table reports the estimation of a regression relating earnings changes to dividend changes considering globally (Panel A) and with dividend increases and decreases treated separately (Panel B) using the Fama and French (2000) approach to predict expected earnings. E denotes earnings before extraordinary items in year (year 0 is the event year). $\mathrm{BV}_{-1}$ is the book value of equity at the end of year $-1 ; \quad D_{t}$ is the annual change in the cash dividend payment, scaled by the share price in the announcement day; ROE is equal to the earnings before extraordinary items in year scaled by the book value of equity at the end of year ; $\mathrm{DFE}_{0}$ is equal to $\mathrm{ROE}_{0}-\mathrm{E} \mathrm{ROE}_{0}$, where $\mathrm{E} \mathrm{ROE}_{0}$ is the fitted value from the crosssectional regression of $\mathrm{ROE}_{0}$ on the $\log$ of total assets in year -1 , the market-to-book ratio of equity in year -1 , and $\mathrm{ROE}_{-1} ; \mathrm{CE}_{0}$ is equal to $\left(\mathrm{E}_{0}-\mathrm{E}_{-1}\right) / \mathrm{BV}_{-1}$. $\mathrm{NDFED}_{0}$ is a dummy variable that takes value 1 if $\mathrm{DFE}_{0}$ is negative and 0 otherwise; $\mathrm{PDFED}_{0}$ is a dummy variable that takes value 1 if $\mathrm{DFE}_{0}$ is positive and 0 otherwise; $\mathrm{NCED}_{0}$ is a dummy variable that takes value 1 if $\mathrm{CE}_{0}$ is negative and 0 otherwise; $\mathrm{PCED}_{0}$ is a dummy variable that takes value 1 if $\mathrm{CE}_{0}$ is positive and 0 otherwise; $\mathrm{DI}$ (DD) is a dummy variable that takes the value 1 for dividend increases (decreases) and 0 otherwise. The regressions were estimated using pooled OLS, FEM and REM. The numbers in parentheses are the t-statistics corrected for heteroscedasticity using the White (1980) method. It reports the F test, a test for the equality of sets of coefficients, and the Hausman (1978) test, a test with $\mathrm{H}_{0}$ : random effects are consistent and efficient, versus $\mathrm{H}_{1}$ : random effects are inconsistent, in order to choose the most appropriate model for each particular sample.

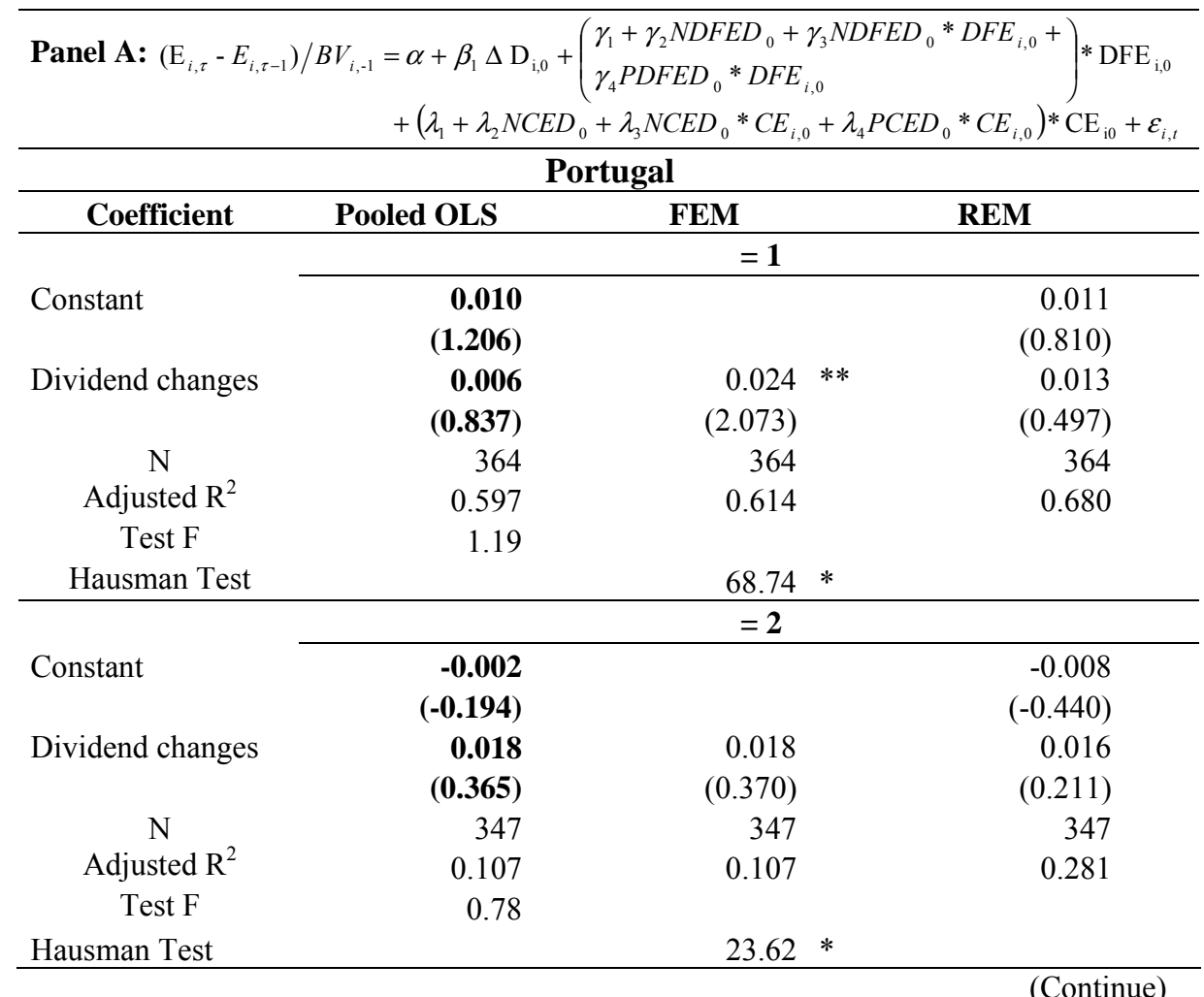

(Continue)

* $\quad$ Significantly different from zero at the $1 \%$ level

** $\quad$ Significantly different from zero at the $5 \%$ level

*** Significantly different from zero at the $10 \%$ level 
Table 3.11 - Regression of earnings changes on dividend changes using Fama and French Approach (continued)

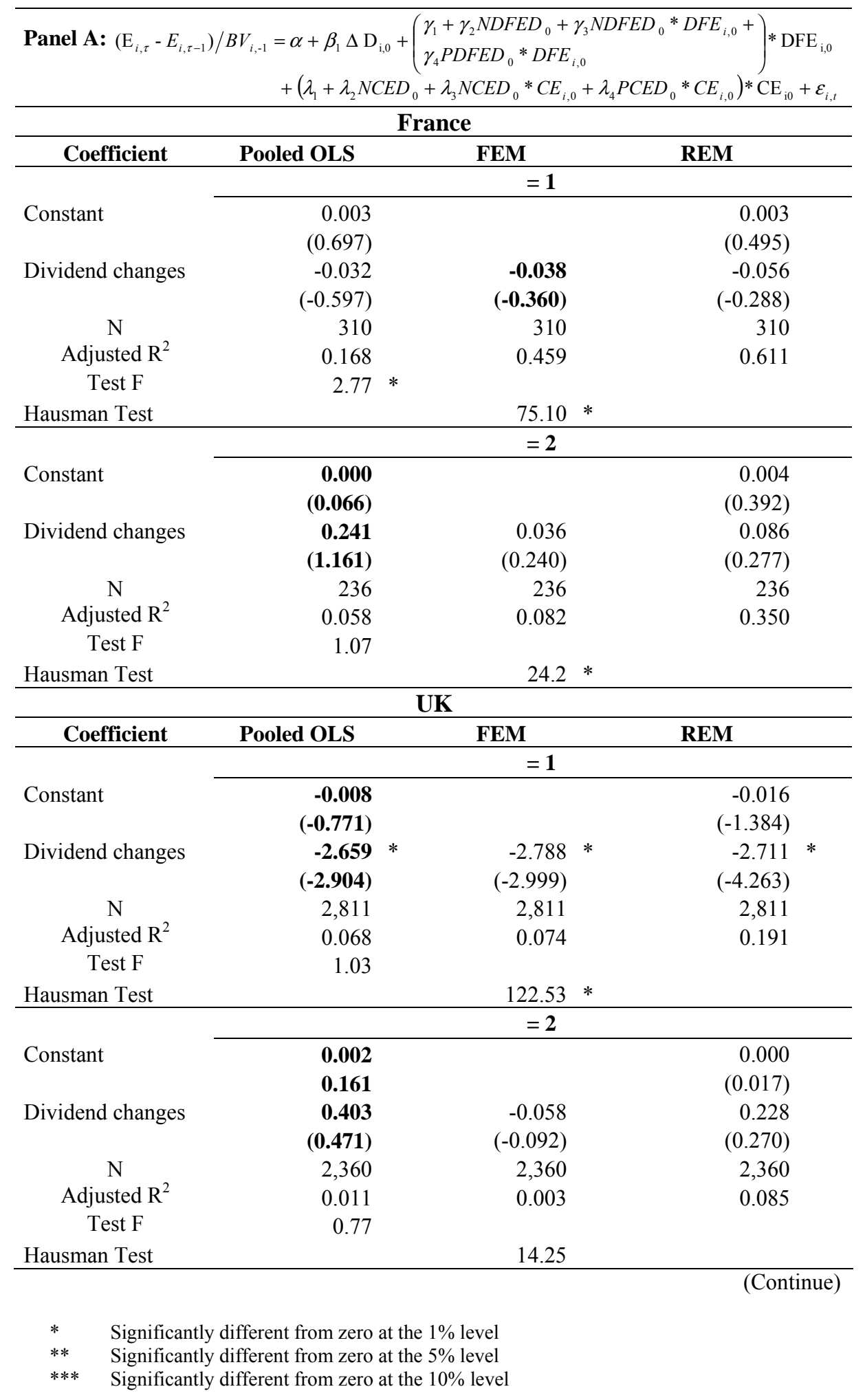


Table 3.11 - Regression of earnings changes on dividend changes using Fama and French Approach (continued)

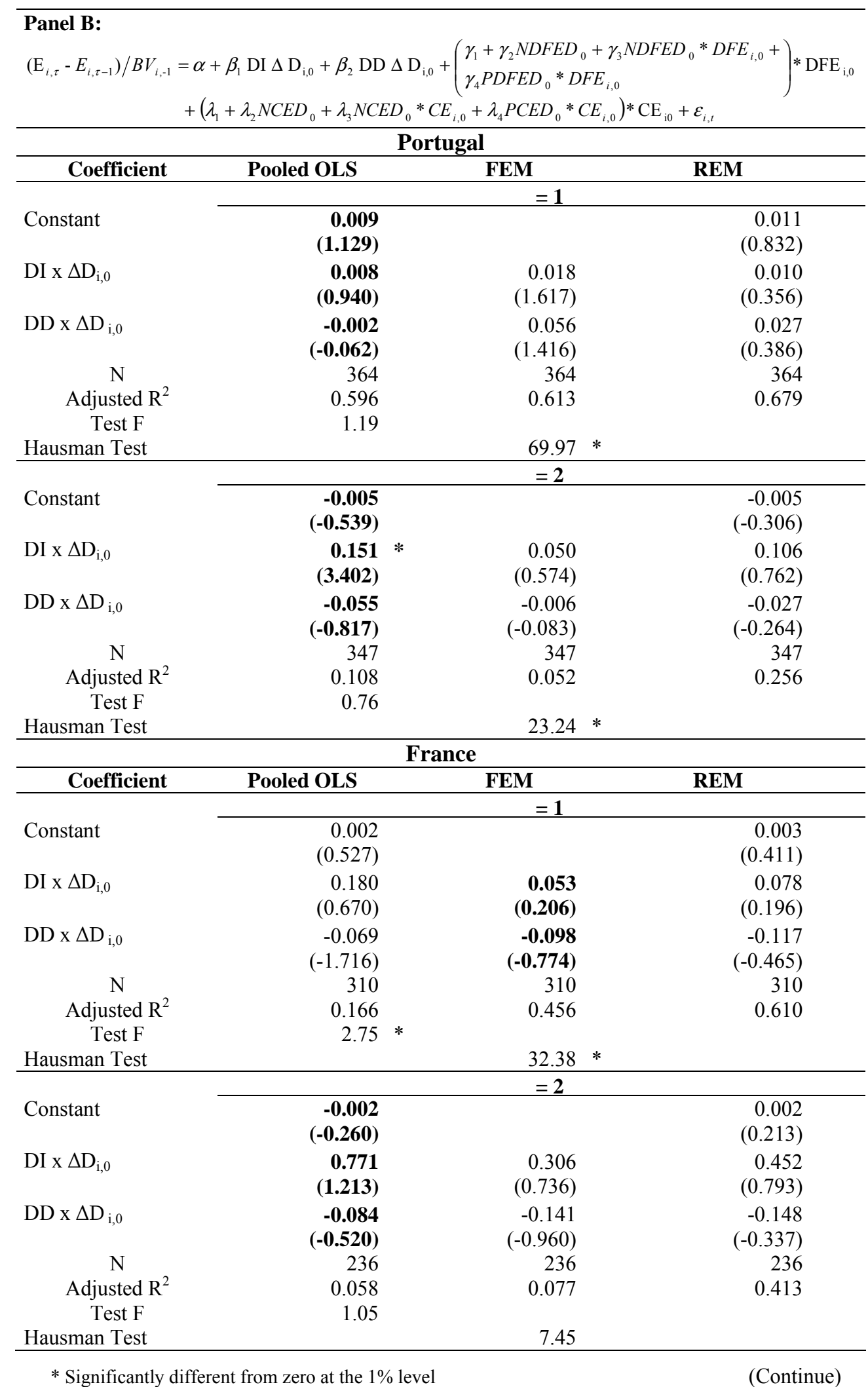


Table 3.11 - Regression of earnings changes on dividend changes using Fama and French Approach (continued)

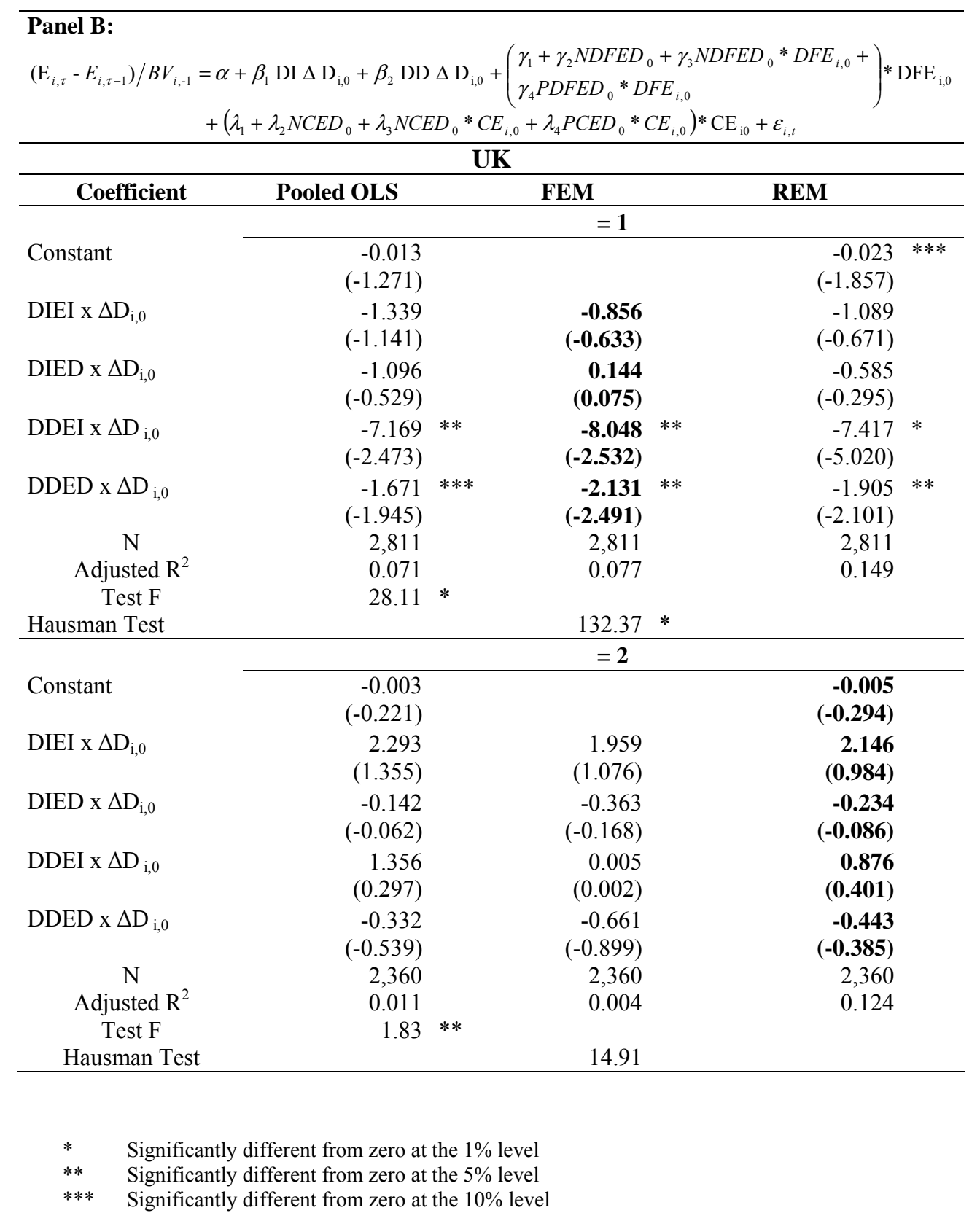




\section{Table 3.12 - Regression of profitability measures changes on dividend changes}

This table reports estimates of regressions relating some profitability measures to dividend changes. ROE is equal to the earnings before extraordinary items in year scaled by the book value of equity at the end of year (Panel A); $\mathrm{ROA}_{\mathrm{i}}$, is equal to the operating income before depreciation in year scaled by book value of assets at the end of year (Panel $\mathrm{B}) ; \mathrm{D} / \mathrm{E}_{\mathrm{i}}$, is the debt to equity ratio calculated as the book value of total debt in year divided by the total book value at the end of year (Panel C); $\mathrm{WCR}_{\mathrm{i}}$, is the working capital ratio, computed as total current assets in year divided by total current liabilities at the end of year

(Panel D); $\mathrm{CF}_{\mathrm{i}}$ is the cash flow, computed as operating income before depreciation less interest expense, income taxes and preferred stock dividends scaled by the total assets at the end of year (Panel $\mathrm{E}) ; \quad \mathrm{D}_{\mathrm{i}, \mathrm{t}}$ is the annual change in the cash dividend payment, scaled by the share price in the announcement day; DI is a dummy variable that takes the value 1 if dividend increases and 0 otherwise; DD is a dummy variable that takes the value 1 if dividend decreases and 0 otherwise; DIEI is a dummy variable that takes value 1 if both dividend and earnings increase and zero otherwise; DIED is a dummy variable that takes value 1 if dividend increases and earnings decrease and zero otherwise; DDEI is a dummy variable that takes value 1 if dividend decreases and earnings increases and zero otherwise; DDED is a dummy variable that takes value 1 if both dividend and earnings decrease and zero otherwise. The regression results were estimated using pooled OLS, FEM and REM. The numbers in parentheses are the t-statistics corrected for heteroscedasticity using the White (1980) method. It reports the F test, a test for the equality of sets of coefficients, and the Hausman (1978) test, a test with $\mathrm{H}_{0}$ : random effects are consistent and efficient, versus $\mathrm{H}_{1}$ : random effects are inconsistent, in order to choose the most appropriate model for each particular sample.

\begin{tabular}{|c|c|c|c|c|c|c|}
\hline \multicolumn{7}{|c|}{$\begin{array}{l}\text { Panel A: } \\
R O A_{, \tau}-\mathrm{ROA}_{i, \tau-1}=\alpha+\beta_{1} \mathrm{DIx}_{\mathrm{N}} \mathrm{D}_{\mathrm{i}, 0}+\beta_{2} \mathrm{DD} \times \Delta \mathrm{D}_{\mathrm{i}, 0}+\beta_{3} \mathrm{ROA}_{i, \tau-1}+\beta_{4}\left(\mathrm{ROA}_{i, 0}-\mathrm{ROA}_{i,-1}\right)+\varepsilon_{i, t}\end{array}$} \\
\hline \multicolumn{7}{|c|}{ Portugal } \\
\hline Coefficient & Pooled OLS & & FEM & & REM & \\
\hline & & & $=1$ & & & \\
\hline Constant & $\begin{array}{r}0.011 \\
(3.071)\end{array}$ & $*$ & & & $\begin{array}{r}0.038 \\
(4.558)\end{array}$ & $*$ \\
\hline DI $x \Delta \mathrm{D}_{\mathrm{i}, 0}$ & $\begin{array}{r}-0.028 \\
(-13.430)\end{array}$ & $*$ & $\begin{array}{r}-0.015 \\
(-2.656)\end{array}$ & $*$ & $\begin{array}{r}-0.019 \\
(-1.823)\end{array}$ & $* * *$ \\
\hline $\mathrm{DD} \times \Delta \mathrm{D}_{\mathrm{i}, 0}$ & $\begin{array}{r}-0.015 \\
(-0.766)\end{array}$ & & $\begin{array}{r}-0.013 \\
(-0.801)\end{array}$ & & $\begin{array}{r}-0.016 \\
(-0.592)\end{array}$ & \\
\hline $\operatorname{ROA}_{i,-1}$ & $\begin{array}{r}-0.233 \\
(-6.404)\end{array}$ & $*$ & $\begin{array}{r}-0.651 \\
(-8.096)\end{array}$ & $*$ & $\begin{array}{r}-0.507 \\
(-10.011)\end{array}$ & $*$ \\
\hline $\operatorname{ROA}_{i, 0}-\mathrm{ROA}_{i,-1}$ & $\begin{array}{r}-0.062 \\
(-0.922)\end{array}$ & & $\begin{array}{r}0.132 \\
(1.764)\end{array}$ & $* * *$ & $\begin{array}{r}0.061 \\
(1.169)\end{array}$ & \\
\hline $\mathrm{N}$ & 364 & & 364 & & 364 & \\
\hline Adjusted $\mathrm{R}^{2}$ & 0.163 & & 0.323 & & 0.466 & \\
\hline Test F & 2.02 & $*$ & & & & \\
\hline Hausman Test & & & 33.73 & $*$ & & \\
\hline & & & $=2$ & & & \\
\hline Constant & $\begin{array}{r}0.010 \\
(3.037)\end{array}$ & $*$ & & & $\begin{array}{r}0.030 \\
(4.347)\end{array}$ & $*$ \\
\hline DI x $\Delta \mathrm{D}_{\mathrm{i}, 0}$ & $\begin{array}{r}-0.038 \\
(-1.116)\end{array}$ & & $\begin{array}{r}-0.014 \\
(-0.436)\end{array}$ & & $\begin{array}{r}-0.024 \\
(-0.588)\end{array}$ & \\
\hline $\mathrm{DD} \times \Delta \mathrm{D}_{\mathrm{i}, 0}$ & $\begin{array}{r}-0.016 \\
(-0.685)\end{array}$ & & $\begin{array}{r}-0.032 \\
(-1.297)\end{array}$ & & $\begin{array}{r}-0.027 \\
(-0.944)\end{array}$ & \\
\hline $\operatorname{ROA}_{i,-1}$ & $\begin{array}{r}-0.213 \\
(-5.996)\end{array}$ & $*$ & $\begin{array}{r}-0.597 \\
(-8.525)\end{array}$ & $*$ & $\begin{array}{r}-0.441 \\
(-9.605)\end{array}$ & $*$ \\
\hline $\mathrm{ROA}_{\mathrm{i}, 0}-\mathrm{ROA}_{\mathrm{i},-1}$ & $\begin{array}{r}-0.052 \\
(-0.897)\end{array}$ & & $\begin{array}{r}-0.007 \\
(-0.113)\end{array}$ & & $\begin{array}{r}-0.037 \\
(-0.739)\end{array}$ & \\
\hline $\mathrm{N}$ & 347 & & 347 & & 347 & \\
\hline Adjusted $\mathrm{R}^{2}$ & 0.114 & & 0.246 & & 0.350 & \\
\hline Test F & 1.72 & $*$ & & & & \\
\hline Hausman Test & & & 60.10 & $*$ & & \\
\hline $\begin{array}{ll}* & \text { Significa } \\
* * & \text { Significa } \\
* * * & \text { Significa }\end{array}$ & $\begin{array}{l}\text { fferent from zero } \\
\text { fferent from zero } \\
\text { fferent from zero }\end{array}$ & $\begin{array}{l}\text { at th } \\
\text { at th } \\
\text { at th }\end{array}$ & $\begin{array}{l}\text { evel } \\
\text { evel } \\
\text { level }\end{array}$ & & (Cont & inue) \\
\hline
\end{tabular}


Table 3.12 - Regression of profitability measures changes on dividend changes (continued)

\begin{tabular}{|c|c|c|c|c|c|c|}
\hline \multicolumn{7}{|c|}{$\begin{array}{l}\text { Panel A: } \\
R O A_{, \tau}-\mathrm{ROA}_{i, \tau-1}=\alpha+\beta_{1} \mathrm{DIx} \mathrm{D}_{\mathrm{i}, 0}+\beta_{2} \mathrm{DD} \mathrm{x} \Delta \mathrm{D}_{\mathrm{i}, 0}+\beta_{3} \mathrm{ROA}_{\tau, \tau-1}+\beta_{4}\left(\mathrm{ROA}_{, 0}-\mathrm{ROA}_{,-1}\right)+\varepsilon_{i, t}\end{array}$} \\
\hline \multicolumn{7}{|c|}{ France } \\
\hline Coefficient & Pooled OLS & & FEM & & REM & \\
\hline \multirow[b]{2}{*}{ Constant } & \multicolumn{6}{|c|}{$=1$} \\
\hline & $\begin{array}{r}0.012 \\
(2.597)\end{array}$ & $*$ & & & $\begin{array}{r}0.024 \\
(4.164)\end{array}$ & $*$ \\
\hline DI x $\Delta \mathrm{D}_{\mathrm{i}, 0}$ & $\begin{array}{r}0.032 \\
(0.181)\end{array}$ & & $\begin{array}{r}-0.036 \\
(-0.218)\end{array}$ & & $\begin{array}{r}-0.007 \\
(-0.020)\end{array}$ & \\
\hline $\mathrm{DD} \times \Delta \mathrm{D}_{\mathrm{i}, 0}$ & $\begin{array}{r}-0.148 \\
(-3.687)\end{array}$ & $*$ & $\begin{array}{r}-0.133 \\
(-0.875)\end{array}$ & & $\begin{array}{r}-0.163 \\
(-0.863)\end{array}$ & \\
\hline $\mathrm{ROA}_{i,-1}$ & $\begin{array}{r}-0.335 \\
(-4.319)\end{array}$ & $*$ & $\begin{array}{r}-0.934 \\
(-5.435)\end{array}$ & $*$ & $\begin{array}{r}-0.545 \\
(-7.107)\end{array}$ & $*$ \\
\hline $\mathrm{ROA}_{\mathrm{i}, 0}-\mathrm{ROA}_{\mathrm{i},-1}$ & $\begin{array}{r}0.037 \\
(0.391)\end{array}$ & & $\begin{array}{r}0.223 \\
(2.973)\end{array}$ & $*$ & $\begin{array}{r}0.068 \\
(1.027)\end{array}$ & \\
\hline $\mathrm{N}$ & 310 & & 310 & & 310 & \\
\hline Adjusted $\mathrm{R}^{2}$ & 0.130 & & 0.274 & & 0.445 & \\
\hline Test F & $1.66^{*}$ & & & & & \\
\hline \multirow[t]{2}{*}{ Hausman Test } & & & 32.72 & $*$ & & \\
\hline & \multicolumn{6}{|c|}{$=2$} \\
\hline Constant & $\begin{array}{r}0.020 \\
(2.763)\end{array}$ & $*$ & & & $\begin{array}{r}0.040 \\
(6.303)\end{array}$ & $*$ \\
\hline DI x $\Delta \mathrm{D}_{\mathrm{i}, 0}$ & $\begin{array}{r}0.251 \\
(1.405)\end{array}$ & & $\begin{array}{r}0.098 \\
(0.982)\end{array}$ & & $\begin{array}{r}0.110 \\
(0.352)\end{array}$ & \\
\hline $\mathrm{DD} \times \Delta \mathrm{D}_{\mathrm{i}, 0}$ & $\begin{array}{r}-0.117 \\
(-0.595)\end{array}$ & & $\begin{array}{r}-0.239 \\
(-1.918)\end{array}$ & $* * *$ & $\begin{array}{r}-0.209 \\
(-0.891)\end{array}$ & \\
\hline $\mathrm{ROA}_{\mathrm{i},-1}$ & $\begin{array}{r}-0.497 \\
(-4.501)\end{array}$ & $*$ & $\begin{array}{r}-1.046 \\
(-6.671)\end{array}$ & $*$ & $\begin{array}{r}-0.871 \\
(-12.686)\end{array}$ & $*$ \\
\hline $\mathrm{ROA}_{\mathrm{i}, 0}-\mathrm{ROA}_{\mathrm{i},-1}$ & $\begin{array}{r}0.024 \\
(0.242)\end{array}$ & & $\begin{array}{r}0.030 \\
(0.419)\end{array}$ & & $\begin{array}{r}0.030 \\
(0.498)\end{array}$ & \\
\hline $\mathrm{N}$ & 235 & & 235 & & 235 & \\
\hline Adjusted $\mathrm{R}^{2}$ & 0.229 & & 0.541 & & 0.639 & \\
\hline Test $\mathrm{F}$ & 2.79 & $*$ & & & & \\
\hline \multirow[t]{2}{*}{ Hausman Test } & & & 77.55 & $*$ & & \\
\hline & & & & & (Cont & nue) \\
\hline $\begin{array}{ll}* & \text { Significa } \\
* * & \text { Significa } \\
* * * & \text { Significa }\end{array}$ & $\begin{array}{l}\text { ifferent from zero a } \\
\text { ifferent from zero a } \\
\text { ifferent from zero a }\end{array}$ & $\begin{array}{l}\text { at } t l \\
\text { at } t \\
\text { at } t\end{array}$ & $\begin{array}{l}\text { evel } \\
\text { evel } \\
\text { level }\end{array}$ & & & \\
\hline
\end{tabular}


Table 3.12 - Regression of profitability measures changes on dividend changes (continued)

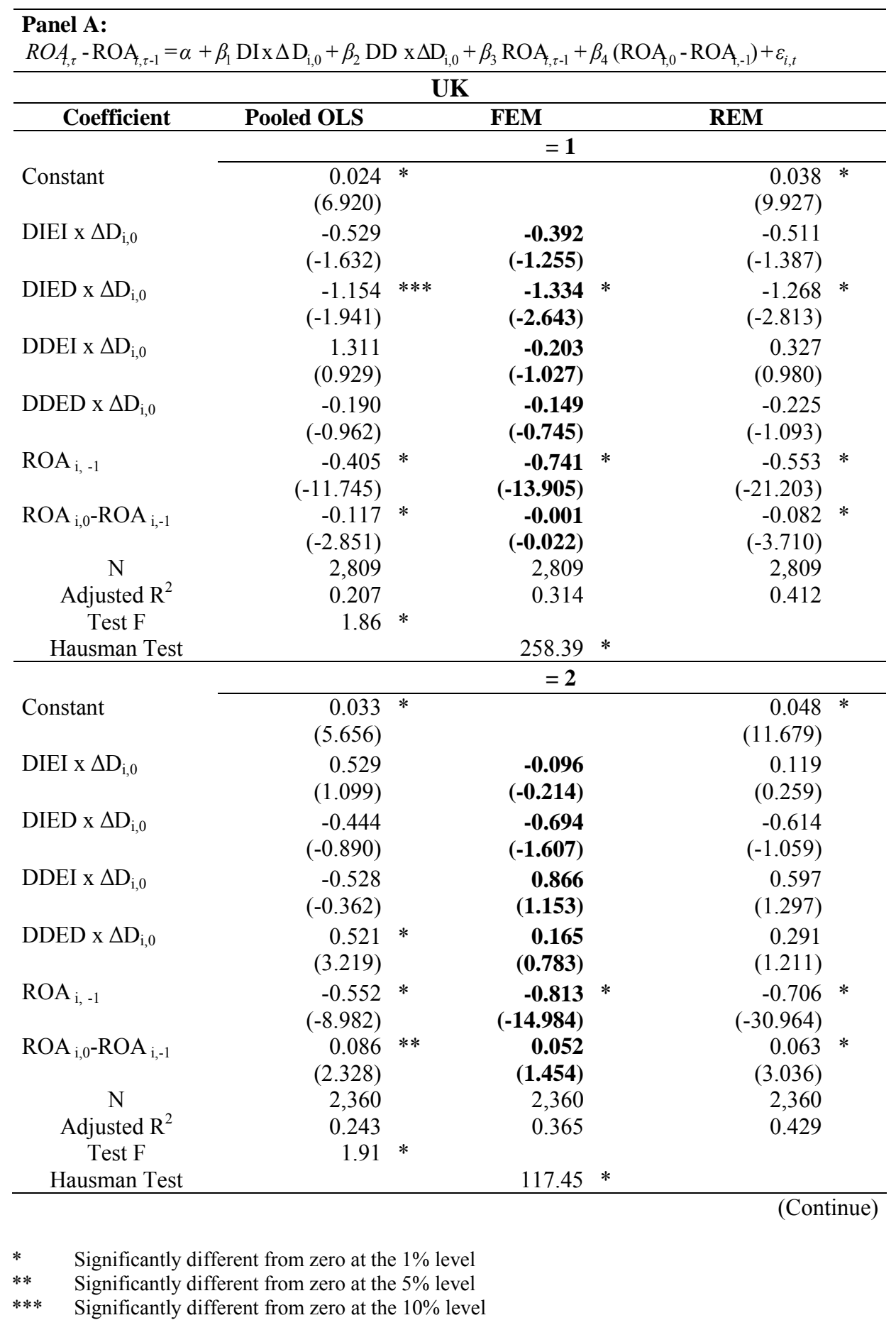


Table 3.12 - Regression of profitability measures changes on dividend changes (continued)

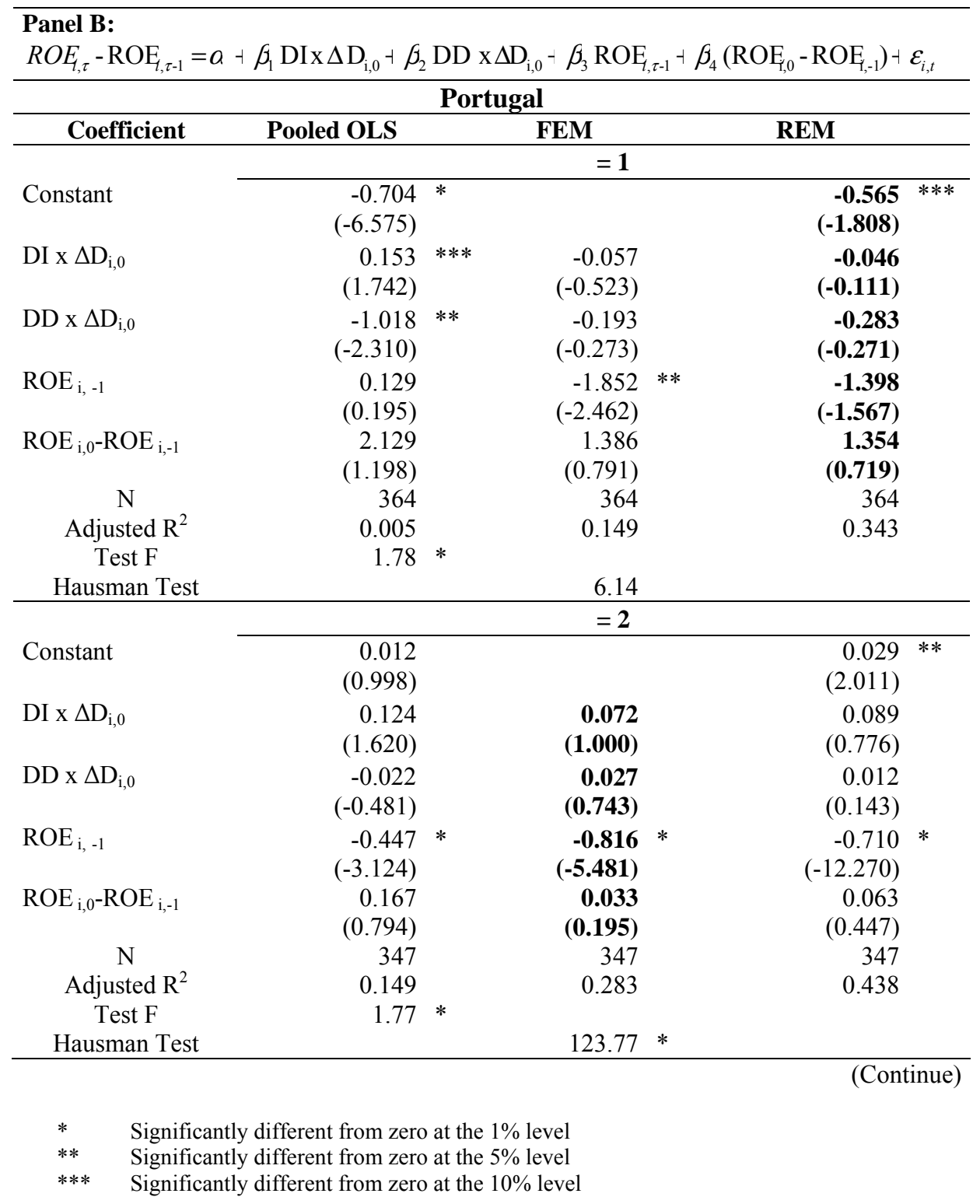


Table 3.12 - Regression of profitability measures changes on dividend changes (continued)

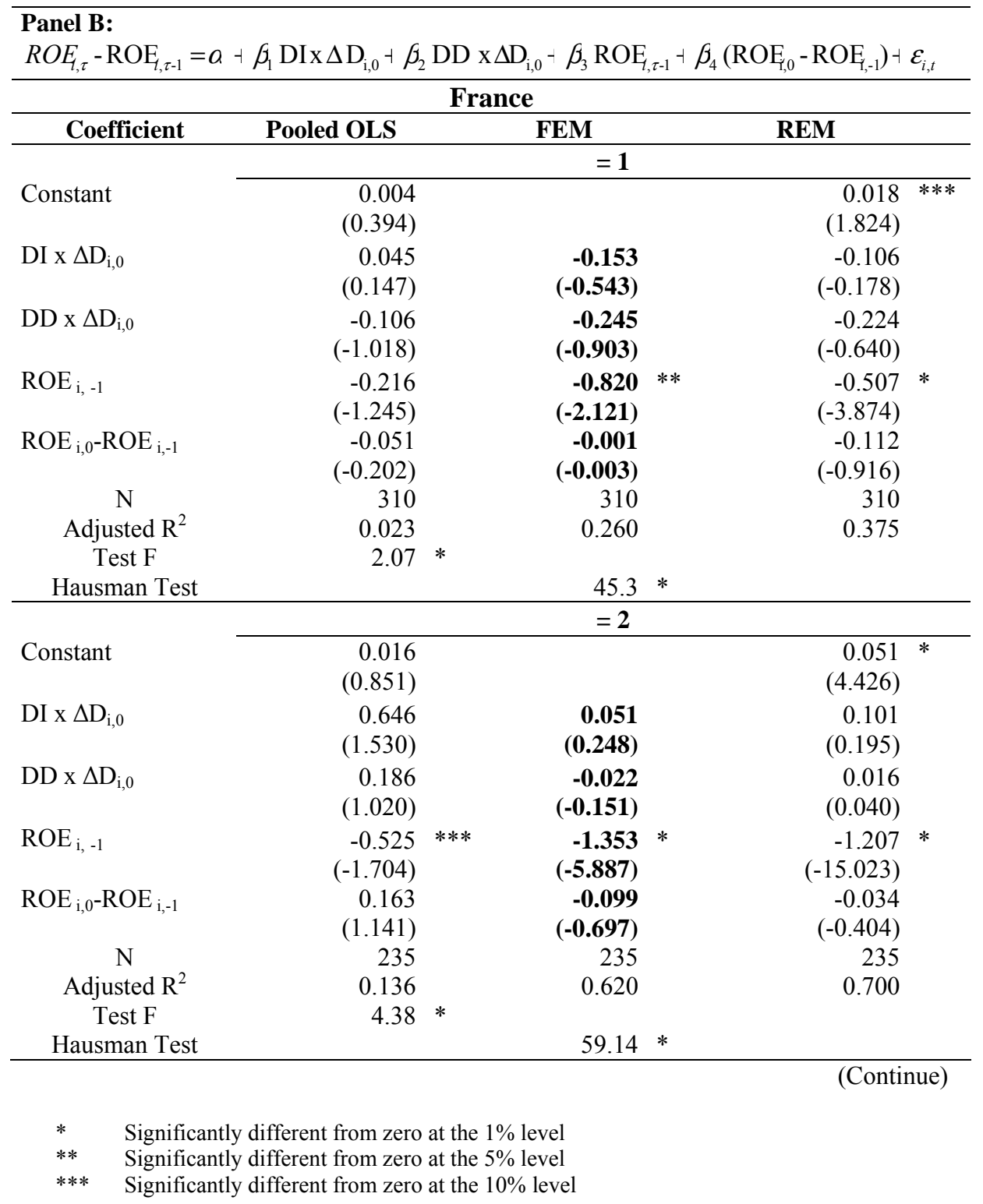


Table 3.12 - Regression of profitability measures changes on dividend changes (continued)

\begin{tabular}{|c|c|c|c|c|c|c|}
\hline $\begin{array}{l}\text { Panel B: } \\
R O E_{l, \tau}-\mathrm{ROE}_{, \tau-1}=\end{array}$ & $\operatorname{DIx} \Delta \mathrm{D}_{\mathrm{i}, 0}-\beta_{2}$ & DD & ${ }_{0}-\beta_{3} \mathrm{ROE}_{1}$ & $\tau-1$ & $\left.\mathrm{E}_{1,0}-\mathrm{ROE}_{1,-1}\right) \dashv$ & \\
\hline & & & & & & \\
\hline Coefficient & Pooled OLS & & FEM & & REM & \\
\hline & & & $=1$ & & & \\
\hline Constant & $\begin{array}{r}0.059 \\
(5.798)\end{array}$ & $*$ & & & $\begin{array}{r}0.088 \\
(10.796)\end{array}$ & $*$ \\
\hline DIEI x $\Delta \mathrm{D}_{\mathrm{i}, 0}$ & $\begin{array}{r}-2.591 \\
(-2.312)\end{array}$ & $* *$ & $\begin{array}{r}-2.666 \\
(-2.559)\end{array}$ & $* *$ & $\begin{array}{r}-2.632 \\
(-2.556)\end{array}$ & $* *$ \\
\hline DIED x $\Delta \mathrm{D}_{\mathrm{i}, 0}$ & $\begin{array}{r}-1.825 \\
(-1.447)\end{array}$ & & $\begin{array}{r}-2.471 \\
(-2.267)\end{array}$ & $* *$ & $\begin{array}{r}-2.104 \\
(-1.668)\end{array}$ & $* * *$ \\
\hline DDEI x $\Delta \mathrm{D}_{\mathrm{i}, 0}$ & $\begin{array}{r}2.651 \\
(1.248)\end{array}$ & & $\begin{array}{r}2.836 \\
(1.495)\end{array}$ & & $\begin{array}{r}2.923 \\
(3.124)\end{array}$ & $*$ \\
\hline DDED x $\Delta \mathrm{D}_{\mathrm{i}, 0}$ & $\begin{array}{r}-0.340 \\
(-0.487)\end{array}$ & & $\begin{array}{r}0.242 \\
(0.350)\end{array}$ & & $\begin{array}{r}-0.131 \\
(-0.228)\end{array}$ & \\
\hline $\mathrm{ROE}_{i,-1}$ & $\begin{array}{r}-0.533 \\
(-9.938)\end{array}$ & $*$ & $\begin{array}{r}-0.975 \\
(-16.401)\end{array}$ & $*$ & $\begin{array}{r}-0.729 \\
(-29.187)\end{array}$ & $*$ \\
\hline $\mathrm{ROE}_{i, 0}-\mathrm{ROE}_{\mathrm{i},-1}$ & $\begin{array}{r}-0.048 \\
(-1.212)\end{array}$ & & $\begin{array}{r}0.115 \\
(2.766)\end{array}$ & $*$ & $\begin{array}{r}0.013 \\
(0.667)\end{array}$ & \\
\hline$\stackrel{\mathrm{N}}{\text { Adjusted } \mathrm{R}^{2}}$ & $\begin{array}{l}2,817 \\
0.263\end{array}$ & & $\begin{array}{l}2,817 \\
0.378\end{array}$ & & $\begin{array}{l}2,817 \\
0.390\end{array}$ & \\
\hline Test $\mathrm{F}$ & 2.01 & $*$ & & & & \\
\hline Hausman Test & & & 85.12 & $*$ & & \\
\hline & & & $=2$ & & & \\
\hline Constant & $\begin{array}{r}0.045 \\
(4.260)\end{array}$ & $*$ & & & $\begin{array}{r}0.085 \\
(6.349)\end{array}$ & $*$ \\
\hline DIEI x $\Delta \mathrm{D}_{\mathrm{i}, 0}$ & $\begin{array}{r}1.573 \\
(1.464)\end{array}$ & & $\begin{array}{r}-0.454 \\
(-0.472)\end{array}$ & & $\begin{array}{r}-0.005 \\
(-0.004)\end{array}$ & \\
\hline DIED $\times \Delta \mathrm{D}_{\mathrm{i}, 0}$ & $\begin{array}{r}-3.017 \\
(-1.516)\end{array}$ & & $\begin{array}{r}-4.803 \\
(-2.573)\end{array}$ & $* *$ & $\begin{array}{r}-4.492 \\
(-2.819)\end{array}$ & $*$ \\
\hline DDEI x $\Delta \mathrm{D}_{\mathrm{i}, 0}$ & $\begin{array}{r}2.961 \\
(1.466)\end{array}$ & & $\begin{array}{r}1.758 \\
(0.934)\end{array}$ & & $\begin{array}{r}1.985 \\
(1.575)\end{array}$ & \\
\hline DDED x $\Delta D_{i, 0}$ & $\begin{array}{r}0.612 \\
(0.903)\end{array}$ & & $\begin{array}{r}-0.026 \\
(-0.033)\end{array}$ & & $\begin{array}{r}0.087 \\
(0.133)\end{array}$ & \\
\hline $\mathrm{ROE}_{\mathrm{i},-1}$ & $\begin{array}{r}-0.554 \\
(-11.908)\end{array}$ & $*$ & $\begin{array}{r}-0.881 \\
(-18.282)\end{array}$ & $*$ & $\begin{array}{r}-0.816 \\
(-36.344)\end{array}$ & $*$ \\
\hline $\mathrm{ROE}_{\mathrm{i}, 0}-\mathrm{ROE}_{\mathrm{i},-1}$ & $\begin{array}{r}-0.020 \\
(-0.484)\end{array}$ & & $\begin{array}{r}-0.007 \\
(-0.219)\end{array}$ & & $\begin{array}{r}-0.008 \\
(-0.451)\end{array}$ & \\
\hline$\underset{\text { Adiusted } \mathrm{R}^{2}}{\mathrm{~N}}$ & $\begin{array}{l}2,366 \\
0223\end{array}$ & & $\begin{array}{l}2,366 \\
0,428\end{array}$ & & $\begin{array}{l}2,366 \\
0542\end{array}$ & \\
\hline Test F & $\begin{array}{r}0.225 \\
2.70\end{array}$ & $*$ & & & & \\
\hline Hausman Test & & & 96.18 & $*$ & & \\
\hline & & & & & (Contin & \\
\hline $\begin{array}{ll}* & \text { Significa } \\
* * & \text { Significa } \\
* * * & \text { Significa }\end{array}$ & $\begin{array}{l}\text { ifferent from zero } \\
\text { ifferent from zero } \\
\text { ifferent from zero }\end{array}$ & $\begin{array}{l}\text { at the } \\
\text { at the } \\
\text { at the }\end{array}$ & $\begin{array}{l}\text { evel } \\
\text { evel } \\
\text { level }\end{array}$ & & & \\
\hline
\end{tabular}


Table 3.12 - Regression of profitability measures changes on dividend changes (continued)

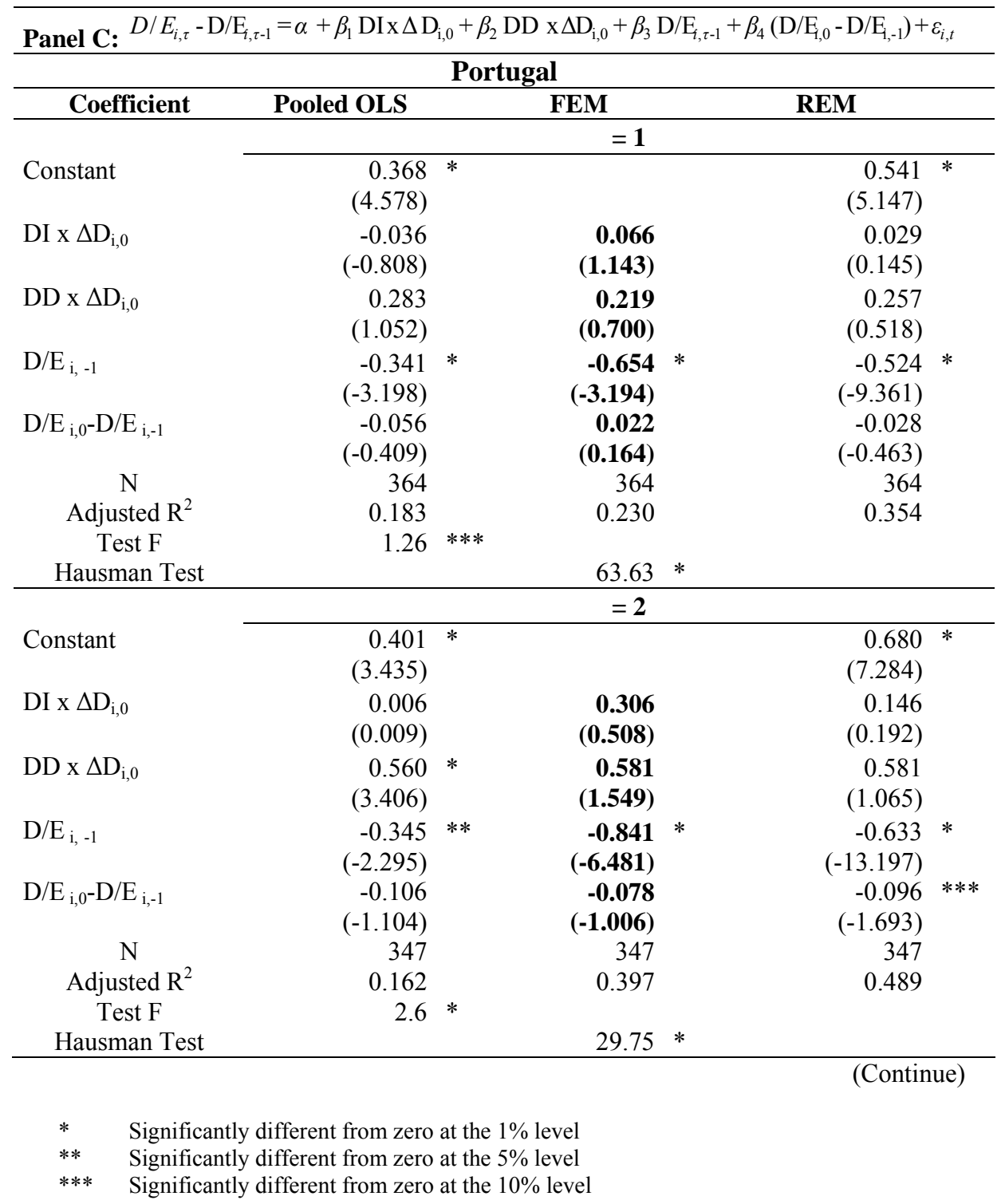


Table 3.12 - Regression of profitability measures changes on dividend changes (continued)

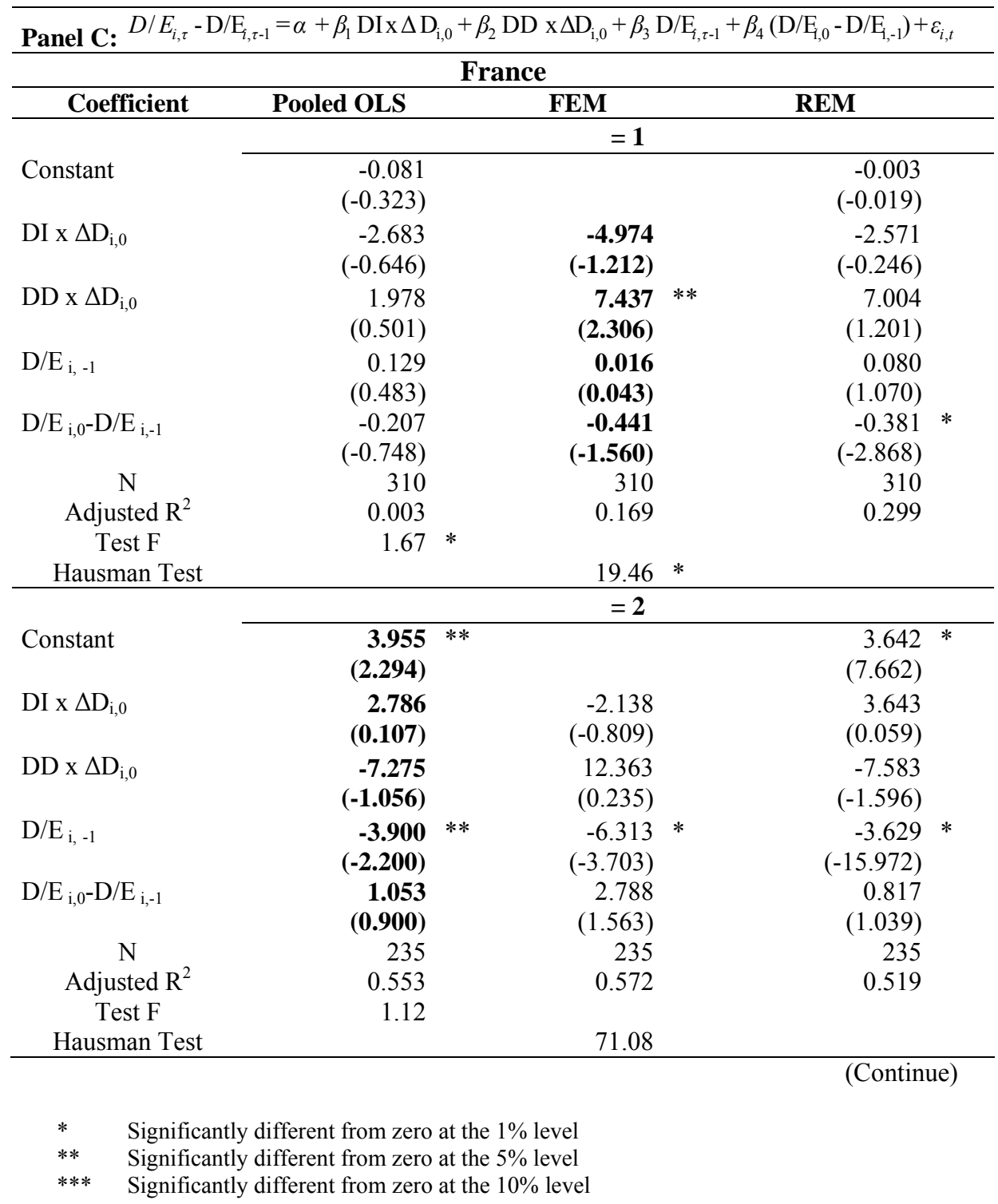


Table 3.12 - Regression of profitability measures changes on dividend changes (continued)

\begin{tabular}{|c|c|c|c|c|c|c|}
\hline \multicolumn{7}{|c|}{$\begin{array}{c}\text { Panel C: } D / E_{i, \tau}-\mathrm{D} / \mathrm{E}_{i, \tau-1}=\alpha+\beta_{1} \mathrm{DIx} \Delta \mathrm{D}_{\mathrm{i}, 0}+\beta_{2} \mathrm{DD} \times \Delta \mathrm{D}_{\mathrm{i}, 0}+\beta_{3} \mathrm{D} / \mathrm{E}_{i, \tau-1}+\beta_{4}\left(\mathrm{D} / \mathrm{E}_{\mathrm{i}, 0}-\mathrm{D} / \mathrm{E}_{1,-1}\right)+\varepsilon_{i, t} \\
\mathbf{U K}\end{array}$} \\
\hline Coefficient & Pooled OLS & & FEM & & REM & \\
\hline \multirow[b]{2}{*}{ Constant } & \multicolumn{6}{|c|}{$=1$} \\
\hline & $\begin{array}{r}0.003 \\
(24.406)\end{array}$ & $*$ & & & $\begin{array}{r}0.003 \\
(18.626)\end{array}$ & \\
\hline DIEI x $\Delta \mathrm{D}_{\mathrm{i}, 0}$ & $\begin{array}{r}-0.191 \\
(-5.273)\end{array}$ & $*$ & $\begin{array}{r}-0.252 \\
(-6.569)\end{array}$ & $*$ & $\begin{array}{r}-0.228 \\
(-10.129)\end{array}$ & $*$ \\
\hline DIED x $\Delta \mathrm{D}_{\mathrm{i}, 0}$ & $\begin{array}{r}0.051 \\
(4.088)\end{array}$ & $*$ & $\begin{array}{r}0.078 \\
(3.342)\end{array}$ & $*$ & $\begin{array}{r}0.067 \\
(3.957)\end{array}$ & $*$ \\
\hline DDEI x $\Delta \mathrm{D}_{\mathrm{i}, 0}$ & $\begin{array}{r}0.044 \\
(4.297)\end{array}$ & $*$ & $\begin{array}{r}0.082 \\
(4.779)\end{array}$ & $*$ & $\begin{array}{r}0.068 \\
(6.556)\end{array}$ & $*$ \\
\hline DDED $\times \Delta \mathrm{D}_{\mathrm{i}, 0}$ & $\begin{array}{r}-0.000 \\
(-0.325)\end{array}$ & & $\begin{array}{r}-0.000 \\
(-0.587)\end{array}$ & & $\begin{array}{r}-0.000 \\
(-0.599)\end{array}$ & \\
\hline $\mathrm{DE}_{\mathrm{i},-1}$ & $\begin{array}{r}-0.001 \\
(-1.736)\end{array}$ & $* * *$ & $\begin{array}{r}-0.001 \\
(-0.650)\end{array}$ & & $\begin{array}{r}-0.001 \\
(-1.389)\end{array}$ & \\
\hline $\mathrm{DE}_{\mathrm{i}, 0}-\mathrm{DE}_{\mathrm{i},-1}$ & $\begin{array}{r}0.000 \\
(1.192)\end{array}$ & & $\begin{array}{r}0.000 \\
(0.053)\end{array}$ & & $\begin{array}{r}0.000 \\
(0.479)\end{array}$ & \\
\hline$\stackrel{\mathrm{N}}{\mathrm{Adiusted} \mathrm{R}^{2}}$ & 2,797 & & $\begin{array}{l}2,797 \\
0149\end{array}$ & & $\begin{array}{l}2,797 \\
0276\end{array}$ & \\
\hline Test F & 2.57 & $*$ & & & & \\
\hline \multirow[t]{2}{*}{ Hausman Test } & & & 46.52 & $*$ & & \\
\hline & & & $=2$ & & & \\
\hline Constant & $\begin{array}{r}0.212 \\
(7.122)\end{array}$ & $*$ & & & $\begin{array}{r}0.259 \\
(13.011)\end{array}$ & $*$ \\
\hline DIEI x $\Delta \mathrm{D}_{\mathrm{i}, 0}$ & $\begin{array}{r}0.222 \\
(0.086)\end{array}$ & & $\begin{array}{r}1.444 \\
(0.573)\end{array}$ & & $\begin{array}{r}0.521 \\
(0.172)\end{array}$ & \\
\hline DIED x $\Delta \mathrm{D}_{\mathrm{i}, 0}$ & $\begin{array}{r}3.050 \\
(0.991)\end{array}$ & & $\begin{array}{r}1.724 \\
(0.541)\end{array}$ & & $\begin{array}{r}3.069 \\
(0.805)\end{array}$ & \\
\hline DDEI $\times \Delta \mathrm{D}_{\mathrm{i}, 0}$ & $\begin{array}{r}-1.764 \\
(-0.854)\end{array}$ & & $\begin{array}{r}-4.763 \\
(-1.185)\end{array}$ & & $\begin{array}{r}-2.374 \\
(-0.779)\end{array}$ & \\
\hline DDED $\times \Delta \mathrm{D}_{\mathrm{i}, 0}$ & $\begin{array}{r}-0.268 \\
(-0.164)\end{array}$ & & $\begin{array}{r}-0.753 \\
(-0.552)\end{array}$ & & $\begin{array}{r}-0.457 \\
(-0.286)\end{array}$ & \\
\hline $\mathrm{DE}_{\mathrm{i},-1}$ & $\begin{array}{r}-0.339 \\
(-6.938)\end{array}$ & $*$ & $\begin{array}{r}-0.747 \\
(-9.246)\end{array}$ & $*$ & $\begin{array}{r}-0.434 \\
(-22.938)\end{array}$ & $*$ \\
\hline $\mathrm{DE}_{\mathrm{i}, 0}-\mathrm{DE}_{\mathrm{i},-1}$ & $\begin{array}{r}-0.098 \\
(-1.653)\end{array}$ & $* * *$ & $\begin{array}{r}-0.086 \\
(-1.608)\end{array}$ & & $\begin{array}{r}-0.102 \\
(-5.447)\end{array}$ & $*$ \\
\hline $\begin{array}{c}\mathrm{N} \\
\text { Adjusted } \mathrm{R}^{2}\end{array}$ & $\begin{array}{l}2,350 \\
0.175\end{array}$ & & $\begin{array}{l}2,350 \\
0.305\end{array}$ & & $\begin{array}{l}2,350 \\
0.316\end{array}$ & \\
\hline Test $\mathrm{F}$ & 1.89 & $*$ & & & & \\
\hline \multirow[t]{2}{*}{ Hausman Test } & & & 19.16 & $*$ & & \\
\hline & & & & & (Contil & \\
\hline $\begin{array}{ll}* & \text { Significa } \\
* * & \text { Significa } \\
* * * & \text { Significa }\end{array}$ & $\begin{array}{l}\text { fferent from zero } \\
\text { fferent from zero } \\
\text { fferent from zero }\end{array}$ & $\begin{array}{l}\text { at the } \\
\text { at the } \\
\text { at the }\end{array}$ & $\begin{array}{l}\text { evel } \\
\text { evel } \\
\text { level }\end{array}$ & & & \\
\hline
\end{tabular}


Table 3.12 - Regression of profitability measures changes on dividend changes (continued)

\begin{tabular}{|c|c|c|c|c|c|c|}
\hline $\begin{array}{l}\text { Panel D: } \\
W C R_{, \tau}-\mathrm{WCR}_{r, \tau-1}=0\end{array}$ & $\operatorname{DIx} \Delta \mathrm{D}_{\mathrm{i}, 0}+\beta_{2} \mathrm{D}$ & $\mathrm{D} \times \Delta \mathrm{I}$ & $\beta_{3} \mathrm{WCR}_{r, \tau-1}+$ & $+\beta_{4}(\mathrm{~V}$ & $\left.\mathrm{WCR}_{\mathrm{,},-1}\right)+\varepsilon_{i, t}$ & \\
\hline & & Por & & & & \\
\hline Coefficient & Pooled OLS & & FEM & & REM & \\
\hline & & & $=1$ & & & \\
\hline Constant & $\begin{array}{r}1.766 \\
(4.380)\end{array}$ & $*$ & & & $\begin{array}{r}2.195 \\
(3.953)\end{array}$ & $*$ \\
\hline DI x $\Delta \mathrm{D}_{\mathrm{i}, 0}$ & $\begin{array}{r}-0.322 \\
(-1.084)\end{array}$ & & $\begin{array}{r}0.379 \\
(-0.965)\end{array}$ & & $\begin{array}{r}-0.340 \\
(-0.208)\end{array}$ & \\
\hline $\mathrm{DD} \times \Delta \mathrm{D}_{\mathrm{i}, 0}$ & $\begin{array}{r}3.618 \\
(2.340)\end{array}$ & $* *$ & $\begin{array}{r}5.927 \\
(1.793)\end{array}$ & $* * *$ & $\begin{array}{r}4.888 \\
(1.194)\end{array}$ & \\
\hline $\mathrm{WCR}_{\mathrm{i},-1}$ & $\begin{array}{r}-0.674 \\
(-4.874)\end{array}$ & $*$ & $\begin{array}{r}-1.067 \\
(-9.048)\end{array}$ & $*$ & $\begin{array}{r}-0.847 \\
(-8.225)\end{array}$ & $*$ \\
\hline $\mathrm{WCR}_{\mathrm{i}, 0}-\mathrm{WCR}_{\mathrm{i},-1}$ & $\begin{array}{r}-0.200 \\
(-1.623)\end{array}$ & & $\begin{array}{r}0.065 \\
(0.573)\end{array}$ & & $\begin{array}{r}-0.090 \\
(-0.942)\end{array}$ & \\
\hline $\mathrm{N}$ & 364 & & 364 & & 364 & \\
\hline Adjusted $\mathrm{R}^{2}$ & 0.421 & & 0.369 & & 0.492 & \\
\hline $\begin{array}{c}\text { Test F } \\
\text { Hausman Test }\end{array}$ & 0.65 & & 26.97 & $*$ & & \\
\hline & & & $=2$ & & & \\
\hline Constant & $\begin{array}{r}2.106 \\
(5.598)\end{array}$ & $*$ & & & $\begin{array}{r}1.823 \\
(5.724)\end{array}$ & $*$ \\
\hline DI x $\Delta \mathrm{D}_{\mathrm{i}, 0}$ & $\begin{array}{r}-4.563 \\
(-2.085)\end{array}$ & $* *$ & $\begin{array}{r}-6.701 \\
(-1.485)\end{array}$ & & $\begin{array}{r}-3.984 \\
(-0.666)\end{array}$ & \\
\hline $\mathrm{DD} \times \Delta \mathrm{D}_{\mathrm{i}, 0}$ & $\begin{array}{r}3.100 \\
(2.785)\end{array}$ & $*$ & $\begin{array}{r}6.731 \\
(1.600)\end{array}$ & & $\begin{array}{r}1.428 \\
(0.324)\end{array}$ & \\
\hline $\mathrm{WCR}_{\mathrm{i},-1}$ & $\begin{array}{r}-0.868 \\
(-13.704)\end{array}$ & $*$ & $\begin{array}{r}-1.026 \\
(-13.384)\end{array}$ & * & $\begin{array}{r}-0.775 \\
(-15.279)\end{array}$ & $*$ \\
\hline WCR $_{i, 0}-$ WCR $_{i,-1}$ & $\begin{array}{r}0.051 \\
(1.904)\end{array}$ & $* * *$ & $\begin{array}{r}0.004 \\
(0.077)\end{array}$ & & $\begin{array}{r}0.078 \\
(1.519)\end{array}$ & \\
\hline $\mathrm{N}$ & 347 & & 347 & & 347 & \\
\hline Adjusted $\mathrm{R}^{2}$ & 0.441 & & 0.371 & & 0.298 & \\
\hline Test $\mathrm{F}$ & 0.54 & & & & & \\
\hline Hausman Test & & & 25.5 & $*$ & & \\
\hline & & & & & (Contin & \\
\hline $\begin{array}{ll}* & \text { Significa } \\
* * & \text { Significa } \\
* * * & \text { Significa }\end{array}$ & $\begin{array}{l}\text { ifferent from zero } \\
\text { ifferent from zero } \\
\text { ifferent from zero }\end{array}$ & $\begin{array}{l}\text { at the } \\
\text { at the } \\
\text { at the }\end{array}$ & $\begin{array}{l}\text { evel } \\
\text { evel } \\
\text { level }\end{array}$ & & & \\
\hline
\end{tabular}


Table 3.12 - Regression of profitability measures changes on dividend changes (continued)

\begin{tabular}{|c|c|c|c|c|c|c|}
\hline \multicolumn{7}{|c|}{$\begin{array}{l}\text { Panel D: } \\
W C R_{i, \tau}-\mathrm{WCR}_{i, \tau-1}=\alpha+\beta_{1} \mathrm{DIx} \Delta \mathrm{D}_{\mathrm{i}, 0}+\beta_{2} \mathrm{DD} \times \Delta \mathrm{D}_{\mathrm{i}, 0}+\beta_{3} \mathrm{WCR}_{i, \tau-1}+\beta_{4}\left(\mathrm{WCR}_{\mathrm{r}, 0}-\mathrm{WCR}_{\mathrm{r}, 1}\right)+\varepsilon_{i, t}\end{array}$} \\
\hline \multicolumn{7}{|c|}{ France } \\
\hline Coefficient & Pooled OLS & & FEM & & REM & \\
\hline \multirow[b]{2}{*}{ Constant } & \multicolumn{6}{|c|}{$=1$} \\
\hline & $\begin{array}{r}0.174 \\
(3.643)\end{array}$ & * & & & $\begin{array}{r}0.160 \\
(3.677)\end{array}$ & * \\
\hline $\mathrm{DI} \times \Delta \mathrm{D}_{\mathrm{i}, 0}$ & $\begin{array}{r}1.203 \\
(1.093)\end{array}$ & & $\begin{array}{r}4.273 \\
(2.216)\end{array}$ & $* *$ & $\begin{array}{r}0.945 \\
(0.346)\end{array}$ & \\
\hline$D D \times \Delta D_{i, 0}$ & $\begin{array}{r}-3.776 \\
(-0.872)\end{array}$ & & $\begin{array}{r}-8.838 \\
(-1.693)\end{array}$ & $* * *$ & $\begin{array}{r}-3.347 \\
(-1.561)\end{array}$ & \\
\hline $\mathrm{WCR}_{\mathrm{i},-1}$ & $\begin{array}{r}-0.160 \\
(-4.033)\end{array}$ & * & $\begin{array}{r}-0.816 \\
(-10.294)\end{array}$ & $*$ & $\begin{array}{r}-0.148 \\
(-4.993)\end{array}$ & $*$ \\
\hline $\mathrm{WCR}_{\mathrm{i}, 0}-\mathrm{WCR}_{\mathrm{i},-1}$ & $\begin{array}{r}-0.061 \\
(-0.642)\end{array}$ & & $\begin{array}{r}0.045 \\
(0.696)\end{array}$ & & $\begin{array}{r}-0.048 \\
(-0.922)\end{array}$ & \\
\hline $\mathrm{N}$ & 309 & & 309 & & 309 & \\
\hline Adjusted $\mathrm{R}^{2}$ & 0.090 & & 0.195 & & 0.027 & \\
\hline Test F & 1.44 & $* *$ & & & & \\
\hline \multirow[t]{2}{*}{ Hausman Test } & & & 145.71 & * & & \\
\hline & & & $=2$ & & & \\
\hline Constant & $\begin{array}{r}0.220 \\
(3.377)\end{array}$ & $*$ & & & $\begin{array}{r}0.303 \\
(4.719)\end{array}$ & $*$ \\
\hline DI x $\Delta \mathrm{D}_{\mathrm{i}, 0}$ & $\begin{array}{r}-0.686 \\
(-0.449)\end{array}$ & & $\begin{array}{r}-1.595 \\
(-0.928)\end{array}$ & & $\begin{array}{r}-1.819 \\
(-0.612)\end{array}$ & \\
\hline$D D \times \Delta D_{i, 0}$ & $\begin{array}{r}6.288 \\
(1.608)\end{array}$ & & $\begin{array}{r}0.982 \\
(0.952)\end{array}$ & & $\begin{array}{r}5.586 \\
(2.432)\end{array}$ & $* *$ \\
\hline $\mathrm{WCR}_{\mathrm{i},-1}$ & $\begin{array}{r}-0.181 \\
(-3.511)\end{array}$ & $*$ & $\begin{array}{r}-0.702 \\
(-6.343)\end{array}$ & $*$ & $\begin{array}{r}-0.243 \\
(-5.510)\end{array}$ & $*$ \\
\hline $\mathrm{WCR}_{\mathrm{i}, 0}-\mathrm{WCR}_{\mathrm{i},-1}$ & $\begin{array}{r}0.020 \\
(0.273)\end{array}$ & & $\begin{array}{r}-0.067 \\
(-1.057)\end{array}$ & & $\begin{array}{r}-0.006 \\
(-0.095)\end{array}$ & \\
\hline$\stackrel{\mathrm{N}}{\text { Adiusted } \mathrm{R}^{2}}$ & 235 & & $\begin{array}{r}235 \\
0177\end{array}$ & & 235 & \\
\hline $\begin{array}{c}\text { Adjusted } \mathrm{R}^{2} \\
\text { Test } \mathrm{F}\end{array}$ & $\begin{array}{r}0.114 \\
1.20\end{array}$ & & 0.177 & & 0.237 & \\
\hline \multirow[t]{2}{*}{ Hausman Test } & & & 52.8 & $*$ & & \\
\hline & & & & & (Contins & \\
\hline $\begin{array}{ll}* & \text { Significa } \\
* * & \text { Significa } \\
* * * & \text { Significa }\end{array}$ & $\begin{array}{l}\text { different from zero } \\
\text { different from zero } \\
\text { different from zero }\end{array}$ & $\begin{array}{l}\text { at th } \\
\text { at th } \\
\text { at th }\end{array}$ & $\begin{array}{l}\text { level } \\
\text { level } \\
\text { level }\end{array}$ & & & \\
\hline
\end{tabular}


Table 3.12 - Regression of profitability measures changes on dividend changes (continued)

\begin{tabular}{|c|c|c|c|c|c|c|}
\hline $\begin{array}{l}\text { Panel D: } \\
W C R_{, \tau}-\mathrm{WCR}_{r, \tau-1}=0\end{array}$ & $\mathrm{DIx} \Delta \mathrm{D}_{\mathrm{i}, 0}+\beta_{2} \mathrm{D}$ & $\mathrm{D} \times \Delta$ & $\beta_{3} \mathrm{WCR}_{, \tau-1-1}+$ & $+\beta_{4}$ & $\left.\mathrm{WCR}_{\mathrm{,},-1}\right)+\varepsilon_{i, t}$ & \\
\hline & & & & & & \\
\hline Coefficient & Pooled OLS & & FEM & & REM & \\
\hline & & & $=1$ & & & \\
\hline Constant & $\begin{array}{r}0.126 \\
(5.595)\end{array}$ & $*$ & & & $\begin{array}{r}0.343 \\
(12.998)\end{array}$ & $*$ \\
\hline DIEI x $\Delta \mathrm{D}_{\mathrm{i}, 0}$ & $\begin{array}{r}-1.313 \\
(-0.761)\end{array}$ & & $\begin{array}{r}-1.180 \\
(-0.698)\end{array}$ & & $\begin{array}{r}-1.026 \\
(-0.584)\end{array}$ & \\
\hline DIED x $\Delta \mathrm{D}_{\mathrm{i}, 0}$ & $\begin{array}{r}-1.218 \\
(-0.458)\end{array}$ & & $\begin{array}{r}-0.714 \\
(-0.298)\end{array}$ & & $\begin{array}{r}-1.319 \\
(-0.599)\end{array}$ & \\
\hline DDEI x $\Delta \mathrm{D}_{\mathrm{i}, 0}$ & $\begin{array}{r}0.590 \\
(0.724)\end{array}$ & & $\begin{array}{r}1.041 \\
(1.279)\end{array}$ & & $\begin{array}{r}0.565 \\
(0.353)\end{array}$ & \\
\hline $\operatorname{DDED} \times \Delta \mathrm{D}_{\mathrm{i}, 0}$ & $\begin{array}{r}-0.128 \\
(-0.145)\end{array}$ & & $\begin{array}{r}-0.341 \\
(-0.423)\end{array}$ & & $\begin{array}{r}0.070 \\
(0.073)\end{array}$ & \\
\hline $\mathrm{WCR}_{\mathrm{i},-1}$ & $\begin{array}{r}-0.092 \\
(-5.754)\end{array}$ & $*$ & $\begin{array}{r}-0.699 \\
(-15.937)\end{array}$ & $*$ & $\begin{array}{r}-0.241 \\
(-15.605)\end{array}$ & $*$ \\
\hline $\mathrm{WCR}_{\mathrm{i}, 0}-\mathrm{WCR}_{\mathrm{i},-1}$ & $\begin{array}{r}-0.154 \\
(-3.978)\end{array}$ & $*$ & $\begin{array}{r}0.090 \\
(2.912)\end{array}$ & $*$ & $\begin{array}{r}-0.120 \\
(-6.001)\end{array}$ & $*$ \\
\hline $\mathrm{N}$ & 2,625 & & 2,625 & & 2,625 & \\
\hline Adjusted $\mathrm{R}^{2}$ & 0.066 & & 0.290 & & 0.303 & \\
\hline Test $\mathrm{F}$ & 2.73 & $*$ & & & & \\
\hline Hausman Test & & & 56.47 & * & & \\
\hline & & & $=2$ & & & \\
\hline Constant & $\begin{array}{r}0.117 \\
(4.877)\end{array}$ & $*$ & & & $\begin{array}{r}0.303 \\
(11.662)\end{array}$ & $*$ \\
\hline DIEI x $\Delta \mathrm{D}_{\mathrm{i}, 0}$ & $\begin{array}{r}3.907 \\
(1.457)\end{array}$ & & $\begin{array}{r}3.769 \\
(2.018)\end{array}$ & $* *$ & $\begin{array}{r}4.250 \\
(2.050)\end{array}$ & $* *$ \\
\hline DIED x $\Delta \mathrm{D}_{\mathrm{i}, 0}$ & $\begin{array}{r}5.320 \\
(1.996)\end{array}$ & $* *$ & $\begin{array}{r}4.167 \\
(1.601)\end{array}$ & & $\begin{array}{r}5.334 \\
(1.955)\end{array}$ & $* * *$ \\
\hline DDEI x $\Delta \mathrm{D}_{\mathrm{i}, 0}$ & $\begin{array}{r}-1.473 \\
(-1.348)\end{array}$ & & $\begin{array}{r}-0.712 \\
(-0.771)\end{array}$ & & $\begin{array}{r}-1.241 \\
(-0.585)\end{array}$ & \\
\hline DDED x $\Delta \mathrm{D}_{\mathrm{i}, 0}$ & $\begin{array}{r}0.326 \\
(0.489)\end{array}$ & & $\begin{array}{r}-0.065 \\
(-0.080)\end{array}$ & & $\begin{array}{r}0.356 \\
(0.331)\end{array}$ & \\
\hline $\mathrm{WCR}_{\mathrm{i},-1}$ & $\begin{array}{r}-0.099 \\
(-5.784)\end{array}$ & $*$ & $\begin{array}{r}-0.718 \\
(-17.473)\end{array}$ & $*$ & $\begin{array}{r}-0.228 \\
(-15.141)\end{array}$ & $*$ \\
\hline $\mathrm{WCR}_{\mathrm{i}, 0}-\mathrm{WCR}_{\mathrm{i},-1}$ & $\begin{array}{r}-0.109 \\
(-3.250)\end{array}$ & $*$ & $\begin{array}{r}-0.028 \\
(-1.050)\end{array}$ & & $\begin{array}{r}-0.108 \\
(-5.110)\end{array}$ & $*$ \\
\hline $\mathrm{N}$ & 2,204 & & 2,204 & & 2,204 & \\
\hline $\begin{array}{c}\text { Adjusted } \mathrm{R}^{2} \\
\text { Test F }\end{array}$ & $\begin{array}{r}0.052 \\
2.87\end{array}$ & $*$ & 0.321 & & 0.292 & \\
\hline Hausman Test & & & 57.94 & $*$ & & \\
\hline & & & & & (Continu & ue) \\
\hline $\begin{array}{ll}* & \text { Significar } \\
* * & \text { Significar } \\
* * * & \text { Significar }\end{array}$ & $\begin{array}{l}\text { ifferent from zero } \\
\text { ifferent from zero } \\
\text { ifferent from zero }\end{array}$ & $\begin{array}{l}\text { at the } \\
\text { at the } \\
\text { at the }\end{array}$ & $\begin{array}{l}\text { evel } \\
\text { evel } \\
\text { level }\end{array}$ & & & \\
\hline
\end{tabular}


Table 3.12 - Regression of profitability measures changes on dividend changes (continued)

\begin{tabular}{|c|c|c|c|c|c|c|}
\hline \multicolumn{7}{|c|}{ Panel E: $C F_{i, \tau}-\mathrm{CF}_{i, \tau-1}=\alpha+\beta_{1} \mathrm{DIx} \Delta \mathrm{D}_{\mathrm{i}, 0}+\beta_{2} \mathrm{DD} \times \Delta \mathrm{D}_{\mathrm{i}, 0}+\beta_{3} \mathrm{CF}_{i, \tau-1}+\beta_{4}\left(\mathrm{CF}_{i, 0}-\mathrm{CF}_{\mathrm{i},-1}\right)+\varepsilon_{i, t}$} \\
\hline \multirow[b]{2}{*}{ Coefficient } & \multicolumn{4}{|c|}{ Portugal } & \multirow{2}{*}{\multicolumn{2}{|c|}{ REM }} \\
\hline & Pooled OLS & & FEM & & & \\
\hline \multirow[b]{2}{*}{ Constant } & \multicolumn{6}{|c|}{$=1$} \\
\hline & $\begin{array}{r}0.004 \\
(3.295)\end{array}$ & $*$ & & & $\begin{array}{r}0.008 \\
(3.093)\end{array}$ & $*$ \\
\hline DI $x \Delta \mathrm{D}_{\mathrm{i}, 0}$ & $\begin{array}{r}-0.014 \\
(-4.089)\end{array}$ & $*$ & $\begin{array}{r}-0.015 \\
(-4.413)\end{array}$ & $*$ & $\begin{array}{r}-0.015 \\
(-3.430)\end{array}$ & $*$ \\
\hline $\mathrm{DD} \times \Delta \mathrm{D}_{\mathrm{i}, 0}$ & $\begin{array}{r}-0.011 \\
(-0.869)\end{array}$ & & $\begin{array}{r}-0.007 \\
(-0.857)\end{array}$ & & $\begin{array}{r}-0.007 \\
(-0.707)\end{array}$ & \\
\hline $\mathrm{CF}_{\mathrm{i},-1}$ & $\begin{array}{r}-0.303 \\
(-3.786)\end{array}$ & $*$ & $\begin{array}{r}-0.637 \\
(-3.549)\end{array}$ & $*$ & $\begin{array}{r}-0.525 \\
(-5.920)\end{array}$ & $*$ \\
\hline $\mathrm{CF}_{\mathrm{i}, 0}-\mathrm{CF}_{\mathrm{i},-1}$ & $\begin{array}{r}-0.339 \\
(-2.033)\end{array}$ & $* *$ & $\begin{array}{r}0.186 \\
(1.640)\end{array}$ & & $\begin{array}{r}0.035 \\
(0.389)\end{array}$ & \\
\hline $\mathrm{N}$ & 364 & & 364 & & 364 & \\
\hline Adjusted R ${ }^{2}$ & $\begin{array}{r}0.365 \\
202\end{array}$ & $*$ & 0.487 & & 0.563 & \\
\hline \multirow[t]{2}{*}{ Hausman Test } & & & 43.77 & $*$ & & \\
\hline & & & $=2$ & & & \\
\hline Constant & $\begin{array}{r}0.005 \\
(2.761)\end{array}$ & $*$ & & & $\begin{array}{r}0.007 \\
(3.636)\end{array}$ & $*$ \\
\hline DI $x \Delta \mathrm{D}_{\mathrm{i}, 0}$ & $\begin{array}{r}-0.010 \\
(-0.412)\end{array}$ & & $\begin{array}{r}-0.004 \\
(-0.223)\end{array}$ & & $\begin{array}{r}-0.008 \\
(-0.428)\end{array}$ & \\
\hline $\mathrm{DD} \times \Delta \mathrm{D}_{\mathrm{i}, 0}$ & $\begin{array}{r}0.005 \\
(0.797)\end{array}$ & & $\begin{array}{r}0.002 \\
(0.292)\end{array}$ & & $\begin{array}{r}0.004 \\
(0.273)\end{array}$ & \\
\hline $\mathrm{CF}_{\mathrm{i},-1}$ & $\begin{array}{r}-0.235 \\
(-2.440)\end{array}$ & $* *$ & $\begin{array}{r}-0.546 \\
(-3.629)\end{array}$ & $*$ & $\begin{array}{r}-0.394 \\
(-6.668)\end{array}$ & $*$ \\
\hline $\mathrm{CF}_{\mathrm{i}, 0}-\mathrm{CF}_{\mathrm{i},-1}$ & $\begin{array}{r}-0.014 \\
(-0.329)\end{array}$ & & $\begin{array}{r}0.039 \\
(0.307)\end{array}$ & & $\begin{array}{r}0.001 \\
(0.006)\end{array}$ & \\
\hline $\mathrm{N}$ & 347 & & 347 & & 347 & \\
\hline Adjusted $\mathrm{R}^{2}$ & 0.046 & & 0.061 & & 0.194 & \\
\hline Test F & 1.06 & & & & & \\
\hline \multirow[t]{2}{*}{ Hausman Test } & & & 37.47 & $*$ & & \\
\hline & & & & & (Conti & nue) \\
\hline $\begin{array}{ll}* & \text { Significa } \\
* * & \text { Significa } \\
* * * & \text { Significa }\end{array}$ & $\begin{array}{l}\text { lifferent from zero } \\
\text { lifferent from zero } \\
\text { lifferent from zero }\end{array}$ & $\begin{array}{l}\text { at the } \\
\text { at the } \\
\text { at the }\end{array}$ & $\begin{array}{l}\text { evel } \\
\text { evel } \\
\text { level }\end{array}$ & & & \\
\hline
\end{tabular}


Table 3.12 - Regression of profitability measures changes on dividend changes (continued)

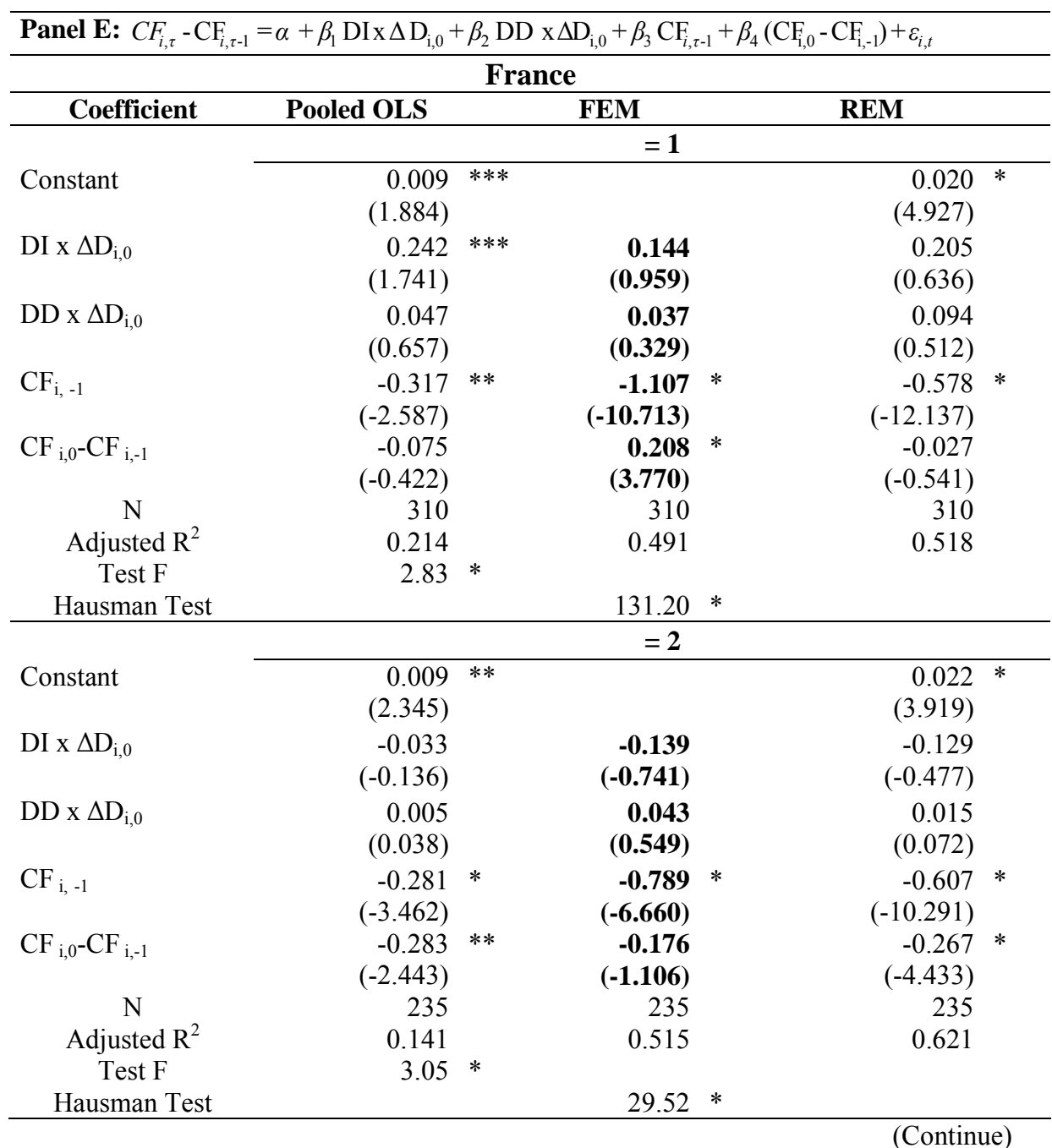

* $\quad$ Significantly different from zero at the $1 \%$ level

** $\quad$ Significantly different from zero at the $5 \%$ level

$* * * \quad$ Significantly different from zero at the $10 \%$ level 
Table 3.12 - Regression of profitability measures changes on dividend changes (continued)

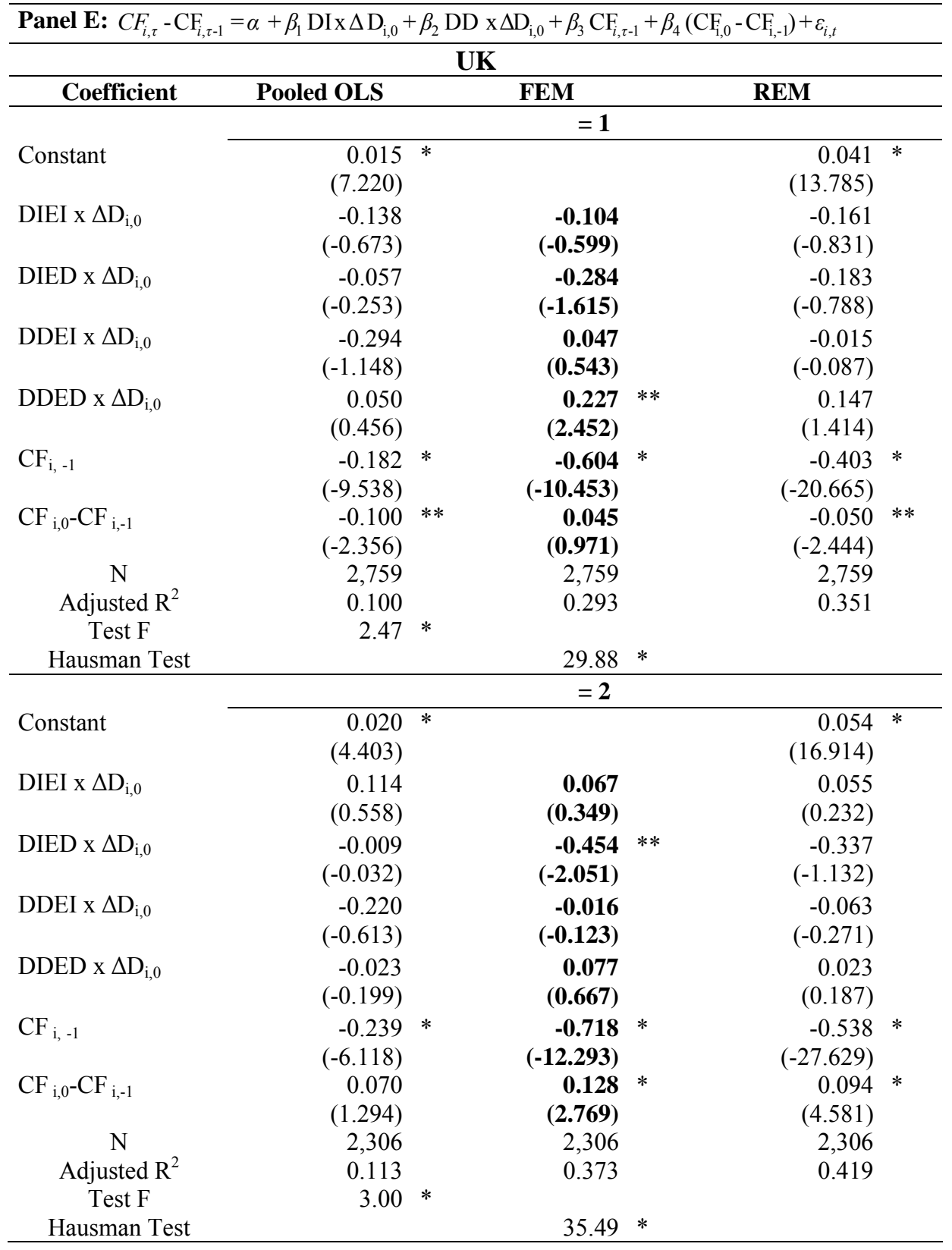

* $\quad$ Significantly different from zero at the $1 \%$ level

** $\quad$ Significantly different from zero at the $5 \%$ level

*** Significantly different from zero at the $10 \%$ level 


\section{Table 3.13 - Change in post-announcement measures}

This table provides mean values and mean differences for some firm characteristics surrounding dividend change announcements: the annual values for the return on assets (ROA) based on operating income before depreciation (Table A), the sales growth (SG) rate, computed as a percentage of the previous year's sales for dividend changes (Table B) and the capital expenditure (CE), computed as a percentage of total assets (Panel C), not reported for the Portuguese sample because the lack of data. $\mathrm{ROA}_{\mathrm{i}, \mathrm{t}}$ is the ROA for share $\mathrm{i}$ on year $\mathrm{t} ; \mathrm{SG}_{\mathrm{i}, \mathrm{t}}$ is the $\mathrm{SG}$ for share $\mathrm{i}$ on year $\mathrm{t}$. The abnormal operating performance, as well as the other variables, is computed as paired differences between the dividend-changing firm and the control firm, considered as our sub-samples of firms that did not change dividends. The significance levels for the means are based on a two-tailed t-test and are reported in parentheses.

\begin{tabular}{|c|c|c|c|c|c|c|c|}
\hline \multicolumn{8}{|c|}{ Panel A: ROA mean and paired differences for distinct periods } \\
\hline \multicolumn{8}{|c|}{$\begin{array}{l}\text { Portugal } \\
\end{array}$} \\
\hline & $\mathbf{N}$ & $\mathbf{R O A}_{\mathrm{i},-1}$ & $\mathbf{R O A}_{\mathrm{i}, 0}$ & $\mathbf{R O A}_{i, 1}$ & $\mathbf{R O A}_{i, 2}$ & $\mathbf{R O A}_{\mathrm{i}, 1}-\mathbf{R O A}_{\mathrm{i}, 0}$ & $\mathbf{O A}_{\mathrm{i}, 2}-\mathbf{R O A}_{\mathrm{i}, 0}$ \\
\hline \multicolumn{8}{|l|}{ Dividend Increases } \\
\hline Sub-sample values & 147 & $\begin{array}{r}0.113 * \\
(15.830)\end{array}$ & $\begin{array}{c}0.103 * \\
(14.661)\end{array}$ & $\begin{array}{c}0.088 * \\
(13.343)\end{array}$ & $\begin{array}{r}0.076 * \\
(12.061)\end{array}$ & $\begin{array}{l}-0.015 * \\
(-3.465)\end{array}$ & $\begin{array}{l}-0.027 * \\
(-4.956)\end{array}$ \\
\hline Paired differences & 94 & $\begin{array}{r}0.002 \\
(0.129)\end{array}$ & $\begin{array}{r}-0.003 \\
(-0.236)\end{array}$ & $\begin{array}{r}-0.008 \\
(-0.817)\end{array}$ & $\begin{array}{r}-0.012 \\
(-1.128)\end{array}$ & $\begin{array}{r}-0.005 \\
(-0.457)\end{array}$ & $\begin{array}{r}-0.009 \\
(-0.824)\end{array}$ \\
\hline \multicolumn{8}{|l|}{ Dividend Decreases } \\
\hline Sub-sample values & 106 & $\begin{array}{r}0.091 * \\
(12.932)\end{array}$ & $\begin{array}{c}0.084 * \\
(11.647)\end{array}$ & $\begin{array}{c}0.081 * \\
(11.023)\end{array}$ & $\begin{array}{c}0.077 * \\
(10.248)\end{array}$ & $\begin{array}{r}-0.003 \\
(-0.568)\end{array}$ & $\begin{array}{r}-0.007 \\
(-1.072)\end{array}$ \\
\hline Paired differences & 94 & $\begin{array}{l}-0.022 * * \\
(-2.051)\end{array}$ & $\begin{array}{l}-0.025 * * \\
(-2.511)\end{array}$ & $\begin{array}{l}-0.016 \text { *** } \\
(-1.678)\end{array}$ & $\begin{array}{r}-0.013 \\
(-1.339)\end{array}$ & $\begin{array}{r}0.009 \\
(0.093)\end{array}$ & $\begin{array}{r}0.012 \\
(1.205)\end{array}$ \\
\hline \multicolumn{8}{|c|}{ France } \\
\hline \multicolumn{8}{|l|}{ Dividend Increases } \\
\hline Sub-sample values & 175 & $\begin{array}{r}0.056 * \\
(19.519)\end{array}$ & $\begin{array}{c}0.058 * \\
(19.371)\end{array}$ & $\begin{array}{c}0.052 * \\
(15.720)\end{array}$ & $\begin{array}{c}0.047 * \\
(13.914)\end{array}$ & $\begin{array}{l}-0.006 * \\
(-2.170)\end{array}$ & $\begin{array}{l}-0.011 * \\
(-3.289)\end{array}$ \\
\hline Paired differences & 27 & $\begin{array}{r}0.004 \\
(0.320)\end{array}$ & $\begin{array}{r}0.005 \\
(0.506)\end{array}$ & $\begin{array}{r}0.005 \\
(0.600)\end{array}$ & $\begin{array}{r}-0.007 \\
(-0.624)\end{array}$ & $\begin{array}{r}0.000 \\
(-0.006)\end{array}$ & $\begin{array}{r}-0.012 \\
(-1.119)\end{array}$ \\
\hline \multicolumn{8}{|l|}{ Dividend Decreases } \\
\hline Sub-sample values & 34 & $\begin{array}{c}0.051 * \\
(5.010)\end{array}$ & $\begin{array}{l}0.058 * \\
(6.207)\end{array}$ & $\begin{array}{l}0.061 * \\
(8.335)\end{array}$ & $\begin{array}{l}0.054 * \\
(7.775)\end{array}$ & $\begin{array}{r}0.003 \\
(0.429)\end{array}$ & $\begin{array}{r}-0.004 \\
(-0.534)\end{array}$ \\
\hline Paired differences & 27 & $\begin{array}{r}-0.016 \\
(-1.201)\end{array}$ & $\begin{array}{r}-0.002 \\
(-0.223) \\
\end{array}$ & $\begin{array}{r}-0.002 \\
(-0.189)\end{array}$ & $\begin{array}{r}-0.003 \\
(-0.241)\end{array}$ & $\begin{array}{r}0.000 \\
(0.033)\end{array}$ & $\begin{array}{r}-0.001 \\
(-0.088)\end{array}$ \\
\hline
\end{tabular}

\footnotetext{
* $\quad$ Significantly different from zero at the $1 \%$ level

** $\quad$ Significantly different from zero at the $5 \%$ level

*** Significantly different from zero at the $10 \%$ level
} 
Table 3.13 - Change in post-announcement measures (continue)

\begin{tabular}{|c|c|c|c|c|c|c|c|}
\hline \multicolumn{8}{|c|}{ Panel A: ROA mean and paired differences for distinct periods } \\
\hline \multicolumn{8}{|c|}{ UK } \\
\hline & $\mathbf{N}$ & $\mathbf{R O A}_{\mathrm{i},-1}$ & $\mathbf{R O A}_{\mathrm{i}, 0}$ & $\mathbf{R O A}_{\mathrm{i}, 1}$ & $\mathbf{R O A}_{i, 2}$ & $\operatorname{ROA}_{i, 1}-\mathbf{R O A}_{i, 0}$ & $\mathbf{R O A}_{i, 2-2}-\mathbf{R O A}_{i, 0}$ \\
\hline \multicolumn{8}{|c|}{ DIEI } \\
\hline Sub-sample values & 1,473 & $\begin{array}{c}0.120 * \\
(58.119)\end{array}$ & $\begin{array}{c}0.111 * \\
(49.537)\end{array}$ & $\begin{array}{c}0.096 * \\
(44.056)\end{array}$ & $\begin{array}{r}0.080 * \\
(32.267)\end{array}$ & $\begin{array}{c}-0.015 * \\
(-7.795)\end{array}$ & $\begin{array}{r}-0.031 * \\
(-11.972)\end{array}$ \\
\hline Paired differences & 216 & $\begin{array}{c}0.056 * \\
(7.318)\end{array}$ & $\begin{array}{c}0.043 * \\
(5.695)\end{array}$ & $\begin{array}{l}0.025 * \\
(3.308)\end{array}$ & $\begin{array}{l}0.015 * * * \\
(1.838)\end{array}$ & $\begin{array}{l}-0.018 * * \\
(-2.331)\end{array}$ & $\begin{array}{c}-0.028 * \\
(-3.626)\end{array}$ \\
\hline \multicolumn{8}{|l|}{ DIED } \\
\hline Sub-sample values & 487 & $\begin{array}{r}0.088 * \\
(26.248)\end{array}$ & $\begin{array}{l}0.085 * \\
(19.779)\end{array}$ & $\begin{array}{r}0.070 * \\
(19.081)\end{array}$ & $\begin{array}{l}0.063 * \\
(13.688)\end{array}$ & $\begin{array}{l}-0.014 * \\
(-3.137)\end{array}$ & $\begin{array}{l}-0.022 * \\
(-4.001)\end{array}$ \\
\hline Paired differences & 216 & $\begin{array}{c}0.038 * \\
(4.567)\end{array}$ & $\begin{array}{l}0.029 * \\
(3.869)\end{array}$ & $\begin{array}{l}0.016^{* * *} \\
(1.941)\end{array}$ & $\begin{array}{l}0.015 * * * \\
(1.712)\end{array}$ & $\begin{array}{r}-0.013 \\
(-1.589)\end{array}$ & $\begin{array}{l}-0.014 * * * \\
(-1.711)\end{array}$ \\
\hline \multicolumn{8}{|l|}{ DDEI } \\
\hline Sub-sample values & 77 & $\begin{array}{l}0.100 * \\
(8.660)\end{array}$ & $\begin{array}{l}0.086 * \\
(9.780)\end{array}$ & $\begin{array}{l}0.069 * \\
(3.123)\end{array}$ & $\begin{array}{l}0.051 * \\
(3.930)\end{array}$ & $\begin{array}{r}-0.017 \\
(-0.836)\end{array}$ & $\begin{array}{l}-0.035 * \\
(-2.785)\end{array}$ \\
\hline Paired differences & 77 & $\begin{array}{l}0.055 * \\
(3.769)\end{array}$ & $\begin{array}{l}0.030 * * \\
(2.615)\end{array}$ & $\begin{array}{r}0.013 \\
(0.564)\end{array}$ & $\begin{array}{r}0.002 \\
(0.147)\end{array}$ & $\begin{array}{r}-0.017 \\
(-1.158)\end{array}$ & $\begin{array}{l}-0.028 * * * \\
(-1.908)\end{array}$ \\
\hline \multicolumn{8}{|l|}{ DDED } \\
\hline Sub-sample values & 106 & $\begin{array}{l}0.031 * \\
(3.264)\end{array}$ & $\begin{array}{l}0.048 * \\
(4.650)\end{array}$ & $\begin{array}{c}0.059 * \\
(5.535)\end{array}$ & $\begin{array}{l}0.043 * \\
(3.997)\end{array}$ & $\begin{array}{r}0.011 \\
(1.065)\end{array}$ & $\begin{array}{r}-0.006 \\
(-0.498)\end{array}$ \\
\hline \multirow[t]{2}{*}{ Paired differences } & 106 & $\begin{array}{l}-0.021 * * * \\
(-1.691)\end{array}$ & $\begin{array}{r}-0.009 \\
(-0.727)\end{array}$ & $\begin{array}{r}-0.001 \\
(-0.097)\end{array}$ & $\begin{array}{r}-0.015 \\
(-1.053)\end{array}$ & $\begin{array}{r}0.008 \\
(0.657)\end{array}$ & $\begin{array}{r}-0.006 \\
(0.493)\end{array}$ \\
\hline & & & & & & & (Continue) \\
\hline $\begin{array}{ll}* & \text { Signific } \\
* * & \text { Signific } \\
* * * & \text { Signific }\end{array}$ & $\begin{array}{l}\text { cantly c } \\
\text { cantly c } \\
\text { cantly c }\end{array}$ & $\begin{array}{l}\text { different from } \\
\text { different from } \\
\text { different from }\end{array}$ & $\begin{array}{l}\text { zero at the } 1 \\
\text { zero at the } 5 \\
\text { zero at the } 1\end{array}$ & $\begin{array}{l}\text { \% level } \\
\% \text { level } \\
0 \% \text { level }\end{array}$ & & & \\
\hline
\end{tabular}


Table 3.13 - Change in post-announcement measures (continue)

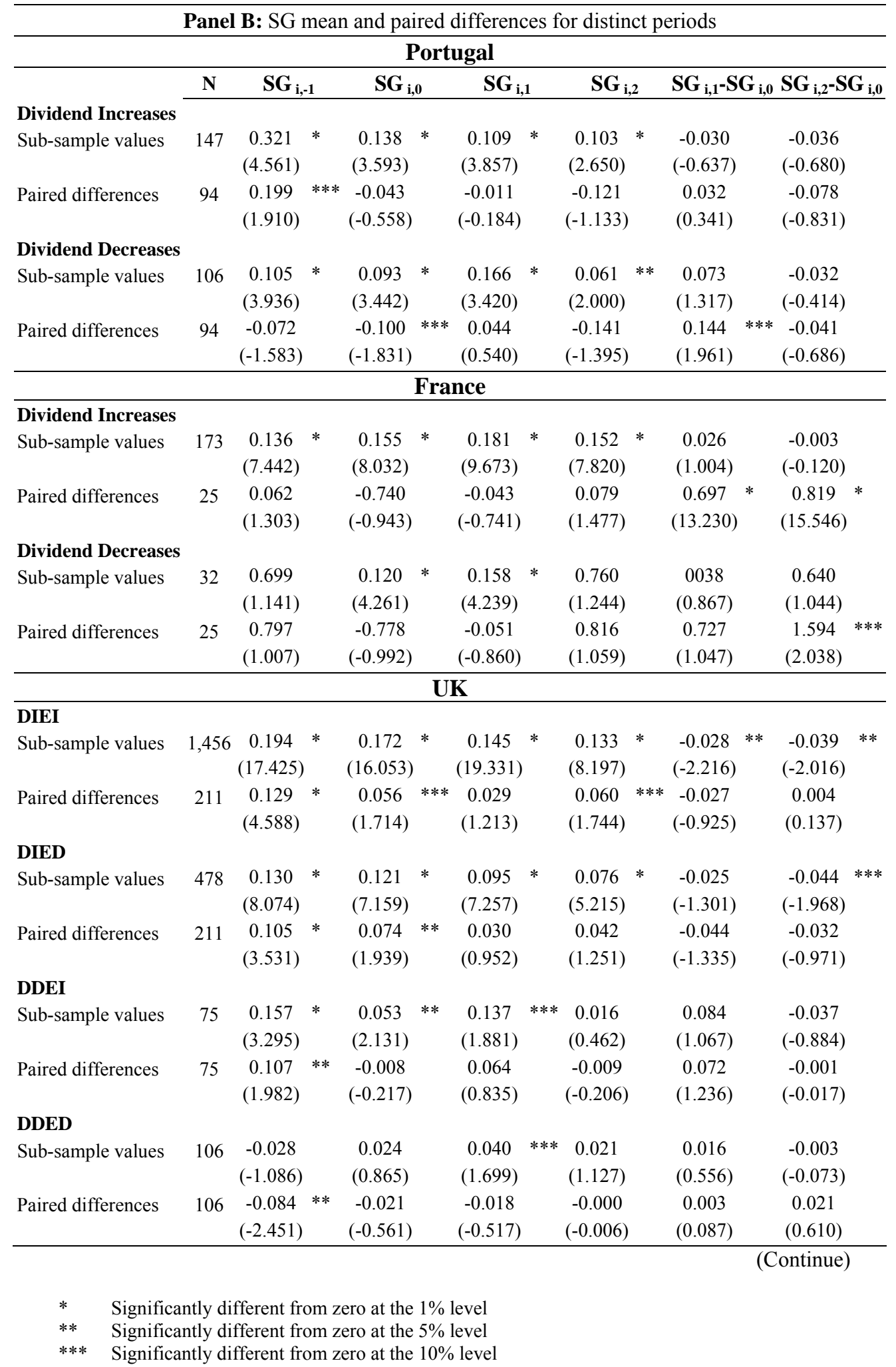


Table 3.13 - Change in post-announcement measures (continue)

\begin{tabular}{|c|c|c|c|c|c|c|c|c|c|c|}
\hline \multicolumn{11}{|c|}{ Panel C: CE mean and paired differences for distinct periods } \\
\hline \multicolumn{11}{|c|}{ France } \\
\hline \multirow{2}{*}{ Dividend Increases } & \multirow[t]{2}{*}{$\mathbf{N}$} & $\mathbf{C E}_{\mathrm{i},-1}$ & \multicolumn{2}{|c|}{$\mathrm{CE}_{\mathrm{i}, 0}$} & \multicolumn{2}{|c|}{$\mathrm{CE}_{\mathrm{i}, 1}$} & \multicolumn{2}{|c|}{$\mathrm{CE}_{\mathrm{i}, 2}$} & \multicolumn{2}{|c|}{$C E_{i, 1}-C E_{i, 0} C E_{i, 2}-C E_{i, 0}$} \\
\hline & & & & & & & & & & \\
\hline Sub-sample values & 175 & $\begin{array}{c}0.058 \\
(12.713)\end{array}$ & $\begin{array}{c}* \quad 0.057 \\
(13.860)\end{array}$ & $*$ & $\begin{array}{c}0.057 \\
(14.259)\end{array}$ & $*$ & $\begin{array}{c}0.053 \\
(17.044)\end{array}$ & * & $\begin{array}{c}-0.001 \\
(-0.366)\end{array}$ & $\begin{array}{l}-0.005 * * * \\
(-1.670)\end{array}$ \\
\hline Paired differences & 26 & $\begin{array}{c}-0.080 \\
(-1.115)\end{array}$ & $\begin{array}{c}-0.083 \\
(-1.754)\end{array}$ & $* * *$ & $\begin{array}{l}-0.100 \\
(-1.381)\end{array}$ & & $\begin{array}{c}-0.067 \\
(-1.814)\end{array}$ & $* * *$ & $\begin{array}{c}-0.017 \\
(-0.323)\end{array}$ & $\begin{array}{c}0.016 \\
(0.304)\end{array}$ \\
\hline \multicolumn{11}{|l|}{ Dividend Decreases } \\
\hline Sub-sample values & 34 & $\begin{array}{c}0.144 \\
(1.513)\end{array}$ & $\begin{array}{c}0.106 \\
(1.976)\end{array}$ & $* * *$ & $\begin{array}{c}0.084 \\
(2.369)\end{array}$ & $* *$ & $\begin{array}{c}0.110 \\
(2.000)\end{array}$ & $* * *$ & $\begin{array}{c}-0.023 \\
(-1.204)\end{array}$ & $\begin{array}{c}0.004 \\
(0.610))\end{array}$ \\
\hline Paired differences & 26 & $\begin{array}{c}-0.091 \\
(-1.240)\end{array}$ & $\begin{array}{c}-0.081 \\
(-1.640)\end{array}$ & & $\begin{array}{l}-0.103 \\
(-1.404)\end{array}$ & & $\begin{array}{l}-0.066 \\
(-1.673)\end{array}$ & & $\begin{array}{c}-0.022 \\
(-0.401)\end{array}$ & $\begin{array}{c}0.015 \\
(0.273)\end{array}$ \\
\hline \multicolumn{11}{|c|}{ UK } \\
\hline \multicolumn{11}{|l|}{ DIEI } \\
\hline Sub-sample values & 1,329 & $\begin{array}{c}0.427 \\
(1.213)\end{array}$ & $\begin{array}{c}0.119 \\
(2.774)\end{array}$ & $*$ & $\begin{array}{c}0.126 \\
(2.347)\end{array}$ & $* *$ & $\begin{array}{c}0.097 \\
(3.160)\end{array}$ & $*$ & $\begin{array}{c}0.007 \\
(0.653)\end{array}$ & $\begin{array}{l}-0.022 * * * \\
(-1.773)\end{array}$ \\
\hline Paired differences & 202 & $\begin{array}{c}0.012 \\
(1.302)\end{array}$ & $\begin{array}{c}0.020 \\
(1.827)\end{array}$ & $* *$ & $\begin{array}{c}0.016 \\
(1.206)\end{array}$ & & $\begin{array}{c}0.005 \\
(0.574)\end{array}$ & & $\begin{array}{c}-0.004 \\
(-0.390)\end{array}$ & $\begin{array}{c}-0.015 \\
(-1.463)\end{array}$ \\
\hline \multicolumn{11}{|l|}{ DIED } \\
\hline Sub-sample values & 436 & $\begin{array}{c}0.078 \\
(14.187)\end{array}$ & $\begin{array}{c}* \quad 0.070 \\
(18.375)\end{array}$ & $*$ & $\begin{array}{c}0.070 \\
(17.300)\end{array}$ & $*$ & $\begin{array}{c}0.065 \\
(18.164)\end{array}$ & $*$ & $\begin{array}{c}0.000 \\
(0.014)\end{array}$ & $\begin{array}{c}-0.005 \\
(-1.502)\end{array}$ \\
\hline Paired differences & 202 & $\begin{array}{c}0.017 \\
(1.578)\end{array}$ & $\begin{array}{c}0.008 \\
(1.139)\end{array}$ & & $\begin{array}{c}0.002 \\
(0.234)\end{array}$ & & $\begin{array}{c}-0.002 \\
(-0.279)\end{array}$ & & $\begin{array}{c}-0.006 \\
(-0.727)\end{array}$ & $\begin{array}{c}-0.010 \\
(-1.212)\end{array}$ \\
\hline \multicolumn{11}{|l|}{ DDEI } \\
\hline Sub-sample values & 66 & $\begin{array}{c}0.073 \\
(7.230)\end{array}$ & $\begin{array}{c}* \quad 0.068 \\
\\
(7.469)\end{array}$ & * & $\begin{array}{c}0.067 \\
(9.175)\end{array}$ & $*$ & $\begin{array}{c}0.061 \\
(7.227)\end{array}$ & * & $\begin{array}{c}-0.001 \\
(-0.216)\end{array}$ & $\begin{array}{c}-0.007 \\
(-0.929)\end{array}$ \\
\hline Paired differences & 66 & $\begin{array}{c}0.005 \\
(0.323)\end{array}$ & $\begin{array}{c}0.005 \\
(0.368)\end{array}$ & & $\begin{array}{c}-0.003 \\
(-0.240)\end{array}$ & & $\begin{array}{c}-0.013 \\
(-0.934)\end{array}$ & & $\begin{array}{l}-0.008 \\
(0.599)\end{array}$ & $\begin{array}{c}-0.018 \\
(-1.348)\end{array}$ \\
\hline \multicolumn{11}{|l|}{ DDED } \\
\hline Sub-sample values & 101 & $\begin{array}{c}0.629 \\
(1.116)\end{array}$ & $\begin{array}{c}0.777 \\
(1.098)\end{array}$ & & $\begin{array}{c}0.475 \\
(1.174)\end{array}$ & & $\begin{array}{c}0.055 \\
(7.543)\end{array}$ & $*$ & $\begin{array}{c}-0.301 \\
(-0.995)\end{array}$ & $\begin{array}{c}-0.722 \\
(-1.021)\end{array}$ \\
\hline Paired differences & 101 & $\begin{array}{c}0.563 \\
(0.999)\end{array}$ & $\begin{array}{c}0.713 \\
(1.008)\end{array}$ & & $\begin{array}{c}0.407 \\
(1.004)\end{array}$ & & $\begin{array}{c}-0.018 \\
(-1.692)\end{array}$ & $* * *$ & $\begin{array}{c}-0.306 \\
(-0.577)\end{array}$ & $\begin{array}{c}-0.732 \\
(-1.378)\end{array}$ \\
\hline
\end{tabular}

* $\quad$ Significantly different from zero at the $1 \%$ level

** Significantly different from zero at the $5 \%$ level

*** Significantly different from zero at the $10 \%$ level 


\section{Table 3.14 - Change in post-announcement measures grouped by operating performance}

This table provides mean values and mean differences for some firm characteristics surrounding dividend change announcements for dividend increases grouped into three groups based on the post-announcement operating performance: top performance group, middle performance group and bottom performance group: the annual values for the return on assets (ROA) based on operating income before depreciation (Table A), the sales growth (SG) rate, computed as a percentage of the previous year's sales for dividend changes (Table B) and the capital expenditure (CE), computed as a percentage of total assets (Panel C), not reported for the Portuguese sample because the lack of data. $\mathrm{ROA}_{\mathrm{i}, \mathrm{t}}$ is the ROA for share $\mathrm{i}$ on year $\mathrm{t}$; $\mathrm{SG}_{\mathrm{i}, \mathrm{t}}$ is the $\mathrm{SG}$ for share $\mathrm{i}$ on year $\mathrm{t}$. The abnormal operating performance, as well as the other variables, is computed as paired differences between the dividend-changing firm and the control firm, considered as our sub-samples of firms that did not change dividends. The significance levels for the means are based on a two-tailed t-test and are reported in parentheses.

\begin{tabular}{|c|c|c|c|c|c|c|c|c|c|c|}
\hline \multicolumn{11}{|c|}{ Panel A: ROA mean and paired differences for distinct periods } \\
\hline \multicolumn{11}{|c|}{ Portugal } \\
\hline \multicolumn{11}{|c|}{$\mathbf{A}_{\mathrm{i}, 1}-\mathbf{R O A}_{\mathrm{i}, 0} \mathbf{R}$} \\
\hline \multicolumn{11}{|c|}{ Top performance group } \\
\hline Sub-sample values & 49 & $\begin{array}{c}0.176 \\
(17.754)\end{array}$ & $\begin{array}{c}* 0.176 * \\
(20.088)\end{array}$ & $\begin{array}{c}0.179 \\
(29.018)\end{array}$ & & $\begin{array}{c}0.144 \\
(15.537)\end{array}$ & $\begin{array}{cc}* & 0.003 \\
& (0.381)\end{array}$ & & $\begin{array}{c}-0.032 \\
(-3.267)\end{array}$ & $*$ \\
\hline Paired differences & 31 & $\begin{array}{c}0.018 \\
(1.087)\end{array}$ & $\begin{array}{c}0.028 \text { ** } \\
(2.134)\end{array}$ & $\begin{array}{c}0.034 \\
(30.059)\end{array}$ & & $\begin{array}{c}0.015 \\
(1.056)\end{array}$ & $\begin{array}{c}0.006 \\
(0.414)\end{array}$ & & $\begin{array}{c}-0.013 \\
(-0.897)\end{array}$ & \\
\hline \multicolumn{11}{|c|}{ Middle performance group } \\
\hline Sub-sample values & 49 & $\begin{array}{c}0.123 \\
(12.945)\end{array}$ & $\begin{array}{c}* 0.113 * \\
(13.401)\end{array}$ & $\begin{array}{c}0.085 \\
(21.942)\end{array}$ & & $\begin{array}{c}0.077 \\
(10.823)\end{array}$ & $\begin{array}{c}-0.027 \\
(-3.424)\end{array}$ & $*$ & $\begin{array}{c}-0.036 \\
(-3.482)\end{array}$ & $*$ \\
\hline Paired differences & 31 & $\begin{array}{c}-0.001 \\
(-0.065)\end{array}$ & $\begin{array}{c}0.003 \\
(0.250)\end{array}$ & $\begin{array}{c}0.004 \\
(3.148)\end{array}$ & & $\begin{array}{c}-0.008 \\
(-0.861)\end{array}$ & $\begin{array}{c}0.001 \\
(0.085)\end{array}$ & & $\begin{array}{c}-0.011 \\
(-0.939)\end{array}$ & \\
\hline \multicolumn{11}{|c|}{ Bottom performance group } \\
\hline Sub-sample values & 49 & $\begin{array}{c}0.039 \\
(4.482)\end{array}$ & $\begin{array}{c}* 0.020 * \\
(3.003)\end{array}$ & $\begin{array}{c}-0.001 \\
(-0.590)\end{array}$ & & $\begin{array}{c}0.006 \\
(1.223)\end{array}$ & $\begin{array}{c}-0.021 \\
(-3.064)\end{array}$ & $*$ & $\begin{array}{c}-0.013 \\
(-1.666)\end{array}$ & \\
\hline Paired differences & 31 & $\begin{array}{c}0.010 \\
(0.740)\end{array}$ & $\begin{array}{c}-0.003 \\
(-0.213)\end{array}$ & $\begin{array}{c}-0.010 \\
(-3.482)\end{array}$ & & $\begin{array}{c}0.135 \\
(14.614)\end{array}$ & $\begin{array}{c}-0.007 \\
(-1.053)\end{array}$ & & $\begin{array}{c}0.138 \\
(20.750)\end{array}$ & $*$ \\
\hline \multicolumn{11}{|c|}{ France } \\
\hline \multicolumn{11}{|c|}{ Top performance group } \\
\hline Sub-sample values & 58 & $\begin{array}{c}0.082 \\
(13.996)\end{array}$ & $\begin{array}{c}0.086 * \\
(13.460)\end{array}$ & $\begin{array}{c}0.093 \\
(20.743)\end{array}$ & & $\begin{array}{c}0.069 \\
(13.229)\end{array}$ & $\begin{array}{c}0.008 \\
(1.371)\end{array}$ & & $\begin{array}{c}-0.017 \\
(-2.728)\end{array}$ & $*$ \\
\hline Paired differences & 9 & $\begin{array}{c}0.009 \\
(0.259)\end{array}$ & $\begin{array}{c}0.018 \\
(0.624)\end{array}$ & $\begin{array}{c}0.063 \\
(11.370)\end{array}$ & & $\begin{array}{c}0.007 \\
(0.304)\end{array}$ & $\begin{array}{c}0.045 \\
(1.603)\end{array}$ & & $\begin{array}{c}-0.011 \\
(-0.392)\end{array}$ & \\
\hline \multicolumn{11}{|c|}{ Middle performance group } \\
\hline Sub-sample values & 58 & $\begin{array}{c}0.048 \\
(14.460)\end{array}$ & $\begin{array}{c}* 0.054 * \\
(16.919)\end{array}$ & $\begin{array}{c}0.050 \\
(64.177)\end{array}$ & & $\begin{array}{c}0.047 \\
(11.835)\end{array}$ & $\begin{array}{c}-0.004 \\
(-1.309)\end{array}$ & & $\begin{array}{c}-0.008 \\
(-1.650)\end{array}$ & \\
\hline Paired differences & 9 & $\begin{array}{c}-0.004 \\
(-0.244)\end{array}$ & $\begin{array}{c}0.008 \\
(0.558)\end{array}$ & $\begin{array}{c}0.004 \\
(1.726)\end{array}$ & & $\begin{array}{c}0.013 \\
(1.571)\end{array}$ & $\begin{array}{c}-0.004 \\
(-0.683)\end{array}$ & & $\begin{array}{c}0.005 \\
(0.854)\end{array}$ & \\
\hline \multicolumn{11}{|c|}{ Bottom performance group } \\
\hline Sub-sample values & 58 & $\begin{array}{c}0.038 \\
(11.093)\end{array}$ & $\begin{array}{c}* 0.037 * \\
(13.876)\end{array}$ & $\begin{array}{c}0.016 \\
(3.920)\end{array}$ & & $\begin{array}{c}0.024 \\
(3.716)\end{array}$ & $\begin{array}{c}-0.021 \\
(-4.015)\end{array}$ & $*$ & $\begin{array}{c}-0.013 \\
(-1.721)\end{array}$ & $* * *$ \\
\hline Paired differences & 9 & $\begin{array}{c}-0.003 \\
(-0.231)\end{array}$ & $\begin{array}{c}0.011 \\
(1.436)\end{array}$ & $\begin{array}{c}0.010 \\
(2.882)\end{array}$ & $* *$ & $\begin{array}{c}-0.003 \\
(-0.182)\end{array}$ & $\begin{array}{c}-0.001 \\
(-0.139)\end{array}$ & & $\begin{array}{c}-0.014 \\
(-1.947)\end{array}$ & $* * *$ \\
\hline
\end{tabular}

* $\quad$ Significantly different from zero at the $1 \%$ level

** $\quad$ Significantly different from zero at the $5 \%$ level

*** Significantly different from zero at the $10 \%$ level 
Table 3.14 - Change in post-announcement measures grouped by operating performance (continued)

\begin{tabular}{|c|c|c|c|c|c|c|c|c|c|c|c|}
\hline \multicolumn{12}{|c|}{ Panel A: ROA mean and paired differences for distinct periods } \\
\hline \multicolumn{12}{|c|}{ UK } \\
\hline & $\mathbf{N}$ & \multicolumn{2}{|c|}{$\mathbf{R O A}_{\mathrm{i},-1}$} & $\mathbf{R O A}_{\mathrm{i}, 0}$ & $\mathbf{R O A}_{\mathrm{i}, 1}$ & \multicolumn{2}{|c|}{$\mathbf{R O A}_{i, 2}$} & \multicolumn{4}{|c|}{$\mathbf{R O A}_{i, 1}-\mathbf{R O A}_{i, 0} \mathbf{R O A}_{i, 2}-\mathbf{R O A}_{i, 0}$} \\
\hline \multicolumn{12}{|c|}{ DIEI } \\
\hline Top performance & & & & & & & & & & & \\
\hline Sub-sample values & 491 & $\begin{array}{c}0.170 \\
(41.004)\end{array}$ & $*$ & $\begin{array}{c}0.170 \\
(40.709)\end{array}$ & $\begin{array}{c}* \quad 0.175 \\
(58.419)\end{array}$ & $\begin{array}{c}* \quad 0.131 \\
(30.234)\end{array}$ & * & $\begin{array}{c}0.005 \\
(1.623)\end{array}$ & & $\begin{array}{c}-0.039 \\
(-7.603)\end{array}$ & * \\
\hline Paired differences & 72 & $\begin{array}{c}0.208 \\
(10.487)\end{array}$ & $*$ & $\begin{array}{c}0.194 \\
(8.886)\end{array}$ & $\begin{array}{cc}* & 0.156 \\
& (79.546)\end{array}$ & $\begin{array}{cc}* & 0.084 \\
& (4.434)\end{array}$ & $*$ & $\begin{array}{c}-0.038 \\
(-1.887)\end{array}$ & $* * *$ & $\begin{array}{c}-0.110 \\
(-5.463)\end{array}$ & * \\
\hline \multicolumn{12}{|c|}{ Middle performance group } \\
\hline Sub-sample values & 491 & $\begin{array}{c}0.103 \\
(43.118)\end{array}$ & $*$ & $\begin{array}{c}0.099 \\
(43.241)\end{array}$ & $\begin{array}{c}* \quad 0.092 \\
\quad(49.899)\end{array}$ & $\begin{array}{cc}* & 0.077 \\
\quad(28.170)\end{array}$ & $*$ & $\begin{array}{c}-0.007 \\
(-2.989)\end{array}$ & * & $\begin{array}{c}-0.022 \\
(-6.665)\end{array}$ & * \\
\hline Paired differences & 72 & $\begin{array}{c}0.067 \\
(7.091)\end{array}$ & * & $\begin{array}{c}0.063 \\
(7.971)\end{array}$ & $\begin{array}{cc}* & 0.053 \\
& (44.506)\end{array}$ & $\begin{array}{cc}* & 0.039 \\
& (4.548)\end{array}$ & $*$ & $\begin{array}{c}-0.010 \\
(-1.163)\end{array}$ & & $\begin{array}{c}-0.024 \\
(-2.792)\end{array}$ & * \\
\hline \multicolumn{12}{|c|}{ Bottom performance group } \\
\hline Sub-sample values & 491 & $\begin{array}{c}0.088 \\
(31.251)\end{array}$ & $*$ & $\begin{array}{c}0.065 \\
(19.417)\end{array}$ & $\begin{array}{c}* \quad 0.021 \\
(6.860)\end{array}$ & $\begin{array}{cc}* & 0.033 \\
& (7.396)\end{array}$ & $*$ & $\begin{array}{c}-0.045 \\
(-10.702)\end{array}$ & * & $\begin{array}{c}-0.033 \\
(-6.687)\end{array}$ & $*$ \\
\hline Paired differences & 72 & $\begin{array}{c}0.060 \\
(4.842)\end{array}$ & * & $\begin{array}{c}0.059 \\
(5.100)\end{array}$ & $\begin{array}{c}* \quad 0.096 \\
(10.016)\end{array}$ & $\begin{array}{cc}* & 0.038 \\
& (2.538)\end{array}$ & $* *$ & $\begin{array}{c}0.037 \\
(2.885)\end{array}$ & * & $\begin{array}{c}-0.021 \\
(-1.776)\end{array}$ & $* * *$ \\
\hline \multicolumn{12}{|l|}{ DIED } \\
\hline \multicolumn{12}{|c|}{ Top performance group } \\
\hline Sub-sample values & 162 & $\begin{array}{c}0.118 \\
(17.401)\end{array}$ & $*$ & $\begin{array}{c}0.134 \\
(16.022)\end{array}$ & $\begin{array}{c}* \quad 0.141 \\
(36.051)\end{array}$ & $\begin{array}{c}* \quad 0.122 \\
(14.628)\end{array}$ & $*$ & $\begin{array}{c}0.007 \\
(0.968)\end{array}$ & & $\begin{array}{c}-0.013 \\
(-1.206)\end{array}$ & \\
\hline Paired differences & 72 & $\begin{array}{c}0.076 \\
(4.253)\end{array}$ & $*$ & $\begin{array}{c}0.090 \\
(4.901)\end{array}$ & $\begin{array}{c}* \quad 0.036 \\
(13.124)\end{array}$ & $\begin{array}{c}* \quad 0.050 \\
\quad(2.637)\end{array}$ & $* *$ & $\begin{array}{c}-0.054 \\
(-2.937)\end{array}$ & * & $\begin{array}{c}-0.040 \\
(-2.176)\end{array}$ & $* *$ \\
\hline \multicolumn{12}{|c|}{ Middle performance group } \\
\hline Sub-sample values & 162 & $\begin{array}{c}0.080 \\
(26.390)\end{array}$ & $*$ & $\begin{array}{c}0.069 \\
(16.028)\end{array}$ & $\begin{array}{cc}* & 0.073 \\
\quad(69.449)\end{array}$ & $\begin{array}{c}* \quad 0.054 \\
\quad(10.207)\end{array}$ & * & $\begin{array}{c}0.004 \\
(0.936)\end{array}$ & & $\begin{array}{c}-0.015 \\
(-2.423)\end{array}$ & $* *$ \\
\hline Paired differences & 72 & $\begin{array}{c}0.046 \\
(5.472)\end{array}$ & $*$ & $\begin{array}{c}0.028 \\
(3.019)\end{array}$ & $\begin{array}{cc}* & 0.027 \\
& (36.945)\end{array}$ & $\begin{array}{cc}* & 0.017 \\
& (1.574)\end{array}$ & & $\begin{array}{c}-0.001 \\
(-0.107)\end{array}$ & & $\begin{array}{c}-0.011 \\
(-1.171)\end{array}$ & \\
\hline \multicolumn{12}{|c|}{ Bottom performance group } \\
\hline Sub-sample values & 162 & $\begin{array}{c}0.067 \\
(10.798)\end{array}$ & $*$ & $\begin{array}{c}0.051 \\
(6.985)\end{array}$ & $\begin{array}{cc}* & -0.000 \\
& (-0.001)\end{array}$ & $\begin{array}{c}0.013 \\
(1.727)\end{array}$ & $* * *$ & $\begin{array}{c}-0.051 \\
(-5.201)\end{array}$ & * & $\begin{array}{c}-0.038 \\
(-3.427)\end{array}$ & * \\
\hline Paired differences & 72 & $\begin{array}{c}0.021 \\
(2.113)\end{array}$ & $* *$ & $\begin{array}{c}0.030 \\
(2.722)\end{array}$ & $\begin{array}{cc}* & 0.074 \\
& (8.064) \\
\end{array}$ & $\begin{array}{c}* \quad 0.029 \\
(1.918) \\
\end{array}$ & $* * *$ & $\begin{array}{c}0.044 \\
(3.777)\end{array}$ & $*$ & $\begin{array}{c}-0.001 \\
(-0.092)\end{array}$ & \\
\hline
\end{tabular}

* $\quad$ Significantly different from zero at the $1 \%$ level

** $\quad$ Significantly different from zero at the $5 \%$ level

*** Significantly different from zero at the $10 \%$ level 
Table 3.14 - Change in post-announcement measures grouped by operating performance (continued)

\begin{tabular}{|c|c|c|c|c|c|c|c|c|c|c|c|c|}
\hline \multicolumn{13}{|c|}{ Panel B: SG mean and paired differences for distinct periods } \\
\hline \multicolumn{13}{|c|}{ Portugal } \\
\hline & $\mathbf{N}$ & \multicolumn{2}{|c|}{$S G_{i,-1}$} & \multicolumn{2}{|c|}{$\mathrm{SG}_{\mathrm{i}, \mathbf{0}}$} & \multicolumn{2}{|c|}{$S G_{i, 1}$} & \multicolumn{2}{|c|}{$\mathrm{SG}_{\mathrm{i}, 2}$} & $\mathrm{SG}_{\mathrm{i}, \mathbf{1}}-\mathrm{SG}_{\mathrm{i}, \mathbf{0}}$ & \multicolumn{2}{|l|}{$\mathrm{SG}_{\mathrm{i}, 2}-\mathrm{SG}_{\mathrm{i}, \mathbf{0}}$} \\
\hline \multicolumn{13}{|c|}{ Top performance group } \\
\hline Sub-sample values & 49 & $\begin{array}{c}0.245 \\
(3.528)\end{array}$ & * & $\begin{array}{c}0.137 \\
(4.605)\end{array}$ & $*$ & $\begin{array}{c}0.119 \\
(5.604)\end{array}$ & * & $\begin{array}{c}0.051 \\
(1.732)\end{array}$ & $* * *$ & $\begin{array}{c}-0.018 \\
(-0.489)\end{array}$ & $\begin{array}{l}-0.086 \\
(-1.782)\end{array}$ & *** \\
\hline Paired differences & 31 & $\begin{array}{c}0.033 \\
(0.296)\end{array}$ & & $\begin{array}{c}-0.162 \\
(-1.536)\end{array}$ & & $\begin{array}{c}-0.040 \\
(-0.748)\end{array}$ & & $\begin{array}{c}-0.069 \\
(-0.886)\end{array}$ & & $\begin{array}{c}0.122 \\
(1.525)\end{array}$ & $\begin{array}{c}0.093 \\
(1.162)\end{array}$ & \\
\hline \multicolumn{13}{|c|}{ Middle performance group } \\
\hline Sub-sample values & 49 & $\begin{array}{c}0.235 \\
(2.643)\end{array}$ & $* *$ & $\begin{array}{c}0.126 \\
(3.203)\end{array}$ & $*$ & $\begin{array}{c}0.064 \\
(1.658)\end{array}$ & & $\begin{array}{c}0.012 \\
(0.204)\end{array}$ & & $\begin{array}{c}-0.062 \\
(-1.088)\end{array}$ & $\begin{array}{c}-0.114 \\
(-1.531)\end{array}$ & \\
\hline Paired differences & 31 & $\begin{array}{c}0.074 \\
(0.463)\end{array}$ & & $\begin{array}{c}-0.007 \\
(-0.078)\end{array}$ & & $\begin{array}{c}0.093 \\
(1.669)\end{array}$ & & $\begin{array}{c}-0.136 \\
(-1.586)\end{array}$ & & $\begin{array}{c}0.100 \\
(1.175)\end{array}$ & $\begin{array}{c}-0.129 \\
(-1.516)\end{array}$ & \\
\hline \multicolumn{13}{|c|}{ Bottom performance group } \\
\hline Sub-sample values & 49 & $\begin{array}{c}0.483 \\
(2.716)\end{array}$ & $*$ & $\begin{array}{c}0.153 \\
(1.447)\end{array}$ & & $\begin{array}{c}0.144 \\
(1.980)\end{array}$ & $* * *$ & $\begin{array}{c}0.245 \\
(2.619)\end{array}$ & $* *$ & $\begin{array}{c}-0.009 \\
(-0.075)\end{array}$ & $\begin{array}{c}0.093 \\
(0.712)\end{array}$ & \\
\hline Paired differences & 31 & $\begin{array}{c}0.547 \\
(1.945)\end{array}$ & $* * *$ & $\begin{array}{c}0.007 \\
(0.071)\end{array}$ & & $\begin{array}{c}0.024 \\
(0.119)\end{array}$ & & $\begin{array}{c}-0.208 \\
(-0.713)\end{array}$ & & $\begin{array}{c}0.017 \\
(0.094)\end{array}$ & $\begin{array}{c}-0.215 \\
(-1.187)\end{array}$ & \\
\hline \multicolumn{13}{|c|}{ France } \\
\hline \multicolumn{13}{|c|}{ Top performance group } \\
\hline Sub-sample values & 57 & $\begin{array}{c}0.151 \\
(6.299)\end{array}$ & * & $\begin{array}{c}0.172 \\
(7.658)\end{array}$ & $*$ & $\begin{array}{c}0.197 \\
(5.526)\end{array}$ & * & $\begin{array}{c}0.194 \\
(4.985)\end{array}$ & $*$ & $\begin{array}{c}0.024 \\
(0.730)\end{array}$ & $\begin{array}{c}0.021 \\
(0.469)\end{array}$ & \\
\hline Paired differences & 9 & $\begin{array}{c}0.247 \\
(3.798)\end{array}$ & * & $\begin{array}{c}-1.084 \\
(-0.947)\end{array}$ & & $\begin{array}{c}0.095 \\
(0.880)\end{array}$ & & $\begin{array}{c}0.068 \\
(0.388)\end{array}$ & & $\begin{array}{c}1.179 \\
(6.091)\end{array}$ & $\begin{array}{l}1.152 * \\
(6.084)\end{array}$ & \\
\hline \multicolumn{13}{|c|}{ Middle performance group } \\
\hline Sub-sample values & 57 & $\begin{array}{c}0.158 \\
(3.629)\end{array}$ & * & $\begin{array}{c}0.143 \\
(3.168)\end{array}$ & $*$ & $\begin{array}{c}0.182 \\
(5.553)\end{array}$ & * & $\begin{array}{c}0.180 \\
(4.985)\end{array}$ & $*$ & $\begin{array}{c}0.039 \\
(0.705)\end{array}$ & $\begin{array}{c}0.037 \\
(0.594)\end{array}$ & \\
\hline Paired differences & 8 & $\begin{array}{c}0.039 \\
(0.577)\end{array}$ & & $\begin{array}{c}-0.029 \\
(-0.447)\end{array}$ & & $\begin{array}{c}-0.151 \\
(-2.041)\end{array}$ & $* * *$ & $\begin{array}{c}0.070 \\
(0.601)\end{array}$ & & $\begin{array}{c}-0.122 \\
(-1.595)\end{array}$ & $\begin{array}{c}0.099 \\
(1.296)\end{array}$ & \\
\hline \multicolumn{13}{|c|}{ Bottom performance group } \\
\hline Sub-sample values & 58 & $\begin{array}{c}0.103 \\
(4.236)\end{array}$ & $*$ & $\begin{array}{c}0.154 \\
(5.189)\end{array}$ & $*$ & $\begin{array}{c}0.167 \\
(5.651)\end{array}$ & * & $\begin{array}{c}0.086 \\
(3.629)\end{array}$ & $*$ & $\begin{array}{c}0.013 \\
(0.302)\end{array}$ & $\begin{array}{l}-0.068 \\
(-1.934)\end{array}$ & \\
\hline \multirow[t]{2}{*}{ Paired differences } & 8 & $\begin{array}{c}0.094 \\
(0.646)\end{array}$ & & $\begin{array}{c}0.024 \\
(0.193)\end{array}$ & & $\begin{array}{c}-0.081 \\
(-1.058)\end{array}$ & & $\begin{array}{c}-0.044 \\
(-0.745)\end{array}$ & & $\begin{array}{c}-0.105 \\
(-1.179)\end{array}$ & $\begin{array}{c}-0.068 \\
(-0.763)\end{array}$ & \\
\hline & & & & & & & & & & \multicolumn{3}{|c|}{ (Continue) } \\
\hline $\begin{array}{ll}* & \text { Significa } \\
* * & \text { Significa } \\
* * * & \text { Significa }\end{array}$ & $\begin{array}{l}\text { nt fro } \\
\text { nt fro } \\
\text { nt fro }\end{array}$ & $\begin{array}{l}m \text { zero at } \\
m \text { zero at } \\
m \text { zero at }\end{array}$ & $\begin{array}{l}t \text { the } 1 \\
t \text { the } 5 \\
t \text { the } 1\end{array}$ & $\begin{array}{l}1 \% \text { level } \\
5 \% \text { level } \\
10 \% \text { leve }\end{array}$ & & & & & & & & \\
\hline
\end{tabular}


Table 3.14 - Change in post-announcement measures grouped by operating performance (continued)

\begin{tabular}{|c|c|c|c|c|c|c|c|c|c|c|}
\hline \multicolumn{11}{|c|}{ Panel B: SG mean and paired differences for distinct periods } \\
\hline \multicolumn{11}{|c|}{ UK } \\
\hline & $\mathbf{N}$ & \multicolumn{2}{|c|}{$S G_{i,-1}$} & \multicolumn{2}{|c|}{ SGA $_{\mathbf{i}, 0}$} & $S G_{i, 1}$ & \multicolumn{2}{|c|}{$\mathrm{SG}_{\mathrm{i}, 2}$} & $\mathrm{SG}_{\mathrm{i}, 1}-\mathrm{SG}_{\mathrm{i}, 0}$ & $\mathrm{SG}_{\mathrm{i}, 2^{-}}-\mathrm{SG}_{\mathrm{i}, 0}$ \\
\hline \multicolumn{11}{|l|}{ DIEI } \\
\hline \multicolumn{11}{|c|}{ Top performance group } \\
\hline Sub-sample values & 478 & $\begin{array}{c}0.257 \\
(9.119)\end{array}$ & $*$ & $\begin{array}{c}0.233 \\
(8.643)\end{array}$ & * & $\begin{array}{c}0.229 \\
(16.647)\end{array}$ & $\begin{array}{c}* \quad 0.175 \\
(15.674)\end{array}$ & $*$ & $\begin{array}{c}-0.003 \\
(-0.111)\end{array}$ & $\begin{array}{l}-0.057 \text { *** } \\
(-1.963)\end{array}$ \\
\hline Paired differences & 69 & $\begin{array}{c}0.255 \\
(6.573)\end{array}$ & * & $\begin{array}{c}0.221 \\
(5.665)\end{array}$ & * & $\begin{array}{c}0.239 \\
(3.265)\end{array}$ & $\begin{array}{cc}* & 0.168 \\
& (3.144)\end{array}$ & $*$ & $\begin{array}{c}0.018 \\
(0.377)\end{array}$ & $\begin{array}{l}-0.053 \\
(1.110)\end{array}$ \\
\hline \multicolumn{11}{|c|}{ Middle performance group } \\
\hline Sub-sample values & 488 & $\begin{array}{c}0.187 \\
(13.516)\end{array}$ & $*$ & $\begin{array}{c}0.155 \\
(14.686)\end{array}$ & * & $\begin{array}{c}0.149 \\
(13.962)\end{array}$ & $\begin{array}{c}* \quad 0.107 \\
\quad(11.011)\end{array}$ & $*$ & $\begin{array}{c}-0.005 \\
(-0.385)\end{array}$ & $\begin{array}{l}-0.048 * \\
(-3.379)\end{array}$ \\
\hline Paired differences & 70 & $\begin{array}{c}0.141 \\
(4.236)\end{array}$ & * & $\begin{array}{c}0.007 \\
(0.086)\end{array}$ & & $\begin{array}{c}0.049 \\
(1.176)\end{array}$ & $\begin{array}{c}0.009 \\
(0.167)\end{array}$ & & $\begin{array}{c}0.042 \\
(0.891)\end{array}$ & $\begin{array}{c}0.002 \\
(0.042)\end{array}$ \\
\hline \multicolumn{11}{|c|}{ Bottom performance group } \\
\hline Sub-sample values & 490 & $\begin{array}{c}0.141 \\
(11.930)\end{array}$ & $*$ & $\begin{array}{c}0.131 \\
(9.081)\end{array}$ & $*$ & $\begin{array}{c}0.057 \\
(4.720)\end{array}$ & $\begin{array}{cc}* & 0.118 \\
& (2.562)\end{array}$ & $* *$ & $\begin{array}{l}-0.074 * \\
(-4.163)\end{array}$ & $\begin{array}{c}-0.013 \\
(-0.268)\end{array}$ \\
\hline Paired differences & 72 & $\begin{array}{c}0.073 \\
(1.589)\end{array}$ & & $\begin{array}{c}0.173 \\
(3.569)\end{array}$ & * & $\begin{array}{c}0.051 \\
(1.472)\end{array}$ & $\begin{array}{c}0.148 \\
(3.111)\end{array}$ & $*$ & $\begin{array}{l}-0.122 * \\
(-2.815)\end{array}$ & $\begin{array}{c}-0.025 \\
(-0.577)\end{array}$ \\
\hline \multicolumn{11}{|c|}{ DIED } \\
\hline Sub-sample values & 159 & $\begin{array}{c}0.168 \\
(4.741)\end{array}$ & $*$ & $\begin{array}{c}0.154 \\
(5.775)\end{array}$ & $*$ & $\begin{array}{c}0.167 \\
(7.411)\end{array}$ & $\begin{array}{cc}* & 0.151 \\
& (5.745)\end{array}$ & $*$ & $\begin{array}{c}0.013 \\
(0.369)\end{array}$ & $\begin{array}{c}-0.003 \\
(-0.074)\end{array}$ \\
\hline Paired differences & 69 & $\begin{array}{c}0.163 \\
(3.025)\end{array}$ & $*$ & $\begin{array}{c}0.161 \\
(2.968)\end{array}$ & * & $\begin{array}{c}0.065 \\
(1.251)\end{array}$ & $\begin{array}{c}0.122 \\
(1.981)\end{array}$ & $* * *$ & $\begin{array}{l}-0.096 \quad * * * \\
(-1.739)\end{array}$ & $\begin{array}{c}-0.039 \\
(-0.707)\end{array}$ \\
\hline \multicolumn{11}{|c|}{ Middle performance group } \\
\hline Sub-sample values & 161 & $\begin{array}{c}0.107 \\
(5.597)\end{array}$ & $*$ & $\begin{array}{c}0.118 \\
(5.450)\end{array}$ & * & $\begin{array}{c}0.097 \\
(5.233)\end{array}$ & $\begin{array}{c}* 0.062 \\
(2.220)\end{array}$ & $* *$ & $\begin{array}{c}-0.022 \\
(-0.908)\end{array}$ & $\begin{array}{c}-0.056 \\
(-1.524)\end{array}$ \\
\hline Paired differences & 70 & $\begin{array}{c}0.050 \\
(1.636)\end{array}$ & & $\begin{array}{c}-0.044 \\
(-0.515)\end{array}$ & & $\begin{array}{c}-0.003 \\
(-0.067)\end{array}$ & $\begin{array}{c}0.019 \\
(0.248)\end{array}$ & & $\begin{array}{c}0.041 \\
(0.818)\end{array}$ & $\begin{array}{c}0.063 \\
(1.257)\end{array}$ \\
\hline \multicolumn{11}{|c|}{ Bottom performance group } \\
\hline Sub-sample values & 157 & $\begin{array}{c}0.115 \\
(4.271)\end{array}$ & $*$ & $\begin{array}{c}0.091 \\
(2.419)\end{array}$ & $* *$ & $\begin{array}{c}0.025 \\
(0.989)\end{array}$ & $\begin{array}{c}0.020 \\
(1.045)\end{array}$ & & $\begin{array}{l}-0.066 \\
(-1.625)\end{array}$ & $\begin{array}{l}-0.071 \quad * * * \\
(-1.751)\end{array}$ \\
\hline \multirow[t]{2}{*}{ Paired differences } & 72 & $\begin{array}{c}0.098 \\
(1.864)\end{array}$ & $* * *$ & $\begin{array}{c}0.132 \\
(1.769)\end{array}$ & $* * *$ & $\begin{array}{c}0.037 \\
(1.036)\end{array}$ & $\begin{array}{c}0.093 \\
(2.332)\end{array}$ & $* *$ & $\begin{array}{l}-0.095 * * \\
(-2.031)\end{array}$ & $\begin{array}{c}-0.039 \\
(-0.834)\end{array}$ \\
\hline & & & & & & & & & & (Continue) \\
\hline $\begin{array}{ll}* & \text { Signific } \\
* * & \text { Signific } \\
* * * & \text { Signific }\end{array}$ & $\begin{array}{l}\text { ent } f \\
\text { ent } f \\
\text { ent } f\end{array}$ & $\begin{array}{l}\text { from zerc } \\
\text { from zerc } \\
\text { from zerc }\end{array}$ & $\begin{array}{l}\mathrm{D} \text { at th } \\
\mathrm{D} \text { at th } \\
\mathrm{b} \text { at th }\end{array}$ & $\begin{array}{l}\text { ne } 1 \% \text { lev } \\
\text { he } 5 \% \text { lev } \\
10 \% \text { le }\end{array}$ & & & & & & \\
\hline
\end{tabular}


Table 3.14 - Change in post-announcement measures grouped by operating performance (continued)

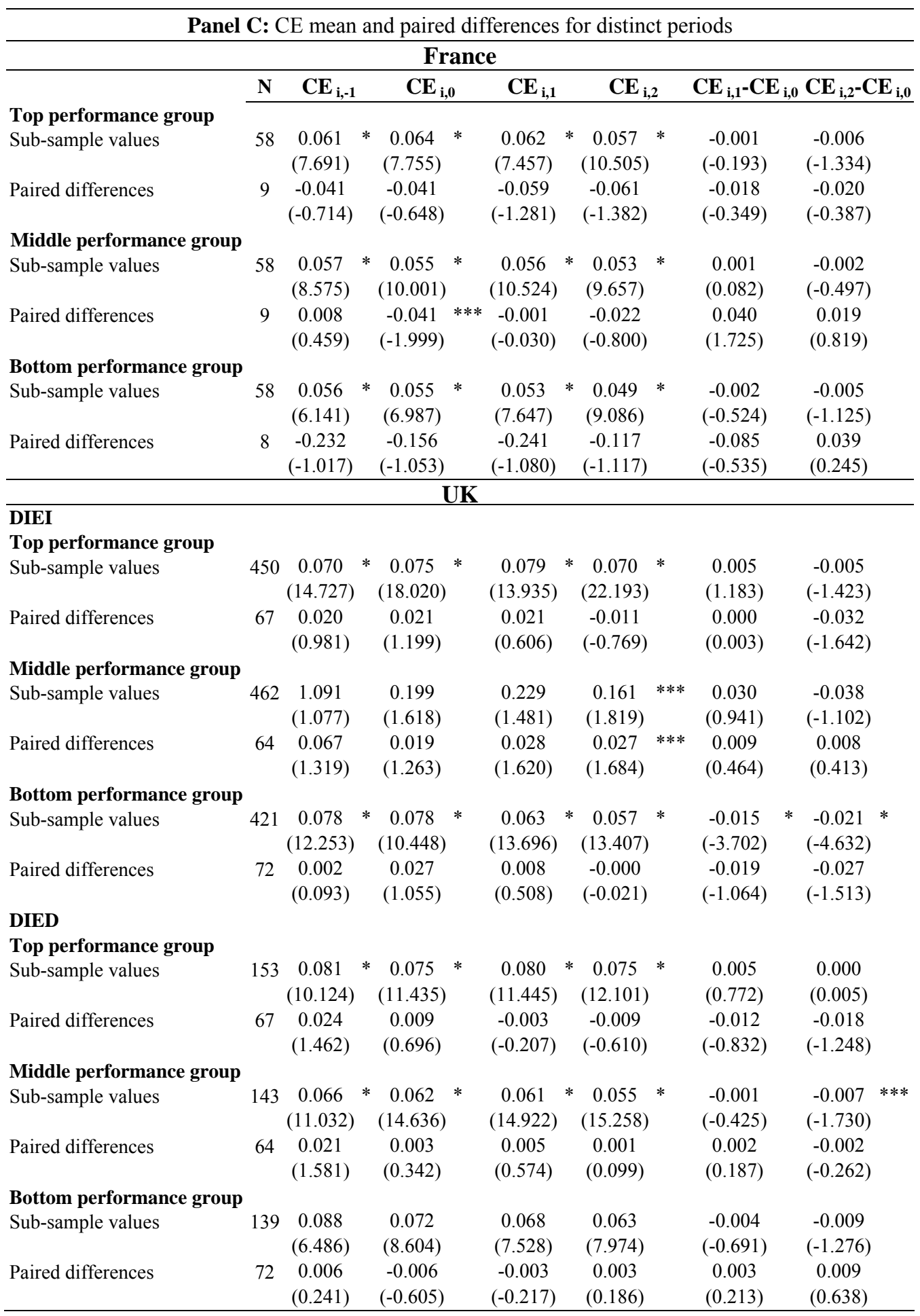

* $\quad$ Significantly different from zero at the $1 \%$ level

** $\quad$ Significantly different from zero at the $5 \%$ level

*** Significantly different from zero at the $10 \%$ level 
Table 3.15 - Regression of cumulative abnormal returns on future performance measures

This table reports estimates of regressions relating some profitability measures and dividend increases to abnormal return for the full dividend increases sample, as well as the top and bottom performance groups, considering the dependent variable as CAR (Panel A) and BHAR (Panel B). $\mathrm{CAR}_{3}$ is the cumulative abnormal return on the 3-day period as calculated by equation $.9 \mathrm{BHAR}_{3}$ is the buy and hold accumulated abnormal return on the 3 -day period as calculated by equation $.10 ; \mathrm{DI}_{\mathrm{i}, 0}$ is the dividend increases per share $\mathrm{i}$ for year $0 ; \mathrm{DIEI}_{\mathrm{i}, 0}$ is the dividend increase per share $\mathrm{i}$ for year 0 when earnings increases; $\mathrm{DIED}_{\mathrm{i}, 0}$ is the dividend increase per share $\mathrm{i}$ for year 0 when earnings decreases; $\mathrm{ROA}_{\mathrm{i}, \mathrm{t}}$ is the ROA for share $i$ in year $t ; R_{i, 2}$ is the measure of the abnormal change in profitability during the two years after the dividend changes, computed as $\left(\mathrm{ROA}_{\mathrm{i}, 2}+\mathrm{ROA}_{\mathrm{i}, 1}\right) / 2-\mathrm{ROA}_{\mathrm{i}, 0} ; \mathrm{CE}_{\mathrm{i}, 0}$ is the capital expenditure for share $\mathrm{i}$, calculated as capital expenditures to the beginning of year total assets; $\mathrm{CE}_{\mathrm{i}, 2}$ is the change in $\mathrm{CE}$ during the two years after the dividend changes, computed as $\left(\mathrm{CE}_{\mathrm{i}, 2}+\mathrm{CE}_{\mathrm{i}, 1}\right) / 2-$

$\mathrm{CE}_{\mathrm{i}, 0} ; \mathrm{SG}_{\mathrm{i}, 0}$ is the sales growth rate for share $\mathrm{i}$, computed as a percentage of the previous year's sales; $\mathrm{SG}_{\mathrm{i}, 2}$ is the change in $\mathrm{SG}$ during the two years after the dividend changes $\left(\mathrm{SG}_{\mathrm{i}, 2}+\mathrm{SG}_{\mathrm{i}, 1}\right) / 2-\mathrm{SG}_{\mathrm{i}, 0}$. The table presents the results estimated using pooled OLS, FEM and REM. The numbers in parentheses are the t-statistics corrected for heteroscedasticity using the White (1980) method. It reports the F test, a test for the equality of sets of coefficients, and the Hausman (1978) test, a test with $\mathrm{H}_{0}$ : random effects are consistent and efficient, versus $\mathrm{H}_{1}$ : random effects are inconsistent, in order to choose the most appropriate model for each particular sample.

\begin{tabular}{|c|c|c|c|c|c|c|}
\hline \multicolumn{7}{|c|}{ Panel A: Dependent Variable - CAR } \\
\hline \multicolumn{7}{|c|}{$\begin{aligned} C A R_{i}=a & +\beta_{1} \Delta \mathrm{DI}_{\mathrm{i}, 0}+\beta_{2}\left(R O A_{i, 0}-R O A_{i,-1}\right)+\beta_{3} \Delta R O A_{i, 2}+\beta_{4}\left(S G_{i, 0}-S G_{i,-1}\right) \dashv \\
& +\beta_{5} \Delta S G_{i, 2}+\beta_{6}\left(C E_{i, 0}-C E_{i,-1}\right)+\beta_{7} \Delta C E_{i, 2}+\varepsilon_{i, t}\end{aligned}$} \\
\hline \multicolumn{7}{|c|}{ France } \\
\hline Coefficient & Pooled OLS & & FEM & & REM & \\
\hline \multirow[b]{2}{*}{ Constant } & \multicolumn{6}{|c|}{ Full dividend increases sample } \\
\hline & $\begin{array}{r}0.007 \\
(2.394)\end{array}$ & $* *$ & & & $\begin{array}{r}0.009 \\
(1.768)\end{array}$ & $* * *$ \\
\hline$\Delta \mathrm{DI}_{\mathrm{i}, 0}$ & $\begin{array}{r}-0.327 \\
(-1.101)\end{array}$ & & $\begin{array}{r}-0.574 \\
(-2.631)\end{array}$ & $* *$ & $\begin{array}{r}-0.502 \\
(-1.380)\end{array}$ & \\
\hline $\mathrm{ROA}_{\mathrm{i}, 0}-\mathrm{ROA}_{\mathrm{i},-1}$ & $\begin{array}{r}0.129 \\
(0.862)\end{array}$ & & $\begin{array}{r}0.118 \\
(0.622)\end{array}$ & & $\begin{array}{r}0.110 \\
(0.614)\end{array}$ & \\
\hline $\mathrm{ROA}_{\mathrm{i}, 2}$ & $\begin{array}{r}0.179 \\
(1.432)\end{array}$ & & $\begin{array}{r}0.239 \\
(1.502)\end{array}$ & & $\begin{array}{r}0.205 \\
(1.494)\end{array}$ & \\
\hline $\mathrm{SG}_{\mathrm{i}, 0}-\mathrm{SG}_{\mathrm{i}, 1}$ & $\begin{array}{r}-0.022 \\
(-1.362)\end{array}$ & & $\begin{array}{r}0.001 \\
(0.038)\end{array}$ & & $\begin{array}{r}-0.008 \\
(-0.310)\end{array}$ & \\
\hline $\mathrm{SG}_{\mathrm{i}, 2}$ & $\begin{array}{r}-0.012 \\
(-0.894)\end{array}$ & & $\begin{array}{r}0.010 \\
(0.659)\end{array}$ & & $\begin{array}{r}0.002 \\
(0.135)\end{array}$ & \\
\hline $\mathrm{CE}_{\mathrm{i}, 0}-\mathrm{CE}_{\mathrm{i},-1}$ & $\begin{array}{r}0.396 \\
(2.108)\end{array}$ & ** & $\begin{array}{r}0.460 \\
(1.822)\end{array}$ & $* * *$ & $\begin{array}{r}0.422 \\
(1.959)\end{array}$ & $* * *$ \\
\hline $\mathrm{CE}_{\mathrm{i}, 2}$ & $\begin{array}{r}0.302 \\
(2.010)\end{array}$ & ** & $\begin{array}{r}0.375 \\
(1.745)\end{array}$ & $* * *$ & $\begin{array}{r}0.337 \\
(1.860)\end{array}$ & $* * *$ \\
\hline $\mathrm{N}$ & 173 & & 173 & & 173 & \\
\hline Adjusted $\mathrm{R}^{2}$ & 0.017 & & 0.097 & & 0.403 & \\
\hline Test $\mathrm{F}$ & 1.19 & & & & & \\
\hline \multirow[t]{2}{*}{ Hausman Test } & & & 5.96 & & & \\
\hline & & & & & (Conti & inue) \\
\hline $\begin{array}{ll}* & \text { Significan } \\
* * & \text { Significan } \\
* * * & \text { Significan }\end{array}$ & $\begin{array}{l}\text { fferent from zero } \\
\text { fferent from zero } \\
\text { fferent from zero }\end{array}$ & $\begin{array}{l}\text { at th } \\
\text { at th } \\
\text { at th }\end{array}$ & $\begin{array}{l}\text { vel } \\
\text { vel } \\
\text { evel }\end{array}$ & & & \\
\hline
\end{tabular}


Table 3.15 - Regression of cumulative abnormal returns on future performance measures (continued)

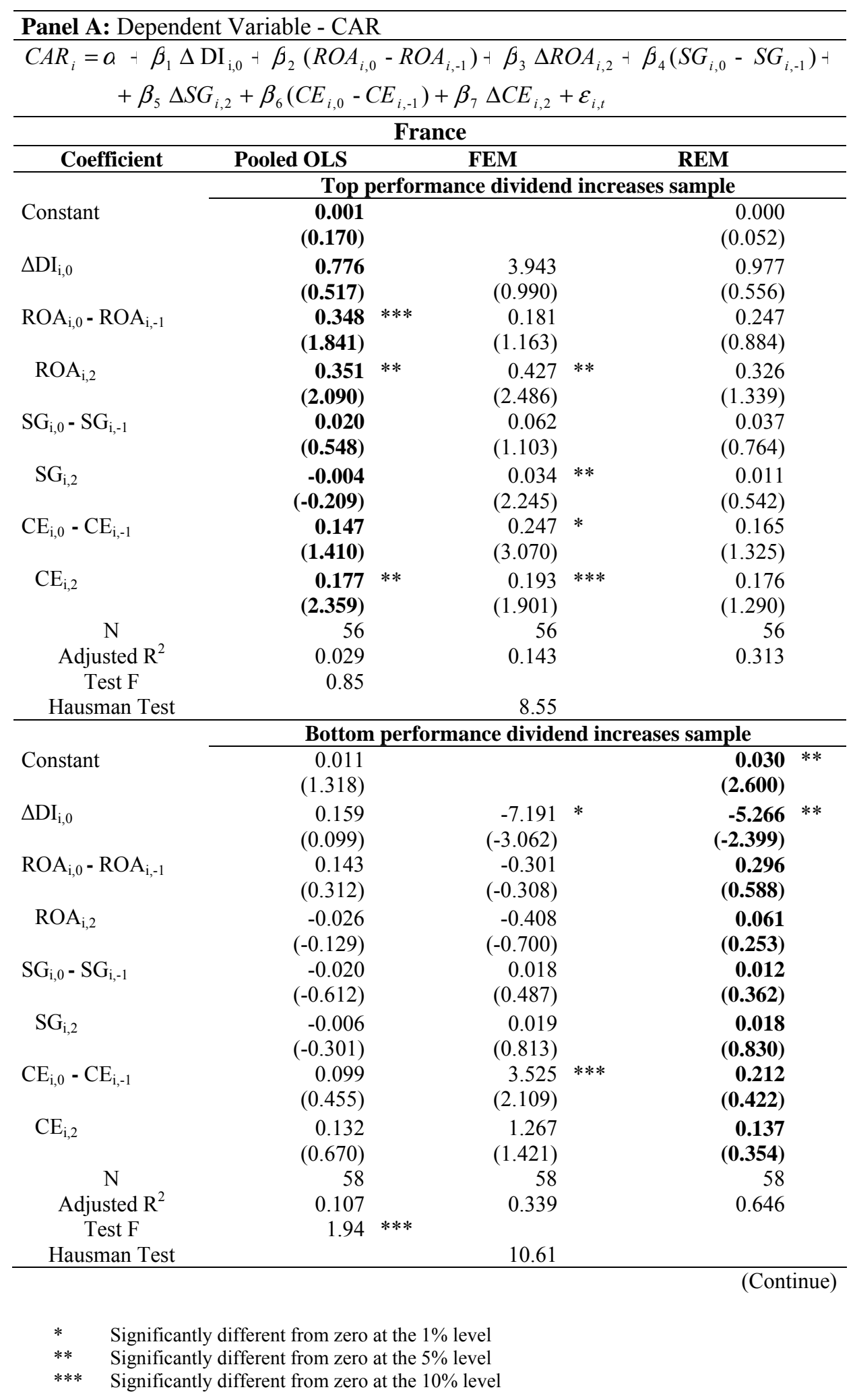


Table 3.15 - Regression of cumulative abnormal returns on future performance measures (continued)

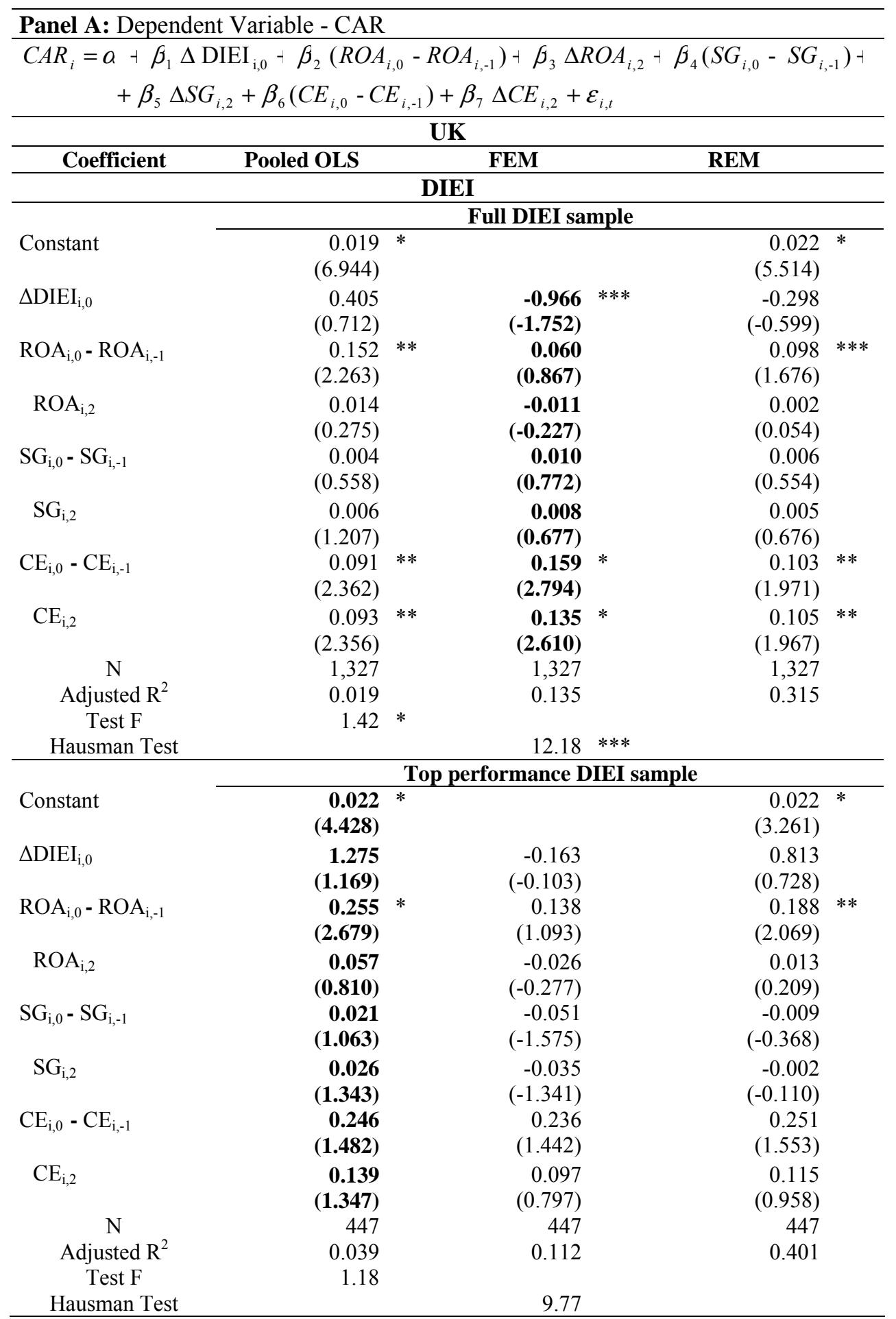

(Continue)

* $\quad$ Significantly different from zero at the $1 \%$ level

** $\quad$ Significantly different from zero at the $5 \%$ level

*** Significantly different from zero at the $10 \%$ level 
Table 3.15 - Regression of cumulative abnormal returns on future performance measures (continued)

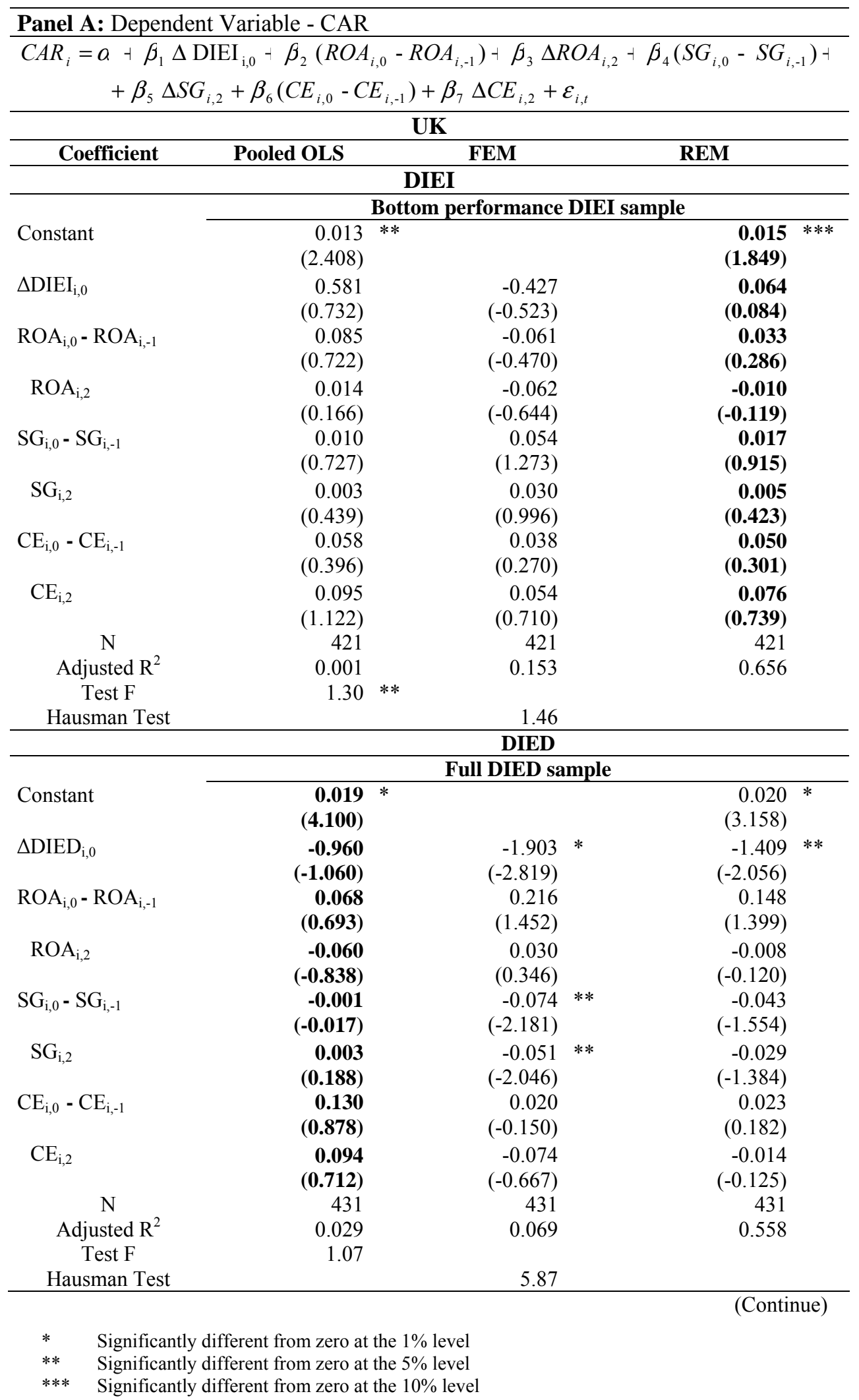


Table 3.15 - Regression of cumulative abnormal returns on future performance measures (continued)

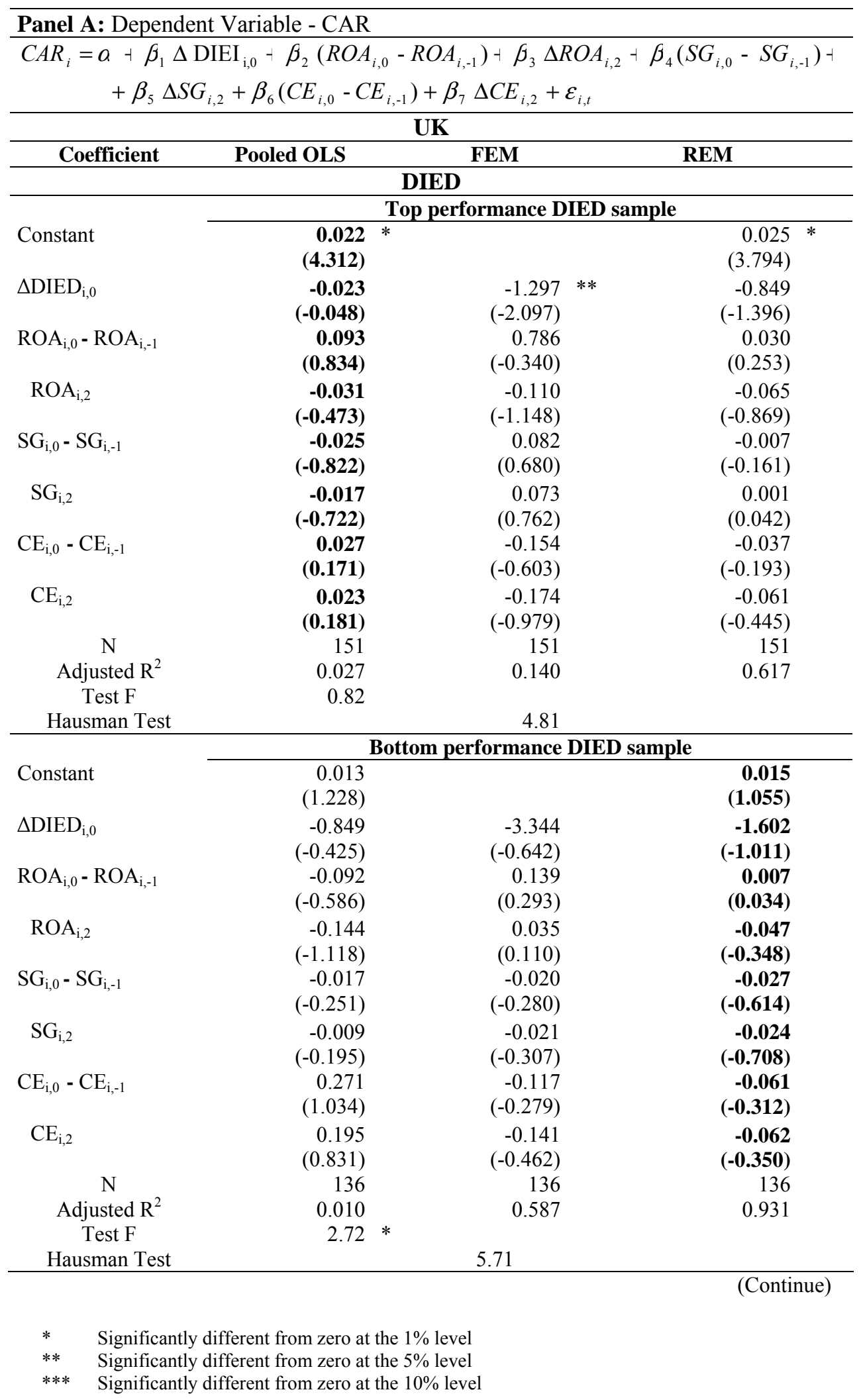


Table 3.15 - Regression of cumulative abnormal returns on future performance measures (continued)

\begin{tabular}{|c|c|c|c|c|c|c|}
\hline \multicolumn{7}{|c|}{$\begin{aligned} \text { BHAR }_{i}= & a-\beta_{1} \Delta \mathrm{DI}_{\mathrm{i}, 0}+\beta_{2}\left(R O A_{i, 0}-R O A_{i,-1}\right) \dashv \beta_{3} \Delta R O A_{i, 2}+\beta_{4}\left(S G_{i, 0}-S G_{i,-1}\right) \dashv \\
& +\beta_{5} \Delta S G_{i, 2}+\varepsilon_{i, t}\end{aligned}$} \\
\hline \multicolumn{7}{|c|}{ Portugal } \\
\hline Coefficient & Pooled OLS & & FEM & & REM & \\
\hline & \multicolumn{6}{|c|}{ Full dividend increases sample } \\
\hline Constant & $\begin{array}{r}-0.001 \\
(-0.174)\end{array}$ & & & & $\begin{array}{r}-0.003 \\
(-0.363)\end{array}$ & \\
\hline$\Delta \mathrm{DI}_{\mathrm{i}, 0}$ & $\begin{array}{r}-0.016 \\
(-0.695)\end{array}$ & & $\begin{array}{r}0.018 \\
(1.126)\end{array}$ & & $\begin{array}{r}0.012 \\
(0.343)\end{array}$ & \\
\hline $\mathrm{ROA}_{\mathrm{i}, 0}-\mathrm{ROA}_{\mathrm{i},-1}$ & $\begin{array}{r}-0.062 \\
(-0.526)\end{array}$ & & $\begin{array}{r}-0.325 \\
(-2.136)\end{array}$ & ** & $\begin{array}{r}-0.254 \\
(-1.717)\end{array}$ & $* * *$ \\
\hline $\mathrm{ROA}_{\mathrm{i}, 2}$ & $\begin{array}{r}-0.145 \\
(-1.926)\end{array}$ & $* *$ & $\begin{array}{r}-0254 \\
(-2.335)\end{array}$ & ** & $\begin{array}{r}-0.217 \\
(-2.090)\end{array}$ & $* *$ \\
\hline $\mathrm{SG}_{\mathrm{i}, 0}-\mathrm{SG}_{\mathrm{i}, 1}$ & $\begin{array}{r}-0.009 \\
(-0.577)\end{array}$ & & $\begin{array}{r}0.005 \\
(0.325)\end{array}$ & & $\begin{array}{r}0.002 \\
(0.216)\end{array}$ & \\
\hline $\mathrm{SG}_{\mathrm{i}, 2}$ & $\begin{array}{r}0.000 \\
(0.006)\end{array}$ & & $\begin{array}{r}0.009 \\
(0.821)\end{array}$ & & $\begin{array}{r}0.008 \\
(0.764)\end{array}$ & \\
\hline $\mathrm{N}$ & 147 & & 147 & & 147 & \\
\hline Adjusted $\mathrm{R}^{2}$ & 0.065 & & 0.178 & & 0.429 & \\
\hline Test $\mathrm{F}$ & 2.29 & * & & & & \\
\hline Hausman Test & & & 45.32 & * & & \\
\hline & \multicolumn{6}{|c|}{ Top performance dividend increases sample } \\
\hline Constant & $\begin{array}{r}-0.001 \\
(-0.527)\end{array}$ & & & & $\begin{array}{r}-0.007 \\
(-0.767)\end{array}$ & \\
\hline$\Delta \mathrm{DI}_{\mathrm{i}, 0}$ & $\begin{array}{r}0.189 \\
(5.891)\end{array}$ & * & $\begin{array}{r}0.452 \\
(2.159)\end{array}$ & ** & $\begin{array}{r}0.383 \\
(3.194)\end{array}$ & \\
\hline $\mathrm{ROA}_{\mathrm{i}, 0}-\mathrm{ROA}_{\mathrm{i},-1}$ & $\begin{array}{r}0.190 \\
(11.879)\end{array}$ & * & $\begin{array}{r}0.267 \\
(1.037)\end{array}$ & & $\begin{array}{r}0.211 \\
(1.177)\end{array}$ & \\
\hline $\mathrm{ROA}_{\mathrm{i}, 2}$ & $\begin{array}{r}0.076 \\
(4.072)\end{array}$ & $*$ & $\begin{array}{r}0.110 \\
(0.770)\end{array}$ & & $\begin{array}{r}0.079 \\
(0.651)\end{array}$ & \\
\hline $\mathrm{SG}_{\mathrm{i}, 0}-\mathrm{SG}_{\mathrm{i},-1}$ & $\begin{array}{r}-0.076 \\
(-9.142)\end{array}$ & $*$ & $\begin{array}{r}-0.119 \\
(-2.428)\end{array}$ & ** & $\begin{array}{r}-0.092 \\
(-3.201)\end{array}$ & \\
\hline $\mathrm{SG}_{\mathrm{i}, 2}$ & $\begin{array}{r}-0.013 \\
(-4.617)\end{array}$ & $*$ & $\begin{array}{r}-0.044 \\
(-1.719)\end{array}$ & & $\begin{array}{r}-0.031 \\
(-1.474)\end{array}$ & \\
\hline $\mathrm{N}$ & 49 & & 49 & & 49 & \\
\hline Adjusted $\mathrm{R}^{2}$ & 0.522 & & 0.546 & & 0.797 & \\
\hline Test $\mathrm{F}$ & 1.03 & & & & & \\
\hline Hausman Test & & & 2.35 & & & \\
\hline & & & & & (Contin & hue) \\
\hline $\begin{array}{ll}* & \text { Significan } \\
* * & \text { Significan } \\
* * * & \text { Significan }\end{array}$ & $\begin{array}{l}\text { rent from zero at } \\
\text { rent from zero at } \\
\text { rent from zero at }\end{array}$ & $\begin{array}{l}\text { the } 1 \\
\text { the } 5 \\
\text { the } 1\end{array}$ & & & & \\
\hline
\end{tabular}


Table 3.15 - Regression of cumulative abnormal returns on future performance measures (continued)

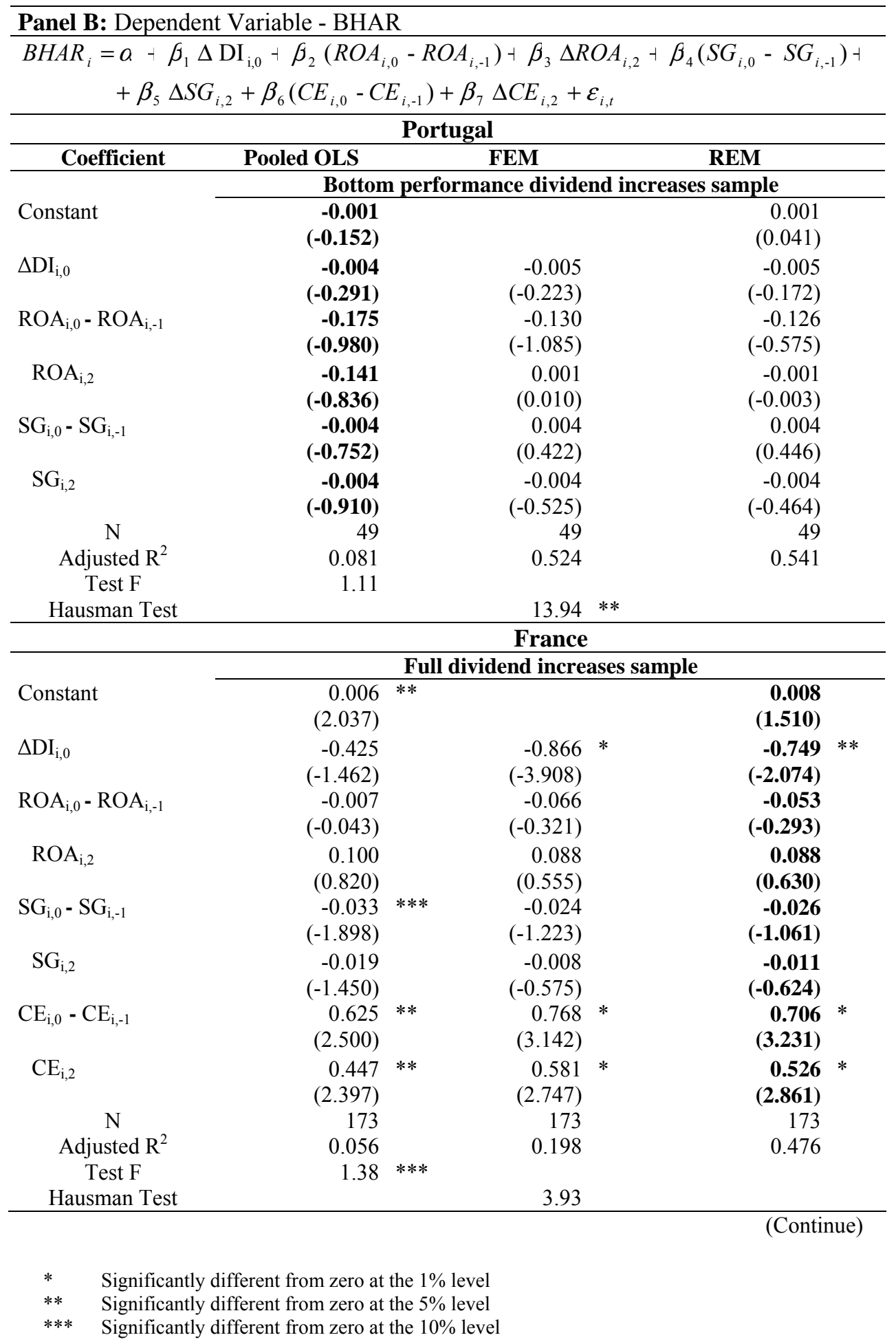


Table 3.15 - Regression of cumulative abnormal returns on future performance measures (continued)

\begin{tabular}{|c|c|c|c|c|c|}
\hline $\begin{array}{r}\text { Panel B: Depenc } \\
\text { BHAR }_{i}=a-\beta \\
+\beta_{5} \Delta\end{array}$ & $\begin{array}{l}\text { Jariable - BHA } \\
\mathrm{I}_{\mathrm{i}, 0}+\beta_{2}(R O A \\
+\beta_{6}\left(C E_{i, 0}-C\right.\end{array}$ & $\begin{array}{l}\mathrm{R} \\
{ }_{0}-R \\
\left.E_{i,-1}\right)\end{array}$ & $\begin{array}{l}-1) \dashv \beta_{3} \Delta R \\
\Delta C E_{i, 2}+\end{array}$ & $\begin{array}{l}O A_{i, 2} \\
\varepsilon_{i, t}\end{array}$ & $\left(S G_{i, 0}-S G_{i,-1}\right) \dashv$ \\
\hline \multicolumn{6}{|c|}{ France } \\
\hline Coefficient & Pooled OLS & & FEM & & REM \\
\hline & \multicolumn{5}{|c|}{ Top performance dividend increases sample } \\
\hline Constant & $\begin{array}{r}-0.004 \\
(-0.490)\end{array}$ & & & & $\begin{array}{r}-0.004 \\
(-0.495)\end{array}$ \\
\hline$\Delta \mathrm{DI}_{\mathrm{i}, 0}$ & $\begin{array}{r}1.491 \\
(0.972)\end{array}$ & & $\begin{array}{r}5.031 \\
(0.950)\end{array}$ & & $\begin{array}{r}1.662 \\
(0.959)\end{array}$ \\
\hline $\mathrm{ROA}_{\mathrm{i}, 0}-\mathrm{ROA}_{\mathrm{i},-1}$ & $\begin{array}{r}0.226 \\
(1.363)\end{array}$ & & $\begin{array}{r}0.104 \\
(0.490)\end{array}$ & & $\begin{array}{r}0.164 \\
(0.572)\end{array}$ \\
\hline $\mathrm{ROA}_{\mathrm{i}, 2}$ & $\begin{array}{r}0.272 \\
(1.920)\end{array}$ & *** & $\begin{array}{r}0.368 \\
(1.986)\end{array}$ & $* * *$ & $\begin{array}{r}0.253 \\
(1.028)\end{array}$ \\
\hline $\mathrm{SG}_{\mathrm{i}, 0}-\mathrm{SG}_{\mathrm{i},-1}$ & $\begin{array}{r}-0.006 \\
(-0.126)\end{array}$ & & $\begin{array}{r}-0.019 \\
(-0.292)\end{array}$ & & $\begin{array}{r}-0.003 \\
(-0.067)\end{array}$ \\
\hline $\mathrm{SG}_{\mathrm{i}, 2}$ & $\begin{array}{r}-0.010 \\
(-0.499)\end{array}$ & & $\begin{array}{r}0.006 \\
(0.343)\end{array}$ & & $\begin{array}{r}-0.004 \\
(-0.196)\end{array}$ \\
\hline$C E_{i, 0}-C_{i,-1}$ & $\begin{array}{r}0.210 \\
(1.576)\end{array}$ & & $\begin{array}{r}0.172 \\
(1.751)\end{array}$ & $* * *$ & $\begin{array}{r}0.194 \\
(1.522)\end{array}$ \\
\hline $\mathrm{CE}_{\mathrm{i}, 2}$ & $\begin{array}{r}0.169 \\
(1.743)\end{array}$ & *** & $\begin{array}{r}0.075 \\
(0.636)\end{array}$ & & $\begin{array}{r}0.136 \\
(0.940)\end{array}$ \\
\hline $\mathrm{N}$ & 56 & & 56 & & 56 \\
\hline Adjusted $\mathrm{R}^{2}$ & 0.007 & & 0.363 & & 0.210 \\
\hline Test $\mathrm{F}$ & 0.61 & & & & \\
\hline Hausman Test & \multicolumn{5}{|c|}{4.06} \\
\hline & \multicolumn{5}{|c|}{ Bottom performance dividend increases sample } \\
\hline Constant & $\begin{array}{r}0.007 \\
(0.891)\end{array}$ & & & & $\begin{array}{r}0.031 \\
(2.427)\end{array}$ \\
\hline$\Delta \mathrm{DI}_{\mathrm{i}, 0}$ & $\begin{array}{r}0.652 \\
(0.362)\end{array}$ & & $\begin{array}{r}-4.609 \\
(-1.692)\end{array}$ & & $\begin{array}{r}-5.857 * \\
(-2.776)\end{array}$ \\
\hline $\mathrm{ROA}_{\mathrm{i}, 0}-\mathrm{ROA}_{\mathrm{i},-1}$ & $\begin{array}{r}-0.166 \\
(-0.318)\end{array}$ & & $\begin{array}{r}-0.013 \\
(-0.018)\end{array}$ & & $\begin{array}{r}0.279 \\
(0.533)\end{array}$ \\
\hline $\mathrm{ROA}_{\mathrm{i}, 2}$ & $\begin{array}{r}-0.041 \\
(-0.160)\end{array}$ & & $\begin{array}{r}-0.439 \\
(-0.940)\end{array}$ & & $\begin{array}{r}0.042 \\
(0.167)\end{array}$ \\
\hline $\mathrm{SG}_{\mathrm{i}, 0}-\mathrm{SG}_{\mathrm{i},-1}$ & $\begin{array}{r}-0.004 \\
(-0.121)\end{array}$ & & $\begin{array}{r}0.032 \\
(1.262)\end{array}$ & & $\begin{array}{r}0.035 \\
(1.116)\end{array}$ \\
\hline $\mathrm{SG}_{\mathrm{i}, 2}$ & $\begin{array}{r}0.003 \\
(0.145)\end{array}$ & & $\begin{array}{r}0.022 \\
(1.403)\end{array}$ & & $\begin{array}{r}0.030 \\
(1.530)\end{array}$ \\
\hline $\mathrm{CE}_{\mathrm{i}, 0}-\mathrm{CE}_{\mathrm{i},-1}$ & $\begin{array}{r}0.150 \\
(0.478)\end{array}$ & & $\begin{array}{r}6.098 \\
(4.577)\end{array}$ & * & $\begin{array}{r}0.566 \\
(1.007)\end{array}$ \\
\hline $\mathrm{CE}_{\mathrm{i}, 2}$ & $\begin{array}{r}0.138 \\
(0.484)\end{array}$ & & $\begin{array}{r}2.541 \\
(3.671)\end{array}$ & $*$ & $\begin{array}{r}0.314 \\
(0.746)\end{array}$ \\
\hline $\mathrm{N}$ & 58 & & 58 & & 58 \\
\hline Adjusted $\mathrm{R}^{2}$ & 0.011 & & 0.627 & & 0.739 \\
\hline Test $\mathrm{F}$ & 3.80 & * & & & \\
\hline Hausman Test & & & 23.68 & * & \\
\hline & & & & & (Continue) \\
\hline $\begin{array}{ll}* & \text { Significan } \\
* * & \text { Significan } \\
* * * & \text { Significan }\end{array}$ & $\begin{array}{l}\text { erent from zero at } \\
\text { erent from zero at } \\
\text { erent from zero at }\end{array}$ & $\begin{array}{l}\text { the } 1 \% \\
\text { the } 5 \%\end{array}$ & & & \\
\hline
\end{tabular}


Table 3.15 - Regression of cumulative abnormal returns on future performance measures (continued)

\begin{tabular}{|c|c|c|c|c|c|c|}
\hline \multicolumn{7}{|c|}{$\begin{aligned} B_{H A R_{i}}= & a+\beta_{1} \Delta \mathrm{DIEI}_{\mathrm{i}, 0}+\beta_{2}\left(R O A_{i, 0}-R O A_{i,-1}\right)+\beta_{3} \Delta R O A_{i, 2}+\beta_{4}\left(S G_{i, 0}-S G_{i,-1}\right)- \\
& +\beta_{5} \Delta S G_{i, 2}+\beta_{6}\left(C E_{i, 0}-C E_{i,-1}\right)+\beta_{7} \Delta C E_{i, 2}+\varepsilon_{i, t}\end{aligned}$} \\
\hline \multicolumn{7}{|c|}{ UK } \\
\hline Coefficient & Pooled OLS & & FEM & & REM & \\
\hline \multicolumn{7}{|c|}{ DIEI } \\
\hline & \multicolumn{6}{|c|}{ Full DIEI sample } \\
\hline Constant & $\begin{array}{r}0.018 \\
(6.009)\end{array}$ & $*$ & & & $\begin{array}{r}0.020 \\
(4.947)\end{array}$ & $*$ \\
\hline$\Delta \mathrm{DIEI}_{\mathrm{i}, 0}$ & $\begin{array}{r}0.561 \\
(0.911)\end{array}$ & & $\begin{array}{r}-0.798 \\
(-1.403)\end{array}$ & & $\begin{array}{r}-0.141 \\
(-0.276)\end{array}$ & \\
\hline $\mathrm{ROA}_{\mathrm{i}, 0}-\mathrm{ROA}_{\mathrm{i},-1}$ & $\begin{array}{r}0.155 \\
(2.266)\end{array}$ & $* *$ & $\begin{array}{r}0.056 \\
(0.770)\end{array}$ & & $\begin{array}{r}0.096 \\
(1.588)\end{array}$ & \\
\hline $\mathrm{ROA}_{\mathrm{i}, 2}$ & $\begin{array}{r}0.006 \\
(0.123)\end{array}$ & & $\begin{array}{r}-0.019 \\
(-0.366)\end{array}$ & & $\begin{array}{r}-0.006 \\
(-0.141)\end{array}$ & \\
\hline $\mathrm{SG}_{\mathrm{i}, 0}-\mathrm{SG}_{\mathrm{i},-1}$ & $\begin{array}{r}0.007 \\
(1.054)\end{array}$ & & $\begin{array}{r}0.003 \\
(0.234)\end{array}$ & & $\begin{array}{r}0.006 \\
(0.542)\end{array}$ & \\
\hline $\mathrm{SG}_{\mathrm{i}, 2}$ & $\begin{array}{r}0.007 \\
(1.543)\end{array}$ & & $\begin{array}{r}-0.001 \\
(-0.018)\end{array}$ & & $\begin{array}{r}0.004 \\
(0.423)\end{array}$ & \\
\hline$C E_{i, 0}-C_{i,-1}$ & $\begin{array}{r}0.079 \\
(1.979)\end{array}$ & ** & $\begin{array}{r}0.163 \\
(2.832)\end{array}$ & * & $\begin{array}{r}0.090 \\
(1.665)\end{array}$ & $* * *$ \\
\hline $\mathrm{CE}_{\mathrm{i}, 2}$ & $\begin{array}{r}0.080 \\
(1.972)\end{array}$ & ** & $\begin{array}{r}0.130 \\
(2.413)\end{array}$ & ** & $\begin{array}{r}0.092 \\
(1.660)\end{array}$ & $* * *$ \\
\hline $\mathrm{N}$ & 1,327 & & 1,327 & & 1,327 & \\
\hline Adjusted $\mathrm{R}^{2}$ & 0.021 & & 0.136 & & 0.313 & \\
\hline Test $\mathrm{F}$ & 1.42 & * & & & & \\
\hline Hausman Test & & & 15.01 & ** & & \\
\hline & \multicolumn{6}{|c|}{ Top performance DIEI sample } \\
\hline Constant & $\begin{array}{r}\mathbf{0 . 0 2 0} \\
(3.651)\end{array}$ & $*$ & & & $\begin{array}{r}0.020 \\
(2.901)\end{array}$ & \\
\hline$\Delta \mathrm{DIEI}_{\mathrm{i}, 0}$ & $\begin{array}{r}1.330 \\
(1.071)\end{array}$ & & $\begin{array}{r}-0.998 \\
(-0.598)\end{array}$ & & $\begin{array}{r}0.629 \\
(0.537)\end{array}$ & \\
\hline $\mathrm{ROA}_{\mathrm{i}, 0}-\mathrm{ROA}_{\mathrm{i},-1}$ & $\begin{array}{r}0.299 \\
(3.564)\end{array}$ & * & $\begin{array}{r}0.157 \\
(1.114)\end{array}$ & & $\begin{array}{r}0.217 \\
(2.272)\end{array}$ & $* *$ \\
\hline $\mathrm{ROA}_{\mathrm{i}, 2}$ & $\begin{array}{r}0.075 \\
(1.155)\end{array}$ & & $\begin{array}{r}-0.023 \\
(-0.220)\end{array}$ & & $\begin{array}{r}0.024 \\
(0.353)\end{array}$ & \\
\hline $\mathrm{SG}_{\mathrm{i}, 0}-\mathrm{SG}_{\mathrm{i},-1}$ & $\begin{array}{r}0.023 \\
(1.080)\end{array}$ & & $\begin{array}{r}-0.072 \\
(-1.840)\end{array}$ & *** & $\begin{array}{r}-0.014 \\
(-0.559)\end{array}$ & \\
\hline $\mathrm{SG}_{\mathrm{i}, 2}$ & $\begin{array}{r}0.027 \\
(1.333)\end{array}$ & & $\begin{array}{r}-0.050 \\
(-1.596)\end{array}$ & & $\begin{array}{r}-0.007 \\
(-0.315)\end{array}$ & \\
\hline $\mathrm{CE}_{\mathrm{i}, 0}-\mathrm{CE}_{\mathrm{i},-1}$ & $\begin{array}{r}0.206 \\
(1.205)\end{array}$ & & $\begin{array}{r}0.211 \\
(1.152)\end{array}$ & & $\begin{array}{r}0.217 \\
(1.276)\end{array}$ & \\
\hline $\mathrm{CE}_{\mathrm{i}, 2}$ & $\begin{array}{r}0.095 \\
(0.882)\end{array}$ & & $\begin{array}{r}0.077 \\
(0.554)\end{array}$ & & $\begin{array}{r}0.079 \\
(0.629)\end{array}$ & \\
\hline $\mathrm{N}$ & 447 & & 447 & & 447 & \\
\hline Adjusted $\mathrm{R}^{2}$ & 0.042 & & 0.117 & & 0.401 & \\
\hline Test $\mathrm{F}$ & 1.18 & & & & & \\
\hline Hausman Test & & & 12.41 & *** & & \\
\hline
\end{tabular}

(Continue)

* $\quad$ Significantly different from zero at the $1 \%$ level

** $\quad$ Significantly different from zero at the $5 \%$ level

*** Significantly different from zero at the $10 \%$ level 
Table 3.15 - Regression of cumulative abnormal returns on future performance measures (continued)

Panel B: Dependent Variable - BHAR

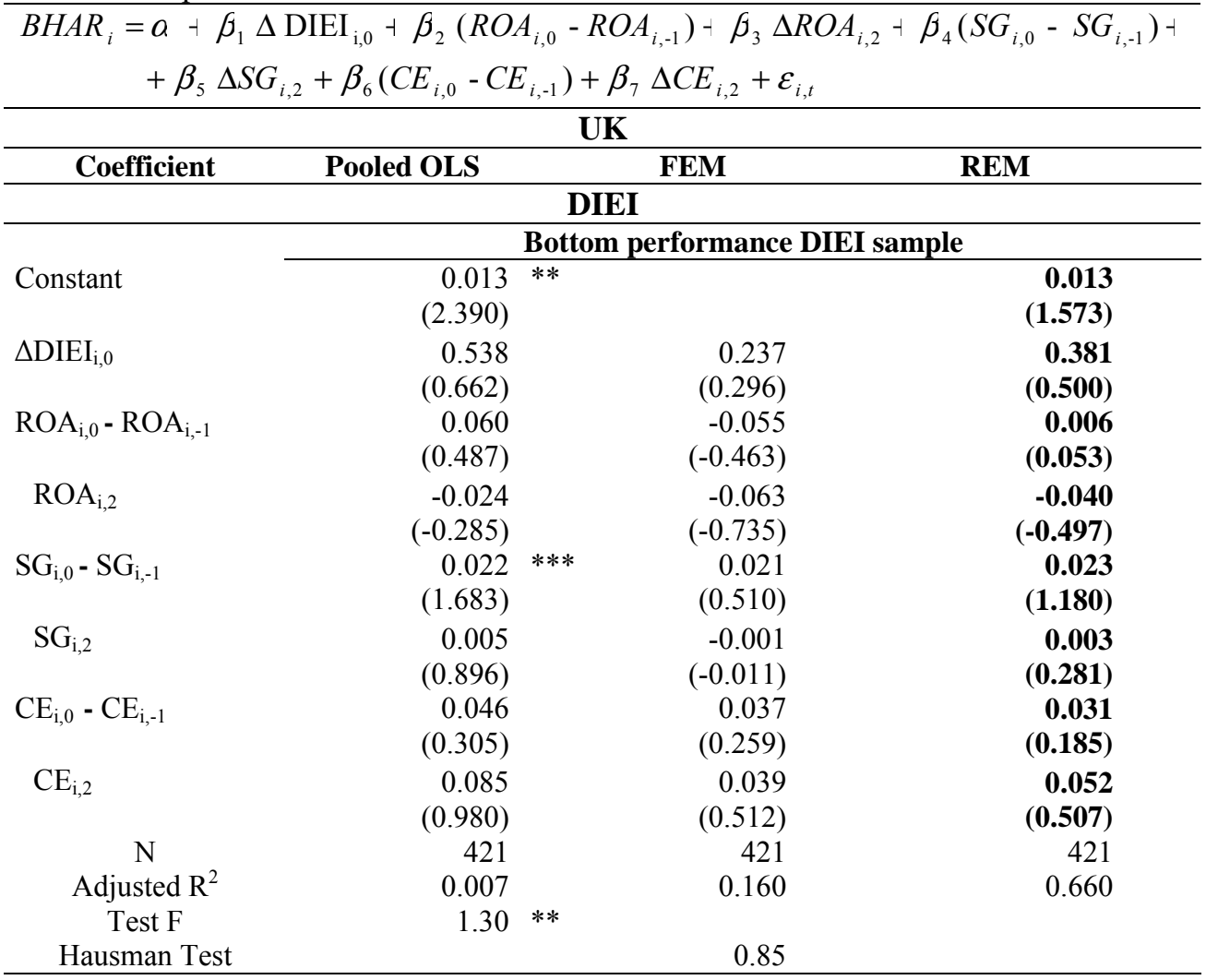

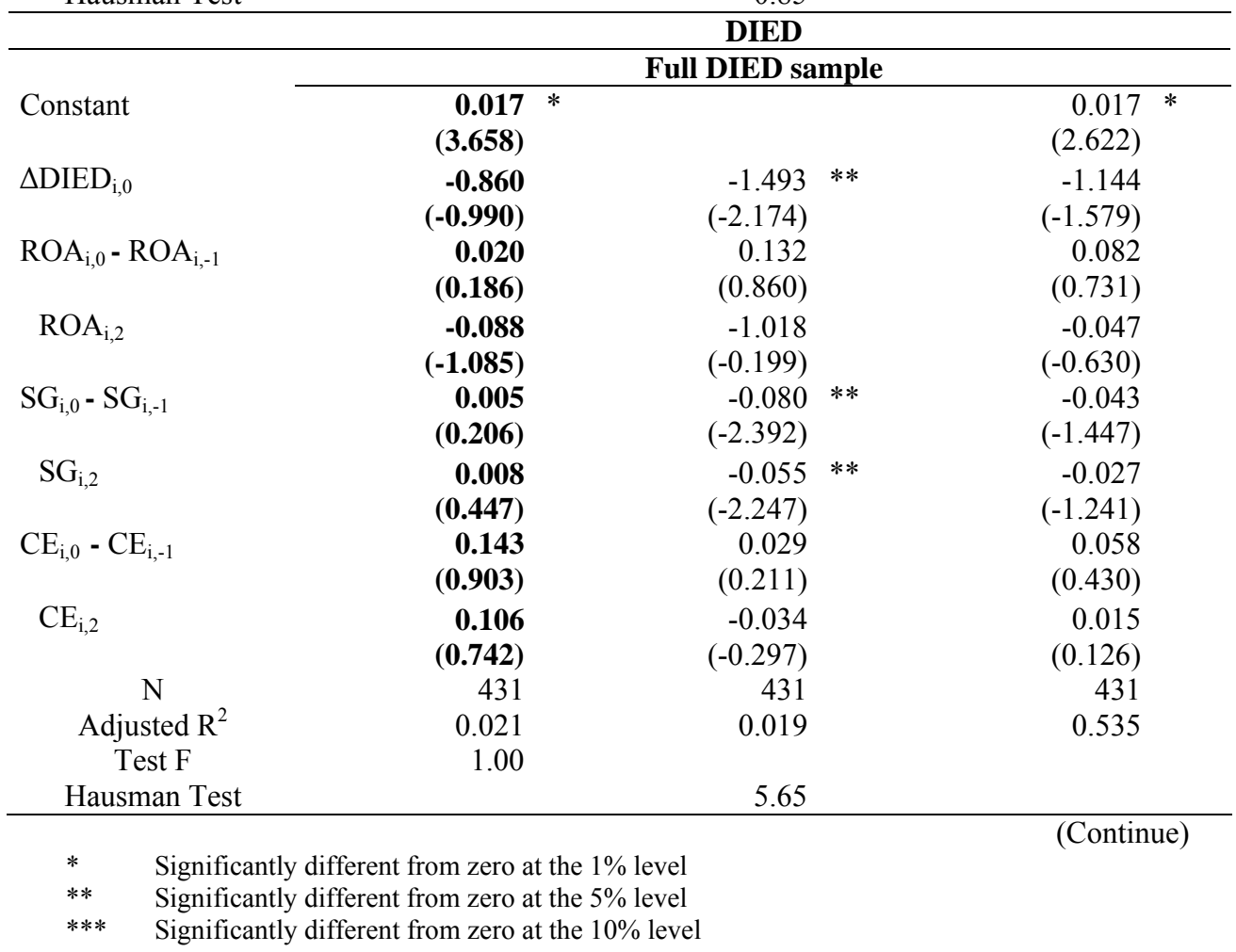


Table 3.15 - Regression of cumulative abnormal returns on future performance measures (continued)

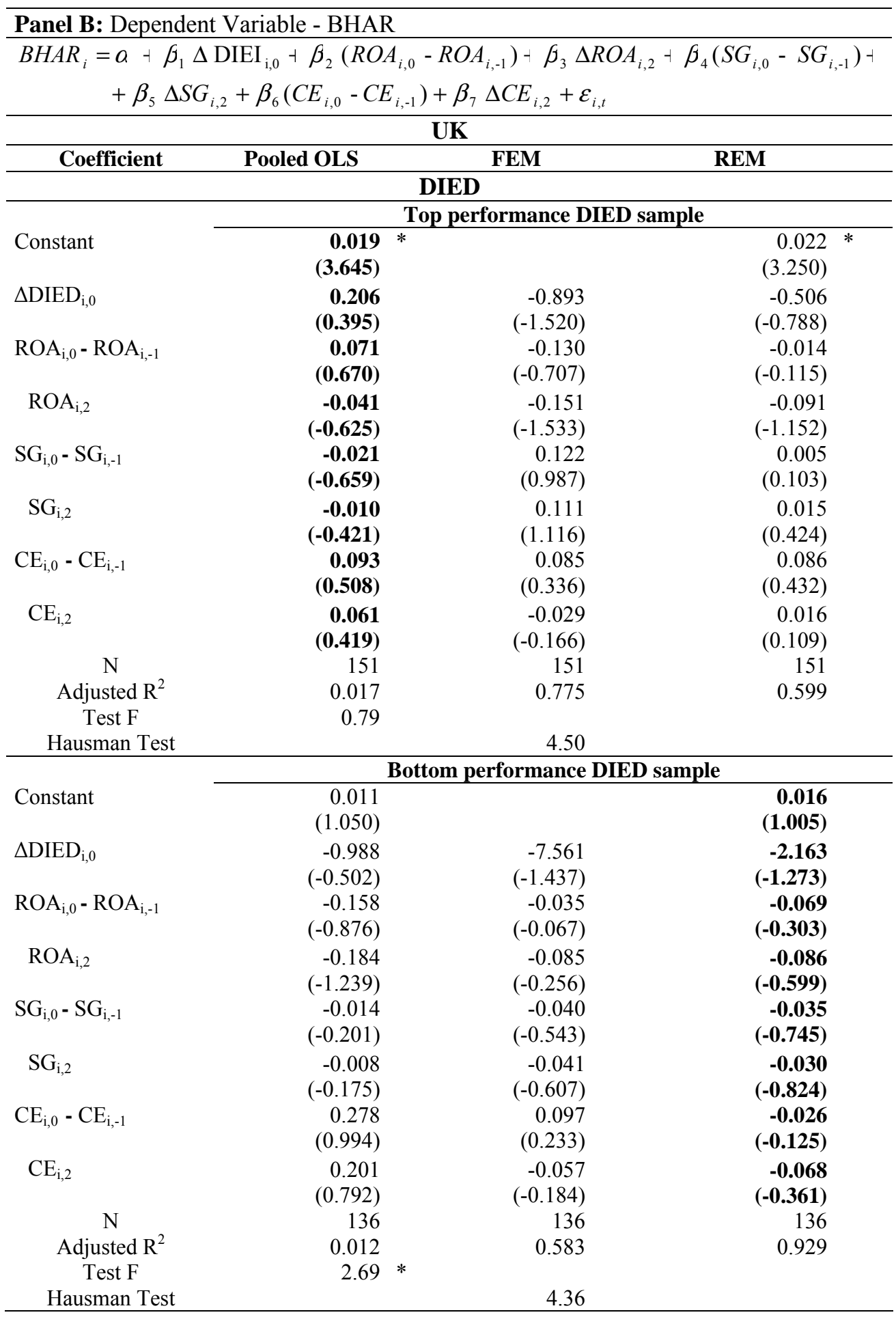

* $\quad$ Significantly different from zero at the $1 \%$ level

** $\quad$ Significantly different from zero at the $5 \%$ level

*** Significantly different from zero at the $10 \%$ level 


\section{Table 3.16 - Regression of price minus book value on dividend changes}

This table reports estimates of regressions relating the difference between the market and book value of equity to dividend changes. $\mathrm{P}_{\mathrm{i}, \mathrm{d}}$ is the price per share the day after the dividend announcement; $\mathrm{BVPS}_{\mathrm{i}, 1}$ is the book value per share at the end of year -1 relative to the dividend event year (year 0$) ; D_{i, t}$ is the annual change in the cash dividend payment, scaled by the share price in the announcement day; DI is a dummy variable that takes the value 1 if dividend increases and 0 otherwise; DD is a dummy variable that takes the value 1 if dividend decreases and 0 otherwise; DIEI is a dummy variable that takes value 1 if both dividend and earnings increase and zero otherwise; DIED is a dummy variable that takes value 1 if dividend increases and earnings decrease and zero otherwise; DDEI is a dummy variable that takes value 1 if dividend decreases and earnings increases and zero otherwise; DDED is a dummy variable that takes value 1 if both dividend and earnings decrease and zero otherwise; $\mathrm{E}_{\mathrm{i}, \mathrm{t}}$ is earnings before extraordinary items in year $t$ relative to the dividend event year; $\mathrm{BV}_{\mathrm{i},-1}$ is the book value of equity at the end of year -1 . The table presents the results estimated using pooled OLS, FEM and REM. The numbers in parentheses are the t-statistics corrected for heteroscedasticity using the White (1980) method. It reports the F test, a test for the equality of sets of coefficients, and the Hausman (1978) test, a test with $\mathrm{H}_{0}$ : random effects are consistent and efficient, versus $\mathrm{H}_{1}$ : random effects are inconsistent, in order to choose the most appropriate model for each particular sample.

\begin{tabular}{|c|c|c|c|c|c|c|}
\hline \multicolumn{7}{|c|}{$\left(\mathrm{P}_{\mathrm{i}, \mathrm{d}}-B V P S_{i,-1}\right) / B V P S_{i,-1}=a+\beta_{1} \mathrm{DI} \times \Delta \mathrm{D}_{\mathrm{i} 0}+\beta_{2} \mathrm{DD} \times \Delta \mathrm{D}_{\mathrm{i}, 0} \dashv \beta_{3}\left(E_{i, 0}-E_{i,-1}\right) / B V_{i,-1}+\varepsilon_{i, t}$} \\
\hline \multicolumn{7}{|c|}{ Portugal } \\
\hline Coefficient & Pooled OLS & & FEM & & REM & \\
\hline Constant & $\begin{array}{r}-0.182 \\
(-4.059)\end{array}$ & * & & & $\begin{array}{r}-0.202 \\
(-1.202)\end{array}$ & \\
\hline DI x $\Delta \mathrm{D}_{\mathrm{i}, 0}$ & $\begin{array}{r}-0.323 \\
(-2.507)\end{array}$ & ** & $\begin{array}{r}-0.075 \\
(-1.583)\end{array}$ & & $\begin{array}{r}-0.082 \\
(-0.574)\end{array}$ & \\
\hline $\mathrm{DD} \times \Delta \mathrm{D}_{\mathrm{i}, 0}$ & $\begin{array}{r}0.510 \\
(2.177)\end{array}$ & ** & $\begin{array}{r}0.040 \\
(0.395)\end{array}$ & & $\begin{array}{r}0.053 \\
(0.278)\end{array}$ & \\
\hline$\left(\mathrm{E}_{\mathrm{i}, 0}-\mathrm{E}_{\mathrm{i},-1}\right) / \mathrm{BV}_{\mathrm{i},-1}$ & $\begin{array}{r}-0.218 \\
(-0.951)\end{array}$ & & $\begin{array}{r}-0.932 \\
(-3.335)\end{array}$ & * & $\begin{array}{r}-0.884 \\
(-3.246)\end{array}$ & $*$ \\
\hline $\mathrm{N}$ & 380 & & 380 & & 380 & \\
\hline Adjusted $\mathrm{R}^{2}$ & 0.007 & & 0.541 & & 0.626 & \\
\hline Test $\mathrm{F}$ & 6.28 & * & & & & \\
\hline Hausman Test & & & 7.29 & $* * *$ & & \\
\hline \multicolumn{7}{|c|}{ France } \\
\hline Coefficient & Pooled OLS & & FEM & & REM & \\
\hline Constant & $\begin{array}{r}-0.341 \\
(-10.785)\end{array}$ & $*$ & & & $\begin{array}{r}-0.339 \\
(-4.695)\end{array}$ & * \\
\hline $\mathrm{DI} \times \Delta \mathrm{D}_{\mathrm{i}, 0}$ & $\begin{array}{r}-4.290 \\
(-3.711)\end{array}$ & * & $\begin{array}{r}-5.097 \\
(-4.625)\end{array}$ & $*$ & $\begin{array}{r}-5.091 \\
(-1.859)\end{array}$ & $* * *$ \\
\hline $\mathrm{DD} \times \Delta \mathrm{D}_{\mathrm{i}, 0}$ & $\begin{array}{r}3.752 \\
(3.405)\end{array}$ & $*$ & $\begin{array}{r}2.872 \\
(4.275)\end{array}$ & $*$ & $\begin{array}{r}2.943 \\
(1.576)\end{array}$ & \\
\hline$\left(\mathrm{E}_{\mathrm{i}, 0}-\mathrm{E}_{\mathrm{i},-1}\right) / \mathrm{BV}_{\mathrm{i}, 1}$ & $\begin{array}{r}0.217 \\
(0.253)\end{array}$ & & $\begin{array}{r}-0.146 \\
(-0.448)\end{array}$ & & $\begin{array}{r}-0.121 \\
(-0.303)\end{array}$ & \\
\hline $\mathrm{N}$ & 356 & & 356 & & 356 & \\
\hline Adjusted $\mathrm{R}^{2}$ & 0.004 & & 0.676 & & 0.759 & \\
\hline Test F & 8.91 & $*$ & & & & \\
\hline Hausman Test & & & 0.94 & & & \\
\hline
\end{tabular}

* $\quad$ Significantly different from zero at the $1 \%$ level

** $\quad$ Significantly different from zero at the $5 \%$ level

*** $\quad$ Significantly different from zero at the $10 \%$ level 
Table 3.16 - Regression of price minus book value on dividend changes (continued)

\begin{tabular}{|c|c|c|c|c|c|c|}
\hline$\left(\mathrm{P}_{\mathrm{i}, \mathrm{d}}-B V P S_{i,-1}\right) / B I$ & $\begin{array}{l}\dashv \beta_{1 A} \text { DIEI } \times \Delta \mathrm{D} \\
\beta_{2 B} \text { DIED x } \Delta \mathrm{D}_{\mathrm{i}, 0}\end{array}$ & +1 & $\begin{array}{l}\text { IED x } \Delta \mathrm{D} \\
\left.-E_{i,-1}\right) / B I\end{array}$ & $i_{i,-1}$ & DEI x $\Delta D_{i}$ & \\
\hline & UI & & & & & \\
\hline Coefficient & Pooled OLS & & FEM & & REM & \\
\hline Constant & $\begin{array}{r}0.994 \\
(63.386)\end{array}$ & * & & & $\begin{array}{r}0.994 \\
(36.418)\end{array}$ & * \\
\hline DIEI x $\Delta \mathrm{D}_{\mathrm{i}, 0}$ & $\begin{array}{r}-0.070 \\
(-2.479)\end{array}$ & ** & $\begin{array}{r}0.011 \\
(0.505)\end{array}$ & & $\begin{array}{r}0.004 \\
(0.209)\end{array}$ & \\
\hline DIED x $\Delta \mathrm{D}_{\mathrm{i}, 0}$ & $\begin{array}{r}-0.225 \\
(-5.155)\end{array}$ & * & $\begin{array}{r}-0.136 \\
(-5.587)\end{array}$ & * & $\begin{array}{r}-0.144 \\
(-6.380)\end{array}$ & * \\
\hline DDEI x $\Delta \mathrm{D}_{\mathrm{i}, 0}$ & $\begin{array}{r}0.108 \\
(2.097)\end{array}$ & ** & $\begin{array}{r}0.069 \\
(2.419)\end{array}$ & ** & $\begin{array}{r}0.073 \\
(4.542)\end{array}$ & * \\
\hline DDED x $\Delta \mathrm{D}_{\mathrm{i}, 0}$ & $\begin{array}{r}0.161 \\
(4.348)\end{array}$ & * & $\begin{array}{r}0.130 \\
(4.775)\end{array}$ & * & $\begin{array}{r}0.133 \\
(16.609)\end{array}$ & * \\
\hline$\left(\mathrm{E}_{\mathrm{i}, 0}-\mathrm{E}_{\mathrm{i},-1}\right) / \mathrm{BV}_{\mathrm{i},-1}$ & $\begin{array}{r}0.002 \\
(4.387)\end{array}$ & * & $\begin{array}{r}0.002 \\
(7.030)\end{array}$ & * & $\begin{array}{r}0.002 \\
(6.774)\end{array}$ & * \\
\hline $\mathrm{N}$ & 3,251 & & 3,251 & & 3,251 & \\
\hline Adjusted $\mathrm{R}^{2}$ & 0.067 & & 0.659 & & 0.673 & \\
\hline Test $\mathrm{F}$ & 11.82 & * & & & & \\
\hline Hausman Test & & & 16.27 & * & & \\
\hline
\end{tabular}

* $\quad$ Significantly different from zero at the $1 \%$ level

** $\quad$ Significantly different from zero at the $5 \%$ level

*** Significantly different from zero at the $10 \%$ level 


\section{CHAPTER 4}

\section{THE EFFECT OF DIVIDEND ANNOUNCEMENTS}

ON FUTURE EARNINGS CONDITIONED TO

THE RELATION BETWEEN DIVIDEND CHANGE ANNOUNCEMENTS AND THE MARKET REACTION 


\subsection{INTRODUCTION}

After considering the classical assumptions of the dividend signalling models, we would like to combine tests that analyse simultaneously the relation between dividend change announcements and: a) the market reaction to dividend changes and b) future earnings changes, which allows us to compare the results of share price reaction surrounding the dividend announcements and examine the relation between dividend changes and contemporaneous as well as future earnings changes. Furthermore, we would like to give special attention to the enigmatic cases in which a market reacts negatively (positively) to dividend increases (decreases), since several authors found similar evidence, but have not attempted to explore it.

The main original contribution of the research starts in this chapter. Firstly, we split the sample in distinct groups, according the relationship between dividend change announcements and the subsequent market share reaction. Secondly, we develop hypotheses to analyse: (i) the relation between current dividend changes and future earnings for those events in which share price changes surrounding the dividend announcement are positively associated with dividend changes (hypothesis $\mathrm{H}_{3 \mathrm{~A}}$ ) and (ii) the same type of relation, but for those events whose share price changes in the announcement period are negatively associated with dividend changes (hypothesis $\mathrm{H}_{3 \mathrm{~B}}$ ). Thirdly, we develop an approach in order to test the formulated hypotheses. After the description of the methodology, we report and discuss the empirical results. To end the chapter, we remark the key conclusions.

\subsection{HYPOTHESES}

In this section, we will formulate the hypotheses in order to analyse the relation between dividend changes and future earnings, conditioned to the relation between dividend change announcements and the subsequent market reaction.

The relationship between dividend changes and the subsequent market reaction surrounding the announcement date can be described by four situations. 
The four situations are presented below:

\begin{tabular}{lcc}
\cline { 2 - 3 } & $\begin{array}{c}\text { Dividend } \\
\text { Increases }\end{array}$ & $\begin{array}{c}\text { Dividend } \\
\text { Decreases }\end{array}$ \\
\hline Positive market reaction & II - PRDI & IJT - PRDD \\
Negative market reaction & IUTJ - NRDI & IV - NRDD \\
\hline
\end{tabular}

Relation between dividend changes and the market reaction

Cells I and IV are consistent with the dividend information content hypothesis. However, as noted above, some authors have found evidence that about a third of its sample have results lie in cells II and III ${ }^{123}$.

In this context, we will focus on the cases where the market reacts differently than would be expected under the dividend information content hypothesis; that is, the enigmatic cases in which market reacts positively to a dividend decrease (cell II) and negatively to a dividend increase (cell III), trying to find reasons that can explain the negative relation between dividend change announcements and subsequent share price reactions in the 3 days surrounding the announcement day. This will be one of the primary contributions of our study.

We start to examine separately the observations in cells I and IV: positive relationship between dividends and the market reaction (the cases expected by dividend signalling theory) and then we analyse the dividend change announcement observations in cells II and III: negative relationship between the two variables (the enigmatic cases).

${ }^{123}$ Asquith and Mullins (1983) verified that about 32\% of their sample firms showed a negative market reaction to dividend initiations. Benesh, Keown and Pinkerton (1984) and Born, Moser and Officer (1988) showed that in 20 to $60 \%$ of the cases, the market reacted positively to dividend decreases and negatively to their increases. Dhillon and Johnson (1994) and Healy, Hathorn and Kirch (1997) found evidence of this enigmatic behaviour in about 34\% (for dividend initiations) and 27\% (for omissions) of their cases in the first study, and $42.5 \%$ of the cases in the second. Sant and Cowan (1994) found that almost $23.4 \%$ of the sample shows a positive reaction to dividend omission announcements. More recently, Dhillon, Raman and Ramírez (2003) and Borokhovich et al. (2004) found that, respectively for the former and the latter study, for about $43 \%$ and $41.7 \%$ of the dividend increase announcements, the market reaction was adverse. 


\subsubsection{Hypothesis 3A - Relation BetWeEn Dividend Changes AND Future EARNINGS FOR THE EVENTS WITH A POSITIVE RELATION BETWEEN DIVIDEND Change ANNOUnCEMENTS AND THE MARKET REACTION}

For the observations in cells I and IV, we develop the following alternative hypothesis:

$H_{3 A}$ : "For the events with a positive relation between dividend change announcements and the market reaction, future earnings are positively associated with current dividend changes"

The underlying idea of this hypothesis is that market reacts positively to a dividend increase announcement and negatively to a dividend decrease announcement, according the assumptions of the dividend information content hypothesis. This suggests that investors expect future earnings to increase, in the first situation and expect future earnings to decrease, in the latter situation. Thus, dividend changes and future earnings should be positively related.

If we fail to reject the null hypothesis associated with $\mathrm{H}_{3 \mathrm{~A}}$, we will infer that, although we observe a signalling effect relating the market reaction to dividend change announcements (positive relationship between dividend changes and share price changes in the 3 days contiguous to the announcement date), the future earnings are not associated with dividend change announcements. Consequently, we find no evidence of dividend information content hypothesis in what concerns the relationship between dividend changes and future earnings, concluding that dividends do not have, per se, the potential to convey information to the market. If we reject the null hypothesis associated with $\mathrm{H}_{3 \mathrm{~A}}$, we can find a positive (hypothesis $\mathrm{H}_{3 \mathrm{~A}}$ ) or a negative association between dividend change announcements and future earnings. If the first situation happens (positive relation), we will infer that a signalling effect exists and it is associated with share price movements in the announcement period and earnings forecast positively related with dividend changes, supporting the dividend information content hypothesis. Otherwise, we find evidence of a negative association between dividend changes and future earnings, contrary to the expected positive relation. Consequently, we find no evidence of dividend information content hypothesis in what concerns the relationship between dividend changes and future earnings. 


\subsubsection{Hypothesis 3B - RELATion BetWeEn Dividend ChANGES AND Future EARNINGS FOR THE EVENTS WITH A NEgATIVE RELATION BETWEEN Dividend Change ANNOUnCEMENTS AND THE MARKET REACTION}

Next, we will explore the situations of a negative relation between dividend changes and the subsequent market reaction (cells II and III) and we begin by investigating possible reasons for this behaviour.

There may be three reasons for the market to react negatively to dividend increases (cell III). First, the market may wrongly interpret the signal conveyed by managers. Second, managers may be signalling falsely, but investors recognise this and react appropriately. Third, it can be the result of the differential tax treatment between dividends and capital gains. However, Elton and Gruber (1970), among other authors, investigated the relationship between corporate dividend policy and investor tax rates and found that the market prefers dividends to capital gains.

Mozes and Rapaccioli (1998) and Abeyratna and Power (2002) found possible reasons for situations in cell II (a positive market reaction to dividend decrease announcements) to happen.

Mozes and Rapaccioli (1998) found evidence that small dividend decreases do not provide a negative signal about future earnings probably because small dividend decreases may represent an attempt to keep resources for future growth opportunities. This may be a possible reason for an inverse relationship between dividend decreases and the subsequent market reaction.

Abeyratna and Power (2002) suggested that dividend decreases may not be bad news to the market concerning firms' future earnings, as assumed by signalling theory, but rather reflect managers' decisions to solve firms' financial problems. Their suggestion follows their evidence of a significant improvement in profitability as well as financial and liquidity ratios in a sample of firms that had, in a certain period, decreases in both dividends and earnings. In this situation, a share price increase could occur in the dividend decrease announcement period.

Finally, we can find some reasons, which can lead to situations in both cells II or III.

Consistent with the maturity hypothesis cited previously, a dividend increase announcement may transmit two types of news: good news, i.e., the firms' systematic 
risk decreased, and bad news, i.e., limited growth opportunities. The former will lead to a positive market reaction and the latter to a negative reaction. Depending on the relative importance, we can be in cell I or III.

Elfakhani (1995) suggests that the share price reaction to dividend signal is determined, jointly, by three factors: the expected content favourableness from the dividend signal (flat, good, bad or ambiguous), the sign of dividend change and the dividend-signalling role (confirmatory, clarificatory or unclear). He states that content favourableness dominates the sign of dividend change since their results show that dividend decreases (increases) signalling good (bad) news bring on positive (negative) market answer. If it happens, we can be either in cell II or III.

Even without analysts' dividend forecasts, the market must anticipate the dividends announced by the firms with a history of high earnings growth. According to Healy, Hathorn and Kirch (1997), the payment of a larger than expected dividend (in the case of dividend increases) may signal that the firm does not have any available investment opportunities that will sustain the earnings growth, and the capital market would react negatively (cell III). Inversely, a smaller than expected cut in dividends (for dividend decreases) may signal that the firms have available investment opportunities that will sustain the earnings growth and the capital market would react positively (cell II).

Another possible and important reason for situations II and III to happen was very recently pointed out by Dhillon, Raman and Ramírez (2003), who highlighted a possible sample misclassification arising from the use of naïve dividend models that does not really distinguish between expected and unexpected dividend changes, and propose the use of dividend expectations based on analysts' forecasts. Their results suggest that if the dividend increase is smaller than was forecasted by analysts, the market may react negatively, leading to cell III; and if the dividend decrease is smaller than forecast by analysts, the market may react positively, leading to cell II. No change dividends can also be associated with negative or positive market reaction, depending on the dividend forecasts $^{124}$.

For the observations in cells II and III, we test the following alternative hypothesis:

\footnotetext{
${ }^{124}$ We consider the dividend forecasts analysis very important, but unfortunately we do not have access to dividend expectations based on analysts' forecasts, so, we cannot control for dividend forecasts.
} 
$H_{3 B}$ : "For the events with a negative relation between dividend change announcements and the market reaction, future earnings are negatively associated with current dividend changes"

The underlying idea of this hypothesis is that, although dividends have increased (decreased), investors forecast a decrease (increase) in future earnings, and the market reacts according to this expectation. Thus, the market reacts negatively to a dividend increase announcement and positively to a dividend decrease announcement. In consequence, dividend changes and future earnings should be negatively related.

If we fail to reject the null hypothesis associated with $\mathrm{H}_{3 \mathrm{~B}}$, we will infer that dividend change announcements and the subsequent market reaction are negatively related, and future earnings are not associated with dividend change announcements. Consequently, we find no evidence of the dividend information content hypothesis in what concerns both the relationship between dividend change announcements and: a) the market reaction and $b$ ) the future earnings changes. If we reject the null hypothesis associated with $\mathrm{H}_{3 \mathrm{~B}}$, we can find a negative (hypothesis $\mathrm{H}_{3 \mathrm{~B}}$ ) or a positive association between dividend change announcements and future earnings changes. If the first situation happens (negative relation), we will find evidence of a negative association between dividend changes and future earnings, as predicted in the alternate hypothesis, existing evidence of a signalling effect but contrary to the sign of dividends, which we have denominated by inverse signalling effect because earnings changes are directly related with the market reaction. So, we will give support to the inverse signalling effect. Otherwise, the market reacts negatively to dividend changes while the relation between dividend changes and future earnings are consistent with the dividend information content hypothesis. This result suggests that the market did not understand the signal given by firms through dividend change announcements. As a result, we will give support to the dividend information content hypothesis, but only in what concerns the relationship between dividend changes and future earnings changes. Globally, we cannot support the dividend signalling hypothesis, since each one of these relations is necessary but not sufficient conditions for the dividend signalling. 


\subsection{METHODOLOGY}

After the identification of the research purposes, it is necessary to define the methodology to be used to test the formulated hypotheses and, consequently, to obtain the main conclusions that are revealed by the empirical work ${ }^{125}$.

\subsubsection{Methodology to Test Hypothesis 3A - Relation BetWeEn Dividend Changes ANd Future Earnings for the Events with a Positive Relation BetWeEn Dividend Change ANNOUnCEMENTS AND THE MARKET REACTION}

To examine the relation between dividend change announcements and the share price reaction in the announcement period in greater detail, we will split the sample according to the market reaction to dividend changes surrounding the announcement period (days -1 to +1 ), considering two distinct groups: 1) the sub-sample of events with a positive relationship between dividend changes and the market reaction, i.e., a positive market reaction to dividend increases (PRDI) and a negative market reaction to dividend decreases (NRDD), which situations are presented in the previous section as cells I and IV, respectively, and 2) the sub-sample of events with a negative relationship between dividend changes and share price reaction in the announcement period, i.e., a negative market reaction to dividend increases (NRDI) and a positive market reaction to dividend decreases (PRDD), identified as cells II and III. We will consider the BHAR to measure the market reaction to dividend change announcements because it is the only common measure to the three samples. Therefore, we will consider that there is a positive reaction to dividend change announcements if the BHAR in the period -1 to +1 is positive, and that there is a negative reaction to dividend change announcements if the BHAR in the period -1 to +1 is negative.

For the sub sample of events with a positive relationship between dividend changes and share price reaction surrounding the announcement day, we formulate the alternative hypothesis $\mathrm{H}_{3 \mathrm{~A}}$.

\footnotetext{
${ }^{125}$ The data and sample selection have been defined in the precedent chapter.
} 
To test $\mathrm{H}_{3 \mathrm{~A}}$, we will consider the following regression, based on the regression model used before:

$$
\begin{aligned}
\left(\mathrm{E}_{i, \tau}-E_{i, \tau-1}\right) / B V_{i,-1}=a & +\beta_{1} \text { PRDI } \times \Delta \mathrm{D}_{\mathrm{i}, 0}-\beta_{2} \mathrm{NRDD} \times \Delta \mathrm{D}_{\mathrm{i}, 0}+\beta_{3} R O E_{i, \tau-1} \dashv \\
& +\beta_{4}\left(E_{i, 0}-E_{i,-1}\right) / B V_{i,-1}+\varepsilon_{i, t}
\end{aligned}
$$

where:

$$
\begin{aligned}
= & 1 \text { and } 2 ; \\
\text { PRDI }= & \text { dummy variable that takes value } 1 \text { if there is a positive reaction to } \\
& \text { dividend increases and } 0 \text { otherwise; } \\
\text { NRDD }= & \text { dummy variable that takes value } 1 \text { if there is a negative reaction to } \\
& \text { dividend decreases and } 0 \text { otherwise. }
\end{aligned}
$$

In this model, we partition the dividend change announcements according to the market reaction surrounding the announcement. Furthermore, we analyse the market reaction to dividend announcements and the association between dividend changes and future earnings in one regression.

For the UK market, we will adapt the regression in order to contemplate the different relationships between dividend and earnings changes. Thus, the regression will be formulated in the following manner:

$$
\begin{aligned}
\left(\mathrm{E}_{i, \tau}-E_{i, \tau-1}\right) / B V_{i,-1} & =a \dashv \beta_{1 A} \text { PRDIEI } \Delta \mathrm{D}_{\mathrm{i}, 0} \dashv \beta_{1 B} \text { PRDIED } \Delta \mathrm{D}_{\mathrm{i}, 0} \dashv \\
& +\beta_{2 A} \operatorname{NRDDEI} \times \Delta \mathrm{D}_{\mathrm{i}, 0}+\beta_{2 B} \operatorname{NRDDED} \times \Delta \mathrm{D}_{\mathrm{i}, 0}+ \\
& +\beta_{3} R O E_{i, \tau-1}+\beta_{4}\left(E_{i, 0}-E_{i,-1}\right) / B V_{i,-1}+\varepsilon_{i, t}
\end{aligned}
$$

where:

$$
\begin{aligned}
= & 1 \text { and } 2 ; \\
\text { PRDIEI }= & \text { dummy variable that takes value } 1 \text { if there is a positive reaction } \\
& \text { to both dividend and earnings increases and } 0 \text { otherwise; } \\
\text { PRDIED = } & \text { dummy variable that takes value } 1 \text { if there is a positive reaction } \\
& \text { to dividend increases and earnings decreases and } 0 \text { otherwise; } \\
\text { NRDDEI = } & \text { dummy variable that takes value } 1 \text { if there is a negative reaction } \\
& \text { to dividend decreases and earnings increases and } 0 \text { otherwise; } \\
\text { NRDDED = } & \text { dummy variable that takes value } 1 \text { if there is a negative reaction } \\
& \text { to both dividend and earnings decreases and } 0 \text { otherwise. }
\end{aligned}
$$

We expect 1 and 2 to be positive and statistically significant, reflecting a positive relation between dividend changes and future earnings.

According to what we have done before, we will we use the modified partial adjustment model suggested by Fama and French (2000) as a control for the non-linearity in the 
relation between future earnings changes and lagged earnings levels and changes. The model is the following:

$$
\begin{aligned}
\left(\mathrm{E}_{i, \tau}-E_{i, \tau}\right) / B & V_{i,-1}=a+\beta_{1} \operatorname{PRDIx} \Delta \mathrm{D}_{\mathrm{i}, 0}+\beta_{2} \operatorname{NRDDx} \Delta \mathrm{D}_{\mathrm{i}, 0} \\
& +\left(\gamma_{1}+\gamma_{2} N D F E D_{0}+\gamma_{3} N D F E D_{0} * D F E_{i, 0}+\gamma_{4} P D F E D_{0} * D F E_{i, 0}\right) * \mathrm{DFE}_{i, 0} \\
& +\left(\lambda_{1}+\lambda_{2} N C E D_{0}+\lambda_{3} N C E D_{0} * C E_{i, 0}+\lambda_{4} P C E D_{0} * C E_{i, 0}\right) * C E_{\mathrm{i}, 0}+\varepsilon_{i, t}
\end{aligned}
$$

In addition, we will do a similar analysis, but considering the negative relationship between dividend change announcements and the subsequent market reaction (BHAR).

\subsubsection{Methodology to Test Hypothesis 3B - Relation Between Dividend Changes and Future Earnings for the Events With a Negative Relation between Dividend Change Announcements and the Market REACTION}

For the sub sample of events with a negative relationship between dividend changes and share prices in the announcement period, we formulate the alternative hypothesis $\mathrm{H}_{3 \mathrm{~B}}$. To test this hypothesis, we will consider the same regression model as in $\mathrm{H}_{3 \mathrm{~A}}$, but considering different dummy variables:

$$
\begin{aligned}
\left(\mathrm{E}_{i, \tau}-E_{i, \tau-1}\right) / B V_{i,-1}=a & +\beta_{1} \operatorname{NRDI} \Delta \mathrm{D}_{\mathrm{i}, 0} \dashv \beta_{2} \mathrm{PRDD} \times \Delta \mathrm{D}_{\mathrm{i}, 0} \dashv \beta_{3} R O E_{i, \tau-1} \dashv \\
& +\beta_{4}\left(E_{i, 0}-E_{i,-1}\right) / B V_{i,-1}+\varepsilon_{i, t}
\end{aligned}
$$

where:

$$
\begin{aligned}
\text { NRDI = } & \text { dummy variable that takes value } 1 \text { if there is a negative reaction to } \\
& \text { dividend increases and } 0 \text { otherwise; } \\
\text { PRDD }= & \text { dummy variable that takes value } 1 \text { if there is a positive reaction to } \\
& \text { dividend decreases and } 0 \text { otherwise. }
\end{aligned}
$$

Once more, we adapt the regression for the UK market in order to consider the different relationships between dividend and earnings changes. The regression will be formulated in the following manner:

$$
\begin{aligned}
\left(\mathrm{E}_{i, \tau}-E_{i, \tau-1}\right) / B V_{i,-1} & =a \dashv \beta_{1 A} \operatorname{NRDIEI} \times \Delta \mathrm{D}_{\mathrm{i}, 0} \dashv \beta_{1 B} \operatorname{NRDIED\times } \Delta \mathrm{D}_{\mathrm{i}, 0}- \\
& +\beta_{2 A} \operatorname{PRDDEI} \times \Delta \mathrm{D}_{\mathrm{i}, 0}+\beta_{2 B} \operatorname{PRDDED} \times \Delta \mathrm{D}_{\mathrm{i}, 0}+ \\
& +\beta_{3} R O E_{i, \tau-1}+\beta_{4}\left(E_{i, 0}-E_{i,-1}\right) / B V_{i,-1}+\varepsilon_{i, t}
\end{aligned}
$$


where:

$$
\begin{aligned}
= & 1 \text { and } 2 ; \\
\text { NRDIEI } & \text { dummy variable that takes value } 1 \text { if there is a negative reaction } \\
& \text { to both dividend and earnings increases and } 0 \text { otherwise; } \\
\text { NRDIED }= & \text { dummy variable that takes value } 1 \text { if there is a negative reaction } \\
& \text { to dividend increases and earnings decreases and } 0 \text { otherwise; } \\
\text { PRDDEI }= & \text { dummy variable that takes value } 1 \text { if there is a positive reaction } \\
& \text { to dividend decreases and earnings increases and } 0 \text { otherwise; } \\
\text { PRDDED }= & \text { dummy variable that takes value } 1 \text { if there is a positive reaction } \\
& \text { to both dividend and earnings decreases and } 0 \text { otherwise. }
\end{aligned}
$$

We expect 1 and 2 to be negative and statistically significant, reflecting a negative relation between dividend changes and future earnings.

Subsequently, we run the following regression to control for the non-linearity in the relation between future earnings changes and lagged earnings levels and changes:

$$
\begin{aligned}
\left(\mathrm{E}_{i, \tau}-E_{i, \tau-1}\right) / B & V_{i, 1}=a+\beta_{1} \operatorname{NRDIx} \Delta \mathrm{D}_{\mathrm{i}, 0}+\beta_{2} \operatorname{PRDDx} \Delta \mathrm{D}_{\mathrm{i}, 0} \\
& +\left(\gamma_{1}+\gamma_{2} N D F E D_{0}+\gamma_{3} N D F E D_{0} * D F E_{i, 0}+\gamma_{4} P D F E D_{0} * D F E_{i, 0}\right) * \mathrm{DFE}_{\mathrm{i}, 0} \\
& +\left(\lambda_{1}+\lambda_{2} N C E D_{0}+\lambda_{3} N C E D_{0} * C E_{i, 0}+\lambda_{4} P C E D_{0} * C E_{i, 0}\right) * \mathrm{CE}_{\mathrm{i}, 0}+\varepsilon_{i, t}
\end{aligned}
$$

Afterwards, we present the obtained empirical results.

\subsection{EMPIRICAL RESULTS}

Both of our previous results and several authors' evidence, like Benesh, Keown and Pinkerton (1984), Dhillon and Johnson (1994) and Healy, Hathorn and Kirch (1997) exhibit a significant percentage of events with a market reaction opposite to the signal of dividend changes.

To examine this phenomenon in greater detail, we split the sample according to the market reaction to dividend changes, as defined in the methodology section. Table 4.1 reports the number of dividend change announcement events for the three samples according to the relationship between dividend change announcements and the share price reaction in the announcement period.

For the Portuguese sample, we observe that of the 279 dividend change announcement events, 159 events exhibit a direct relation between dividend changes and the BHAR, while the remainder 120 events show an inverse relation between the two variables. For 
the French sample, the values are, respectively, of 297, 156 and 141, and finally, for the UK sample, the values are 2,935, 1,762 and 1,173.

The results indicate that, respectively in the Portuguese, the French and the UK sample, approximately $57 \%, 53 \%$ and $60 \%$ of the events exhibit a positive relationship between dividend change announcements and the subsequent market reaction (not all statistically significant), which behaviour is consistent with the dividend signalling hypotheses (dividends containing information regarding the firm's future prospects). However, we find evidence, respectively for the Portuguese, the French and the UK samples, of about $43 \%, 47 \%$ and $40 \%$ of dividend change events showing an inverse relationship between dividend change announcements and the market reaction in the 3 days surrounding the announcement day, the majority of which being dividend increases with negative BHAR. This evidence is in accordance with several authors' results and confirms the need to examine these enigmatic situations.

We start to examine the events with a positive relationship between dividend changes and the market reaction. Next, we analyse the enigmatic cases of dividend change announcement observations with a negative relationship between the two variables.

\subsubsection{Test Results of Hypothesis 3A - RElation BetweEn Dividend Changes AND Future Earnings for the Events With a Positive Relation BETWEen Dividend Change AnNouncements ANd THE MARKet ReACTION}

In what follows, we analyse the relationship between dividend changes and future earnings, for the events with a positive relationship between dividend changes and the market reaction, in order to test hypothesis 3A. According to this hypothesis, for firms whose share price changes in the announcement period are positively associated with dividend changes, a positive relation between dividend changes and future profitability

is expected, measured in terms of future earnings changes. We assume that the market reacts positively to dividend increases because it expects future earnings to increase and reacts negatively to dividend decreases because it expects future earnings to decrease, which is in accordance with the dividend signalling hypothesis. 
The pooled least squares, the FEM and the REM estimation results of regression 4.1 are shown in Table 4.2. The best model for each particular sample and year is chosen according to the F statistic and the Hausman test, and is highlighted.

To simplify, we do not report the correlation matrix of the exogenous variables. Variables show low correlations. The higher correlation coefficients, for all the three markets, are between the ROE and the earnings changes in the announcement year for $=1$. The coefficient is around $75 \%$ in the Portuguese sample, approximately $70 \%$ in the French sample and is below $20 \%$ in the UK market. All the other correlation coefficients are below 25\%. In general, the correlation coefficients do not appear to be sufficiently large to cause concern about multicollinearity problems.

The Portuguese sample results exhibit a positive and significant coefficient, at the $5 \%$ level, on dividend increases (with subsequent positive market reaction) for both years, as predicted ${ }^{126}$. This means that future earnings are positively related to dividend increases. Thus, the results concerning a positive reaction to dividend increases support hypothesis $\mathrm{H}_{3 \mathrm{~A}}$ and provides evidence for the dividend information content hypothesis. The coefficient on the negative reaction to dividend decreases is positive for $=1$, but negative for $=2$, contrary to what is expected. However, it is not statistically significant for both periods. This means that, although we observe a signalling effect related to the market reaction to dividend decreases, we cannot reject the null hypothesis associated with $\mathrm{H}_{3 \mathrm{~A}}$ and, consequently, we do not find evidence supporting the dividend information content hypothesis in what concerns the relationship between dividend changes and future earnings. This evidence is in accordance with Nissim and Ziv (2001) verification, since these authors found evidence of dividend increases associated with future profitability (measured in terms of earnings), whereas dividend decreases are not related to future profitability, after controlling for current profitability.

The French sample results show a positive coefficient on the PRDI events for both years. However, it is not statistically significant for the two periods. Thus, we find no evidence supporting the dividend information content hypothesis for the dividend increase events. The coefficient on the negative reaction to dividend decreases is negative for the two periods, contrary to what is expected. However, it is only

\footnotetext{
${ }^{126}$ Previously, when analysing the relation between dividend increases and future earnings, we find a positive relation, although not statistically significant, between these two variables (see Table 3.10 ). This difference may be due to the dividend increase events with a negative market reaction.
} 
marginally significant for $=2$, at the $10 \%$ level. This means that, although we observe a signalling effect related to the market reaction to dividend decreases, the future earnings are not related to dividend changes, except for $=2$, but even in this period, they are only marginally related. Generally, and similar to Table 3.10 results, we can say that we find no evidence supporting the dividend information content hypothesis in what concerns the relationship between dividend changes and future earnings.

The UK sample results exhibit statistically insignificant values for all the coefficients on dividend increase events, and for both periods. Thus, we find no evidence supporting the dividend information content hypothesis for the dividend increase events in what concerns the relationship between dividend changes and future earnings. The fact that, for $=1$, the coefficient on PRDIEI is positive, while the coefficient on PRDIED is negative, although both not significant, could be an indication of a strong power of current earnings over current dividends in explaining the firm's future prosperity. Indeed, the coefficient on current earnings changes is negative and statistically significant at $1 \%$ level. This evidence is in agreement with our previous conclusions, as well as with Abeyratna and Power (2002) results, among others.

The coefficient on the negative reaction to dividend decreases and earnings increases is positive for the two periods, as expected, but it is only statistically significant for $=2$, at the $5 \%$ level. The coefficient on the negative reaction to both dividend and earnings decreases is also expected to be positive, but it is negative for the two periods, and statistically significant for $=1$, at the $1 \%$ level. We would like to try to understand the reasons behind failing to document a positive relation between dividend changes and future earnings for the NRDDED events. The fact that the coefficient on NRDDEI is positive, while the coefficient on NRDDED is negative for the two periods, could be again an indication of current earnings having a stronger power in explaining the firm's future prosperity than current dividends. In summary, the results for the dividend decrease events are not consistent. Although we observe a signalling effect related to the market reaction to dividend decreases, we only reject the null hypothesis associated with $\mathrm{H}_{3 \mathrm{~A}}$ for two coefficients. For $=1$, we reject the null hypothesis associated with $\mathrm{H}_{3 \mathrm{~A}}$ for the NRDDED events, but the relation between future earnings and dividend changes is negative, finding no support for the signalling hypothesis. For $=2$, we reject the null hypothesis for the NRDDEI events, finding a positive relation between 
future earnings and dividend changes, as expected, supporting, only for this events, the dividend information content hypothesis. In summary, we find weak evidence supporting the dividend information content hypothesis.

In Table 4.3 we show the re-estimated coefficients of the regression models using the Fama and French (2000) methods, according to the regression 4.2 , in order to overcome the problem of the mean reversion process of earnings being non-linear. Comparing the results from Table 4.2 to those of Table 4.3, we notice that, globally, the results are quite similar. The main differences occur in the Portuguese and in the French markets. In the Portuguese sample, the coefficient on a positive reaction to dividend increases is now only statistically significant for $=2$, which cancel some support to the signalling hypothesis, found before. However, in the French sample, the coefficient on a positive reaction to dividend increases becomes now statistically significant for $=2$, at the $5 \%$ level, giving some support to the dividend signalling hypothesis. Neither of the other coefficients has changed considerably, so, in global terms, the conclusions obtained before remain valid. One interesting evidence is the fact that the three coefficients that are positive and statistically significant occurs always for $=2$, which is an indication that the information content effect reinforces over time.

Overall, after controlling for the non-linear patterns in the behaviour of earnings, the results obtained do not allow us to reject the null hypothesis associated with $\mathrm{H}_{3 A}$ for the majority of the coefficients. Only 3 of the 16 coefficients exhibit a positive and significant relation between future earnings and dividend changes (one for each country, and all for = 2). Consequently, although we observe a signalling effect related to the market reaction to dividend change announcements (positive relationship between dividend changes and share price changes in the 3 days contiguous to the announcement date), we find weak support to the hypothesis $H_{3 A}$. Therefore, in global terms, the results provide weak evidence for the dividend information content hypothesis.

We will try to understand the reasons why the association between the future earnings and the dividend changes is negative for the NRDDED events in the UK market, addressing this question by analysing the firm-specific variables that can influence this relationship and trying to analyse the firm characteristic differences among the different groups of events. 
After analysing the events for which the behaviour is consistent with the dividend signalling hypothesis in what concerns the relationship between dividend change announcements and the subsequent market reaction, we will evaluate the events with a reverse relation between these two variables.

\subsubsection{Test Results of Hypothesis 3B - RElation BETWEen DiVIDEND Changes AND Future EARnings for the Events With a Negative Relation BETWEen Dividend Change ANNOUnCEMENTS AND THE MARKET REACTION}

We analyse the relationship between dividend changes with a respective reverse market reaction and future earnings, in order to analyse hypothesis $\mathrm{H}_{3 \mathrm{~B}}$. According to this hypothesis, for firms whose share prices' change in the dividend announcement period is negatively associated with the dividend change, a negative relation between dividend changes and future profitability is expected, measured in terms of future earnings changes. We assume that if the market reacts negatively (positively) to dividend increases (decreases) is because it expects future earnings to decrease (increase).

The pooled least squares, the FEM and the REM estimation results of regression 4.3 are shown in Table 4.4. The best model for each particular sample and year is chosen according to the F statistic and the Hausman test, and is presented in bold.

Again to simplify, we do not report the correlation matrix of the exogenous variables. The higher correlation coefficients, for all the three markets, are between the ROE and the earnings changes in the announcement year for $=1$. The coefficient is around $50 \%$ in the Portuguese sample, bellow $50 \%$ in the French sample and about $22 \%$ in the UK market. All the other correlation coefficients are below 22\%. Thus, the correlation coefficients do not appear to be sufficiently large to cause concern about multicollinearity problems.

The Portuguese sample results exhibit a positive coefficient on dividend increases with a negative market reaction for both years, contrary to what is expected. However, it is only marginally significant for $=2$, at the $10 \%$ level. Thus, although the market reacts negatively to dividend increases, the future earnings are consistent with the dividend information content hypothesis. This is an indication that the market did not understand 
the signal given by firms through dividend increase announcements, as we have already conclude previously, testing the first hypothesis. Although for $=2$ the results exhibit a statistically significant relation between dividend changes and future earnings, we find no evidence of the dividend signalling hypothesis for the relation between dividend changes and share price movements in the announcement period, so, in general terms, we cannot give support to the dividend signalling hypothesis.

The coefficient on the positive reaction to dividend decreases is negative for both years, as expected. However, it is only statistically significant for the first period, at the $10 \%$ level. This result suggests that, although dividends have decreased, investors forecast an increase in future earnings, and the market reacts according to this expectation, existing evidence of a signalling effect but contrary to the sign of dividends, which we have denominated by inverse signalling effect. Therefore, as we reject the null hypothesis associated with $\mathrm{H}_{3 \mathrm{~B}}$ (and earnings and dividends are negatively related) for the first year after the dividend change announcement, we give support to the inverse signalling effect, but only for $=1$, which can be interpreted as a capability to predict the future firm's prospects in a short term period.

For the case of the French sample, none of the coefficients on dividend changes is statistically significant. Thus, we do not reject the null hypothesis. As we find no evidence of a positive relation between dividend change announcements and the subsequent market reaction as well as between dividend changes and future earnings, we give no support the dividend information content hypothesis.

The UK sample results exhibit a significant value for two coefficients: the one of a negative reaction to both dividend and earnings increases (NRDIEI) and the other of a positive reaction to dividend decreases and earnings increases (PRDDEI). The coefficient on NRDIEI is negative for $=1$, as expected, but negative for $=2$. The coefficient on PRDDEI is negative, as supposed, but only statistically significant for the first period. For $=1$, the rejection of the null hypothesis associated with $\mathrm{H}_{3 \mathrm{~B}}$ for the NRDIEI and PRDDEI variables provide evidence for the inverse signalling hypothesis. For $=2$, the rejection of NRDIEI variable (positive signal) indicates that, although the relation between dividend changes and future earnings is consistent with the dividend signalling effect, the market reaction to dividend change announcements is inverse. This 
suggests that the market did not understand the signal given by the firms through the dividend change announcements.

The fact that, for $=1$, the coefficients on NRDIEI and PRDDEI are negative and significant, while they are positive for $=2$ (although only significant for the first case), could be an indication of a strong power of investors predicting the short term earnings behaviour over the long term. Indeed, future earnings changes are in accordance with market reaction for the first period, but in contrast with market reaction two years after the dividend and earnings change announcements. This evidence suggests that the investors' forecasting capability decays over time.

Table 4.5 shows the re-estimated coefficients using the Fama and French (2000) methods, according to the regression 4.4 , in order to overcome the problem of the mean reversion process of earnings being non-linear. Comparing the results from Table 4.4 to those of Table 4.5, we notice that, globally, the results are quite similar. The two main differences occur in the Portuguese and in the UK markets.

In the case of the Portuguese sample, the coefficient on the negative reaction to dividend increases (NRDI) is no more statistically significant for $=2$, but becomes statistically significant for $=1$, being positive, contrary to the expected. The conclusion obtained before for $=2$ is now evidenced for $=1$, that, although the market reacts negatively to dividend increases, the future earnings are consistent with the dividend information content hypothesis, suggesting that the market did not understand the signal given by firms through dividend increase announcements. All the other coefficients are statistically not different from zero.

In the case of the UK sample, the coefficients that are now statistically significant are the two coefficients on the positive reaction to dividend decreases (PRDDEI and PRDDED), both negative (for $=1$ ) and the coefficient on NRDIEI, positive (for $=2$ ). The differences are that, for $=1$, NRDIEI is now statistically insignificant and the coefficient on PRDDED becomes significant. Neither of the other coefficients has changed considerably.

Overall, after controlling for the non-linear patterns in the behaviour of earnings, the results obtained do not allow us to reject the null hypothesis associated with $\mathrm{H}_{3 B}$ for the majority of the coefficients. Only 1 of the 4 coefficients, for the Portuguese sample, and 
3 of the 8, for the UK market, are statistically significant. For the dividend decrease events in the UK market, we find some evidence of the inverse signalling hypothesis. For the dividend increases in the Portuguese market, it seems that the market do not understand the signal conveyed by firms' dividend policy.

\subsection{CONCLUSIONS}

To summarise the results obtained so far, we can conclude that:

- After controlling for the non-linear patterns in the behaviour of earnings, the results obtained do not allow us to reject the null hypothesis associated with $\mathrm{H}_{3 \mathrm{~A}}$ for the majority of the coefficients. Only one coefficient was statistically significant for each country: for the Portuguese and the French markets, it was the coefficient on PRDI, both for $=2$ and for the UK it was the coefficient on NRDDEI, also for the second year. Consequently, we find, for all the 3 countries, only weak evidence for the dividend information content hypothesis. Moreover, the results show that these three coefficients are all statistically significant for $=$ 2, which is an indication that the information content effect reinforces over time;

- Testing the second hypothesis, the results obtained do not allow us to reject the null hypothesis associated with $\mathrm{H}_{3 \mathrm{~B}}$ for the French market. Hence, we find no evidence of a relation between future earnings and dividend changes. Thus, the results do not provide evidence for the dividend information content hypothesis. In what concerns the Portuguese market, the global results suggest no relation between future earnings and dividend changes. However, for one situation (NRDI,

$=1$ ), the results exhibit evidence that, although the market reacts negatively to dividend changes, the future earnings are consistent with the dividend information content hypothesis, suggesting that the market did not understand the signal given by firms through dividend change announcements. The same evidence is also found for a coefficient on the UK sample (NRDIEI, = 2);

- We find no evidence of the inverse signalling effect, except for the UK market, where we find a weak support to the hypothesis that for the events with a negative relation between dividend change announcements and the market reaction, future 
earnings are negatively associated with current dividend changes (PRDDEI and PRDDED, both for $=1$ ). This result suggests that the UK market investors have more capability to predict future earnings than the investors of the Portuguese and the French markets.

We would like to understand the reasons behind failing to document a negative relation between dividend changes and future earnings for some of the negative reaction to dividend increases (in the Portuguese and the UK samples). In these situations, the positive relation between the two variables is in accordance with the dividend signalling hypothesis, but the market reaction is contradictory. One possible reason for this to happen can be the fact that the market has wrongly interpreted the signal conveyed by managers. Another reason can be associated with the expected dividend. Healy, Hathorn and Kirch (1997) and Dhillon, Raman and Ramírez (2003) conclude that the payment of a larger than expected dividend may signal that the firm does not have any available investment opportunities that will sustain the earnings growth and the capital market would react negatively.

Other possible reasons for a positive reaction to dividend decreases beyond the investors' expectations about firms' future earnings, as assumed by the signalling theory and tested here, can be associated with the magnitude of dividend decreases, expected dividend and managers decisions to solve financial problems. Mozes and Rapaccioli (1998) found evidence that small dividend decreases do not provide a negative signal about future earnings probably because small dividend decreases may represent an attempt to keep resources for future growth opportunities. Healy, Hathorn and Kirch (1997) and Dhillon, Raman and Ramírez (2003) conclude that the payment of a smaller than expected cut in dividends may signal that the firms have available investment opportunities that will sustain the earnings growth, and so the capital market would react positively and Abeyratna and Power (2002) suggested that dividend decreases may reflect managers' decisions to solve firms' financial problems.

We wonder if the adverse relation between dividend change announcements and the market reaction could be endorsed to the failure of the naïve dividend changes model rather than to a real adverse reaction to dividend changes.

In the next section, we will try to assess if there is any difference among the different events with capacity to explain these distinct behaviours, namely analysing the firm 
characteristic differences among the distinct groups of events and the relation between firm-specific factors and the market reaction in the dividend announcement period. 
TABLES 


\section{Table 4.1 - Sub Sample Selection}

This table reports the number of dividend change announcement events for the Portuguese, the French and the UK samples, according to the relationship between dividend change announcements and the share price reaction in the announcement period.

\begin{tabular}{|c|c|c|}
\hline \multicolumn{3}{|l|}{ Portugal } \\
\hline & \multicolumn{2}{|c|}{ Events } \\
\hline & Number & $\%$ \\
\hline Dividend increases with positive BHAR & 86 & 54.43 \\
\hline Dividend increases with negative BHAR & 72 & 45.57 \\
\hline Dividend increases & 158 & 100.00 \\
\hline Dividend decreases with negative BHAR & 73 & 60.33 \\
\hline Dividend decreases with positive BHAR & 48 & 39.67 \\
\hline \multirow[t]{2}{*}{ Dividend decreases } & 121 & 100.00 \\
\hline & 279 & \\
\hline Dividend increases with positive BHAR & 86 & 30.82 \\
\hline Dividend decreases with negative BHAR & 73 & 26.16 \\
\hline Direct relation between dividend changes and $B H A R$ & 159 & 56.99 \\
\hline Dividend increases with negative BHAR & 72 & 25.81 \\
\hline Dividend decreases with positive BHAR & 48 & 17.20 \\
\hline Inverse relation between dividend changes and $B H A R$ & 120 & 43.01 \\
\hline Dividend increases with null BHAR & 0 & 0.00 \\
\hline Dividend decreases with null BHAR & 0 & 0.00 \\
\hline No relation between dividend changes and BHAR & $\mathbf{0}$ & $\mathbf{0 . 0 0}$ \\
\hline Total of Dividend Change Announcement Events & 279 & 100.00 \\
\hline \multicolumn{3}{|l|}{\begin{tabular}{|c|} 
France \\
\end{tabular}} \\
\hline & \multicolumn{2}{|c|}{ Events } \\
\hline & Number & $\%$ \\
\hline Dividend increases with positive BHAR & 127 & 54.04 \\
\hline Dividend increases with negative BHAR & 108 & 45.96 \\
\hline Dividend increases & 235 & 100.00 \\
\hline Dividend decreases with negative BHAR & 29 & 46.77 \\
\hline Dividend decreases with positive BHAR & 33 & 53.23 \\
\hline \multirow[t]{2}{*}{ Dividend decreases } & 62 & 100.00 \\
\hline & 297 & \\
\hline Dividend increases with positive BHAR & 127 & 42.76 \\
\hline Dividend decreases with negative BHAR & 29 & 9.76 \\
\hline Direct relation between dividend changes and $B H A R$ & 156 & 52.53 \\
\hline Dividend increases with negative BHAR & 108 & 36.36 \\
\hline Dividend decreases with positive BHAR & 33 & 11.11 \\
\hline Inverse relation between dividend changes and $B H A R$ & 141 & 47.47 \\
\hline Dividend increases with null BHAR & 0 & 0.00 \\
\hline Dividend decreases with null BHAR & 0 & 0.00 \\
\hline No relation between dividend changes and BHAR & $\mathbf{0}$ & $\mathbf{0 . 0 0}$ \\
\hline Total of Dividend Change Announcement Events & 297 & 100.00 \\
\hline
\end{tabular}


Table 4.1 - Sub Sample Selection (continued)

\begin{tabular}{|c|c|c|}
\hline \multicolumn{3}{|l|}{ UK } \\
\hline & \multicolumn{2}{|c|}{ Events } \\
\hline & Number & $\%$ \\
\hline DIEI with positive BHAR & 1201 & 62.20 \\
\hline DIEI with negative BHAR & 730 & 37.80 \\
\hline DIEI & 1,931 & 100.00 \\
\hline DIED with positive BHAR & 448 & 61.29 \\
\hline DIED with negative BHAR & 283 & 38.71 \\
\hline DIED & 731 & 100.00 \\
\hline DDEI with negative BHAR & 46 & 42.59 \\
\hline DDEI with positive BHAR & 62 & 57.41 \\
\hline$D D E I$ & 108 & 100.00 \\
\hline DDED with negative BHAR & 67 & 40.61 \\
\hline DDED with positive BHAR & 98 & 59.39 \\
\hline \multirow[t]{2}{*}{$D D E D$} & 165 & 100.00 \\
\hline & 2,935 & \\
\hline DIEI with positive BHAR & 1,201 & 40.92 \\
\hline DIED with positive BHAR & 448 & 15.26 \\
\hline DDEI with negative BHAR & 46 & 1.57 \\
\hline DDED with negative BHAR & 67 & 2.28 \\
\hline Direct relation between dividend changes and BHAR & 1,762 & 60.03 \\
\hline DIEI with negative BHAR & 730 & 24.87 \\
\hline DIED with negative BHAR & 283 & 9.64 \\
\hline DDEI with positive BHAR & 62 & 2.11 \\
\hline DDED with positive BHAR & 98 & 3.34 \\
\hline Inverse relation between dividend changes and $B H A R$ & 1,173 & 39.97 \\
\hline DIEI with null BHAR & 0 & 0.00 \\
\hline DIED with null BHAR & 0 & 0.00 \\
\hline DDEI with null BHAR & 0 & 0.00 \\
\hline DDED with null BHAR & 0 & 0.00 \\
\hline No relation between dividend changes and BHAR & $\mathbf{0}$ & 0.00 \\
\hline Total of Dividend Change Announcement Events & 2,935 & 100.00 \\
\hline
\end{tabular}




\section{Table 4.2 - Regression of earnings changes on dividend changes for positive association between dividend change announcements and subsequent market reaction}

This table reports the estimation of a regression relating earnings changes to dividend changes for the sub sample of events whose market reaction is positively related with dividend changes. $E_{i}$, denotes earnings before extraordinary items in year (year 0 is the event year); $\mathrm{BV}_{\mathrm{i},-1}$ is the book value of equity at the end of year $-1 ; D_{i, t}$ is the annual change in the cash dividend payment, scaled by the share price in the announcement day; PRDI (NRDD) is a dummy variable that takes the value 1 for a positive (negative) reaction to dividend increases (decreases) and 0 otherwise; PRDIEI (PRDIED) is a dummy variable that takes value 1 for a positive reaction to dividend increases and earnings increases (decreases) and 0 otherwise; NRDDEI (NRDDED) is a dummy variable that takes value 1 for a negative reaction to dividend decreases and earnings increases (decreases) and 0 otherwise; $\mathrm{ROE}_{\mathrm{i},-1}$ is equal to the earnings before extraordinary items in year -1 scaled by the book value of equity at the end of year -1 . The regression results are estimated using pooled OLS, FEM and REM. The numbers in parentheses are the tstatistics corrected for heteroscedasticity using the White (1980) method. It reports the F test, a test for the equality of sets of coefficients, and the Hausman (1978) test, a test with $\mathrm{H}_{0}$ : random effects are consistent and efficient, versus $\mathrm{H}_{1}$ : random effects are inconsistent, in order to choose the most appropriate model for each particular sample.

\begin{tabular}{|c|c|c|c|c|c|c|}
\hline \multicolumn{7}{|c|}{$\begin{aligned}\left(\mathrm{E}_{i, \tau}-E_{i, \tau-1}\right) / B V_{i,-1}=a & +\beta_{1} \text { PRDI x } \Delta \mathrm{D}_{\mathrm{i}, 0}+\beta_{2} \text { NRDD } \\
& +\beta_{4}\left(E_{i, 0}-E_{i,-1}\right) / B V_{i,-1}+\varepsilon_{i, t}\end{aligned}$} \\
\hline \multicolumn{7}{|c|}{ Portugal } \\
\hline Coefficient & Pooled OLS & & FEM & & REM & \\
\hline & & & $=1$ & & & \\
\hline Constant & $\begin{array}{r}0.053 \\
(4.101)\end{array}$ & $*$ & & & $\begin{array}{r}0.068 \\
(3.309)\end{array}$ & \\
\hline PRDI x $\Delta \mathrm{D}_{\mathrm{i} .0}$ & $\begin{array}{r}-0.017 \\
(-2.413)\end{array}$ & $* *$ & $\begin{array}{r}0.029 \\
(2.217)\end{array}$ & $* *$ & $\begin{array}{r}0.019 \\
(0.705)\end{array}$ & \\
\hline $\mathrm{NRDD} \times \Delta \mathrm{D}_{\mathrm{i} .0}$ & $\begin{array}{r}0.090 \\
(1.679)\end{array}$ & $* * *$ & $\begin{array}{r}0.042 \\
(1.092)\end{array}$ & & $\begin{array}{r}0.055 \\
(0.734)\end{array}$ & \\
\hline $\mathrm{ROE}_{\mathrm{i} .-1}$ & $\begin{array}{r}-0.637 \\
(-5.462)\end{array}$ & $*$ & $\begin{array}{r}-0.879 \\
(-4.265)\end{array}$ & $*$ & $\begin{array}{r}-0.831 \\
(-9.447)\end{array}$ & $*$ \\
\hline$\left(\mathrm{E}_{\mathrm{i}, 0}-\mathrm{E}_{\mathrm{i},-1}\right) / \mathrm{BV}_{\mathrm{i},-1}$ & $\begin{array}{r}-0.207 \\
(-1.794)\end{array}$ & $* * *$ & $\begin{array}{r}0.086 \\
(0.528)\end{array}$ & & $\begin{array}{r}0.027 \\
(0.339)\end{array}$ & \\
\hline $\mathrm{N}$ & 152 & & 152 & & 152 & \\
\hline Adjusted $\mathrm{R}^{2}$ & 0.603 & & 0.666 & & 0.785 & \\
\hline Test F & 1.42 & $* * *$ & & & & \\
\hline Hausman Test & & & 24.46 & $*$ & & \\
\hline & & & $=2$ & & & \\
\hline Constant & $\begin{array}{r}0.001 \\
(0.044)\end{array}$ & & & & $\begin{array}{r}0.023 \\
(0.967)\end{array}$ & \\
\hline PRDI x $\Delta \mathrm{D}_{\mathrm{i} .0}$ & $\begin{array}{r}0.130 \\
(1.907)\end{array}$ & $* * *$ & $\begin{array}{r}0.136 \\
(2.213)\end{array}$ & $* *$ & $\begin{array}{r}0.133 \\
(1.173)\end{array}$ & \\
\hline NRDD x $\Delta D_{i .0}$ & $\begin{array}{r}-0.065 \\
(-0.891)\end{array}$ & & $\begin{array}{r}-0.038 \\
(-0.846)\end{array}$ & & $\begin{array}{r}-0.038 \\
(-0.432)\end{array}$ & \\
\hline $\mathrm{ROE}_{i,-1}$ & $\begin{array}{r}-0.386 \\
(-1.998)\end{array}$ & $* *$ & $\begin{array}{r}-0.761 \\
(-3.387)\end{array}$ & $*$ & $\begin{array}{r}-0.695 \\
(-6.886)\end{array}$ & \\
\hline$\left(\mathrm{E}_{\mathrm{i}, 0}-\mathrm{E}_{\mathrm{i},-1}\right) / \mathrm{BV}_{\mathrm{i},-1}$ & $\begin{array}{r}0.344 \\
(2.451)\end{array}$ & $* *$ & $\begin{array}{r}-0.173 \\
(-1.182)\end{array}$ & & $\begin{array}{r}0.007 \\
(0.082)\end{array}$ & \\
\hline $\mathrm{N}$ & 147 & & 147 & & 147 & \\
\hline Adjusted $\mathrm{R}^{2}$ & 0.182 & & 0.441 & & 0.600 & \\
\hline Test F & 2.01 & $*$ & & & & \\
\hline Hausman Test & & & 73.88 & $*$ & & \\
\hline $\begin{array}{ll}* & \text { Significant } \\
* * & \text { Significant } \\
* * * & \text { Significant }\end{array}$ & $\begin{array}{l}\text { erent from zero at } \\
\text { erent from zero at } \\
\text { erent from zero at }\end{array}$ & $\begin{array}{l}\text { the } 1^{0} \\
\text { the } 5^{\circ} \\
\text { the } 10\end{array}$ & & & (Contir & aue) \\
\hline
\end{tabular}


Table 4.2 - Regression of earnings changes on dividend changes for positive association between dividend change announcements and subsequent market reaction (continued)

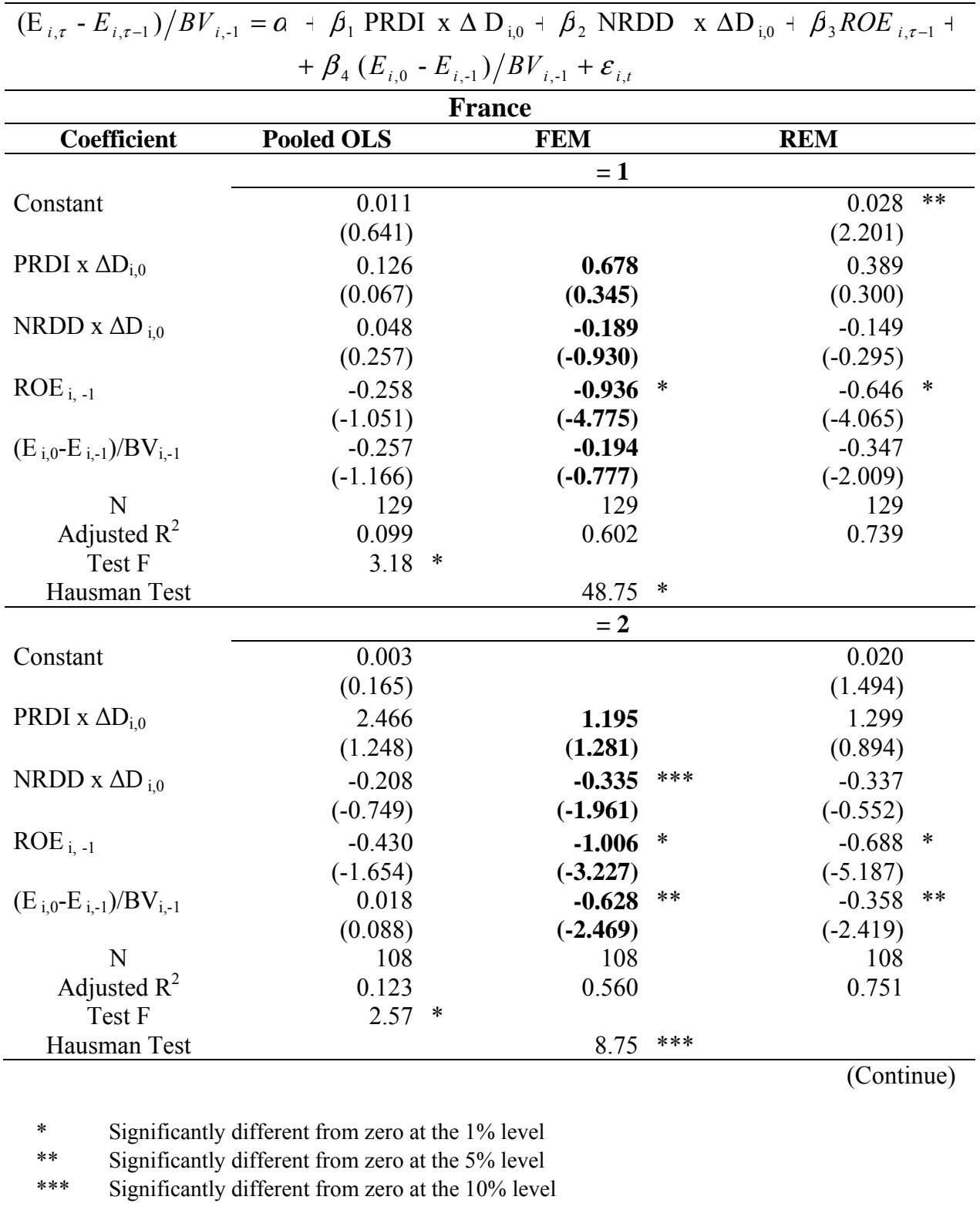


Table 4.2 - Regression of earnings changes on dividend changes for positive association between dividend change announcements and subsequent market reaction (continued)

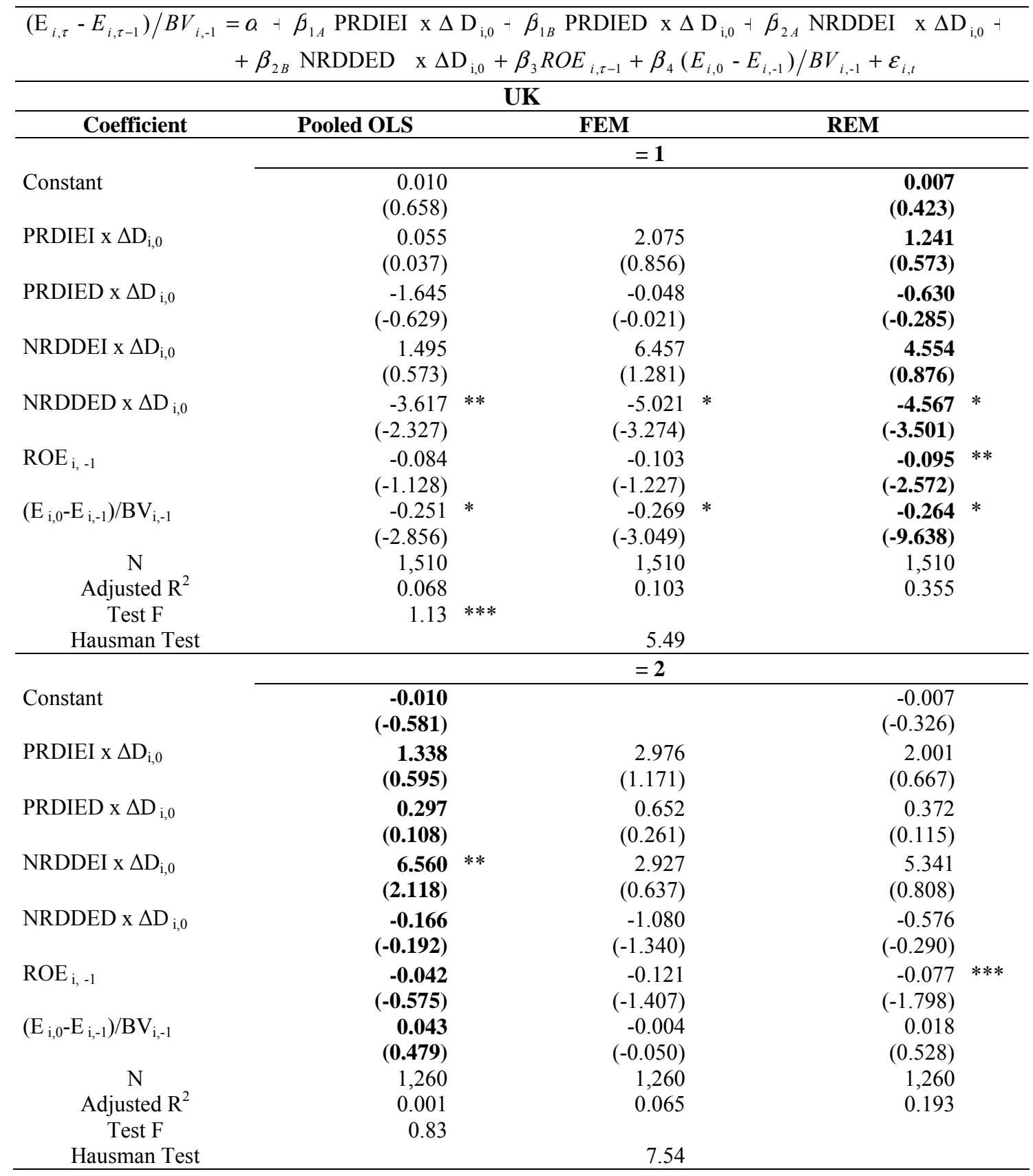

* $\quad$ Significantly different from zero at the $1 \%$ level

** $\quad$ Significantly different from zero at the $5 \%$ level

$* * * \quad$ Significantly different from zero at the $10 \%$ level 


\section{Table 4.3 - Regression of earnings changes on dividend changes for positive association between dividend change announcements and subsequent market reaction using Fama and French Approach}

This table reports the estimation of a regression relating earnings changes to dividend changes for the sub sample of events whose market reaction is positively related with dividend changes. $\mathrm{E}_{\mathrm{i}}$, denotes earnings before extraordinary items in year (year 0 is the event year); $\mathrm{BV}_{\mathrm{i},-1}$ is the book value of equity at the end of year $-1 ; D_{i, t}$ is the annual change in the cash dividend payment, scaled by the share price in the announcement day; $\mathrm{ROE}_{\mathrm{i}}$, is equal to the earnings before extraordinary items in year scaled by the book value of equity at the end of year ; $\mathrm{DFE}_{\mathrm{i}, 0}$ is equal to $\mathrm{ROE}_{\mathrm{i}, 0}-\mathrm{E} \mathrm{ROE}_{\mathrm{i}, 0}$, where $\mathrm{ROE}_{\mathrm{i}, 0}$ is the fitted value from the cross-sectional regression of $\mathrm{ROE}_{\mathrm{i}, 0}$ on the $\log$ of total assets in year -1, the market-tobook ratio of equity in year -1 , and $\mathrm{ROE}_{\mathrm{i},-1} ; \mathrm{CE}_{\mathrm{i}, 0}$ is equal to $\left(\mathrm{E}_{\mathrm{i}, 0}-\mathrm{E}_{\mathrm{i},-1}\right) / \mathrm{BV}_{\mathrm{i},-1} ; \mathrm{NDFED}_{0}$ is a dummy variable that takes value 1 if $\mathrm{DFE}_{i, 0}$ is negative and 0 otherwise; $\mathrm{PDFED}_{0}$ is a dummy variable that takes value 1 if $\mathrm{DFE}_{\mathrm{i}, 0}$ is positive and 0 otherwise; $\mathrm{NCED}_{0}$ is a dummy variable that takes value 1 if $\mathrm{CE}_{\mathrm{i}, 0}$ is negative and 0 otherwise; $\mathrm{PCED}_{0}$ is a dummy variable that takes value 1 if $\mathrm{CE}_{\mathrm{i}, 0}$ is positive and 0 otherwise; PRDI (NRDD) is a dummy variable that takes the value 1 for a positive (negative) reaction to dividend increases (decreases) and 0 otherwise; PRDIEI (PRDIED) is a dummy variable that takes value 1 for a positive reaction to dividend increases and earnings increases (decreases) and 0 otherwise; NRDDEI (NRDDED) is a dummy variable that takes value 1 for a negative reaction to dividend decreases and earnings increases (decreases) and 0 otherwise. The regression results are estimated using pooled OLS, FEM and REM. The numbers in parentheses are the t-statistics corrected for heteroscedasticity using the White (1980) method. It reports the F test, a test for the equality of sets of coefficients, and the Hausman (1978) test, a test with $\mathrm{H}_{0}$ : random effects are consistent and efficient, versus $\mathrm{H}_{1}$ : random effects are inconsistent, in order to choose the most appropriate model for each particular sample.

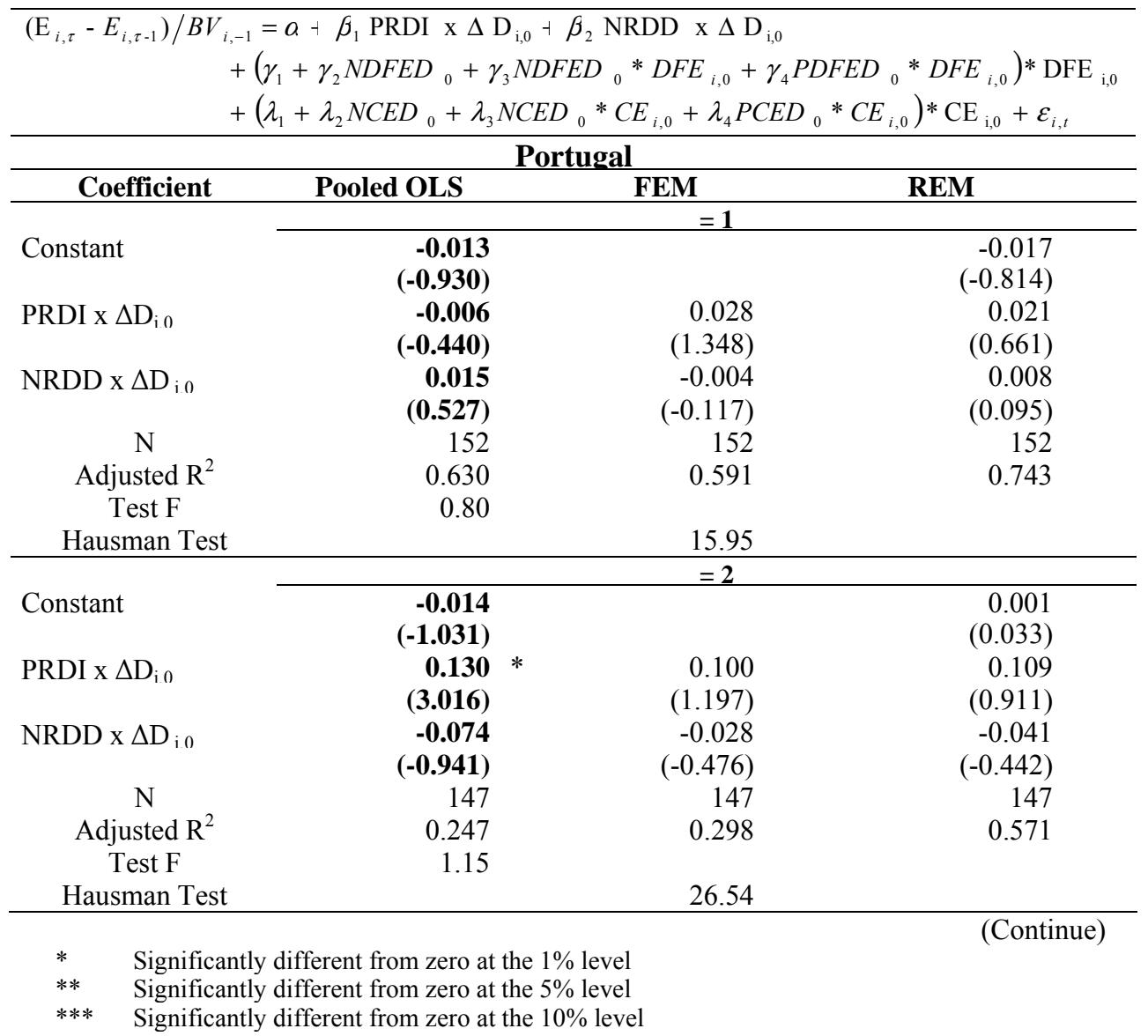


Table 4.3 - Regression of earnings changes on dividend changes for positive association between dividend change announcements and subsequent market reaction using Fama and French Approach (continued)

\begin{tabular}{|c|c|c|c|c|}
\hline$\left(\mathrm{E}_{i, \tau}-E_{i, \tau}{ }_{1}\right) / B V_{i,}$ & $\begin{array}{l}\dashv \beta_{1} \text { PRDI x } \Delta \\
-\gamma_{2} N D F E D_{0}+\gamma \\
-\lambda_{2} N C E D_{0}+\lambda_{3}\end{array}$ & $\partial_{i, 0}$ & $\begin{array}{l}\operatorname{RDD}_{\mathrm{X}} \Delta \mathrm{D}_{\mathrm{i}} \\
* D F E_{i, 0}+\gamma \\
C E_{i, 0}+\lambda_{4} P C\end{array}$ & $\begin{array}{l}\left.* D F E_{i, 0}\right) * \mathrm{DFE}_{\mathrm{i}, 0} \\
\left.{ }_{0}\right) * \mathrm{CE}_{\mathrm{i}, 0}+\varepsilon_{i, t}\end{array}$ \\
\hline & & & & \\
\hline Coefficient & Pooled OLS & & FEM & REM \\
\hline & & & $=1$ & \\
\hline Constant & 0.012 & & & 0.012 \\
\hline & (1.486) & & & $(0.957)$ \\
\hline PRDI x $\Delta \mathrm{D}_{\mathrm{i}, 0}$ & 1.172 & & 1.505 & 1.458 \\
\hline & $(0.660)$ & & $(0.871)$ & (1.131) \\
\hline NRDD x $\Delta \mathrm{D}_{\mathrm{i}, 0}$ & 0.074 & & -0.245 & -0.186 \\
\hline & $(0.287)$ & & $(-1.002)$ & $(-0.370)$ \\
\hline $\mathrm{N}$ & 128 & & 128 & 128 \\
\hline Adjusted $\mathrm{R}^{2}$ & 0.252 & & 0.590 & 0.742 \\
\hline Test $\mathrm{F}$ & 2.36 & * & & \\
\hline Hausman Test & & & 81.64 & \\
\hline & & & $=2$ & \\
\hline Constant & -0.167 & & & -0.006 \\
\hline & $(-1.398)$ & & & $(-0.326)$ \\
\hline PRDI $x \Delta D_{i, 0}$ & 4.096 & $* *$ & 0.362 & 2.596 \\
\hline & (2.104) & & $(0.202)$ & (1.434) \\
\hline NRDD x $\Delta D_{i, 0}$ & -0.360 & & -0.240 & -0.575 \\
\hline & $(-1.256)$ & & $(-0.789)$ & $(-0.783)$ \\
\hline $\mathrm{N}$ & 108 & & 108 & 108 \\
\hline Adjusted $\mathrm{R}^{2}$ & 0.151 & & 0.304 & 0.593 \\
\hline Test $\mathrm{F}$ & 1.33 & & & \\
\hline Hausman Test & & & 25.52 & \\
\hline
\end{tabular}

* $\quad$ Significantly different from zero at the $1 \%$ level

** Significantly different from zero at the $5 \%$ level

*** Significantly different from zero at the $10 \%$ level 
Table 4.3 - Regression of earnings changes on dividend changes for positive association between dividend change announcements and subsequent market reaction using Fama and French Approach (continued)

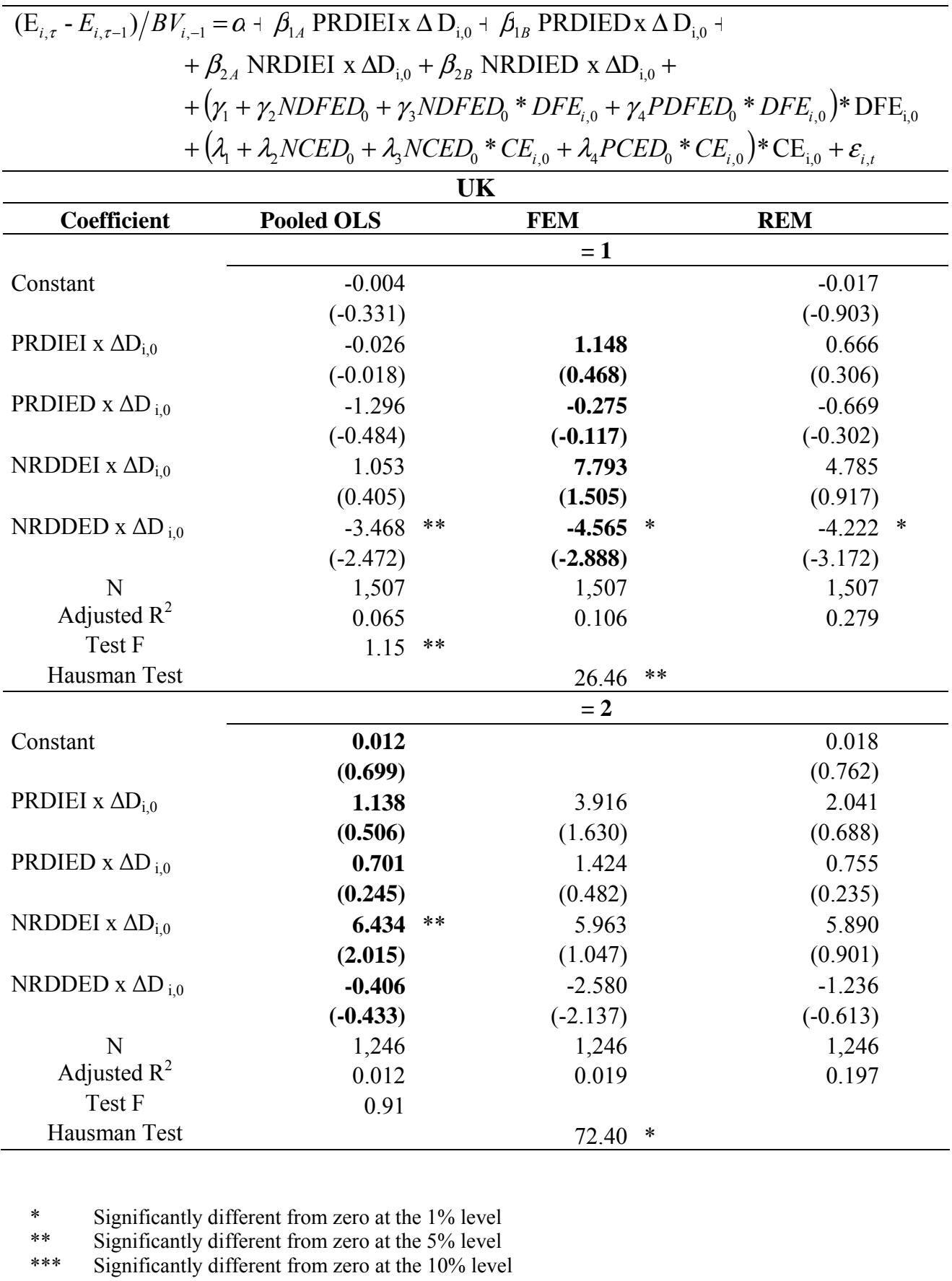




\section{Table 4.4 - Regression of earnings changes on dividend changes for negative association between dividend change announcements and subsequent market reaction}

This table reports the estimation of a regression relating earnings changes to dividend changes for the sub sample of events whose market reaction is negatively related with dividend changes. $E_{i}$, denotes earnings before extraordinary items in year (year 0 is the event year); $\mathrm{BV}_{\mathrm{i},-1}$ is the book value of equity at the end of year $-1 ; D_{i, t}$ is the annual change in the cash dividend payment, scaled by the share price in the announcement day; NRDI (PRDD) is a dummy variable that takes the value 1 for a negative (positive) reaction to dividend increases (decreases) and 0 otherwise; NRDIEI (NRDIED) is a dummy variable that takes value 1 for a negative reaction to dividend increases and earnings increases (decreases) and 0 otherwise; PRDDEI (PRDDED) is a dummy variable that takes value 1 for a positive reaction to dividend decreases and earnings increases (decreases) and 0 otherwise; $\mathrm{ROE}_{\mathrm{i},-1}$ is equal to the earnings before extraordinary items in year -1 scaled by the book value of equity at the end of year -1 . The regression results are estimated using pooled OLS, FEM and REM. The numbers in parentheses are the t-statistics corrected for heteroscedasticity using the White (1980) method. It reports the F test, a test for the equality of sets of coefficients, and the Hausman (1978) test, a test with $\mathrm{H}_{0}$ : random effects are consistent and efficient, versus $\mathrm{H}_{1}$ : random effects are inconsistent, in order to choose the most appropriate model for each particular sample.

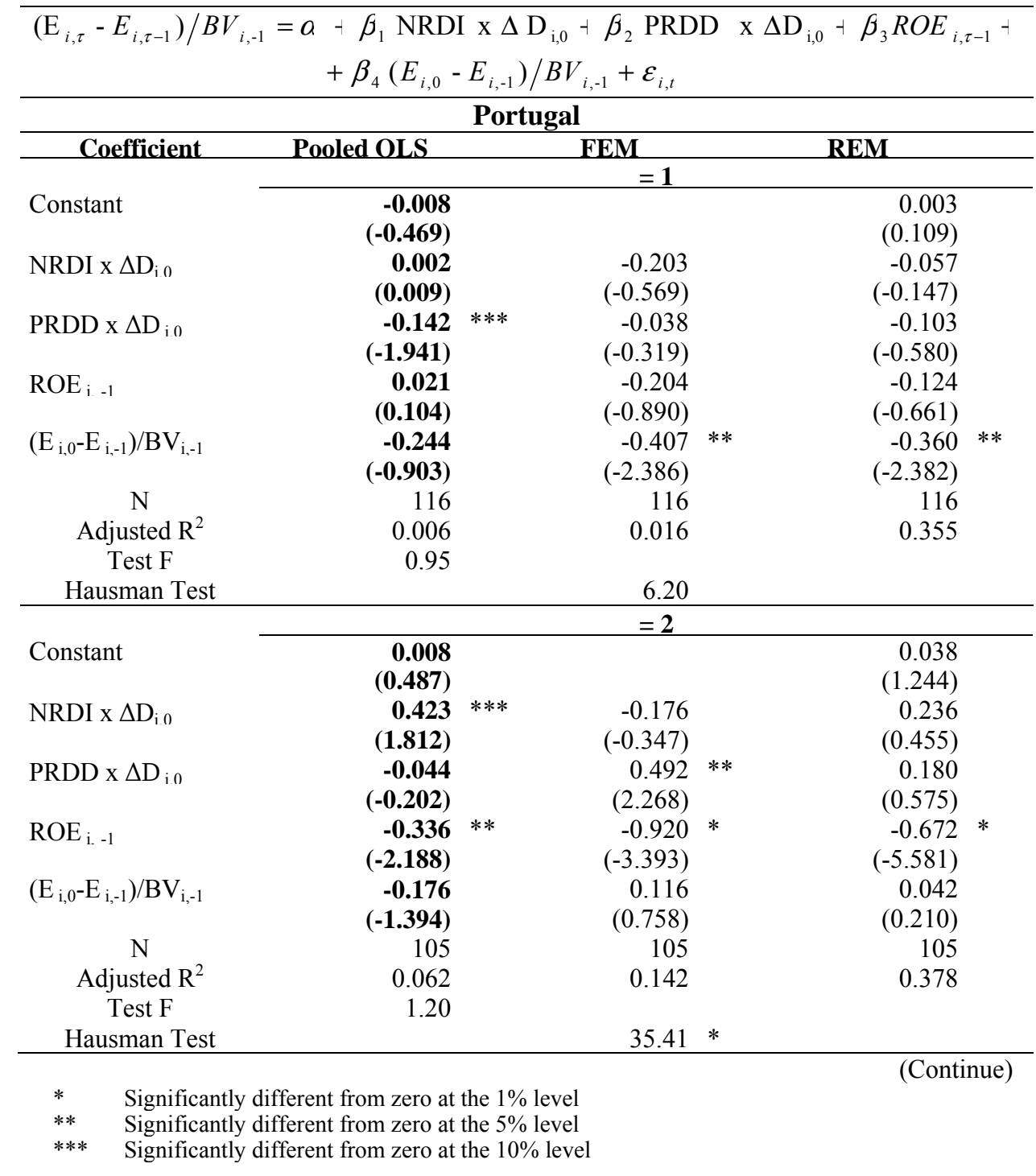


Table 4.4 - Regression of earnings changes on dividend changes for negative association between dividend change announcements and subsequent market reaction (continued)

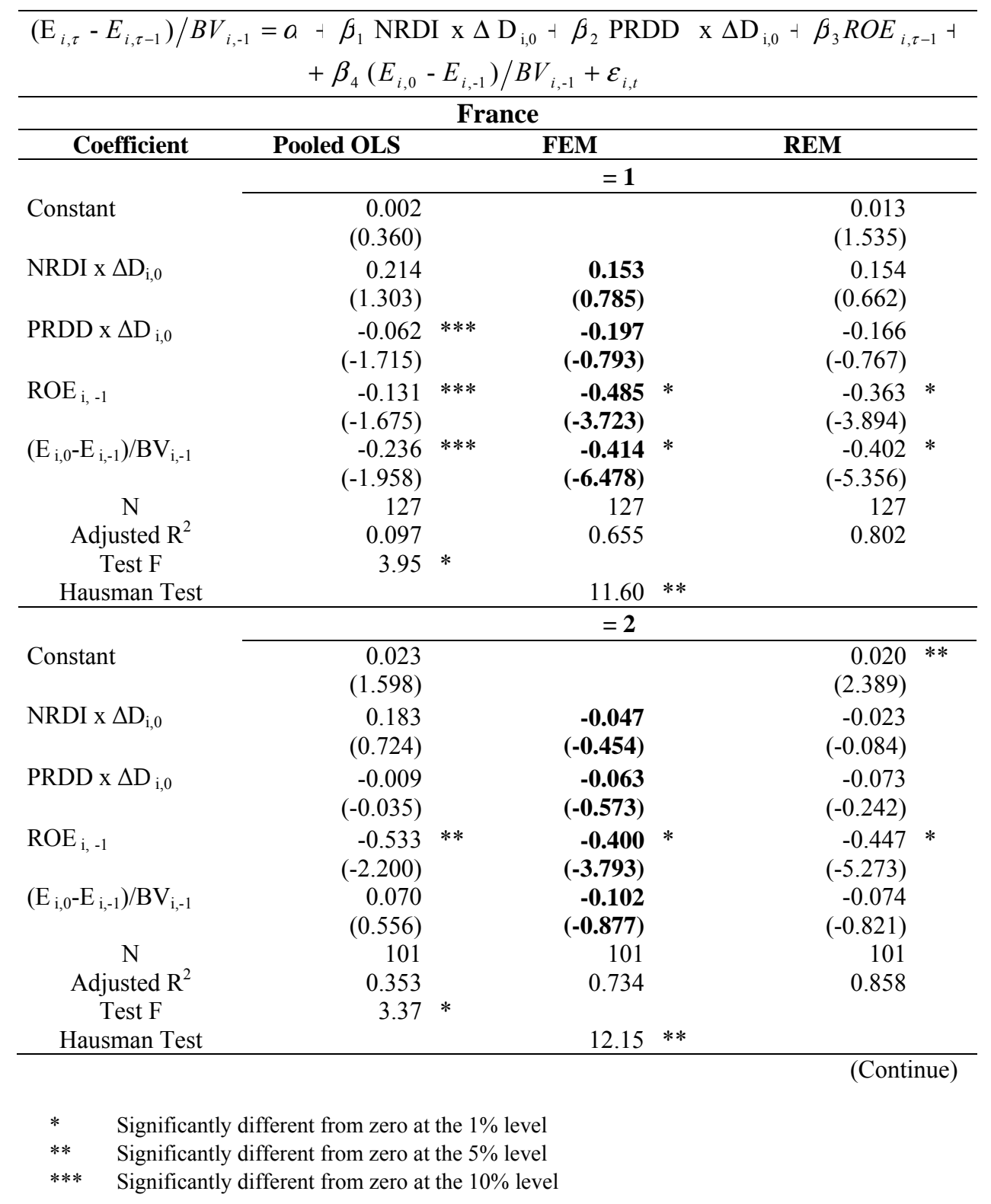


Table 4.4 - Regression of earnings changes on dividend changes for negative association between dividend change announcements and subsequent market reaction (continued)

\begin{tabular}{|c|c|c|c|c|c|c|}
\hline$\left(\mathrm{E}_{i, \tau}-E_{i, \tau-1}\right) / B V_{i,-}$ & $\begin{array}{l}\beta_{1 A} \text { NRDIEI } \times \Delta \\
\text { PRDDED } \times \Delta D\end{array}$ & $\begin{array}{l}D_{i, 0} \\
i_{i, 0}+\end{array}$ & $\begin{array}{l}\text { NRDIED x } \\
E_{i, \tau-1}+\beta_{4}(L\end{array}$ & $\begin{array}{l}\Delta \mathrm{D}_{\mathrm{i}, 0} \\
E_{i, 0}-\end{array}$ & $\begin{array}{l}\text { PRDDEI } \times \Delta \text { D } \\
3 V_{i,-1}+\varepsilon_{i, t}\end{array}$ & $i_{i, 0}-$ \\
\hline & & & & & & \\
\hline Coefficient & Pooled OLS & & FEM & & REM & \\
\hline & & & $=1$ & & & \\
\hline Constant & $\begin{array}{r}0.020 \\
(1.127)\end{array}$ & & & & $\begin{array}{r}0.025 \\
(1.041)\end{array}$ & \\
\hline NRDIEI $x \Delta D_{i, 0}$ & $\begin{array}{r}-3.943 \\
(-1.764)\end{array}$ & $* * *$ & $\begin{array}{r}-2.642 \\
(-1.553)\end{array}$ & & $\begin{array}{r}-3.260 \\
(-1.148)\end{array}$ & \\
\hline NRDIED x $\Delta D_{i, 0}$ & $\begin{array}{r}-1.959 \\
(-0.522)\end{array}$ & & $\begin{array}{r}5.268 \\
(1.033)\end{array}$ & & $\begin{array}{r}1.819 \\
(0.369)\end{array}$ & \\
\hline PRDDEI x $\Delta \mathrm{D}_{\mathrm{i}, 0}$ & $\begin{array}{r}-8.159 \\
(-2.437)\end{array}$ & $* *$ & $\begin{array}{r}-7.472 \\
(-2.166)\end{array}$ & $* *$ & $\begin{array}{r}-7.613 \\
(-4.630)\end{array}$ & $*$ \\
\hline $\operatorname{PRDDED} \times \Delta \mathrm{D}_{\mathrm{i}, 0}$ & $\begin{array}{r}-0.186 \\
(-0.294)\end{array}$ & & $\begin{array}{r}-1.269 \\
(-1.658)\end{array}$ & $* * *$ & $\begin{array}{r}-0.645 \\
(-0.469)\end{array}$ & \\
\hline $\mathrm{ROE}_{\mathrm{i},-1}$ & $\begin{array}{r}-0.137 \\
(-1.755)\end{array}$ & $* * *$ & $\begin{array}{r}-0.261 \\
(-2.708)\end{array}$ & * & $\begin{array}{r}-0.215 \\
(-5.393)\end{array}$ & $*$ \\
\hline$\left(\mathrm{E}_{\mathrm{i}, 0}-\mathrm{E}_{\mathrm{i},-1}\right) / \mathrm{BV}_{\mathrm{i},-1}$ & $\begin{array}{r}-0.045 \\
(-0.556)\end{array}$ & & $\begin{array}{r}-0.094 \\
(-1.349)\end{array}$ & & $\begin{array}{r}-0.079 \\
(-2.409)\end{array}$ & $* *$ \\
\hline $\mathrm{N}$ & 1,029 & & 1,029 & & 1,029 & \\
\hline Adjusted $\mathrm{R}^{2}$ & 0.036 & & 0.073 & & 0.374 & \\
\hline Test $\mathrm{F}$ & 1.09 & & & & & \\
\hline Hausman Test & & & 15.43 & $* *$ & & \\
\hline & & & $=2$ & & & \\
\hline Constant & $\begin{array}{r}-0.038 \\
(-1.816)\end{array}$ & $* * *$ & & & $\begin{array}{r}-0.040 \\
(-1.510)\end{array}$ & \\
\hline NRDIEI $x \Delta D_{i, 0}$ & $\begin{array}{r}7.547 \\
(3.124)\end{array}$ & $*$ & $\begin{array}{r}8.285 \\
(2.766)\end{array}$ & * & $\begin{array}{r}7.655 \\
(2.071)\end{array}$ & $* *$ \\
\hline NRDIED x $\Delta D_{i, 0}$ & $\begin{array}{r}-0.162 \\
(-0.041)\end{array}$ & & $\begin{array}{r}2.168 \\
(0.588)\end{array}$ & & $\begin{array}{r}0.641 \\
(0.109)\end{array}$ & \\
\hline PRDDEI x $\Delta \mathrm{D}_{\mathrm{i}, 0}$ & $\begin{array}{r}0.262 \\
(0.051)\end{array}$ & & $\begin{array}{r}-1.192 \\
(-0.651)\end{array}$ & & $\begin{array}{r}-0.464 \\
(-0.191)\end{array}$ & \\
\hline PRDDED x $\Delta D_{i, 0}$ & $\begin{array}{r}-0.255 \\
(-0.327)\end{array}$ & & $\begin{array}{r}-3.655 \\
(-2.112)\end{array}$ & $* *$ & $\begin{array}{r}-1.545 \\
(-0.879)\end{array}$ & \\
\hline $\operatorname{ROE}_{i,-1}$ & $\begin{array}{r}-0.090 \\
(-1.078)\end{array}$ & & $\begin{array}{r}-0.126 \\
(-1.276)\end{array}$ & & $\begin{array}{r}-0.105 \\
(-2.209)\end{array}$ & $* *$ \\
\hline$\left(\mathrm{E}_{\mathrm{i}, 0}-\mathrm{E}_{\mathrm{i},-1}\right) / \mathrm{BV}_{\mathrm{i},-1}$ & $\begin{array}{r}-0.009 \\
(-0.106)\end{array}$ & & $\begin{array}{r}-0.085 \\
(-0.955)\end{array}$ & & $\begin{array}{r}-0.054 \\
(-1.439)\end{array}$ & \\
\hline $\mathrm{N}$ & 882 & & 882 & & 882 & \\
\hline Adjusted $\mathrm{R}^{2}$ & 0.003 & & 0.008 & & 0.344 & \\
\hline Test $\mathrm{F}$ & 0.98 & & & & & \\
\hline Hausman Test & & & 6.55 & & & \\
\hline
\end{tabular}

* $\quad$ Significantly different from zero at the $1 \%$ level

** $\quad$ Significantly different from zero at the $5 \%$ level

*** $\quad$ Significantly different from zero at the $10 \%$ level 


\section{Table 4.5 - Regression of earnings changes on dividend changes for negative association between dividend change announcements and subsequent market reaction using Fama and French Approach}

This table reports the estimation of a regression relating earnings changes to dividend changes for the sub sample of events whose market reaction is negatively related with dividend changes. $E_{i}$, denotes earnings before extraordinary items in year (year 0 is the event year); $\mathrm{BV}_{\mathrm{i},-1}$ is the book value of equity at the end of year $-1 ; D_{i, t}$ is the annual change in the cash dividend payment, scaled by the share price in the announcement day; $\mathrm{ROE}_{\mathrm{i}}$, is equal to the earnings before extraordinary items in year scaled by the book value of equity at the end of year ; $\mathrm{DFE}_{i, 0}$ is equal to $\mathrm{ROE}_{i, 0}-\mathrm{EROE}_{\mathrm{i}, 0}$, where $\mathrm{ROE}_{\mathrm{i}, 0}$ is the fitted value from the cross-sectional regression of $\mathrm{ROE}_{\mathrm{i}, 0}$ on the log of total assets in year -1, the market-to-book ratio of equity in year -1 , and $\mathrm{ROE}_{\mathrm{i},-1} ; \mathrm{CE}_{\mathrm{i}, 0}$ is equal to $\left(\mathrm{E}_{\mathrm{i}, 0}-\mathrm{E}_{\mathrm{i},-1}\right) / \mathrm{BV}_{\mathrm{i},-1} ; \mathrm{NDFED}_{0}$ is a dummy variable that takes value 1 if $\mathrm{DFE}_{\mathrm{i}, 0}$ is negative and 0 otherwise; $\mathrm{PDFED}_{0}$ is a dummy variable that takes value 1 if $\mathrm{DFE}_{\mathrm{i}}$, is positive and 0 otherwise; $\mathrm{NCED}_{0}$ is a dummy variable that takes value 1 if $\mathrm{CE}_{\mathrm{i}, 0}$ is negative and 0 otherwise; $\mathrm{PCED}_{0}$ is a dummy variable that takes value 1 if $\mathrm{CE}_{\mathrm{i}, 0}$ is positive and 0 otherwise; NRDI (PRDD) is a dummy variable that takes the value 1 for a negative (positive) reaction to dividend increases (decreases) and 0 otherwise; NRDIEI (NRDIED) is a dummy variable that takes value 1 for a negative reaction to dividend increases and earnings increases (decreases) and 0 otherwise; PRDDEI (PRDDED) is a dummy variable that takes value 1 for a positive reaction to dividend decreases and earnings increases (decreases) and 0 otherwise. The regression results are estimated using pooled OLS, FEM and REM. The numbers in parentheses are the t-statistics corrected for heteroscedasticity using the White (1980) method. It reports the F test, a test for the equality of sets of coefficients, and the Hausman (1978) test, a test with $\mathrm{H}_{0}$ : random effects are consistent and efficient, versus $\mathrm{H}_{1}$ : random effects are inconsistent, in order to choose the most appropriate model for each particular sample.

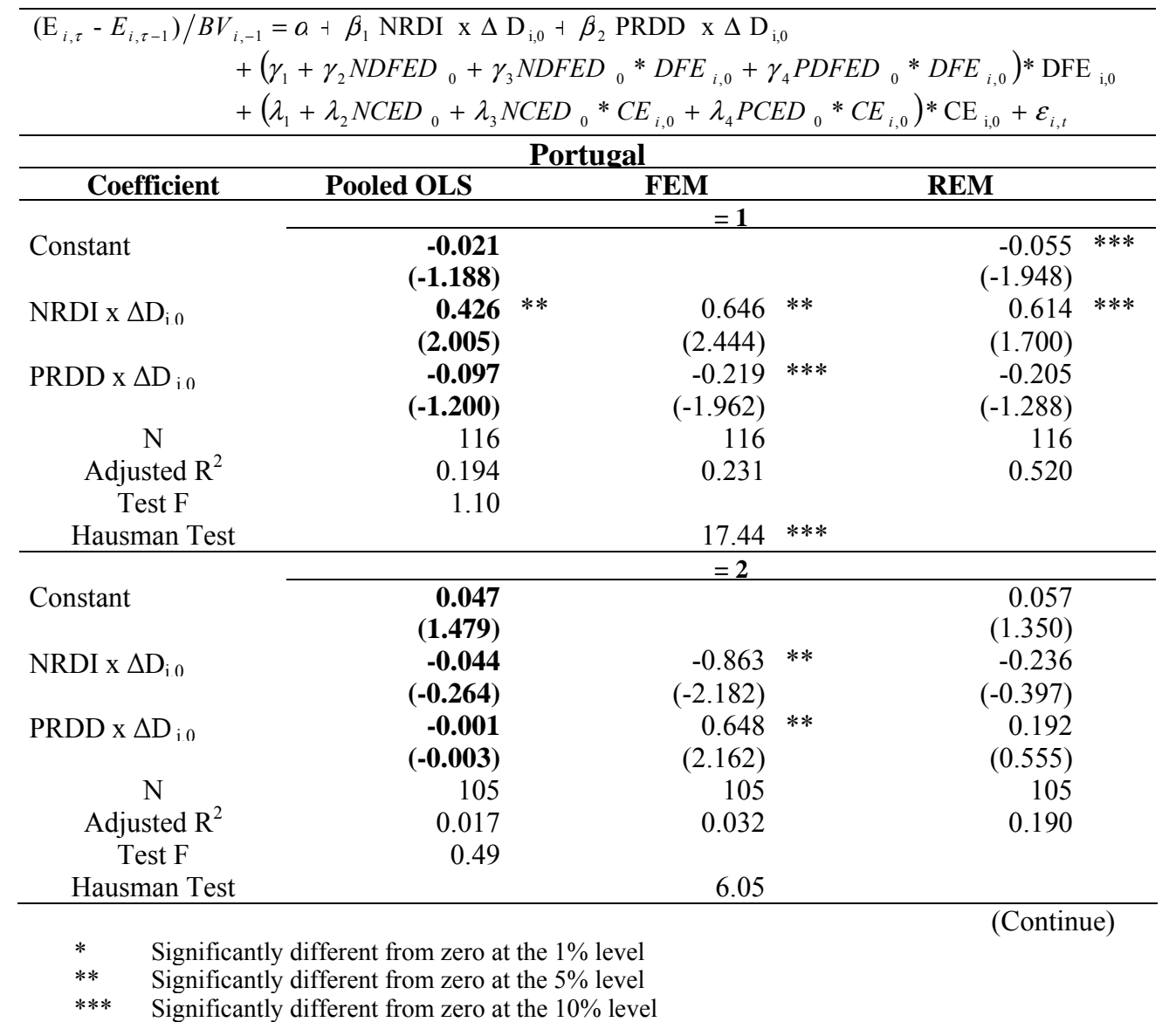


Table 4.5 - Regression of earnings changes on dividend changes for negative association between dividend change announcements and subsequent market reaction using Fama and French Approach (continued)

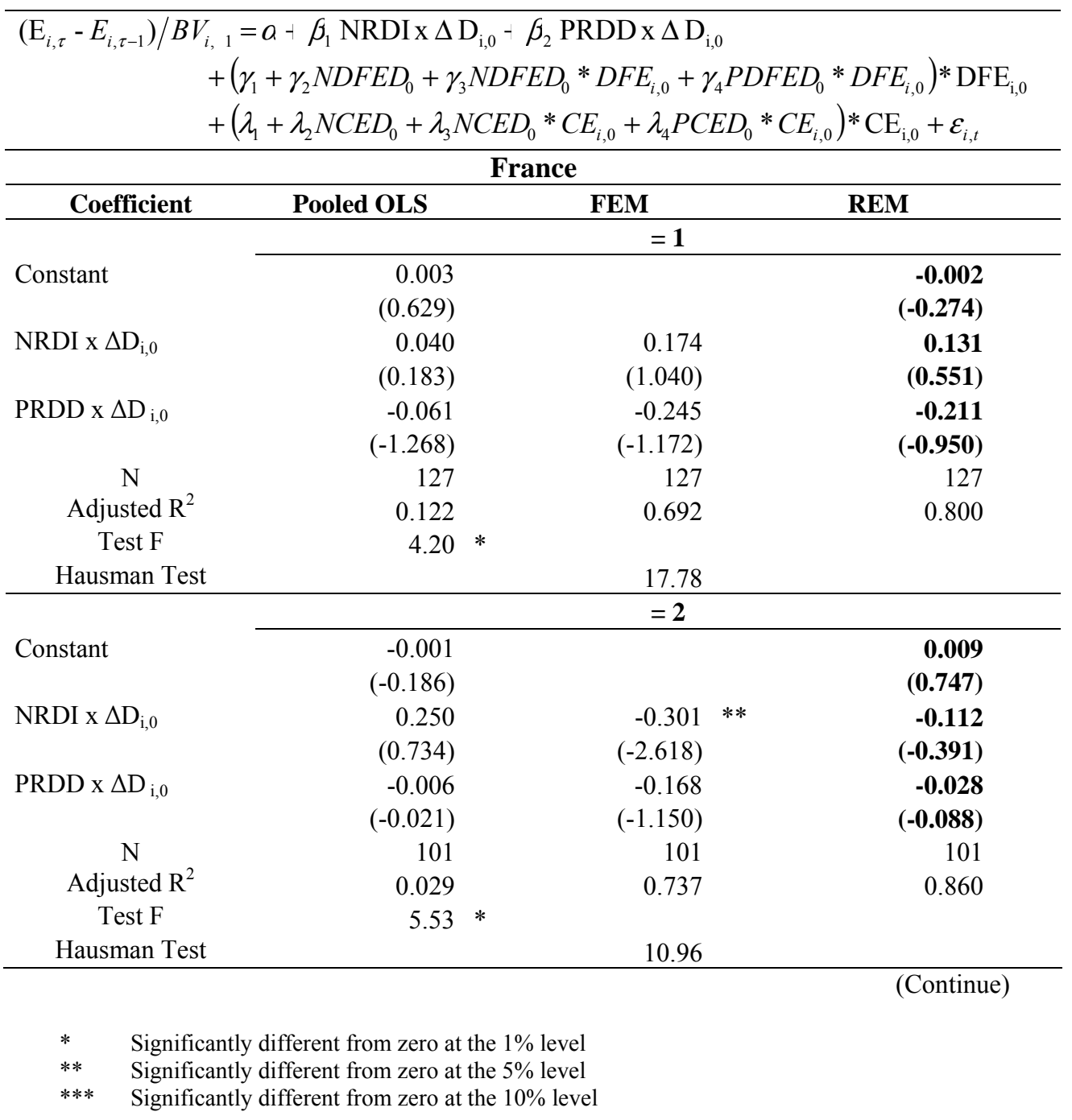


Table 4.5 - Regression of earnings changes on dividend changes for negative association between dividend change announcements and subsequent market reaction using Fama and French Approach (continued)

\begin{tabular}{|c|c|c|c|c|c|c|}
\hline \multirow{2}{*}{\multicolumn{7}{|c|}{$\begin{aligned}\left(\mathrm{E}_{i, \tau}-E_{i, \tau-1}\right) / B & V_{i,-1}=a+\beta_{1 A} \text { NRDIEIx } \Delta \mathrm{D}_{\mathrm{i}, 0} \dashv \beta_{1 B} \text { NRDIEDx } \Delta \mathrm{D}_{\mathrm{i}, 0} \dashv \\
& +\beta_{2 A} \text { PRDIEI } \times \Delta \mathrm{D}_{\mathrm{i}, 0}+\beta_{2 B} \text { PRDIED x } \Delta \mathrm{D}_{\mathrm{i}, 0}+ \\
& +\left(\gamma_{1}+\gamma_{2} N D F E D_{0}+\gamma_{3} N D F E D_{0} * D F E_{i, 0}+\gamma_{4} P D F E D_{0} * D F E_{i, 0}\right) * \mathrm{DFE}_{\mathrm{i}, 0} \\
& +\left(\lambda_{1}+\lambda_{2} N C E D_{0}+\lambda_{3} N C E D_{0} * C E_{i, 0}+\lambda_{4} P C E D_{0} * C E_{i, 0}\right) * \mathrm{CE}_{\mathrm{i}, 0}+\varepsilon_{i, t}\end{aligned}$}} \\
\hline & & & & & & \\
\hline \multirow[t]{2}{*}{ Coefficient } & Pooled OLS & & FEM & & REM & \\
\hline & \multicolumn{6}{|c|}{$=1$} \\
\hline Constant & $\begin{array}{r}-0.017 \\
(-0.908)\end{array}$ & & & & $\begin{array}{r}-0.043 \\
(-1.590)\end{array}$ & \\
\hline NRDIEI x $\Delta \mathrm{D}_{\mathrm{i}, 0}$ & $\begin{array}{r}-3.296 \\
(-1.436)\end{array}$ & & $\begin{array}{r}-2.365 \\
(-1.314)\end{array}$ & & $\begin{array}{r}-2.632 \\
(-0.960)\end{array}$ & \\
\hline NRDIED x $\Delta \mathrm{D}_{\mathrm{i}, 0}$ & $\begin{array}{r}-1.072 \\
(-0.296)\end{array}$ & & $\begin{array}{r}6.955 \\
(1.483)\end{array}$ & & $\begin{array}{r}3.381 \\
(0.709)\end{array}$ & \\
\hline PRDDEI x $\Delta \mathrm{D}_{\mathrm{i}, 0}$ & $\begin{array}{r}-8.533 \\
(-2.494)\end{array}$ & $* *$ & $\begin{array}{r}-9.408 \\
(-2.532)\end{array}$ & $* *$ & $\begin{array}{r}-8.813 * \\
(-5.488)\end{array}$ & * \\
\hline PRDDED x $\Delta D_{i, 0}$ & $\begin{array}{r}-0.579 \\
(-0.807)\end{array}$ & & $\begin{array}{r}-1.879 \\
(-2.200)\end{array}$ & $* *$ & $\begin{array}{r}-1.218 \\
(-0.909)\end{array}$ & \\
\hline $\mathrm{N}$ & 1,029 & & 1,029 & & 1,029 & \\
\hline Adjusted $\mathrm{R}^{2}$ & 0.083 & & 0.165 & & 0.429 & \\
\hline Test $\mathrm{F}$ & 1.23 & ** & & & & \\
\hline \multirow[t]{2}{*}{ Hausman Test } & & & 41.73 & * & & \\
\hline & & & $=2$ & & & \\
\hline Constant & $\begin{array}{r}-0.032 \\
(-1.367)\end{array}$ & & & & $\begin{array}{r}-0.059 * \\
(-1.907)\end{array}$ & \\
\hline NRDIEI x $\Delta D_{i, 0}$ & $\begin{array}{r}6.036 \\
(2.330)\end{array}$ & $* *$ & $\begin{array}{r}8.563 \\
(2.658)\end{array}$ & * & $\begin{array}{r}6.897 \\
(1.863)\end{array}$ & $* * *$ \\
\hline NRDIED x $\Delta \mathrm{D}_{\mathrm{i}, 0}$ & $\begin{array}{r}0.383 \\
(0.101)\end{array}$ & & $\begin{array}{r}4.137 \\
(1.103)\end{array}$ & & $\begin{array}{r}2.149 \\
(0.369)\end{array}$ & \\
\hline PRDDEI x $\Delta \mathrm{D}_{\mathrm{i}, 0}$ & $\begin{array}{r}0.259 \\
(0.052)\end{array}$ & & $\begin{array}{r}0.086 \\
(0.039)\end{array}$ & & $\begin{array}{r}0.392 \\
(0.162)\end{array}$ & \\
\hline PRDDED x $\Delta D_{i, 0}$ & $\begin{array}{r}-0.635 \\
(-0.722)\end{array}$ & & $\begin{array}{r}-2.505 \\
(-1.361)\end{array}$ & & $\begin{array}{r}-1.346 \\
(-0.766)\end{array}$ & \\
\hline $\mathrm{N}$ & 882 & & 882 & & 882 & \\
\hline Adjusted $\mathrm{R}^{2}$ & 0.018 & & 0.021 & & 0.355 & \\
\hline Test $\mathrm{F}$ & 1.01 & & & & & \\
\hline Hausman Test & & & 27.43 & * & & \\
\hline
\end{tabular}

* $\quad$ Significantly different from zero at the $1 \%$ level

** $\quad$ Significantly different from zero at the $5 \%$ level

$* * * \quad$ Significantly different from zero at the $10 \%$ level 


\section{CHAPTER 5}

\section{THE EFFECT OF FIRM-SPECIFIC FACTORS \\ ON THE MARKET REACTION TO \\ DIVIDEND ANNOUNCEMENTS}




\subsection{INTRODUCTION}

In this chapter we wish to analyse whether market reaction to dividend change announcements is associated with firm-specific factors. To do so, we formulate the last hypothesis relating the firm specific factors to the market share price reaction around the dividend change announcements date to evaluate whether the firm-specific factors can influence the market reaction in the dividend announcement period.

After the definition of the testable hypothesis, we define the methodology not forgetting that we wish to analyse whether other information accessible to the market at the dividend announcement date can convey information to shareholders beyond that of dividend announcements, helping the market to understand a firm's dividend change announcement. As far as we know, this is the first study to combine different approaches in order to detect possible circumstances for dividend increases (decreases) to be seen as bad (good) news by the market.

We then present the empirical results and discuss them. The chapter closes with a brief summary.

\subsection{HYPOTHESIS}

According to the information content hypothesis, the strength of the market reaction to dividend change announcements is a function of how much information is exposed. Several authors through the years have documented the relationship between the valuation effect of dividend changes and firm-specific variables, such as Asquith and Mullins (1983), Eddy and Seifert (1988), Haw and Kim (1991), Mitra and Owers (1995) and Hathorn and Kirch (1997). For example, some authors found a negative relationship between firm size and abnormal returns around the dividend announcement date Eddy and Seifert (1988), Haw and Kim (1991) and Mitra and Owers (1995), among others . Ghosh and Woolridge (1988) concluded that the most significant factors are the percentage change of dividends, the firm's size and the share performance before the announcement date. In addition, Healy, Hathorn and Kirch (1997) suggest that a firm's dividend yield, PER, debt/equity ratio and current ratio have an effect on the probability 
that the capital market will react negatively to an initial dividend announcement, which can be important to explain the inverse relation between dividend change announcements and the market reaction.

We formulate an alternative hypothesis with the purpose of analysing if there are firmspecific factors that influence the market reaction around dividend change announcements. This prediction can be tested by the following hypothesis:

$H_{4}$ : "Firm-specific factors affect the market reaction around the dividend change announcements date"

If we find firm-specific variables significantly associated with price changes in the dividend announcement period, such as firm size, firm growth and financial leverage, we will have evidence of firm-specific factors influencing the market reaction to dividend announcements, and, potentially, find some reasons for a negative relationship between dividends and share price movements in the announcement period ${ }^{127}$.

\subsection{METHODOLOGY}

In this section, we present the methodology to be used to test the last hypothesis formulated, with the purpose of test whether firm-specific variables have influence on the market reaction to dividend change announcements.

The hypothesis 4 is associated with the analysis of firm-specific factors that can affect the market share price reaction surrounding dividend change announcements. The dividend information content hypothesis states that through dividend change announcements investors receive a signal concerning management's assessment of the firm's future prosperity. The intensity of the market reaction to any dividend announcement depends on the amount of new information, it contains for the investor.

\footnotetext{
127 Although we analyse firm-specific characteristics that can influence the relation between dividends and the market reaction, we would also like to examine country-specific variables, such as taxes, the financing system and the concentration of ownership equity with the purpose to analyse the different behaviour among the three country samples considered in this work. However, this study is beyond the scope of our thesis. We believe it constitutes an interesting theme for future research and further development of the study.
} 
Several authors have documented a relationship between market share price reaction to dividend change announcements and firm-specific factors, such as Asquith and Mullins (1983), Ghosh and Woolridge (1988), Eddy and Seifert (1988), Haw and Kim (1991), Mitra and Owers (1995) and Healy, Hathorn and Kirch (1997).

Asquith and Mullins (1983) found that market reaction to dividend announcements depends on the magnitude of the dividend payment. Ghosh and Woolridge (1988) concluded that, for firms that omit or cut dividends, the most significant firm specific factors that influence this relationship are the percentage change in dividend, the firms' size, the share performance before the announcement date and the negative information released before the dividend change. Eddy and Seifert (1988) and Haw and Kim (1991) found a negative relation between firm size and abnormal returns for firms that increase dividends and Mitra and Owers (1995) found a similar relation for firms that initiate dividends. These results are consistent with Miller and Rock's (1985) position that the dividend announcement effect varies across firms with different degrees of information asymmetry. Healy, Hathorn and Kirch (1997) results suggested that firms whose capital market have reacted negatively to an initial dividend announcement documents lower dividend yield ratio and PER than firms whose reaction was positive and higher debt/equity ratio, current ratio and growth earnings before the announcement period.

In selecting the specific factors to study, we were guided by information-oriented variables which include proxies to measure the information content of dividend change announcements, trying to identify the factors that contribute significantly to the market reaction to dividend announcements. The factors are the firm size, the percentage change in dividends, the earnings growth, the market to book ratio, the price/earnings ratio and the debt/equity ratio.

We start by testing the relation between the market reaction to a dividend change announcement (in the event period) and the firm specific factors that we suppose can influence this relation, estimating the following regression, based on Ghosh and Woolridge (1988):

$$
\left|B H A R_{i,-1 \text { to }+1}\right|=\alpha+\beta_{1} F S_{i}+\beta_{2}\left|P C D_{i}\right|+\beta_{3}\left|E G_{i}\right|+\beta_{4} M B_{i}+\beta_{5} P E R_{i}+\beta_{6} D E_{i}+\varepsilon_{i, t} \quad 5.1
$$

where:

$\mathrm{FS}_{\mathrm{i}}=$ firm size for share $\mathrm{i}$, computed as the natural log of market value of common equity at the end of the year before the dividend change year;

$\mathrm{PCD}_{\mathrm{i}}=$ percentage change of dividends for share $\mathrm{i}$, computed as the annual 
change in dividends divided by the share price in the announcement day;

$\mathrm{EG}_{\mathrm{i}}=$ earnings growth rate for share $\mathrm{i}$, computed as the average earnings growth rate based on the year prior to the dividend change year;

$\mathrm{MB}_{\mathrm{i}}=$ market to book ratio for share $\mathrm{i}$, calculated by dividing the market price per share at the dividend change announcement date by the book value per share at the end of the year before the dividend change year;

$\mathrm{PER}_{\mathrm{i}}=$ price earning ratio for share $\mathrm{i}$, computed as the price per share at the announcement date divided by the earnings per share at the end of the year before the dividend change year;

$\mathrm{DE}_{\mathrm{i}}=$ debt/equity ratio for share $\mathrm{i}$, calculated as the book value of total debt divided by the total book value of equity at the end of the year prior to the dividend change announcement.

Interpretation of the signs of some variables will differ depending on the dividend changes direction. To overcome the problem of interpreting the coefficient signal depending on the direction of dividend changes, and consistent with Haw and Kim (1991), we consider the absolute term of such variables. All financial variables are measured at the end of the firm's fiscal year immediately prior to the dividend announcement. The dependent variable is the BHAR for two reasons. Firstly, it is the only common measure for the three samples. Secondly, we have already considered this variable to split the sample according to the market reaction to dividend change announcements. The independent variables are explained bellow ${ }^{128}$ :

\subsubsection{FIRM SIZE (FS)}

Firm size is associated with information asymmetry, since less information is available to the market about smaller firms, which attract less institutional interest and, as a result, are subject to less scrutiny by financial analysts. In addition, they receive less coverage in the financial press. To the extent that informational asymmetry is greater for small firms than for large firms Haw and Kim (1991), the information content of dividend announcements will be greater for small firms. Smaller firms have less information available in the market, so, when they announce dividend changes, it generates greater market surprises that induce a larger reaction by the market. Therefore, we expect this

\footnotetext{
${ }^{128}$ We would like to analyse other variables, namely to explore the issue of the propriety firms' control, such as the free float and the firms' structure of property, but unfortunately, we could not obtain the necessary data on time, since, for example, for the Portuguese market, it is not available in any database. We will try to explore it in future studies.
} 
coefficient to have a negative signal. We use market capitalization as a surrogate for firm size. FS is defined as the natural $\log ^{129}$ of market value of common equity at the end of the year before the dividend change year.

\subsubsection{Percentage Change in Dividends (PCD)}

Following Asquith and Mullins (1983), we consider the percentage change of dividends as a proxy for the information content of dividend changes. PCD is defined as the change in dividends divided by the share price in the announcement day. To overcome the problem of interpreting the coefficient signal depending on the direction of dividend changes, and consistent with Haw and Kim (1991) approach, we will consider the absolute term of this variable. Assuming that a bigger change reveals more information, the coefficient of this variable is expected to be positive.

\subsubsection{EARNINGS GROWTH (EG)}

Prior earnings are examined to test whether their growth magnitude is a predictor of the market reaction to dividend change announcements. EG is computed as the average earnings growth rate based on the year prior to the dividend change year ${ }^{130}$. For the same reasons pointed out in the last factor, we will consider the absolute term of this variable. It is expected a positive relation between earnings growth and the market reaction to dividend change announcements.

\subsubsection{MARKET TO BOOK RATIO (MB)}

For a proxy to Tobin's Q, we consider the market to book ratio as an indication of investors' expectation of a firm's growth prospects or investment opportunities, and thus as a proxy for firm maturity and for firms' growth opportunities. MB is calculated

\footnotetext{
${ }^{129} \mathrm{We}$ use the logarithm of market value because it would better conform to the characteristics of symmetry and normality.

${ }^{130}$ Special care will be taken when calculating percentage changes involving a negative value of earnings to ensure that any change in sign did not give a false picture of any deterioration or improvement in earnings.
} 
by dividing the market price per share at the dividend change announcement date by the book value per share at the end of the year before the dividend change year. A high ratio value means that a firm has strong growth prospects. Firms with fewer investment opportunities will have more free cash flows and so can pay higher dividends. Furthermore, by paying more dividends, they will reduce agency costs. Assuming the assumptions of free cash flow hypothesis Jensen (1986), the market reaction to a dividend increase must be higher for firms with fewer investment opportunities, so the coefficient of this variable is expected to be negative.

\subsubsection{Price/EARnings RAtio (PER)}

PER is computed as the price per share divided by the earnings per share. A high PER may result from high price or low earnings. Thus, it may mean that investors believe the firm has growth opportunities and/or its earnings and cash flows are relatively safe. For firms that increase their dividends, it may also signal that they have less growth prospects than expected and thus dividend increases may be a negative signal, causing the market to review its perceptions downward. Therefore, we cannot determine, a priori, the direction of the relation between this ratio and the market reaction to dividend change announcements.

\subsubsection{DEBT/EQUITY RATIO (DE)}

Debt to equity ratio is used as a proxy for firms' financial risk. DE is computed as the book value of total debt (book value of total long term and short term debt) divided by the total book value of equity at the end of the year prior to the dividend change announcement. Assuming the reluctance of managers to decrease dividends Lintner (1956), the higher the financial risk, the lower the probability that a firm increase dividends if managers are unsure about their capacity to continue paying dividends. Therefore, the market will react strongly to a dividend change announcement for firms with higher DE ratios. As a result, we expect this coefficient to have a positive signal. 
Schematically, we present below the variables, abbreviations and the expected signs of the regression coefficients:

\begin{tabular}{lcc}
\hline \multicolumn{1}{c}{ Variables } & Abbreviations & Expected sign \\
\hline Firm Size & FS & - \\
Percentage Change in Dividends (absolute terms) & PCD & + \\
Earnings Growth (absolute terms) & EG & + \\
Market to Book Ratio & MB & - \\
Price/Earnings Ratio & PER & $?$ \\
Debt/Equity Ratio & DE & + \\
\hline Independent variables, abbreviations, and the expected signal of the regression coefficients
\end{tabular}

To see if the proxies are highly correlated and, in effect, proxying for one another, we will analyse the correlation between the independent variables.

Following, we wish to look at the contribution of the firm specific variables in explaining the market reaction to dividend change announcements, but identifying the different types of events, looking separately for dividend increase announcements and dividend decrease announcements.

For the Portuguese and the French samples, the regression can be expressed as:

$$
\begin{aligned}
\mid B_{H A R_{i,-1 \mathrm{t}+1} \mid=} & \alpha+\beta_{1 A} \mathrm{DI} \times F S_{i}+\beta_{1 B} \mathrm{DD} \times F S_{i}+\beta_{2 A} \mathrm{DI} \times P C D_{i} \mid+ \\
& +\beta_{2 B} \mathrm{DD} \times P C D_{i}\left|+\beta_{3 A} \mathrm{DI}\right| E G_{i}\left|+\beta_{3 B} \mathrm{DD} \times E G_{i}\right|+ \\
& +\beta_{4 A} \mathrm{DI} \times M B_{i}+\beta_{4 B} \mathrm{DD} \times M B_{i}+\beta_{5 A} \mathrm{DI} \times P E R_{i}+ \\
& +\beta_{5 B} \mathrm{DD} \times P E R_{i}+\beta_{6 A} \mathrm{DI} \times E_{i}+\beta_{6 B} \mathrm{DD} \times D E_{i}+\varepsilon_{i, t}
\end{aligned}
$$

For the UK market we need to consider more dummy variables in order to identify the relation between dividend and earnings announcements. Thus, we will have a total of twenty four explanatory variables, i.e., six independent variables times four. The regression can be expressed in the following manner:

$$
\begin{aligned}
\left|B H A R_{i,-1 \mathrm{to}+1}\right|= & \alpha+\beta_{1} \Phi \times F S_{i}+\beta_{2} \Phi \times\left|P C D_{i}\right|+\beta_{3} \Phi \times\left|E G_{i}\right|+ \\
& +\beta_{4} \Phi \times M B_{i}+\beta_{5} \Phi \times P E R_{i}+\beta_{6} \Phi \times D E_{i}+\varepsilon_{i, t}
\end{aligned}
$$

where is the vector of coefficients for the dummy variables relating the dividend and earnings changes, set equal to 1 respectively, if (a) both dividend and earnings increases; (b) dividend increases and earnings decreases; (c) dividend decreases and earnings increases; (d) both dividend and earnings decreases, and 0 otherwise.

Afterwards, we will run a logistic regression to analyse the relation between the probability of a negative (positive) market reaction to dividend increase (decrease) announcements and the firm-specific characteristics. 
For the dividend increase events, we express the regression as:

$$
B H A R I_{i,-1 \mathrm{to}+1}=a-\beta_{1} F S_{i}-\beta_{2} \mathrm{LPCD}_{1} \dashv \beta_{3} \mathrm{LEG}_{\mathrm{i}}+\beta_{4} L M B_{i}+\beta_{5} L P E R_{t}+\beta_{6} L D E_{i}+\varepsilon_{t} \quad 5.3 \mathrm{a}
$$

where:

$$
\begin{array}{ll}
\text { BHARI }_{\mathrm{i},-1 \text { to }+1}= & \begin{array}{l}
\text { dummy variable that takes value } 1 \text { if } \mathrm{BHAR}_{\mathrm{i},-1 \text { to }+1} \text { is } \\
\text { negative and } 0 \text { otherwise; }
\end{array} \\
\mathrm{LPCD} & \text { natural logarithm of }(\mathrm{PCD}+1) ; \\
\mathrm{LEG} & =\text { natural logarithm of }(\mathrm{EG}+1) ; \\
\mathrm{LMB} & \text { natural logarithm of }(\mathrm{MB}+1) ; \\
\mathrm{LPER} & =\text { natural logarithm of }(\mathrm{PER}+1) ; \\
\mathrm{LDE} & =\text { natural logarithm of }(\mathrm{DE}+1) .
\end{array}
$$

For the dividend decrease events, we express the regression in the subsequent manner:

$$
B H A R D_{1,-1 \mathrm{to}+1}=a \dashv \beta_{1} F S_{i} \dashv \beta_{2} \mathrm{LPCD}_{1} \dashv \beta_{3} \mathrm{LEG}_{\mathrm{i}} \dashv \beta_{4} L M B_{i} \dashv \beta_{5} L P E R_{\mathrm{f}} \dashv \beta_{6} L D E_{i} \dashv \varepsilon_{t} \quad 5.3 \mathrm{~b}
$$

where $\mathrm{BHARD}_{\mathrm{i},-1 \text { to }+1}$ is a dummy variable that takes value 1 if $\mathrm{BHAR}_{\mathrm{i},-1 \text { to }+1}$ is positive and 0 otherwise.

Finally, we will analyse the firm characteristics according to the market reaction to dividend change announcements. Thus, we will consider the sub-samples defined previously. Specifically, we wish to study whether specific factors can be distinguished between the dividend increase events with a positive market reaction (PRDI) and a negative market reaction (NRDI) and between the dividend decrease events with a negative market reaction (NRDD) and a positive reaction (PRDD).

\subsection{EMPIRICAL RESULTS}

In this section, we will test the relationship between the valuation effect of a dividend change and selected firm-specific variables to analyse whether the market reaction to dividend change announcements is associated with firm-specific factors. 


\subsubsection{Relation between the Market Reaction to Dividend Change ANNOUNCEMENTS AND THE FIRM-SPECIFIC CHARACTERISTICS}

To evaluate whether firm-specific factors affect the market reaction in the dividend announcement period, we test the relationship between the cumulative abnormal return in the dividend announcement period (BHAR (o +1 ) and the firm-specific variables, estimating the regression 5.1. Results are shown in Table 5.1.

We start by estimating the Pearson correlations among the independent variables. Panel A of Table 5.1 presents the correlation matrix among the exogenous variables along with the statistical significance. We are expecting higher values for the correlation between MB ratio and PER. Indeed, for both the Portuguese and French samples, the higher correlation coefficient is between the PER and the market to book ratio, but still below $50 \%$ in the former sample and below $40 \%$ in the latter. Consequently, we can conclude that these two variables are not proxying for one another. In the UK sample, the highest correlation coefficient is between the market to book ratio and the debt to equity ratio, exhibiting a value of $40.2 \%$. In general, although we have some significant correlations, the coefficients are not very high (always bellow 50\%), so it does not appear to be sufficiently large to cause concern about multicollinearity problems.

The pooled least squares, the FEM and the REM estimation results of regression 5.1 for all the dividend change events (dividend increases and decreases) are reported in Panel B. The best model is chosen according to the F statistic and the Hausman test, and is presented in bold. For all the three samples the best model is the REM.

Portuguese results show that, with the exception of the coefficient for the firm size, all the other sample coefficients present the expected signal. However, all of them are statistically insignificant. Consequently, we find no variables showing statistical significance in explaining the cumulative abnormal returns on the dividend announcement period.

Regarding the French sample, and looking for the REM results, we can see that all the variables have the predicted sign except for the firm size and the earnings growth rate. However, they are both statistically insignificant. Only one firm specific factor contributes in explaining the market reaction to dividend changes, which is the DE ratio. However, it is only statistically significant at the $10 \%$ level. 
In contrast with prior studies Haw and Kim (1991), Ghosh and Woolridge (1988) and Mitra and Owers (1995), we did not find a significant relationship between firm size and the cumulative abnormal returns for both the Portuguese and the French markets. This can probably be explained by the similar size of Portuguese and French firms that constitute the sample.

Finally, the UK results exhibit for all the coefficients the predicted sign except for the $\mathrm{MB}$ ratio, but its value is not statistically different from zero. Two out of the six independent variables contribute in explaining the market return in the 3 days surrounding the dividend change announcements. The significant variables are the earnings growth rate and the PER. This last coefficient, whose signal we could not predict in advance, is negative, implying that higher PER values are associated with a smaller market reaction do dividend changes. The EG rate appears to be the most powerful explanatory variable between the two. It suggests that investors have different expectations as to dividend announcements depending on a firm's prior history of earnings growth Healy, Hathorn and Kirch (1997) .

Our global results show that, considering all the dividend change events, the only market where we have firm specific variables with power to explain the market abnormal returns in the announcement period is the UK. The explanatory variables that contribute in explaining the BHAR in the 3 days surrounding the dividend change announcements are the earnings growth and the PER. The reason behind failing to document the predicted sign in some coefficients could be an indication that it is associated with the opposite relation between dividend change announcements and the subsequent market reaction.

\subsubsection{RELATION BETWEEN THE MARKET REACTION TO DIVIDEND INCREASE AND DIVIDEND DECREASE ANNOUNCEMENTS AND FIRM-SPECIFIC CHARACTERISTICS}

Afterwards, we are interested in exploring the power of these variables in explaining the market reaction to the different dividend change events. Hence, we include dummy variables in the preceding regression to identify dividend increases and decreases. 
The pooled least squares, the FEM and the REM estimation results obtained when we run the regression 5.2 to determine the contribution of the firm specific variables in explaining the market reaction to dividend change announcements, with dummies to identify the different types of events, are reported in Table 5.2. The best model is chosen according to the F statistic and the Hausman test. Once again, the best model for all the samples is the REM.

Looking for the Portuguese REM results, we can see that the coefficient on market to book value is positive for the dividend increase events, contrary to the expected sign, and negative for the dividend decrease events, which could suggest a possible reason for dividend increase events associated with a negative market reaction. However, those coefficients, like all the others, are statistically insignificant. Consequently, we conclude that, for the Portuguese sample, none of the firm specific variables contribute to explain the market reaction in each of the two distinct groups of events.

Regarding the French sample, the results show that, although some explanatory variables have different signs for the dividend increase and dividend decrease events, none of the coefficients are statistically different from zero. For the French market, we conclude, like in the Portuguese sample, that none of the firm specific variables contribute to explaining the market reaction in each of the two distinct groups of events.

The UK results show that the coefficients on the DE ratio have different signs in the different groups of events. However, none of those coefficients is statistically significant. Six out of the twenty four explanatory coefficients are statistically significant. The variables that contribute to explain the dependent variable are the PCD for the DIEI events, the earnings growth for the DIEI, DIED and DDED events, the MB ratio for the DIED events and finally, the PER for the DIED events. However, the MB ratio does not have the predicted sign.

Regarding the percentage change of dividends, the result suggests that the higher the dividend increases, when the earnings also increase, the higher the market reaction. This evidence appears to be consistent with the dividend signalling hypothesis and is in agreement with the results of Eddy and Seifert (1992). The fact that this coefficient is positive and statistically significant for the DIEI events, and negative for the DIED events, although not statistically significant, suggests evidence of our previous 
conclusion that earnings announcements convey information beyond what is revealed by dividend change announcements.

All the significant coefficients on earnings growth rate are positive, according to the expected sign. Earnings growth effects are less significant in the dividend decreases case than in the dividend increases case.

Contrary to the expected sign, the coefficient on MB is positive for the dividend increases, but only statistically significant for the DIED events. It suggests that investors do not interpret this relation according to the assumptions of the free cash flow hypothesis; otherwise the coefficient will be negative. On the other side, this could be an indication that dividend increases that are preceded by high MB ratios convey good future prospects, and so, the market reacts positively, suggesting some evidence of the dividends signalling hypothesis. Because of the independency between firms and shareholders, the investors can privilege the dividend increase announcements over other type of information, such as the MB ratio. In fact, on this market we find some evidence, although weak, of the dividend information content hypothesis.

Finally, the coefficient on PER, for which we have not predicted, a priori, a specific sign, is negative. This result suggests that, when a dividend increase is preceded by a high PER, investors might interpret it as an indication that firms have less growth prospects than expected, and reacts accordingly, revising its perceptions downward.

Our results considering the dividend increase and dividend decrease events separately are quite similar to the ones obtained without distinguishing the two types of events. The only market where we have firm specific variables with power to explain the market abnormal returns in the announcement period is the UK. The explanatory variables that contribute in explaining the BHAR in the 3 days surrounding the dividend change announcements are the earnings growth, and, only for dividend increase events, the percentage change of dividends, the MB ratio and the PER. The reason behind the evidence of some different signs for the distinct types of events (dividend increases and decreases) on the same firm-specific variable could be an indication that it is associated with the opposite relation between dividend change announcements and the subsequent market reaction. 


\subsubsection{ROBUSTNESS}

To evaluate the robustness of the results, we repeated the analysis using alternative explanatory variables, reflecting other firm-specific factors ${ }^{131}$.

Fist, we include an additional liquidity variable that measures the adequacy of a firm's cash resources to meet its near-term cash obligations, the working capital ratio, computed as total current assets divided by total current liabilities at the end of year before the announcement period, as defined in chapter 3. Running the several regressions, the results show that the coefficient on WCR is always statistically insignificant, not contributing in explaining the market reaction surrounding dividend change announcements. Globally, the goodness of fit of the regression models when we introduce the WCR variable slightly decreases ${ }^{132}$. In all cases, we obtain similar results for the other coefficients, so, our conclusions are kept unchanged.

In addition, we include a variable to measure the financial constraints. A commonly used index to measure financial constraints is the $\mathrm{KZ}$ index, as it was denominated by Lamont et al. (2001). The index constructed by these authors uses the coefficients of the regression of Kaplan and Zingales (1997) work. As this index is composed by five variables and we have already used some of them in the regression 5.1 , we will adopt the cash flow to assets ${ }^{133}$ measure (CF) as a proxy for the financial constraints, which is also popular in the empirical tests done in this domain, computed as operating income before depreciation minus interest expense, income taxes and preferred stock dividends scaled by the total assets at the end of the year before the dividend announcement, as previously defined. Globally, the increases in the adjusted $\mathrm{R}^{2}$ when we introduce the $\mathrm{CF}$ variable are worthless ${ }^{134}$. The results show that the coefficient on CF is statistically insignificant for all the three countries, not contributing in explaining the market reaction surrounding dividend change announcements.

\footnotetext{
${ }^{131}$ For simplicity reasons, the results are not reported in the study, but available from authors upon request.

${ }^{132}$ For instance, in the case of regression 5.1 results, the adjusted $\mathrm{R}^{2}$ declines from $31.8 \%$ to $31.6 \%$, from $35 \%$ to $34.8 \%$ and from $20.7 \%$ to $20.1 \%$, respectively for the Portuguese, the French and the UK samples.

${ }^{133}$ The other four variables of the KZ index are: the market to book ratio, debt to total capital, dividends to total capital and cash holdings to capital.

${ }^{134}$ In the case of regression 5.1 results, the adjusted $\mathrm{R}^{2}$ increases, on average, about $0.1 \%$ in the three samples.
} 
As these two variables do not change our conclusions, we decide to not consider these additional firm-specific variables in the following analysis.

\subsubsection{Relation between the Probability of a Negative (Positive) Market REACTION TO DIVIDEND INCREASE (DECREASE) ANNOUNCEMENTS AND FIRM- SPECIFIC CHARACTERISTICS}

The next step consists of analysing the relation between the probability of a negative (positive) market reaction to dividend increase (decrease) announcements and the firmspecific characteristics.

Table 5.3 presents the results of the logistic regression 5.3 for dividend increase events (Panel A) and for dividend decrease events (Panel B).

Panel A presents the regression results of the relation between the probability of a negative market reaction to dividend increase announcements and firm specific characteristics. The factors that, in global terns, contribute to a negative market reaction are the firm size, the EG, the MB ratio and the DE ratio.

The results of the Portuguese sample exhibit two coefficients statistically significant and negative, which are the logarithm of earnings growth (LEG) and the logarithm of debt to equity ratio (LDE). The French results present one negative and marginally significant coefficient, at the $10 \%$ level, which is the logarithm of market to book ratio (LMB). The UK sample presents three out of the six variables as statistically significant. The LDE is negative and the firm size (FS) and the LMB are positive. This last one was negative in the French sample.

The evidence that in the UK the coefficient on FS is positive and statistically significant suggests that firms with higher size have a higher probability of a negative market reaction. One possible reason might be the fact that the information asymmetry is smaller for bigger firms, as they have more information available in the market and are subject to more scrutiny by financial analysts. Consequently, the investors of bigger firms have more information, beyond that of dividend changes, to assess and thus, to react. This result appears to be consistent with the evidence obtained by Haw and Kim (1991), Eddy and Seifert (1992) and Mitra and Owners (1995). 
The fact that the coefficient on earnings growth rate is negative suggests that the higher the earnings growth, the less the probability that the market will react negatively to a dividend increase announcement. Since earnings growth are a primary source of information regarding future dividends Lintner (1956) and results of Table 3.6 , it is possible that the prior earnings growth may be a predictor of the market reaction at the announcement period.

The LMB ratio is negative and significant in France, which is a signal that the higher the $\mathrm{MB}$ ratio, the less the probability that the market reacts negatively to dividend increases. In the UK market, the opposite happens. The coefficient is positive and significant, suggesting that a high MB ratio increases the likelihood that the market reacts negatively to dividend increases. The different reaction in the two countries might be related to the way shareholders interpret the information, and to the firm characteristics. The result of UK sample suggests that the market has a higher probability to react negatively to dividend increases if firms have growth opportunities. This seems to be in contrast with the previous results (Table 5.2) and in accordance with the free cash flow hypothesis. The French result suggests that the market reacts mainly and positively to dividend increases. This could imply that investors believe that high MB firms that increase dividends are signalling continuing growth opportunities, which is in accordance with the dividend signalling hypothesis. Another possible reason for that to happen can be associated with the firm's stage. Perhaps French firms are, generally, in the maturity stage and MB is high, not because of a high market value of equity, but because of an obsolete book value.

LDE is negative and significant in two out of the three countries (Portugal and the UK), suggesting that a high debt to equity ratio decreases the likelihood that the market reacts negatively to a dividend increase announcement. This evidence does not suggest that markets react negatively when firm's debt is high because of the greater risk of covenant, like the results of Healy, Hathorn and Kirch (1997), but instead suggests, according the opinion of Ross (1977), that good quality firms are able to differentiate themselves from lesser quality firms by assuming a higher leverage ratio. Investors can interpret this as a signal that managers are sure about their capacity to continue paying dividends. This evidence can be an indication that leverage and dividends are complementary signalling mechanisms. 
In sum, firms with negative market reactions to dividend increase announcements have, on average, higher size, lower earnings growth rate and lower debt to equity ratios. These results suggest that, for bigger firms under low earnings growth rate and low DE ratio, the market interprets a dividend increase as a negative signal.

Panel B presents the regression results of the relation between the probability of a positive market reaction to dividend decrease announcements and firm specific characteristics. The only factor that contributes significantly to a positive market reaction is the PER, and only for the French market. It is negative and statistically significant at the 5\% level. The Portuguese and the UK samples exhibit no coefficients statistically significant.

The fact that PER is negative means that it contributes to a lower probability that the market reacts positively to a dividend decrease. This could imply that investors believe that high PER firms that decrease dividends are conveying to the market information that they have less growth prospects than expected.

Summarising, firms with positive market reactions to dividend decrease announcements tend to have, on average, lower PER, but only for the case of the French market. This suggests that under a low PER, the French market interprets a dividend decrease as a positive signal. For the other two samples, our results do not find support for a relationship between firm specific characteristics and the probability of a positive market reaction to dividend decrease announcements.

\subsubsection{DIFFERENCES IN FIRM-SPECIFIC CHARACTERISTICS ACCORDING THE DISTINCT MARKET REACTION TO Dividend ChANGE ANNOUNCEMENTS}

Finally, we wish to analyse the differences in firm characteristics between the distinct market reaction (positive or negative) to dividend increase and dividend decrease announcements in order to see if there are any systematic differences between events with a positive and a negative market reaction for each of the two types of events.

Table 5.4 presents the mean values for the selected specific factors and the t-statistic test for the differences between the means of the two groups (PRDI versus NRDI and NRDD versus PRDD events). 
Looking for the mean differences between the dividend increase events with a positive market reaction and those with a negative reaction, we can see that there are significant differences between the means of the firm size for the UK, the means of the percentage change of dividends for the UK, the means of earnings growth for Portugal and the UK, the means of MB ratio for the French and the UK markets, the means of the PER for the UK and, finally, the means of the DE ratio for the Portuguese sample.

We use firm size as a proxy for the information asymmetry. Consistent with the signalling hypothesis, we expect that smaller firms, which are likely to experience greater information asymmetry, tend to use dividends to signal firm's future prospects, and that the market consider this information as worthy and reacts positively to dividend increases. Therefore, we wait for firms with a direct relation between dividend increases and the market reaction having a smaller size than those with an inverse relation between the two variables. Thus, consistent with the assumptions of the signalling hypothesis, we expect to have lower values for the first group compared to the second one. Indeed, for the UK sample, the only one where the mean difference is significant, we have a lower firm size mean value for the first group. Consistent with the signalling hypothesis, we find that smaller firms in the UK market, which are likely to experience greater information asymmetry, tend to use dividends as a signal mechanism. This evidence is consistent with Miller and Rock's (1985) position that the dividend announcement effect varies across firms with different degrees of information asymmetry.

Assuming that a bigger change of dividends reveals more information, we expect to find higher mean values for the group with a direct relation between dividend changes and market reaction. According to what is expected, we find significant higher mean values for the percentage change of dividends in the events characterised by a direct relation between dividend increases and the market reaction for the UK sample. Although it also happens in the Portuguese sample, the mean difference is not significant. This is an indication of the market reaction being a function of how much information is revealed.

Past earnings growth can be associated with expectations of future earnings growth. Thus, assuming dividend increase announcements convey good information about future earnings prospects, we expect to have higher earnings growth mean values for the first group compared to the second one. As we can see, this happens for all the three samples, but the difference is only significant for the Portuguese and the UK samples. 
The market to book ratio can be considered as a proxy for the firms' growth opportunities. A high ratio can be a signal that a firm has strong growth prospects. According to the free cash flow assumptions, firms with fewer investment opportunities will have more free cash flows and so can pay higher dividends. Hence, we expect to have higher mean values for the MB ratio in the NRDI events than in the PRDI events, reflecting a negative reaction to earnings distributed that must be retained to finance the future growth prospects. In fact, it happens in the UK market. The results are consistent with the ones obtained in Table 5.3 (Panel A), where we conclude that a high MB ratio increases the likelihood that the market reacts negatively to dividend increases. On the other hand, according to the dividend signalling hypothesis, we can interpret a high MB ratio as conveying optimistic information to the market about firm's future earnings prospects as a sequence of growth opportunities and, consequently, firms with a positive market reaction to dividend increase announcements will have higher values for the MB ratio. Indeed, this situation happens in the French market. This result is also consistent with the evidence of Table 5.3 (Panel A) for this sample, where we find evidence that the higher the MB ratio, the less the probability that the market reacts negatively to dividend increases.

The PER mean value is significantly lower (higher) for the events with a positive (negative) market reaction in the UK sample. This result is in accordance with the one exhibited in Table 5.2, suggesting that, when firms announce dividend increases, the market interprets a high PER as a signal that firms have less growth opportunities then expected, adjusting its perceptions downwards.

As we have already mentioned, Ross (1977) shows that good quality firms are able to differentiate themselves from lesser quality firms by assuming a higher leverage ratio. Consequently, we suppose that the events in the first group may be associated with higher levels of debt to equity ratio compared to the other events. It happens for all the samples, but the mean difference is only statistically significant for the Portuguese case. This result suggests, once more, that leverage and dividends are complementary signalling mechanisms.

Afterwards, we analyse the differences between the dividend decrease events with a negative market reaction and those with a positive reaction. 
Looking for the mean differences, we can see that there are significant differences between the means of the firm size, the percentage change of dividends and the earnings growth for the UK, and between the means of earnings growth, of MB ratio and of PER for the French sample. For the Portuguese sample, none of the mean differences is statistically significant.

The firm size is smaller for the events with a negative market reaction to dividend decreases, as expected. This could be an indication that the market considers the information about smaller firms as worthy, because it is scarce, and reacts negatively to dividend decreases.

Regarding the percentage change of dividends, although we have a significant mean difference, the mean values for both types of events are similar.

In what concerns the earnings growth, the results of France and the UK are different. We expect that the past earnings growth could have some effect in the market reaction, according to their good or bad performance, contributing positively to the market reaction, in the former situation, and negatively in the later. Thus, we expect to find higher mean values for the events with a positive market reaction compared to the events with a negative reaction. Indeed, in the UK market, the mean earnings growth is negative for the events with a negative reaction to dividend decreases and is positive for the events with a positive market reaction. Once more, it suggests that earnings are at least as informative as dividends, or even more informative. This conclusion was found in prior research, such as in the works of Abeyratna and Power (2002) and Francis, Schipper and Vincent (2005), for single class shares in the US market. Surprisingly, in the French market, the behaviour is opposite, with positive earnings growth in the NRDD events and negative earnings growth in the PRDD events. Maybe the French investors do not consider the EG rate information to react in the event period. Indeed, we find no evidence for EG contributing to explain the market reaction in the dividend announcement period (Tables 5.1 and 5.2).

For the French market, the dividend decrease events with a negative market reaction present higher mean values for the MB ratio and for the PER. One possible reason for these results might be, for both the $\mathrm{MB}$ ratio and the PER, the fact that the market realises the high values of these ratios as a good new about future growth opportunities (associated with the information content perspective, and not with the free cash flow 
hypothesis), do not understanding the reason why, in these circumstances, firms decrease dividends, reacting worse in these situations (dividend decreases by firms with good prospects about future growth opportunities). Another reason could be the stage of the maturity of French firms with high ratios because of the low values of the denominators (book value of equity and earnings, respectively).

Summarising, the results exhibit evidence that, for the dividend increase events, the firm size, the market to book ratio and the pricelearnings ratio tend to be higher for the events with a negative market reaction. The percentage change of dividends, the earnings growth and the debt/equity ratio tend to be lower for the events with a negative market reaction. These results could be interpreted as an indication that investors punish dividend increases when they have a lower magnitude, when the earnings growth is lower and when firms have strong growth prospects but increase dividends instead of retaining them to finance new projects.

For the dividend decrease events, the results are not so robust, but suggest that the firm size and the earnings growth (with the exception of the French sample) tend to be higher for the events with a positive market reaction and the pricelearnings ratio tend to be lower in this type of events. This suggests that the market can react positively to dividend decreases when past earnings have grown.

\subsection{CONCLUSIONS}

Analysing the hypothesis that some firm-specific factors contribute to explain the cumulative abnormal return, we obtain the main results:

- When we consider all the dividend changes, the only markets where we have firm specific variables with power to explain the market abnormal returns in the announcement period are France and the UK. The explanatory variables that contribute in explaining the BHAR in the 3 days surrounding the dividend change announcements are the DE ratio, in the first market, and the earnings growth and the PER in the latter one. Although we find weak evidence of firmspecific variables influencing the market reaction surrounding the events period, the finding that investors have different expectations as to dividend 
announcements depending on a firm's prior history of earnings growth is consistent with the results of Healy, Hathorn and Kirch (1997);

- When we consider dividend increases and decreases separately the results are not very different. The only market where we have firm specific variables with power to explain the market abnormal returns in the announcement period is the UK. The explanatory variables that contribute in explaining the BHAR in the announcement period are the earnings growth, and, only for dividend increase events, the percentage change of dividends, the MB ratio and the PER. The evidence that the higher the dividend increases, the higher the market reaction suggests that the share price adjustment to dividend changes occurs in response to the information content of these decisions, which is consistent with the dividend signalling hypothesis and in agreement with several prior results, such as Eddy and Seifert (1992);

- The reason behind the evidence of some different signs for the distinct types of events (dividend increases and decreases) on the same firm-specific variable could be an indication that it is associated with the opposite relation between dividend change announcements and the subsequent market reaction;

- Globally, for the Portuguese and the French markets our evidence fails to support that there are firm-specific factors that contribute in a consistent way to explain the abnormal market return. The only country for which we find some evidence is the UK;

- Analysing the relation between the probability of a negative market reaction to dividend increase announcements and the firm-specific factors, the results suggest that firms with negative market reactions to dividend increase announcements have, on average, higher size, lower earnings growth rate and lower debt to equity ratios. Globally, these results are consistent with the ones of Ross (1977), Haw and Kim (1991), Eddy and Seifert (1992) and Mitra and Owners (1995). This evidence suggests that dividend increases of big firms with low earnings growth and low levels of debt can be seen as a bad new ${ }^{135}$;

- Analysing the relation between the probability of a positive market reaction to dividend decrease announcements and the firm-specific factors, our results do

${ }^{135}$ This possibility lacks of further research. 
not find support for a significant relationship between these variables, except for the French market, which evidence suggests that firms with positive market reactions to dividend decreases tend to have, on average, lower PER;

- The distinct results between the French and the UK samples could be related with differences in ownership and governance between the two countries. The first one is a bank based system with ownership concentration, where asymmetric information and agency problems are solved differently than in the latter country, which is a market-based system;

- When we compare the means differences of the firm-specific variables between the events with a positive and a negative market reaction for both the dividend increase and dividend decrease events, the findings indicate that, for the dividend increase events, the firm size, the market to book ratio and the price/earnings ratio tend to be higher for the events with a negative market reaction. The percentage change of dividends, the earnings growth and the debt/equity ratio tend to be lower for the events with a negative market reaction. The finding that firms with a positive reaction to dividend increases tend to have higher DE ratio suggests that firms signalling with dividends may be associated with higher levels of debt ratio, which is in accordance with Mougoué and Rao (2003). For the dividend decrease events, the results are not so robust, but suggest that the firm size and the earnings growth (with the exception of the French sample) tend to be higher for the events with a positive market reaction and the price/earnings ratio tend to be lower in this type of events;

- These results are an indication that investors penalise dividend increases when they have a lower magnitude, when the earnings growth are lower and when firms have a strong growth prospects but increase dividends instead of retain them to finance new project and suggests that the market can react positively to dividend decreases if the past earnings have grown;

- The finding indicating that, for the UK sample, earnings change announcements convey information beyond what is revealed by dividend change announcements is consistent with our previous results as well as with DeAngelo, DeAngelo and Skinner (1992), Abeyratna and Power (2002) and Francis, Schipper and Vincent (2005) evidence. 
Globally speaking, and having in consideration the evidence obtained so far, the results suggest that in the UK, where information asymmetry is higher than in the other two countries considered in this study, managers tend to use dividends as a mechanism to mitigate it, which is in accordance with Lasfer and Zenonos (2004) evidence. In France and in Portugal, countries characterised by a bank-based system, and where information asymmetry is lower than in the UK, there is no pronounced need to use dividends to convey information to the market, being the signalling effect of dividends less important, which results validate the ones of Aivazian, Booth and Cleary (2003a) and Goergen, Renneboog and Silva (2005). Furthermore, this evidence is consistent with the axiom that there is a smaller signalling function in the bank-based system. 
TABLES 


\section{Table 5.1 - Regression of BHAR on firm specific variables and correlation matrix}

This table reports the estimation of a regression relating cumulative abnormal return (BHAR) in the announcement period to firm specific variables and the correlations between the independent variables. Panel A presents the Pearson correlations between independent variables. $\mathrm{FS}_{\mathrm{i}}$ is the firm size (natural log of market value of common equity at the end of the year before the dividend change year); $\mathrm{PCD}_{\mathrm{i}}$ is the percentage change of dividends (the annual change in dividends divided by the share price in the announcement day); $\mathrm{EG}_{\mathrm{i}}$ is the earnings growth rate (the average earnings growth rate based on the year prior to the dividend change year); $\mathrm{MB}_{\mathrm{i}}$ is the market to book ratio (market price per share at the dividend change announcement date divided by the book value per share at the end of the year before the dividend change year); $\mathrm{PER}_{\mathrm{i}}$ is the price earning ratio (the price per share at the announcement date divided by the earnings per share at the end of the year before the dividend change year); $\mathrm{DE}_{\mathrm{i}}$ is the debt to equity ratio (the book value of total debt divided by the total book value of equity at the end of the year prior to the dividend change announcement). Panel B presents the regression results estimated using pooled OLS, FEM and REM. The numbers in parentheses are the t-statistics corrected for heteroscedasticity using the White (1980) method. It reports the F test, a test for the equality of sets of coefficients, and the Hausman (1978) test, a test with $\mathrm{H}_{0}$ : random effects are consistent and efficient, versus $\mathrm{H}_{1}$ : random effects are inconsistent, in order to choose the most appropriate model for each particular sample.

\begin{tabular}{|c|c|c|c|c|c|c|}
\hline \multicolumn{7}{|c|}{ Panel A: Pearson correlations between independent variables (significance in parenthesis) } \\
\hline \multicolumn{7}{|c|}{ Portugal } \\
\hline \multirow{3}{*}{ Firm Size (FS) } & FS & PCD & EG & MB & PER & DE \\
\hline & 1.000 & -0.047 & 0.087 & $0.413^{*}$ & $0.211^{*}$ & 0.051 \\
\hline & & $(0.433)$ & $(0.145)$ & $(0.000)$ & $(0.000)$ & $(0.397)$ \\
\hline \multirow[t]{2}{*}{ \% Change Div. (PCD) } & & 1.000 & $0.189 *$ & -0.031 & -0.025 & -0.019 \\
\hline & & & $(0.001)$ & $(0.603)$ & $(0.675)$ & $(0.748)$ \\
\hline \multirow[t]{2}{*}{ Earnings Growth (EG) } & & & 1.000 & 0.026 & -0.056 & 0.001 \\
\hline & & & & $(0.670)$ & $(0.350)$ & $(0.990)$ \\
\hline \multirow[t]{2}{*}{ Market to Book (MB) } & & & & 1.000 & $0.488^{*}$ & 0.141 \\
\hline & & & & & $(0.000)$ & $(0.018)$ \\
\hline \multirow[t]{2}{*}{ PER } & & & & & 1.000 & 0.007 \\
\hline & & & & & & $(0.907)$ \\
\hline \multirow[t]{3}{*}{ Debt/Equity (DE) } & & & & & & 1.000 \\
\hline & & & & & & \\
\hline & FS & PCD & EG & MB & PER & $\mathbf{D E}$ \\
\hline \multirow[t]{2}{*}{ Firm Size (FS) } & 1.000 & 0.078 & 0.021 & $0.370^{*}$ & 0.091 & $0.127 * *$ \\
\hline & & $(0.178)$ & $(0.717)$ & $(0.000)$ & $(0.116)$ & $(0.029)$ \\
\hline \multirow[t]{2}{*}{ \% Change Div. (PCD) } & & 1.000 & 0.001 & 0.020 & -0.015 & -0.079 \\
\hline & & & $(0.984)$ & $(0.731)$ & $(0.799)$ & $(0.173)$ \\
\hline \multirow[t]{2}{*}{ Earnings Growth (EG) } & & & 1.000 & 0.086 & $0.154^{*}$ & 0.033 \\
\hline & & & & $(0.137)$ & $(0.008)$ & $(0.575)$ \\
\hline \multirow[t]{2}{*}{ Market to Book (MB) } & & & & 1.000 & $0.371^{*}$ & $-0.216^{*}$ \\
\hline & & & & & $(0.000)$ & $(0.000)$ \\
\hline \multirow[t]{2}{*}{ PER } & & & & & 1.000 & -0.060 \\
\hline & & & & & & $(0.305)$ \\
\hline Debt/Equity (DE) & & & & & & 1.000 \\
\hline
\end{tabular}

* $\quad$ Significantly different from zero at the $1 \%$ level

** Significantly different from zero at the 5\% level

*** Significantly different from zero at the $10 \%$ level 
Table 5.1 - Regression of BHAR on firm specific variables and correlation matrix (continued)

\begin{tabular}{|c|c|c|c|c|c|c|}
\hline \multicolumn{7}{|c|}{ Panel A: Pearson correlations between independent variables (significance in parenthesis) } \\
\hline \multicolumn{7}{|c|}{ UK } \\
\hline \multirow{3}{*}{ Firm Size (FS) } & FS & PCD & EG & MB & PER & DE \\
\hline & 1.000 & 0.024 & -0.008 & $0.127^{*}$ & $0.184^{*}$ & $0.115^{*}$ \\
\hline & & $(0.201)$ & $(0.677)$ & $(0.000)$ & $(0.000)$ & $(0.000)$ \\
\hline \multirow[t]{2}{*}{ \% Change Div. (PCD) } & & 1.000 & 0.026 & 0.034 & -0.018 & -0.012 \\
\hline & & & $(0.163)$ & $(0.072)$ & $(0.340)$ & $(0.536)$ \\
\hline \multirow[t]{2}{*}{ Earnings Growth (EG) } & & & 1.000 & 0.001 & 0.017 & $-0.045 * *$ \\
\hline & & & & $(0.965)$ & $(0.365)$ & $(0.015)$ \\
\hline \multirow[t]{2}{*}{ Market to Book (MB) } & & & & 1.000 & $0.313^{*}$ & $0.402 *$ \\
\hline & & & & & $(0.000)$ & $(0.000)$ \\
\hline \multirow[t]{2}{*}{ PER } & & & & & 1.000 & 0.023 \\
\hline & & & & & & $(0.219)$ \\
\hline Debt/Equity (DE) & & & & & & 1.000 \\
\hline
\end{tabular}

\begin{tabular}{|c|c|c|c|c|}
\hline $\begin{array}{l}\text { Panel B: } \\
\left|B H A R_{i,-1 \text { to }+1}\right|=\alpha+\end{array}$ & $S_{i}+\beta_{2} \mid P C D$ & ${ }_{i}\left|+\beta_{3}\right| E G_{i}$ & $\mid+\beta_{4} M$ & $+\beta_{6} D E_{i}+\varepsilon_{i, t}$ \\
\hline & & Portugal & & \\
\hline Coefficient & Pooled OLS & & FEM & REM \\
\hline Constant & $\begin{array}{r}0.033 \\
(2.409)\end{array}$ & ** & & $\begin{array}{r}0.019 \\
(0.649)\end{array}$ \\
\hline Firm Size & $\begin{array}{r}-0.001 \\
(-0.990)\end{array}$ & & $\begin{array}{r}0.001 \\
(0.392)\end{array}$ & $\begin{array}{r}0.000 \\
(0.009)\end{array}$ \\
\hline$\%$ Change of Divid. & $\begin{array}{r}0.000 \\
(0.007)\end{array}$ & & $\begin{array}{r}0.004 \\
(1.281)\end{array}$ & $\begin{array}{r}0.003 \\
(0.539)\end{array}$ \\
\hline Earnings Growth & $\begin{array}{r}0.002 \\
(1.090)\end{array}$ & & $\begin{array}{r}0.002 \\
(1.193)\end{array}$ & $\begin{array}{r}0.002 \\
(1.375)\end{array}$ \\
\hline Market to Book ratio & $\begin{array}{r}0.002 \\
(0.969)\end{array}$ & & $\begin{array}{r}-0.003 \\
(-0.754)\end{array}$ & $\begin{array}{r}-0.001 \\
(-0.380)\end{array}$ \\
\hline Price/Earnings ratio & $\begin{array}{r}0.000 \\
(0.019)\end{array}$ & & $\begin{array}{r}0.000 \\
(0.482)\end{array}$ & $\begin{array}{r}0.000 \\
(0.436)\end{array}$ \\
\hline Debt to Equity ratio & $\begin{array}{r}0.002 \\
(0.993)\end{array}$ & & $\begin{array}{r}0.003 \\
(1.218)\end{array}$ & $\begin{array}{r}0.003 \\
(1.440)\end{array}$ \\
\hline $\mathrm{N}$ & 279 & & 279 & 279 \\
\hline Adjusted $\mathrm{R}^{2}$ & 0.008 & & 0.068 & 0.318 \\
\hline Test $\mathrm{F}$ & 1.30 & *** & & \\
\hline Hausman Test & & & 2.20 & \\
\hline & & & & (Continue) \\
\hline $\begin{array}{ll}* & \text { Significantly } \\
* * & \text { Significantly } \\
* * * & \text { Significantly }\end{array}$ & $\begin{array}{l}\text { ent from zero at } t \\
\text { ent from zero at } t \\
\text { ent from zero at } t\end{array}$ & $\begin{array}{l}\text { he } 1 \% \text { level } \\
\text { he } 5 \% \text { level } \\
\text { he } 10 \% \text { level }\end{array}$ & & \\
\hline
\end{tabular}


Table 5.1 - Regression of BHAR on firm specific variables and correlation matrix (continued)

\begin{tabular}{|c|c|c|c|c|c|c|}
\hline \multirow{2}{*}{\multicolumn{7}{|c|}{$\frac{\left|B H A R_{i,-1 \text { to }+1}\right|=\alpha+\beta_{1} F S_{i}+\beta_{2}\left|P C D_{i}\right|+\beta_{3}\left|E G_{i}\right|+\beta_{4} M B_{i}+\beta_{5} P E R_{i}+\beta_{6} D E_{i}+\varepsilon_{i, t}}{\text { France }}$}} \\
\hline & & & & & & \\
\hline Coefficient & Pooled OLS & & FEM & & REM & \\
\hline Constant & $\begin{array}{r}0.041 \\
(3.229)\end{array}$ & $*$ & & & $\begin{array}{r}0.019 \\
(\mathbf{0 . 8 7 2})\end{array}$ & \\
\hline Firm Size & $\begin{array}{r}-0.001 \\
(-0.903)\end{array}$ & & $\begin{array}{r}0.005 \\
(1.590)\end{array}$ & & $\begin{array}{r}0.001 \\
(0.333)\end{array}$ & \\
\hline$\%$ Change of Divid. & $\begin{array}{r}-0.024 \\
(-0.247)\end{array}$ & & $\begin{array}{r}0.216 \\
(1.308)\end{array}$ & & $\begin{array}{r}0.070 \\
(0.521)\end{array}$ & \\
\hline Earnings Growth & $\begin{array}{r}-0.001 \\
(-1.743)\end{array}$ & $* * *$ & $\begin{array}{r}-0.001 \\
(-0.313)\end{array}$ & & $\begin{array}{r}-0.001 \\
(-0.551)\end{array}$ & \\
\hline Market to Book ratio & $\begin{array}{r}-0.000 \\
(-0.059)\end{array}$ & & $\begin{array}{r}-0.008 \\
(-2.086)\end{array}$ & $* *$ & $\begin{array}{r}-0.002 \\
(-0.772)\end{array}$ & \\
\hline Price/Earnings ratio & $\begin{array}{r}-0.001 \\
(-0.916)\end{array}$ & & $\begin{array}{r}0.000 \\
(0.374)\end{array}$ & & $\begin{array}{r}-0.000 \\
(-0.043)\end{array}$ & \\
\hline Debt to Equity ratio & $\begin{array}{r}0.004 \\
(1.658)\end{array}$ & $* * *$ & $\begin{array}{r}0.005 \\
(1.106)\end{array}$ & & $\begin{array}{r}0.005 \\
(1.777)\end{array}$ & $* * *$ \\
\hline $\mathrm{N}$ & 297 & & 297 & & 297 & \\
\hline Adjusted $\mathrm{R}^{2}$ & 0.001 & & 0.068 & & 0.350 & \\
\hline Test $\mathrm{F}$ & 1.35 & ** & 0.096 & & & \\
\hline Hausman Test & & & 6.51 & & & \\
\hline & & $\overline{\mathbf{U}}$ & & & & \\
\hline Coefficient & Pooled OLS & & FEM & & REM & \\
\hline Constant & $\begin{array}{r}0.079 \\
(7.895)\end{array}$ & $*$ & & & $\begin{array}{r}0.071 \\
(5.617)\end{array}$ & \\
\hline Firm Size & $\begin{array}{r}-0.002 \\
(-3.021)\end{array}$ & $*$ & $\begin{array}{r}0.003 \\
(1.691)\end{array}$ & $* * *$ & $\begin{array}{r}-0.001 \\
(-1.566)\end{array}$ & \\
\hline$\%$ Change of Divid. & $\begin{array}{r}0.196 \\
(2.375)\end{array}$ & $* *$ & $\begin{array}{r}0.072 \\
(0.826)\end{array}$ & & $\begin{array}{r}0.114 \\
(1.234)\end{array}$ & \\
\hline Earnings Growth & $\begin{array}{r}0.007 \\
(4.613)\end{array}$ & $*$ & $\begin{array}{r}0.006 \\
(3.829)\end{array}$ & * & $\begin{array}{r}0.006 \\
(4.557)\end{array}$ & $*$ \\
\hline Market to Book ratio & $\begin{array}{r}0.001 \\
(2.554)\end{array}$ & $* *$ & $\begin{array}{r}-0.001 \\
(-0.654)\end{array}$ & & $\begin{array}{r}0.001 \\
(1.140)\end{array}$ & \\
\hline Price/Earnings ratio & $\begin{array}{r}-0.000 \\
(-1.387)\end{array}$ & & $\begin{array}{r}-0.001 \\
(-3.212)\end{array}$ & $*$ & $\begin{array}{r}-0.001 \\
(-1.981)\end{array}$ & $* *$ \\
\hline Debt to Equity ratio & $\begin{array}{r}0.000 \\
(0.022)\end{array}$ & & $\begin{array}{r}0.007 \\
(2.559)\end{array}$ & $* *$ & $\begin{array}{r}0.002 \\
(\mathbf{1 . 0 8 9 )}\end{array}$ & \\
\hline $\mathrm{N}$ & 2,889 & & 2,889 & & 2,889 & \\
\hline Adjusted $\mathrm{R}^{2}$ & 0.018 & & 0.079 & & 0.207 & \\
\hline Test F & 1.38 & * & & & & \\
\hline Hausman Test & & & 3.47 & & & \\
\hline
\end{tabular}

* $\quad$ Significantly different from zero at the $1 \%$ level

** $\quad$ Significantly different from zero at the 5\% level

*** $\quad$ Significantly different from zero at the $10 \%$ level 


\section{Table 5.2 - Regression of BHAR on firm specific variables with dummies}

This table reports the estimation of a regression relating the BHAR in the event period to firm specific factors using dummy variables to identify dividend increase and decrease events. $\mathrm{FS}_{\mathrm{i}}$ is the firm size, computed as the natural log of market value of common equity at the end of the year before the dividend change year; $\mathrm{PCD}_{\mathrm{i}}$ is the percentage change of dividends, computed as the annual change in dividends divided by the share price in the announcement day; $\mathrm{EG}_{\mathrm{i}}$ is the earnings growth rate, computed as the average earnings growth rate based on the year prior to the dividend change year; $M_{i}$ is the market to book ratio, calculated by dividing the market price per share at the dividend change announcement date by the book value per share at the end of the year before the dividend change year; $\mathrm{DE}_{\mathrm{i}}$ is the debt to equity ratio, calculated as the book value of total debt divided by the total book value of equity at the end of the year prior to the dividend change announcement; DI (DD) is a dummy variable that takes the value 1 if dividend increases (decreases) and 0 otherwise; is the vector of coefficients for the dummy variables relating dividend and earnings changes, set equal to 1 respectively, if both dividend and earnings increases, dividend increases and earnings decreases, dividend decreases and earnings increases, both dividend and earnings decreases, and 0 otherwise. The regression results are estimated using pooled OLS, FEM and REM. The numbers in parentheses are the t-statistics corrected for heteroscedasticity using the White (1980) method. It reports the F test, a test for the equality of sets of coefficients, and the Hausman (1978) test, a test with $\mathrm{H}_{0}$ : random effects are consistent and efficient, versus $\mathrm{H}_{1}$ : random effects are inconsistent, in order to choose the most appropriate model for each particular sample.

\begin{tabular}{|c|c|c|c|}
\hline \multirow{2}{*}{\multicolumn{4}{|c|}{ 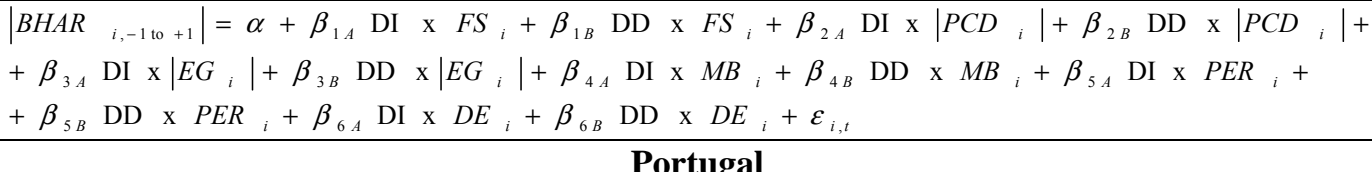 }} \\
\hline & & & \\
\hline $\begin{array}{c}\text { Coefficient } \\
\end{array}$ & Pooled OLS & 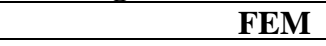 & REM \\
\hline Constant & $\begin{array}{r}0.034 \\
(2.229)\end{array}$ & $* *$ & $\begin{array}{r}0.018 \\
(0.603)\end{array}$ \\
\hline DI $x$ FS & $\begin{array}{r}-0.001 \\
(-0.846)\end{array}$ & $\begin{array}{r}0.001 \\
(0.457)\end{array}$ & $\begin{array}{r}0.000 \\
(0.031)\end{array}$ \\
\hline DD $x$ FS & $\begin{array}{r}-0.001 \\
(-1.064)\end{array}$ & $\begin{array}{r}0.001 \\
(0.530)\end{array}$ & $\begin{array}{r}0.000 \\
(0.082)\end{array}$ \\
\hline DI x PCD & $\begin{array}{r}-0.000 \\
(-0.010)\end{array}$ & $\begin{array}{r}0.004 \\
(1.278)\end{array}$ & $\begin{array}{r}0.004 \\
(0.533)\end{array}$ \\
\hline $\mathrm{DD} \times \mathrm{PCD}$ & $\begin{array}{r}-0.003 \\
(-0.160)\end{array}$ & $\begin{array}{r}0.005 \\
(0.234)\end{array}$ & $\begin{array}{r}0.004 \\
(0.123)\end{array}$ \\
\hline DI $x$ EG & $\begin{array}{r}0.002 \\
(0.993)\end{array}$ & $\begin{array}{r}0.002 \\
(1.093)\end{array}$ & $\begin{array}{r}0.002 \\
(1.322)\end{array}$ \\
\hline $\mathrm{DD} \times \mathrm{EG}$ & $\begin{array}{r}0.001 \\
(0.213)\end{array}$ & $\begin{array}{r}0.001 \\
(0.312)\end{array}$ & $\begin{array}{r}0.001 \\
(0.211)\end{array}$ \\
\hline DI x MB & $\begin{array}{r}0.004 \\
(0.841)\end{array}$ & $\begin{array}{r}-0.000 \\
(-0.027)\end{array}$ & $\begin{array}{r}0.001 \\
(0.262)\end{array}$ \\
\hline $\mathrm{DD} \times \mathrm{MB}$ & $\begin{array}{r}0.000 \\
(0.378)\end{array}$ & $\begin{array}{r}-0.006 \\
(-1.373)\end{array}$ & $\begin{array}{r}-0.004 \\
(-0.826)\end{array}$ \\
\hline DI x PER & $\begin{array}{r}-0.000 \\
(-0.839)\end{array}$ & $\begin{array}{r}-0.000 \\
(-0.607)\end{array}$ & $\begin{array}{r}-0.000 \\
(-0.476)\end{array}$ \\
\hline DD $\times$ PER & $\begin{array}{r}0.002 \\
(1.359)\end{array}$ & $\begin{array}{r}0.000 \\
(1.306)\end{array}$ & $\begin{array}{r}0.000 \\
(0.947)\end{array}$ \\
\hline DI x DE & $\begin{array}{r}0.002 \\
(0.803)\end{array}$ & $\begin{array}{r}0.003 \\
(1.091)\end{array}$ & $\begin{array}{r}0.003 \\
(1.304)\end{array}$ \\
\hline DD $\times$ DE & $\begin{array}{r}0.002 \\
(0.586)\end{array}$ & $\begin{array}{r}0.002 \\
(0.408)\end{array}$ & $\begin{array}{r}0.002 \\
(0.436)\end{array}$ \\
\hline$\frac{\mathrm{N}}{\text { Adjusted } \mathrm{R}^{2}}$ & $\begin{array}{r}279 \\
0.026\end{array}$ & $\begin{array}{r}279 \\
0.047\end{array}$ & $\begin{array}{r}279 \\
0.309\end{array}$ \\
\hline $\begin{array}{c}\text { Test } \mathrm{F} \\
\text { Hausman Test }\end{array}$ & 1.28 & 2.41 & \\
\hline
\end{tabular}

(Continue)

* $\quad$ Significantly different from zero at the $1 \%$ level

** $\quad$ Significantly different from zero at the $5 \%$ level

*** Significantly different from zero at the $10 \%$ level 
Table 5.2 - Regression of BHAR on firm specific variables with dummies

(continued)

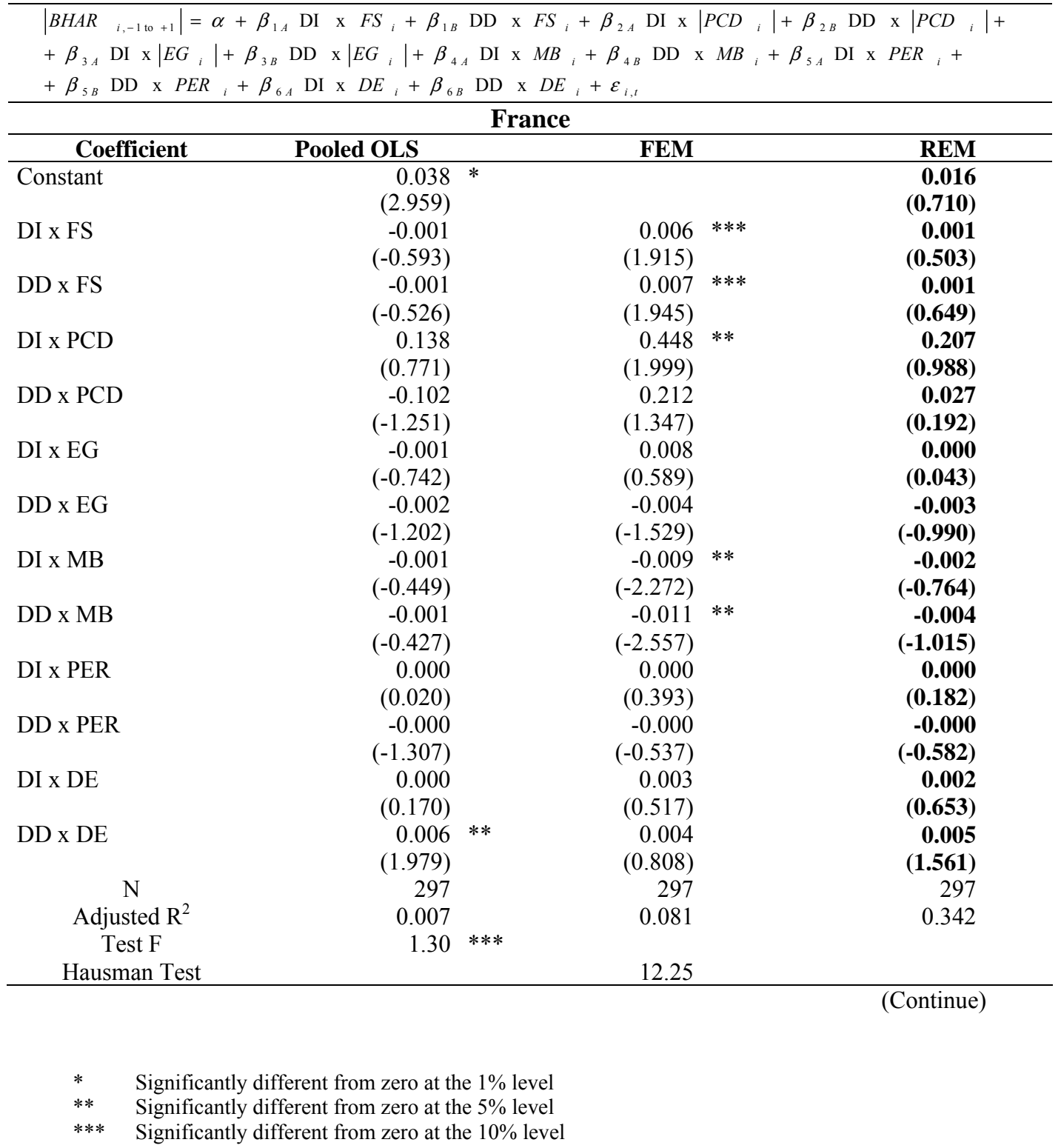


Table 5.2 - Regression of BHAR on firm specific variables with dummies

(continued)

\begin{tabular}{|c|c|c|c|c|c|c|}
\hline $\mid B H A R_{i}$ & $\begin{aligned}= & \alpha+\beta_{1} \Phi \\
& +\beta_{4} \Phi \times N\end{aligned}$ & $\begin{array}{l}x F S \\
1 B_{i}+\end{array}$ & $\begin{array}{l}P C D_{i} \mid+ \\
R_{i}+\beta_{6}\end{array}$ & $\begin{array}{l}\beta_{3} \Phi \\
\Phi \times L\end{array}$ & $\begin{array}{l}\boldsymbol{T}_{i} \mid+ \\
\mathcal{E}_{i, t}\end{array}$ & \\
\hline & & & & & & \\
\hline Coefficient & Pooled OLS & & FEM & & REM & \\
\hline Constant & $\begin{array}{r}0.073 \\
(7.051)\end{array}$ & $*$ & & & $\begin{array}{r}0.067 \\
(5.396)\end{array}$ & $*$ \\
\hline DIEI $x$ FS & $\begin{array}{r}-0.002 \\
(-2.966)\end{array}$ & $*$ & $\begin{array}{r}0.004 \\
(1.865)\end{array}$ & $* * *$ & $\begin{array}{r}-0.001 \\
(-1.612)\end{array}$ & \\
\hline DIED x FS & $\begin{array}{r}-0.001 \\
(-1.716)\end{array}$ & $* * *$ & $\begin{array}{r}0.004 \\
(1.976)\end{array}$ & $* *$ & $\begin{array}{r}-0.001 \\
(-0.930)\end{array}$ & \\
\hline DDEI $x$ FS & $\begin{array}{r}-0.000 \\
(-0.209)\end{array}$ & & $\begin{array}{r}0.005 \\
(2.324)\end{array}$ & $* *$ & $\begin{array}{r}0.000 \\
(0.154)\end{array}$ & \\
\hline DDED $\times$ FS & $\begin{array}{r}-0.001 \\
(-1.480)\end{array}$ & & $\begin{array}{r}0.004 \\
(1.853)\end{array}$ & $* * *$ & $\begin{array}{r}-0.001 \\
(-0.934)\end{array}$ & \\
\hline DIEI x PCD & $\begin{array}{r}0.901 \\
(2.624)\end{array}$ & $*$ & $\begin{array}{r}0.482 \\
(1.640)\end{array}$ & & $\begin{array}{r}0.691 \\
(2.543)\end{array}$ & $* *$ \\
\hline DIED x PCD & $\begin{array}{r}0.190 \\
(0.479)\end{array}$ & & $\begin{array}{r}-0.230 \\
(-0.566)\end{array}$ & & $\begin{array}{r}-0.058 \\
(-0.174)\end{array}$ & \\
\hline DDEI x PCD & $\begin{array}{r}-0.279 \\
(-1.385)\end{array}$ & & $\begin{array}{r}-0.290 \\
(-1.254)\end{array}$ & & $\begin{array}{r}-0.290 \\
(-1.216)\end{array}$ & \\
\hline DDED x PCD & $\begin{array}{r}0.222 \\
(2.360)\end{array}$ & $* *$ & $\begin{array}{r}0.148 \\
(1.501)\end{array}$ & & $\begin{array}{r}0.172 \\
(1.358)\end{array}$ & \\
\hline DIEI x EG & $\begin{array}{r}0.006 \\
(2.685)\end{array}$ & $*$ & $\begin{array}{r}0.005 \\
(2.184)\end{array}$ & $* *$ & $\begin{array}{r}0.005 \\
(2.761)\end{array}$ & $*$ \\
\hline DIED x EG & $\begin{array}{r}0.008 \\
(2.867)\end{array}$ & $*$ & $\begin{array}{r}0.007 \\
(2.761)\end{array}$ & $*$ & $\begin{array}{r}0.007 \\
(2.880)\end{array}$ & $*$ \\
\hline DDEI x EG & $\begin{array}{r}0.004 \\
(0.389)\end{array}$ & & $\begin{array}{r}-0.001 \\
(-0.117)\end{array}$ & & $\begin{array}{r}0.002 \\
(0.240)\end{array}$ & \\
\hline DDED x EG & $\begin{array}{r}0.009 \\
(2.021)\end{array}$ & $* *$ & $\begin{array}{r}0.008 \\
(1.656)\end{array}$ & $* * *$ & $\begin{array}{r}0.008 \\
(2.096)\end{array}$ & $* *$ \\
\hline DIEI x MB & $\begin{array}{r}0.001 \\
(2.568)\end{array}$ & $* *$ & $\begin{array}{r}-0.000 \\
(-0.536)\end{array}$ & & $\begin{array}{r}0.000 \\
(1.059)\end{array}$ & \\
\hline DIED x MB & $\begin{array}{r}0.001 \\
(1.292)\end{array}$ & & $\begin{array}{r}0.001 \\
(0.775)\end{array}$ & & $\begin{array}{r}0.001 \\
(1.885)\end{array}$ & $* * *$ \\
\hline DDEI x MB & $\begin{array}{r}0.001 \\
(1.260)\end{array}$ & & $\begin{array}{r}0.000 \\
(0.097)\end{array}$ & & $\begin{array}{r}0.001 \\
(0.570)\end{array}$ & \\
\hline DDED x MB & $\begin{array}{r}-0.000 \\
(-0.063)\end{array}$ & & $\begin{array}{r}-0.001 \\
(-1.125)\end{array}$ & & $\begin{array}{r}-0.000 \\
(-0.312)\end{array}$ & \\
\hline DIEI x PER & $\begin{array}{r}-0.000 \\
(-0.009)\end{array}$ & & $\begin{array}{r}-0.000 \\
(-2.783)\end{array}$ & $*$ & $\begin{array}{r}-0.000 \\
(-1.006)\end{array}$ & \\
\hline DIED $x$ PER & $\begin{array}{r}-0.000 \\
(-3.120)\end{array}$ & $*$ & $\begin{array}{r}-0.001 \\
(-3.859)\end{array}$ & $*$ & $\begin{array}{r}-0.000 \\
(-2.776)\end{array}$ & $*$ \\
\hline DDEI x PER & $\begin{array}{r}-0.000 \\
(-1.433)\end{array}$ & & $\begin{array}{r}-0.001 \\
(-1.528)\end{array}$ & & $\begin{array}{r}-0.000 \\
(-0.945)\end{array}$ & \\
\hline DDED x PER & $\begin{array}{r}0.000 \\
(0.628)\end{array}$ & & $\begin{array}{r}0.000 \\
(0.127)\end{array}$ & & $\begin{array}{r}0.000 \\
(0.530)\end{array}$ & \\
\hline DIEI x DE & $\begin{array}{r}-0.000 \\
(-0.090)\end{array}$ & & $\begin{array}{r}0.006 \\
(1.983)\end{array}$ & $* *$ & $\begin{array}{r}0.002 \\
(0.653)\end{array}$ & \\
\hline DIED x DE & $\begin{array}{r}0.004 \\
(1.164)\end{array}$ & & $\begin{array}{r}0.010 \\
(2.499)\end{array}$ & $* *$ & $\begin{array}{r}0.006 \\
(1.620)\end{array}$ & \\
\hline DDEI x DE & $\begin{array}{r}-0.013 \\
(-1.608)\end{array}$ & & $\begin{array}{r}-0.004 \\
(-0.425)\end{array}$ & & $\begin{array}{r}-0.009 \\
(-0.890)\end{array}$ & \\
\hline DDED x DE & $\begin{array}{r}-0.014 \\
(-1.927)\end{array}$ & $* * *$ & $\begin{array}{r}-0.006 \\
(-0.848)\end{array}$ & & $\begin{array}{r}-0.011 \\
(-1.377)\end{array}$ & \\
\hline $\mathrm{N}$ & 2,889 & & 2,889 & & 2,889 & \\
\hline Adjusted $\mathrm{R}^{2}$ & 0.024 & & 0.082 & & 0.152 & \\
\hline $\begin{array}{c}\text { Test } F \\
\text { Hausman Test }\end{array}$ & 1.36 & * & 5.43 & & & \\
\hline
\end{tabular}

* $\quad$ Significantly different from zero at the $1 \%$ level

** $\quad$ Significantly different from zero at the $5 \%$ level

*** Significantly different from zero at the $10 \%$ level 


\section{Table 5.3 - Logistic regression of the negative (positive) reaction to dividend increase (decrease) announcements and firm specific variables}

This table reports the estimation of a logistic regression relating the negative reaction to dividend increase announcements (Panel A) and the positive reaction to dividend decrease announcements (Panel B) and firm specific variables. $B H A R I_{i,-1}$ to +1 is a dummy variable that takes value 1 if $\mathrm{BHAR}_{\mathrm{i},-1 t^{+}+1}$ is negative and 0 otherwise; $\mathrm{BHARD}_{\mathrm{i}, 1 \text { to }+1}$ is a dummy variable that takes value 1 if $\mathrm{BHAR}_{\mathrm{i},-1 \text { to }+1}$ is positive and 0 otherwise; $\mathrm{FS}_{\mathrm{i}}$ is the firm size, computed as the natural log of market value of common equity at the end of the year before the dividend change year; $\mathrm{LPCD}_{\mathrm{i}}$ is the natural logarithm of annual change in dividends divided by the share price in the announcement day $+1 ; \mathrm{LEG}_{\mathrm{i}}$ is the natural logarithm of average earnings growth rate based on the year prior to the dividend change year +1 ; $\mathrm{LMB}_{\mathrm{i}}$ is natural logarithm of market price per share at the dividend change announcement date by the book value per share at the end of the year before the dividend change year $+1 ; \mathrm{LDE}_{\mathrm{i}}$ is the natural logarithm of book value of total debt divided by the total book value of equity at the end of the year prior to the dividend change announcement +1 . We report the coefficient values and the $p$-values.

\begin{tabular}{|c|c|c|c|}
\hline \multicolumn{4}{|l|}{$\begin{array}{l}\text { Panel A: Dividend Increases } \\
B H A R I_{-1+1+1}=a+\beta_{1} F S_{i}+\beta_{2} \mathrm{LP}\end{array}$} \\
\hline \multicolumn{4}{|c|}{ Portugal } \\
\hline & Coefficient & p-value & \\
\hline Constant & 3.506 & 0.067 & $* * *$ \\
\hline Firm Size & -0.123 & 0.263 & \\
\hline Log $\%$ Change of Dividends & -5.301 & 0.230 & \\
\hline Log Earnings Growth & -1.311 & 0.005 & $*$ \\
\hline Log Market to Book ratio & -0.671 & 0.319 & \\
\hline Log Price/Earnings ratio & -0.031 & 0.913 & \\
\hline Log Debt to Equity ratio & -0.930 & 0.059 & $* * *$ \\
\hline $\mathrm{N}$ & 158 & & \\
\hline Nagelkerke $\mathrm{R}^{2}$ & 0.169 & & \\
\hline \multicolumn{4}{|c|}{ France } \\
\hline & Coefficient & p-value & \\
\hline Constant & -0.759 & 0.597 & \\
\hline Firm Size & 0.049 & 0.596 & \\
\hline Log \% Change of Dividends & 4.809 & 0.721 & \\
\hline Log Earnings Growth & -0.610 & 0.101 & \\
\hline Log Market to Book ratio & -0.816 & 0.076 & $* * *$ \\
\hline Log Price/Earnings ratio & 0.220 & 0.422 & \\
\hline Log Debt to Equity ratio & -0.249 & 0.523 & \\
\hline $\mathrm{N}$ & 235 & & \\
\hline Nagelkerke $\mathrm{R}^{2}$ & 0.035 & & \\
\hline
\end{tabular}

(Continue)

* $\quad$ Significantly different from zero at the $1 \%$ level

$* * \quad$ Significantly different from zero at the $5 \%$ level

*** Significantly different from zero at the $10 \%$ level 
Table 5.3 - Logistic regression of the negative (positive) reaction to dividend increase (decrease) announcements and firm specific variables (continued)

\begin{tabular}{lcc}
\hline Panel A: Dividend Increases & \\
$B H A R I_{i,-1 \text { to }+1}=a+\beta_{1} F S_{i}+\beta_{2} \mathrm{LPCD}_{1}+\beta_{3} \mathrm{LEG}_{\mathrm{i}}+\beta_{4} L M B_{i}+\beta_{5} L P E R_{i}+\beta_{6} L D E_{i}+\varepsilon_{t}$ \\
\hline & $\mathbf{U K}$ & $\mathbf{\text { p-value }}$ \\
\cline { 2 - 3 } Constant & -1.601 & 0.000 \\
Firm Size & 0.059 & $0.011 * *$ \\
Log \% Change of Dividends & 0.594 & 0.944 \\
Log Earnings Growth & 0.053 & 0.666 \\
Log Market to Book ratio & 0.165 & $0.031 * *$ \\
Log Price/Earnings ratio & 0.010 & 0.918 \\
Log Debt to Equity ratio & -0.326 & $0.015 * *$ \\
$\mathrm{~N}$ & 2,623 & \\
Nagelkerke $\mathrm{R}^{2}$ & 0.092 & \\
\hline
\end{tabular}

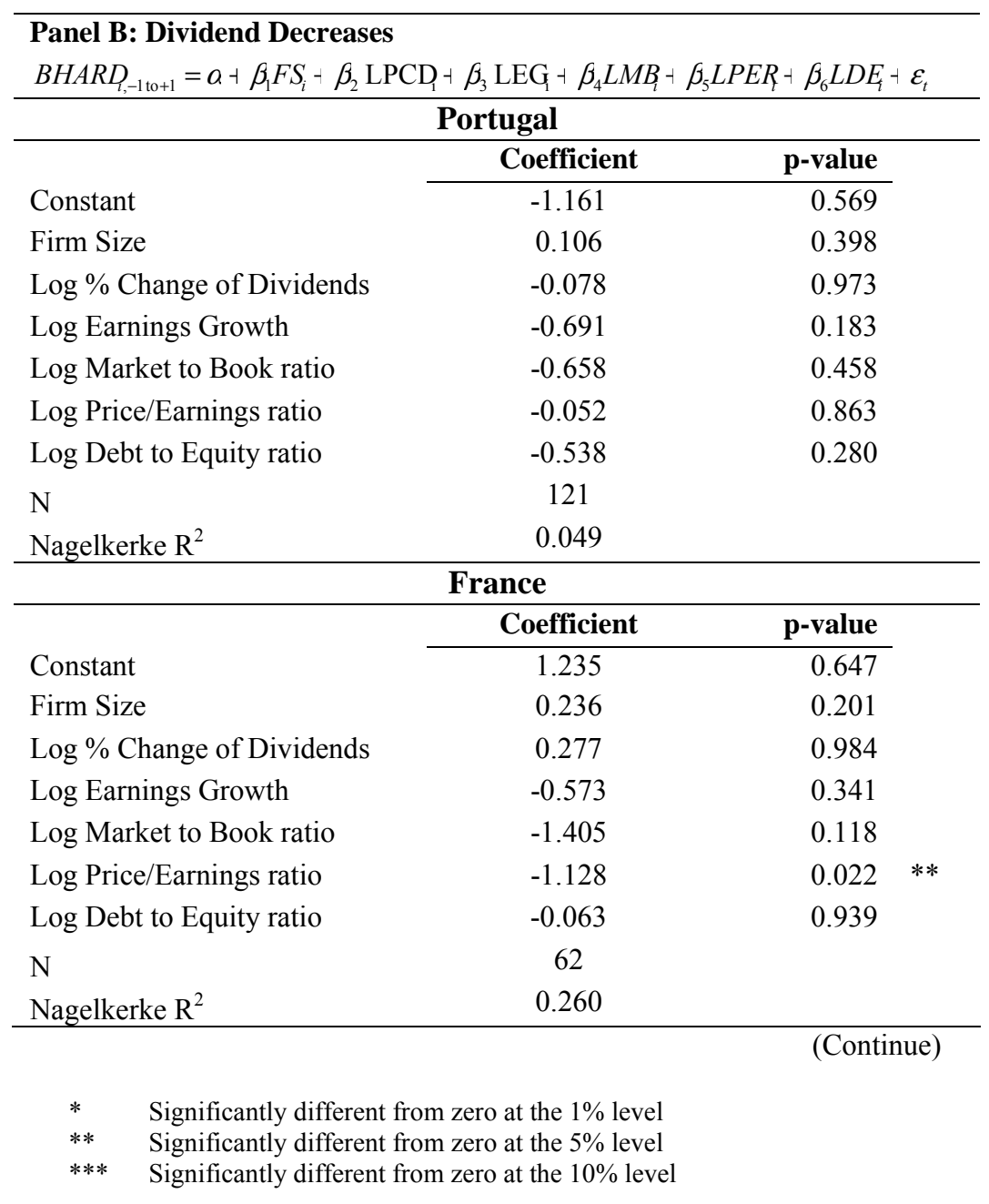


Table 5.3 - Logistic regression of the negative (positive) reaction to dividend increase (decrease) announcements and firm specific variables (continued)

\begin{tabular}{lcc}
\hline \multicolumn{3}{l}{ Panel B: Dividend Decreases } \\
$B H A R D_{,-1 \text { to+1 }}=a+\beta_{1} F S_{i}-\beta_{2} L P C D_{1}+\beta_{3} L E G+\beta_{4} L M B_{1}+\beta_{5} L P E R+\beta_{6} L D E_{i}+\varepsilon_{t}$ \\
\hline & $\mathbf{U K}$ \\
\cline { 2 - 3 } Constant & Coefficient & p-value \\
Firm Size & -0.963 & 0.401 \\
Log \% Change of Dividends & 0.060 & 0.349 \\
Log Earnings Growth & 3.309 & 0.508 \\
Log Market to Book ratio & 0.246 & 0.418 \\
Log Price/Earnings ratio & 0.155 & 0.543 \\
Log Debt to Equity ratio & -0.012 & 0.960 \\
$\mathrm{~N}$ & -0.164 & 0.706 \\
Nagelkerke $\mathrm{R}^{2}$ & 266 \\
\hline
\end{tabular}

* $\quad$ Significantly different from zero at the $1 \%$ level

** Significantly different from zero at the $5 \%$ level

*** $\quad$ Significantly different from zero at the $10 \%$ level 


\section{Table 5.4 - Selected specific variables for the sub-samples of events, according to the relationship between dividend change announcements and the BHAR}

This table reports the mean values of selected specific factors for the different groups classified according to the relation between dividend change announcements and the subsequent market reaction. $\mathrm{FS}_{\mathrm{i}}$ is the firm size for share i, computed as the natural log of market value of common equity at the end of the year before the dividend change year; $\mathrm{PCD}_{\mathrm{i}}$ is the percentage change of dividends for share $\mathrm{i}$, computed as the annual change in dividends divided by the share price in the announcement day; $\mathrm{EG}_{\mathrm{i}}$ is the earnings growth rate for share $\mathrm{i}$, computed as the average earnings growth rate based on the year prior to the dividend change year; $\mathrm{MB}_{\mathrm{i}}$ is the market to book ratio for share $\mathrm{i}$, calculated by dividing the market price per share at the dividend change announcement date by the book value per share at the end of the year before the dividend change year; $\mathrm{PER}_{\mathrm{i}}$ is the price earning ratio for share $\mathrm{i}$, computed as the price per share at the announcement date divided by the earnings per share at the end of the year before the dividend change year; $\mathrm{DE}_{\mathrm{i}}$ is the debt/equity ratio for share $\mathrm{i}$, calculated as the book value of total debt divided by the total book value of equity at the end of the year prior to the dividend change announcement; PRDI identifies the events with a positive reaction to dividend increases; NRDD identifies the events with a negative reaction to dividend decreases; NRDI identifies the events with a negative reaction to dividend increases; PRDD identifies the events with a positive reaction to dividend decreases. In addition, the table also presents the value of the $t$-statistic to test for the differences between the means of two groups.

\begin{tabular}{|c|c|c|c|c|c|c|c|c|}
\hline \multicolumn{9}{|c|}{ Relation between dividend changes and BHAR } \\
\hline Variables & $\begin{array}{c}\text { PRDI } \\
\text { (I) }\end{array}$ & $\begin{array}{c}\text { NRDI } \\
\text { (II) }\end{array}$ & \multicolumn{2}{|c|}{$\begin{array}{l}\text { t - statistic } \\
\text { (I)-(II) }\end{array}$} & $\begin{array}{l}\text { NRDD } \\
\text { (III) }\end{array}$ & $\begin{array}{c}\text { PRDD } \\
\text { (IV) }\end{array}$ & \multicolumn{2}{|c|}{$\begin{array}{l}\text { t - statistic } \\
\text { (III)-(IV) }\end{array}$} \\
\hline \multicolumn{9}{|c|}{ Portugal } \\
\hline Firm size & 17.118 & 16.762 & 1.574 & & 17.019 & 17.122 & -0.443 & \\
\hline$\%$ Change in dividends & 0.082 & 0.026 & 1.023 & & -0.078 & -0.075 & 0.726 & \\
\hline Earnings growth & 0.892 & 0.292 & 3.253 & $*$ & 0.116 & -0.049 & -0.72 & \\
\hline Market to book ratio & 0.868 & 0.810 & 0.536 & & 0.828 & 0.718 & 0.891 & \\
\hline Price/earnings ratio & 9.548 & 10.296 & -0.195 & & 11.223 & 12.313 & -0.132 & \\
\hline Debt/Equity ratio & 1.015 & 0.659 & 2.668 & $*$ & 1.044 & 0.781 & 1.013 & \\
\hline \multicolumn{9}{|c|}{ France } \\
\hline Firm size & 13.711 & 13.583 & 0.853 & & 13.426 & 13.630 & -0.392 & \\
\hline$\%$ Change in dividends & 0.004 & 0.004 & 0.301 & & -0.009 & -0.014 & 0.731 & \\
\hline Earnings growth & 0.365 & 0.325 & 0.438 & & 0.810 & -0.040 & 1.708 & $* * *$ \\
\hline Market to book ratio & 0.856 & 0.672 & 1.760 & $* * *$ & 1.209 & 0.638 & 2.116 & $* *$ \\
\hline Price/earnings ratio & 22.972 & 22.696 & 0.462 & & 25.939 & 15.806 & 3.006 & $*$ \\
\hline Debt/Equity ratio & 0.999 & 0.978 & 0.092 & & 1.160 & 1.297 & -0.528 & \\
\hline \multicolumn{9}{|c|}{ UK } \\
\hline Firm size & 16.592 & 16.808 & -5.097 & $*$ & 16.198 & 16.436 & -2.198 & $* *$ \\
\hline$\%$ Change in dividends & 0.004 & 0.003 & 3.009 & $*$ & -0.020 & -0.021 & 5.831 & * \\
\hline Earnings growth & 0.127 & 0.026 & 1.672 & $* * *$ & -0.382 & 0.242 & -3.524 & $*$ \\
\hline Market to book ratio & 2.911 & 3.228 & -3.141 & $*$ & 2.302 & 2.260 & 0.997 & \\
\hline Price/earnings ratio & 18.123 & 19.030 & -6.604 & $*$ & 18.880 & 18.559 & 0.614 & \\
\hline Debt/Equity ratio & 0.495 & 0.465 & 0.120 & & 0.606 & 0.555 & 0.478 & \\
\hline
\end{tabular}

* $\quad$ Significantly different from zero at the $1 \%$ level

** $\quad$ Significantly different from zero at the $5 \%$ level

*** $\quad$ Significantly different from zero at the $10 \%$ level 
CHAPTER 6

\section{CONCLUSIONS}




\subsection{SUMMARY AND CONCLUSIONS}

Over the last four decades, the information content of dividend change announcements has been one of the studied topics in the field of finance, but it remains a controversial issue. Despite the empirical research supporting the classical assumptions of the dividend information content hypothesis of a positive relationship between dividend change announcements and the market reaction surrounding the announcement date as well as between dividend change announcements and future earnings changes, it must be interpreted with caution in light of the somewhat mixed evidence in the literature. Indeed, recent studies have found no evidence of a significant relationship between dividend change announcements and both the market reaction and future earnings changes, not supporting the dividend information content hypothesis.

In this research we addressed these major two issues of the impact of dividend change announcements in the light of the information content of dividend change announcements. In addition, we concentrated on the issue of an adverse relationship between dividend change announcements and the market reaction in the announcement period, which is, to the best of our knowledge, an unexplored topic in this field of finance. Finally, we analysed whether market reaction to dividend change announcements is associated with firm-specific factors.

In chapter 3 we find no support on the French market for the dividend information content hypothesis in what concerns the relation between dividend change announcements and the market reaction, and only a weak support on the Portuguese and the UK markets. Furthermore, we have documented a significant percentage of cases where the relation between dividend change announcements and share price reaction is reverse in all the three samples. After accounting for non-linearity in the mean reversion process, an aspect not explored in the majority of the studies to date, the global results do not give support to the assumption of dividend signalling hypothesis that dividend change announcements are positively related with future changes in earnings. Thus, like Benartzi et al. (2005), we conclude that dividend changes contain no information about future earnings.

Nevertheless, we found some evidence of the window dressing phenomenon and the maturity hypothesis, supported mainly with the UK data, which reinforces the evidence 
of Grullon, Michaely and Swaminathan (2002). Moreover, the UK results suggest that earnings announcements have information power beyond that of dividend announcements, which is consistent with the conclusion of DeAngelo, DeAngelo and Skinner (1992), Conroy, Eades and Harris (2000) and Francis, Schipper and Vincent (2005), among others.

In chapter 4 we try to add another piece on the dividend "puzzle" by examining, in general, the effect of dividend announcements on future earnings conditioned to the relation between dividend change announcements and the market reaction. In particular, we tried to explore the events with a negative relation between dividend change announcements and the market reaction in the three-day window surrounding the dividend announcement date. For the events with a positive relation between dividend change announcements and the market reaction, the results provide weak evidence for the dividend information content hypothesis in what concerns the relationship between dividend changes and future earnings. For the enigmatic events with a negative relation between dividend change announcements and the market reaction, in global terms, we find no evidence of the dividend information content hypothesis in what concerns the relationship between dividend changes and future earnings. Furthermore, we find no evidence of the inverse signalling effect, except for the UK market, where we find a weak support to the hypothesis that for the events with a negative relation between dividend change announcements and the market reaction, future earnings are negatively associated with current dividend changes. This result suggests that the UK market investors have more capability to predict future earnings than the investors of the Portuguese and the French markets.

In chapter 5 we investigated whether firm-specific factors influence the market reaction to dividend change announcements. To do so, we formulate the hypothesis relating the firm specific factors to the market share price reaction surrounding the dividend change announcements date. Globally, our evidence fails to support that there are firm-specific factors that contribute in a consistent way to explain the abnormal market return for the Portuguese and the French markets. Considering both all the dividend change events and the dividend increase and decrease events separately, the only market where we have firm specific variables with power to explain the market abnormal returns in the announcement period is the UK. The explanatory variables that contribute in explaining the BHAR in the 3 days surrounding the dividend change announcements are the EG 
and the PER, for all the dividend change events, the percentage change of dividends, the $\mathrm{MB}$ ratio and the PER for dividend increases and the EG for dividend decreases. Moreover, the evidence suggests that firms with a negative market reaction to dividend increase announcements have, on average, higher size, lower earnings growth rate and lower debt to equity ratios. The results do not show a relation between firm specific characteristics and the probability of a positive market reaction to dividend decrease announcements, except for the French market, which tends to have, on average, lower PER. The reason behind failing to document the predicted sign in some coefficients could be an indication that it is associated with the opposite relation between dividend change announcements and the subsequent market reaction.

When we compared the means differences of the firm-specific variables between the events with a positive and a negative market reaction for both the dividend increase and dividend decrease events, we documented that, for the dividend increase events, the firm size, the market to book ratio and the price-earnings ratio tend to be higher for the events with a negative market reaction. The percentage change of dividends, the earnings growth and the debt to equity ratio tend to be lower for the events with a negative market reaction. These results could be interpreted as an indication that investors penalise dividend increases when they have a lower magnitude, when the past earnings growth are lower and when firms have a strong growth prospects but increase dividends instead of retain them to finance new projects and suggests that the market can react positively to dividend decreases if past earnings have grown.

Overall, we do not find support for the dividend signalling content hypothesis, which is consistent with some recent studies, such as those of DeAngelo, DeAngelo and Skinner (1996), Benartzi, Michaely and Thaler (1997) and Benartzi et al. (2005). The weak support we find for this hypothesis is associated with the UK market, where information asymmetry is higher than in the other two countries, which leads us to believe that in market-based systems managers tend to use dividends, in some extent, as a mechanism to mitigate the information asymmetry, which is in accordance with Lasfer and Zenonos (2004) evidence. In France and in Portugal, countries characterised by a bank-based system, and where information asymmetry is lower than in the UK, there is no need to use dividends to convey information to the market, being the signalling effect of dividends less important, which results validate the ones of Aivazian, Booth and Cleary (2003a) and Goergen, Renneboog and Silva (2005). Furthermore, this evidence is 
consistent with the axiom that there is a smaller signalling function in the bank-based system.

The discussion of our contribution in methodology is important for several reasons. In fact, the extensions we develop beyond the classical methodology provide additional evidence regarding the information content of dividend hypothesis. It provides a deeper analysis in the dividend policy field and affords an additional insight into the cases where the market reacts differently than is theoretically expected according to the dividend policy signalling hypothesis. Finally, it contributes to go further in the analysis of the relation between firm-specific variables and the market reaction to dividend change announcements.

\subsection{SUGGESTIONS FOR FUTURE RESEARCH}

The issue of the information content of dividends is far from been solved. As Black (1976, p. 5) comments: “What should corporations do about dividend policy? We don't know”. Although this statement is from 1976, it is still applicable nowadays. Very recently, about the dividend subject, Chu and Partington (2005, p. 2) state that "(...) this remains a controversial issue". Thus, the research in this domain of corporate finance is still not over.

In terms of suggestions for future research in this field, we wish to consider particular aspects that can improve the methodology as well as the empirical results and the subsequent conclusions of this study. The key suggestions are:

- Split the UK sample into sub-periods in order to analyse the impact of a major change in dividend taxation introduced in the UK in July, 2, 1997: the Finance Act 1997 (FA97). Before the FA97 reforms, the UK tax system was relatively unusual in discriminating in favour of dividend distributions, compared with retention of profit within the firm;

- Try to obtain information about dividend forecasts in order to consider them when computing unexpected dividend changes, considering the difference between the dividend announced and the dividend forecast. If we could not manage this data, we might consider a proxy for the forecasts of dividends; 
- Relate dividend and earnings announcements as well as earnings forecasts in order to see whether the information conveyed by a dividend change announcement depends on the earnings announcements or on the reliability of earnings forecasts before the dividend change announcements;

- Consider only dividend change announcements with a significant magnitude. The information conveyed by higher dividend change announcements Benesh, Keown and Pinkerton (1984) and Grullon, Michaely and Swaminathan (2002) might allow for a better assessment of the market reaction to dividend change announcements;

- Try to identify when a dividend increase announcement could be bad news, and when a dividend decrease announcement could be good news;

- Extent the approach to other markets and analyse them together. We would like to see whether different country results could be associated with civil versus common law based countries, with bank versus market based system countries or with the degree of ownership concentration.

A possible path of future research might be the consideration of control macroeconomic variables, such as the market growth and the market liquidity, to see if it has some influence on the dividend policy and on the relationship between the dividend policy and the share prices, as well as country-specific variables, such as taxes and a variable to distinguish between bank-based and market-based system countries, with the purpose of analysing the different behaviour among the samples considered in the study.

Another suggestion for future research might be the examination with more detail of the maturity hypothesis related with dividend policy, as we have found some support for this hypothesis.

Finally, we would like to develop a theoretical model to predict consistent versus not consistent market reactions to dividend change announcements, in the context of the dividend signalling hypothesis. 


\section{APPENDICES}




\section{Appendix 1}

\section{Variable definitions}

This table provides the variable names and its definitions

\begin{tabular}{|c|c|}
\hline Variable & Definition \\
\hline $\mathrm{P}_{\mathrm{t}}$ & Market value, or price, of the firm's equity at date t \\
\hline $\mathrm{d}_{\mathrm{i}, \mathrm{t}}$ & Dividends of share i paid at date $t$ \\
\hline $\mathrm{d}^{*}{ }_{\mathrm{i}, \mathrm{t}}$ & Desired dividends of share i paid at date $t$ \\
\hline $\mathrm{i}$ & Target payout ratio for share $\mathrm{i}$ \\
\hline$a_{i}$ & Constant, related to dividend growth for share i \\
\hline$c_{i}$ & Partial adjustment factor for share $\mathrm{i}$ \\
\hline$e_{t}$. & Expected value operator conditioned on the date $t$ information \\
\hline $\mathrm{D}_{\mathrm{i}, \mathrm{t}}$ & Dividend per share $\mathrm{i}$ announced in year $\mathrm{t}$ \\
\hline $\mathrm{EPS}_{\mathrm{i}, \mathrm{t}}$ & Earnings per share $\mathrm{i}$ in year $\mathrm{t}$ \\
\hline DIEI & $\begin{array}{l}\text { Dummy variable that takes value } 1 \text { if both dividend and earnings increases and } 0 \text { otherwise } \\
\text { (UK market) }\end{array}$ \\
\hline DIED & $\begin{array}{l}\text { Dummy variable that takes value } 1 \text { if dividend increases and earnings decreases and } 0 \\
\text { otherwise (UK market) }\end{array}$ \\
\hline DDEI & $\begin{array}{l}\text { Dummy variable that takes value } 1 \text { if dividend decreases and earnings increases and } 0 \\
\text { otherwise (UK market) }\end{array}$ \\
\hline DDED & $\begin{array}{l}\text { Dummy variable that takes value } 1 \text { if both dividend and earnings decreases and } 0 \\
\text { otherwise (UK market) }\end{array}$ \\
\hline $\mathrm{D}_{\mathrm{i}, \mathrm{t}}$ & Change of dividend per share i for year $\mathrm{t}$ \\
\hline $\mathrm{P}_{\mathrm{i}, 0}$ & Price of share $\mathrm{i}$ in the announcement day \\
\hline $\mathrm{AR}_{\mathrm{i}, \mathrm{t}}$ & Abnormal return for share $\mathrm{i}$ in day $\mathrm{t}$ \\
\hline $\mathrm{R}_{\mathrm{i}, \mathrm{t}}$ & Return for share $\mathrm{i}$ in day $\mathrm{t}$ \\
\hline $\mathrm{R}_{\mathrm{f}, \mathrm{t}}$ & Risk-free rate in day $\mathrm{t}$ \\
\hline $\mathrm{R}_{\mathrm{m}, \mathrm{t}}$ & Market return for day $\mathrm{t}$ \\
\hline $\mathrm{i}$ & Systematic risk of share $\mathrm{i}$ \\
\hline CAR & Cumulative abnormal return \\
\hline BHAR & Buy-and-hold abnormal return \\
\hline CAAR & Cumulative adjusted abnormal return \\
\hline $\mathrm{CAR}_{3}$ & $\begin{array}{l}\text { Cumulative abnormal return for share } \mathrm{i} \text { on the } 3 \text {-day period, as formulated in the } 3 \\
\text { approaches: CAR; BHAR or CAAR }\end{array}$ \\
\hline DI & Dummy variable that takes value 1 if dividend increases and zero otherwise \\
\hline $\mathrm{DD}$ & Dummy variable that takes value 1 if dividend decreases and zero otherwise \\
\hline $\mathrm{E}_{\mathrm{i}, \mathrm{t}}$ & Earnings before extraordinary items for share $\mathrm{i}$ in year $\mathrm{t}$ \\
\hline
\end{tabular}




\section{Appendix 1}

\section{Variable definitions (continued)}

\begin{tabular}{|c|c|}
\hline Variable & Definition \\
\hline $\mathrm{BV}_{\mathrm{i}, \mathrm{t}}$ & Book value of equity for share $i$ at the end of year $t$ \\
\hline $\mathrm{ROE}_{\mathrm{i},-1}$ & Return on equity for share $\mathrm{i}$, calculated as $\mathrm{E}_{\mathrm{i},-1} / \mathrm{BV}_{\mathrm{i},-1}$ \\
\hline $\mathrm{DFE}_{\mathrm{i}, 0}$ & $\mathrm{ROE}_{\mathrm{i}, 0}-\mathrm{E} \mathrm{ROE}_{\mathrm{i}, 0}$ \\
\hline $\mathrm{E} \mathrm{ROE}_{\mathrm{i}, 0}$ & $\begin{array}{l}\text { Fitted value from the cross-sectional regression of } \mathrm{ROE}_{\mathrm{i}, 0} \text { on the } \log \text { of total assets in year - } \\
1 \text {, the market-to-book ratio of equity in year }-1 \text {, and } \mathrm{ROE}_{\mathrm{i}-1}\end{array}$ \\
\hline $\mathrm{CE}_{\mathrm{i}, 0}$ & $\left(\mathrm{E}_{\mathrm{i}, 0}-\mathrm{E}_{\mathrm{i},-1}\right) / \mathrm{BV}_{\mathrm{i},-1}$ \\
\hline $\mathrm{NDFED}_{0}$ & Dummy variable that takes value 1 if $\mathrm{DFE}_{\mathrm{i}, 0}$ is negative and 0 otherwise \\
\hline $\mathrm{PDFED}_{0}$ & Dummy variable that takes value 1 if $\mathrm{DFE}_{\mathrm{i}, 0}$ is positive and 0 otherwise \\
\hline $\mathrm{NCED}_{0}$ & Dummy variable that takes value 1 if $\mathrm{CE}_{\mathrm{i}, 0}$ is negative and 0 otherwise \\
\hline $\mathrm{PCED}_{0}$ & Dummy variable that takes value 1 if $\mathrm{CE}_{\mathrm{i}, 0}$ is positive and 0 otherwise \\
\hline $\mathrm{PM}_{\mathrm{i}}$ & $\begin{array}{l}\text { Profitability measure that consists of five financial performance measures (ROA, ROE, } \\
\text { D/E, WCR and CF) at date }\end{array}$ \\
\hline $\mathrm{ROA}_{\mathrm{i}}$ & $\begin{array}{l}\text { Return on assets for share i, computed as operating income before depreciation divided by } \\
\text { book value of assets at the end of year }\end{array}$ \\
\hline $\mathrm{ROE}_{\mathrm{i}}$ & Return on equity for share $\mathrm{i}$, at the end of year \\
\hline $\mathrm{D} / \mathrm{E}_{\mathrm{i}}$ & $\begin{array}{l}\text { Debt to equity ratio for share i, calculated as the book value of total debt divided by the } \\
\text { total book capital at the end of year }\end{array}$ \\
\hline $\mathrm{WCR}_{\mathrm{i}}$, & $\begin{array}{l}\text { Working capital ratio for share } \mathrm{i} \text {, computed as total current assets divided by total current } \\
\text { liabilities at the end of year }\end{array}$ \\
\hline $\mathrm{CF}_{\mathrm{i}}$ & $\begin{array}{l}\text { Cash flow for share i, computed as operating income before depreciation minus interest } \\
\text { expense, income taxes and preferred stock dividends scaled by the total assets at the end of } \\
\text { year }\end{array}$ \\
\hline $\mathrm{DI}_{\mathrm{i}, 0}$ & Dividend increase changes per share $\mathrm{i}$ in the announcement year \\
\hline $\mathrm{ROA}_{\mathrm{i}, 2}$ & $\begin{array}{l}\text { Measure of the abnormal change in profitability during the two years after dividend } \\
\text { changes, computes as }\left(\mathrm{ROA}_{\mathrm{i}, 2}+\mathrm{ROA}_{\mathrm{i}, 1}\right) / 2-\mathrm{ROA}_{\mathrm{i}, 0}\end{array}$ \\
\hline $\mathrm{SG}_{\mathrm{i}, 0}$ & Sales growth rate for share $i$, computed as a percentage of the previous year's sales \\
\hline $\mathrm{SG}_{\mathrm{i}, 2}$ & $\begin{array}{l}\text { Change in } \mathrm{SG} \text { during the two years after the dividend changes, computes ad }\left(\mathrm{SG}_{\mathrm{i}, 2}+\right. \\
\left.\mathrm{SG}_{\mathrm{i}, 1}\right) / 2-\mathrm{SG}_{\mathrm{i}, 0}\end{array}$ \\
\hline $\mathrm{CE}_{\mathrm{i}, 0}$ & $\begin{array}{l}\text { Capital expenditure for share i, calculated as capital expenditures to the beginning of year } \\
\text { total assets }\end{array}$ \\
\hline $\mathrm{CE}_{\mathrm{i}, 2}$ & $\begin{array}{l}\text { Change in } \mathrm{CE} \text { during the two years after the dividend changes, computed as }\left(\mathrm{CE}_{\mathrm{i}, 2}+\right. \\
\left.\mathrm{CE}_{\mathrm{i}, 1}\right) / 2-\mathrm{CE}_{\mathrm{i}, 0}\end{array}$ \\
\hline$P_{i, d}$ & Price per share $\mathrm{i}$ on the day after the dividend announcement \\
\hline BVPS $_{i,-1}$ & Book value per share $i$ at the end of year -1 relative to the dividend event year (year 0 ) \\
\hline PRDI & $\begin{array}{l}\text { Dummy variable that takes value } 1 \text { if there is a positive reaction to dividend increases and } \\
0 \text { otherwise }\end{array}$ \\
\hline NRDD & $\begin{array}{l}\text { Dummy variable that takes value } 1 \text { if there is a negative reaction to dividend decreases and } \\
0 \text { otherwise }\end{array}$ \\
\hline
\end{tabular}

(Continue) 


\section{Appendix 1}

\section{Variable definitions (continued)}

\begin{tabular}{|c|c|}
\hline Variable & Definition \\
\hline PRDIEI & $\begin{array}{l}\text { Dummy variable that takes value } 1 \text { if there is a positive reaction to both dividend and } \\
\text { earnings increases and } 0 \text { otherwise (UK market) }\end{array}$ \\
\hline PRDIED & $\begin{array}{l}\text { Dummy variable that takes value } 1 \text { if there is a positive reaction to dividend increases and } \\
\text { earnings decreases and } 0 \text { otherwise (UK market) }\end{array}$ \\
\hline NRDDEI & $\begin{array}{l}\text { Dummy variable that takes value } 1 \text { if there is a negative reaction to dividend decreases and } \\
\text { earnings increases and } 0 \text { otherwise (UK market) }\end{array}$ \\
\hline NRDDED & $\begin{array}{l}\text { Dummy variable that takes value } 1 \text { if there is a negative reaction to both dividend and } \\
\text { earnings decreases and } 0 \text { otherwise (UK market) }\end{array}$ \\
\hline NRDI & $\begin{array}{l}\text { Dummy variable that takes value } 1 \text { if there is a negative reaction to dividend increases and } \\
0 \text { otherwise }\end{array}$ \\
\hline PRDD & $\begin{array}{l}\text { Dummy variable that takes value } 1 \text { if there is a positive reaction to dividend decreases and } \\
0 \text { otherwise }\end{array}$ \\
\hline NRDIEI & $\begin{array}{l}\text { Dummy variable that takes value } 1 \text { if there is a negative reaction to both dividend and } \\
\text { earnings increases and } 0 \text { otherwise (UK market) }\end{array}$ \\
\hline NRDIED & $\begin{array}{l}\text { Dummy variable that takes value } 1 \text { if there is a negative reaction to dividend increases and } \\
\text { earnings decreases and } 0 \text { otherwise (UK market) }\end{array}$ \\
\hline PRDDEI & $\begin{array}{l}\text { Dummy variable that takes value } 1 \text { if there is a positive reaction to dividend decreases and } \\
\text { earnings increases and } 0 \text { otherwise (UK market) }\end{array}$ \\
\hline PRDDED & $\begin{array}{l}\text { Dummy variable that takes value } 1 \text { if there is a positive reaction to both dividend and } \\
\text { earnings decreases and } 0 \text { otherwise (UK market) }\end{array}$ \\
\hline $\mathrm{FS}_{\mathrm{i}}$ & $\begin{array}{l}\text { Firm size for share i, computed as the natural log of market value of common equity at the } \\
\text { end of the year before the dividend change year }\end{array}$ \\
\hline $\mathrm{PCD}_{\mathrm{i}}$ & $\begin{array}{l}\text { Percentage change of dividends for share } \mathrm{i} \text {, computed as the annual change in dividends } \\
\text { divided by the share price in the announcement day }\end{array}$ \\
\hline $\mathrm{EG}_{\mathrm{i}}$ & $\begin{array}{l}\text { Earnings growth rate for share i, computed as the average earnings growth rate based on } \\
\text { the year prior to the dividend change year }\end{array}$ \\
\hline $\mathrm{MB}_{\mathrm{i}}$ & $\begin{array}{l}\text { Market to book ratio for share i, calculated by dividing the market price per share at the } \\
\text { dividend change announcement date by the book value per share at the end of the year } \\
\text { before the dividend change year }\end{array}$ \\
\hline $\mathrm{PER}_{\mathrm{i}}$ & $\begin{array}{l}\text { Price earning ratio for share } \mathrm{i} \text {, computed as the price per share at the announcement date } \\
\text { divided by the earnings per share at the end of the year before the dividend change year }\end{array}$ \\
\hline $\mathrm{DE}_{\mathrm{i}}$ & $\begin{array}{l}\text { Debt/equity ratio for share } \mathrm{i} \text {, calculated as the book value of total debt divided by the total } \\
\text { book value of equity at the end of the year prior to the dividend change announcement }\end{array}$ \\
\hline BHARI $_{i,-1 \text { to }+1}$ & Dummy variable that takes value 1 if $\mathrm{BHAR}_{\mathrm{i},-1 \text { to }+1}$ is negative and 0 otherwise \\
\hline BHARD $_{i,-1}$ to +1 & dummy variable that takes value 1 if $\mathrm{BHAR}_{\mathrm{i}, 1 \text { to }+1}$ is positive and 0 otherwise \\
\hline LPCD & Natural logarithm of $(\mathrm{PCD}+1)$ \\
\hline LEG & Natural logarithm of $(\mathrm{EG}+1)$ \\
\hline LMB & Natural logarithm of $(\mathrm{MB}+1)$ \\
\hline LPER & Natural logarithm of $(\mathrm{PER}+1)$ \\
\hline LDE & Natural logarithm of $(\mathrm{DE}+1)$ \\
\hline
\end{tabular}




\section{Appendix 2}

F test for the significance of the firms' effects in panel data analysis

The $\mathrm{F}$ test to test the significance of the group effects implies a test of the hypothesis that i equals zero. Symbolically, the null hypothesis to be tested is:

$$
\begin{aligned}
& \mathrm{H}_{0}: \quad{ }_{1}={ }_{2}=\ldots \quad \text { n } \quad \mathrm{i}=1,2, \ldots \mathrm{n} \\
& \mathrm{H}_{\mathrm{a}}: \quad \text { i } \quad \text { j (i } \quad \text { j) } \quad \mathrm{t}=1,2, \ldots \mathrm{T}
\end{aligned}
$$

The $\mathrm{F}$ ratio used for the test is:

$$
F(\mathrm{n}-1, \mathrm{nT}-\mathrm{n}-\mathrm{K})=\frac{\left(\mathrm{R}_{\mathrm{SR}}^{2}-\mathrm{R}_{\mathrm{CR}}^{2}\right) /(n-1)}{\left(1-R_{S R}^{2}\right) /(n T-n-K)}
$$

where SR indicates the fixed effects model and CR indicates the common effects model with only a single overall constant term.

If the panels are unbalanced, adjustments to the total counts are made. By using the number of observations in the regression instead of $\mathrm{nT}$ to account for the total number of observations, proper $\mathrm{F}$ test is computed.

If we do not reject the null hypothesis that i equals zero, we do not need to analyse the fixed and random models, and we will analyse the pooled OLS results. On the other hand, if we reject the null hypothesis that i equals zero, we will have differences among the firms, and we will analyse the fixed and random effects model estimators. 


\section{Appendix 3}

Hausman's (1978) test

The Hausman test is a formal test that can help us to choose between the fixed and the random effects model. The null hypothesis underlying the Hausman test is that the FEM and the REM estimators do not differ substantially. Symbolically, the null hypothesis to be tested is:

$$
\begin{aligned}
& \mathrm{H}_{0}: \operatorname{plim}\left(\hat{\beta}_{\mathrm{FE}}-\hat{\beta}_{R E}\right)=0 \\
& \mathrm{H}_{\mathrm{a}}: \operatorname{plim}\left(\hat{\beta}_{\mathrm{FE}}-\hat{\beta}_{R E}\right) \neq 0
\end{aligned}
$$

The general idea of the Hausman test is that two estimators are compared: one which is consistent under both the null and alternative hypothesis and one which is consistent under the null hypothesis only. A significant difference between the two estimators indicates that the null hypothesis is unlikely to hold.

The steps for carrying out the Hausman test are as follows:

1) Compute the Hausman test statistic as:

$$
t_{H}=\left(\hat{\beta}_{\mathrm{FE}}-\hat{\beta}_{R E}\right)^{\prime}\left[\hat{\mathrm{V}}\left\{\hat{\beta}_{F E}\right\}-\hat{\mathrm{V}}\left\{\hat{\beta}_{R E}\right\}\right]-{ }^{1}\left(\hat{\beta}_{F E}-\hat{\beta}_{R E}\right)
$$

where the $\hat{V} s$ denote estimates of the true covariance matrices;

2) The test statistic developed by Hausman has an asymptotic Chi-squared distribution with $\mathrm{K}$ degrees of freedom, ${ }_{\mathrm{k}}^{2}$, where $\mathrm{K}$ is the number of elements in ;

3) A test of significance level is given by the decision rule:

$$
\text { Reject } \mathrm{H}_{0} \text { if } \mathrm{t}_{\mathrm{H}}>{ }^{2}(\mathrm{k}) \text {, }
$$

If the null hypothesis is rejected, the conclusion is that REM is not appropriate and that we may be better off using the FEM, in which case statistical inferences will be conditional on the ${ }_{i}$ in the sample. 


\section{Appendix 4}

White's (1980) test

One of the important assumptions of the classical linear regression model is the assumption of homoscedasticity, i.e., the variance of each disturbance term, $u_{i}$, conditional on the chosen values of the explanatory variables, is a constant number equal to ${ }^{2}$. Symbolically:

$$
\mathrm{E}\left(\mathrm{u}_{\mathrm{i}}^{2}\right)=2 \quad \mathrm{i}=1,2, \ldots, \mathrm{n}
$$

The steps for carrying out White's test for heteroscedasticity are the following:

1) Estimate the main regression by the OLS procedure, obtain the residuals and square it;

2) Regress the squared residuals against a constant, all the explanatory variables in the main regression, their squared values, and the cross products of the regressors. If some of the explanatory variables are dummy variables, the squared term will be equal to the original variable, and hence should not be included separately, as otherwise there will be exact multicollinearity and the regression cannot be run;

3) Compute the statistic $n \cdot R^{2}$, where $n$ is the number of observations and $R^{2}$ is the unadjusted R-squared from the auxiliary regression on step 2. The statistic $n . R^{2}$ is asymptotically distributed as a chi-squared with $p$ degrees of freedom, ${ }_{\mathrm{p}}^{2}$, where $\mathrm{p}$ is the number of regressors, excluding the constant term, that is,

$$
n \cdot R^{2} \underset{\text { asy }}{\sim} \chi_{d f}^{2}
$$

4) If the chi-square value obtained exceeds the critical chi-square value at the chosen level of significance, the conclusion is that there is heteroscedasticity. 


\section{Appendix 5}

\section{Kruskal-Wallis Test}

The Kruskal-Wallis test is a nonparametric test based on the ranks of the sample observations that permits to test the null hypothesis that the k population means ( ) are the same. Symbolically, the null hypothesis to be tested is:

$$
\begin{aligned}
& \mathrm{H}_{0}: \quad{ }_{1}={ }_{2}={ }_{\mathrm{i}}=\ldots={ }_{k} \\
& \mathrm{H}_{\mathrm{a}}: \quad \mathrm{i} \quad \mathrm{j}, \quad \mathrm{i}, \mathrm{j}
\end{aligned}
$$

The steps for carrying out the Kruskal-Wallis test are as follows:

1) Pool the sample observations together and rank them in ascending order, using the average of adjacent ranks in the case of ties;

2) Compute the Kruskal-Wallis (KW) statistic:

$$
K W=\frac{12}{n(n+1)} \sum_{i=1}^{k} \frac{R_{i}^{2}}{n_{i}}-3(n+1)
$$

where $\mathrm{k}$ is the number of samples; $\mathrm{n}_{\mathrm{i}}$ are the sample sizes; $\mathrm{n}$ denote the total number of sample observations $\left(n=n_{1}+n_{2}+\ldots+n_{k}\right)$ and $R_{i}$ are the sums of ranks for the k samples;

3) The distribution is well approximated by the chi-squared distribution with (k-1) degrees of freedom, ${ }_{(\mathrm{k}-1)}^{2}$, that is,

$$
K W \underset{\text { asy }}{\sim} \chi_{(k-1)}^{2}
$$

4) A test of significance level is given by the decision rule:

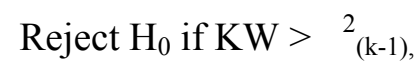


BIBLIOGRAPHY 


\section{REFERENCES}

Abeyratna, Gunasekarage and Power, David M., 2002, "The Post-announcement Performance of Dividend-changing Companies: The Dividend-signalling Hypothesis Revisited", Accounting and Finance 42, 131-151.

Achen, Chistopher H., 1982, "Interpreting and Using Regression", Sage Publications, Beverly Hills, California, 82-83, in Gujarati, Damodar N., 2003, Basis Econometrics, Fourth Edition, McGraw-Hill, Irwin.

Aharony, Joseph and Dotan, Amihud, 1994, "Regular Dividend Announcements and Future Unexpected Earnings: An Empirical Analysis", The Financial Review 29 (1), 125-151.

Aharony, Joseph and Swary, Itzhak, 1980, "Quarterly Dividend and Earnings Announcements and Stockholders' Returns: An Empirical Analysis", The Journal of Finance 35 (1), 1-12.

Aivazian, Varouj, Booth, Laurence and Cleary, Sean, 2002, "Why Some Firms Smooth their Dividends and Why Others Don't?", Working Paper, Rotman School of Management, University of Toronto.

Aivazian, Varouj, Booth, Laurence and Cleary, Sean, 2003a, "Dividend Policy and the Organization of Capital Markets", Journal of Multinational Financial Management 13 (2), 101-121.

Aivazian, Varouj, Booth, Laurence and Cleary, Sean, 2003b, "Do Emerging Market Firms Follow Different Dividend Policies from U.S. Firms?", The Journal of Financial Research 26 (3), 371-388.

Allen, Dave E. and Rachim, Veronica S., 1996, "Dividend Policy and Stock Price Volatility: Australian Evidence", Applied Financial Economics 6 (2), 175-188.

Allen, David E. and Izan, H. Y., 1992, "Dividend Policy: The Issues”, Managerial Finance 18 (1), 1-8.

Allen, Franklin, Bernardo Antonio E. and Welch, Ivo, 2000, "A Theory of Dividends Based on Tax Clientele", The Journal of Finance 55 (6), 2499-2536.

Allen, Franklin and Michaely, Roni, 2003, Payout Policy, North-Holland Handbook of Economics, Amsterdam, Elsevier, North-Holland, Chapter 7, 337-429.

Ambarish, Ramasastry, John, Kose and Williams, Joseph, 1987, "Efficient Signalling with Dividends and Investments", The Journal of Finance 42 (2), June, 321-343.

Amihud, Yakov and Li, Kefei, 2002, "The Declining Information Content of Dividend Announcements and the Effect of Institutional Holdings", Working Paper, Stern School of Business, New York University.

Amihud, Yakov and Murgia, Maurizio, 1997, "Dividends, Taxes, and Signalling: Evidence from Germany", The Journal of Finance 52 (1), 397-408.

Ang, James S. and Peterson, David R., 1985, "Return, Risk, and Yield: Evidence from Ex Ante Data", The Journal of Finance 40 (2), 537-548.

Arnott, Robert D. and Asness, Cliford S., 2001, "Does Dividend Policy Foretell Earnings Growth?", Working Paper, SSRN Working Papers. 
Arnott, Robert D. and Asness, Cliford S., 2003, "Surprise! Higher Dividends = Higher Earnings Growth", Financial Analysts Journal, 70-87.

Asquith, Paul and Mullins, David W., 1983, "The Impact of Initiating Dividend Payments on Shareholder Wealth", The Journal of Business 56 (1), 77-96.

Auerbach, Alan J. and Hasset, Kevin A., 2000, "On the Marginal Source of Investment Funds", NBER Working Paper $\mathrm{n}^{\circ}$ W7821.

Bailey, Warren, 1988, "Canada's Dual Class Shares: Further Evidence on the Market Value of Cash Dividends", The Journal of Finance 43 (4), 1143-1160.

Baker, H. Kent, Powell, Gary E. and Veit, E. Theodore, 2002, "Revisiting Managerial Perspectives on Dividend Policy", Journal of Economics and Finance 26 (3), 267-283.

Baker, Malcolm P. and Wurgler, Keffreu, 2002, "Why are Dividends Disappearing? An Empirical Analysis", Harvard NOM Working Paper nº 03-12.

Ball, Ray J. and Watts, Ross, 1972, "Some Time Series Properties of Accounting Income", The Journal of Finance 27 (3), 663-681.

Baltagi Badi H., 1995, Econometric Analysis of Panel Data, Wiley, Chichester.

Baltagi Badi H. and Chang, Young-Jae, 1994, "Incomplete Panels: A Comparative Study of Alternative Estimators for the Unbalanced One-way Error Component Regression Model", Journal of Econometrics 62 (2), 67-89.

Banerjee, Suman, Gatchev, Vladimir A. and Spindt, Paul A., 2002, "To Pay or not to Pay? The Dividend Dilemma of the Liquid Firm", Working Paper, Freeman School of Business, Tulane University.

Barber, Brad M. and Lyon, John. D., 1997, "Detecting Long-run Abnormal Stock Returns: The Empirical Power and Specification of Test Statistics?", Journal of Financial Economics 43 (3), 341-372.

Beiner, Stefan, 2001, “Theories and Determinants of Dividend Policy”, Working Paper, Universitat St. Gallen.

Bell, Leonie and Jenkinson, Tim, 2002, "New Evidence of the Impact of Dividend Taxation and on the Identity of the Marginal Investor", The Journal of Finance 57 (3), 1321-1346.

Benartzi, Shlomo, Grullon, Gustavo, Michaely, Roni and Thaler, Richard, 2005, "Dividend Changes do not Signal Changes in Future Profitability", The Journal of Business, 78 (5), forthcoming.

Benartzi, Shlomo, Michaely, Roni and Thaler, Richard, 1997, "Do Changes in Dividends Signal the Future or the Past?", The Journal of Finance 52 (3), 1007-1034.

Benesh, Gary A., Keown, Arthur J. and Pinkerton, John M., 1984, “An Examination of Market Reaction to Substantial Shifts in Dividend Policy", The Journal of Financial Research 7 (2), 131-142.

Benzinho, José M., 2004, "The Dividend Policy of the Portuguese Corporations: Evidence from Euronext Lisbon", Working Paper, SSRN Working Papers.

Bernheim, B. Douglas, 1991, "Tax Policy and the Dividend Puzzle", RAND Journal of Economics 22 (4), 455-476. 
Bernheim, B. Douglas and Wantz, Adam, 1995, "A Tax-Based Test of the Dividend Signaling Hypothesis", The American Economic Review 85 (3), 532-551.

Bernstein, Peter L., 2001, "The Real Economy and the Unreal Economy", Economics \& Portfolio Strategy, Peter L. Bernstein, Inc., in Arnott, Robert D. and Asness, Clifford S., 2001, "Does Dividend Policy Foretell Earnings Growth?”, Working Paper, SSRN Working Papers.

Bhattacharya, Sudipto, 1979, "Imperfect Information, Dividend Policy, and 'The Bird in the Hand Fallacy", Bell Journal of Economics 10 (1), 259-270.

Billings, Bruce K. and Morton, Richard M., 1999, "Do Stock Prices Fully Reflect Information in Dividends about Future Earnings?", Working Paper, Florida State University.

Black, Fischer, 1976, "The Dividend Puzzle", The Journal of Portfolio Management, Winter 2 (2), 5-8.

Black, Fischer and Scholes, Myron 1974, "The Effects of Dividends Yield and Dividend Policy on Common Stock Prices and Returns", Journal of Financial Economics 1 (1), 1-22.

Boehme, Rodney D. and Sorescu, Sorin. M., 2002, “The Long-run Performance Following Dividend Initiations and Resumptions: Underreaction or Product of Chance?", The Journal of Finance 57 (2), 871-900.

Born, Jeffery A., Moser, James T. and Officer, Dennis T., 1988, "Changes in Dividend Policy and Subsequent Earnings", Journal of Portfolio Management 14 (4), 56-62.

Borokhovich, Kenneth A., Brunarski, Kelly R., Harman, Yvette and Kehr, James, 2004, "Dividends, Firm Value and Agency Costs", Working Paper presented at 2004 FMA Annual Meeting.

Bradley, Michael, Capozza, Dennis R. and Seguin, Paul J., 1998, "Dividend Policy and Cash-Flow Uncertainty”, Real State of Economics 26 (4), 555-580.

Bratton, William W., 2005, “The New Dividend Puzzle”, Georgetown Law Journal 93 (3), forthcoming.

Brav, Alon, Graham, John R., Harvey, Campbell R. and Michaely, Roni, 2005, "Payout Policy in the 21st Century", Journal of Financial Economics 77 (3), 483-528.

Brealey, Richard, A and Myers, Stewart, C., 1998, Princípios de Finanças Empresariais, $5^{\text {a }}$ Edição, McGraw-Hill.

Brealey, Richard, A, Myers, Stewart, C. and Marcus, Alan C., 2001, Fundamentals of Corporate Finance, 3rd Edition, McGraw Hill.

Brennan, Michael J., 1970, “Taxes, Market Valuation and Corporate Financial Policy”, National Tax Journal 23 (4), 417-427.

Brickley, James, A., 1983, "Shareholder Wealth, Information Signalling and the Specially-Designated Dividend: An Empirical Study", Journal of Financial Economics $12(2), 187-210$.

Brook, Yaron, Charlton, William T. Jr. and Hendershott, Robert J., 1998, "Do Firms Use Dividends to Signal Large Future Cash Flow Increases?", Financial Management 27 (3), 46-57. 
Brooks, LeRoy and Buckmaster, Dale, 1976, "Further Evidence on the Time Series Properties of Accounting Income", The Journal of Finance 31 (4), 1359-1373.

Brown, Lawrence D. and Rozeff, Michael, 1979, "Univariate Time Series Models of Quarterly Accounting Earnings per Share", Journal of Accounting Research, 17 (1), 179-189.

Brown, Stephan J. and Warner, Jerold B., 1985, "Using Daily Stock Returns - The Case of Event Studies", Journal of Financial Economics 14 (1), 3-31.

Buckley, Adrian, Ross, Stephen A., Westerfield, Randolph W. and Jaffe, Jefrey F., 1998, Corporate Finance: Europe, 1st Edition, McGraw-Hill International (UK) Limited.

Bulan, Laarni T., Subramanian, Narayanan and Tanlu, Loyd D., 2004, "On the Timing of Dividend Initiations", Working Paper, SSRN Working Papers.

Chang, Suckjeong J. and Chen, Son-Nan, 1991, "Information Effects of Earnings and Dividend Announcements on Common Stock Returns: Are They Interactive?", Journal of Economics and Business 43 (3), 179-192.

Charest, Guy, 1978, "Dividend Information, Stock Returns and Market Efficiency: Part II", Journal of Financial Economics 6 (2-3), 297-330.

Chen, Chung and Wu, Chunchi, 1999, "The Dynamics of Dividends, Earnings and Prices: Evidence and Implications for Dividend Smoothing and Signalling", Journal of Empirical Finance 6 (1), 29-58.

Chen, Gongmeng, Firth, Michael and Gao, Ning, 2002, "The Information Content of Concurrently Announced Earnings, Cash Dividends, and Stock Dividends: An Investigation of the Chinese Stock Market", Journal of International Financial Management \& Accounting 13 (2), 101-124.

Chen, Nai-Fu, Grundy, Bruce and Stambaugh, Robert F., 1990, "Changing Risk, Changing Risk Premiums, and Dividend Yield Effects”, Journal of Business 63 (1), 5170 .

Choe, Hyuk, 1990, "Intertemporal and Cross-sectional Variation of Corporate Dividend Policy", Dissertation Manuscript, University of Chicago, in Dewenter, Kathryn L. and Warther, Vincent A., 1998, "Dividends, Asymmetric Information, and Agency Conflicts: Evidence from a Comparison of the Dividend Policies of Japanese and U.S. Firms", The Journal of Finance 53, (3), 879-904.

Christie, William G., 1994, "Are Dividends Omissions Truly the Cruellest Cut of All?", Journal of Financial and Quantitative Analysis 29 (3), 459-480.

Chu, Hung and Partington, Graham, 2005, "The Market Valuation of Cash Dividends: The Case of the CRA Bonus Issue", Working Paper presented at 2005 Annual Meeting of EFMA.

Conroy, Robert M., Eades, Kenneth M. and Harris, Robert S., 2000, "A Test of the Relative Pricing Effects of Dividends and Earnings: Evidence from Simultaneous Announcements in Japan”, The Journal of Finance 55 (3), 1199-1227.

Copeland, Thomas E. and Weston, J. Fred, 1992, Financial Theory and Corporate Policy, 3 rd Edition Addison-Wesley Publishing Company.

Crama, Yves, Leruth, Luc, Renneboog, Luc and Urbain, Jean-Pierre, 2003, "Corporate Governance Structures, Control and Performance in European Markets: A 
Tale of Two Systems", Social Responsibility: Corporate Governance Issues 17 (1), 125-151.

Curto, J. J. Dias, 2002, Lições de Econometria, Texts of support to the course of "Event Studies in Finance", taught in the PhD. classes during the 2001/2002 scholar year.

Cyert, Richard, Kang, Sok-Hyon and Kumar, Praveen, 1996, "Managerial Objectives and Firm Dividend Policy: A Behavioral Theory and Empirical Evidence", Journal of Economic Behavior \& Organization 31 (2), 157-174.

Damodaran, Aswath, 1997, Corporate Finance: Theory and Practice, New York: John Wiley and Sons, Inc.

DeAngelo, Harry and DeAngelo Linda, 1990, "Dividend Policy and Financial Distress: An Empirical Investigation of Troubled NYSE Firms", The Journal of Finance 45 (5), 1415-1431.

DeAngelo, Harry, DeAngelo Linda and Skinner, Douglas J., 1992, "Dividends and Losses", The Journal of Finance 47 (5), 1837-1863.

DeAngelo, Harry, DeAngelo, Linda and Skinner, Douglas J., 1996, "Reversal of Fortune: Dividend Signaling and the Disappearance of Sustained Earnings Growth", Journal of Financial Economics 40 (3), 341-371.

DeAngelo, Harry, DeAngelo, Linda and Skinner, Douglas J., 2000, "Special Dividends and the Evolution of Dividend Signaling", The Journal of Financial Economics 57 (3), 309-354.

DeAngelo, Harry, DeAngelo, Linda and Skinner, Douglas J., 2004, "Are Dividends Disappearing? Dividend Concentration and the Consolidation of Earnings", The Journal of Financial Economics 72 (3), 445-456.

Demirguc-Kunt, Asli and Levine, Ross, 1999, "Bank-based and Market-based Financial Systems: Cross-Country Comparisons”, World Bank Policy Working Paper $n^{\circ}$ 2143.

Denis, David J., Denis, Diane K. and Sarin, Atulya, 1994, “The Information Content of Dividend Changes: Cash Flow Signalling, Over investment, and Dividend Clienteles", Journal of Financial and Quantitative Analysis 29 (4), 567-587.

Dewenter, Kathryn L. and Warther, Vincent A., 1998, "Dividends, Asymmetric Information, and Agency Conflicts: Evidence from a Comparison of the Dividend Policies of Japanese and U.S. Firms", The Journal of Finance 53 (3), 879-904.

Dhillon, Upinder S. and Johnson, Herb, 1994, "The Effect of Dividend Changes on Stock and Bond Prices", The Journal of Finance 49 (1), 281-289.

Dhillon, Upinder S., Raman, Kartik and Ramírez, Gabriel G., 2003, “Analyst's Dividend Forecasts and Dividend Signalling”, Working Paper, SSRN Working Papers.

Dielman, Terry E. and Oppenheimer, Henry, R., 1984, "An Examination of Investor Behaviour during Periods of Large Dividend Changes", Journal of Financial and Quantitative Analysis 19 (2), 197-216.

Dyl, Edward and Weigand, Robert A., 1998, "The Information Content of Dividend Initiations: Additional Evidence", Financial Management 27 (3), 27-35.

Eades, Kenneth, Hess, Patrick J. and Kim, E. Han, 1984, "On Interpreting Security Returns during the Ex-Dividend Period", Journal of Financial Economics 13 (1), 3-34. 
Easterbrook, Frank H., 1984, "Two Agency-Cost Explanations of Dividends", The American Economic Review 74 (4), 650-659.

Easton, Stephen, 1991, "Earnings and Dividends: Is There an Interaction Effect?", Journal of Business Finance \& Accounting 18 (2), 255-266.

Eddy, Albert and Seifert, Bruce, 1988, "Firm Size and Dividend Announcements", The Journal of Financial Research 11 (4), 295-302.

Elfakhani, Said, 1995, "An Empirical Examination of the Information Content of Balance Sheet and Dividend Announcements: A Signalling Approach", Journal of Financial and Strategic Decisions 8 (2), 65-76.

Elton, Edwin J. and Gruber, Martin J., 1970, "Marginal Stockholder Tax Rates and the Clientele Effect", Review of Economics and Statistics 52 (1), 68-74.

Fama, Eugene F., 1998, "Market Efficiency, Long-term Returns and Behavioural Finance", Journal of Financial Economics 49 (3), 283-306.

Fama, Eugene F. and Babiak, Harvey, 1968, "Dividend Policy: An Empirical Analysis", Journal of the American Statistical Association 63 (324), 1132-1161.

Fama, Eugene F. and French, Kenneth R., 1998, "Taxes, Financing Decisions and Firm Value", Journal of Finance 53 (3), 819-842.

Fama, Eugene F. and French, Kenneth R., 2000, "Forecasting Profitability and Earnings", Journal of Business 73 (2), 161-175.

Fama, Eugene F. and French, Kenneth R., 2001, "Disappearing Dividends: Changing Firm Characteristics or Lower Propensity to Pay?", Journal of Financial Economics 60 (1), 3-43.

Farinha, Jorge, 2003, "Dividend Policy, Corporate Governance and the Managerial Entrenchment Hypothesis: An Empirical Analysis", Journal of Business Finance and Accounting 30 (9-10), 1173-1209.

Farrar, Donald E. and Selwyn, Lee L., 1967, "Taxes, Corporate Financial Policy and Return to Investors", National Tax Journal 20 (4), 444-454.

Feldstein, Martin and Green, Jerry, 1983, "Why do Companies Pay Dividends?", American Economic Review 73 (1), 17-30.

Fernandes, Carla and Martins, António, 2002, "A Teoria Financeira Tradicional e a Psicologia dos Investidores: Uma Análise Empírica", Estudos de Gestão - Portuguese Journal of Management Studies 7 (1), 43-76.

Fernández, A. Garcia and Jorge, Manuel L., 1999, "La Relevancia de los Dividendos para Explicar el Valor de Mercado de las Acciones", Working Paper presented at the X Congresso of Asociación Española de Contabilidad y Administración de Empresas (AECA).

Fernández, A. Garcia and Jorge, Manuel L., 2003, "Factores Explicativos de la Política de Dividendos: Evidencias Empíricas en Mercados Bursátiles Europeos", Working Paper presented at the XII Congress of AECA.

Ferris, Stephen P., Sen, Nilanjan and Yui, Ho Pei, 2004, "International Trends in Dividend Payment: the Influence of Legal Regime", Working Paper presented at 2004 FMA Annual Meeting. 
Francis, Jennifer, Schipper, Katherine and Vincent, Linda, 2005, "Earnings and Dividend Informativeness when Cash Flows are Separated from Voting Rights", Journal of Accounting and Economics 39 (2), 329-360.

Frank, Murray and Jagannathan, Ravi, 1998, "Why do Stock Prices Drop by Less than the Value of the Dividend? Evidence from a Country without Taxes", Journal of Financial Economics 47 (2), 161-188.

Frankfurter, George M. and Wood, Bob G., 2002, "Dividend Policy Theories and their Empirical Tests", International Review of Financial Analysis 11 (2), 111-138.

Freeman, Robert N., Ohlson, James A. and Penman, Stephen H., 1982, "Book Rateof-return and Prediction of Earnings Changes: An Empirical Investigation", Journal of Accounting Research 20 (2), 639-653.

Friend, Irwin and Pucket, Marshall, 1964, "Dividends and Stock Prices", American Economic Review 54 (5), 656-682.

Garrett, Ian and Priestley, Richard, 2000, "Dividend Behavior and Dividend Signaling”, Journal of Financial and Quantitative Analysis 35 (2), 173-189.

Gaud, Philippe, Elion, Jani, Hoesli, Martin and Bender, André, 2005, "The Capital Structure of Swiss Companies: An Empirical Analysis Using Dynamic Panel Data", European Financial Management Review 11 (1), 51-70.

Ghosh, Chinmoy and Woolridge, J. Randall, 1988, "An Analysis of Shareholder Reaction to Dividend Cuts and Omissions?", The Journal of Financial Research 11 (4), 281-294.

Glen, Jack D., Karmokolias, Yannis, Miller, Robert R. and Shah, Sanjay, 1995, "Dividend Policy and Behavior in Emerging Markets", Working Paper $\mathrm{n}^{0}$ 26, International Finance Corporation.

Goergen, Marc, Renneboog, Luc and Silva, Luis Correia, 2005, "When do German Firms Change their Dividends?”, Journal of Corporate Finance 11 (2), 375-399.

Goldstein, Michael A. and Fulter, Kathleen P., 2003, "Dividend Policy and Market Movements", Working Paper, SSRN Working Papers.

Gonedes, Nicholas J., 1978, "Corporate Signalling, External Accounting, and Capital Market Equilibrium: Evidence on Dividends, Income and Extraordinary Items", Journal of Accounting Research 16 (1), 26-79.

Gordon, Myron, 1959, "Dividends, Earnings and Stock Price", Review of Economics and Statistics 41 (2), 99-105.

Gordon, Myron, 1961, The Investment, Financing and Valuation of the Corporation, Burr Ridge, III: Richard D. Irwin, in Ross, Stephen A., Westerfield, Randolph W. and Jordan, Bradford D., 1998, Fundamentals of Corporate Finance, 4th Edition, McGraw-Hill Companies, Inc.

Gordon, Myron, 1963, “Optimal Investment and Financing Policy”, The Journal of Finance 18 (2), 264-272.

Gordon, Roger H. and Bradford, David F., 1980, "Taxation and the Stock Market Valuation of Capital Gains and Dividends: Theory and Empirical Results", Journal of Public Economics 14 (2), 109-136. 
Graham, Benjamin, Dodd David and Cottle, Sidney, 1962, Security Analysis, 1st Edition, McGraw-Hill, New York.

Graham, John R. and Kumar, Alok, 2005, "Do Dividend Clienteles Exist? Evidence on Dividend Preferences of Retail Investors", The Journal of Finance, forthcoming.

Greene, William H., 2000, Econometric Analysis, 4th Edition, Prentice Hall International Inc.

Grinblatt, Mark, Masulis, Ronald W. and Titman, Sheridan, 1984, "The Valuation Effects of Stock Splits and Stock Dividends", Journal of Financial Economics, 13 (4), 461-490.

Grinblatt, Mark and Titman, Sheridan, 1998, Financial Markets and Corporate Strategy, 1st Edition, McGraw-Hill.

Grullon, Gustavo and Michaely, Roni, 2002, "Dividends, Share Repurchases, and the Substitution Hypothesis", The Journal of Finance 57 (4), 1649-1684.

Grullon, Gustavo, Michaely, Roni and Swaminathan, Bhaskaran, 2002, "Are Dividends Changes a Sign of Firm Maturity?", The Journal of Business 75 (3), 387-424.

Gugler, Klaus and Yurtoglu, Burcin B., 2003, “Corporate Governance and Dividend Policy Payout in Germany”, European Economic Review 47 (4), 731-758.

Gujarati, Damodar N., 2003, Basis Econometrics, Fourth Edition, McGraw-Hill, Irwin.

Gurgul, Henryk, Madjosz, Pawel and Mestel, Roland, 2003, "GARCH Modelling of Austrian Stock Market Reactions on Dividend Announcements", Working Paper, VII Ogólnopolskie Seminarium Nauukowe.

Gwilym, Owain A., Morgan, Gareth and Thomas, Stephen, 2000, "Dividend Stability, Dividend Yield and Stock Returns: UK Evidence", Journal of Business Finance \& Accounting 27 (3-4), 261-281.

Handjinicolaou, George and Kalay, Avner, 1984, "Wealth Redistributions of Changes in Firm Value: An Analysis of Returns to Bondholders and Stockholders around Dividend Announcements", Journal of Financial Economics 13 (1), 35-64.

Harris, John M., Roenfeldt, Rodney L. and Cooley, Philip L., 1983, "Evidence of Financial Leverage Clienteles", The Journal of Finance 38 (4), 1125-1132.

Harris, Trevor S., Hubbard, R. Glenn and Kemsley, Deen, 2001, "The Share Price Effects of Dividend Taxes and Tax Imputation Credits", Journal of Public Economics 79 (3), 569-596.

Hausman, Jerry A., 1978, "Specification Tests in Econometrics", Econometrica 46 (6), 1251-1271.

Haw, In-Mu H. and Kim, Wi-Saeng, 1991, "Firm Size and Dividend Announcement Effect", Journal of Accounting, Auditing and Finance 6 (3), 325-347.

Healy, Joanne, Hathorn, John and Kirch, David, 1997, "Earnings and the Differential Information Content of Initial Dividend Announcements", Accounting Enquiries 6 (2), 187-220.

Healey, Paul M. and Palepu, Krishna G., 1988, "Earnings Information Conveyed by Dividend Initiations and Omissions”, Journal of Financial Economics 21 (2), 149-176. 
Heaton, James B., 2002, "Managerial Optimism and Corporate Finance", Financial Management 31 (2), 33-45.

Holder, Mark E., Langrehr, Frederic W. and Hexter, J. Lawrence, 1998, "Dividend Policy Determinants: An Investigation of the Influences of Stakeholder Theory", Financial Management 27 (3), 73-82.

Horne, James C. Van and Wachowicz, John M. Jr., 1998, Fundamentals of Financial Management, 10th Edition Prentice-Hall, Inc.

Ikenberry, David, Lakonishok, Josef and Vermaelen, Theo, 1995, "Market Underreaction to Open Market Share Repurchases", Journal of Financial Economics 39 (2-3), 181-208.

Jensen, Michael, 1986, "Agency Costs of Free Cash Flow, Corporate Finance, and Takeover", American Economic Review 76 (2), 323-329.

Jensen, Michael C. and Meckling, William H., 1976, "Theory of the Firm: Managerial Behaviour, Agency Costs and Capital Structure", Journal of Financial Economics 3 (4), 305-360.

John, Kose and Lang, Larry H. P., 1991, "Insider Trading around Dividend Announcements: Theory and Evidence", The Journal of Finance 46 (4), 1361-1389.

John, Kose and Williams, Joseph, 1985, "Dividends, Dilution, and Taxes: A Signalling Equilibrium“, The Journal of Finance 40 (4), 1053-1070.

Johnston, Jack and DiNardo, John, 2001, Métodos Econométricos, $4^{\text {a }}$ Edição, McGraw-Hill.

Joos, Peter and Plesko, George A., 2004a, "Costly Dividend Signaling: The Case of Loss Firms with Negative Cash Flows”, Working Paper no 4474-04, MIT Sloan School of Management.

Joos, Peter and Plesko, George A., 2004b, "Valuing Loss Firms", Working Paper no 4491-04, MIT Sloan School of Management.

Kahneman, Daniel and Tversky, Amos, 1982, "The Psychology of Preferences", Scientific American 246, 167-173, in Frankfurter, George M. and Wood, Bob G., 2002, "Dividend Policy Theories and their Empirical Tests", International Review of Financial Analysis 11 (2), 111-138.

Kalay, Avner, 1982, "The Ex-Dividend Behaviour of Stock Prices: A Re-examination of the Clientele Effect", The Journal of Finance 37 (4), 1059-1070.

Kalay, Avner and Loewenstein, Uri, 1986, "The Informational Content of the Timing of Dividend Announcements", Journal of Financial Economics 16 (3), 373-388.

Kalay, Avner and Michaely, Roni, 2000, "Dividends and Taxes: A Re-examination", Financial Management 29 (2), 55-75.

Kane, Alex, Lee, Young K. and Marcus, Alan, 1984, "Earnings and Dividends Announcements: Is There a Corrobation Effect?", The Journal of Finance 39 (4), 10911099.

Kao, Chihwa and Wu, Chunchi, 1994, "Tests of Dividend Signaling Using the MarshMerton Model: A Generalized Friction Approach", Journal of Business 67 (1), 45-68. 
Kaplan, Steven N. and Zingales, Luigi, 1997, "Do Investment-cash Flow Sensitivities Provide Useful Measures of Financing Constraints?", The Quarterly Journal of Economics 112 (1), 169-215.

Keim, Donald B., 1985, "Dividend Yields and Stock Returns: Implications of Abnormal January Returns", Journal of Financial Economics 14 (3), 473-489.

Koch, Adam S. and Sun, Amy X., 2004, "Dividend Changes and the Persistence of Past Earnings Changes", The Journal of Finance 59 (5), 2093-2116.

Koski, Jennifer Lynch and Sruggs, John T., 1998, "Who Trades Around the ExDividend Day? Evidence from NYSE Audit File Data", Financial Management 27 (3), 58-72.

Kumar, Praveen, 1988, "Shareholder-Manager Conflict and the Information Content of Dividends", Review of Financial Studies 1 (2), 111-136.

Kumar, Jayesh, 2003, "Determinants of Dividend Payout Policy in India", Working Paper, SSRN Working Papers.

Kwan, Clarence C. Y., 1981, "Efficient Market Tests of the Informational Content of Dividends Announcements: Critique and Extension", Journal of Financial and Quantitative Analysis, 16 (2), 193-206.

La Porta, Rafael, Lopes-de-Silanes, Florencio, Shleifer, Andrei and Vishny, Robert W., 1998, "Law and Finance", The Journal of Political Economy 106 (6), 1113-1155.

La Porta, Rafael, Lopes-de-Silanes, Florencio, Shleifer, Andrei and Vishny, Robert W., 2000, "Agency Problems and Dividend Policies around the World", The Journal of Finance 55 (1), 1-33.

Lai, Gene C., Song, Zhiyi and Fung, Hung-Gay, 2004, "Is Signaling Hypothesis of Dividend Policy Dead?", Working Paper presented at 2004 FMA Annual Meeting.

Lakanishok, Joseph and Vermaelen, Theo, 1983, "Tax Reform and Ex-Dividend Day Behavior", The Journal of Finance 38 (4), 1157-1179.

Lakanishok, Joseph and Vermaelen, Theo, 1986, "Tax-Induced Trading Around ExDividend Days", Journal of Financial Economics 16 (3), 287-319.

Lamont, Owen A., Polk, Christopher and Saá-Requejo, Jesús, 2001, "Financial Constraints and Stock Returns", The Review of Financial Studies 14 (2), 529-554.

Lang, Larry H.P. and Litzenberger, Robert H., 1989, "Dividend Announcements: Cash Flow Signalling Versus Free Cash Flow Hypothesis", Journal of Financial Economics 24 (1), 181-191.

Lasfer, Meziane M. and Zenonos, Maria, 2004, "The Market Valuation of Dividend Announcements in the UK, Germany, France and Italy", Working Paper presented at 2004 FMA Annual Meeting.

Laub, P. Michael, 1976, "On the Informational Content of Dividends", Journal of Business 49 (1), 73-85.

Lease, Ronald C., Kalay, Avner, Loewenstein, Uri, John, Kose and Sarig, Oded H., 2001, Política de Dividendos y sus Efectos sobre el Valor de la Empresa, Ediciones Gestión 2000, S.A., Barcelona. 
Lee, Hei Wai and Ryan, Patricia A., 2000, "The Information Content of Dividend Initiations and Omissions: The Free Cash Flow and Dividend Signaling Hypotheses", The Journal of Research in Finance 3 (2), 196-277.

Lee, Hei Wai and Ryan, Patricia A., 2002, "Dividends and Earnings Revisited: Cause or Effect?", American Business Review 20 (1), 117-122.

Leftwich, Richard and Zmijewski, Marke E., 1994, "Contemporaneous Announcements of Dividends and Earnings", Journal Accounting, Auditing \& Finance, 9 (4), 725-762, in Chen, Gongmeng, Firth, Michael and Gao, Ning, 2002, "The Information Content of Concurrently Announced Earnings, Cash Dividends, and Stock Dividends: An Investigation of the Chinese Stock Market", Journal of International Financial Management \& Accounting 13 (2), 101-124.

Lewellen, Wilbur G., Stanley, Kenneth L., Lease, Ronald C. and Schlarbaum, Gary G., 1978, "Some Direct Evidence on the Dividend Clientele Phenomenon", The Journal of Finance 33 (5), 1385-1399.

Lie, Eric, 2000, "Excess Funds and Agency Problems: An Empirical Study of Incremental Cash Disbursements", The Review of Financial Studies 13 (1), 219-248.

Lintner, John, 1956, "Distribution of Incomes of Corporations among Dividends, Retained Earnings and Taxes", The American Economic Review 46 (2), 97-113.

Lintner, John, 1962, "Dividends, Earnings, Leverage, Stock Prices, and the Supply of Capital to Corporations", Review of Economics and Statistics 44 (3), 239-269.

Lippert, Robert L., Nixon, Terry D. and Pilotte, Eugene A., 2000, "Incentive Compensation and the Stock Price Response to Dividend Increase Announcements", The Financial Review 35, (4) 69-94.

Lipson, Marc L., Maquieira, Carlos P. and Megginson, William, 1998, "Dividend Initiations and Earnings Surprises", Financial Management 27 (3), 36-45.

Litzenberger, Robert H. and Ramaswamy, Krishna, 1979, "The Effect of Personnel Taxes and Dividends on Capital Asset Prices: Theory and Empirical Evidence", Journal of Financial Economics 7 (2), 163-196.

Litzenberger, Robert H. and Ramaswamy, Krishna, 1980, "Dividends, Short Selling Restrictions, Tax-Induced Investor Clienteles and Market Equilibrium", The Journal of Finance 35 (2), 469-485.

Litzenberger, Robert H. and Ramaswamy, Krishna, 1982, "The Effects of Dividends on Common Stock Process: Tax Effects or Information Effects", The Journal of Finance 37 (2), 429-443.

Loderer, Claudio and Roth, Lukas, 2005, "Do Cash Payouts Justify Share Prices? Evidence from the NYSE, Amex and NASDAQ", Working Paper presented at 2005 Annual Meeting of EFMA.

Long, John B., 1978, "The Market Valuation of Cash Dividends: A Case to Consider", Journal of Financial Economics 6 (2-3), 235-264.

Lonie, A. A., Abeyratna, Gunasekarage, Power, David M. and Sinclair, C. D., 1996, "The Stock Market Reaction to Dividend Announcements: A UK Study of Complex Market Signals", Journal of Economic Studies 23 (1), 32-52. 
Low, Soo-Wah, Glorfeld, Louis, Hearth, Douglas and Rimbey, James N., 2001, "The Link between Bank Monitoring and Corporate Dividend Policy: The case of Dividend Omissions", Journal of Banking and Finance 25 (11), 2069-2087.

Marsh, Terry A. and Merton, Robert C., 1987, "Dividend Behaviour for the Aggregate Stock Market", The Journal of Business 60 (1), 1-40.

Masulis, Ronald W. and Trueman, Brett, 1988, "Corporate Investment and Dividend Decisions under Differencial Personal Taxation", Journal of Financial and Quantitative Analysis 23 (4), 369-385.

Michaely, Roni and Murgia, Maurizio, 1995, "The Effect of Tax Heterogeneity on Prices and Volume arounf Ex-dividend Day: Evidence from the Milan Stock Exchange", The Review of Financial Studies 8 (2), 369-399.

Michaely, Roni, Thaler, Richard H. and Womack, Kent L., 1995, "Price Reactions to Dividend Initiations and Omissions: Overreaction or Drift?", The Journal of Finance, 50 (2), 573-608.

Mikhail, Michael B., Walther, Beverly R. and Willis, Richard H., 2003, "Reactions to Dividend Changes Conditional on Earnings Quality", Journal of Accounting, Auditing \& Finance 18 (1), 121-151.

Miller, Merton and Modigliani, Franco, 1961, "Dividend Policy, Growth, and the Valuation of Shares", The Journal of Business 34 (4), 411-433.

Miller, Merton H. and Rock, Kevin, 1985, "Dividend Policy Under Asymmetric Information”, The Journal of Finance 40 (4), 1031-1051.

Miller, Merton H. and Scholes, Myron S., 1978, "Dividends and Taxes", Journal of Financial Economics 6 (4), 333-364.

Miller, Merton H. and Scholes, Myron S., 1982, "Dividends and Taxes: Some Empirical Evidence", Journal of Political Economy, 90 (6), 1108-1142.

Mitra, Devashis and Owers, James E., 1995, "Dividend Initiation Announcement Effects and the Firm's Information Environment", Journal of Business Finance and Accounting 22 (4), 551-573.

Morgan, Ian G., 1982, "Dividends and Capital Asset Prices", The Journal of Finance 37 (4), 1071-1086.

Mougoué, Mbodja and Rao, Ramesh P., 2003, “The Information Signaling Hypothesis of Dividends: Evidence from Cointegration and Causality Tests", Journal of Business Finance \& Accounting 30 (3-4), 441-478.

Mozes, Haim A. and Rapaccioli, Donna C., 1998, "The Link between Dividend Changes and Future Earnings", The Journal of Financial Statement Analysis 3 (3), 2939.

Myers, Stewart, 1977, "Determinants of Corporate Borrowing”, Journal of Financial Economics 5 (2), 147-175.

Nissim, Doron, 2003, "Discussion - Reactions to Dividend Changes Conditional on Earnings Quality", Journal of Accounting, Auditing \& Finance 18 (1), 153-161.

Nissim, Doron and Ziv, Amir, 2001, "Dividend Changes and Future Profitability", The Journal of Finance 56 (6), 2111-2133. 
Ofer, Aharon R. and Siegel, Daniel R., 1987, "Corporate Financial Policy, Information, and Market Expectations: An Empirical Investigation of Dividends", The Journal of Finance 42 (4), 889-911.

Ofer, Aharon R. and Thakor, Anjan V., 1987, "A Theory of Stock Price Responses to Alternative Corporate Cash Disbursement Methods: Stock Repurchases and Dividends", The Journal of Finance 42 (2), 365-394.

Ohlson, James A., 1995, "Earnings, Book Values and Dividends in Equity Valuation", Contemporary Accounting Research 11 (2), 661-687.

Olson, Gerard T. and McCann, P. Douglas, 1994, "The Linkages Between Dividends and Earnings", The Financial Review 29 (1), 1-22.

Omet, Ghassan, 2004, "Dividend Policy Behaviour in the Jordanian Capital Market", International Journal of Business 9 (3), 287-299.

Osobov, Igor, 2004, "Why Are Dividends Disappearing? An International Comparison", Working Paper presented at 2004 FMA Annual Meeting.

Penman, Stephen H., 1983, "The Predictive Content of Earnings Forecasts and Dividends", The Journal of Finance 38 (4), 1181-1199.

Penman, Stephen H., and Sougiannis, Theodore, 1997, "The Dividend Displacement Property and the Substitution of Anticipated Earnings for Dividends in Equity Valuation", The Accounting Review 72 (1), 1-21.

Pettit, Richardson, 1972, "Dividend Announcements, Security Performance, and Capital Market Efficiency", The Journal of Finance 27 (5), 993-1007.

Pettit, Richardson R., 1976, "The Impact of Dividends and Earnings Announcements: A Reconciliation", The Journal of Business 49 (1), 86-96.

Pettit, Richardson R., 1977, "Taxes, Transaction Costs and the Clientele Effect of Dividends", Journal of Financial Economics 5 (3), 419-436.

Poterba, James, 1986, "The Market Valuation of Cash Dividends: The Citizens Utilities Case Reconsidered”, Journal of Financial Economics 15 (3), 395-406.

Poterba, James and Summers, Lawrence. H., 1984, "New Evidence that Taxes Affect the Valuation of Dividends", The Journal of Finance 39, 1397-1416.

Prevost, Andrew, Rao, Ramesh P. and Wagster, John D., 2002, "Dividend Imputation and Shareholder Wealth: The Case of New Zealand", Journal of Business Finance \& Accounting 29 (7-8), 1079-1104.

Rao, Ramesh K. S., 1987, Financial Management: Concepts and Applications, 1st Edition, Macmillan Publishing Company.

Reddy, Y. Subba, 2003, "Dividend Policy of Indian Firms: An Analysis of Trends and Determinants", Working Paper, The ICFAI University Press.

Reynolds, Noel R., 2004, “The Firm's Payout Policy Choice and Stockholder Wealth Maximization", Working Paper presented at 2004 FMA Annual Meeting.

Richardson, Gordon, Sefcik, Stephan and Thompson, Rex, 1986, "A Test of Dividend Irrelevance Using Volume Reactions to a Change in Dividend Policy", Journal of Financial Economics 17 (2), 313-334. 
Riley, John, 1979, "Informational Equilibrium", Econometrica 47, 331-359, in John, Kose and Williams, Joseph, 1985, "Dividends, Dilution, and Taxes: A Signalling Equilibrium“" The Journal of Finance 40 (4), 1053-1070.

Romon, Frédéric, 2000, "Contribution of Dividend Policy Stability to the Measurement of Dividend Announcement and Ex-dividend Effects on the French Market", Working Paper, Université de Valenciennes.

Rosenberg, Barr and Marathe, Vinay, 1979, "Tests of Capital Asset Pricing Model Hypothesis", Research in Finance 1, 115-224.

Ross, Stephen A., 1977, "The Determination of Financial Structure: The IncentiveSignalling Approach", Bell Journal of Economics 8 (1), 23-40.

Ross, Stephen A., Westerfield, Randolph W. and Jordan, Bradford D., 1998, Fundamentals of Corporate Finance, 4th Edition, McGraw-Hill Companies, Inc.

Rozeff, Michael, 1982, "Growth, Beta and Agency Costs as Determinants of Dividend Payout Ratios", Journal of Financial Research 5 (3), 249-259.

Ryan, Patricia A., Besley, Scott and Lee, Hei Wai, 2000, "An Empirical Analysis of Reactions to Dividend Policy Changes for NASDAQ Firms", Journal of Financial and Strategic Decisions 13 (1), 35-44.

Ryan, Patricia A. and Lee, Hei W., 1998, "A Further Examination of the Information Content of Specially Designated Dividends", Journal of Accounting and Finance Research 5 (2), 72-80.

Sahu, Chinmoy, 2002, “An Empirical Test of Stable Dividend Hypothesis", Finance India 16 (2), 613-626.

Sant, Rajiv and Cowan, Arnold R., 1994, "Do Dividends Signal Earnings? The Case of Omitted Dividends", Journal of Banking and Finance 18 (6), 1113-1133.

Saxena, Atul K., 1999, "Determinants of Dividend Payout Policy: Regulated versus Unregulated Firms", Working Paper, www.westga.edu/ bquest/1999/payout.html.

Shefrin, Hersh M. and Statman, Meir, 1984, "Explaining Investor Preference for Cash Dividends", Journal of Financial Economics 13 (2), 253-282.

Shleifer, Andrei and Vishny, Robert W., 1986, "Large Shareholders and Corporate Control”, Journal of Political Economy 94 (3), 461-488.

Skinner, Douglas J., 2004, "What do Dividends Tell us About Earnings Quality?", Working Paper, Columbia Business School, University of Michigan.

Szewczyk, Samuel H., Tsetsekos, George P. and Zantout, Zaher Z., 1997, "Do Dividend Omissions Signal Future Earnings or Past Earnings?", Journal of Investing 6 (1), 40-53.

Travlos, Nickolaos, Trigeorgis, Lenos and Vafeas, Nikos, 2001, "Share-holder Wealth Effects of Dividend Policy Changes in an Emerging Stock Market: The Case of Cyprus", Multinational Finance Journal 5 (2), 87-112.

Verbeek, Marno, 2004, A Guide to Modern Econometrics, 2nd Edition, John Wiley \& Sons, Ltd.

Viswanath, P. V., Kim, Yu Kyung and Pandit, Jayant, 2002, "Dilution, Dividend Commitments and Liquidity: Do Dividend Changes Reflect Information Signalling?", Review of Quantitative Finance and Accounting 18 (4), 359-379. 
Zeng, Tao, 2003, "What Determines Dividend Policy: A Comprehensive Test", Journal of American Academy of Business 2 (2), 304-309.

Zhen Li, Oliver, 2003, "Dividend Change, Institutional Ownership and Shareholder Wealth", Working Paper, SSRN Working Papers.

Watts, Ross, 1973, "The Information Content of Dividends", The Journal of Business 46 (2), 191-211.

Watts, Ross, and Leftwich, Richard, 1977, "The Time Series of Annual Accounting Earnings", Journal of Accounting Research 15 (2), 253-271.

Williams, Joseph, 1988, "Efficient Signalling with Dividends, Investment, and Stock Repurchases", The Journal of Finance 43 (3), 737-747.

White, Halbert, 1980, "A Heteroscedasticity-consistent Covariance Matrix Estimator and a Direct Test for Heteroscedasticity", Econometrica 48 (4), 149-170.

Woolridge, J. Randall, 1983, "Dividend Changes and Security Prices", The Journal of Finance 38 (5), 1607-1615.

Woolridge, J. Randall and Ghosh, Chinmoy, 1985, "Dividend Cuts: do they always Signal Bad News?", Midland Corporate Finance Journal 3 (2), 20-32.

Yoon, Pyung Sig and Starks, Laura T., 1995, "Signalling, Investment Opportunities, and Dividend Announcements", The Review of Financial Studies 8 (4), 995-1018. 